The Journeys of a Taymiyyan Sufi 


\title{
Studies on Sufism
}

\author{
Edited by \\ Rachida Chih \\ Erik S. Ohlander \\ Florian Sobieroj
}

VOLUME 6

The titles published in this series are listed at brill.com/sufi 


\title{
The Journeys of a Taymiyyan Sufi
}

\author{
Sufism through the Eyes of \\ Imād al-Dìn Aḥmad al-Wāsițì (d. 711/1311)
}

By

Arjan Post

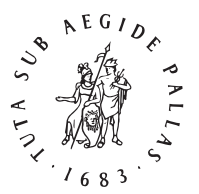

B R I L L

LEIDEN | BOSTON 
This is an open access title distributed under the terms of the CC BY-NC 4.o license, which permits any non-commercial use, distribution, and reproduction in any medium, provided the original author(s) and source are credited. Further information and the complete license text can be found at https://creativecommons.org/licenses/by-nc/4.o/

The terms of the cc license apply only to the original material. The use of material from other sources (indicated by a reference) such as diagrams, illustrations, photos and text samples may require further permission from the respective copyright holder.

Cover illustration: Antique photograph of a cemetery on the slopes of Mount Qāsyūn in Damascus, which is where al-Wāsiți is said to have been buried. Photo: istockphoto.com/ilbusca.

The Library of Congress Cataloging-in-Publication Data is available online at http://catalog.loc.gov LC record available at http://lccn.loc.gov/2020026828

Typeface for the Latin, Greek, and Cyrillic scripts: "Brill”. See and download: brill.com/brill-typeface.

\section{ISSN 2468-0087}

ISBN 978-90-04-43129-4 (hardback)

ISBN 978-90-04-37755-4 (e-book)

Copyright 2020 by Arjan Post. Published by Koninklijke Brill NV, Leiden, The Netherlands. Koninklijke Brill NV incorporates the imprints Brill, Brill Hes \& De Graaf, Brill Nijhoff, Brill Rodopi, Brill Sense, Hotei Publishing, mentis Verlag, Verlag Ferdinand Schöningh and Wilhelm Fink Verlag. Koninklijke Brill NV reserves the right to protect this publication against unauthorized use.

This book is printed on acid-free paper and produced in a sustainable manner. 
To My Wife, Chaimae

\& Our Children, Eleonora \& Jacob 
Arjan Post - 978-90-04-37755-4

Downloaded from Brill. com $04 / 26 / 2023$ 03:36:10PM via free access 


\section{Contents}

Acknowledgments XI

List of Illustrations XIV

Transcription Table XV

List of Abbreviations XVI

Introduction 1

1 A Contextual Approach to Studying Sufism(s) 2

2 Situating Ibn Taymiyya's Circle in Its Context 6

3 Sufism, Traditionalists, and the Circle of Ibn Taymiyya 9

4 Book Outline: al-Wāsițīs Two Journeys 15

\section{PART 1}

The Physical Journey (al-Rihla)

Introduction: Al-Wāsițī’s Autobiography 21

1 Leaving Home, Bastion of the Spectacular Rifāīis 27

1 Al-Wāsițìs Early Context 27

1.1 Wāsit under the Ilkhanids 30

1.2 An Ilkhanid-Rifā̄i Friendship? 33

2 Al-Wāsițī Versus The Rifāìyya 36

2.1 Shaykhdom in the Rifäiyya 39

2.2 Rifā̄i Practice: Samā $\bar{c}^{c}$ and Miracle-Working 48

2.3 Depictions of the Rifāiyya: Antinomians or Mainstream Sufis? 53

3 Al-Wāsițī's Final Years in Iraq 58

3.1 The Sober Shäfí ‘u Jurists 59

3.2 The BaghdadiSufis 62

Appendix 1: The Line of Rifā̄ī Shaykhs in Umm 'Ubayda and Wāsiṭ 68

2 Scholastic Sufism of the Alexandrian Shādhiliyya 70

1 The Egyptian Context 70

1.1 Stagnation and War 71

1.2 Egypt's Sufi Capital? 76

2 Enter the Shādhiliyya of Alexandria 82

2.1 The Network of the Early Shädhiliyya 85

2.2 The Doctrine of the Early Shädhiliyya 94 


\subsection{The Success of the Shädhiliyya 103}

3 The Final Steps: From Heretics to the Saved Sect 118

1 Cairene Convents and Monistic Sufis 118

1.1 The Sufis of Convention 119

1.2 The Heresy of the Ittihādiyya 125

2 Conversion to the Saved Sect: Ibn Taymiyya's Damascene Circle 134

2.1 Sufism and Hanbali Piety in Damascus 134

2.2 In the Company of Ibn Taymiyya: Șuhba under the Shaykh al-Islām 142

2.3 A Shaykh of Sufism for the Taymiyyan Circle 155

Appendix 2: The Hadith-Scholars Attended By The Taymiyyan Circle 169 Appendix 3: Biographies of al-Wāsițī's Companions from Ibn Taymiyya's

Circle 170

\section{PART 2}

\section{The Spiritual Journey (al-Sulūk)}

Introduction: Sulūk as Sufism 177

4 Traditionalist Sufism: Outlining the Foundations of the Journey 182

1 Introduction 184

2 The Muhammadan Way (al-Tarīqa al-Muhammadiyya) 183

2.1 The Origins of the Tarīqa Muḥammadiyya 184

2.2 How to Practice the Muhammadan Way 190

2.3 The Role of the Shaykh in the Muhammadan Way 197

3 Sound Ma'rifa of God and His Attributes 200

3.1 What is Ma'rifa of God? 201

3.2 Affirmation versus Metaphorical Interpretation 204

3.3 The Critical Importance of Direction 208

4 What Sufism is Not: Refuting the Deviations of Sufis 214

4.1 SufiAudition (Samāc) 215

4.2 Philosophy and Kalām 220

4.3 The Monistic Akbarians 225

5 Conclusion 231 
5 Progressing Towards the Beloved through the Degrees of

Witnessing 233

1 Introduction 233

2 Putting Ma'rifa into Practice 236

2.1 Servitude through the Divine Names and Attributes 238

2.2 The Heart as the Locus of Witnessing 243

3 The Sequence of the Degrees of Witnessing (Tartīb al-Mashāhid) 248

3.1 The Heart's Witnessing of Divinity (Mashhad al-Ilāhiyya) 250

3.2 The Heart's Witnessing of Lordship (Mashhad al-Rubübiyya) 255

3.3 Al-Wāsițīs Shaykhs and Their Teachings Regarding Divinity and Lordship 260

3.4 Other Degrees of Witnessing by the Heart 262

3.5 The Spirit's Witnessing of Union (al-Jam $\left.{ }^{c}\right)$ and Singularity (al-Fardāniyya) $\quad 264$

4 Conclusion 274

Conclusion 277

Bibliography 285

Index of Qur'an and Hadīth References 308

Index of Technical Terms 309

Index of Persons, Groups, and Places 316 
Arjan Post - 978-90-04-37755-4

Downloaded from Brill. com $04 / 26 / 2023$ 03:36:10PM via free access 


\section{Acknowledgments}

The book before you is a slightly altered version of my doctoral dissertation, which I wrote over the course of three years at Utrecht University and successfully defended on 27 November 2017. The last year that I worked on it was, in many ways, the most challenging. On 11 April 2017, after a particularly tough pregnancy, my wife, Chaimae, gave birth to our daughter, Eleonora. In the months that followed, it was a struggle to get through each day, as our dear habiba experienced much distress adjusting to the new world she had just entered. At the same time, I had to work harder than ever before to make the deadline I had set for myself. This I could not have done without the continuous support of my wife on every level imaginable. Although she has always been supportive of me, it is now clear to me that she had by then realized that these last months were crucial not merely for a deadline, but, above all, because it was high time I finished this project, which was beginning to take its toll on me. I am truly grateful for her patience and understanding, and for putting up with my grumpy moods whenever I felt progression was frustratingly slow. I cannot thank her enough for this. During the process of preparing this book for publication, our son Jacob was born. To me, this ties all my effort that went into it to the two greatest gifts in our lives: our children.

Next I want to thank my family and friends, all of whom have in some way played a role in the process of completing this work before you. My parents, Ton and Digna, have been a constant tower of strength throughout my life, as have my brother, Johan, and my sister, Meika. My in-laws have likewise been extremely supportive of me, for which I am very grateful; I have to make special mention of my brother-in-law Mohammed for all the moments of solidarity we shared whenever we'd work together!

It is befitting here to mention that I feel a sincere sense of guilt for my shortcomings towards my friends (Salahuddin, Pieter, Juan Ahmed, Léon Buskens, shaykh Abdur Rahman Fitzgerald, Soheib, Lieven, Ahmed, Younass, Berk, and all others I forgot to mention here!); especially in recent years, when the mixture of work and family life frequently made it difficult for me to give them their due. I am thankful for their understanding in that regard. A special word of appreciation is due to my dear friend Timothy Farid for all the beautiful maps he edited for this book.

I also want to thank all my former colleagues at Utrecht University for their role in my academic career. First and foremost, I must mention my $\mathrm{PhD}$ supervisor, Christian Lange, to whom I am particularly grateful for allowing me to switch from Ibn Taymiyya to al-Wāsițī, and for giving me the space and support 
to develop my own approach to the source material. My dear friend Pieter Coppens was, and ever remains, a source of valuable advice and inspiration. The atmosphere at the Islamic studies department was ever stimulating intellectually thanks to the presence of such people as Simon O'Meara, Joas Wagemakers, Nico Landman, Mehdi Sajid, Eric van Lit, Yunus Yaldiz, Sophie Spaan, Andrei Tirtan, Maxim Abdul Latif, and Hayat Ahlili. My friend and colleague (formerly in Utrecht and now in Leuven) Umar Ryad has been very supportive in the past year as I started my tenure track at KU Leuven, and often motivated me to finish this book and get it published, for which my thanks are due!

I also benefited greatly from meeting with my teachers and colleagues in Taymiyyan and Mamluk studies: Jon Hoover, his group of $\mathrm{PhD}$ candidates, Caterina Bori, Farid Suleiman, and Abdullah Sliti. Jon Hoover, Jo van Steenbergen, and two anonymous reviewers all read an earlier draft of this book and made many valuable suggestions for improvement. I am also grateful to Lisa Nielson for providing me with two rare manuscripts of works by al-Wāsiți, one of which turned out to be a crucial source in many ways. Two colleagues I never met, but without whom this book would never have come to fruition, are Muhammad Abū al-Faḍl al-Qūnawī and Walīd b. Muhammad al-'Alī, who devoted their precious time to editing the works of al-Wāsiți. I am greatly indebted to them both, as their editions were the cornerstone of my research. Sadly, it has come to my attention that Walīd b. Muhammad al-'Alī was one of the innocent casualties of the terrorist attack in Ouagadougou, Burkina Faso, on 14 August 2017. I hope to honor his memory through the present study of al-Wāsițī. I also want to mention Gino Schallenbergh here, who passed away on 14 December 2017: I like to think he would have appreciated that I publish this book as a KU Leuven professor, thus continuing his legacy of studying the role of Sufism in Ibn Taymiyya's circle.

It was my desire to not only describe the places al-Wāsițī visited, but also give a glimpse of what remains of them today - to, in a sense, really make the journey with him. I have been able to add beautiful pictures of several of the buildings that directly or indirectly played a role in the Hanbali Suf's life thanks to Ross Burns, Ahmad Mahdi Salih (who drove all the way from Baghdad to Umm 'Ubayda to take pictures for me of shaykh al-Rifāī's mosque!), Andrew Michael Chugg, 'Imād al-Armashī, the Ashmolean Museum of Art and Archaeology, the Walters Art Museum in Baltimore, and the Fine Arts Library of Harvard University.

I have to express my sincere appreciation to the Netherlands Organisation for Scientific Research (De Nederlandse Organisatie voor Wetenschappelijk Onderzoek) for their generous grant, which has made this book possible. Thanks to their funding, I have been able to focus on a topic of my own 
choosing for four years. After finishing the final draft, Muhammad Ridwaan of Qalam Editing did a wonderful job copy-editing this book. Last but not least, a big thanks to the folks at Brill (especially Nienke Brienen-Moolenaar) and the editors of the Studies on Sufism series for wanting to publish my work and remaining patient with me. This journey has been a great privilege, for which I am ever grateful!
Arjan Post
Leuven, Belgium
17 February 2020 


\section{Illustrations}

$1 \quad$ Map of the places al-Wāsiți visited on his journey 26

2 The front of one of Wāsiț's gates 28

3 Remains of Wāsiț 28

4 The current-day mosque that contains the Rifācī mausoleum in Umm 'Ubayda 45

5 The entrance to the mosque of Aḥmad al-Rifấcī 45

6 The mausoleum of Ahmad al-Rifăc̄ì 46

7 An Ottoman impression of Alexandria dating from $1525 \quad 7^{2}$

8 Seventh/thirteenth-century Alexandria with the approximate location of the earliest Shādhilī convent 77

$9 \quad$ Remains of the northeastern corner tower of Alexandria's walls 81

10 Diagram of the Shādhilī network 92

11 The great Muẓaffarī Mosque (a.k.a. Jāmi` al-Ḥanābila) in al-Ṣāliḥiyya, Damascus 163

12 Al-Madrasa al-'Umariyya in al-Șāliḥiyya, Damascus 163

13 On the left is the gate of Dār al-Hadīth al-Ashrafiyya al-Barrāniyya with al-Madrasa al-Murshidiyya to its right, in al-Ṣāliḥiyya, Damascus 164

14 Minaret of the Karīmī Mosque in the Qubaybāt quarter of Damascus 164

15 The gate of Dār al-Hadìth al-Ashrafiyya in the old city of Damascus 165

16 The remains of the carved mihrāb of Dār al-Hadìth al-Nūriyya in the old city of Damascus 165

17 The gate of al-Madrasa al-Mismāriyya in the old city of Damascus 166

18 The minaret of al-Madrasa al-Mismāriyya in the old city of Damascus 166

19 Map of Mamluk Damascus with the mosques and madrasas ran and/or attended by traditionalists $\quad 167$

20 A schematic representation of al-Wāsițīs traditionalist Sufi cosmology 213 


\section{Transcription Table}

\section{Consonants}

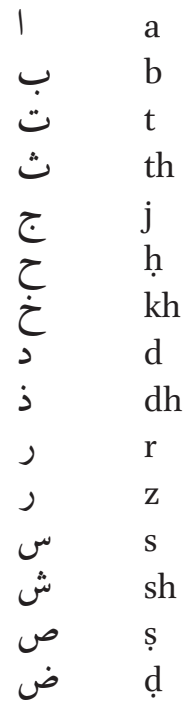

Short Vowels

fatha a kasra i

damma $\mathrm{u}$

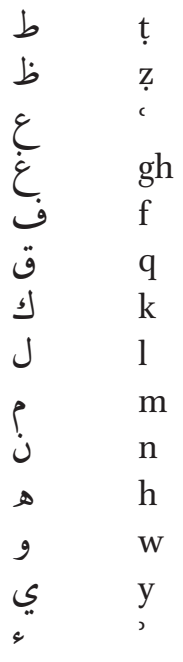

Long Vowels

$\begin{array}{cc}\downarrow & \bar{a} \\ - & \overline{\mathbf{l}} \\ \mathrm{g} & \overline{\mathrm{u}}\end{array}$




\section{Abbreviations}

\section{Literature}

Ann. Isl. Annales Islamologiques

BSOAS Bulletin of the School of Oriental and African Studies

EI $^{2} \quad$ The Encyclopaedia of Islam, 2nd edition, 11 vols. Edited by H.A.R. Gibbs, B. Lewis, Ch. Pellat, C. Bosworth et. al. Leiden: Brill, 1960-2002

EI 3 The Encyclopaedia of Islam, 3rd edition. Edited by Kate Fleet, Gudrun Krämer, Denis Matringe, John Nawas, Everett Rowson. Leiden: Brill, 2007-present

EIr Encyclopaedia Iranica. (E-journal). Edited by Ehsan Yarshater. London and Costa Mesa, Calif., 1982-

CHIR V Cambridge History of Iran. Volume V. The Saljuk and Mongol Periods. Edited by J.A. Boyle. Cambridge: Cambridge University Press, 1968

IGOAS Institute for Graeco-Oriental and African Studies

IJMES International Journal of Middle East Studies

JESHO Journal of the Economic and Social History of the Orient

JHS Journal of the History of Sufism

JMIAS Journal of the Muhyiddin Ibn Arabi Society

JNES Journal of Near Eastern Studies

JSAI Jerusalem Studies in Arabic and Islam

Jss Journal of Sufi Studies

MSR Muslim Studies Review

REI Revue des Études Islamiques

TRHS Transactions of the Royal Historical Society

NCHI The New Cambridge History of Islam. Edited by David O. Morgan, Anthony Reid. Cambridge: Cambridge University Press, 2010

\section{Abbreviations of Arabic Invocations}

Șallā Allāh 'alayhi wa-sallam (may God bless him and grant him peace) $=(S ̣)$

Radì Allah 'anhu (may God be pleased with him) $=(\mathrm{R})$

'Alayhi al-salām (may peace be upon him) $=$ ('A)

Ta'āla $($ exalted is $\mathrm{He})=(\mathrm{T})$

Subhāanahu (glorified is $\mathrm{He})=(\mathrm{S})$

Subhānahu wa-ta'a $\bar{l} \bar{a}$ (glorified and exalted is $\mathrm{He}$ ) $=(\mathrm{ST})$

'Azza wa-jalla (mighty and majestic is $\mathrm{He})=\left({ }^{\mathrm{A}} \mathrm{AJ}\right)$ 


\section{Introduction}

In the summer of 2014 I visited the Universitätsbibliothek Basel to view the Nachlass of Fritz Meier, a collection of personal unpublished papers and notes the late Swiss scholar of Sufism bequeathed to the university. At that time, I still aspired to devote my $\mathrm{PhD}$ project to the much-debated Hanbali shaykh al-Islām Taqī al-Dīn Aḥmad Ibn Taymiyya (d. 728/1328) and his supposedly fraught relationship with tașawwuf, commonly known in the West as Sufism. I was aware that Meier's Nachlass contains some material that deals with this very topic and was hence curious to see what I would find. As I went through the many pages of the Nachlass, I came across a note concerning 'Imād al-Dīn Abū al-'Abbās Aḥmad al-Wāsițī, who was known to me as a companion of Ibn Taymiyya. I had found out long before that al-Wāsițī was in fact recognized by his contemporaries as a șūfı, a notion that intrigued me given his membership of Ibn Taymiyya's circle. In that regard, Meier made an observation that caught my attention. Referring to al-Wāsițī as 'al-Hizāmī', he wrote:

This is a case of connection between Sufism and orthodox Hanbalism, at the same time a convergence of the Šādiliyya and Ibn Taymiyya. In the person of Ibn Taymiyya and in the person of Ibn 'Ațā' Allāh al-Sikandarī the two positions clash with each other. They merge in Hizāmī. Šādilism is a return to classical Sufism, or at least a recollection thereof, [it is a form of] classicism. Ibn Taymiyya represents a reform of Sunna, an attempt to brush off the contaminated traditionalism and reconnect with the ancient foundations of orthodoxy. Both of these seem to have converged here in Hizāmī. Hizāmī sought to link the acceptable and good of Šādilī mysticism with the oldest form of Islam. Hizāmī recognized Ibn Taymiyya as a great reformer and leader, and was on his part recognized by Ibn Taymiyya as a great Sufi. It is appealing that Hizāmī did not abandon Sufism, but simply put it on a Hanbalī basis. ${ }^{1}$

By coincidence, just a few months earlier in March, I discovered that a large number of al-Wāsițìs works had quite recently been edited and published. Since Meier did not disclose the source on which he based the above-quoted observation, I was curious as to whether I could find proof for it in al-Wāsițìs own books. Meier thus gave me the final nudge I needed to start reading the

1 Fritz Meier, "Profet als lebensvorbild: šādilī und hạbalī in personalunion," Nachlass Fritz Meier, Universitätsbibliothek Basel, NL o323 D 1.7, translation my own. 
material that was to become the main source for the research I would conduct for the next three years - though at that point I still simply wanted to see whether al-Wāsiți would be of any use to our understanding of Ibn Taymiyya's relationship with Sufism. As I skimmed through several of the titles at my disposal, I was fascinated by the richness of al-Wāsitị's thought on Sufism and realized that we have here a scholar who deserves to be studied in his own right. And this is exactly what the present book sets out to do. But before I turn to discuss the relevance of studying al-Wāsiți and the approach of this volume, some preliminary remarks must be made concerning Sufism, traditionalism, and Ibn Taymiyya, for it is within the scholarly discussions on these topics that we must attempt to situate al-Wāsițī.

\section{A Contextual Approach to Studying Sufism(s)}

What is tașawwuf? In truth, it is hard to come up with an umbrella definition that includes its many differing, and sometimes seemingly contradictory, manifestations. Tașawwuf is far from monolithic. While for long the tendency has been to view it as Islam's 'mysticism' and the șuffyya as its 'mystics,' this basically leaves us with an equally thorny problem: What is mysticism? Who are mystics? The common use among scholars of the latter terms seems to be inherited from our Orientalist predecessors, who had the anachronistic tendency to understand Islam through the lens of Christianity. Apart from the Western-centrism implicitly present when using the terms mysticism and mystic, there is also the problem that they are difficult to define in a way that includes all groups and individuals historically associated with the terms tașawwuf and șuffi. Sara Sviri has looked at the formative period of tașawwuf and observed that, according to her definition of mysticism and mystic, some figures she identifies as mystics were not called șūfis, and some figures who were called șüfis cannot be identified as mystics. ${ }^{2}$ For such reasons, there have been several scholars who have rightly problematized the use of mysticism and mystic. ${ }^{3}$ A recent critique comes from Nathan Hofer, who has opted to simply use the modern terms 'Sufism' and 'Suf' instead, because they 'bear

2 Sarah Sviri, "Sufism: Reconsidering Terms, Definitions and Processes in the Formative Period of Islamic Mysticism," in Les maîtres soufis et leurs disciples des IIIe-Ve siècles de l'hégire (IXe$X I$ ) : enseignement, formation et transmission, ed. Geneviève Gobillot \& Jean-Jacques Thibon (Beirut: Institut français du Proche-Orient, 2012), p. 32.

3 See for instance: Omid Safi, "Bargaining with Baraka: Persian Sufism, "Mysticism," and PreModern Politics," The Muslim World 90:3-4 (200o): pp. 26o-263; Nile Green, Sufism: A Global History (Malden:Wiley-Blackwell, 2012), pp. 1-4. p.125; Lloyd Ridgeon, "Mysticism in Medieval 
some resemblance to local medieval usage," that is, to 'tașawwuf' and 'șūfi' respectively. ${ }^{4}$ In the present study we will likewise avoid mysticism and mystic and instead use Sufism and Sufi. And rather than attempting to provide a definition for them, my aim will be to let the objects of our inquiry explain to us in their own terms how they gave substance to 'Sufism' and 'being Suf' in the period that stretches from roughly the middle of the seventh/thirteenth century up to the early eighth/fourteenth century.

In this epoch Sufism in its many manifestations had become an integral part of the Sunni world, that is, the regions dominated by Muslims who identified themselves as belonging to the Ahl al-Sunna wa-al-Jamäa $a$. Antinomian and controversial Sufi currents certainly existed, but it was not uncommon that these would be criticized and censured by the very scholars who were themselves Sufis. It is a historical reality that taşawwuf was widely acknowledged as one of the legitimate religious sciences ('ulüm' in Arabic), on par with other fields of knowledge such as specialist theology (kalām or uṣül al-dīn) and jurisprudence (figh). ${ }^{5}$ The class of jurists was in most cases not a category separated from the specialized theologians or the Sufis. One could be jurist, theologian, and Sufi at the same time - and indeed, in the realm of the Mamluks and the Ilkhanids, this increasingly became the rule rather than the exception. ${ }^{6}$ The milieu of the professional scholars, the 'ulam $\bar{a}$, thus comprised different layers of identity between which there was cross-pollination and mobility. And with the rise of the phenomenon of the Sufi order - still called 'tā'ifa' (pl. țawāi if) rather than 'tariqa' (pl. țuruq), the common designation in later centuries

Sufism," in Cambridge Companion to Sufism, ed. Lloyd Ridgeon (Cambridge: Cambridge University Press, 2014), p. 125.

4 However, Nathan Hofer also notes that the term Sufism is not altogether unproblematic either because, strictly speaking, tașawwuf cannot be called an '-ism,' see: The Popularisation of Sufism in Ayyubid and Mamluk Egypt, 1173-1325 (Edinburgh: Edinburgh University Press, 2015), p. 4. On the issue of terminology, see also: Pieter Coppens, Seeing God in Sufi Qur'an Commentaries: Crossings between This World and the Otherworld (Edinburgh: Edinburgh University Press, 2018), pp. 6-10.

5 On the notion that Sufism as "ilm al-tașawwuf' was considered one of the religious sciences, see for instance: Richard McGregor, "The Problem of Sufism," MSR XIII (2009): pp. 75-76, where he refers to Ibn Khaldūn's Muqaddima.

6 Éric Geoffroy, Le soufisme en Égypte et en Syrie sous les derniers Mamelouks et les premiers Ottomans: orientations spirituelles et enjeux culturels (Damascus: Institut français d'études arabes de Damas, 1995), pp. 65-9o; Michael Chamberlain, Knowledge and Social Practice in Medieval Damascus, 119o-1350 (Cambridge: Cambridge University Press, 1994), p. 128; Hofer, The Popularisation of Sufism, pp. 7-11. 
- affiliation with a Sufi genealogy (silsila) traced back to a renowned shaykh became widespread in all layers of medieval Muslim society. ${ }^{7}$

It has been argued that, at least from the ninth to tenth century onwards, the classical Sufis may be considered perfectly "orthodox" (Sunni) Muslims. ${ }^{8}$ While I agree with what is intended by this claim, there is again a problem of terminology here that we must address - one that will in part help us better understand the diversity within Sufism. Unlike Christianity, Islam never knew a fixed orthodoxy that enforced a specific doctrine to regulate what is correct belief and what is incorrect (and hence heterodox). What was considered normative and mainstream in terms of dogma differed over time and space. Like the term mysticism, the value of 'orthodoxy' for our field of study has therefore been questioned. ${ }^{9}$ Josef van Ess has noted this problem and suggested that the term may only be useful when understood as the "dominant opinion" and "mainstream position" as it existed within a particular spatial-temporal context. In that sense it could be said - as van Ess does - that Islam knows not one orthodoxy, but multiple local orthodoxies. ${ }^{10}$ This is a very valid point that I believe also bears relevance for the way one could approach the different manifestations of Sufism. For if the Sufi is indeed "orthodox" and there existed multiple "orthodoxies," then it will be useful to question which trend of Sufism was associated with which "orthodoxy."

Now, while this study will henceforth avoid the latter term due to its historical incompatibility with Islam, it is to some degree possible to identify a more

$7 \quad T a \bar{a} i f a$ is a generic term that literally means 'group,' and could refer to all kinds of organized groups in society. For Sufis in the period under consideration, țāifa referred to the order organized around the leadership of a shaykh. The word tariqa still signified the Sufi method taught by that shaykh, cf. Geoffroy, Le Soufisme, pp. 269-270, and p. 90 for the initiation of 'ulamā' into Sufi genealogies.

$8 \quad$ Bernd Radtke, "Warum ist der Sufi Orthodox?" Der Islam, 71 (1994): pp. 302-307.

9 Among the several important contributions are: Bernard Lewis, "Some Observations on the Significance of Heresy in the History of Islam," Studia Islamica 1 (1953): pp. 42-63; Alexander D. Knysh "Orthodoxy' and 'Heresy' in Medieval Islam: An Essay in Reassessment," The Muslim World 83:1 (1993): pp. 48-67; and for a more recent criticism in the same vein as that of Knysh: Brett Wilson, "The Failure of Nomenclature: The Concept of 'Orthodoxy' in the Study of Islam," Comparative Islamic Studies 3:2 (2007): pp. 169-194. An overview of the criticism leveled at the term orthodoxy has been provided by Christian R. Lange, "Power, Orthodoxy and Salvation in Classical Islamic Theology," in Islamic Studies in the Twenty-First Century, ed. Léon Buskens \& Annemarie van Sandwijk (Amsterdam: Amsterdam University Press, 2016), pp. 135-152. For a discussion of orthodoxy in light of the study of Sufism, see: McGregor, "The Problem of Sufism," pp. 71-74 \& 78-83. 
widely understood category of normative religiosity. ${ }^{11}$ However, I would argue that this category should not only be understood in terms of dogmas of a certain school of thought claiming monopoly over Sunni theology. What was considered normative in a certain locality at a certain time was also shaped by embodied forms of religion, and by broader ideas about the sociopolitical, economic, and cultural expressions of Islam. And even in a specific locality, it may be possible to recognize different categories of people with very differing notions of normativity. So clearly, if we attempt to distinguish normativity in Islam, this must always be done against a specific context with an open mind to the different forces that may have helped shape it.

Like all manifestations of religiosity, Sufism was never disconnected from the context in which it existed. For instance, it has been observed that Sufism in the Turco-Persian cultural context was markedly different from that of the Arab cultural context. ${ }^{12}$ What was considered normative when it came to Sufism evidently had to do with the cultural dimension in which it was practiced. Furthermore, around the period that concerns us, historical circumstances such as wars and economic growth or decline led to streams of migrants resettling in other parts of the Muslim world, where they subsequently reshaped the local religious landscape. What was considered normative when it came to Sufism was, of course, affected by historical context as well. By taking such factors into consideration, we may investigate the relationship between various trends of Sufism and the contexts in which they were practiced. We may thereby attempt to understand better why, for instance, a certain manifestation of the Sufi path was accepted as perfectly normative by one group of people and not by another.

11 I am aware that the late Shahab Ahmed regards it as "misplaced" to replace the category of orthodoxy with normativity as suggested by Sherali Tareen, "Normativity, Heresy, and the Politics of Authenticity in South Asian Islam," The Muslim World 99:3 (20o9): p. 526. However, I do not strictly speaking intend to use normativity here as the needed alternative for orthodoxy, nor do I follow Tareen's definition of the term. I actually think Ahmed is right to say that the normative is different from the orthodox in that it "is produced by a much more diffuse set of social actors and discursive practices than those of the 'ulamä'/"religious experts" alone, and does not seek or enjoy the same authority of sanction," see: Shahab Ahmed, What is Islam? The Importance of Being Islamic (New Jersey: Princeton University Press, 2017), p. 285n 85. This agrees with the point I am trying to make above, namely that Muslim scholars were not the sole force responsible for what was regarded as normative religiosity in a particular community of a particular context, but that this involved other dimensions that should be taken into account as well. Period, 1200-1550 (Salt Lake City: University of Utah Press, 1994), p. 99; Éric Geoffroy, Introduction to Sufism (World Wisdom, 2010), pp. 190-191, and by the same author, Le Soufisme, pp. $250-258$. 
To be clear, I am not attempting to make any essentialist claims when describing what is normative to a particular group of people in a particular context. For as intended by van Ess when he speaks of Islamic orthodoxies, what we identify as mainstream is not static but rather evolves, and is renegotiated and adapted according to circumstances. ${ }^{13}$ It cannot therefore be defined along strict lines. To exemplify how a contextualized approach to normativity could nevertheless be useful and at the same time take into consideration the fluidity of this category, let us look at a case that will be central to this book: the place of Sufism in the traditionalist community of early Mamluk Damascus and, more specifically, in the circle of Ibn Taymiyya.

\section{Situating Ibn Taymiyya's Circle in Its Context}

Ibn Taymiyya's circle consisted mostly of Hanbalīs and Shāfi'îs who belonged to the Ahl al-Hadith, the 'partisans of tradition,' or 'traditionalists.' This intellectual current, which has historically been represented most vividly by the Hanbali school, strove to base religious knowledge (almost) exclusively on the Qur'an, the Sunna, and the presumed consensus of the Muslim community. Although there certainly are exceptions, the traditionalists have generally displayed a suspicious, at times even highly critical, attitude towards the interference of reason with these sources, especially in their formulation of theology (which they term 'ușūl al-dīn'). This approach put them at odds with the rationalist Ahl al-Kaläm (or mutakallimūn), the scholars of speculative theology. The latter group allowed much more space for reason in determining how to interpret the divine sources to extract therefrom the articles of faith (sing. al'aqìda, pl. al-'aqā'id). The Ash'arī school - named after its eponymous founder, Abū al-Hasan al-Ash'arī (d. 324/936) - gradually became the dominant trend of kaläm in the Sunni world and was adopted in particular by jurists of the Shāfíi and Mālikī schools of law. Because both the traditionalists and the Ash'arīs put themselves forward as the true representatives of normative Sunni theology, they frequently clashed with each other. ${ }^{14}$

13 Lange, "Power, Orthodoxy and Salvation," p. 152, quoting Van Ess, Der Eine und das Andere, p. 1299 .

14 Note that in this definition the 'traditionalist' is set apart from the 'traditionist' in that the latter signifies someone who is a scholar of hadith, which does not necessarily means that he or she abides by the above stated traditionalist principles regarding the Islamic sources. Here I follow George Makdisi's definition as presented in: "Ash'arī and the Ash'arites in Islamic Religious History," Studia Islamica, no. 17 (1962): p. 49. On the traditionalists, see also: Marshall G. S. Hodgson (who prefers to call them 'the Hadith 
If we look at the spatial-temporal context of early Mamluk Damascus, we could say that the city itself contained at least two theological groups: a community of Ḥanbalī/Shāfiē traditionalists and a community of Ḥanafì/Mālikī/ Shāfi'i mutakallimūn (mostly Ash'arīs). If we home in on the city's traditionalist fraction, we find that the religiosity that existed among them was influenced by several other factors, such as the presence of Hanbali families that had emigrated from Iraq and Palestine due to the Mongol invasion and the Crusades respectively. The Ahl al-Hadith here was thus not a monolithic group per se, including both Ḥanbalīs and Shāfi'ìs of different cultural backgrounds, at times differing in the way they positioned themselves vis-à-vis their theological outlook. ${ }^{15}$ A good example of this is Ibn Taymiyya himself, who sought to defend the traditionalist creed through a very rational argumentation, an approach not all his traditionalist colleagues appreciated - among whom the shaykh's own pupil, Shams al-Dīn al-Dhahabī (d. 748/1348). ${ }^{16}$ Furthermore, it would be a gross simplification to assert that traditionalists and Ash'arīs were two perpetually segregated groups, since they had to coexist in the same professional stratum. Interaction would occur, for instance, through their shared interest in collecting and studying tradition among the city's hadìth-scholars. Traditionalist Shāfi'is would especially have had to maneuver between their Hanbalī colleagues and their fellow Ash'arī Shāfî̄s. Thus, although I have chosen to view the traditionalists of early Mamluk Damascus as a specific community with its own notions of normativity, its boundaries were clearly not always sharply delineated.

In spite of this observation, for the sake of analysis there is still value in identifying the traditionalists as a distinct group in the context we just described, and to delineate certain elements of normativity that were particular

folk'), The Venture of Islam, Volume 1: The Classical Age of Islam (University of Chicago Press, 1974), pp. 386-392. For the distinction between (Hanbalī) traditionalism and rationalist kalām, see also: Binyamin Abrahamov, Islamic Theology: Traditionalism and Rationalism (Edinburgh: Edinburgh University Press, 1998), p. ix; Geoffroy, Le Soufisme, p. 82; Christopher Melchert, "The Piety of the Hadith Folk," IJMEs, vol. 34, no. 3 (2002): pp. 431 \& 434. For a brief historical overview of Hanbalī theology, see:Jon Hoover, "Hanbalī Theology," in The Oxford Handbook of Islamic Theology, ed. Sabine Schmitdke (Oxford: Oxford University Press, 2016), pp. 625-633.

15 George Makdisi, "Hanbalite Islam," in Studies on Islam, trans. \& ed. Merlin L. Swartz (New York: Oxford University Press, 1981), pp. 263-264.

16 For Ibn Taymiyya's rational approach to traditionalist theology, see the recent excellent study of Sophia Vasalou, Ibn Taymiyya's Theological Ethics (New York: Oxford University Press, 2015), pp. 238-241. For al-Dhahabī's "uber-traditionalist" stance, see: Caterina Bori, "al-Dhahabī", in $E I^{3}, 2016$, p. 75. For a good overview of Ibn Taymiyya's theology, and its divergence from the classical traditionalist position, see: Hoover, "Hanbalī Theology," pp. $637-638$. 
to them. Ultimately, the difficulties of defining boundaries here have to do with the dynamic character of (group) identity. I understand identity as per Gerd Baumann and Andre Gingrich as that which "designates social subjectivities as persons and groups of persons." These subjectivities are "multidimensional and fluid; they include power-related ascriptions by selves as well as by others; and they simultaneously combine sameness, or belonging, with alterity, or otherness." ${ }^{17}$ Very simply put, identity is construed through 'selfing' and 'othering.' As we have just seen with regard to the traditionalists, there is a fluidity to this process of identity-making that works differently on different levels. Baumann has explained this through what he calls 'the grammar of segmentation,' which he based on the anthropological theory of Evans-Pritchard. If we apply this model to the above-discussed case, then we could say that on a lower level of segmentation the traditionalists may reject the Ash'arīs as the 'other' due to conflicting notions of normativity; for instance, when it comes to the way they understand God's divine attributes. On the other hand, on a higher level of segmentation they may share notions of normativity; for instance, when attending an audition of hadith under a renowned shaykh, or in opposition to a common theological foe. ${ }^{18}$ Baumann has therefore argued that "[f]usion and fission, identity and difference are not matters of absolute criteria in this grammar, but functions of recognizing the appropriate segmentary level."19 The traditionalists of early Mamluk Damascus can thus be studied as a delineated group with its own notions of normativity particular to their identity, as long as we are conscious of the segmentary level on which we operate.

It is within this group in this context that I want to situate Ibn Taymiyya and his circle of companions and followers in order to better understand the place of Sufism among them. For if we look at the kind of Sufism that al-Wāsiți taught amidst the Damascene traditionalist community, we will find that the very process of selfing and othering resulted in a Sufi doctrine that was particular to this context - a 'traditionalist Sufism' that in certain respects distinguished itself from other trends of Sufism that simultaneously existed elsewhere and among other groups. Having said that, it should be noted that a specific traditionalist affinity with Sufism has been recognized before. It is therefore necessary to have a closer look at the previous scholarship on the relationship between Sufism and traditionalism, especially with respect to Ibn Taymiyya and his circle.

17 Gerd Baumann and Andre Gingrich, Grammars of Identity/Alterity: A Structural Approach (New York: Berghahn Books, 20o6), p. x.

18 Ibid. pp. 21-24.

19 Ibid. p. 23. 
In the introductory paragraph I quoted Meier stating that al-Wāsiṭi had put Sufism "on a Hanbali basis." Whether intended or not, this remark hints at the prevalent notion that the Hanbalīs had something of a troubled relationship with tașawwuf..$^{20}$ It is as if prior to al-Wāsițī Sufism had never been adapted to Hanbalism. Now, in the context of the early third/ninth century, Christopher Melchert has indeed made notice of an overall "traditionalist suspicion of Sufism" and concluded that the piety of the traditionalists was "at odds" with that of the Sufis. ${ }^{21}$ Elsewhere, Melchert argued in the same vein that Ahmad Ibn Hanbal (d. 241/855) himself was clearly "hostile to crucially important precursors of the Classical Sufis" and would likely have had little sympathy for Sufism as it developed after him. ${ }^{22}$ However, Melchert also noted that, about a century later, the Hanbali and Sufi traditions did "surprisingly" seem to meet in the person of al-Barbahārī (d. 329/941). ${ }^{23}$ This is perhaps not as surprising as one may think.

Even if there was some concrete opposition to proto-Sufism among early traditionalists, this attitude did not survive for long. Scholars such as George Makdisi, Ahmet Karamustafa, and Laury Silvers have observed that the early Sufis from around the fourth/tenth century were generally aligned with the traditionalist movement through their shared interest in hadith. ${ }^{24}$ That medieval sources nevertheless present us with examples of Hanbalī scholars from subsequent generations who displayed animosity towards certain Sufis or Sufi practices was not a shift away from this alignment, but rather had to do with the shift Sufism made away from traditionalism; or to put it differently, the shift Sufism made away from the traditionalist understanding of

20 Note of this attitude has been made, for instance by: George Makdisi, "The Hanbali School and Sufism," Humaniora Islamica, 2 (1974): p. 72; Geoffroy, Le Soufisme, p. 62; Josef van Ess, "Sufism and its Opponents," in Islamic Mysticism Contested: Thirteen Centuries of Controversies and Polemics, ed. F. de Jong \& Bernd Radtke (Leiden: Brill, 1999), p. 29. Christopher Melchert, "The Piety of the Hadith Folk," pp. 431-432, and on p. 429 he uses "Max Weber's terms of ideal types" to argue that traditionalist piety may be described as "an ascetic (moralistic) orientation" as opposed to the 'mystical' orientation of the sufis. Christopher Melchert, "The Hanābila and the Early Sufis," Arabica, T. 48, Fasc. 3 (2001): p. 359, and pp. $355^{-360}$ for a general overview of Ibn Hanbal's opinion of proto-Sufis. This attitude was also observed by Van Ess, "Sufism and its Opponents," pp. 28-29.

23 Ibid. p. 367.

24 See for instance: Ahmet Karamustafa, Sufism:The Formative Period (Berkeley/Los Angeles: University of California Press, 2007), pp. 22-23; Laury Silvers-Alario, "The Teaching Relationship in Early Sufism: A Reassessment of Fritz Meier's Definition of the shaykh al-tarbiya and the shaykh al-ta'lim," The Muslim World 93, 1 (2003): p. 91; Makdisi, "The Hanbali School and Sufism," p. 72; Geoffroy, Le Soufisme, pp. 98-100. 
what normative Sunni Islam embodies. It has been shown, for instance, that Ibn 'Aqī (d. 513/119) and Ibn al-Jawzì (d. 597/1201), though generally known as critics of the Sufis, had in all likelihood both been positively involved with Sufism as well. ${ }^{25}$ Addressing the objectives of the traditionalists in that regard, Makdisi has gone as far as to allege that " $t$ ] he Hanbali School preserves Sufism in the spirit of the early Sufis who ... belonged to the Ahl al-Hadith." ${ }^{26}$ While this is admittedly a rather bold statement, he was not alone in noticing a trend he referred to as 'traditionalist Sufism' that could occasionally be hostile towards ecstatic and rationalist kaläm-aligned trends of Sufism. ${ }^{27}$

Unfortunately, there are but few examples of traditionalist Sufi shaykhs who left behind teachings in writing, which makes it difficult to study how they may have distinguished themselves from other trends of Sufism. Some of the noteworthy authorities who have been studied are Abū al-Abbās Ibn 'Ațā' (d. 309/922), ${ }^{28}$ Abū Manșūr Ma'mar al-Ișfahānī (d. 418/1027), ${ }^{29}$ 'Abd Allāh alAnșāī al-Harawī (d. 481/1089),, ${ }^{30}$ and 'Abd al-Qādir al-Jīlānī (or al-Jìlī) (d. 561/1166). ${ }^{31}$ We must note, however, that these shaykhs all have in common that they never became prolific authors. It is perhaps partly for that reason that

25 For Ibn 'Aqīl, see: George Makdisi, Ibn 'Aqil: Religion and Culture in Classical Islam (Edinburgh: Edinburgh University Press, 1997), pp. 216-217; for Ibn al-Jawzī, see: Merlin L. Swartz. Ibn al-Jawzìs Kitāb al-Qușșāṣ wa'l-Mudhakkirīn (Beirut: Dar el-Machreq Éditeurs, 1986), pp. 23-25.

26 Makdisi, "The Hanbali School and Sufism," p. 72.

27 Karamustafa, Sufism, pp. 87-96; Van Ess, "Sufism and its Opponents," pp. 29-30; Makdisi, "The Hanbali School and Sufism," p. 72, and by the same author, Ibn 'Aqil, p. 216.

28 Studied by Richard Gramlich in: Abu l-Abbās b. 'Ață': Sufi und Koranausleger (Stuttgart: Deutsche Morgenländische Gesellschaft Kommissionverlag, F. Steiner, 1995).

29 Studied by Serge de Laugier de Beaurecueil in: "La voie du privilegie: petit traité d'Abu Mansur Ma'mar al-Isfahani," in Mélanges Taha Husain: offerts par ses amis et ses disciples á l'occasion de son 7oième anniversaire, ed. 'Abd al-Rahmmān Badawī (Cairo: Dar Al-Maaref, 1962), pp. 65-76.

30 Studied by Serge de Laugier de Beaurecueil in: Khwādja Abdullāh Anșārī (396-481H./10o61089): mystique Hanbalite (Beirut: Librairie Orientale, 1965); also: A. G. Ravan Farhadi, Abdullah Ansari of Herat (1006-1089 C.E.): An Early Sufi Master (Richmond, Curzon Press, 1996).

31 Except for a Tafsìr, all Arabic works attributed to al-Jilānī have been translated into English by the late Muhtar Holland and published by al-Baz Publishing. Of all the abovementioned traditionalist Sufis, al-Jīlānī has been studied most extensively. There are a few studies in different languages, such as: Walther Braune, Die Futūh al-Gaib des 'Abd alQãdir (Berlin: De Gruyter, 1933), André Demeerseman, Nouveau regard sur la voie spirituelle d'Abd al-Qâdir al-Jilânî et sa tradition (Paris: Vrin, 1988), and the dissertation by Pascal Held, The Hanbali School and Mysticism in Sixth/Twelfth Century Baghdad (University of Chicago, 2016); and more recently Hamza Malik's book The Grey Falcon: The Life and Teaching of Shaykh Abd Al-Qādir Al-J̄lānī (Leiden: Brill, 2019). 
the influence that traditionalists in particular have historically had on the development of Sufism has received little notice.

A widely known exception is Ibn Taymiyya, though this is for the most part due to the considerable list of writings he composed wherein he criticizes the Sufis. Both in and outside of academia he is therefore still frequently perceived as the archenemy of Sufism. And because he is often negatively portrayed as the intellectual forefather of today's extremist Salafis, who are well-known for their opposition to Sufism, his anti-Sufi image seems more prevalent than ev$\mathrm{er}^{32}$ This reputation has since long been contested, however, starting with Henri Laoust, who already noticed in 1939 that Ibn Taymiyya had a "frank intellectual affinity with the ethico-mystical tendencies of a moderate tasawwuf." 33 He argued that, rather than attacking Sufism as a whole, the Hanbalī shaykh aimed his pen at specific deviant trends he recognized, such as monistic Sufism. ${ }^{34}$ Since Laoust, an increasing number of scholars have described Ibn Taymiyya's position vis-à-vis Sufism in similar terms, such as Joseph Bell, ${ }^{35}$ Fritz Meier, ${ }^{36}$ Thomas Michel, ${ }^{37}$ Emil Homerin, ${ }^{38}$ and Alexander Knysh to name a few. ${ }^{39}$ Broadly speaking, the general consensus seems to be that the

32 Yahya Michot gives a good overview of several biased representations of Ibn Taymiyya, see: Muslims under non-Muslim rule (Oxford: Interface Publications, 2006), pp. 123-128. For the Salafis' opposition to Sufism and their appropriation of Ibn Taymiyya, see for instance: Joas Wagemakers, "Why Salafis Have Anti-Sufi Attitudes," OASIS, June 21, 2017, accessed June 29, 2017, <http://www.oasiscenter.eu/articles/jihadism-and-violence/2017/ o6/21/why-salafis-have-anti-sufi-attitudes?utm_campaign=Who+are+the+Sufis $\%{ }_{3} \mathrm{f}_{+-+}$ Newsletter+n.+-+2017\&utm_medium $=$ email\&utm_source=CamoNewsletter $>$.

33 Henri Laoust, Essai sur les doctrines sociales et politiques de Taki-d-Din Ahmad b. Taimiya, canoniste hanbalite né à Harràn en 661/1262, mort à Damas en 728/1328 (Cairo: Impr. de l'Institut français d'archéologie orientale, 1939), p. 89.

34 Ibid. pp. 89-93.

35 Joseph N. Bell, Love Theory in Later Hanbalite Islam (Albany: State University of New York Press, 1979), p. 94.

36 Fritz Meier, "The Cleanest about Predestination: A Bit of Ibn Taymiyya," in Essays on Islamic Piety and Mysticism, trans. John O'Kane (Leiden: Brill, 1999), p. 313 (originally published as: "Das sauberste über die vorbestimmung: Ein stück Ibn Taymiyya," Saeculum 32 (1981): pp. 74-89).

37 Thomas Michel, "Ibn Taymiyya's Sharh on the Futūḥ al-Ghayb of 'Abd al-Qādir al-Jīlān̄̄," Hamdard Islamicus, vol. 4, no. 2 (1981): p. 9.

38 Th. Emil Homerin, "Ibn Taymiyya's Al-Süfìyah wa-al-Fuqarā’," Arabica 32 (1985): p. 244.

39 Alexander D. Knysh, Ibn 'Arabi in the Later Islamic Tradition: The Making of a Polemical Image in Medieval Islam (Albany: State University of New York Press, 1999), pp. 87-88. More recent contributions have also drawn on the work of their predecessors, such as: Qais Assef, "Le soufisme et les soufis selon Ibn Taymiyya," Bulletin d'Etudes Orientales LX (2012): pp. 102-104, and: Diego R. Sarrio, "Spiritual anti-elitism: Ibn Taymiyya's doctrine of sainthood (walāya)," Islam and Christian-Muslim Relations, 22:3 (2011): p 287. 
shaykh's polemical effort in the field of Sufism was aimed at purifying it of those elements he considered alien to Islam, so as to keep it strictly in accordance with the Qur'an and the Sunna as he understood it from the framework of traditionalism. Because he accepted the vast majority of the early Sufis as traditionalists, he argued that his vision of pure Sufism was actually in perfect accordance with the kind they had practiced and preached. This is, of course, very much in line with what Makdisi saw as the general attitude towards Sufism among the Hanbalīs as noted above.

But does this mean that Ibn Taymiyya himself also consciously practiced Sufism? Did he teach or preach Sufism? Was he a Sufi? These questions have not yet received definitive answers. In that respect an important contribution that must not be left unmentioned is George Makdisi's article from 1974, which set out to prove that Ibn Taymiyya was not only sympathetic towards classical Sufism, but was in fact himself a Sufi of the Qādiriyya, the order traced back to the aforementioned Hanbalī Sufi 'Abd al-Qādir al-Jīlānī. ${ }^{40}$ Some scholars such as Éric Geoffroy, ${ }^{41}$ Yahya Michot, ${ }^{42}$ and Josef van Ess ${ }^{43}$ have accepted Makdisi's evidence for this theory, whereas others such as Meier ${ }^{44}$ and Michel ${ }^{45}$ found it unconvincing and remained skeptical. We can thus conclude that while the prejudice that Ibn Taymiyya had a strict anti-Sufi agenda has been debunked for good, his exact personal relationship with Sufism remains somewhat shrouded in mystery.

More recently scholars have also taken an interest in the circle of people around Ibn Taymiyya, most notably his pupil Ibn Qayyim al-Jawziyya (d. 751/1350). ${ }^{46}$ Among the academic research done on the latter figure we again find special attention for Sufism. In their respective articles on the life and works of Ibn al-Qayyim, Birgit Krawietz and Livnat Holtzman have both

40 George Makdisi, "Ibn Taymīya: A Șūfĩ of the Qādiriyya Order," American Journal of Arabic Studies, vol. 1 (1974): pp. 123-124.

41 Geoffroy, Le Soufisme, p. 225.

42 Yahya Michot, "Ibn Taymiyya's Commentary on the Creed of al-Hallāj," in Sufism and Theology, ed. Ayman Shihadeh (Edinburgh: Edinburgh University Press, 2007), p. 123.

43 Van Ess, "Sufism and its opponents," p. 31.

44 Meier, "The Cleanest about Predestination," pp. 317-318n 9,

45 Michel, "Ibn Taymiyya's Sharh," p. 3.

46 I have already made note of this development in my article: "A Glimpse of Sufism from the Circle of Ibn Taymiyya: An Edition and Translation of al-Baclabakkīs (d. 734/1333) Epistle on the Spiritual Way (Risālat al-Sulūk)," JSS 5 (2016): p. 157, where I refer to Caterina Bori's contributions: "Ibn Taymiyya wa-Jamā'atuhu," in Ibn Taymiyyah and his Times, ed. Yossef Rapoport \& Shahab Ahmed (Lahore: Oxford University Press, 2010) pp. 23-52, and: "The collection and edition of Ibn Taymīyah's works: Concerns of a disciple," MSR XIII (2009): pp. $47-67$. 
regarded him as a Sufi, in part due to his numerous writings that appear to fall under the category of Sufism. ${ }^{47}$ However, it could be argued against this that even if his writings seem "Sufic" to us as modern readers, this does not mean that they were intended as such. The question of his affinity with Sufism has been dealt with in more detail by Ovamir Anjum and the late Belgian scholar Gino Schallenbergh in their respective work on the Madārij al-sālikin. Anjum considered the latter book Ibn al-Qayyim's "most developed spiritual discourse ... and arguably an authentic development of Ibn Taymiyyah's ideas as well," and hence an ideal source to "explore the vexed question of their relationship to Sufism." ${ }^{38} \mathrm{He}$ concluded that even though both master and pupil never identified themselves as Sufis, they "endorsed Sufism devoid of mysticism, and wished to recover the earliest tradition of Sufism when mystical knowledge had not challenged the primacy of scriptural knowledge."49 Schallenbergh arrived at a somewhat similar conclusion in his earlier study of the Sufi terminology used in the Madārij, where he hypothesized that Ibn al-Qayyim and Ibn Taymiyya "professed possibly a Sufism that ... aimed foremost at a spiritualization of the šaría." ${ }^{\prime 50}$ In a later article, however, he adjusted this conclusion, stating instead that Ibn al-Qayyim in all likelihood "saw it as his task to offer an alternative spirituality to Sufism." ${ }^{11}$ Thus, while Ibn al-Qayyim is clearly a vital source for our understanding of Taymiyyan thought on Sufism, the work done

47 Birgit Krawietz provides a brief description of Ibn al-Qayyim's Sufi writings in: "Ibn Qayyim al-Jawzīyah: His Life and Works," MSR X (2006): pp. 47-55. On p. 47 she calls Ibn al-Qayyim a "Sufi-Hanbalite," a term she borrows from: Makdisi, "Hanbalite Islam," p. 247. For Livnat Holtzman's list of Ibn al-Qayyim's Sufi writings, see: "Ibn Qayyim al-Jawziyyah," in Essays in Arabic Literary Biography II: 1350-1850, ed. Devin J. Stewart \& Joseph E. Lowry (Wiesbaden: Harrassowitz Verlag, 2009), pp. 218-219. On p. 218 she argues that Ibn alQayyim is portrayed by his biographers as an "extremely devoted Suf." It must be noted, however, that they never explicitly call him such.

48 Ovamir Anjum, "Sufism Without Mysticism? Ibn Qayyim al-Ğawziyyah's Objectives in Madāriğ al-Sālikīn," Oriente Moderno, XC 1 (2010): p. 159.

49 Ibid. p. 177. Anjum defines mysticism "as a mode of cognition which does not merely experience ecstasy or divine illumination (kašf or mukāšafah) of scriptural knowledge, but also turns that experience into discursive knowledge independent of scriptural knowledge. Mysticism does not necessarily oppose the Scripture but the crucial point is that it may, for mysticism claims a separate, often superior, epistemological authority" (p. 158).

50 Gino Schallenbergh, "Intoxication and Ecstasy: Sufi Terminology in the Work of Ibn Qayyim al-Ğawzìya," in Proceedings of the 6th, 7 th and 8th colloquium on the history of Egypt and Syria in the Fatimid, Ayyubid and Mamluk Eras, ed. Jo van Steenbergen \& Urbain Vermeulen (Leuven: Uitgeverij Peeters, 2005), p. 474.

$5^{1} \quad$ Gino Schallenbergh, "Ibn Qayyim al-Jawziyya's Manipulation of Sufi Terms: Fear and Hope," in Islamic Theology, Philosophy and Law: Debating Ibn Taymiyya and Ibn Qayyim Al-Jawziyya, ed. Birgit Krawietz \& Georges Tamer (Berlin: de Gruyter, 2013), p. 120. 
on him has not yet unequivocally answered whether tașawwuf as an Islamic science was really consciously taught, studied, and practiced in the circle of Ibn Taymiyya.

This finally bring us back to al-Wāsiți, the companion of Ibn Taymiyya who had supposedly put Sufism on a Hanbali basis. As such, he is potentially an important source for our knowledge of the kind of Sufism that was practiced among the traditionalists of early Mamluk Damascus, and specifically in the circle of Ibn Taymiyya. Although he has certainly not been overlooked by academics, still very little work has been done on him. Henri Laoust was perhaps the first scholar to notice him in an article that paraphrased his entry from Ibn Rajab's (d. 795/1397) biographical dictionary of Hanbalīs. ${ }^{52}$ After that, he has sporadically been mentioned in several publications that in some way deal with Sufism and/or members of Ibn Taymiyya's circle. ${ }^{53}$ Joseph Bell and Livnat Holtzman have both stated that al-Wāsițī was an important teacher of Ibn alQayyim and may have greatly influenced his early acquaintance with the discipline of Sufism, as well as inspired his later composition of the Madārij. ${ }^{54}$ Al-Wāsiți was also named several times in Alexander Knysh's study on the medieval polemics against Muhyī al-Dīn Ibn 'Arabī as one of the latter's Sufi critics. Knysh remarked in a footnote that al-Wāsițī had written at least three works to refute Ibn 'Arabī, all of which were unfortunately left unstudied as he did not have access to them. ${ }^{55}$ Caterina Bori has written an article on the group dynamics of Ibn Taymiyya's circle wherein she summarized and analyzed a letter al-Wāsiți had written to seven of its members, imploring them to hold fast to their shaykh. ${ }^{56}$ By far the most relevant publication on our list is, to my knowledge, the only one dedicated solely to the Hanbali Sufi. In 1995, Éric Geoffroy published a nineteen-page article that discussed what he believed to be a unique manuscript of a Sufi work by al-Wāsiți preserved in the Zāhiriyya

52 Henri Laoust, "Le Hanbalisme sous les Mamlouks Bahrides (658/784-126o/1382)," in Revue des Études Islamiques 28 (1960): pp. 61-62.

53 Besides the list of publications given above, I also found mention of al-Wāsiți in: Louis Pouzet, Damas au VIIe-XIIIe siècle: vie et structures religieuses d'une métropole islamique (Beirut: Dar el-Machreq, 1988), p. 234; Joel L. Kraemer, "The Andalusian Mystic Ibn Hūd and the Conversion of the Jews," in Israel Oriental Studies XII (1992): pp. 67 \& 69.

54 Bell, Love Theory, pp. 93-94; Holtzman, "Ibn Qayyim al-Jawziyyah," p. 209.

55 Knysh, Ibn 'Arabi in the Later Islamic Tradition, pp. 66, 113, 218, 33on 69, 359n 2.

$5^{6}$ Bori, "Ibn Taymiyya wa-Jamā'atuhu," pp. 26-29. This letter was available to Bori as it was preserved in: Shams al-Dīn Muḥammad Ibn 'Abd al-Hādī, al-Uqūd al-durriyya min manāqib shaykh al-islām Aḥmad b. Taymiyya, ed. Muḥammad Ḥāmid al-Fiqī (Beirut: Dār al-kitāb al-'arabī, 2010), pp. 306-337. The same letter was also used as a source in a footnote of Abdul Hakim I. Al-Matroudi's book The Hanbali School of Law and Ibn Taymiyyah: Conflict or Conciliation (London: Routledge, 2010), p. 203. 
Library of Damascus. ${ }^{57}$ His aim was to summarize several of the characteristic elements of the Sufi doctrine he recognized therein and make suggestions concerning al-Wāsițīs influences. In line with Meier's notes on al-Wāsitịi, he found several instances of clear Shādhilī-inspired teachings. ${ }^{58}$ Naturally, he also considered how the manuscript is of relevance to our knowledge of Ibn Taymiyya's relationship with Sufism, and concluded that al-Wāsițīs testimony "proves that the shaykh al-Islām has indeed been the spiritual director of Sufis."59 Moreover, taking Ibn Taymiyya's Qādirī affiliation for granted, he hypothesized that al-Wāsițī must have been instructed by his Hanbalī master in the teachings of the Qãdiriyya, even though, he admits, no mention of the Sufi order is made in the manuscript. ${ }^{60}$

Apart from the above publications, there has been no research into alWāsițī, and the theory that Ibn Taymiyya was his (or anyone else's) teacher in tașawwuf as put forth by Geoffroy has not been further explored. The reason for that is quite simple, I believe: until recently, practically all of al-Wāsițìs writings have only been available in manuscript form. However, now that we actually have the majority of them at our disposal in printed editions, including many titles that were not studied by Geoffroy, it is high time that we give this Sufi from Ibn Taymiyya's circle his due.

\section{Book Outline: al-Wāsițīs Two Journeys}

In order to systematically study al-Wāsițī this book is split into two parts. This division is based on two journeys that are described in his writings: The first part will be concerned with al-Wāsițīs riḥla, the physical journey he made to find a teacher who could guide him to the level of religious perfection to which he aspired. The second part will be concerned with his sulük, the inward spiritual journey he put down in writing in Damascus and taught to his students as a teacher of Sufism there. Like most Sufis, he believed that the very purpose of tașawwuf was to take the latter journey and traverse a sequence of spiritual stations in order to reach the ultimate goal of friendship with God (wilāya, or waläya). As we will see throughout the coming chapters, his formulation of

57 Éric Geoffroy, "Le traité de soufisme d'un disciple d'Ibn Taymiyya: Aḥmad 'Imād al-dīn al-Wāsițī (m. 711/1311)," Studia Islamica, no. 82 (1995): p. 85, translation my own. The Damascene manuscript is in fact not unique, as the published edition I will discuss below is based on a manuscript from Istanbul.

$5^{8} \quad$ Ibid. pp. $86-88 \& 97-98$.

59 Ibid. p. 102.

6 o Ibid. p. 97 . 
sulük was the direct product of all he had accumulated during his rihla through the Muslim world. One of the purposes of distinguishing between these two journeys is therefore to evaluate how al-Wāsițīs physical movement in search of guidance influenced the way he eventually systematically formulated his spiritual movement on the Sufi path.

We will follow both journeys through a detailed analysis of all his writings that have been available to me. Apart from three titles in manuscript form, we will rely on published editions. It must be noted that none of these have been critically edited, as they were all exclusively based on a single manuscript. The majority of them have been made available thanks to Muhammad Abū al-Faḍl al-Qūnawī, who first published a lengthy collective volume of treatises by alWāsițî in 2010, and another one of equal length in 2014. In addition, the late Walīd b. Muhammad al-'Alī has likewise been working on a series of shorter volumes with editions of al-Wāsițîs's writings. Coincidentally, some of the titles found therein are also present in either of the two volumes published by alQunawī. This is probably in part due to the fact that both scholars have based their editions on the same manuscript, a collective volume of works by alWāsițī held in the Hacı Selim Ağa Library in Istanbul (under shelf number 404). The manuscript's scribe, one Muhammad b. 'Abd al-Raḥmān al-Dimashqī, finished copying it in 805/1402, which is less than a century after al-Wāsițîs passing in 711/1311. According to al-Qūnawī there is good reason to believe that this al-Dimashqi relied on copies that were based on the original manuscripts, since his grandfather, Ibn Ṭūlūbghā (d. 749/1348), is known to have copied directly from al-Wāsițị's own handwritten work. ${ }^{61}$ So although most titles at our disposal are based on this one manuscript, it seems to be relatively reliable considering its transmission history. Rather than merely describing what alWāsițīs writings tell us, we will aim at contextualizing and historicizing them.

In order to prepare the reader for what is to come in the next chapters, it will be helpful to briefly explain how part one of the current book applies this approach differently from part two by presenting a chapter overview:

61 For the list of al-Wāsițîs works used in this book, see the bibliography, pp. 284-287. For al-Qūnawī's remarks on the manuscript, see: al-Wāsițī, al-Imādiyyāt: Majmū' fìhi rasā̄il li-al-imām Imād al-Dìn al-Wāsițī al-ma'rūf bi-Ibn Shaykh al-Hazzāmiyya, ed. Muhammad b. 'Abd Allāh Aḥmad (Abū al-Faḍl al-Qūnawī) (Beirut: Dār al-kutub al-ilmiyya, 2010), p. 16, and also: al-Wāsițī, Qawā'id fí al-sulūk ilā Allāh ta'ālā aw: al-Sayr 'alā al-minhāj, ed. Muḥammad b. 'Abd Allāh Aḥmad (Abū al-Faḍl al-Qūnawī) (Beirut: Dār al-bashāìr alislāmiyya, 2014), p. 18. For al-'Alī's remarks on the manuscript, see: al-Wāsițī, Talqūh alasrār bi-lawāmi' al-anwār li-al-'ulamā’ al-abrār, ed. Walīd b. Muhammad b. 'Abd Allāh al'Alī (Beirut: Dār al-bashāiir al-islāmiyya, 2014), pp. 32-33, and also: al-Wāsițī, al-Sirr almașūn wa-al-iilm al-makhzūn fihi lawāìh min al-mahabba wa-shu'ūn, ed. Walīd b. Muḥammad b. 'Abd Allāh al-'Alī (Beirut: Dār al-bashāiir al-islāmiyya, 2013), p. 29. 
The first part consists of three chapters. Chapter 1 follows al-Wāsițî's account of his years in Iraq. We begin in Wāsiț, where he grows up among Sufis of the Rifā̄ì order and starts his training in jurisprudence among Shāfíi jurists. Then we follow his migration from his hometown to Baghdad, where he accompanies another group of Sufis whose affiliation is not clearly specified. Chapter 2 focuses solely on his time among the Shādhilīs of Alexandria, whose teachings will later greatly influence his own formulation of Sufism as both Meier and Geoffroy have noted. In chapter 3 we begin with his stay in several Cairene Sufi convents, where he is confronted for the first time with Sufis who follow Ibn 'Arabi's school of thought. Then we turn to his final destination, Damascus, where, awed by the city's traditionalist fraction, he adopts the Hanbalī school and becomes a member of Ibn Taymiyya's circle. Here he spends the final years of his life teaching his own traditionalist version of Sufism.

By thus following the stages of his journey through his personal account we are provided with a unique emic view of the religious groups he accompanied. For each of these we will critically assess his descriptions of them on the basis of primary and secondary literature. Whenever works produced by members of these groups are relevant in relation to al-Wāsiți's account these will be consulted. In addition, a plethora of chronicles that deal with the period in question will also be consulted. ${ }^{62}$ These sources allow us to reconstruct the main doctrines of the groups under consideration, and in some instances their respective network of people. They also allow us to sketch an image of the sociopolitical, cultural, historical, and spatial context in which al-Wāsiți encountered them.

The purpose of this endeavor is to historicize al-Wāsițīs rihla and at the same time situate each group he accompanied in its own context. It will thereby be argued that the extent to which these groups were able to successfully establish themselves in their respective spatial context can to some degree be connected to the notions of normativity that were prevalent there. At the same time this part of the book means to capitalize on al-Wāsițìs rị̣la in order to provide new historical insights into the practices, beliefs, and group structure of the early Rifāiiyya, the early Shādhiliyya, and the Damascene circle of Ibn Taymiyya.

The second part of this book consists of two chapters. In chapter 4 we will distinguish the foundations of the Sufi path as described in al-Wāsițīs writings.

62 The present study has benefited greatly from a considerable variety of searchable digitalized Arabic works of history (tärīkh) and biographical dictionaries (țabaqāt) that have been accessed through the digital library al-Maktaba al-shāmila. 
The first of these is his doctrine on intimate knowledge ( $m a^{\prime}$ rifa) of the Prophet Muhammad, which is centered around what he calls 'the Muhammadan way' (al-țariqa al-Muhammadiyya); the second is his doctrine on intimate knowledge of God, which he very much defines in traditionalist terms; the third is his polemics against what he saw as the deviations of the Sufi path. In chapter 5 we will analyze his doctrine of the degrees of witnessing God, which brings us to the conclusion of the Sufi path as he formulated it.

Throughout these two chapters we will use our study of al-Wāsițīs physical journey as the context against which we may understand the contents of his spiritual journey. We will thereby attempt to recognize where certain episodes described and analyzed in part 1 may have shaped his views on Sufism, where and how he appears to have appropriated material from the different religious groups and scholars he accompanied, and how he was an original thinker in his own right. Particular focus will be put on the manner in which his Sufi teachings were formulated within the framework of traditionalism. It will be argued that while some of his ideas and concepts in the field of Sufism can be traced back to either Ibn Taymiyya or the Shādhiliyya, others may be understood as a counter-reaction to some of the Sufi practices he had observed and disapproved of, while yet others appear to have been the product of his own creative thought. Such observations will showcase how 'selfing' and 'othering' was an important force behind the way he construed his Sufi doctrine, and that the common thread guiding this creative process was his understanding of traditionalist Islam.

It is hoped that this study will be of value in at least three different ways. First, for the general field of Sufi studies, it provides a window into numerous trends of Sufism that existed in some of the most prominent centers of Muslim learning in al-Wāsitịis epoch. This allows us to see how diversely 'Sufism' and 'being Sufi' was given substance in various contexts of roughly the same period, and consider how this diversity may be related to differing notions of normativity. Second, by studying al-Wāsiț̣’s writings we are offered an exceptional glimpse into the kind of Sufism that was accepted and practiced in the traditionalist community of Damascus at the beginning of the eighth/fourteenth century, a subject that has hitherto hardly been studied. Third, for the specific field of Taymiyyan studies, this book provides new information concerning the role allotted to Sufism in the circle of Ibn Taymiyya and how this circle operated. In addition, it aims to answer whether Ibn Taymiyya functioned as something of a Sufi shaykh for the people around him and whether he actually was himself a Sufi. 
PART 1

The Physical Journey (al-Riḥla) 
Arjan Post - 978-90-04-37755-4

Downloaded from Brill. com $04 / 26 / 2023$ 03:36:10PM via free access 


\section{Al-Wāsițīs Autobiography}

I shall be telling this with a sigh

Somewhere ages and ages hence:

Two roads diverged in a wood, and I-

I took the one less traveled by,

And that has made all the difference.

RoBERT FROST, The Road Not Taken

Chapters 1 to 3 of this book follow the course of al-Wāsițis life through a detailed study of the autobiographical passages from his writings. There is one source in particular that stands out from all others in that regard: an autobiographical treatise of about forty pages, which he wrote at the beginning of the eighth/fourteenth century ("fi ra's al-sab'imi'a"), in all likelihood not long after he had become a member of Ibn Taymiyya's circle. ${ }^{1}$ It is published as 'Rihlat al-Imām Ibn Shaykh al-Hazzāmiyyīn min al-tașawwuf al-munharif ilà tașawwuf ahl al-hadith wa-al-athar,' which we may render as 'The Journey of Imam Ibn Shaykh al-Hazzāmiyyīn [al-Wāsițī] from deviant Sufism to the Sufism of the traditionalists.'2 Although this title evidently reflects the editor's bias, it is not difficult to argue that it does do justice to reality as al-Wāsițī himself saw it.

The narrative he himself very clearly puts forth is that he indeed traveled from several deviant manifestations of the Sufi path to finally arrive unto the one that was in all respects in accordance with the purest form of Islam: traditionalism. This, he explains in the treatise's introduction, is also the very reason he had decided to write it: to warn his readers against the many misguided groups (mostly Sufis, but also jurists) that had become prevalent in his age and

1 Al-Wāsițī, Rihla, p. 16.

2 This is the title given by the editor, Abū al-Faḍl al-Qūnawī, who states in his introduction that the original manuscript does not contain a title (cf. p. 8). The current study relies on the first edition published in Konya, Turkey by the editor himself in 2005. There is a second print of the same edition in the collective volume al-Imādiyyāt, from the hand of the same editor and published in Beirut by Dār al-kutub al-ilmiyya (pp. 25-51) in 2010. There do not appear to be any differences between the two prints. 
guide them towards a form of religiosity that effectively combines jurisprudence, theology, and Sufism in the most appropriate way:

I wanted to describe the state of my journey (rihlatī) during my spiritual search and what I have come across of groups (tawäif) that deviate from truth and rightness ... so that it may provide insight and proof for the seeker of guidance in our age and become a stairway to knowledge (ma'rifa) of what God (T) desires from His servants regarding their religious requirements, beliefs ( $u q \bar{u} d)$, and spiritual states $(a h \mathfrak{h} w \bar{a} l) .^{3}$

Simply put, he expresses the hope that his readers - most probably traditionalists interested in the Sufi path - learn from his experiences during his journey so that they would discern why the course he chose in the end is the only correct course, and all others are false. The idea for it, so he tells us, came to him after a study of the biography (sira) of the Prophet Muhammad, wherein he read the tale of the well-known Persian Companion Salmān al-Fārisī and his journey towards Islam. This account inspired him because he found that there were similarities between Salmān's journey and his own. ${ }^{4}$ Looking back on his travels from Wāsiṭ to Baghdad, Alexandria, Cairo, and Damascus, and reflecting on the different groups he had encountered, the sentiment he seems to convey is that, like Salmān, God had guided him away from misguidance towards the pure religion revealed to the Prophet Muhammad.

Since his descriptions of this journey provide the pillars upon which chapters 1 to 3 are built, it is necessary to make note of several critical considerations that are important for the scholarly approach in this part of the present book with regard to the genre of autobiography. This is, after all, the genre of literature with which we are dealing here.

Historians have long neglected autobiography as a historical source, for the greater part because the genre revolves around writing about the 'self,' and was thence naturally regarded as being much more suspect to subjectivity than other genres of historical writing. It is only rather late in the second half of the twentieth century that the study of autobiographies rapidly developed into a subfield of its own. This development was undoubtedly to a large degree facilitated by the emergence of the new critical theory of deconstruction, which severely challenged notions of objectivity and historical truth. ${ }^{5}$

3 Al-Wāsițī, Rị̣la, p. 15.

4 Ibid.

5 On this development, see: Charles Berryman, "Critical Mirrors: Theories of Autobiography," Mosaic: An Interdisciplinary Critical Journal, vol. 32, no. 1 (March 1999): pp. 71-75; the remainder of the article provides a good overview of the study of autobiographies. 
Doors opened to consider autobiographical texts as historical sources, sources that may in fact provide unique information due to their paradoxical nature - for, as Albert E. Stone defines it, autobiography is "simultaneously historical record and literary artefact, psychological case history and spiritual confession, didactic essay and ideological statement." ${ }^{6}$ As such, autobiographies may contain deliberate misrepresentations and lies - which is of course among the main reasons why academics have previously disregarded the genre. However, as Jennifer Jensen Wallach amongst others has argued, these misrepresentations and lies may actually be of great value to the historian, because one "might learn a great deal about how an individual perceived herself and her times (if the witness's misrepresentation is honest), or about how she would like to be remembered (if her lies are more calculated)."7 The first-person perspective of autobiography allows one to see a past world through the eyes of its author, and emphatically reconstruct and "re-feel" what he or she has gone through. Moreover, Wallach argues, autobiographies are literally verifiable, for although they may "stretch, evade, or incorrectly portray the truth, they are grounded in real people, places, and things ..." 8 Thus, by critically studying such texts in combination with other primary and secondary sources related to the geographical and historical context of their respective authors, one can extract historical data from them. ${ }^{9}$

In spite of the fact that it is a primary source that may tell us a lot about the religious context of the autobiographer, there has been relatively little attention for autobiography within the field of religious studies. ${ }^{10}$ Indeed, when it comes to the study of the medieval Muslim world specifically, there are but few contributions by academics that rely heavily upon one or more autobiographical texts. It must be noted that while Muslim scholars certainly produced writings that fall within the genre, it was no common practice in premodern times to write a book that explicitly revolves around oneself. Nevertheless, several examples of autobiographical texts by premodern figures from the Muslim world are available today, and several have in fact been translated into English and other European languages. ${ }^{11}$ To my knowledge, the best attempt at a com-

$6 \quad$ As quoted in Berryman, "Critical Mirrors," p. 8o.

7 Jennifer Jensen Wallach, "Building a Bridge of Words: The Literary Autobiography as Historical Source Material," Biography 29.3 (2006): p. 450.

8 Ibid. p. 459 .

$9 \quad$ Ibid. pp. $447-449$.

$10 \quad$ Jens Schlamelcher, "Religious Studies," in Handbook of Autobiography / Autofiction, ed. Martina Wagner-Egelhaaf (Berlin: De Gruyter, 2019), vol. I, pp. 161-162.

11 For autobiographical writings related to Sufism, see for instance: Abū Ḥāmid Muhammad b. Muhammad al-Ghazālī, Al-Ghazali's Path to Sufism. His Deliverance from Error: AlMunqidh min al-Dalal, trans. Richard J. McCarthy (Louisville, KY: Fons Vitae Publishing, 
plete survey of this genre is found in the volume Interpreting the Self (2001), edited by Dwight F. Reynolds, though it only focuses on autobiographies written in Arabic. ${ }^{12}$

For our present purpose of critically reading al-Wāsițîs Riḥla, Reynolds' volume makes a distinction between different categories of autobiographies that can be useful. Based on the book's categorization, our Iraqi Sufi very clearly follows the literary conventions of the category that is called "spiritual autobiographical writings." In such writings

... the author's path of spiritual development constitutes the central focus of the text. They are thus by definition texts that portray primarily an "inner self" and are constructed on a model of transformation and development. They are also, even more clearly than their scholarly counterparts, constructed as models for emulation in the sense that embedded in the text is a call or an invitation to the reader to travel the same spiritual path. Several of these texts culminate with the author's "conversion" to the spiritual or mystical life and may thus also be linked to conversion autobiographies such as those by Samaw'al al-Maghribī, who converted to Islam in the twelfth century, and the Christian writer Fray Anselmo Turmeda, who converted to Islam in the fourteenth century. ${ }^{13}$

There are two characteristic elements of the spiritual autobiography mentioned above that are of particular relevance to us: first, that it is written as a model for emulation and, second, that it may sometimes work towards a specific moment of conversion to the mystical life. Such a conversion narrative is fittingly described by Hartman Leitner as follows:

He who recounts his conversion does not simply reconstruct events in retrospect, but literally describes himself in the language of his (new) faith. The conversion narrative is nothing more than an act of self-description, in which the speaker narratively constructs his identity as a

200o); Ahmad b. Muhammad Ibn 'Ajība, The Autobiography of the Moroccan Sufi, trans. Jean-Louis Michon \& David Streight (Louisville, KY: Fons Vitae, 1999); Rūzbihān b. Abī al-Nașr Baqlī, The Unveiling of Secrets: Diary of a Sufi Master, trans. Carl W. Ernst (Chapel Hill NC: Parvardigar Press, 1997).

For an overview of the study of premodern Arabic autobiograpgies I refer the reader to the recent survey in that regard by Susanne Enderwitz, "Classical Arabic Autobiography," in Handbook of Autobiography / Autofiction, ed. Martina Wagner-Egelhaaf (Berlin: De Gruyter, 2019), vol. II, pp. 827-849.

13 Dwight F. Reynolds (ed.), Interpreting the Self: Autobiography in the Arabic Literary Tradition (Berkeley: University of California Press, 2001), p. 47. 
convert, presenting himself as a convert. The form of narrative does not refer to an event independent of the narrative, but is itself already a level of representation. ${ }^{14}$

As already noted above, al-Wāsiți writes in the very introduction to his autobiography that his main purpose is to provide guidance for seekers of God by simultaneously warning them against deviant groups and providing directions towards the true spiritual path. He does so by recounting his own road to traditionalist Islam, thus writing his story as a model of development with the point where he converted to the Ahl al-Hadith and harmonized his Sufi doctrine with its principles as the ultimate outcome of spiritual perfection.

He effectively tells this story through the lens of the person he had become in Damascus, thus judging the religious groups he had previously come across in a way that may not always reflect the thoughts and feelings he truly experienced as he accompanied them prior to his conversion. Hence, it remains difficult, indeed in most cases impossible, to reconstruct where the critical conclusions he claims to have arrived at during his journey are not simply insights that he came to develop as a member of Ibn Taymiyya's circle - views that he projected back in the Rihla for the sake of his conversion narrative. In chapter 1, for instance, we will see that he puts forth the claim in his autobiography that he had something of a natural disposition towards traditionalist theology quite early on in his life, even as a follower of the Shāfi'i school. However, his Rihla remains silent in regard to the Ash'arī creed to which he was in all likelihood exposed when he studying Shāfi'i jurisprudence as a youth, which is seemingly hinted at in another (presumably earlier) treatise he wrote about God's attributes. His omission of any exposure to Ash'arism at that time in his life may very well have been a conscious choice in consideration of his audience, which was probably predominantly traditionalist. But again, the reality of such matters cannot be verified. Although we must thus remain critical of the moral and theological judgments al-Wāsițī claims to have come to during his journey, especially in consideration of the conversion narrative he adopts, the current study will first and foremost read them as reflections of the way he wants his readers to perceive himself and his times. In that sense they represent the worldview of a medieval traditionalist Sufi.

In spite of these critical considerations, there is certainly much to be found in al-Wāsițīs autobiographical writings that can be historicized. In fact, it is,

14 Hartman Leitner, "Wie man ein neuer Mensch wird, oder: Die Logik der Bekehrung," in Biographische Sozialisation, ed. Erika M. Hoerning (Berlin: De Gruyter, 20oo), p. 65 (translation my own). 


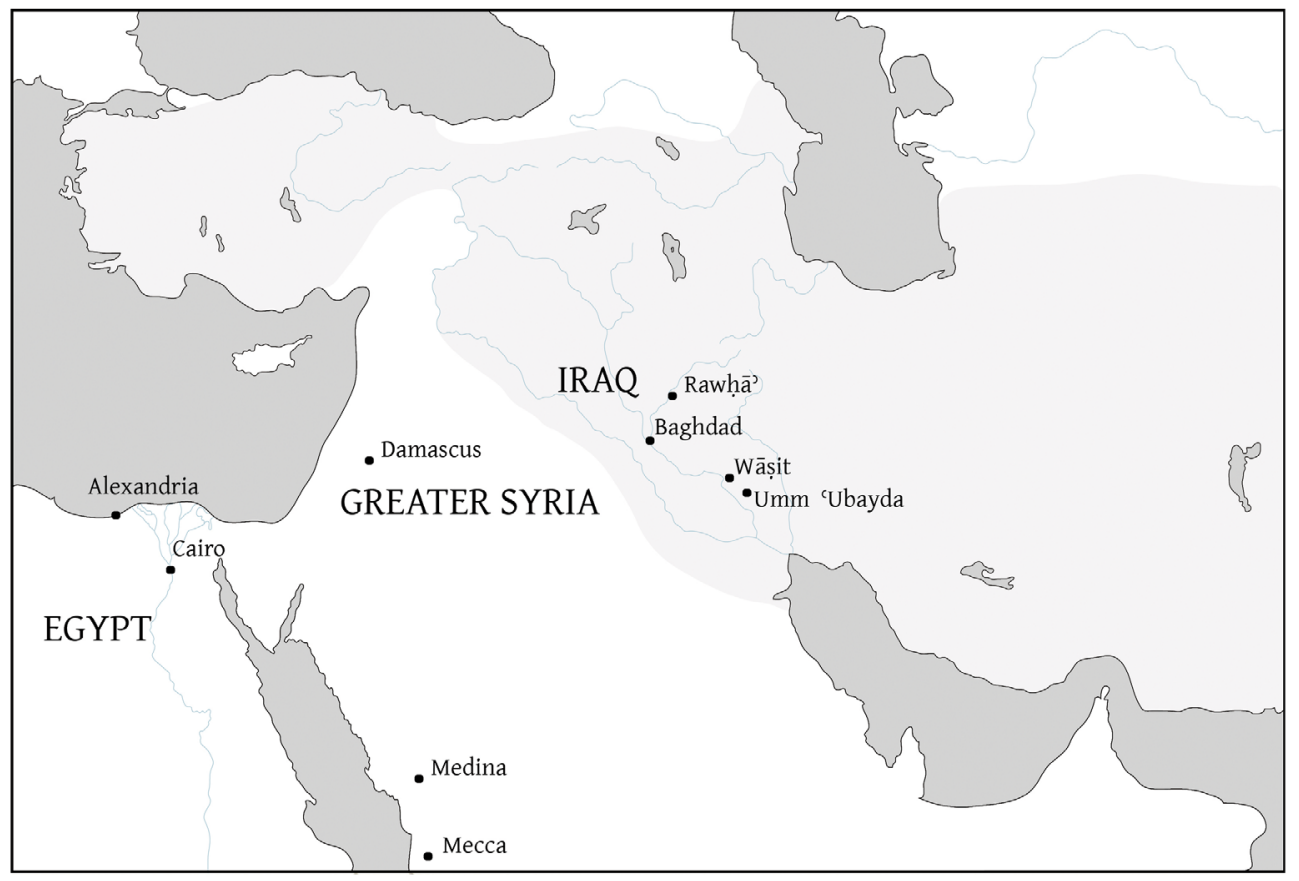

Lands under Ilkhanid suzerainty

FIGURE 1 Map of the places al-Wāsițī visited on his journey

above all, in the passages that set out to describe the routines of the religious groups he accompanied that the following chapters will provide unique insights from a first-person perspective. As I have already mentioned in the introduction, the abundant primary and secondary sources about these groups, and the contexts in which our Iraqi Sufi found them, has made it possible to critically examine the veracity of his descriptions. Having said that, we may now begin with his Riḥla, from his Iraqi hometown of Wāsiṭ. 


\section{Leaving Home, Bastion of the Spectacular Rifā̄īs}

The site of Wāsit in modern-day Iraq hardly shows any trace of the city's former glory. According to legend, the city's location was chosen by its founder, the Umayyad governor al-Ḥajjāj b. Yūsuf (d. 95/714), after a Christian monk claimed to have read in divine scripture that there would be a mosque there that would not cease to exist as long as there remains anyone who professes God's oneness. ${ }^{1}$ Alas, this prediction did not prove to be true, for the city was abandoned around the middle of the ninth/fifteenth century after having suffered several sieges. This was followed by a gradual change in the course of the Tigris River, which turned further and further east, leaving the city, which had once lain directly on its right bank, in a barren desert. Thus, by the eleventh/ seventeenth century there was nothing left of the fertile grounds, gardens, reeds, and date palms that had characterized Wāsiț, and the city had become a ghost town in ruin. ${ }^{2}$

However, Wāsit was still a flourishing city in the seventh/thirteenth century, even after it was conquered by the Mongols. A century before that, after a long period of strife, the political and religious policy of the thirty-fourth 'Abbāsid caliph, al-Nāșir li-Dīn Allāh (r. 575-622/118o-1225), ensured that the caliphate of Iraq was able to expand and solidify, which brought a period of peace, prosperity, and expansion for Wāsit as a center of Sunni Islam as well. ${ }^{3}$ This policy

1 For the full story, see Muhammad Ibn Jarīr al-Ṭabarī, The History of al-Ṭabarī. Volume XXIII. The Zenith of the Marwānid House, trans. Martin Hinds (Albany, N.Y.: State University of New York Press, 1990), p. 71.

2 C. Edmund Bosworth, "Wāsiț: the rise and disappearance of a great Islamic city," in GraecoArabica: Festschrift in Honour of V. Christides, ed. George K. Livadas (Athens: IGOAS, 2004), pp. 87-88; Mondher Sakly, and Robert Darley-Doran, "Wasit (Wāsiț)," in Historic Cities of the Islamic World, ed. C. Edmund Bosworth (Leiden / Boston: E.J. Brill, 2007), p. 551; Guy LeStrange, The Lands of the Eastern Caliphate: Mesopotamia, Persia, and Central Asia from the Moslem Conquest to the Time of Timur (Cambridge: Cambridge University Press, 1905), pp. 39-40.

3 For a study on al-Nāṣir, see Angelika Hartmann, An-Nāṣir li-Dīn Allāh, 1180-1225: Politik, Religion, Kultur in der späten 'Abbāsidenzeit (Berlin: Walter de Gruyter, 1975), chapter 3 in particular. For a more recent study that gives a good overview of al-Nāșir's politics, see Erik S. Ohlander, Sufism in an Age of Transition: 'Umar al-Suhrawardī and the Rise of the Islamic Mystical Brotherhoods (Leiden: Brill, 2008), pp. 16-27; Bosworth, "Wāsiț," p. 84; Sakly and Darley-Doran, "Wasit (Wāsiț)," p. 553. 


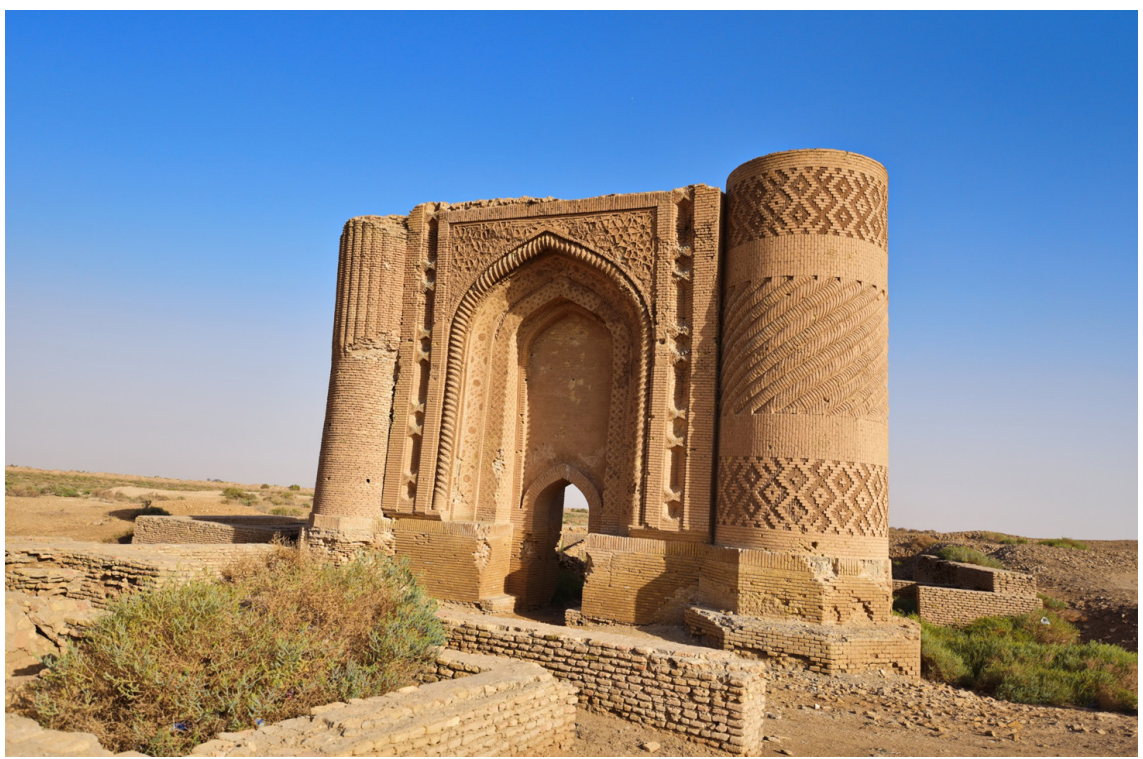

FIGURE 2 The front of one of Wāsiț's gates.

(C) AHMAD MAHDI SALIH

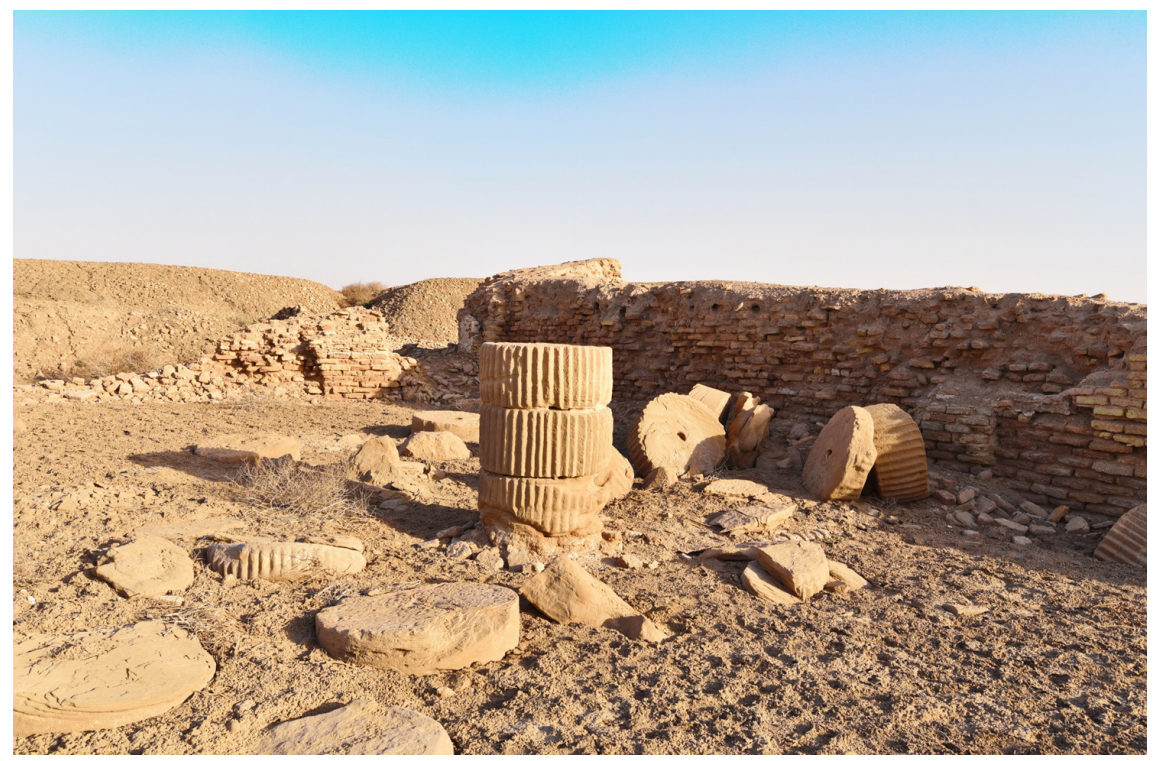

FIGURE 3 Remains of Wāsiṭ.

(c) AHMAD MAHDI SALIH 
was continued up till the caliph al-Mustanșir bi-Allāh (r. 623-640/1226-1242) but ended violently with the Mongols' execution of the latter's son and successor, al-Musta'șim bi-Allāh (r. 640-656/1242-1258), who would go into history as the last caliph of Baghdad. ${ }^{4}$ On 4 Șafar 656/10 February 1258, Baghdad fell before the military strength of Hülagü's Mongol troops. He had been sent westwards into Persia by his brother Möngke Khan, the third Khan after his grandfather Čingiz, with the order to expand the empire. From the lands Hülagü conquered he soon raised his own Mongol dynasty known as the Ilkhanate, which remained in power for almost a century. After Baghdad, Hülagü sent two of his generals, Köke-Ilge and Qara Boghā, to conquer the rest of Mesopotamia. A few months later in Rabī' I/April of the same year, they took Wāsiț, which reportedly cost the city 40,000 lives, and devastated its quarter on the opposite east side of the Tigris. ${ }^{5}$

It would be almost two years after the supposed massacre of Wāsit that 'Imād al-Dīn Aḥmad al-Wāsiṭi was born in this very city, on either 11 or 12 Dhū al-Hijja 657, corresponding to 29 or 3 o November 1259.6 It is likely that he grew up in Hazzāmūn, a large quarter (mahalla) in the east of Wāsiț, as several sources mention he was known as Ibn shaykh al-Hazzämiyyin: the son of the shaykh of Ḥazzāmūn's inhabitants. ${ }^{7}$ His father, Ibrāhīm b. 'Abd al-Raḥmān b.

4 Marshall G. S. Hodgson, The Venture of Islam, Volume 2: the Expansion of Islam in the Middle Periods (University of Chicago Press, 1977), p. 285; Henri Laoust, "Le Hanbalisme sous le califat de Bagdad (241/855-656/1258)." REI I (1959): pp. 117-118.

5 This quarter had once been a separate pre-Islamic town by the name of Kaskar; see: Bertold Spuler, Die Mongolen in Iran: Politik, Verwaltung und Kultur der Ilchanzeit 1220-1350 (Leiden: E.J. Brill, 1985), pp. 46-50; Bosworth, "Wāsiț," pp. 85-86.

6 Cf. Shams al-Dīn Muhammad b. Aḥmad al-Dhahabī, Tārīkh al-Istām wa-wafayāt al-mashāhìr wa-al-ą lām, ed. 'Umar 'Abd al-Salām al-Tadmurī (Beirut: Dār al-kutub al-'Arabī, 1993), vol. 48, p. 331; Zayn al-Dīn 'Abd al-Raḥmān Ibn Rajab, al-Dhayl 'alā țabaqāt al-ḥanābila, ed. 'Abd alRaḥmān b. Sulaymān al-'Uthaymīn (Riyad: Maktabat al-'Ubaykān, 2005), vol. 4, p. 380.

7 Note that the sources sometimes refer to this quarter as al-Hazzāmiyya, and that it is sometimes misspelled as al-Ḥarāmiyya or al-Ḥarāmiyyīn, cf. Ibn Rajab, Dhayl, vol. 4, p. 380; Shams al-Dīn Muḥammad b. Aḥmad al-Dhahabī, Kitāa tadhkirat al-ḥuffāz (Beirut: Dār al-kutub al'ilmiyya, 1998), vol. 4, pp. 191-192; Aḥmad Ibn Ḥajar al-'Asqalānī, al-Durar al-kāmina fì àyān al-mia al-thāmina, ed. Muḥammad 'Abd al-Mu'īd Ḍān (Hyderabad: Majlis dāirat al-macārif al-'uthmāniyya, 1972), vol. 5, pp. 8-9; al-Dhahabī, Tārīkh, vol. 48, p. 331. Yāqūt al-Ḥamawī erroneously mentions that this quarter would have contained the mausoleums of one Muhammad b. Ibrāhīm, a descendent of 'Alī b. Abī Țālib, and of 'Uzayr, the son of the Prophet Aaron. These graves are actually located in the province Maysān, see: Shihāb al-Dīn Abū 'Abd Allāh Yāqūt al-Ḥamawī, Mu jam al-buldān (Beirut: Dār al-șādir, 1995), vol. 2, p. 252; LeStrange, The Lands of the Eastern Caliphate, p. 43. Also see the introduction of Aslam b. Sahl Bahshal al-Wāsițī, Tārīkh Wāsiț, ed. Kūrkīs 'Awwād (Beirut: 'Ālam al-kutub, 1986), p. 25. 
Mas'ūd b. 'Umar al-Wāsițī al-Hazzāmī, was in fact a shaykh of the Rifā'î̀ țāifa. ${ }^{8}$ In his autobiography al-Wāsiṭi describes him as follows:

I was born and raised among a group $(t \underline{a} i f a)$ of the Aḥmadiyya [Rifā'iyya], because my father - may God forgive him! - was one of their leaders and viziers (wuzara $\left.\bar{a}^{\prime}\right)$ of their shaykhs. He was obedient [to them], maintaining a state of excessive service (naf ${ }^{c}$ ) by fulfilling the needs of people, feeding [them] food, and warding off any [personal] desire, as is the way of the Ahmadiyya fuqarä. 9

We know little more of al-Wāsițîs family, except that he may have had an older brother by the name of Ishāa (as indicated by his father's kunya), and that he had a younger brother who was born approximately a year after him. The latter eventually became a Sufi shaykh in Wāsiț himself, and passed away in 738/1338, having reached a venerable age. ${ }^{10}$ The fact that al-Wāsițīs father was a Sufi shaykh and his brother too became one - perhaps also of the Rifāiiyya - shows that his family probably enjoyed a certain status in Wāsiț, and that Sufism played an important role in their lives. At any rate, the Rifāci țā'ifa certainly played a dominant role in shaping the early life of al-Wāsiți himself and, as we shall see, his experiences would soon lead him to question the proper bounds of Sufism. We will thoroughly examine this further below, where we will also discuss the Rifāiyya in more detail. However, we must first consider the background against which the first half of al-Wāsițīs life unfolded in order to better understand his trajectory.

1.1

Wàsit under the Ilkhanids

While one may expect that the Mongol conquest of Wāsit would have a deep impact on the city for years to come, I have found nothing in our sources

8 Although the quote that follows does not have al-Wāsițī referring to his father as a shaykh, he does explicitly refer to him as a shaykh in another treatise, cf. Mizān al-shuyūkh, p. 246; see also: Ibn Rajab, Dhayl, vol. 4, p. 381.

9 Al-Wāsițī, Rị̣la, p. 17. Note that the term faqīr, pl. fuqarā', which I shall transliterate throughout this book rather than translate, is a typical term by which followers of the Rifâ'iyya referred to themselves. In Sufism, it is mostly used to signify the Sufi's contentment with nothing but God, which implies a sense of poverty in this world, cf. for instance Khaliq Ahmad Nizami, "Faḳī," in $E I^{2}$ : p. 757; for the Rifā̄īs, this may very well had to do with their particular method of sober living as well, as we shall see in the next section.

10 Shams al-Dīn Muḥammad b. Aḥmad al-Dhahabī, Dhayl Tārīkh al-islām, ed. Māzin Sālim Bā Wazīr (Riyad: Dār al-mughnī li-al-nashr wa-al-tawzī‘, 1988), p. 126; al-'Asqalānī, Durar, vol. 5, pp. 8-9. 
suggesting that the ensuing period under Ilkhanid rule was particularly difficult for its inhabitants. In fact, the city was partially reconstructed and soon fared fairly well economically. The Ilkhanids annexed the city to Baghdad and had it governed by a local religious head (sadr). By the end of the century they had its mints reopened, which had previously given the city great strategic importance but had been closed since the end of the fourth/tenth century. ${ }^{11} \mathrm{~A}$ few decades into the eighth/fourteenth century the Moroccan traveler Ibn Bațtūta would describe Wāsiṭ as a city with many gardens and trees and considered its inhabitants to be among the most excellent people of Iraq. He also mentions having visited a huge madrasa that contained 300 rooms to house students who want to memorize the Qur'an. ${ }^{2}$

That Wāsit was once more prospering is not so strange in view of the fact that the Mongols actually appreciated the advantages of peace and order. The Orientalist notion that their defeat of the Iraqi caliphate commenced the destruction of Islamic civilization has since long been disproven by scholars. It has even been contended that the material damage of the conquest was exaggerated by contemporary Muslim historians in order to demonize their Mongol enemies. In practice, whenever the Mongols established themselves in a particular territory, they actually aimed to establish peace and security. ${ }^{13}$ Their interest for trade created opportunities for people of the lower class and gave rise to a whole new middle class; and their support for sciences that captured their interest led to intercultural exchange of knowledge, and gave rise to new intellectual developments in the lands they conquered. ${ }^{14}$

As for religious policy, although the first Ilkhanid rulers were non-Muslims, it appears that for the most part the predominantly Sunni population of Iraq and Iran had little trouble practicing their religion as they had before. Čingiz Khan's law secured a certain measure of religious freedom which, initially, was sustained more or less under the Ilkhanids as well. It is noteworthy in that regard that Sufi organizations, which were already gaining ground in the previous century, continued to do so under Mongol rule. ${ }^{15}$

11 Bosworth, "Wāsiț," p. 86; Sakly and Darley-Doran, "Wasit (Wāsiṭ)," p. 553, and for the mints of Wāsiț, see pp. 554-555.

Muḥammad b. 'Abd Allāh al-Ṭanjī Ibn Bațțūṭa, Riḥlat Ibn Batțūṭa al-musammāh Tuhfat al-nuzzār fì gharāìb al-amșār wa-'ajā'ib al-asfār, ed. 'Abd al-Hādī Tāzī (Rabat: Akādīmīyat al-Mamlaka al-Maghribiyya, 1997), vol. 2, pp. 7-9.

For this nuance in the scholarly view of the Mongol conquest, see for instance Bernard Lewis, "The Mongols, the Turks and the Muslim Polity," TRHS, vol. 18 (1968): pp. 49-56.

14 Ibid. See also: Beatrice Forbes Manz, "The rule of the infidels: the Mongols and the Islamic world," in NCHI: pp. 157-158.

15 Manz, "The rule of the infidels," pp. 154-155. 
Since al-Wāsiți left the country around the year 683/1284, we know that he lived under the rule of Hülagü (r. 654-663/1256-1265), Abaqa (r. 663-68o/12651282), Tegüder (r. 68o-683/1282-1284), and perhaps briefly under Arghūn (r. 683-69o/1284-1291). ${ }^{16}$ When we look closer at their policy, we do find that the stance vis-à-vis religion of the first two Ilkhans, Hülagü and his son and successor Abaqa, gave rise to occasional tension between them and their Muslim subjects. While not opposed to Islam as such, Hülagü did view the Sunni caliphate as a dangerous threat to Mongol hegemony. After several Shi'ite communities had surrendered to him during his conquest, the famous Ismaîli scholar Nașīr al-Dīn al-Ṭūsì (d. 672/1274) became his personal adviser. It was in fact al-Ṭusī who encouraged him to sack the Sunni capital of Baghdad. However, after Hülagü's death not much of this apparent Mongol-Shi'ite alliance remained.

The sometimes unsympathetic attitude towards Islam under the rule of Hülagü and Abaqa also had to do with the fact that the Ilkhanate was at war with the Muslim Mamluks. Most of the Mongol elite during their reign had turned to Buddhism, while many of the women in the Ilkhanid family were Christian. They thus employed a certain religious rhetoric to justify their great military success by claiming that they enjoyed divine favor, and that their defeat of the caliphate was God's punishment of the Muslims. Moreover, without much result, they tried to capitalize religion by forging alliances with European Christian rulers to set up joint military campaigns against the Mamluks. ${ }^{17}$ In spite of this attitude, when it came to the lands under their control, they were not out to eradicate Islam. Even though there were instances where mosques were closed and estates owned by Muslims were confiscated, they never suppressed Islam or any other religion by force. Only when their Muslim subjects joined the Mamluks, in opposition to them, would they resort to violence to subdue them.

The policy soon changed in favor of Islam under Tegüder, another son of Hülagü, who had become Muslim as a young boy and taken the name Ahmad. He tried to rectify what his predecessors had done by opening new mosques and madrasas, giving back estates that had previously been confiscated, and supporting the yearly hajj pilgrimage. He also made clever use of his conversion to eliminate the legitimacy of the Mamluk rulers as the sole protectors of

16 Al-Wāsițī, Riḥla, p. 33.

17 On the ideological background of the Mongol policy in their war against the Mamluks, see the excellent study of Broadbridge, Kingship and Ideology, pp. 28-38. 
Islam. ${ }^{18}$ And even though his successor Arghūn was a strict Buddhist, the latter could not undo all the decrees that had been instigated by Tegüder. ${ }^{19}$

\subsection{An Ilkhanid-Rifä ${ }^{\top} \grave{\iota}$ Friendship?}

All in all, it appears that the Ilkhanids were generally not hostile towards the Sunni Muslims of Mesopotamia, so that al-Wāsiți would probably have noticed little of the Mongol occupation in terms of the religious life in his native city. If anything, Wāsit may have even enjoyed the favor of the Mongol rulers. Although not explicitly mentioned in the sources, this is not unthinkable when we consider that there was likely some relationship between the Mongols and the Rifāis Sufis, who were still chiefly located in and around Wāsit in the first half of the seventh/thirteenth century. Because this provides important background to al-Wāsițī's account of the Rifāiiyya, we will briefly review the evidence for this below.

Rifâ'i sources give the impression that the early order had a deep connection with Wāsit and its direct environment. Their grand convent (riwāq) was but a day's journey from the city, in a village called Umm 'Ubayda, south of Wāsit in the marshlands of lower Iraq, the bața $i h .^{20}$ Hence, we find that besides the eponyms Ahmadiyya and Rifāiiyya - which come from the name of its founder, Ahmad al-Rifā̄i (d. 578/1182) - the ța $\bar{a}^{\prime} i f a$ was also referred to as the Bață’ihiyya.$^{21} \mathrm{Al}$-Rifấî̀'s own background in Sufism was strongly connected to the Sufi tradition of the region. He had been initiated by two local masters of Sufism: His first shaykh, the Shāfi'ìjurist 'Alī b. Muhammad Abū Faḍl al-Qurashī al-Wāsițī, known as Ibn al-Qāri' (d. 539/1144), operated in Wāsiṭ. After al-Rifā'ī had memorized the Qur'an in his father's village, he went there to study under him. This al-Wāsițī reportedly gave him ijāzas in the outward and inward sciences of Islam, and named him his sole successor (khaliffa). ${ }^{22}$ After the shaykh

18 Ibid. pp. 39-44.

19 Spuler, Die Mongolen, pp. 198-20o; Alessandro Bausani, "Religion under the Mongols," in CHIr V: pp. 538-541.

20 The Rifā'i sources always refer to grand convent of Umm 'Ubayda as al-riwāq. Ibn Bațtutța mentions that "the riwāq is a great convent (ribāt 'ażìm)." Cf. Ibn Bațtūṭa, Riḥla, vol. 2, p. 9.

21 Al-Dhahabī, Tārīkh, vol. 40, p. 255.

22 Although he is referred to in the Rifāì sources as the Shāfici shaykh of Wāsiț, I have not found any entry for him in al-Subkī's Ṭabaqāt al-shäficiyya. For traditional Rifā̄ī views of him, see Aḥmad b. Muhammad al-Witrī, Rawḍat al-nāzirīn wa-khulāsat manāqib alșāliḥin (Baghdad: [publisher unknown], 1976), p. 17; Hāshim b. Sađd al-Aḥmadī, Ghanimat al-farīqayn min hikam al-ghawth al-Rifã đ̇A Abì al-'Alamayn, ed. Aḥmad Ramzah b. Hammūd Juḥā Abū al-Hudā (Published by the author, 2014), p. 144; 'Izz al-Dīn Aḥmad al-Fārūthī, Irshād al-muslimin li-țariqat shaykh al-muttaqin, ed. Aḥmad Ramzah b. Ḥammūd Juhāā Abū al-Hudā ([Egypt?]: Dār al-țibā'a al-āmira, 2011), pp. 38-41, p. 78; 'Izz al-Dīn Aḥmad b. 
passed away, al-Rifā'ì turned to his second spiritual master, his paternal uncle, shaykh Manșūr b. Yaḥyā al-Bațāiḥ̄i (d. 540/1145), who was born in Umm 'Ubayda and had established a grand convent by the Tigris River near Wāsiț. In the year of the latter's death, he also appointed his nephew al-Rifāī as his successor and left all his convents to him, thereby putting him in charge of his legacy. ${ }^{23}$ This shows that even before al-Rifā'ī made a name for himself as a Sufi authority, the roots of his movement were already anchored in Wāsiṭ and the adjacent marshlands.

His influence in the region would only expand further in the years that followed his appointment as the successor to both his shaykhs, so that it may have even become somewhat of a Rifā̄ì bastion. After al-Rifācī chose his native town Umm 'Ubayda as his headquarters, this became the spiritual center of his order, with Wāsit as its nearest intellectual center. We thus find that preachers (wu“āa) from Wāsit would come to al-Rifā'î’s lectures (majālis) about Sufism in Umm 'Ubayda and ask him questions about all kinds of subjects. ${ }^{24}$ We also find that a number of his most distinguished followers were Shāfīi jurists from Wāsit. ${ }^{25}$ On that basis it becomes plausible to assume that when the father of our al-Wāsiți is referred to as "the shaykh of Hazzāmūn's inhabitants," as mentioned above, this indicates that at least this particular quarter of Wāsit was dominated by the Rifā'iyya. It is difficult to determine the extent to which other orders of that time, such as the Qãdiriyya and the somewhat later Suhrawardiyya, were also successful in gaining a following in this area. As a local order, the Rifāiiyya clearly had a great advantage over their fellow Iraqi competitors, many of whom were perhaps still much more rooted in Baghdad. ${ }^{26}$

It is not exactly clear when, how, and to what degree the Ilkhanids formed a relationship with the Rifāiyya. The report that speaks of the earliest contact between them is, to my knowledge, al-Dhahabì's story of how the

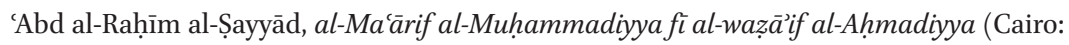
1305/1888), pp. 31-33.

23 Al-Aḥmadī, Ghanimat al-farìqayn, p. 142; al-Fārūthī, Irshād al-muslimīn, pp. 49-52.

24 'Abd al-Karīm b. Muhammad al-Rāifīi, Sawād al-'aynayn fì manāqib al-ghawth Abì alAlamayn (Al-Muhammadiyya (Egypt): al-Mațbaca al-Mīriyya, 1884), p. 7.

25 Al-Fārūthī, a contemporary of al-Wāsițī who will be discussed further below, is himself a good example of one such shaykh. He was definitely an important figure in the Rifā'iyya of Wāsiț, especially because he was also a celebrated jurist there. He himself gives an overview of what he calls the elite of al-Rifấi's direct followers; out of the 19 entries he gives, five are scholars from Wāsit, two come from nearby villages, and the rest from other cities in Iraq. See al-Fārūthī, Irshād al-muslimīn, pp. 224-253.

26 According to Trimingham, the early Qādiriyya remained very much a Baghdadi order, cf. J. Spencer Trimingham, The Sufi Orders in Islam (New York: Oxford University Press, 1998), pp. 37-40; for the Suhrawardiyya, see: Bausani, "Religion under the Mongols," p. 545. 
above-mentioned third Ilkhan, Tegüder, converted to Islam. This would have occurred after he witnessed Rifāi $\overline{1}$ fuqarā’ perform a spectacle by walking on fire before his father, Hülagü. According to al-Dhahabī, that was also the reason why Tegüder chose Ahmad as his Muslim name, after the țăiff's eponymous founder. ${ }^{27}$ If indeed historically grounded, this would show that the first Ilkhan, Hülagü, had already noticed the Rifā̄īs, and that Tegüder may very well have favored them when he came to power. Although Reuven Amitai rightfully states that al-Dhahabì's report is not on the whole unproblematic, we should not immediately discard it when we consider other insightful references to the link between the Ilkhanids and the Rifāis. ${ }^{28}$ Another example is again found in al-Dhahabīs Tārīkh, where he mentions a "misguided individual" by the name of Khalīl Ibn Badr (d. 642/1244), who claimed to be a Rifấī Sufi. Al-Dhahabī rebukes him for dressing like the Qalandariyya, drinking wine, eating hashish, and, most importantly, for gaining a position of power for himself through the Mongols (taqawwa $\bar{a}$ bi-al-tatār). ${ }^{29}$ Something similar is found concerning one Șâliḥ al-Aḥmadī al-Rifā'ī (d. 707/1307), a Rifāīi shaykh who, according to Ibn Kathīr, was honored by the Mongols when they reached Damascus at the beginning of the eighth/fourteenth century, trying once more to expand into Mamluk territory. If we are to believe Ibn Kathī's account, the Mongol general Qutlughshāh even stayed with him in his house during this episode. ${ }^{30}$

While by no means conclusive, such reports do provide some background for al-Wāsițī's bitter words about the Rifā'iyya in his autobiography, where he reflects on his days as a youth with them. After severely criticizing several of the practices he claims to have seen among them, he concludes:

That is why it is only right that the Mongols (al-tatar) have come to rule their land and gained mastery over them! In fact, they are content [having them] in their country, because [the Mongols] believe in them and venerate them. ... Perhaps the last caliphs of Baghdad only came to an end for the simple fact that they did not disavow these kind of things [that the Rifā̄is do]; for instead of changing this [behavior], they preserved it for them - and that is why God brought them to an end! ${ }^{31}$

27 Al-Dhahabī, Tārīkh, vol. 51, p. 140.

28 Reuven Amitai, "The Conversion of Tegüder Ilkhan to Islam," JSAI 25 (2001): pp. 18-20.

29 Al-Dhahabī, Tārīkh, vol. 47, p. 118.

$30 \quad$ Abū al-Fidā’ Ismācīl b. 'Umar Ibn Kathīr, al-Bidāya wa-al-nihāya, ed. 'Alī Shīrī (Beirut: Ḍar ihyā’’ al-turāth al-'arabī, 1988), vol. 14, p. 52.

31 Al-Wāsițī, Riḥla, p. 19. 
A few pages later, he makes a similar statement, saying: "What I believe is that, God willing, the only way for the Mongols to overpower the people of Islam is through the evil of these groups," by which he explicitly refers to those who follow Ahmad al-Rifā'î and other shaykhs like him. ${ }^{32}$ If we take the above into account, we can with some caution conclude that there must have indeed existed a friendly relationship of some sort between the Rifā'iyya and the Mongol rulers.

It is in the atmosphere described above that al-Wāsițī would grow increasingly uncomfortable with the traditions and customs that his father - and probably his family also - adhered to. The next section will be devoted specifically to this chapter of his life, by offering a historical analysis of his views on the Rifā'iyya. This will be followed by a section on al-Wāsițìs final years in Iraq.

\section{$2 \quad$ Al-Wāsițī versus the Rifā'iyya}

Although the passages about the Rifāciyya from al-Wāsițīs autobiography appear to have a purely polemical function, they can tell us something about their practices in the area of Wāsit around the middle of the seventh/thirteenth century; and although al-Wāsiṭi does not disclose a lot about his personal life during his time in Wāsiț, reading between the lines sometimes reveals the struggle of a young critical mind seeking the path he sees most fitting to arrive unto God spiritually - wușūl, as he often calls it. We thus find that while he likes his readers to believe that his disdain for the ways of the Rifā̄i Sufis resulted from divine guidance, there was clearly an element of individual research at play. He tells us:

One of the graces that God (T) bestowed upon me is that He created an instinct in me during my childhood (al-hâal al-țuüliyya) by which I used to know that they have no basis [for their practices], and that the truth is beyond that which they call to. I would hold fast to al-Qushayrī's Risāla, the Kitāb al-Qūt, and the Ihy $\bar{a}$. I was inherently aware of their falsehood, although it is practically impossible to bring it to light because they are in power [in the region] (al-dawla lahum). Thus, there is no possibility at all to expose it! 33

$32 \quad$ Ibid. p. 25 .

33 Ibid. pp. $26-27$. 
This statement implies that, as I suggested before, the Rifāiyya was indeed dominant in the region, to the extent that it was difficult to express criticism towards the order's practices. It also shows that al-Wāsițì's critical attitude would have derived, at least partially, from an individual study of classical Sufi manuals. Abū al-Qāsim al-Qushayrì’s Risāla, Abū Ṭālib al-Makkī's Qūt al-qulūb, and Abū Ḥāmid al-Ghazālì's Ihyy a' 'ulūm al-dìn to which he refers here were not only technical manuals on the Sufi way, but were all to a certain extent meant to defend its legitimacy as an Islamic science as well. The form of Sufism propounded therein may therefore have appeared much more sober and scholastic to our still young Iraqi Sufi than what he observed from the Rifāi 1 fuqara $\vec{a}^{3}$ around him. ${ }^{34}$

But what exactly did he observe, and in how far can we verify the veracity of his statements? Since scholars to date have written but very little on the early Rifāciyya, this endeavor requires a critical comparison between al-Wāsițîs descriptions as found in his autobiography and what Rifāī sources tell us about their doctrines and rituals. By comparing the accounts from both sides we can in some measure historicize them.

For that purpose, we will refer to five of the earliest available books concerned in some way with the Rifāi țăi ifa by affiliated scholars, some of whom were contemporaries of al-Wāsiți. 35 These are:

- Ghanimat al-farīqayn min hikam al-ghawth al-Rifä̀ Abì al-Alamayn by one Hāshim b. Sad al-Ahmadì (533-630/1139-1233), an otherwise unknown figure who was initiated by al-Rifā̄i himself. ${ }^{36}$ This work, which opens with a biography of al-Rifā̄ī, consists of discourses and epistles related from the shaykh.

- Sawād al-'aynayn fì manāqib al-ghawth Abì al-Alamayn by the celebrated Shāfíi jurist 'Abd al-Karīm b. Muḥammad al-Rāfi'ì al-Qazwīnī (555623/116o-1226). ${ }^{37}$ As indicated by its title, this is a biography of al-Rifā̄i $\overline{1}$. It is

34 For the scholastic nature of these works, see for instance: Éric Geoffroy, Le soufisme en Égypte et en Syrie sous les derniers Mamelouks et les premiers Ottomans: orientations spirituelles et enjeux culturels (Damascus: Institut français d'études arabes de Damas, 1995), p. 95 .

35 I have used Aḥmad Ramzah b. Ḥammūd Juhā Abū al-Hudā’s extensive overview of the earliest Rifā̄ì sources for the list presented here, as found in his introduction to al-Fārūthī, Irshäd al-muslimin, pp. 24-25.

36 Ibid. p. 24 .

37 The colophon of this book mentions Rajab 588/July 1192 as its date of completion, cf. alRāfī̄, Sawād al-'aynayn, p. 29. Although omitted in the list of al-Rāfi'i’s works found in al-Subkī's Tabaqāt, there is no reason to doubt its authenticity, especially in light of the fact that al-Fārūthī cites from it twice in his Irshād, cf. pp. 108 and 209; for the list, see Tāj al-Dīn 'Abd al-Wahhāb al-Subkī, Țabaqāt al-shāfíiyya al-kubrā, ed. Maḥmūd Muḥammad 
noteworthy that, although not widely attested to, the author was reportedly initiated into the Rifấiyya by al-Ṣayyād, who composed the next work on our list. ${ }^{38}$

- Al-Ma'ārif al-Muhammadiyya fì al-wazāî̉ al-Ahmmadiyya by 'Izz al-Dīn Ahmmad b. 'Abd al-Rahīm al-Ṣayyād (574-670/1178-1271), a grandson of alRifā̄ī who eventually founded a separate Rifāī branch. ${ }^{39}$ This work is unique in our list in that it is the only explicit Rifāì Sufi manual, thus providing the most detailed account of the ță iffa's doctrines and rituals.

- The final two works on our list are particularly important in that they were both written by 'Izz al-Dīn Ahmad b. Ibrāhīm al-Fārūthī (614-694/12181295), who was one of al-Wāsițīs teachers in Shāfíi jurisprudence. ${ }^{40}$ In that light, his writings not only represent the views of an important contemporary in time, but also in space, as he was probably the most distinguished hadìth-scholar and jurist of Wāsiṭ during the years al-Wāsițī lived in his native city. ${ }^{41}$ And since al-Fārūthī is known to have invested people with the Rifā̄ī Sufi cloak (khirqa), it is likely that he was also one of Wāsiț's chief Rifāīi shaykhs. ${ }^{42}$ His first work on the order, al-Naf̣ha al-miskiyya fi al-suläla

al-Ṭanāḥī \& 'Abd al-Fattāḥ Muḥammad al-Ḥulw (al-Muhandisīn, Jīzah: Hajar li-al-țibāca wa-al-nashr wa-al-tawzī', 1992), vol. 8, pp. 281-282.

38 Al-Rāfi'ì's initiation by al-Ṣayyād is attested to by al-Fārūthī. Note that al-Fārūthī may very well have been a disciple of al-Rāfi'i when he was still an adolescent, as he calls him "our shaykh," something which could further support al-Rāfi'ì's Rifācī affiliation; see al-Fārūthī, Irshād al-muslimīn, pp. 108 and 205. Al-Subkī does not mention any connection to Sufis in his entry of al-Rāfi'ì, although he does relate that he was a renunciant (zāhid) who performed miracles (karāmāt); al-Nawawī reportedly called him "one of the righteous who reached the state of stability (al-șāliḥin al-mutamakkinin)," stability (tamkin) being the final stage of the spiritual path in Sufi terminology, cf. al-Subkī, Țabaqāt al-shäficiyya, vol. 8, pp. 283-284.

39 According to al-Fārūthī, al-Ṣayyād left Iraq in 622/1225 out of pious fear for his growing fame there, which could threaten his spiritual state. He traveled through the Hijāz, Yemen, Syria, and finally settled in Egypt, initiating pupils and opening convents (ribäts) along the way. Cf. Irshäd al-muslimīn, pp. pp. 203-210; see also: C. Edmund Bosworth, "Rifā'iyya," in $E I^{2}$ : vol. 8, p. $5^{25}$.

$40 \quad$ Ibn Rajab, al-Dhayl, vol. 4, p. 381.

41 He is referred to in several biographical dictionaries as the shaykh of Iraq, see for instance: 'Afîf al-Dīn 'Abd Allāh b. As'ad al-Yāfi'ī, Mir'āt al-jinān wa-'ibrat al-yaqzān fì ma'rifat mā ya'tabaru min ḥawādith al-zamān, ed. Khalīl al-Manșūr (Beirut: Dār al-kutub al-ilmiyya, 1997), vol. 4, p. 167; and: Taqī al-Dīn Abū al-Faḍl Muhammad Ibn Fahd, Laḥz al-alhāz bidhayl țabaqāt al-ḥuffāz (Beirut: Dār al-kutub al-'ilmiyya, 1998), p. 6o. 
al-Rifäiyya al-zakiyya, is a short epistle devoted to the genealogy of al-Rifāìi. His second work, Irshād al-muslimin li-taríqat shaykh al-muttaqin, is a much larger volume that contains biographies of al-Rifā̄ì and his most distinguished followers up to al-Fārūthī's time, and cites several of al-Rifā'ī's discourses and litanies (sing. hizb, pl. aḥzāb).

In order to systematically compare the views expressed by al-Wāsiṭī and his Rifāī counterparts, we will analyze three general themes: The first concerns the position and role of the shaykh, or spiritual master, in the order; the second concerns the practice of the Rifā̄iss, which focuses on their gatherings of Sufi audition $(s a m \bar{a})$ and miracle-working; the third theme brings the former two together to see what the overall depictions of the Rifāiyya can tell us about them. This is followed by a concluding discussion to scrutinize how our understanding of the tâaifa can be of value to the scholarly discourse on the form of Sufism practiced in al-Wāsițīs early Iraqi context.

\subsection{Shaykhdom in the Rifä iyya}

One of the first matters that al-Wāsiți addresses with regard to the Rifāīs in his autobiography pertains to the position that they assign to their shaykhs. According to his observation, they consider the shaykh to be someone with extraordinary capabilities, who, for reasons he does not explicitly disclose, plays a pivotal role in their lives:

failing to acknowledge his Rifāī affiliation, cf. Taqī al-Dīn 'Abd al-Raḥmān al-Wāsițī, Tiryāq al-muhibbīn fi țabaqāt khirqat al-mashāyikh al-'ārifīn (Cairo: Mațba'at Muhammad Mușțaāa, 1305/1888), p.18, as cited by Ohlander, "Fārūthī”; see also: al-Yāficī, Mir'āt, vol. 4, p. 167; al-Subkī, Țabaqāt, vol. 8, p. 6; Ibn Kathīr, al-Bidāya , vol. 13, p. 404. However, alFārūthì's own two works mentioned above conclusively show that he first and foremost considered himself a Rifāī Sufi. Al-Nafha al-miskiyya was written in in 675/1276 (as mentioned by al-Fārūthī in the book itself on p. 4); in it, we find al-Fārūthī praising God for the blessing of having made him one of al-Rifāī's followers, see: al-Fārūthī, al-Nafṭa al-miskiyya fì al-sulāla al-rifāìyya al-zakiyya (al-Āsitāna al-'Aliyya: Maṭba'at Muḥammad As'ad, 1883), p. 11. His Irshäd al-muslimīn was written in 684/1285 (as mentioned by alFārūthī in the book itself on p. 267); here we find al-Fārūthi saying it is not allowed for a Rifā̄i faqìr to join any other țẳifa, because the Rifāiiyya contains all the distinguished secrets of servitude and the spiritual realities of Muhammadan wisdom, cf. p. 115. Both works repeatedly state that Aḥmad al-Rifāīi was the greatest shaykh of all times, thereby asserting the superiority of his țẳifa. Both works also show that al-Fārūthī grew up in a family of loyal Rifā̄i Sufis. He relates two silsilas that connect him to al-Rifā̄î̀, as can be seen in appendix 1, p. 68, and also: al-Fārūthī, al-Naf̣̂a al-miskiyya, pp. 13-14. This shows that al-Fārūthī would not only have invested pupils with the khirqa of the Suhrawardiyya, but very likely also that of the Rifāiyya. For Ohlander's doubt concerning which khirqa exactly he invested, cf. Sufism in an Age of Transition, pp.114-115, n165. 
Instead of worship, it is their shaykhs who are firmly settled in their hearts, so that they turn to them during calamities and invoke them during their mishaps. The shaykh is to his followers like a prophet - in fact, it may be that they venerate him more than they venerate the prophets! For instance, they lower their heads in prostration and uncover them when they are in his presence, seeking refuge from his anger and his spiritual and hidden punishments ('uqūbātihi al-bāținiyya al-ghaybiyya). They believe that he utters whatever he desires, that he can make the living die, heal the sick, and shoot his arrow at anyone he likes, thereby killing that person! ${ }^{43}$

Our Iraqi Sufi hardly mentions the founder of the order, Aḥmad al-Rifā'īi but is

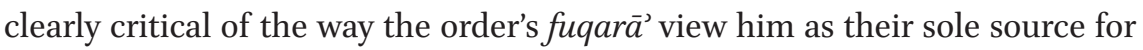
religious life: "They have no desire for the conduct ( $\bar{a} d \bar{a} b)$ of the Messenger $(S \subseteq)$ in their worship and practices. Instead, they desire the lifestyle of their grandshaykh (sirat shaykhihim al-akbar)" 44 - which is without a doubt in reference to al-Rifāì

It is highly likely that there was indeed a strong emphasis on the shaykh in the early Rifāi 1 țài $i f a$ already. Al-Ṣayyād's manual is quite explicit regarding the proper conduct that the faqir should have with the shaykh whom he has taken as his spiritual guide (murshid), and proudly states that "the Ahmadiyya have the strongest reverence ( $\left.\operatorname{ta} \mathrm{z}^{\mathrm{i}} \mathrm{im}\right)$ for their shaykhs." ${ }^{45}$ This reverence manifested in specific etiquettes that were to be upheld in the presence of the shaykh, such as the example of uncovering one's head in his presence given by al-Wāsiți above, something which Ibn Taymiyya confirms as a habit practiced by Rifācī Sufis. ${ }^{46}$ Such reverence is explained by al-Ṣayyād in a section of his manual wherein he names the fundaments of Rifāi $\bar{s}$ sulük, the method used to achieve spiritual realization. These are specified as follows: The faqï begins by sending prayers (șalāt) upon the Prophet Muhammad and perfecting the obligatory and supererogatory acts of worship, after which he should turn himself to the direction of prayer (qibla) and connect his heart to the spiritual guide (murshid). The first station in Rifā'i sulük is then to be annihilated in the shaykh (maqām al-fanä' fí al-shaykh), so that the faqïr subjects himself to him completely and is fit for his tarbiyya, his spiritual training in the Sufi way. It is only

43 Al-Wāsițī, Rihlala, p. 17.

44 Ibid. p. 18.

45 Al-Ṣayyād, al-Måāifi al-Muhammadiyya, p. 117.

46 Ibn Taymiyya, Majmū' Fatāwā (henceforth $M F$ ), ed. 'Abd al-Raḥmān b. Muhammad b. Qāsim (Riyad: Wizārat al-shu'ūn al-islāmiyya wa-al-awqāf wa-al-da'wat wa-al-irshād, 1995), vol. 11, p. 494. 
then that he can continue to become annihilated in the Prophet (fana $\bar{a}^{\prime} f \imath$ alrasūl), after which he will finally become susceptible to annihilation in God

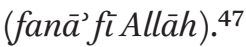

As for the special feats attributed to the Rifāīi shaykhs, al-Wāsițīs description of their special powers seems very much in line with the manner in which Aḥmad al-Rifăì's's status as a friend of God (sing. walī, pl. awliy $\left.\bar{a}^{\prime}\right)$ is portrayed by his followers. Al-Ahmadī, for instance, relates a discourse from al-Rifā̄ī himself about the rank known as the ghawth, the helper. He defines it as the station in which the friend of God has the power to freely dispose, forbid, and command atoms (maqām al-tașarruf wa-al-nahȳ wa-al-amrfì al-dharrāt), which is highly reminiscent of what certain Sufis associate with the technical term 'himma,' the creative power God grants His closest friends. ${ }^{48}$ The same discourse goes on to explain that every age knows a shaykh who is raised to this station and thereby becomes a representative of Muhammad on earth (näaib an an al$n a b \bar{\imath}) .{ }^{49}$ That al-Rifāì ì was actually referring to himself by this description is by no means left to speculation. He is quoted, saying: "Truly - and God be praised! - I possess this rank (martaba) and inherited the chain of this Muhammadan representation (al-niyāba al-Muhammadiyya). ${ }^{50}$ In a hagiographic tale, alFārūthī relates that, before al-Rifāììs birth, some of the greatest friends of God anticipated his coming and ordered their companions to follow him if they were to live long enough. They acknowledged that he would be the master of his age, which would be under his command and disposal, and that the power (dawla) would belong to him and his household (dhurriyya) until the Day of Judgment. ${ }^{51}$

His supreme position in the hierarchy of God's friends alluded to here is something all our Rifāīi authors explicitly agree on. It would surely have been

$47 \quad$ Ibid. pp. 122-123.

48 It is interesting to note that Najm al-Dīn Kubrā (d. 618/1221), the eponymous founder of the Kubrawiyya order, is responsible for a distinct interpretation of the term himma, which subsequently spread in Persia and Central Asia. In his doctrine, it is associated with a high spiritual rank of friendship with God wherein the friend of God has free disposal (tașarruf) and can thereby perform supernatural feats as he pleases. While it may appear problematic that the friend of God is gifted with a kind of spiritual control in the physical world, which seemingly blurs the line between God and servant, it is argued that the ultimate source of this power is God. For a good overview of the theory behind this term in the works of several Sufis, see: Lloyd Ridgeon, 'Aziz Nasafi (Richmond: Curzon, 1998), pp. 159-165, and also Annemarie Schimmel, Mystical dimensions of Islam (Chapel Hill: University of North Carolina press, 1975), p. 257.

49 Al-Aḥmadī, Ghanìmat al-farīqayn, pp. 8o-82.

50 Ibid. p. 82.

$5^{1} \quad$ Al-Fārūthī, al-Naf̣̣a al-miskiyya, p. 10. 
this conviction that led to the critical importance of his persona to the lives of his followers, which induced al-Wāsițī to censure them as we have seen. They would call al-Rifầì by the honorific 'Abū al-Alamayn,' literally 'the father of the two distinguishing marks,' which al-Rāfi'ì and al-Ṣayyād explain as referring to his attainment of both the station of the ghawth and the qutb, the latter signifying the spiritual axis and the leader of the friends of God. ${ }^{52}$ This certainly puts in perspective al-Ṣayyād's statement that it is obligatory for every Rifāì faqir to know the rank of their founding shaykh, because for them the spiritual path and the shaykh were intertwined, and hence two sides of the same coin. ${ }^{53}$

Another aspect of al-Rifā'ì's high spiritual rank that we find repeated in all the works of our Rifā'i shaykhs is his genealogical link to the family-line of the Prophet Muhammad. Al-Fārūthī's Naf̣̣a has no other purpose but to demonstrate that al-Rifā'ī was part of the Prophetic genealogy. ${ }^{54}$ In his Irshād he tells us that the cloak of initiation of the Banū Rifā'a is thence called 'khirqat Ahl al-Bayt,' the cloak of the Prophetic Household, because al-Rifā'î's Sufi genealogy (silsila) consists entirely of descendants of the Prophet. ${ }^{55}$ Likewise, alAhmadì and al-Rāfi'i both give us the complete silsila of their shaykh, with the latter adding that there was once a man who had disavowed its authenticity, only to affirm it after Fāțima, the Prophet's daughter, rebuked him for that in a dream. ${ }^{56}$ It is because of this claim to genealogy that al-Ṣayyād devotes several pages in his Sufi manual to love for the Ahl al-Bayt, which he considers a re-

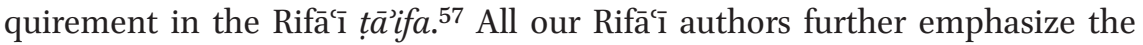
profound relationship between al-Rifā̄ī and the Prophet by relating a miracle (karāma) that would have occurred during the shaykh's visit to Medina when performing his hajj. It is said that when he greeted the Prophet with the words "peace be upon you my grandfather," the Prophet replied to his greeting, saying "and peace be upon you my son." When the Prophet then stretched out his hand from the grave, al-Rifā'i kissed it. ${ }^{58}$ In combination with his genealogical connection, his followers' belief that such this-worldly and physical contact with the Prophet actually occurred would not only have affirmed his high spiritual rank to them, but also his exceptionally close affinity to the Prophet.

\footnotetext{
52 Al-Rāficī, Sawād al-'aynayn, pp. 15-17; al-Ṣayyād, al-Ma'ārif al-Muḥammadiyya, pp. 6o-62.

53 Al-Ṣayyād, al-Måāifif al-Muhammadiyya, p. 31.

54 Al-Fārūthī, al-Nafḥa al-miskiyya, pp. 4-7 and p. 13.

55 Al-Fārūthī, Irshād al-muslimìn, p. 37 and p. 73.

56 Al-Aḥmadī, Ghanìmat al-farīqayn, pp. 19-24; al-Rāfì̄i, Sawād al-'aynayn, p. 4.

57 Al-Șayyād, al-Ma'ārif al-Muhammadiyya, pp. 26-31.

$5^{8}$ Al-Ṣayyād, al-Ma'ārif al-Muhammadiyya, p. 59; al-Rāfìī, Sawād al-'aynayn, pp. 10-11; alAḥmadī, Ghanìmat al-farīqayn, p. 25; al-Fārūthī, Irshād al-muslimìn, pp. 88-9o and p. 165.
} 
Undoubtedly related to this affinity is what may be seen as Shi'ite inclinations in the early Rifā'ì order. Both al-Fārūthī and al-Aḥmadī state that al-Rifā'ī was the greatest friend of God after the Prophet's Companions (șahāba) and the twelve Imams of the Prophetic family-line (a'immat al-älal-ithnay 'ashar). ${ }^{59}$ We also find al-Fārūthī stating that one shaykh once had a dream in which the Prophet said to him: "My son Ahmad [al-Rifā̄ī] is the thirteenth Imam of guidance from my Household (Ahl Baytī)." Obviously aware of the Shi'ite connotation, al-Fārūthī adds that every knower of God ('ārif) affirms the twelve Imams, who were themselves knowers, although not in the sense of those who assert that they were infallible. ${ }^{60}$ This remark is, of course, directed at the way the Shi'ites view the Imams. High regard for the twelve Imams in our sources is not necessarily surprising, as the possible influence of Shi'ism on Sufism in this particular context has been noted before. In his chapter on religion under the Mongols in Iran, Allesandro Bausani speaks of "Sufism with a Shi'i tinge" as the most important religious feature of this context. ${ }^{61}$ While the Rifāi ì sources cited above seem to support Bausani's observation, we must at the same time be careful not to underestimate the importance of the Ahl al-Bayt in Sunni tradition, especially in the Sufi orders, where we frequently find that silsilas are traced back to the Prophet's cousin and son-in-law, 'Alī b. Abī Taalib.

In any case, al-Wāsiți too speaks of Shi'i tendencies in his critical account of the Rifāiyya. He brings this up in relation to the ța $i f a$ 's practices surrounding the visitation (ziyāra) of the Rifāì mausoleum in Umm 'Ubayda:

When I was a child, they would take me to visit the mausoleum (ziyanrat qubba) of the shaykh [Ahmad al-Rifāì], traveling by mount to the village in which he is buried (that being Umm 'Ubayda). Whenever the

59 Al-Aḥmadī, Ghanimat al-farīqayn, p. 25; al-Fārūthī, Irshād al-muslimīn, pp. 106-107.

6o Al-Fārūthī, Irshād al-muslimīn, p. 106.

61 Bausani, "Religion under the Mongols," p. 547. Éric Geoffroy likewise states that Sufism in the Turco-Persian world of our context contained crypto-Shi'ite influences, cf. Le soufisme, p. 66. Another example of the influence of Shi'ism on Sufism can be found in the works of the seventh-/thirteenth-century Transoxanian Sufi 'Azìz Nasafì. Although coming from a Sunni background, there are clear influences of Isma'îlism in his Persian writings. The concept of the twelve Imams is hinted at in what he quotes from his own shaykh, Sacd-alDīn-e Hammūya (d. 65o/1252) of the Kubrawiyya order, who stated that there can only be twelve friends of God (awliy $\left.\bar{a}^{\prime}\right)$ in the Muslim community; see: Hermann Landolt, "Nasafi, 'Aziz." EIr. Lloyd Ridgeon remarks that while some scholars have thus considered Nasafi a sort of Shi'ite Sufi, none of the Shi'ite tendencies in his writings are convincing enough to put forth such a claim (Ridgeon, 'Aziz Nasafi, pp. 190-195). The same, of course, goes for the Rifāiiyya: while we may discern matters that could have been influenced by Shi'ite theology, I have not come across anything in my study of our sources that would in any way imply a strong Shi'ite element in the țăiifa. 
mausoleum came in sight, they would uncover their heads and implore [God] and supplicate [Him], and sometimes they would also cry and weep. Their hearts would become tender and they would pray for their needs. Then, when coming to the gate of the shaykh's mausoleum, they would uncover their heads and prostrate on its threshold, and I, in my youthful innocence, would prostrate with them. They would stand still at its gate in a state of humility for a long time - and God knows that they do not attach such great importance to the Ka'ba as they do to the mausoleum of the shaykh! But whenever they would see the mausoleum of the shaykh, who would have the courage to enter it? In fact, among them are some who had reached a venerable age, who have no notion of what is inside the mausoleum! There is also a column in the convent (riwāq), and they would circle around this column seven times. ${ }^{62}$ Thus, standing still (wuqūf) at the gate of the mausoleum is like 'Arafa and this column is like the Ka'ba, so that it becomes like a pilgrimage ( ajjj $\left.^{a n}\right)$ to them, in the same way as the Rāfida [i.e. the Shi'ites] perform pilgrimage to the grave of Ḥusayn! ${ }^{63}$

Al-Wāsitị goes on to write that it was related to him about one of their shaykhs: "that he would enter a state of ritual consecration (ihrām) whenever the mausoleum came in sight and that he would divest himself of his tailored garments so that he could enter the village [Umm 'Ubayda]. He would reach the aim of his ziyāra and then release himself from his state of ihrām." ${ }^{\prime 4}$

Of particular interest here is how he compares the practices of the Rifäis during ziyāra with the hajj pilgrimage. Although none of the Rifāì sources describe these particular acts of entering the state of ihrām, wuqū f, and țawäf, it is known that in some places of the Muslim world the practice of ziyāra did indeed closely follow the hajj rituals, and may have occasionally functioned as a substitute for the hajj. ${ }^{65}$ While this is not necessarily something that is peculiar to Shi'ites, it is also true that the ziyāra of shrines constituted an integral part of Shi'ite practice, especially when it came to the grave of Husayn, the grandson of the Prophet. ${ }^{66}$ However, our Rifāī sources make no mention of a particular set of rituals that ought to be practiced upon visiting the mausoleum, so it is

\footnotetext{
62 The act of circumambulating the Ka'ba, țawäf, is one of the rituals during the Muslim pilgrimage (hajj).

63 Al-Wāsiṭī, Rihlala, p. 20.

64 Ibid. p. 21. Note that the state of ihrām is a legal requisite to perform hajj.

65 See for instance Josef W. Meri, The Cult of Saints Among Muslims and Jews in Medieval Syria (Oxford: Oxford University Press, 2002), pp. 135-138.

66

Ibid. pp. 140-141.
} 


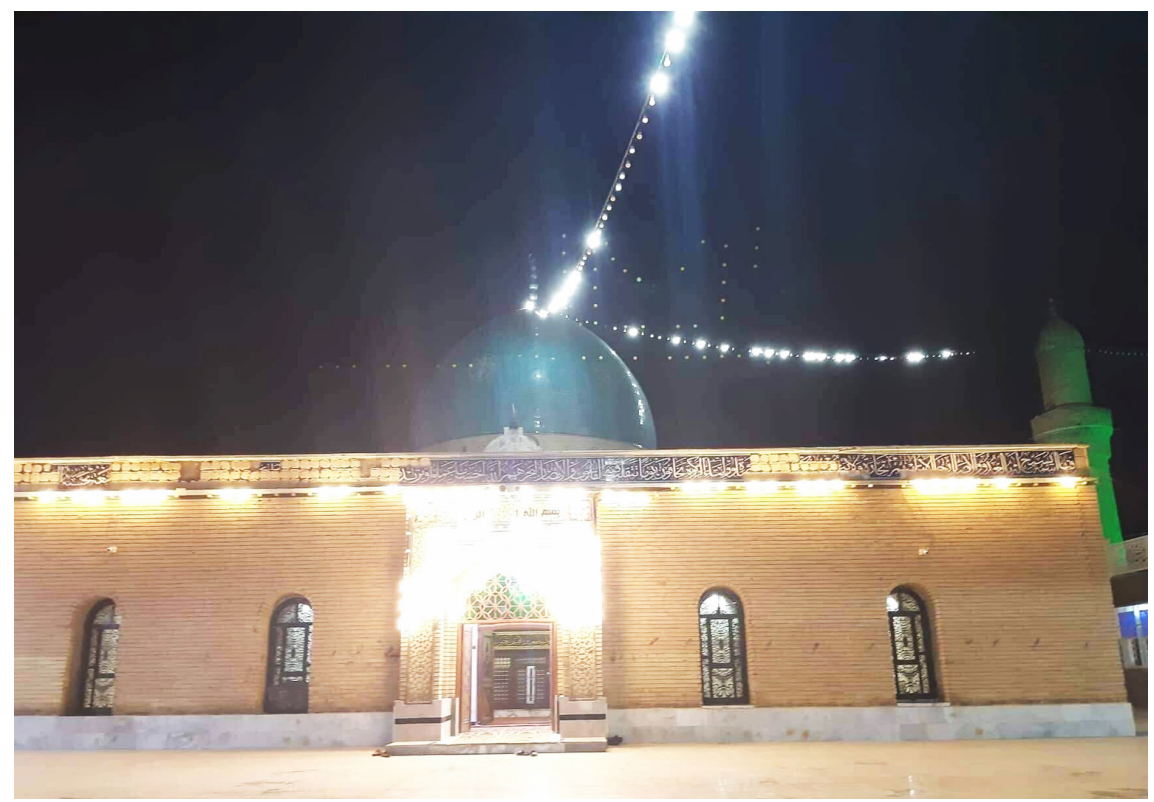

FIGURE 4 The current-day mosque that contains the Rifāề mausoleum in Umm 'Ubayda. (C) AHMAD MAHDI SALIH

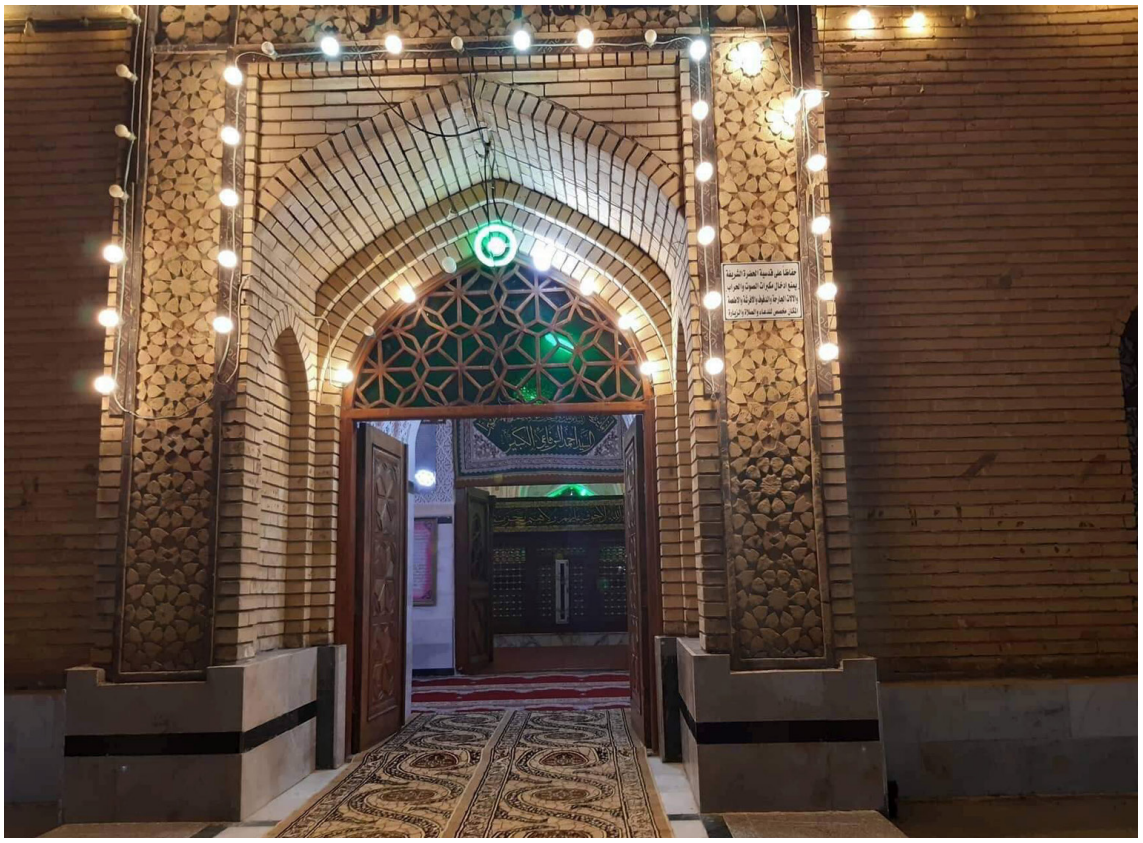

FIGURE 5 The entrance to the mosque of Aḥmad al-Rifāì̄.

(C) AHMAD MAHDI SALIH 


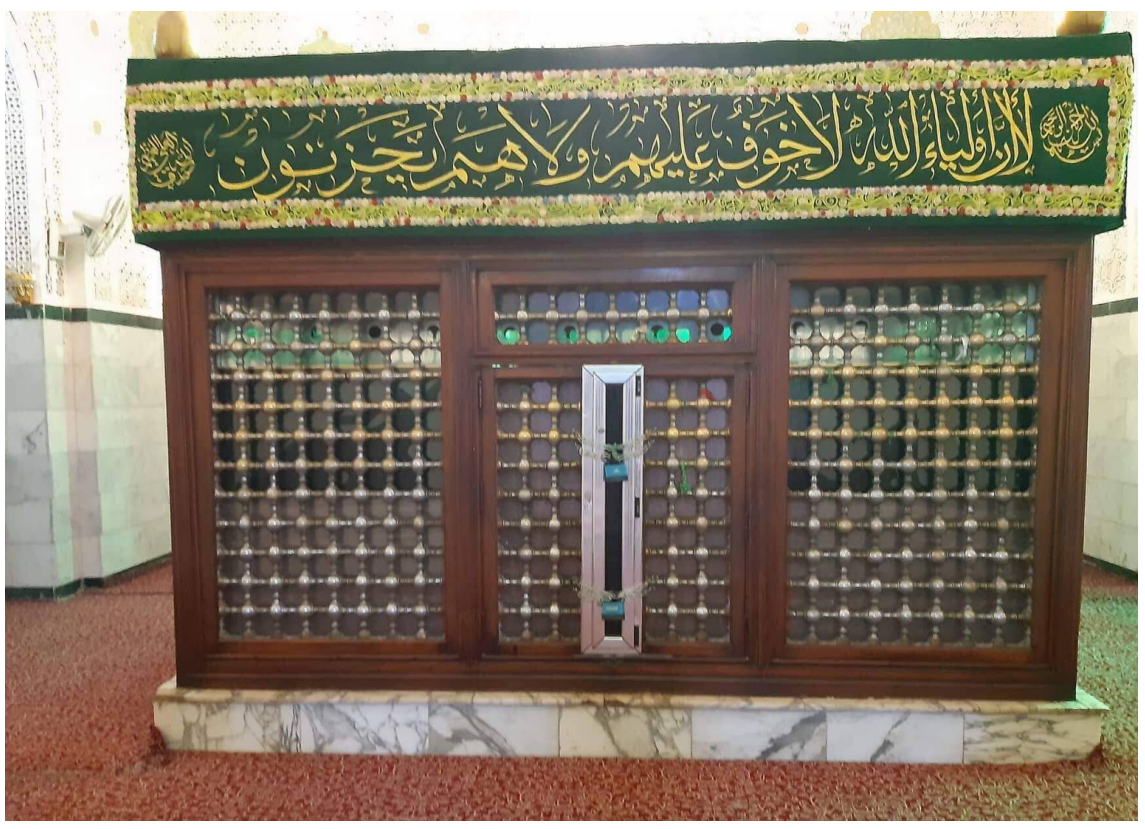

FIGURE 6 The mausoleum of Aḥmad al-Rifāīì.

(c) AHMAD MAHDI SALIH

impossible to judge how far al-Wāsitî's observations were standardized customs in the order.

What his observations do tell us, and what is corroborated by our other sources, is that the shaykh continued to play an important role in the lives of his followers after his death as an object of ziyāra. They would hold festivals (sing. mawsim, pl. mawāsim) in honor of al-Rifāìi, which would start on Thursday evenings, and went hand in hand with public sama $\bar{a}^{c}$ gatherings, on which more shall follow in the next section. ${ }^{67}$ We find an anecdote in that regard from al-Fārūthī, who describes how his father took him to Umm 'Ubayda in $622 / 1225$ for the Rifāì festival, al-mawsim al-Aḥmadī, when he was eight years old: 68

A room in the convent (riwāq) was specially assigned for my father. Groups of people and lovers (muhibbün) had erected huts and tents

$67 \quad$ Note that in Islamic tradition the next day starts after the maghrib-prayer, which is in the evening, so that technically, the mawāsim started on Fridays. That is because, so al-Sāyyād also explains, a tradition of the Prophet relates that every Friday is a day of feast ( ${ }^{i} \bar{l} d$ ), cf. al-Ṣayyād, al-Ma'ārif al-Muhammadiyya, p. 89.

Al-Fārūthī, Irshād al-muslimìn, p. 90. 
around Umm 'Ubayda so that the desert, the villages, and the fields became filled with pilgrims (zuwwār). On Friday they opened the noble mausoleum and tomb of Ahmad [al-Rifāīi], and thousands and thousands of people came to perform the visitation (ziyāra) ${ }^{69}$

While possibly an overestimation, Ibn Battetuta too claims that thousands of people were at the riwā $q$ when he went to Umm 'Ubayda to visit the mausoleum. ${ }^{70}$

We generally do not know exactly what the customs were when people visited the tomb of a pious man or woman in medieval Muslim societies. ${ }^{71}$ Nevertheless, several scholars have shown that it was not uncommon to implore the deceased individual to mediate with God, a practice referred to in Arabic by such terms as tawassul, wasilla, and istighātha. ${ }^{72}$ It is highly likely that the purpose of visiting al-Rifāī was to seek such mediation, and perhaps also that of his successors, all of whom were buried in the same mausoleum. ${ }^{73}$ That tawassul was practiced by the Rifāiss is corroborated by al-Ṣayyād, who gives a detailed account of the manner in which this ought to be performed. He explains that the faqï should be in a state of ritual purity, pray two cycles of prayer, praise the Prophet, and then turn himself to the direction of Umm 'Ubayda. He goes on to relate a lengthy prayer that should then be directed towards al-Rifāìi, which contains abundant lines of praise for the shaykh and ends with a plea for his help. ${ }^{74}$ We must bear in mind that al-Ṣayyād does not specifically connect this to the act of ziyāra, and that neither the other Rifāīi authors nor alWāsiți make mention of anything of this sort. But the mere example of al-Ṣayyād's description of tawassul combined with the fact that we know of its existence as a custom in many different contexts of the Muslim world at that

\footnotetext{
69 Ibid. p. 91.

$70 \quad$ Ibn Batțūța, Rihla, vol. 2, p. 9.

71 Boaz Shoshan, Popular Culture in Medieval Cairo (New York: Cambridge University Press, 1993), p. 22.

72 For examples of scholars who discuss the ziyāra of tombs and seeking the intercession of pious individuals, see for the Mamluk context: Meri, The Cult of Saints, in particular chapter 3; and Christopher Schurman Taylor, In the Vicinity of the Righteous: Ziyāra and the Veneration of Muslim Saints in Late Medieval Egypt (Leiden: Brill, 1998), in particular chapter 4. See also Geoffroy, Le soufisme, p. 372; for an example of its existence in the context of Iraq, see for instance Makdisi, Ibn 'Aqil, pp. 209-212.

The line of succession of shaykhdom in the riwāq of Umm 'Ubayda consisted solely of descendants of al-Rifāīi all of whom were all buried there as well. Appendix 1 on p. 68-69 gives the line of shaykhs of the Rifā'iyya up to the time of al-Fārūthī.

Al-Ṣayyād, al-Ma'āîf al-Muhammadiyya, pp. 112-114.
} 
time makes it plausible to assume that this was done by visitors of the Rifầ mausoleum as well.

\subsection{Rifā̄ic Practice: Samā' and Miracle-Working}

We have thus far seen that the shaykh, and in particular the $t \bar{a}$ 'ifa's founder, played a central role in the Rifāiyya: in life as the highest worldly and spiritual authority on earth, and after death as an object of ziyära and, presumptively, intercession as well. The fact that Rifā'ì sources substantiate much of al-Wāsițìs overall descriptions, be it directly or indirectly, shows that his outlook on the $t \bar{a}$ if $a$ can indeed be of historical value, albeit with due caution. With that in mind, we may now address the tă 'ifa's sama $\bar{a}^{c}$ gatherings and miracle-working, two intertwined central elements of Rifāè practice in which not only its shaykhs would have partaken, but also the generality of its followers.

The practice of $s a m \bar{a}^{c}$, which may be translated as 'audition' or 'spiritual concert,' is a ritual that is not easily defined due to its various manifestations. The Swiss scholar Fritz Meier rendered it as "musikhören," which he described as a session wherein Sufi poems are recited by singers, often accompanied by specific musical instruments, meant to bring about a rapture in listeners that arouses rhythmic movement which the Sufis call dancing (raqs). ${ }^{75}$ Although $s a m \bar{a}$ ' is not necessarily synonymous with the ritual of $d h i k r$, the remembrance of God, the two are connected with each other in the majority of the Sufi orders, as Meier also noted. When it comes to the early Rifā'iyya this was most likely the case as well. Our sources can be found referring to samā' and $d$ hikr interchangeably, which gives the impression that they were not necessarily differentiated from each other. ${ }^{76}$

Below we will continue reading al-Wāsițìs autobiography and focus on the way it illustrates how among the Rifāciyya a public samā' gathering could evolve into a spectacle of miraculous feats. Since it is, above all, al-Sayyād's manual that elaborates extensively upon this aspect of the țäifa in a section on the Rifāì festival (mawsim), we shall use some of the details found therein to complement the account of al-Wāsiți in order to sketch a more complete image.

Our Iraqi Sufi commences by describing what a $s a m \bar{a}^{c}$ congregation in the Rifāiiyya looked like as he witnessed it during his youth. It would be made up of both men and women, among whom would be Rifāî̀ shaykhs, reciters and

75 Fritz Meier, "Der Derwischtanz: Versuch eines Überblicks," Asiatische Studien 8 (1954): pp. 122-124.

76 Ibid. pp. 133-135. Meier actually states that this is particularly the case for the Shādhiliyya, but also for many other Sufi groups, among which he also counts the later Rifāiiyya. For the distinction between dhikr and samăc, see also Geoffroy, Le Soufisme, pp. 407-408. 
singers of Sufi poems, and people holding banners. ${ }^{77}$ That banners were actually carried during such gatherings is confirmed by al-Ṣayyād, who identifies this as a characteristic custom of the order. According to his Sufi manual, this is based on the tradition of the Prophet's Companions who would carry banners during the lesser struggle (al-jihäd al-aṣghar) - the military campaigns to fight the enemies of Islam - and thus the fuqara $\bar{a}$ carry them during the greater struggle (al-jihād al-akbar) - the spiritual combat against the ego (nafs). ${ }^{78}$

The account of al-Wāsitị goes on to mention that upon reaching the location of the $s a m \bar{a}$, the women in the gathering would be placed in the vicinity around the circle of men, so that their faces could be seen in the background. ${ }^{79}$ This is very much problematized by al-Wāsitị, who recapitulates the issue of women in the țẩifa several times in his autobiography. His main complaint in that regard revolves around the interaction between women and men, especially the shaykhs, which, in his view, poses a serious threat to Islamic morality. He adds that this also applies to the handsome young boy (al-șabi al-jamīl), whom he puts in the same category as women when it comes to the correct moral restrictions between sexes. While he gives examples of (intersexual) interaction among the Rifāīs that may not seem too serious, such as women and boys merely sleeping in the same house as the shaykh, or massaging his feet to obtain blessings, he also recounts instances where such contact had grave consequences, such as pregnancy from fornication $(z i n \bar{a}) .{ }^{80}$ As would be expected, we find nothing explicit about this in the works of our Rifāi authors. There is, however, a chapter in al-Fārūthī's Irshād that discusses some of the slander that was apparently directed at the ță iffa's founder. Here we do find an example of a complaint about al-Rifāi that reached the caliph of Baghdad in 550/1155: "they said [to the caliph] that he [al-Rifāis i] gathers men and women in the same circle (halqa) to remember God." ${ }^{81}$ Upon hearing this, the caliph sent someone to spy on their dhikr gatherings. When his servant returned, he reported that he had become deeply convinced that al-Rifāī actually holds fast to the Sunna, and that the complaints about him were false accusations, motivated by envy. ${ }^{82}$ Whether al-Wāsițīs allegations of fornication are true or not,

77 Al-Wāsițī, Riḥla, p. 19.

78 Al-Ṣayyād, al-Ma'ärif al-Muhammadiyya, p. 89. This concept of the greater and the lesser jihād in Islamic tradition is based on a hadith, in which the Prophet is related to have made this distinction. For a study of this phenomenon, see for instance: David Cook, Understanding Jihad (Berkeley: University of California Press, 2005), chapter 2.

79 Al-Wāsițī, Riḥla, p. 19.

8 o Ibid. p. 21 and p. 23 .

81 Al-Fārūthī, Irshād al-muslimīn, p. 81.

82 Ibid. 
this shows that it was possibly customary for the țāiffa to openly have women attending their dhikr gatherings together with men.

Besides mentioning that there would be music and dancing (raqș), al-Wāsiți discloses little more about the actual rituals of the $\operatorname{sam}_{\bar{a}}^{c} .^{83}$ Al-Ṣayyād, however, provides some details in that regard that may be of interest to us in order to understand the ța $\vec{a}^{\prime} i a^{\prime}$ 's theory behind it. The beating of drums (dufüf) that was common during the gatherings, for instance, is justified by him as a permissible act (mubāh $)$ according to the Shāfici school of jurisprudence. He explains that, according to the Sufis, this practice contains two deeper secrets: it brings about a state of happiness with God, and it raises the spiritual aspiration (himma) of the seeker. ${ }^{84}$ The actual raqs is something that al-Rifā' 1 is said to have linked to the practice of a group of angels that dance and remember God under His Throne. Hence, the knowers of God dance during their remembrance as well. When they do so, their spirits (arwāhn) are with God and for God, which is contrasted with the hypocritical Sufi, who dances for himself and by himself. It is thus upon the faqir to dance with the spirit rather than the body, for when he truly remembers God, he will also be remembered by Him. ${ }^{85}$ That the $s a m \bar{a}^{c}$ and the raqș were not undisputed in scholarly circles is clear from the fact that al-Ṣayyād quotes from al-Rifāī that if your ecstasy (wajd) and your goal (qașd) are false, and you only remember God by the tongue, you will surely be like those whom the "veiled" jurists (al-fuqahä' al-mahjübūn) rightfully mock when they say "the fuqarä' dance!" 86

While the dance is certainly reprimanded by al-Wāsițī, it is the supposed supernatural abilities that the $s a m \bar{a}^{c}$ would generate in some of its participants that bother him the most. He gives a vivid example of this in the following passage:

When the $s a m \bar{a}$ ' is being performed, those among them who reach a state of bewilderment turn to snakes, which lay prepared in bags. They pull them out and gnaw on them out of their own free will (qadm al-khiyār), so that [the snake's] blood streams around the corners of their mouths.

83 Al-Wāsițī, Rị̣la, p. 17.

84 Al-Ṣayyād, al-Ma ārif al-Muḥammadìyya, p. 89.

85 Ibid. p. 82.

86 Ibid. p. 83. Note that the critical attitude of some jurists when it comes to $s a m \bar{a}^{c}$ and the raqs was by no means exclusively directed at the Rifāiiyya, but at the practice in general. This was already the case in the time of the Malāmatī Sufi Abū 'Abd al-Rahmān al-Sulamī (d. 412/1021), who wrote the earliest treatise in defense of $s a m \bar{a}^{`}$ and raqs, which attests to the existence of and debate about the ritual in his time already. On this, see: Kenneth Honerkamp, "Abū 'Abd al-Rahmān al-Sulamī (d. 412/1201) on Samā' Ecstasy and Dance," JHS, 4 (2003): pp. 1-13. 
They subsequently blow this out over the people, claiming that it transforms to saffron and fruit in their mouths! I have seen among them someone who eats frogs, which he puts in his pockets before the $s a m \bar{a}^{c}$. Then, when the ritual is in process, he pulls one out and nibbles on it! There is no one who reproaches them for this, neither among our jurists, nor among our pious. Instead, we have come to view these innovations (bida $)$ as a well-known custom and an evident trademark [of the țăi ifa]. ${ }^{87}$

That such feats were actually performed by Sufis of the Rifấiyya is attested to in several other historical works from around the epoch that concerns us. A description that is very similar to al-Wāsițīs is found in the Rihla of Ibn Batțūtạ, who writes that he had witnessed how Rifā̄i fuqarā’ bit off snakes' heads and danced and rolled in fire during one of their sama $\bar{a}^{c}$ gatherings he attended. ${ }^{88}$ Earlier sources reveal a similar image. It is related from Sibṭ Ibn alJawzì (d. 654/1256) that the followers of al-Rifāī were known to ride on wild animals, play with snakes, and climb in palm trees to let themselves fall from a great height without feeling any pain. ${ }^{89}$ Because it is often cited by later Muslim historians, al-Rifāî̀'s entry in the Wafayāt of Ibn Khallikān (d. 681/1282) is also noteworthy. He mentions that the shaykh's followers experience strange states $(a h w \bar{a} l)$, such as eating live snakes, walking through fire, and that it is said that they ride lions in their country. ${ }^{90}$ It can thus be concluded with some certainty that a kind of thaumaturgy indeed existed, at least in some instances of the $t \bar{a}$ iffa's practice of $s a m \bar{a}$.

It is, then, all the more surprising that of all the works by Rifāi shaykhs I examined, I only found al-Ṣayyād explicitly treating this subject. He actually describes miracle-working as an inherent part of Rifāīi rite. During the festivals (mawāsim), he explains, the fuqarä' may display manifestations of their elevated spiritual states, which occur due to the temporary suspension of natural laws (khawāriq). This ability emanates from the blessing (baraka) of al-Rifāīi himself, he says, because all miraculous feats performed by his followers are graces that God bestows onto him. And since the charismatic powers of the

$87 \quad$ Al-Wāsiṭī, Riḥla, p. 19.

88 Ibn Bațūța, Rihla, vol. 2, pp. 9-10.

89 As quoted by Muhammad b. Tahyāa al-Tādhifî (d. 963/1556) in Qalāìd al-jawāhir fì manāqib tāj al-awliy $\bar{a}^{\prime}$ wa-ma'din al-asfiyà' wa-sulțān al-awliyā' al-shaykh Muhyū al-Dīn 'Abd alQādir al-Jīlānī, ed. Aḥmad Farīd al-Mazīdī (Beirut: Dār al-kutub al-'ilmiyya, 2010), p. 314.

9o Shams al-Dīn Abū al-'Abbās Aḥmad Ibn Khallikān, Wafayāt al-a'yān wa-anbā' abnā’ alzamān. Ed. Iḥsān 'Abbās (Beirut: Dār al-șādir, 1968), vol. 1, p. 172; al-Dhahabī, for instance, copies this description in his Tārīkh, vol. 40, p. 255, as does 'Abd al-Hayy Ibn al-Imād alḤanbalī, Shadharāt al-dhahab fì akhbār man dhahab, ed. Maḥmūd al-Arnā’ūt (Damascus/ Beirut: Dār Ibn Kathīr, 1986), vol. 6, pp. 427-428. 
friends of God (karāmāt al-awliya $\bar{a}^{3}$ ) are in reality the miracles (mujizāt) of the Prophet Muhammad, they all have their precedent in Islamic tradition. Hence, al-Ṣayyād continues, being able to fall from a high place or enter a fire has its precedent in the Prophet Abraham, who was unaffected when he was thrown into a fire by Nimrod; drinking poison or recovering from injuries has its precedent in the Prophet Muhammad, who miraculously bore such tribulations; and riding lions has its precedent in 'Abd Allāh b. 'Umar, the Companion of the Prophet who was known to have pulled a lion by the ear to remove it from a road it was blocking. ${ }^{11}$ This shows that, at least from the point of view of the Rifāī branch of al-Ṣayyād, these practices were commonly accepted and that they were justified by connecting them to examples from Islamic tradition.

As we shall see in the next paragraph, there is reason to question the presence of such thaumaturgy in the earliest manifestation of the order. It is nonetheless probable that it had become something typical of their sam $\bar{a}^{\prime}$ gatherings by the time of al-Wāsitịis youth. This is confirmed by an anecdote of the latter's own shaykh in figh, al-Fārūthī, wherein he describes a samā'session he attended in the convent of Umm 'Ubayda. This was led by the last grandshaykh of the Rifāciyya he would live to see, Shams al-Dīn Muhammad b. 'Abd al-Rahīm alRifāì (d. 704/1305), whose reputation he says was well-known in Wāsiṭ. He then praises his miracle-working and recalls the following example:

He started a circle of remembrance (halqat al-dhikr) in the courtyard of the riwāq. As he reached a state of ecstasy, he pushed a column made of polished stone that was halfway in the ground. He removed it from its place with his hand after which he shattered it to pieces, [even though] this was something that twenty men would not be able to lift! ${ }^{92}$

It is interesting to note that this anecdote proves a point made by al-Wāsițī in his autobiography, namely, it was not only the common people who would attend such meetings of the Rifāiyya, but also reputable Muslim scholars. Men of knowledge, he argues, should actively fight such baseless innovations as

$91 \quad$ Al-Ṣayyād, al-Macāî al-Muhammadiyya, p. go. For this particular story of Abraham in Muslim tradition, see for instance Muhammad Ibn Jarīr al-Ṭabarī, The History of al-Tabarī. Volume II. Prophets and Patriarchs, trans. William M. Brinner (Albany, N.Y.: State University of New York Press, 1987), pp. 58-61. For the episode of Muhammad's poisoning, see again al-Ṭabarī, The History of al-Tabarī. Volume VIII. The Victory of Islam, trans. Michael Fishbein (Albany, N.Y.: State University of New York Press, 1997), pp. 123-124. For the story about 'Abd Allāh b. 'Umar confronting a lion, see for instance Kamāl al-Dīn Muḥammad b. Mūsā al-Damīrī, Hayāt al-ḥayawān al-kubrā (Beirut: Dār al-kutub al(ilmiyya, 2010), vol. 1, p. 11.

Al-Fārūthī, Irshād al-musliminn, p. 223. 
practiced by the Rifāiss. But instead they actually support and participate in them. Ironically, it is here that we find the only instance where he refers by name to the most distinguished teacher he had in Wāsiț:

The great hadith-scholars among their followers and adherents, such as 'Izz al-Dīn al-Fārūthī, attend their sama $\bar{a}^{`}$ gatherings. I [once] came to him when I was still an adolescent and said to him: "the Prophet (Ș) said that every newly invented thing is an innovation. Then what is the status of this samā?" It took him a while to answer me and this did not please him. The farthest his piety would extend to was to dislike having the $s a m \bar{a}^{c}$ in a mosque. But sometimes he [himself] attended it in the mosque, in covert dissimulation..$^{93}$ [ [personally] saw him in a mosque in which a $\operatorname{sam} \bar{a}^{c}$ was being held. So this is the state of the shaykhs and hadith-scholars? Now how can the Muhammaddan truth and the religion that separates truth from falsity exist among such people?! In fact, how can it be explained and taught, not to speak of spreading it and making it triumph?!94

\subsection{Depictions of the Rifā 'iyya: Antinomians or Mainstream Sufis?}

The common thread of al-Wāsiți’s autobiography has thus far led us through some of the Rifāiiyya's distinctive features he observed during his early years as an adolescent among them. He finishes his account with a conclusion that reiterates much of what we have already seen. He blames the Rifā'is for introducing the traveler on the Sufi path $(a l-s \bar{a} i r)$ to innovations such as relations with women and young boys, sleeping with them, grabbing live snakes, stepping into fire, and participating in $s a m \bar{a}^{c}$ gatherings. ${ }^{95}$ Such things exist among them, he argues, because the țäifa originated among shaykhs of the bațäih marshlands: "It is a fact that whenever city folk follow peasant shaykhs of the country (mashāyikh al-barr al-fallähinn), even if they are friends [of God] (awliy $\vec{a})$, their religion becomes corrupted and their state of affairs is altered. That is because idiocy (qillat al-aql) is evident among the countryfolk, and God did not sent a Prophet who belonged to them, nor to the desert Arabs!"96 The city folk's state of affairs, he continues, can therefore only be adjusted by following trained scholars ('ulamāo $) \cdot{ }^{97}$ In conclusion, he writes that he subsequently distanced himself from the Rifāiiyya in order to focus on the study of jurisprudence.

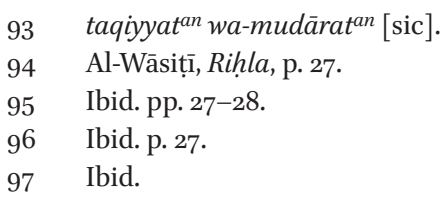


If we reflect on what drove al-Wāsiți's negative depiction of the Sufi order, it may be argued that this principally revolved around the way he came to delineate the proper boundaries of Sufism. This did not have to do with Sufism as such, as he clearly accepts it as an integral part of Islam. It was rather a matter of defining what constituted normative Sufism and what did not that gave rise to his critical views. As we have noted before, this was probably largely due to his individual study of Sufi manuals, which would soon be complemented by the study of God's commands and prohibitions when he turned to the jurists ( fuqahà) of Wāsit. As he explains in his autobiography, he then came to realize that there should be an equilibrium between the science of jurisprudence, the outward dimension of Islam, and the science of Sufism, the inward dimension of Islam. It was, in short, his realization that the Rifāiyya were lacking in their regard for the law that drove him to question their Sunni credentials.

When we consider the success of the țẳifa in Wāsiṭ and the marshlands, this raises important questions for our understanding of Sufism in the context of Ilkhanid southern Iraq. First, why does it appear from the sources that the Rifā̄īs were not widely contested by Wāsiț's Muslim scholars, whom one would assume to have functioned as the local custodians of Sunni normativity? Our study has already shown that the opposite was rather the case, namely, many Shāfici 1 fuqah $\bar{a}^{\prime}$ were themselves members of the Rifā'ì order and that it was apparently even difficult to express criticism about its practices. When elaborating on his study under the local jurists, we find al-Wāsițī confirming once more that he met fuqahä’ who were themselves members of the Rifā'iyya: "The remarkable thing is that I found among them some who firmly believe in this group [the Rifāiiyya] and who, in spite of their religious knowledge, call to the deviation of their way."98 If this was the case, and al-Wāsițîs critical attitude can thus be seen as an exception rather than the rule, could we then consider the Rifāiiyya as an example of what constituted normative Sufism in the context of seventh-/thirteenth-century Wāsit and its surroundings?

This does not appear to be the dominant view among scholars of Sufism, many of whom have portrayed the Rifāiiyya as a Sufi order that advocated extreme asceticism, and whose followers could occasionally be described as "heterodox" and "antinomian." In most instances, such depictions are probably based on the way the order is described by medieval Muslim historians, of which we have made note above. ${ }^{99}$ However, such an approach completely neglects the reception and position of the țăiff in its early Iraqi context.

98 Al-Wāsițī, Riḥla, p. 3 o.

99 See for instance: Denis Gril, "Esotérisme contre hérésie: 'Abd al-Rahmân al-Bistâmî, un représentant de la science des lettres à Bursa dans la première moitié du Xve siècle," in 
A few scholars have actually opted that the Rifāis is were probably more mainstream than some have made them out to be. Karamustafa has argued that, although their thaumaturgy may appear to clash with the scholastic norms of Muslim jurists, in general they do not seem to have deviated from social convention. Therefore, he says, they should not be counted among such world-renouncing Derwish groups as the Qalanders, the Haydaris, and the Abdāls of Rūm, whose radically ascetic, antinomian, and antisocial practices were the product of what he calls "deviant renunciation." Instead, he considers the Rifā'iyya order the product of "institutional Sufism," the scholastic Sufi tradition that revolved around mild asceticism and the cult of saints, and which gradually gave rise to well-organized brotherhoods. ${ }^{100}$ Reuven Amitai relies heavily on Karamustafa's two categories of deviant renunciation and institutional Sufism, and likewise rejects the assumption that the Rifāiyya were by definition Sufis of the antinomian kind. ${ }^{101}$ While both scholars thus bring a nuance to the biased depictions of the Rifầiss, their respective studies lack the textual evidence to support their shared thesis. It is here where our analysis of al-Wāsițī and the Rifāilyya may be of particular value and offer new insights into the țấifa's position in relation to its local trend of normative religiosity.

It is true that a certain method of renunciation, or zuhd, must have formed an integral part of the $t \bar{a} i f a$. However, it is difficult to establish with certainty how this was given form in their daily lives. Al-Fārūthī relates that the method (țarīq) of al-Rifāīi is characterized by lowliness (dhull), submission (inkisār), poverty (maskana), neediness (iftiqār), humility (khud̄uc), and helplessness (hayra), and that no other path to God will be greater and more difficult. ${ }^{102} \mathrm{We}$ find a similar set of terms to characterize the $t \bar{a}$ 'if $f$ 's method in the works of

Syncrétismes Et Hérésies Dans L'Orient Seljoukide Et Ottoman (XIVe-XVIIIe Siècles): Actes Du Colloque Du Collège De France, Octobre 20or, ed. Gilles Veinstein (Paris: Peeters, 2005), p. 191; Schimmel, Mystical Dimensions, pp. 248-249; David S. Margoliouth, "al-Rifā̄̄ī, Ahmad b. 'Ali," in $E I^{2}$ : vol. 8, pp. 524-525; J. Spencer Trimingham, The Sufi Orders in Islam (New York: Oxford University Press, 1998), pp. 37-40; Knysh, Islamic Mysticism, p. 210; Richard Gramlich, Die Wunder der Freunde Gottes: Theologien und Erscheinungsformen des islamischen Heiligenwunders (Stuttgart: Steiner Verlag Wiesbaden, 1987), pp. 229-300; Geoffroy, Le Soufisme, p. 210.

100 Karamustafa, God's Unruly Friends, pp. 55-56, and pp. 90-100.

101 Reuven Amitai uses this argument to prove that the conversion of the Mongols did not occur because antinomian Sufis had so many similarities with Shamanism. He convincingly shows that it were rather the moderate establishment mystics who contributed to spreading Islam among the Mongols, and he considers the Rifā̄is to be an example of this, see: "Sufis and Shamans: Some Remarks on the Islamization of the Mongols in the Ilkhanate," JESHO 42 (1999): pp. 38-40.

Al-Fārūthī, al-Nafha al-miskiyya, p. 10. 
al-Rāfi'ì, al-Ahmmadī, and al-Ṣayyād. ${ }^{103}$ This image of world-renunciation as the order's method is also confirmed in several biographical dictionaries of medieval authors who had no affiliation with the țäiffa. The Mamluk historians alSubkī and al-Dhahabī both cite an almost identical saying of al-Rifāìi in which he reportedly says: "I have not seen a shorter, easier, and more sound path [to God] than lowliness, neediness, and submission to the magnificence of God's command ..."104 While this suggests that it may have been a common notion that Rifāi i doctrine was built on renunciant ideals, this does not mean that the fuqara $\bar{a}$ were required to reject sharîa-law and cut themselves off from society. Indeed, al-Ahmadì quotes from al-Rifā'i that zuhd is not to eat badly or dress coarsely, but rather to rid your heart of this world. ${ }^{105}$ Several sources also give the impression that being in the service of the fuqara $\bar{a}$, physically and financially, and establishing a deep sense of altruism may have also been characteristic of Rifā'i renunciation. ${ }^{106}$ None of these elements seem to be of a particularly antinomian nature.

It may very well be that the ța iifa had a more sober approach to Sufism than some scholars have thought, at least in its earliest manifestation. This notion is only reinforced by the considerable effort all our Rifāi ì sources put into vouching for the Sunni credentials of their order's eponymous founder. On many occasions they can be found depicting the Rifāi order as the path of the Qur'an and the Sunna, and al-Rifāi $\overline{1}$ as the most knowledgeable scholar in that regard..$^{107}$ Al-Rifâ'î's spiritual routine is also portrayed as a sober set of practices, consisting of spiritual seclusion (khalwa), the frequent remembrance of God (dhikr), and sending prayers and blessings upon the Prophet. He would reportedly order his pupils to read the Qur'an often, perform supererogatory (nawäfil) and nightly prayers (qiy àm al-layl), and recite the țāiffa's litanies every day. He forbade excessive sleeping, eating, and being overly occupied with matters that

103 Al-Rāfi'ì, Sawād al-'aynayn, p. 19; al-Ahmadī, Ghanīmat al-farīqayn, p. 68; al-Ṣayyād, alMa'āif al-Muhammadiyya, p. 84.

104 Shams al-Dīn Muḥammad b. Aḥmad al-Dhahabī, Siyar a ‘ām al-nubalā’’ ed. Shu'ayb alArnā’ūṭ et al. (Mu’assasat al-risāla, 1985), vol. 21, p. 79; and very similar in al-Subkī, Țabaqāt al-shäficyya, vol. 6, p. 25 .

105 Al-Aḥmadī, Ghanimat al-farīqayn, p.66.

106 We have already seen al-Wāsițī characterizing the Rifāīi way thus above, when he describes his father. Ibn Fahd describes al-Fārūthī in a similar way: "He (R) possessed great altruism (ithār) - neither dirham nor dinar remained with him! I have been told that a merchant, known as Ibn al-Suwayqī, would send him a thousand dinars each year, but that he would be rid of it in the shortest time, spending it [all] before it was even obtained for the sake of the fuqarā' and the brethren." Cf. Ibn Fahd, Lahz al-alhäz, p. 61.

107 Al-Rāfi'ì, Sawād al-'aynayn, p. 11 and p. 14; al-Ahmadī, Ghanimat al-farīqayn, p. 51, pp. 110111, and p. 125; al-Ṣayyād, al-Ma'ārif al-Muhammadiyya, p. 116. 
are allowed according to Islamic law (mubāhăt), something that shows he would have had a deep respect for the sharita. ${ }^{108}$ On the other hand, when confronted by an innovation (bid'a) or anything that contradicts the revealed law, they all describe al-Rifā̄i as a particularly harsh adversary. He is thus quoted in all our sources as refuting philosophy and the concepts of divine indwelling $(h u l \bar{u} l)$ or monism (ittihā $d)$. These things, he reportedly said, are a disease of the spiritual path because they threaten the affirmation of God's absolute unity (tawhìd), which is the cornerstone of faith. ${ }^{109}$ In matters of creed (itiqād) we even find al-Rifāī taking a somewhat traditionalist stance, where he is quoted as follows by al-Ṣayyād: "The people closest to heresy are the would-be Sufis (mutașawwifa) who are distracted from worshipping God by entering into discussions (kalām) about the divine essence (dhāt) and the divine attributes (șifāt)."110 In such matters, al-Ṣayyād claims, he preferred to abstain from any form of interpretation (tafsir $).{ }^{111}$

There is perhaps a certain irony in the fact that the image of al-Rifấi as a scholastic and sober Sufi shaykh is more or less confirmed by many medieval authors who could themselves at times be critical of the Sufi order. ${ }^{112}$ Even Ibn Taymiyya and al-Dhahabī, both of whom were particularly harsh towards contemporary Rifā'i Sufis, come to the defense of the order's eponymous founder. Al-Dhahabī holds that corruption only entered the țăi ifa after the Mongol conquest of Iraq, which gave birth to satanic states among its followers, such as entering fire, riding lions, and playing with snakes. He believed that the ță if $a^{\prime}$ s founder and the righteous among his followers are innocent of these matters. ${ }^{113}$ Ibn Taymiyya, too, acknowledges that many innovations only entered the Rifā' $\overline{1}$ order after the death of its founder. ${ }^{114}$ The Sufi biographer Jāmī expresses a

108 While mubāhāt are allowed, there is a carefulness in Islamic law with such matters, due to the fear that they may eventually lead to matters that are forbidden, cf. al-Fārūthī, Irshād al-muslimin, p. 102; al-Ahmadī, Ghanimat al-farīqayn, p. 6o.

109 Al-Rāfīì, Sawād al-'aynayn, p. 28; al-Ahmmadī, Ghanimat al-farīqayn, p. 49, pp. 94-95, and p. 135; al-Ṣayyād, al-Macāî al-Muhammadìya, p. 64; al-Fārūthī, Irshād al-muslimīn, pp. 100-101.

110 Al-Ṣayyād, al-Máāirif al-Muḥammadiyya, p. 3.

111 Ibid. pp. 4-5.

112 See for instance: Șalāḥ al-Dīn Khalīl al-Ṣafadī, al-Wâfí bi-al-wafayāt, ed. Ahmad al-Arnāūūt \& Turkī Mușțafā (Beirut: Ḍar ị̣yā̄ al-turāth, 200o), vol. 7, p. 143; Ibn Kathīr, al-Bidāya, vol. 12, p. 382; al-Subkī, Țabaqāt al-shāficiyya, vol. 2, p. 5; Ibn al-'Imād, Shadharāt, vol. 6, p. 427 .

113 Shams al-Dīn Muḥammad b. Aḥmad al-Dhahabī, al-Tbar fì khabar man ghabar, ed. Abū Hājar Muḥammad al-Sa'īd b. Basyūnī Zaghlūl (Beirut: Dār al-kutub al-'ilmiyya, 1985), vol. 3, p. 75 .

114 Ibn Taymiyya, $M F$, vol. 111, p. 494. 
similar opinion in his entry on al-Rifấi ${ }^{115}$ In that regard it is worthwhile adding that while our Rifāìi sources certainly attribute several miracles to their grandshaykh, they never relate the kind of thaumaturgy that had apparently became customary during the order's samā' gatherings at the time of al-Wāsițì's youth. There may thus be some truth to the notion that such miracle-working as we have described above was only later incorporated into the tă $a f a$, though it remains impossible to say what may have caused this shift based on the current study. ${ }^{116}$ If this is indeed what happened, then it becomes all the more interesting that the incorporation of new practices into the Rifāiiyya apparently did not lead to much controversy in and around al-Wāsiț̣̄s hometown.

Whatever the case may be, our study here exemplifies how deeply notions of normative religiosity depend on context. If, as some scholars have seemingly done, we paint an image of the Rifā'is on the basis of biased depictions of their medieval Muslim critics alone, this would indeed lead us to believe that we are dealing with a somewhat controversial Sufi order. However, by looking at the position of the Rifā̄is in their bastion of the Iraqi marshlands and Wāsit, one gets the impression that their practices apparently did not cross the boundaries of local conceptions of normativity. Comparing the works of our Rifā'i authors with al-Wāsițī's account of the ță $i f a$ has proven a useful tool in that regard. For in spite of al-Wāsitị̂s effort to explain in polemical terms how the Rifā'iyya deviated from his conception of normative Sufism, he has provided us with descriptions that have been of great value for our overall analysis of the order's position in its early local context. On the basis of our study of these sources we can conclude that Rifāī Sufism was in all likelihood generally regarded as perfectly normative in Wāsit and its surroundings, and could even be seen as the dominant trend of Sufism there.

\section{Al-Wāsițīs Final Years in Iraq}

While al-Wāsițī implies that it was essentially his frustration with the Rifāiyya that convinced him to leave Wāsit for good, a desire to seek knowledge with the jurists and Sufis of Baghdad may have also played a role. It must be noted that his autobiography never explicitly mentions that he actually migrated to the Iraqi capital, although it does contain a brief section on his involvement

115 Nūr al-Dīn 'Abd al-Rạ̣mān b. Aḥmad al-Jāmī, Nafaḥāt al-uns min ḥaḍarāt al-quds, ed. Muḥammad Adīb al-Jādir (Beirut: Dār al-kutub al-'ilmiyya, 2003), vol. 2, p. 709.

116 Geoffroy and Morgoliouth have both argued that thaumaturgy indeed entered the order later, perhaps one or two centuries after the death of its founder, Geoffroy, Le Soufisme, p. 210, and Margoliouth, "al-Rifä $\bar{\imath}$ " vol. 8, pp. 524-525. 
with a circle of Baghdadi Sufis. ${ }^{117}$ It is through the Hanbali biographer Ibn Rajab that we know he started studying Shāfi'i figh in Wāsiț, and then traveled to Baghdad to continue his studies under a group of Shāfi îs there. ${ }^{118}$ His description of the jurists he accompanied can therefore be taken as his general impression of them, and not as particular to Wāsit or Baghdad. In the following pages we will continue with a study of his account of them and the Baghdadi Sufi circle he joined.

\subsection{The Sober Shäfí Iurists}

In al-Wāsițī's days, his native town was still a metropolis of some repute in the field of Muslim learning. Its scholars were especially known as masters of qira'ät, the different styles of Qur'anic recitation. ${ }^{119}$ As in the rest of Iraq, the majority of Wāsiț's jurists were probably Sunnis who followed either the Shāfi'i or the Ḥanafì school. The Hanbalī school, which al-Wāsițī would switch to upon settling in Damascus, may also have had some following. Since the death of its founder, Ahmad Ibn Hanbal (d. 241/855), Baghdad had been the capital of Hanbalism, but the Mongol conquest had struck a severe blow to its overall influence in Iraq. ${ }^{120}$ In theology, the Ash'arī school appears to have been widely represented and, albeit to a limited degree, facilitated philosophical discussions within their formulation of normative Sunni theology. ${ }^{121}$ The Shi'ites were still very much a minority group in this context.

Because al-Wāsițī's father was a Shāfi'ì, it was only natural that he followed the same madhhab. Of the several madrasas known to have existed in Wāsit, there was one dedicated solely to Shäfi'i figh in the city's east, which may very

\footnotetext{
117 Al-Wāsițī, Rị̣la, p. 31.

118 Ibn Rajab, Dhayl, vol. 4, p. 381.

119 Bosworth, "Wāsiț," pp. 8o-81.

120 The Shāfīi and Ḥanafì madhhab were already the dominant schools in Iraq during the Seljuq period, and continued to be so in the century that followed. The Ilkhan Oljeitü (r. 703-716/1304-1316) was known to support them until he became tired of the constant arguments between adherents of the two schools, cf. Bausani, "Religion under the Mongols," pp. 543-544. Since the death of its founder, Ahmad Ibn Hanbal, Baghdad had been the main center of Hanbalism. Thanks to the pro-Sunni policy, the school's influence thrived under the last caliphs of the Iraqi capital, but collapsed after it was conquered by the Mongols, cf. Laoust, "Le Hanbalisme," pp. 116-121. Bosworth remarks that Wāsiṭ was a "predominantly Sunni city, with a strong Ḥanbalī element in it," cf. Bosworth, "Wāsiț," p. 85, and see also: Alessandro Bausani, "Religion in the Saljuq Period," in cHIr v: pp. 283-284. While it is difficult to judge in how far this was really the case, we do find several examples of Hanbalīs who traveled to Wāsit to study Qur'anic recitation, see: Ibn Rajab, Dhayl, vol. 3, p. 126, p. 362, and p. 55o, and vol. 4, p. 21.

121 Hodgson, The Venture of Islam, Volume 2, p. 323; Bausani, "Religion in the Saljuq Period," p. 285 .
} 
well have been attended by al-Wāsițī when he decided to study jurisprudence. ${ }^{122}$ It is difficult to say exactly how far he delved into the discipline. He does relate a list of the most prominent books from which his masters would quote when discussing fiqh-issues (sing. mas'ala, pl. masä'il), which may indicate that he reached a certain degree of proficiency in the Shāfi'i tradition. He names alTanbīh and al-Muhadhdhab, both by Abū Isḥāq Ibrāhīm al-Shirāzī (d. 476/1083), al-Wajīz and al-Wasịt, both by Abū Hāmid al-Ghazālī (d. 505/1111), al-'Azìz fì

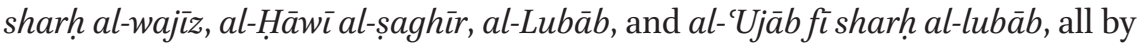
Najm al-Dīn 'Abd al-Ghaffār al-Qazwīnī (d. 665/1266), and al-Muharrar, by alRāfi 'î, whom we have already come across as a member of the Rifā'iyya. ${ }^{123}$ Several classical sources confirm that these works were indeed considered by many as some of the most celebrated figh-books in the madhhab around the period that concerns us. ${ }^{124} \mathrm{Al}-\mathrm{Wa}$ àiți states in his autobiography that he mainly devoted himself to jurisprudence because he had become convinced of the necessity of having intimate knowledge of God's laws. After all, so he tells us, it is thereby that one knows which deeds lead to God's reward and which deeds lead to His punishment. As he saw it, his switch to figh was "a light and a guide during dark times."125

But while he was initially pleased to be among a class of Muslims he considered superior to the Rifā'īs, he soon found himself disappointed once more due to their sole occupation with jurisprudence. His statement that "they are only concerned with fiqh, nothing else"126 in all likelihood alludes to their lack of concern for the inward dimension of Islam, that is, Sufism. He also hints at this in his Talqịh al-afhām, where he states that many righteous jurists may reach

122 This was Madrasat al-Barrāniyya; in his study on the schools of Wāsiț, Nājī Ma'rūf mentions that he found three different names of Shāfīi madrasas in the city: al-Madrasa al-Barrāniyya, Madrasat Khațlaburs, and al-Madrasa al-Sharābiyya. He argues that these were not three separate schools, but rather one and the same madrasa, whose name changed several times over the years. Cf. Nājī Ma'rūf, Madāris Wāsiṭ (Baghdad: Mațba't al-irshād, 1966), pp. 16-17. I have found very little about these schools, besides the mention of one Yahyyā b. 'Abd Allāh Abū Zakariyyā al-Wāsițī (d. 738/1337) who apparently studied under al-Fārūthī and later became a teacher at the Barrāniyya; see al-Subkī, Ṭabaqāt alshäfíiyya, vol. o1, p. 391. Al-Wāsițī, Riḥla, p. 29.

Al-Tanbīh, al-Muhadhdhab, al-Wajizz, and al-Wasiț, are mentioned by celebrated Shāficì jurist al-Nawawī (d. 676/1277) as the greatest masterpieces of Shāfíi jurisprudence, cf. Muḥyī al-Dīn Yaḥyā al-Nawawī, Tahdhīb al-asmā’ wa-al-lughāt (Beirut: Dār al-kutub al'ilmiyya, 1977), vol. 1, p. 3. 'Abd al-Ghaffār al-Qazwīnī was also an important authority in the madhhab, whose Hīwwi in particular was famed; see for instance: al-Subkī, Tabaqāt al-shāfíiyya, vol. 8, pp. 277-278; al-Dhahabī, Tārīkh, vol. 49, pp. 197-198; Yāfi'ī, Mir'āt, vol. 4, pp. 126-127. For al-Rāfiè's book, see al-Subkī, Tabaqāt al-shāficiyya, vol. 8, p. 281. 
outward steadfastness (istiqāma) but taste nothing of the works of the heart. Some of them, he adds, may even reject the inner-path altogether, thinking that all things beyond their outward knowledge are innovations (bida $\left.{ }^{\text {can }}\right) .{ }^{127}$ He thus concludes that, just as the Rifā'is were lacking in figh, the jurists were lacking in tasawwuf, so that the latter too did not offer him the religious balance he sought: "I remained with them for a period of time, being confined like a bird in a cage, only getting a breath of fresh air from the books of the Sufis!"128

Another aspect of the jurists' approach to religion he claims to have been critical of is their deep knowledge of figh-discussions, while neglecting the actual sources on which these are based, namely, the Qur'an and the Sunna. However, as with all the opinions he formulates in his autobiography, we must heed the possibility that he may have been projecting back on the past opinions that he only came to hold later on in his life as a Hanbali convert. As this could very well be the case here, we may assume that it was, above all, his desire for a balanced inward and outward experience of religion that was at the heart of his growing unease with the jurists.

The same goes for his supposed critical attitude towards their acceptance of ilm al-kalām as a legitimate Islamic science. Here too we are dealing with an opinion he probably held later on in his life after having been exposed to proponents of traditionalist theology, but not yet as a student of jurisprudence in Wāsiț. For although he seemingly shies away from admitting any direct affiliation with Ash'arism in his autobiography, he would surely have been exposed to the school's teachings there. It is, for instance, doubtful that he would not have studied any basic text of Ash'arī kalām with some of his shaykhs in figh. Most of them, if not all, ascribed to Ash'arism when it came to creed. This is evidently implied in his autobiography where he states that he found them particularly fond of Fakhr al-Dīn al-Rāzì (d. 606/1209), the celebrated Shāfíi Ash'arī theologian:

Among them are those who combine [the study of] the principles of jurisprudence (ușül al-figh) with the specialized vocabulary (iștilāhh) of [Fakhr al-Dīn] Ibn al-Khațîb [al-Rāzī], while venerating and magnifying him, affirming that he is the greatest Imam and one of the pillars of this religion. ${ }^{129}$

As for his own exposure to Ash'arism among the Shāfi'is, there is a short theological tract that he probably wrote in Damascus shortly before switching to 
the Hanbali school, wherein he hints at this. In it he explains that he reached a point where he was greatly confused about the theological doctrines that opt for a metaphorical interpretation of the divine attributes (șifāt) that are mentioned in the holy texts:

Among those who believe in these doctrines $(a q w \bar{a} l)$, or in some of them, there are people who have a standing in my heart, such as a group of the Shāfi'i jurists from among the Ash'arīs. That is because I follow the school of al-Shāfi'i $(\mathrm{R})$ and I learned the obligations and rulings of my religion [from them]. I found the likes of these venerable shaykhs believing in these kind of doctrines. But they were my shaykhs and I had complete faith in them due to their erudition and knowledge. ${ }^{130}$

So even though he would come to denounce the Ash'arīs completely, especially when he turned to Hanbalism, the above quote seems to suggest that, initially, he did not question their doctrine. This was simply what was being taught by his shaykhs, whom he clearly held in high regard, and for most of whom being Shāfí̄ and Ash'arī would have gone hand in hand. It is thus all the more likely that al-Wāsiți followed this example when he was still a young student.

\subsection{The Baghdadi Sufis}

As he felt increasingly discontent with what the jurists had to offer him in terms of religiosity, his switch to Baghdad may have felt as an opening to new prospects for his intellectual and spiritual hunger. From Wāsit it was an eightday journey to the capital of Iraq, which would have offered many opportunities to seek knowledge among the scholars and Sufis that the city housed so abundantly. ${ }^{131}$

It is here where al-Wāsiți entered a master-disciple relationship (șuḥba) amidst the aforementioned Sufis he calls muțāwi'at al-baghādida, which we may render as 'obedient followers of the Baghdadi Sufis.' This title likely indicates that they ascribed to the Baghdad school of Sufism. ${ }^{132}$ Although not ex-

130 Al-Wāsițī, Risāla fù ithbāt, p. 26.

131 Vasilii Vladimirovich Bartold, An historical geography of Iran, tr. Svat Soucek, ed. C. Edmund Bosworth (Princeton, N.J. : Princeton University Press, 1984), p. 203.

132 Al-Wāsiți, Rịhla, p. 31. For an explanation of the concept of șụ̣ba, see: Ohlander, Sufism, p. 28. Also note that I am aware that there did exist a Sufi order that was known by the name 'Muțāwi'a.' However, it is very unlikely that this is what al-Wāsițī is referring to, since this particular order was known to have flourished only between the fifteenth and eighteenth centuries in Egypt, as a branch of Ahmad al-Badawì's (d. 675/1276) Ahmmadiyya. They also appear to have been highly controversial, which does not exactly concur with the way al-Wāsițī describes them. On this Muțāwi'a, see for instance: Khaled El-Rouayheb, 
plicitly stated as such in his autobiography, we find proof for this in $Q \bar{a}$ ida $f_{\imath}$ așnāfal-ta'alluh, another short work of al-Wāsițī with several autobiographical passages:

The first path that I entered was the path of Sufism (tașawwuf) according to the spiritual presence of Sufis (rūhanniyyat al-șüfiyya) such as Junayd, Abū Sa īd al-Kharrāz, and their contemporaries. This was after [I had taken] the path of jurisprudence (figh) according to the school of al-Shāfi'ì, by which the details of the religious obligations and the Sunna are known. ${ }^{133}$

Here, he describes the branch of Sufism he became involved with after his study of jurisprudence as the path of Junayd (d. 289/910) and al-Kharrāz (d. ca. 286/899), two of the foremost representatives of the Baghdad school of Sufism. ${ }^{134}$ The word 'baghädida' in his autobiography is therefore very likely meant as a reference to those Sufi masters who represented this school. We may then assume that, although al-Wāsiți does not link the Sufis he accompanied in Baghdad to any particular țâi ifa, they likely identified themselves as belonging to this tradition.

Because al-Wāsiți presents us with very little information about them it is practically impossible to find additional material that may help us identify them. There is but one clue in his autobiography that tells us something more about their background, which is where he describes that

they venerate the [Sufi] shaykhs (al-mashāyikh), though not like the first group [i.e. the Rifāiiyya]. Nevertheless, there is among them a branch of that kind, who uncover their heads at the mausoleum of Ibn Idrīs and kiss its threshold - and I did this with them when I was a young man although they do not fall into the same filthy deeds [that the Rifāiyya do]..$^{135}$

Without doubt, the Ibn Idrīs mentioned here is Abū al-Ḥasan 'Alī Ibn Idrīs alRawḥā'ī al-Ba'qūbī (d. 619/1222) - sometimes misspelled as al-Ya'qūbī - a direct

"Heresy and Sufism in the Arabic-Islamic world, 1550-1750: Some preliminary observations," BSOAS, 73, (2010): pp. 361-362; Michael Winter, Society and religion in early Ottoman Egypt: studies in the writings of 'Abd al-Wahhāb al-Sha'rānì (New Brunswick N.J. etc.: Transaction Books, 1982), p. 104; Geoffroy, Le soufisme, p. 206. Al-Wāsițī, Qã̄ida fí aṣnāf al-tảalluh, p. 149.

134 For the Baghdad school of Sufism, see: Karamustafa, Sufism, on Junayd, p. 18, on al-Kharrāz, pp. 7-10.

135 Al-Wāsițī, Rihlala, p. 32. 
pupil of two renowned Baghdadi Sufi masters, the Hanbalī shaykh 'Abd alQādir al-Jīlānī (d. 561/1166), and the lesser-known shaykh 'Alī al-Hìtī (d. 564/1169). Now, Ibn Idrīs had a Sufi convent (ribāt t) in a village called Rawḥā', near the city Ba'qūba, which is a day's journey from Baghdad. As attested to in several historical sources, he was buried there in a mausoleum that was erected in his convent, and indeed became an object of ziyāra. ${ }^{136}$ The fact that alWāsiți only mentions his name in the section on the Baghdadi Sufis may be taken as an indication that they were affiliated with his silsila.

Nevertheless, this still leaves us with very little on the possible background of these Sufis. There is hardly anything to be found concerning the Sufi doctrine and legacy of Ibn Idrīs, let alone anything that points to a particular tă if that followed from his teachings. Since al-jīlānì was one of his masters in Sufism, it is very well possible that he was in some way at the outset of what could be identified as the earliest manifestation of the Qādiriyya order. Such a suggestion must be treated with great caution, however, since our knowledge of the early țẳifa is very scant. Al-Jīlānī himself may even have had little or nothing to do with its actual formation, and much of what would later be attributed to the Hanbalī shaykh was likely quite far from his actual teachings. ${ }^{137}$ It is of-

136 See: al-Dhahabī, Siyar, vol. 22, pp. 177-178; al-Dhahabī, Tārīkh, vol. 44, pp. 455-456; al-Tādhifì, Qalā’id, pp. 381-382; and for other references, see 'Umar Salīm 'Abd al-Q̨ādir Tall's study of Sufis in twelfth-century Baghdad: Mutașawwifat Baghdād:fíal-qarn al-sādis al-hijrì/al-thānī 'ashar al-mīlādī: dirāsa tārīkhiyya (Amman: Dār al-ma’mūn li-al-nashr wa-al-tawzī', 2009), p. 148.

137 Much work remains to be done when it comes to the critical study of al-Jīlānì's teachings and Sufi order. Jacqueline Chabbi has perhaps been most critical when it comes to alJilānì's role as a Sufi shaykh. She argues that the Hanbalī master should be viewed as the patron and not the founder of the Qādiriyya. She even goes as far as to state that al-Jīlānī ran a madrasa rather than a ribāt, and that his success was not due to his brilliance in the field of mysticism, but due to his ability to preach $(w a z)$, which is how fame was acquired in his times, so she argues. She concludes that he should therefore be seen as a man of his age who made good use of the opportunities that he found around him; see: "Abd alKâdir al-Djilânî, personnage historique," StI 38 (1973): in particular p. 76, and pp. 100-101. Some of the clearest cases where we find al-Jilānì's name connected to teachings that were not his own are the several books that are incorrectly attributed to him. Ibn Rajab only mentions al-Ghunya and Futūh al-ghayb as his authentic works (cf. Ibn Rajab's Dhayl, vol. 1 p. 248), and most other titles are likely dubious. Examples of inauthentic works are a tafsìr attributed to him, which contains explanations of God's attributes that contradict the traditionalist position, cf. al-jīlānī, Tafsìr al-jūlānī, ed. Aḥmad Farīd alMizyadī (Beirut: Beirut: Dār al-kutub al-ilmiyya, 2009), see for instance vol. 3, pp. 138-140, where God's sitting on the Throne (istiwa $\bar{a}^{\prime}$ ) is interpreted as His dominion (istilla $\left.\vec{a}^{\prime}\right)$, and vol. 2, p. 304 where the eye of God ('ayn) is interpreted as God's guard, proximity, or safekeeping. The same goes for the book Sirr al-asrār wa mažhar al-anwār (Dihlī: Kutubkhāna Ishā'at al-Islām, 1985), on pp. 81-83, where we find that only the Ḥanafī and Shāfi ī position with regard to special prayers are mentioned, and not the Hanbalī. That the fabulous tales attributed to the shaykh soon after his passing were not on the whole 
ten overlooked that al-Jilānī was in fact a true traditionalist in creed, and was considered the shaykh of the Hanbaliss in his time. Nonetheless, there is no reason to doubt Ibn Idrīs' șuḥba-relationship with al-Jīlānī, especially in consideration of his apparent Hanbalī leanings. Both Ibn Taymiyya and Ibn Rajab relate that Ibn Idrīs once asked al-Jīlānī whether there has ever been a friend of God (wali $)$ who followed a creed other than that of Ahmad Ibn Hanbal, to which the shaykh replied: "there never was, and there never will."138 It can hardly be a coincidence that the most distinguished pupils of Ibn Idris mentioned in the biographical sources were Hanbalīs from Baghdad. The fact that they all transmitted hadith from him as well only adds to his apparent appreciation for traditionalism. ${ }^{139}$ Among these pupils we find the Hanbali Sufis Abū Zakariyyā Yahyyā al-Ṣarșarī and 'Alī b. Sulaymān al-Khabbāz, both killed in 656/1258 fighting the Mongols from the latter's convent (zāwiya) in Baghdad. The Ḥanbalī jurist Kamāl al-Dīn 'Alī Ibn Waḍḍāh al-Shahrābābī (d. 672/1273), who was a friend of al-Ṣarșarī, also received the khirqa from Ibn Idrīs, but does not appear to have initiated disciples himself. ${ }^{140}$ Unfortunately, there is no way to uncover how the legacy of Ibn Idrīs' Sufi circle continued beyond the lives of these Hanbalīs.

undisputed is evident from Ibn Taymiyya and al-Dhahabī, both of whom clearly respected al-Jīlānī but were troubled by the legends that were erected around his persona; see: Ibn Taymiyya, Bughyat al-murtād fíal-radd 'alā al-mutafalsifa wa-al-Qarāmița wa-al-Bātininiyya ahl al-ilhāad min al-qā̉ilīn bi-al-ḥulūl wa-al-ittihâad, ed. Mūsā b. Sulaymān Duwaysh (Medina: Maktabat al-'ulūm wa-al-hiikam, 1995), p. 493, and al-Dhahabī, Tärīkh, vol. 39, p. 100.

138 Ibn Rajab, Dhayl, vol. 2, p. 20o. Ibn Taymiyya, Dar'ta'ārud al-'aql wa-al-naql, ed. Muhammad Rashād Sālim (Riyad: Jāmi‘at al-imām Muhammad b. Sacūd al-islāmiyya, 1991), vol. 5, p. 5, and also in his Kitāb al-istiqāma, ed. Muḥammad Rashād Sālim (Riyad: Jāmi‘at alimām Muḥammad b. Sacūd al-Islāmiyya, 1983), vol. 1, p. 85. That al-Jīlānī was a staunch advocate of the traditionalist creed is clear from the section on the divine attributes in his Ghunya, where he also dismisses 'ilm al-kalām and Ash'arism, see: al-Jīlānī, al-Ghunya lițālibì țarīq al-haqq 'azza wa jalla ( fì al-akhlāq wa-al-tașawwuf wa-al-adāb al-islāmiyya), ed. Abū 'Abd al-Raḥmān Șalāḥ b. Muḥammad Ibn 'Uwayḍa (Beirut: Dār al-kutub al-ilmiyya, 2007), vol. 1, pp. 121-127. It also appears to be hinted at in al-Fath al-rabbānī, a collection of discourses by al-jīlānī that was compiled by students, where we find the following quote from the shaykh: "the Lord is upon the Throne, as He said, with no question of anthropomorphism (tashbih), the negation of attributes (tat țil) or ascribing bodily form (tajsīm)." See: al-Fath al-Rabbānī wa-al-fayḍ al-raḥmānī. (Cairo: al-Maktaba al-azhariyya li-al-turāth, 2008), p. 86. On al-Jīlāni’s traditionalist theology, see also: Malik, The Grey Falcon, chapter 4.

139 For his role as a teacher of hadith, see for instance: Ibn Rajab, Dhayl, vol. 4, p. 32, p. 38, and p. 111.

140 For al-Ṣarșarī and al-Khabbāz, see Ibn Rajab, Dhayl, vol. 4, pp. 31-39. On Ibn Waḍḍāḥ, see Ibn Rajab, Dhayl, vol. 4, p. 111, and al-Dhahabī, Tārīkh, vol. 5o, pp. 102-103. 
We are thus completely at the mercy of al-Wāsițīs autobiography for our image of the Sufis he accompanied in Baghdad. Based on the above, we can only say that it is possible that he came in contact with adherents of the traditionalist creed in Baghdad - which, we should not forget, had since long been the Hanbalī capital - although he makes no mention of this anywhere. If this was indeed the case, he may (as he himself seems to claim) already have started to move away from Ash'arism in favor of traditionalism before migrating from Iraq.

Like with the Shāfi'ìs, al-Wāsițī's autobiography tells us that he was initially relieved to have found an approach to religion that seemed to quench his spiritual and intellectual thirst. He states that the Baghdadi Sufis were "a thousand times better than the previous two groups," for he found them upholding a much greater degree of balance in their religiosity. They pursued the Sufi path while being simultaneously conscious of God's law by adhering to the juristic schools (madhāhib al-fuqahä'). ${ }^{141}$ In his Qāंida fi așnāf al-ta'alluh, he provides some additional details about their approach to Sufism. He states that, unlike the jurists, they realize that the Muhammadan $\operatorname{sharit}^{-} a$ is useful for the masses ('awāmm) but that it is not enough to satisfy the burning desire (ihtirāq) of someone who truly seeks God. He expounds that their method is aimed at disciplining oneself through such practices as nightly vigilance, hunger, poverty, and relying only on God for one's provision. That way, he says, one can attain something of the traces of divine proximity (qurb), which manifest through the perception of certain attributes of God (sifāt). ${ }^{142}$

In spite of this, al-Wāsiți eventually became disappointed once more because of certain deviant traits (al-akhlāq al-munharifa) he claims to have perceived among them. Although their spiritual way may certainly lead to witnessing something of the Divine (shuhūd), he says, it is still cut off from the most complete spiritual reality he calls 'al-amr al-kulli.'143 He elaborates on what these deviant traits are in his autobiography, where he describes them as a people who wear patched Sufi cloaks (ahl dalūq wa-muraqqa'ātwa-sharāshị riq $\bar{a}^{c}$ ), hinting at their seemingly renunciant lifestyle, while in practice being mostly occupied with worldly desires (shahawāt), such as good food, befriending the rich, and obtaining donations from them. Like the Rifāciyya, he criticizes them for wasting their servitude of God ('ubüdiyya) with samā' gatherings, during which they skillfully dance but taste nothing of the Divine. ${ }^{144}$ It is worth nothing that, although there is little more to substantiate the possible link be-

\footnotetext{
141 Al-Wāsițī, Riḥla, p. 31.

142 Al-Wāsițī, Qā'ida fı́ aṣnāf al-ta’alluh, p. 15 o.

143 Ibid.

144 Al-Wāsițī, Riḥla, pp. 31-32.
} 
tween these Sufis and Ibn Idrīs, the latter's circle is known to have held sama $\bar{a}^{c}$ gatherings as well. ${ }^{145}$

The gist of his critique is that he found them striving to appear as Sufis, while not truly aspiring for the goal of the Sufi path, which is to reach a profound connection with God. In other words, he found that the means have become the ends in their practice of the science of tasawwuf. Now, it is unlikely that he had already formulated the borders of what constitutes traditionalist Sufism as he would come to do in Damascus. So just as with the Rifāiiyya, his critiques appear to have emerged from his own knowledge and understanding of Sufism which he took from the Sufi manuals he studied:

No one [among them] speaks of seeking arrival [unto God] (wușūl) at all, for this is a discipline that has diminished.... I associated with them, but their state did not please me. I knew through my instinct that the matter [I pursued] is superior to this, and I would only get a breath of fresh air from the books of the Sufis. ${ }^{146}$

Upon closing his account of Iraq, al-Wāsiți concludes that, looking back on his experiences thus far, he found all the groups he accompanied falling short in traveling the path unto God. People were either only focused on worship with no knowledge of God's law, on jurisprudence with no knowledge of the spiritual path, or on following a Sufi tradition without actually fulfilling its purpose.

But God (T) put intimate knowledge of Him (ma'rifa) and nearness to Him (qurb) in my heart, so that it became enraptured. I did not know the reality of what befell my heart, and could not find anyone who could guide me to what I was seeking, acquaint me with my medicine, or explain to me what this passionate love (haymān) was that befell me. Thus I remained bewildered and confused, unable to find stability, while my heart became depressed from all the groups that I accompanied and associated with. ${ }^{147}$

This, he tells us, occurred around the year 683/1284, when he must have been about twenty-six years old. It finally convinced him to leave Iraq in search of something better. He would never again return.

\footnotetext{
145 That Ibn Idrīs partook in samā' gatherings is hinted at in Ibn Rajab's Dhayl, vol. 3, p. 445. Ibn Rajab explicitly mentions that Ibn Idrīs' disciple, al-Ṣarșarī, did attend sama $\bar{a}^{c}$ gatherings in Dhayl, vol. 4, p. 34 .

146 Al-Wāsițī, Rị̣la, p. 32.

147 Ibid. p. 33 .
} 


\section{Appendix 1: The Line of Rifā̄̄ Shaykhs in Umm 'Ubayda and Wāsit}

\section{Umm 'Ubayda}

Aḥmad Abū al-'Abbās

al-Rifāàì (d. 578/1182)<smiles>C1CCCC1</smiles>

Sayf al-Dīn 'Alī b. 'Uthmān

al-Rifāī (d. 584/1188) $)^{149}$

Mumahhid al-Dīn 'Abd al-Rahīm

b. 'Uthmān al-Rifā̄ī (d. 6o4/1208) ${ }^{150}$<smiles>[Li][Ca]</smiles>

Muḥ̂̄i al-Dīn Abū Isḥāq Ibrāhīm al-A`zab al-Rifā̄ī (d. 6og/1212) $)^{151}$
Wāsit

'Izz al-Dīn Abū al-Faraj 'Umar b. Aḥmad al-Fārūthī al-Wāsițī (d. 585/1189) ${ }^{148}$

Muhỵī al-Dīn Abū Isḥāq

Ibrāhīm al-Fārūthī al-Wāsițī

\section{Shams al-Dīn Muhammad b. 'Abd}

'Izz al-Dīn Aḥmad b. Ibrāhīm

al-Rahīm al-Rifā̄ì (d. 629/1232) $)^{152}$ al-Fārūthī (d. 694/1295)

Abū al-Ḥasan 'Alī (nicknamed 'Abd

al-Muḥsin) al-Rifāī (d. 63o/1233) 153

Quṭb al-Dīn Abū al-Ḥasan 'Alī b.

'Abd al-Rahīm al-Rifāc̄̄ (d. 636/1238)'154

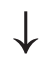

Najm al-Dīn Aḥmad b. 'Alī

al-Rifā̄ì (d. 645/1247) $)^{155}$

148 According to al-Fārūthī, his grandfather was granted the leadership of outward knowledge and the spiritual path in Wāsiț, cf. Irshād al-muslimīn, p. 236.

149 Aḥmad al-Rifāīì was his maternal uncle, ibid. p. 188.

150 The brother of his predecessor, Sayf al-Dīn, ibid. p. 191.

151 A Grandson of al-Rifācīi, ibid. pp. 194-195.

152 His predecessor, Muḥȳ al-Dīn, was his maternal uncle, ibid. p. 211.

153 The brother of his predecessor, Shams al-Dīn, ibid. p. 213.

154 Another brother to his predecessor, Ibid. p. 218.

155 Ibid. p. 220. 
$\downarrow$

Quṭb al-Dīn Aḥmad b. Shams al-Dīn

Muhammad al-Rifā̄ī (d. 670/1272) 156<smiles>[CH][AlH]</smiles>

Shams al-Dīn Muhạmmad b. 'Abd

al-Raḥīm al-Rifāīì (d. 704/1305) $)^{157}$

156 Ibid. p. 222.

157 He is the last successor mentioned by al-Fārūthī, ibid. p. 223 . 


\section{Scholastic Sufism of the Alexandrian Shādhiliyya}

\section{The Egyptian Context}

[Al-Wāsițī] performed the greater pilgrimage and joined a circle of [Shāfíī jurists] in Mecca. For a period of time he lived in some of the Sufi convents (khawāniq) in Cairo, where he [also] associated with circles of jurists. However, his heart was not reassured by anything of the modern [Sufi] groups (al-țawäif) [he found there]. He joined the Shādhiliyya group in Alexandria and found that they had what he was looking for, pertaining to gleams of experiential knowledge (ma'rifa), divine love (mahabba), and a method for the spiritual path (sulük). Hence, he acquired that from them and benefited from them, and followed their way and their guidance. ${ }^{1}$

Thus Ibn Rajab sums up a significant part of al-Wāsițīs life, which covers the moment he decided to leave Iraq to the years he spent in Egypt. I say significant because his experiences in Egypt would leave a lasting impression on him and strongly influence the writings he would later produce in Damascus. Both his association with the Alexandrian Shädhiliyya, the țầifa named after the Moroccan Sufi Abū al-Ḥasan 'Alī al-Shādhilī (d. 656/1258), and his time spent in Cairene Sufi convents, were essential components in the final shaping of his interpretation of Sufism. The current chapter is dedicated to his Alexandrian era, which we will again study through his autobiography and other relevant primary sources. Before we can do so, there are two issues regarding our source material that we must briefly address.

First, contrary to Ibn Rajab's account, al-Wāsițīs autobiography tells us that he actually joined the Shādhiliyya in Alexandria before he tried his luck in Sufi convents, with no mention of these being Cairene, or of Cairo at all for that matter. We can nevertheless assume that his account of the time he lived in Sufi convents concerns the period he spent in Cairo as related by Ibn Rajab above. In the following pages we will naturally follow the chronology provided by al-Wāsiți himself in his autobiography, and start with his description of the Shādhiliyya. We will turn to his Cairene days in the next chapter.

1 Ibn Rajab, Dhayl, vol. 4, p. 381. 
Second, the sources reveal practically nothing about the dates of al-Wāsițîs travels, so that it is impossible to say exactly how long he stayed where. Although our Iraqi Sufi himself makes no mention at all of Mecca, he may very well have stayed there for a considerable time. As we have seen, he left Iraq around 683/1284, and most likely entered Alexandria somewhere after 686/1287, the year in which Abū al-Abbās Aḥmad al-Mursī died. ${ }^{2}$ When alWāsiți made his switch from Alexandria to Cairo is also impossible to say, but we can make an approximate estimation of the year he left Cairo. In his Mukhtașar sìrat rasūl Allāh he states that he traveled for almost fifteen years, searching for the most sound pathway to God, until he finally found it in Damascus. ${ }^{3}$ Calculating from the approximate date he left Iraq, we can thus estimate that he was in Damascus around the year 698/1299. This is supported by al-Dhahabī's Tārīkh wherein we find that al-Wāsiți once met with the Sufi Badr al-Dīn Ḥasan Ibn Hūd, whom we know lived in Damascus, where he passed away in 699/130o. ${ }^{4}$ Hence, our Iraqi Sufi would had to have entered the Syrian capital some time before that.

With this estimated timespan we now commence with al-Wāsițīs Alexandrian years. This chapter is divided into two parts. The first part will provide contextual background to early Mamluk Alexandria, a city that is far too often neglected in the study of Sufism. The second part makes up the bulk of this chapter and focuses specifically on al-Wāsițịs account of the Shādhiliyya. The latter section will not only help us understand al-Wāsițīs own formulation of Sufism as studied in part 2 of this book, but also provide new details on the early Shādhiliyya.

\subsection{Stagnation and War}

Named after the Macedonian king Alexander the Great, the city of Alexandria (al-Iskandariyya in Arabic) had become part of the early Muslim empire under the second caliph, 'Umar b. al-Khaț̣āb. Almost seven centuries later, when alWāsițī reached the city, it was part of the Bahrī Mamluk domains, which roughly encompassed what is today Egypt, Syria, Lebanon, Jordan, and Palestine, and also controlled the Hijaz. In spite of Alexandria's relative prosperity in comparison with previous centuries, it was at that time in the process of losing its significance as a regional political and administrative center. It may,

2 Since al-Mursī had been the Shādhilī shaykh of Alexandria, and everything indicates that alWāsițī only got to meet al-Mursì's pupils, but never the shaykh himself, he probably entered Alexandria only after his passing.

3 Al-Wāsițī, Mukhtașar sīrat rasūl Allāh, Manuscript in Leiden University: Or. 482, f.2b.

4 Al-Dhahabī, Tārīkh, vol. 52, p. 401. Ibn al-'Imād, Shadharāt, vol. 7, p. 78o. On Ibn Hūd, see for instance: Kraemer, "The Andalusian Mystic," pp. 59-73. 


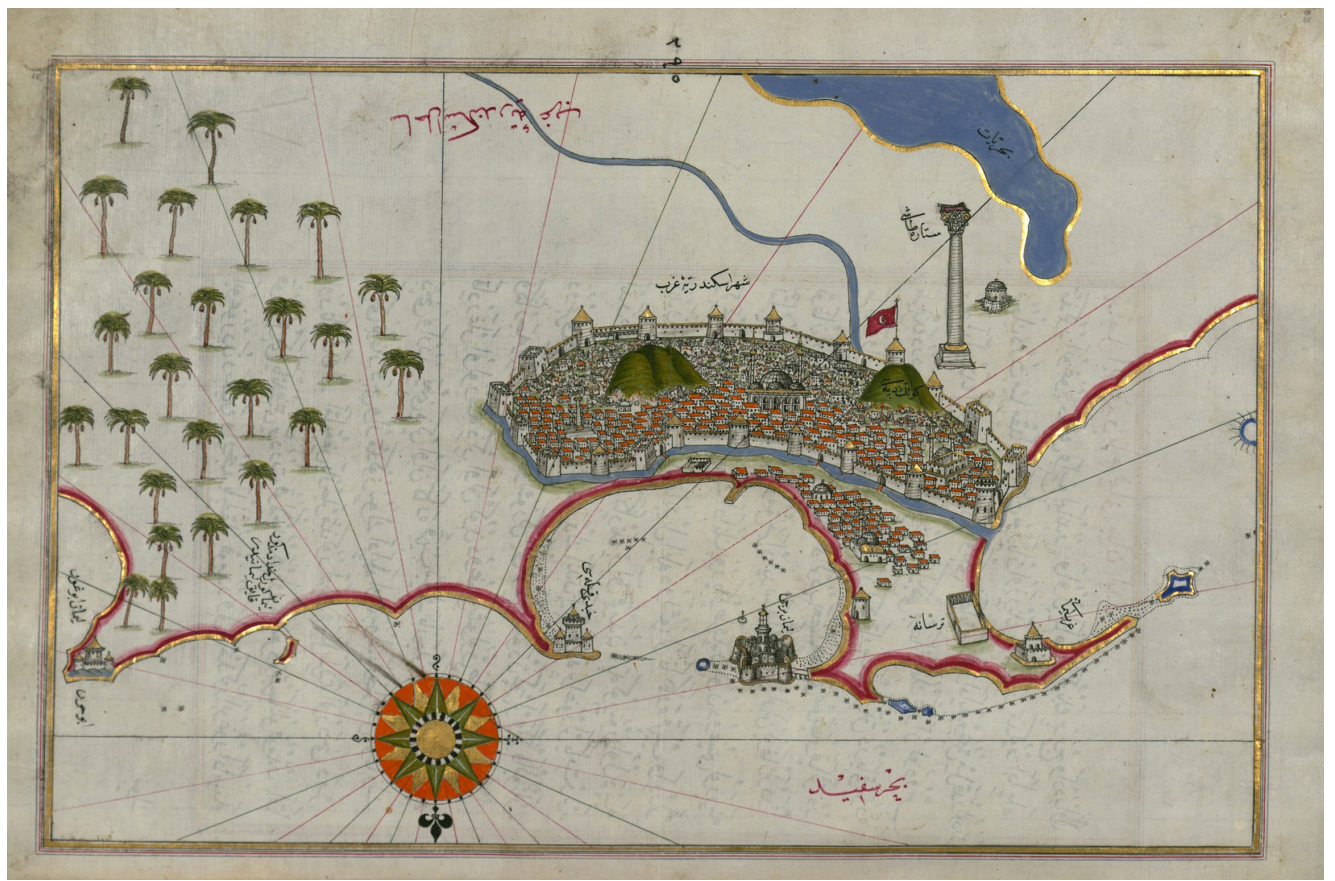

FIgURE 7 An Ottoman impression of Alexandria dating from 1525, Piri Preis, Kitāb-i Bahriye, W.658: f. 302A.

(C) THE WALters ART MUSEUM, Baltimore

then, come as somewhat of a surprise that during this very period of economic and institutional stagnation, the city was at the same time transforming into one of the most important centers of Sufism in Egypt. Since an understanding of this transformation will be of relevance to the current chapter, we will go through several historical developments that were at the heart of this matter, and thereby simultaneously provide the necessary context to al-Wāsițīs time among the Shādhiliyya.

Our Iraqi Sufi's journey into Mamluk lands probably went via the pilgrimage route from Baghdad to Mecca, and from Mecca to Alexandria, between which he may have passed through Cairo for the first time as well. ${ }^{5}$ Reaching Alexandria by land must have been an impressive sight. It is related that the white, massive walls that surrounded its old center made it appear as a bright shining city. Outside the walls there were several suburbs and graveyards to be found. Barren desert was not far away, but there was also fertile land around

5 For the pilgrimage routes, see: William C. Brice, An Historical Atlas of Islam (Leiden: E.J. Brill, 1981), p. 22. 
Alexandria, most notably to its south near Lake Maryūt, where one would find agricultural areas and recreational gardens. The city's southern gate, the Bāb al-Sidra, served as the main entrance through which travelers from Fusțât (Old Cairo) would enter. Inside the walls was the political center near the western gate, the Bāb al-Akhdiar. Commerce and industry was concentrated along the Mahajja avenue, which ran from the eastern gate, the Bāb al-Rashīd, to the city center. ${ }^{6}$ As we shall see, al-Wāsiți would probably have spent most of his time outside the walls in the northern quarter of Alexandria, which started from the sea gate, the Bāb al-Bahrr, to the city's northern extremity. There were ports on both sides of this quarter, with the western one catering to Muslim ships, and the eastern one to non-Muslim ships. Needless to say, as Alexandria's landing place for traders and merchants from many corners of the world, this was a multiethnic and multireligious environment. ${ }^{7}$ Organized in kinds of guilds, groups of merchants had their own warehouses, or funduqs, from where they ran their businesses. And business was good indeed. The merchants of Alexandria accumulated a great deal of wealth, to the extent that some families became true merchant dynasties. ${ }^{8}$

Now, one would expect that the city itself prospered tremendously under the booming business of these international traders. This, however, was not the case. As a gateway between the Middle East, the northern Mediterranean, and the Islamic occident, Alexandria was indeed of vital importance to the trade of Egypt. But that was precisely the problem; because Fusțāt had been transformed into the major marketplace of Egypt in this epoch, the country's maritime cities came to function as stops on the road to the center. Already from the Ayyubid period onwards, Alexandria's own interests were subjugated to those of the sultanate, so that its sole role became that of Egypt's major port city. As such, local interests were not only regarded as inferior to those of the sultanate, but even as potentially harmful to the prosperity of the capital. ${ }^{9}$

Through their respective studies of the Geniza documents, both Abraham L. Udovitch and Miriam Frenkel have provided exceptionally valuable

6 Doris Behrens-Abouseif, "Topographie d'Alexandrie médiévale," in Alexandrie médiévale 2, ed. Christian Décobert (Cairo: Institut Français d'Archéologie Orientale, 2010), p. 114,

7 Miriam Frenkel, "Medieval Alexandria: Life in a Port City," al-Masāq:Journal of the Medieval Mediterranean, 26:1, (2014): pp. 9-20, and p. 27. For a map of Alexandria that shows the locations of the several names mentioned here, see p. 77 .

8 Subhi Labib, R. Guest \& C. Edmund Bosworth, "Alexandria (al-Iskandariyya; in EI1, alIskandarìya)," in Historic Cities of the Islamic World, ed. C. Edmund Bosworth (Leiden/Boston: E.J. Brill, 2007), pp. 19-20, and Christian Décobert, "Alexandrie au XıIIe siècle: Une nouvelle topographie," in Alexandrie médiévale 1, ed. Christian Décobert and Jean-Yves Empereur (Cairo: Institut Français d'Archéologie Orientale, 1998), p. 76.

9 Décobert, “Alexandrie au Xııı siècle," pp. 78-79, and Labib et al. “Alexandria," p. 20. 
contributions to our knowledge of this development that started around the middle of the fifth/eleventh century. ${ }^{10}$ Udovitch's reading of the Geniza has revealed that important transactions would take place in Cairo rather than Alexandria, so that the latter city served as a point of entry and departure, but not exchange. Prices were apparently higher in Alexandria as well, while commodities from Cairo appear to have generally been regarded as being of a higher quality, to the extent that one Alexandrian wrote about his city that: "nothing is worthwhile buying here."11 While Frenkel corroborates this image, she argues that it would be unjust to subsequently view Alexandria as a peripheral city. Instead she opts to view it as a "gateway city," a term she borrows from urban geographers. In contrast to central cities, she explains, gateway cities develop between areas of production on a site of transportational significance. They are characterized by long-distance trade and are dependent on central cities for their products. ${ }^{12}$

Besides having transformed into a gateway city under pressure of the Ayyubid economic policy, the Alexandria al-Wāsițī saw had been deeply affected by another event of the preceding two centuries: the Crusades. Its location at the Mediterranean Sea made it one of the main maritime entrances into the Muslim world from Europe, and thus strategically important as a frontier city (thaghr) to both the Ayyubid sultans and their Mamluk successors. ${ }^{13}$ Famous in the West as Saladin, the first Ayyubid ruler Șalāh al-Dīn (r. 570-589/11741193) visited the city several times and put in considerable effort to strengthen its fortifications against the European Crusaders. He had already dealt with two Crusader sieges at Alexandria before his ascension to the throne, and was thus bent on reconstructing its walls and towers, something which would continue well into the Bahrī Mamluk era. With his eyes on an invasion from Europe, he also invested in the city's religious resources, such as Sufi convents, madrasas, and mosques, in order to unify his kingdom under the banner of

10 The Cairo Geniza is a repository with centuries-old documents that were found in an old Cairene synagogue in the previous century. Because the variety of its religious and secular texts may contain the name(s) of God, it was stored so as to be preserved from desecration, cf. Abraham L. Udovitch, "Alexandria in the 11th and 12th Centuries. Letters and Documents of the Cairo Geniza Merchants: an Interim Balance Sheet," in Alexandrie médiévale 2, ed. Christian Décobert (Cairo: Institut Français d'Archéologie Orientale, 2010), p. 99.

$11 \quad$ Ibid. p. 101.

12 Frenkel, "Medieval Alexandria," p. 34.

13 Martina Müller-Wiener, Eine Stadtgeschichte Alexandrias von $564 / 1169$ bis in die Mitte des 9./15. Jahrhunderts: Verwaltung und innerstädtische Organisationsformen (Berlin: Schwarz, 1992), p. 2. 
Sunni Islam. ${ }^{14}$ Despite Șalāḥ al-Dīn's measures, instability soon increased after his passing, as the Ayyubid dynasty was not only facing foes from outside, but was also dealing with internal strife. ${ }^{15}$

Although the Mamluk sultans likewise had their fair share of internal conflicts, and Egypt and Syria were under almost constant threat from both Crusader and Mongol invaders, the second half of the seventh/thirteenth century was a somewhat more stable period for Alexandria. The Mamluk sultan al-Malik al-Z̄āhir Rukn al-Dīn Baybars I (r. 658-676/126o-1277) was a brilliant strategist who, like Șalāḥ al-Dīn, effectively employed religion as a means to stabilize his realm. For instance, in 661/1262 he forbade taverns, wine presses, and hashish, and cleared the city of prostitutes. ${ }^{16}$ He thereby displayed his role as the upholder of proper religious morality and the protector of Islam, and simultaneously emphasized the city's religious character. In 671/1272 there were new rumors of another imminent Christian attack on Alexandria which proved false in the end, but nevertheless motivated Baybars to provide it with extra reinforcements. ${ }^{17}$

When al-Wāsițī entered the city, it was relatively peaceful under the rule of Sultan al-Malik al-Manșūr Sayf al-Dīn Qalāwūn (r. 678-689/1279-129o). The latter understood very well that wars could not be won without revenues. Since the sultanate lacked its own commercial fleet, he sought to increase trade by making Alexandria attractive for European merchants. Alexandria thus remained the most important port of Egypt, as the place where Christian merchants from across the Mediterranean traded and ran their own funduqs, and where embassies of European powers arrived and embarked, and treatises with them were made. ${ }^{18}$ Christian merchants were well received and the city's governor was intructed to provide their funduqs with protection at all times, in particular on Fridays when Alexandria's Muslim population gathered for the jumu'a prayer. Qalāwūn, in turn, received taxes from them which, among other things, enabled him to invest in the Mamluk army. ${ }^{19}$ The favorable effects of Qalāwūn's trade policy on Alexandria were felt well after his passing. For

14 Müller-Wiener, Eine Stadtgeschichte Alexandrias, p. 17 and p. 263; Hofer, The Popularisation of Sufism, p. 40.

15 Décobert, "Alexandrie au XıIIe siècle," pp. 72-74.

16 Peter Thorau, The lion of Egypt: Sultan Baybars I and the Near East in the thirteenth century (London: Longman, 1992), p. 196.

17 Ibid. p. 224.

18 European merchants would come from such places as Genoa, Venice, Pisa, Ragusa, Provence, and Catalonia. See for instance: Labib et al. "Alexandria," p. 18.

19 Linda S. Northrup, From slave to sultan: the career of al-Manșūr Qalāwūn and the consolidation of Mamluk rule in Egypt and Syria (678-689 A.H./1279-129o A.D.) (Stuttgart: Franz Steiner Verlag, 1998), pp. 282-294. 
instance, when the Nile was low in 694/1295 and pestilence and famine broke out in Egypt, Alexandria benefited from the grains it was able to import from across the Mediterranean, which was owed to the sultan's good relations with Frankish lands. ${ }^{20}$ Yet, we must note that in the same year Sultan al-Malik alNāṣir Nāșir al-Dīn Muhammad (1st r. 693-694/1294-1295) sent his highestranking emir to Alexandria to deal with Frankish piracy around the coast. ${ }^{21}$ This shows that while al-Wāsițī certainly lived in a more or less stable Alexandria, the whole of the seventh/thirteenth century can nonetheless be characterized by continuous vigilance towards the possibility of Frankish raids or attacks.

\section{$1.2 \quad$ Egypt's Sufi Capital?}

We have thus far seen that seventh-/thirteenth-century Alexandria saw a change in its economical and institutional functioning. In both instances this was connected to a larger scheme of developments in Egypt. Intertwined with this was another important development that can help us understand why alWāsițī may have been drawn to Alexandria. The current section will demonstrate that the religious landscape of the maritime city in his time had transformed considerably to the point that it was one of Egypt's main Sufi centers, and perhaps for a certain period even its Sufi capital, thereby overshadowing Cairo.

Sufism already played an important role in the religious policy of the Ayyubids and continued to do so under the Mamluks. Besides the many examples that we have of sultans and emirs who, seemingly driven by genuine spiritual concerns, attached themselves to Sufi shaykhs or displayed deep reverence for pious figures, we can also discern a political dimension to their involvement with Sufism. ${ }^{22}$ In the context of Alexandria this can be seen for the first time under Salāh al-Dīn who, as mentioned earlier, invested in the city's religious resources as part of his agenda to propogate Sunni Islam as the Ayyubid

20 Peter M. Holt, Early Mamluk diplomacy (1260-1290): treaties of Baybars and Qalāwūn with Christian rulers (Leiden: Brill, 1995), p. 28.

21 Donald P. Little, An introduction to Mamlük historiography: an analysis of Arabic annalistic and biographical sources for the reign of al-Malik an-Nāșir Muhammad ibn Qalä'ūn (Wiesbaden: Franz Steiner Verlag, 1970), p. 4.

22 Many scholars have pointed to the relations between officials and Sufis, see for instance: Geoffroy, Le Soufisme, p. 123-127; Müller-Wiener, Eine Stadtgeschichte Alexandrias, p. 24; Décobert, "Alexandrie au XıIIe siècle," p. 80 and p. 93; Alexander D. Knysh, Ibn 'Arabi in the Later Islamic Tradition: The Making of a Polemical Image in Medieval Islam (Albany: State University of New York Press, 1999), 51; see also the references of Hofer concerning the spiritual concern of the Ayyubids and Mamluks, in: The Popularisation of Sufism, pp. 49-50, and 59 . 


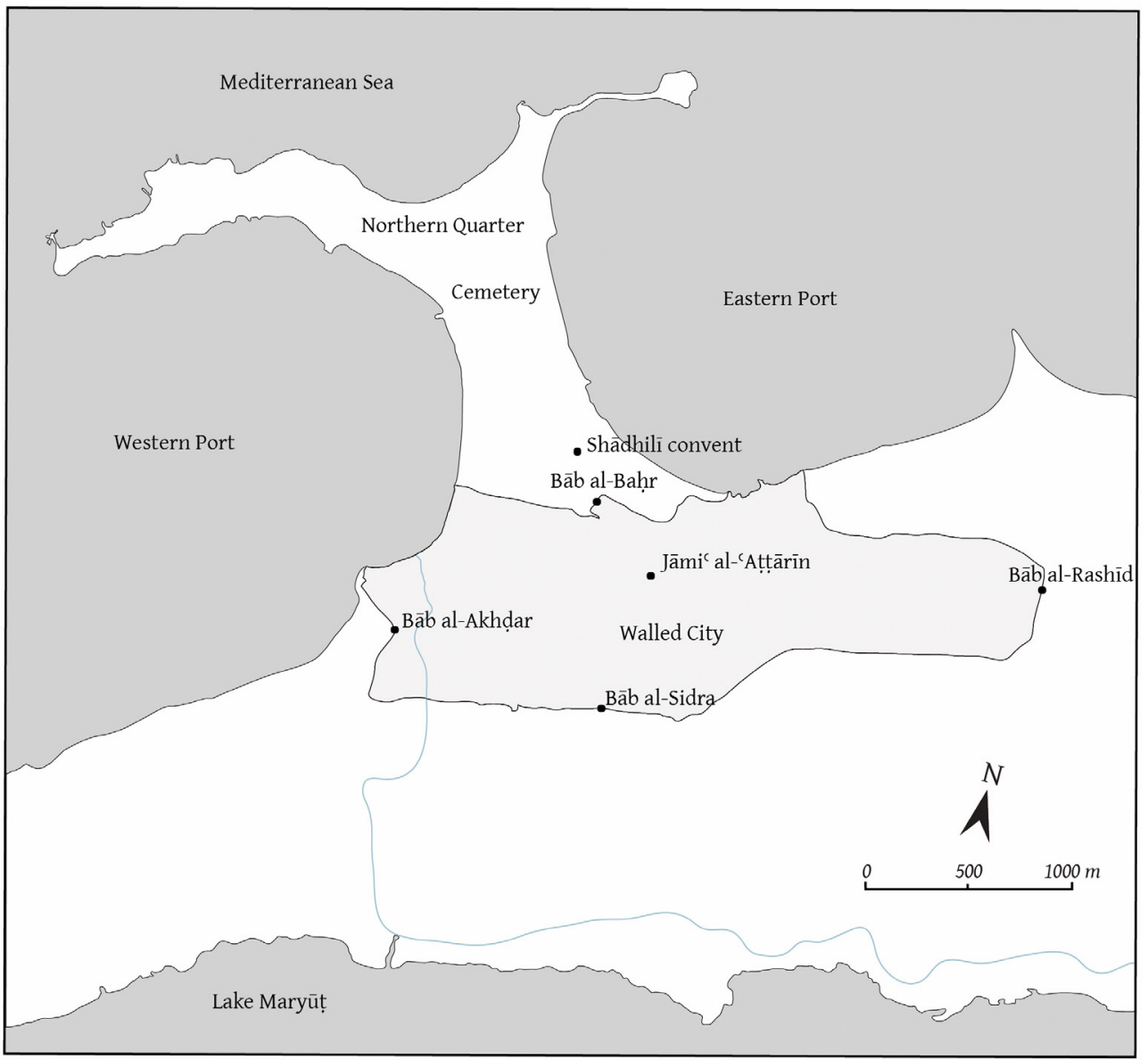

FIGURE 8 Seventh/thirteenth-century Alexandria with the approximate location of the earliest Shādhilī convent. Map adapted from Behrens-Abouseif, "Topographie," p. 126

ideology. One of these investments was the establishment and sponsoring of khānqāhs (sing. khānqāh, pl. khawāniq), the Persian word for Sufi convents. Both the Ayyubids and the Mamluks were favorably disposed towards organized Sufi groups and utilized the convents they sponsored to spread a shari'abased spirituality that anchored Sufism in Sunni scripturalism. One would thus find that, besides the science of tașawwuf, Islamic law would be taught at these khānqāhs. ${ }^{23}$

23 Geoffroy, Le Soufisme, pp. 166-167; Éric Geoffroy, "Les milieux de la mystique musulmane à Alexandrie aux Xıııe et XIVe siècles," in Alexandrie médiévale 2, ed. Christian Décobert 
At the same time, the Mongol conquest and the Reconquista in al-Andalus brought to Egypt an influx of foreigners from the east and the west of the Muslim world, among whom many were affiliated with Sufi shaykhs from their native lands, or were even themselves considered as spiritual masters. ${ }^{24}$ While this was certainly not Egypt's earliest contact with Sufism, this did introduce new and different manifestations of the Sufi path. ${ }^{25}$ In Iraq, the emergence of the first true Sufi orders that traced their origins to a particular shaykh with a particular method was already a known phenomenon, as we have seen with the Rifā'iyya in al-Wāsițīs birthplace, for instance. However, it is not exactly clear when this trend started to take root in Egyptian soil. It may very well have been the importation of Iraqi Sufism that came with immigrants hailing from the still recently fallen eastern caliphate that instigated the rapid rise of distinct Sufi orders in Egypt from roughly the second half of the seventh/thirteenth century onwards. A good example of this is found in the Iraqi Rifā'i shaykh Abū al-Fath al-Wāsițī (d. ca. 632/1234), who settled in Alexandria to spread the Rifā̄i order.

However, most newcomers to Alexandria did not come from the fallen caliphate, but from the Maghrib and al-Andalus. For centuries Alexandria had already been an important stop on the hajj pilgrimage route for Muslims coming from the west, some of whom would end up settling in the city. ${ }^{26}$ It is very well possible that its position as a frontier city during the Crusades also attracted especially western Sufis, driven by a pious sense of duty to defend the faith in jih $\bar{a} d$ against the Franks. This would certainly not have been an alien sentiment to the great numbers that were forced to flee from the Reconquista. It is thus claimed, for instance, that the Moroccan shaykh Abū al-Hasan alShādhilī, who had settled in Alexandria in $642 / 1244$, fought alongside his disciples during the 648/125o battle of Manșūra against the Crusaders. ${ }^{27}$ Besides

(Cairo: Institut Français d'Archéologie Orientale, 2010), p. 170; Décobert, "Alexandrie au Xiıre siècle," pp. 8o-81; Hofer, The Popularisation of Sufism, p. 41; Th. Emil Homerin, "Saving Muslim Souls: The Khānqāh and the Sufi Duty in Mamluk Lands," MSR III (1999): p. 66.

24 Hofer, The Popularisation of Sufism, p. 250.

25 Th. Emil Homerin, "Sufis and their Detractors in Mamluk Egypt," in: Islamic Mysticism Contested:Thirteen Centuries of Controversies and Polemics, ed. Frederick de Jong \& Bernd Radtke (Leiden, Netherlands: Brill, 1999), p. 246, where the author also refers us to a list of Egyptian Sufis presented in Jalāl al-Dīn 'Abd al-Raḥmān b. Abī Bakr al-Suyūṭī, Ḥusn al-muhạdạa fì tārīkh Mișr wa-al-Qāhira, ed. Muḥammad Abū al-Fạ̣l Ibrāhīm (Cairo: Dār ihyāà al-kutub al-'arabiyya, 1967), vol. 1, pp. 511-530.

26 Geoffroy, "Les milieux," p. 169.

27 Geoffroy states that it is related that even as al-Shādhili was nearly blind, he participated in the battle of Manșūra. However, the two earliest biographies dedicated to the shaykh, 
holy war, many North African and Andalusi seekers of the spiritual path were undoubtedly attracted to Alexandria because of the renowned masters of the western Sufi tradition that lived there. The school of the legendary Andalusi Sufi sage Abū Madyan Shu'ayb (d. 594/1198) entered Alexandria with the coming of his disciple, 'Abd al-Razzāq al-Jazūī (d. 595/1198), who spent the remainder of his life there. ${ }^{28}$ The well-known Risāla of Șafì al-Dīn Ibn Abī al-Manșūr (d. 682/1283) provides biographical entries for eight of al-Jazūlì's disciples he met in Alexandria, all of whom he considered masters in their own right. ${ }^{29}$ While he must not have met al-Jazūlì's most famous pupil, Abū Muhammad Șāliḥ b. Yanșarān al-Mājirī (d. 631/1234), we know that he too stayed in Alexandria for twenty years and had a considerable following. ${ }^{30}$

The influence that these historical circumstances had on Alexandria's religious sphere was visible on multiple levels. When it came to jurisprudence, the strong presence of Muslims from the west ensured the dominance of the Mālikī school, although there was also a visible Shāfi'i community. In theology, adherents of both madhhabs ascribed mostly to the Ash'arī school. ${ }^{31}$ With regard to the science of tasawwuf, we find that Alexandria's Sufis were able to successfully form networks around numerous authoritative spiritual masters; and thanks to the government's favorable stance towards Sufism, several of these shaykhs were well facilitated to spread their teachings. The above-mentioned Rifāīi shaykh al-Wāsițī was thus able to teach the Sufi way from Alexan-

Lațāif al-minan and Durrat al-asrār, do not explicitly mention this, nor the battle for that matter. Both works do contain an anecdote that places al-Shādhilī in Manșūra, with Durrat al-asrār adding that he expressed his worry about the safety of Alexandria, which, I would argue, does suggest that the reader is expected to be aware of the context of the Crusader invasion. See: Muḥammad b. Abī al-Qāsim Ibn al-Ṣabbāgh, Kitāb Durrat al-asrār wa-tuhfat al-abrār (Tunis: Mațba'at al-tūnisiyya al-rasmiyya, 1886), pp. 147-148, and: Tāj al-Dīn Aḥmad Ibn 'Ațā̄' Allāh al-Iskandarī, Latạiif al-minan fì manāqib al-Shaykh Abī al'Abbās al-Mursī wa-shaykhihi al-Shādhil̄ Abì al-Hasan, ed. Khalīl 'Imrān al-Manșūr (Beirut: Dār al-Kutub al-'Tlmiyya, 2005), p. 9o, and: Geoffroy, "Les milieux," p. 170.

28 Geoffroy, "Les milieux," p. 171.

29 Șafī al-Dīn al-Ḥusayn al-Azdī Ibn Abī al-Manșūr, La risāla de Șafíal-Dīn Ibn Abī al-Manșūr Ibn Zāfir: biographies des maîtres spirituels connus par un cheikh égyptien du viIe-XIIIe siècle, ed. \& trans. Denis Gril (Cairo: Institut français d'archéologie orientale du Caire, 1986), pp. 99b-102b.

30 On al-Jazūīi, see Abū Yađqūb Yūsuf al-Tādilī, al-Tashawwuf ilā rijāl al-tașawwuf wa-akhbār Abī al-'Abbās al-Sabtī, ed. Aḥamd al-Tawfìq (Rabat: Manshūrāt kulliyyat al-ādāb, 1997), p.327. Al-Mājirī was still alive when al-Tādilī (d. 617/1220) wrote the latter work, and is described by him as one of the greatest shaykhs of his time; see al-Tashawwuf, p. 41. On al-Mājirī, see also: Khayr al-Dīn al-Ziriklī, al-A'āam: qāmūs tarājim li-ashhar al-rijāl wa-alnisā' min al-'arab wa-al-musta'ribīn wa-al-mustashriqīn (Beirut: Dār al-iilm al-malāyīn, 2002), vol. 3, p. 199.

$31 \quad$ Labib et al. "Alexandria," p. 17. 
dria's grand mosque, Jāmi al-'Atțāāīn, as was al-Shādhilī and his successor, Abū al-'Abbās al-Mursī, after him. ${ }^{32}$ Furthermore, the sultanate provided al-Jazūī as well as al-Shādhilī with housing in towers of the city's northern walls, and the latter even appears to have been granted space in the citadel (qal'a) to use as his Sufi convent. ${ }^{33}$ There are in fact many more examples of Sufi shaykhs who were in some way honored by Ayyubid and Mamluk officials. Al-Jazūlì's disciple Wajīh al-Dīn Ibn 'Awf was the imam of Alexandria's main mosque and was visited by the Ayyubid sultan Șalāh al-Dīn. ${ }^{34}$ The famous Alexandrian Sufi Abū al-Qāsim al-Qabbārī (d. 662/1264) became so widely noted as a pious man that he was visited by the Mamluk sultan Baybars I and several Mamluk notables. ${ }^{35}$ All of this tells us that by the middle of the seventh/thirteenth century Alexandria had not only become a safe haven for Sufis, but in fact one of the most important - if not the most important - centers of Sufism in Egypt. ${ }^{36}$

Another aspect of this development that we must touch upon briefly here is the change in Alexandria's sacred topography through the establishments of independent convents. Although by no means clear-cut, the period under consideration appears to have known something of a distinction between the "state-sponsored" khānqāh type convent and the self-sufficient ribāt or zāwiya type convent. ${ }^{37}$ We can thus observe that while the khänqāhs were certainly put to use by the city's Sufis, there were also several shaykhs who were able to start their own convents without any help or interference from the sultanate. The majority of these convents were located in Alexandria's northern quarter, just outside the city walls near the Bāb al-Bahr. This is where one could find the ribāts of the Shādhilī Abū al-'Abbās al-Mursī, the Rifāī al-Wāsițī, and the convent of Abū 'Abd Allāh al-Shātịīi, the successor of the Alexandrian Sufi master

32 On the history of this mosque in Alexandria, see Behrens-Abouseif, "Topographie," pp. 121-122. On Sufis teaching in the mosque, see: Ibn al-Ṣabbāgh, Kitāb Durrat al-asrār, p. 147; Geoffroy, "Les milieux," p. 177.

33 Ibn al-Ṣabbāgh, Durrat al-asrār, p. 14 and p. 147.

34 Ibn Abī al-Manșūr, La risāla, p. 102b.

35 Décobert, "Alexandrie au Xıııe siècle," p. 84.

36 It is noteworthy to point to the fact that out of the 155 Sufi authorities named by Șafi alDīn in his Risāla, at least 30 were from Alexandria or were based there for a considerable time. I owe this observation to Décobert, "Alexandrie au XIIIe siècle," p. 84, where he refers to Ibn Abī al-Manșūr, La risāla, pp. 98-110.

37 Geoffroy, Le Soufisme, pp. 168-171, and Décobert, "Alexandrie au XIIIe siècle," p. 93; Hofer, The Popularisation of Sufism, p. $5^{2}$. It must be noted that the classical sources are not always clear when it comes to both the terms used to refer to religious instututions and the roles allotted to them. On this, see also: Jonathan Porter Berkey, The Transmission of Knowledge in Medieval Cairo: A Social History of Islamic Education (Princeton, N.J.: Princeton University Press, 1992), pp. $48-5$ o. 


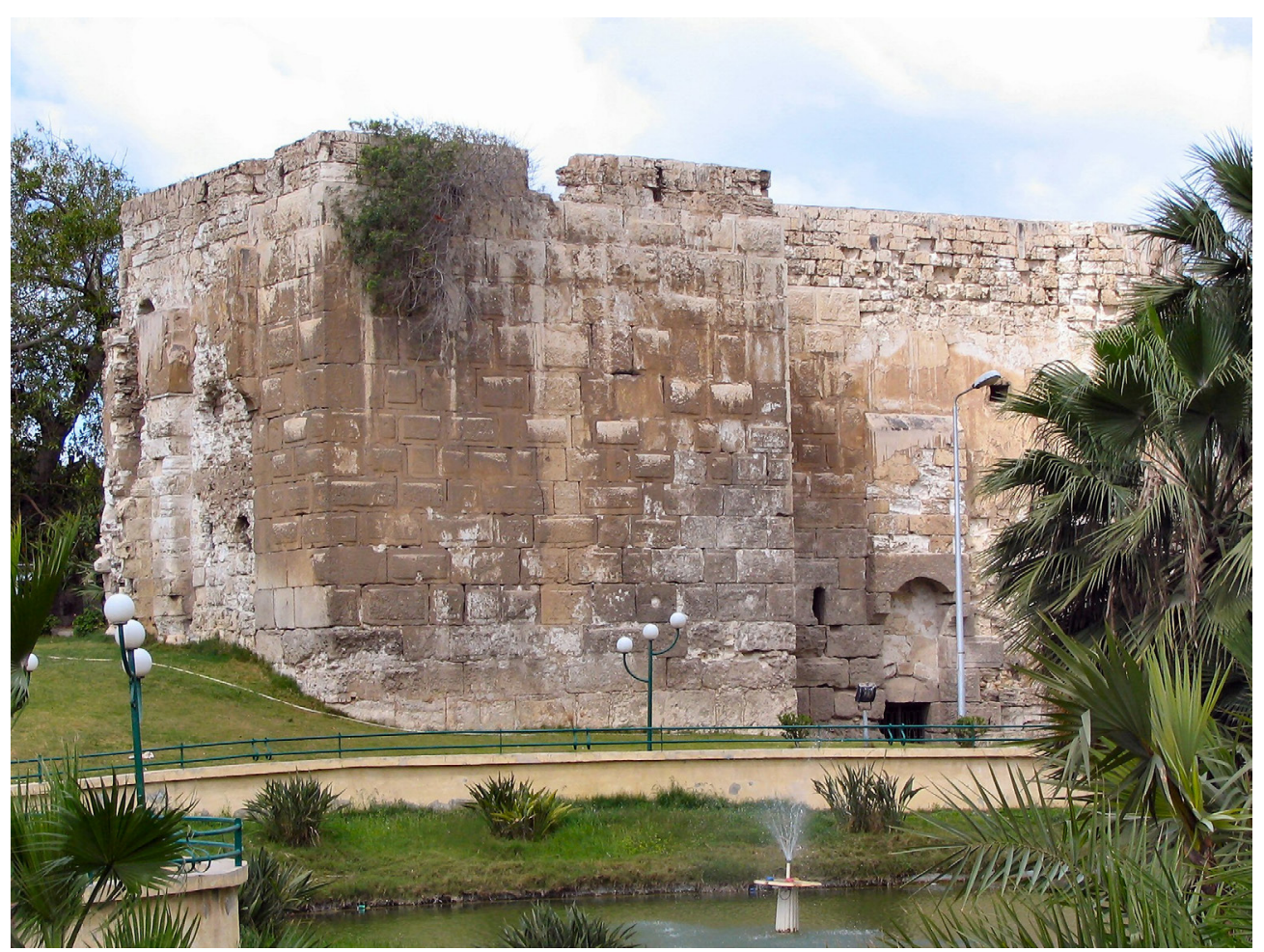

FIGURE 9 Remains of the northeastern corner tower of Alexandria's walls. On its right used to be the Bāb Rashīd. @ Andrew Michael Chugg, <http://www.alexanderstomb. com>

Aḥmad Abū al-'Abbās al-Ra's (d. 615/1218). ${ }^{38}$ In many cases such enterprises would be financed with the help of a wealthy Alexandrian merchant who attached himself to a spiritual master. This was, for example, what enabled the construction of the mosque over al-Mursī's grave in 706/1308, which was financed by one Zayn al-Dīn, who also paid for its muezzin, imam, and caretaker. ${ }^{39}$ It can thus be said that Alexandria's trend of Sufism not only flourished intellectually through the presence of spiritual authorities and their massive following, but also in terms of topography. Christian Décobert has contended

38 There were other ribāts in Alexandria as well, such as that of Abū 'Abd Allāh al-Așāiir, that of al-Jazūlī, which was in the city's wall near Kom el-Dikka, that of Ibn 'Abd Allāh alḤakkārī (d. 683/1284), and a khānqāh of Bìlīk al-Muhsinīi, founded by Sufis from the east, see: Décobert, "Alexandrie au xııı siècle," pp. 85-87, and Ibn Abī al-Manșūr, La risāla, p. 104b.

39 Ibn al-Ṣabbāgh, Durrat al-asrār, p. 157; for the date, see: Décobert, "Alexandrie au XIIIe siècle," p. 85 . 
that this development in the field of Sufism owed much to Alexandria's marginalization which, as we have seen, was due to its economic stagnation and the constant Frankish threat. This, he believes, allowed for the establishment of convents as autonomous religious enterprises that were able to play a significant role on a local level. There thus appears to have been a link between the city's administrative decline and the emergence of a new form of religiosity. In other words, Alexandria's shift away from being a city known for trade actually facilitated its transformation into a city known for piety. ${ }^{40}$

This milieu provided exceptionally fertile grounds for the Shādhiliyya with its Maghribi roots to lay the foundations that would enable it to grow into one of the most influential Sufi orders of Islamic history. It was naturally not hard for Alexandria's considerable population of Muslims of western origin to embrace the path of the Maghribi shaykh al-Shādhili and his Andalusi successor, al-Mursī, so that the Shādhiliyya easily incorporated the school of Abū Madyan, which since its establishment had taken a prominent place among the city's Sufis. ${ }^{41}$ From the middle of the seventh/thirteenth century onwards the Shādhili ța $\bar{t}^{i} f a$ spread rapidly across Egypt and beyond through the effort of its shaykhs, thus attracting spiritual seekers towards Alexandria from all over the Muslim world. At least until roughly the turn of the century, the time around which Tāj al-Dīn Ibn 'Ațầ' Allāh al-Iskandarì (d. 709/1309) started preaching the Shādhilī way from al-Azhar's pulpit in Cairo, Alexandria remained the homebase of the Shādhiliyya. ${ }^{42}$ The importance of Alexandria not only as a center of Sufism, but as the main center of the Shādhiliyya, is an important observation for us, as this may very well have played a decisive role in al-Wāsițìs choice to head for the maritime city. As the stronghold of the early Shādhilīs, it would not have been difficult for a seeker on the Sufi path to end up in their convent in the city's northern quarter. With that in mind, we now return to the account of his journey, which will tell us firsthand what he encountered among them.

\section{Enter the Shādhiliyya of Alexandria}

The somewhat concise section in al-Wāsiț̣is autobiography on the Shādhilī Sufis he accompanied may at first sight appear to reveal very little about their teachings and practices. It is nevertheless exactly in his brevity that we may distinguish what were, at least according to his observation, some of the

40 Décobert, "Alexandrie au xıIIe siècle," pp. 95-96.

41 Geoffroy, "Les milieux," p. 172.

42 Ibid. p. 178. 
prominent characteristics of Shādhilī doctrine as preached in Alexandria somewhere during the final fifteen years of the seventh/thirteenth century.

As has been done in chapter 1, we will again aim to historicize and expound upon al-Wāsițī's account through an in-depth study of other primary sources that make mention of the early Shādhiliyya. The most notable of these are listed below:

- The majority of the published works of Ibn 'Ațā' Allāh al-Iskandarī, the first shaykh to write books on Sufism according to the Shādhilī way. These are: his Kitāb al-hikam, a collection of spiritual aphorisms written before 686/1287, when al-Mursī was still alive; ${ }^{43}$ Kitāb al-tanwìr fì isqāt al-tadbìr, finished in 695/1296 according to Brockelmann, and perhaps his clearest elucidation of Shādhilī doctrine; ${ }^{44}$ Lațāaif al-minan fìmanāqib al-Shaykh Abì al-'Abbās al-Mursī wa-shaykhihi al-Shādhilì Abì al-Hasan, a biographical work concerned mostly with his own shaykh, al-Mursī, but also with alShādhilī. It must have been composed after Kitāb al-tanwìr, from which it quotes; ${ }^{45}$ 'Unwān al-tawfíq fi $\bar{a} d \bar{a} b$ al-țariq, a commentary on a poem about the Sufi way by Abū Madyan; Miftāḥ al-falāḥ wa-miṣbāḥ al-arwāḥ fì dhikr Allāh al-Karìm al-Fattāh, a small volume concerned with the remembrance of God; and al-Qașd al-mujarrad fi ma'rifat al-ism al-mufrad, about the divine names and attributes of God and their purpose in the spiritual way. I must point out that some scholars have doubted Ibn 'Ațā' Allāh's authorship of the latter two works. However, since I have found that both works have overlapping passages, and both appear to be consistent with his other writings, I see no reason to doubt their authenticity. ${ }^{46}$ Finally, there are also let-

43 According to Victor Danner, Ibn 'Ațāillāh's Ṣüfi Aphorisms (Kitāb al-Ḥikam) (Leiden: E.J. Brill, 1973), p. 15 .

44 Carl Brockelmann, Geschichte der arabischen litteratur (Leiden: Brill, 1996), vol. 2, p. 143.

45 Al-Iskandarī, Lațāif al-minan, p. 135.

46 For doubts concerning their authenticity, see for instance: al-Ziriklī, al-Alām, vol. 1, p. 222 (he only mentions Miftāh), and Hofer, The Popularisation of Sufism, p. 130-131. The latter's arguments are that both works contain no references to Ibn 'Ațā' Allāh's shaykhs, that they are not consistent with his style or the content of his other known writings, and that early biographies do not mention them. As for the first argument, Ibn 'Ațā' Allāh's Hikam also contains no references to his shaykhs but is known to be authentic. As for the second argument, it is striking that both al-Qașd and Miftăh have an almost identical description of the types of dhikr that can be done; compare al-Qașd al-mujarrad fi ma'rifat al-ism almufrad, ed. Khālid Muḥammad Khamīs (Cairo: Maktabat al-khānjī, 20o8), p. 72 with Miftāḥ al-falāḥ wa-mișbāḥ al-arwāh:fì dhikr Allāh al-karim al-fattāh, ed. Muhammad 'Abd al-Salām Ibrāhīm (Beirut: Dār al-kutub al-ilmiyya, 2005), pp. 30-33. Furthermore, there seems to be an overlap between al-Qașd, p. 46 and Lațäif al-minan, pp.137-138, and between al-Qașd, p. 48 and the Hikam, see: Ibn 'Ațä' Allāh (m. 709/1309) et la naissance de la confrérie šădilite / Ibn 'Ațā' Allāh (709/ı309) wa-nash'at al-țarīqa al-Shādhiliyya, ed. \& 
ters by Ibn 'Ațā' Allāh and by anonymous pupils of his which have been consulted.

- Kitāb Durrat al-asrār wa-tuhfat al-abrār by the Tunisian Shādhilī Sufi Muhammad b. Abī al-Qāsim Ibn al-Ṣabbāgh (d. 720/1320). After Ibn 'Ațā' Allāh's Lațāif al-minan, this is the earliest biography of al-Shādhilī. It also contains a chapter with sayings of other Shādhilī affiliates.

- Zinat al-nawāzir wa-tuhfat al-khawāțir by Jamāl al-Dīn Rāfic b. Muḥammad b. Shāfi al-Ṣumaydì (d. 718/1319). This is a collection of discourses that Rāfic heard directly from Ibn 'Ațā' Allāh during his classes on Sufism in Cairo. ${ }^{47}$

- I have also made abundant use of biographical dictionaries of the tabaqāt -genre, which need not all be mentioned here. Of particular importance have been three authors who were known to have been in contact with Shādhilī affiliates: 'Afîf al-Dīn 'Abd Allāh b. As'ad al-Yāfi'ì (d. 768/1367), whose profound respect for the Shādhiliyya is evident;"8 Sirāj al-Dīn 'Umar Ibn al-Mulaqqin (d. 804/1402), who was invested with the Shādhili Sufi cloak (khirqa) by Ibn 'Ațā̄ Allāh's brother, Sharaf al-Dīn Abū al-Barakāt Muhammad;49 and 'Abd al-Wahhāb al-Sha'rānī (d. 973/1565), who was sympathetic to the Shādhiliyya. ${ }^{50}$

In line with the structure of chapter 1, I have again identified three general themes to systematically study al-Wāsiți’s account. We will start by scrutinizing what can be said of the Shādhili țăiifa in al-Wāsițìs epoch in terms of its

trans. Paul Nwyia (Beirut: Dar El-Machreq Éditeurs, 199o), p. 129; and between Miftāh, p. 36 and Lată $i f$ al-minan, p. 114. As for the third argument, most early biographies do not give any titles. For instance, al-Subkī only names al-Tanwìr, cf. Țabaqat al-shäfíiyya, vol. 9, p. 23; al-Yāfici only names Lațāif al-minan and states that he has a number of other writings on the divine secrets, cf. Mir'āt, vol. 4, p. 185; and al-'Asqalānī only says that he has numerous writings (tașānīf 'adīda), without mention of any titles, cf. al-Durar al-kāmina, vol. 1, p. 324. Somewhat later biographies start to make mention of the first three titles I have mentioned above, e.g. al-Suyūțī, Husn al-muhāọara, vol. 1, p. 524, and 'Abd alWahhāb b. Aḥmad al-Sha'rānī, al-Ṭabaqāt al-kubrā, al-musamma: Lawāqị̣ al-anwār alqudsiyya fì manāqib al-'ulamā' wa-al-șüfiyya, ed. Aḥmad 'Abd al-Rahīm Sāyiḥ and Tawfīq 'Alī Wahba (Cairo: Maktabat al-thaqāfa al-dīniyya, 2005), vol. 2, p. 41. Examples of scholars who did consider al-Qașd and Miftāh authentic are Victor Danner, Ibn 'Ațāillāh's Șūfi Aphorisms, pp. 12-13, and Abū al-Wafā' al-Ghunaymī, Ibn 'Ațā' Allāh al-Sikandarī watașawwufuhu (Cairo: Maktabat al-anjlū al-mișriyya, 1969), pp. 107-111.

Jamāl al-Dīn Rāfi` b. Muḥammad b. Shāfi` al-Șumaydī, Zīnat al-nawāzir wa-tuhfat alkhawāṭir, ed. Yūsuf Aḥmad (Beirut: Kitāb nāshirūn, 2013), p. 31.

48 Al-Yāfi'ī repeatedly praises al-Shādhilī and his affiliates in his Mir'āt and refers to them as shaykhs whose status as friends of God is undisputed; see for instance: vol. 2, p. 13 where he calls al-Shādhilī a quṭtb, and vol. 3, p. 142 where he recognizes his friendship with God. This occurred in Alexandria, see: Sirāj al-Dīn Abū Ḥafṣ 'Umar Ibn al-Mulaqqin, Ṭabaqāt al-awliyā', ed. Nūr al-Dīn Sharībah (Cairo: Maktabat al-Khānjī, 1994), p. 5 o1.

As observed by Winter, Society and Religion, p. 72. 
network and formation as a distinct order; the second theme will be the Sufi doctrine that was prevalent among its followers; the final section will examine the success of the Shādhilīs and how this relates to the decision of our Iraqi Sufi to ultimately distance himself from them.

\subsection{The Network of the Early Shädhiliyya}

I have mentioned earlier that while the Rifāiiyya could already rightfully be called a Sufi order during al-Wāsițī's lifetime, it is not exactly clear when in the Egyptian Mamluk context Sufi groups became distinct orders, set up around the person and teachings of a particular shaykh. And even when we can clearly speak of a Sufi order proper, its exact moment of conception is in most cases difficult to ascertain, as the eponymous founder in all likelihood did not actually set it up himself. Rather, what became a Sufi order was likely construed by later followers who began to define the borders of their identity and behavior as a Sufi group, which they then traced back this eponymous shaykh. It is this gap in our understanding of medieval Sufism that has recently triggered Nathan Hofer to legitimately question what he calls the "institutionalization" of the early Shādhiliyya. ${ }^{51}$

Hofer argues that it is not until the early eight/fourteenth century that we find the first traces of al-Shādhilī's identity and method as the focal point for a group of Sufis to trace their authority back to. This, he holds, indicates that it must have taken nearly fifty years after the death of its eponymous founder before an actual institutionalized țāifa crystalized. ${ }^{52}$ He views Ibn 'Ațā' Allāh al-Iskandarì's hagiography Lațāif al-minan as a crucial basis from which Shādhilī Sufism as a distinct identity was construed:

By providing his readers with a narrative model for their devotions and doctrines, al-Iskandari formulated the contours of what it meant to follow al-Shādhilī and be a Shādhilī Sufi. Once a coherent model was in place, the subsequent formalisation of that model - what I call the 'institutionalised identity' of al-Shādhilī - became possible as Sufis began to narrate and embody the doctrines and practices implicit in the model. ${ }^{53}$

$5^{1} \quad$ Hofer, The Popularisation of Sufism, pp. 16-18, where he defines institutations as (1) social (generated and preserved through relations in a group); (2) normative (constraining and enabling the groups's behavior); (3) performative (the learned behaviours linked to a specific language of a group); (4) objective (for the group's members); and (5) dynamic (and thus subject to change).

$5^{2} \quad$ Ibid. pp. 111-112.

53 Ibid. p. 113 . 
By disseminating an idealized version of al-Shādhilī’s life, doctrine, and praxis, Ibn 'Ațầ' Allāh was, in a sense, the architect of this institutionalized Shādhilī identity. Hofer suspects that, in doing so, Ibn 'Ațā' Allāh simultaneously cemented his own career as the new leader of the Shādhili țăi ifa. He would thus have written Lațāif al-minan for two reasons: first, to legitimize the role of his own master, al-Mursī, as the spiritual successor to al-Shādhilī; and, second, to legitimize his own role as the spiritual successor of al-Mursī and spokesperson of the Shādhiliyya after him. ${ }^{54}$

The implication of Hofer's theory is that when al-Wāsiți entered a masterdisciple relationship of suhba under one of al-Mursì's students not long after 686/1287, he did not in fact become part of a distinct Sufi țāifa with its own distinct doctrine. Because, as we shall see, al-Wāsițī's autobiography gives the impression that this notion is incorrect, I have gone through the rich source material on the Shādhiliyya discussed above to see whether his account can be substantiated. The fruits of this labor are presented in the current section. I will argue that, at least in the final fifteen years of the seventh/thirteenth century, there was already a network of shaykhs that formed a distinct Sufi group, whose identity was inseparably linked to the person of al-Shādhilī via al-Mursī and which could justly be called a Sufi țāifa.

Al-Wāsiți makes it very clear that what he found in Alexandria was a țăiifa that identified itself with the name of Abū al-Hasan al-Shādhilī. When we return to where we left off in the previous chapter with the account of his journey, expressing his grief at the several disappointments he experienced in Iraq, he goes on to write: "But God (T) was kind to me, for I met a group $(t \vec{a} i f a)$ in Alexandria who recognized my goal and my search, so that I found a little bit of intimacy (ba'd al-uns) among them."55

Interestingly, his autobiography does not once state the name of this țāiffa, nor of any of its members. It could be that he did so out of reverence for them, and in particular for his own shaykh in the Shādhilī way, as his account does go on to denounce certain issues that he found problematic in their approach to Sufism. Perhaps he felt uncomfortable attaching the names of people he still greatly respected to his criticism. We can nevertheless be sure that he is referring to the Shādhiliyya when he speaks of this Alexandrian $t \bar{a}$ i ifa, not only thanks to Ibn Rajab's entry quoted at the beginning of the present chapter, but also because al-Wāsiți himself explicitly affirms that he was involved with them in two other works. After describing his time among the Baghdadi Sufis in his Q⿱äcida fí așnāf al-tảalluh, he says that he subsequently "turned to the

54 Ibid. pp. 113-114.

55 Al-Wāsițī, Rị̣la, pp. 33. 
way (tarīq) of the Shādhiliyya." ${ }^{\prime 6}$ And in a letter to one shaykh Ahmad alMaghribī we find him refuting the notion that a spiritual taste (dhawq) or unveiling (kashf) is by definition authentic, a view that was apparently upheld by the Shādhilīs: "I have only heard this statement or something similar to it from the group (ță $i f a)$ of the shaykh, the knower ('āriff), Abū al-Ḥasan al-Shādhilī."ñ

What can be said about this țāifa based on other primary sources? Granted, it is difficult to say much about the early Shādhiliyya, first, because there is hardly any material from its own adherents that predates the works of Ibn 'Ațâ' Allāh and, second, because biographical sources often make no mention at all of Sufi affiliation - and when they do, the information is often very meagre. The modern-day image of the early ța i ifa is that the line of its shaykhs started with al-Shādhilī, followed by al-Mursī, and that Ibn 'Ațā' Allāh was its third spiritual leader. This image neglects that while Ibn 'Ațā' Allāh certainly played a crucial role in the ța iifa as one of its most significant representatives in Cairo and the first of its shaykhs to compose works on Sufism, there were several other disciples of al-Mursī who were probably just as important in advertising the Shādhilī way. A noteworthy indication of this is found in a poem by al-Yāfi'i $\overline{1}$, wherein he eulogizes a hundred Sufi shaykhs and reserves several verses for Shādhilī affiliates. After praising al-Shādhilī and al-Mursī, he continues as follows:

Through [the guidance of al-Mursī] al-Iṣbahānī became the star (najm) of their ${ }^{58}$ sky,

And the moon of their guidance - their sword is a helper for those who possess little.

And esteemed was the servant Yāqūt, the ruby (yāqūt) around their neck,

By being firm upon the excellence of the spiritual way (sulūk).

And to Ibn 'Ațā' they granted the banner of divine friendship (wilāya),

And for illness [they granted him] a cure that dispels corruption

With which Dāwūd was treated, until this servant was cured,

And thus became a remedy for the calamity of disobedience.

And Marjānī, who was adorned with the pearls (marjān) of their ocean,

Dressed in garment embellished with the most splendid subtleties. ${ }^{59}$

56 Al-Wāsițī, Qā'ida fì aṣnāf al-ta’alluh, p. 151.

57 Al-Wāsițī, Risālatuhu ilā al-shaykh Ahmmad al-Maghribì, p. 110.

$5^{8}$ I have translated the suffix " $h \bar{a}$ " recurring throughout the quoted verses as "their." It must be noted that since al-Yāfici does not present us with the complete poem, it is not possible to establish what he is referring to.

59 Al-Yāfi'ì, Mir'àt, vol. 4, p 175. 
Composed by a scholar who was a contemporary to several of the masters who are named, this poem is significant in that it attests to the existence of a network of shaykhs who during their respective lifetimes must have all enjoyed a position of authority. It will be useful to have a closer look at their background, and to add several other figures who are mentioned in the sources as Shādhili affiliates in order to see what can be said about the way they were related to one another.

The first verse quoted from al-Yāfi'î's poem is clearly a reference to the person who was al-Wāsițī's own Shādhilī shaykh in Alexandria: the Persian Najm al-Dīn 'Abd Allāh b. Muḥammad al-Iṣbahānī (or Ișfahānī). ${ }^{60}$ The most important source on him is al-Yāfi'i $\overline{1}$, who had met him in Mecca and describes him as having been a handsome man with a long beard and an awe-inspiring appearance. ${ }^{61}$ Born in 643/1245 in current-day Iran, Najm al-Dīn probably lived in Shiraz for some time, where he accompanied a Sufi guide by the name of Abū 'Alī Barghash al-Shirāzī. ${ }^{62}$ It may have been this shaykh who told him to go to Egypt, where he would meet the spiritual axis $(q u t \underline{b})$ of his time. A hagiographic tale describes that Najm al-Dīn was captured by bandits (or Mongols, in another version) during his journey to Egypt, but was able to escape after he was freed by a shaykh who miraculously appeared to him when he recited a poem about his hazardous situation. Once Najm al-Dīn arrived in Alexandria and was directed towards al-Mursī by some of his followers, he discovered that it was in fact al-Mursī who had freed him from his captivity. ${ }^{63}$ From that moment on he remained a pupil of al-Mursī until his shaykh's passing in 686/1287. Several years before the turn of the century, Najm al-Dīn left Alexandria for good to spend the remainder of his life in Mecca, where he became the main representative of the Shādhiliyya. ${ }^{64} \mathrm{He}$ seems to have enjoyed some status there as

6o Al-Dhahabī, Tārîkh, vol. 48, p. 274, note that the editions of al-Dhahabìs Dhayl, p. 206 and al-Asqalānī's al-Durar al-Kämina, vol. 3, p. 86 both erroneously state that Najm al-Dīn accompanied (șaḥiba) al-Wāsițī.

$61 \quad$ Al-Yāfíī, Mir'àt, vol. 4, p. 198

62 Al-Ṣumaydī, Zìnat al-nawāzir, p. 107.

63 Al-Yāfi'ì, Mirāät, vol. 4, p. 198, and al-Iskandarī, Lațāìif al-minan, p. 69. Note that Ibn al-Ṣabbāgh relates a completely different story: he states that, in search of the quțb, Najm al-Dīn took a boat that broke down and was miraculously saved from the water by alMursī; see: Ibn al-Ṣabbāgh, Durrat al-asrār, p. 157.

64 Najm al-Dīn must already have been in Mecca several years before 699/1299, since that is the year Abū Muhammad al-Marjānī passed away in Tunis, and he is said to have met with him in the sanctuary, see: Ibn al-Ṣabbāgh, Durrat al-asrār, p. 157. See also: al-Ṣafadī, alWāfì, vol. 17, pp. 321-322; Al-Yāfi'ī, Mir'āt, vol. 4, p. 199; al-Iskandarī, Lațāìif al-minan, p. 68; al-'Asqalānī, al-Durar al-kamina, vol. 3, p. 86; al-Dhahabī, Tärīkh, vol. 48, p. 274; Ibn alMulaqqin, Țabaqāt al-awliyā', p. 459 . 
a spiritual master, as it is said that all the great shaykhs who arrived in the holy city would meet with him. ${ }^{65}$ Although the sources make no mention of him having had disciples, the fact that al-Wāsiți took him as his master suggests that he was already a full-fledged shaykh of tarbiya, able to teach the Sufi way well before he left Alexandria for the holy precinct.

The next verse in al-Yāfi'î’s poem refers to Yāqūt b. 'Abd Allāh al-Ḥabashī (d. 732/1331), who like Najm al-Dīn had been a disciple of al-Mursī. Very little is known of him, but it is certain that he became the foremost Shādhili shaykh in Alexandria after the passing of his master. He must therefore have had a considerable following, although few examples are mentioned in biographical literature. ${ }^{66}$ Among them we find Ḥasan (or Ḥusayn) al-Khabbāz (d. 791/1389) and Shams al-Dīn Muḥammad b. Aḥmad Ibn al-Labbān (d. 749/1348). It is not known whether these two disciples knew one another, but they certainly had several things in common. Both were Shāfi'is, both married one of Yāqūt's daughters, and both represented the Shādhiliyya in Cairo. The former, alKhabbāz, established a convent of his own in the city's vicinity and is mentioned as having invested disciples with the Shādhilī Sufi cloak (khirqa) on the authority of his shaykh, Yāqūt. ${ }^{67}$ The second disciple, the Shāfi' jurist Ibn alLabbān, reportedly taught the Shādhilī way from the Cairene Mosque of 'Amr b. al-'Ạ̦̣. ${ }^{6}$

The next two verses in al-Yāfi'î's poem are reserved for Ibn 'Ațā̄' Allāh and his most celebrated disciple, the Mālikī jurist Sharaf al-Dīn Dāwūd Ibn Bākhilā (or

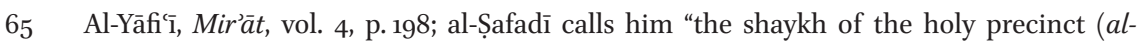
haram)," cf. al-Wāfì, vol. 17, p. 321.

66 While Yāqūt is mentioned in many biographical dictionaries, the entries on him are all meager. Al-Dhahabī refers to him as "the renunciant of Alexandria (zāhid al-Iskandariyya)," cf. al-Dhahabī, al-Tbar, vol. 4, p. 93. His fame in Alexandria is also attested to by Ibn Bațțūta, who was initiated by him, cf, Rihla, vol. 1, p. 187. As for the entries on Yāqūt, see: Ibn al-Mulaqqin, Țabaqāat al-awliyā’, pp. 478-479; al-Yāfi'ì, Mir’āt, vol. 4, p. 213; Taqī al-Dīn Aḥmad b. 'Alī al-Maqrīīi, al-Sulūk li-ma'rifat duwal al-mulūk, ed. Muḥammad 'Abd al-Qādir 'Ațā (Beirut: Dār al-kutub al-'ilmiyya, 1997), vol. 3, pp. 161-162; al-Suyūṭī, Husn al-muhạậara, vol. 1, p. 525; Jamāl al-Dīn Yūsuf b. 'Abd Allāh Ibn Taghrī Birdī, al-Nujūm al-zāhira fì mulūk Mișr wa-al-Qāhira (Cairo: Wizārat al-thaqāfa wa-al-irshād al-qawmī, 1929-1938), vol. 9, p. 295.

67 Shams al-Dīn Muḥammad b. 'Abd al-Raḥmān al-Sakhāwī, al-Daw's al-lāmic li-ahl al-qarn al-tāsi' (Beirut: Dār maktabat al-ḥayāt, 1980), vol. 2, p. 5o. See also: Ibn Taghrī Birdī, alNujūm al-zāhira, vol. 11, p. 385; al-Maqrīzì, al-Sulūk, vol. 5, p. 271; al-Sha'rānī, al-Ṭabaqāt al-kubrā, vol. 2, p. 176.

68 Al-Subkī, Țabaqat al-shāfíiyya, vol. 8, pp. 94-96; al-Yāíīi, Mir'āt, vol. 4, p. 248; Taqī al-Dīn Abū Bakr b. Aḥmad Ibn Qāạī Shahba, Ṭabaqat al-shāfíiyya, ed. 'Abd al-'Alīm Khān (Beirut: 'Ālam al-kutub, 1986), vol. 3, pp. 52-54; Jamāl al-Dīn 'Abd al-Raḥmān b. al-Ḥasan al-Isnawī, Țabaqāt al-shāfíiyya, ed. Kamāl Yūsuf al-Ḥūt (Beirut: Dār al-kutub al-'ilmiyya, 2002), vol. 2, p. 194 . 
Mākhilā) al-Iskandarī (d. 733/1332). Ibn 'Ațā̄ Allāh, a native Alexandrian, had already migrated to Cairo while al-Mursī was still alive, and would eventually become the primary representative of the Shādhiliyya there. ${ }^{69}$ It is noteworthy that, according to al-Sha'rānī, Ibn 'Ațā' Allāh became the pupil (tilmìdh) of Yāqūt once al-Mursī had passed away, which suggests that it was Yāqūt who was considered the main shaykh of the tă iff after al-Mursī, and not Ibn 'Ațā' Allāh. ${ }^{70}$ It is likely that Ibn 'Ațā' Allāh traveled regularly through Egypt as both al-Shādhilī and al-Mursì had done before him, probably to spread the Shādhilī way and stay in touch with the several Shädhilī fractions that were stationed in other cities. He would surely have passed by Alexandria during such trips which, together with his correspondence via letters, preserved his link with the Shādhilī capital..$^{71}$ As Alexandrian disciples of al-Mursī, there is no doubt that Yāqūt, Ibn 'Ațầ' Allāh, and Najm al-Dīn knew one another. Ibn 'Ațā' Allāh viewed his two colleagues as knowers of God, and his own pupil, the aforementioned Rāfi', relates that both Yāqūt and Najm al-Dīn testified that Ibn 'Ațầ' Allāh is a quṭb. ${ }^{72}$ As for Ibn 'Ațā̄ Allāh's student Ibn Bākhilā, while his role as a shaykh in the țāifa remains unclear due to a scarcity of biographical information, we do know that he lived and died in Alexandria as a contemporary of Yāqūt. ${ }^{73}$

Most pupils of Ibn 'Ațā' Allāh would naturally have lived in Cairo, however. Noteworthy are two Cairene disciples who also appear to have been connected in some way to important Shādhilī figures of Alexandria. The first, Rāfí, would

69 Ibn 'Ațā' Allāh was already in Cairo in $684 / 1285$, as attested to by a poem he sent from there to Makīn al-Dīn al-Asmar in Alexandria, see: Tāj al-Dīn Aḥmad Ibn 'Ațā̄ Allāh alIskandarī, Min kalām sayyidī al-mușannif wa-inshādihi wa-qașā̉idihi, MS. Or. 329(2), Leiden University, fol. 68b.

70 Al-Sha'rānī, al-Ṭabaqāt al-kubrā, vol. 2, p. 41.

71 For Ibn 'Ațā' Allāh's correspondence with Alexandria, see his Tartīb al-sulūk, wa-yalīhā Risāla fì adab al-iilm, ed. Khālid Zahrī (Beirut: Dār al-kutub al-ilmiyya, 20o6), p. 45; see also footnote 69 . According to al-Ghunaymī, he sent the letter contained therein in 694/1295, cf. al-Ghunaymī, Ibn 'Ațā' Allāh, p. 101. For Ibn 'Ațā' Allāh's travels, see the letter by one of his pupils: Anon, Risāla li-ba'd fuqarā'sayyidī al-shaykh Tāj al-Dīn Ibn 'Ațā' Allāh radī Allāh 'anhu, MS. Or. 329(7b), Leiden University, fol. 94b-95a; here we find mention of Ibn 'Ațā' Allāh having travelled to Alexandria and Damiette in 707/1307. See also: alIskandarī, Lațäifi al-minan, p. 148, where we find that he met with Sultan al-Malik al-Manșūr Ḥussām al-Dīn Lājīn in Alexandria, which means that he must have visited the city before 698/1299, the year in which the sultan died.

72 Al-Iskandarī, Lațāiif al-minan, pp. 75-76, and al-Ṣumaydī, Zìnat al-nawāzir, p. 22.

73 Ibn al-Mulaqqin, Țabaqāt al-awliyā', pp. 517-518; Muhammad b. Muhammad Makhlūf, Shajarat al-nūr al-zakiyya fi țabaqāt al-Mālikiyya, ed. 'Abd al-Majīd Khayālī (Beirut: Dār al-kutub al-'ilmiyya, 2003), vol. 1, p. 293; al-'Asqalānī, al-Durar al-kāmina, vol. 2, p. 226;

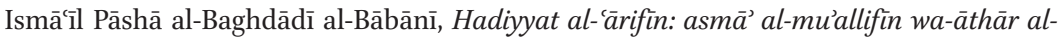
mușannifin (Istanbul: Wikālat al-Ma'ārif, 1951), vol. 1, pp. 36o-361. 
surely have entered the Shādhilī network when he studied Qur'anic recitation under the Shāfíi jurist Makīn al-Dīn al-Asmar al-Lakhmī (d. 692/1293), a direct disciple of al-Shādhilī. ${ }^{74}$ Although I found no mention of him having met Yāqūt or Najm al-Dīn, he was clearly aware of their position in the Shādhiliyya when he states about them that "there is no doubt about their friendship [with God] (wilāya) and the greatness of their rank (sha'n)."75 Besides Rāfi', we find that Ibn 'Ațā' Allāh's disciple Shihāb al-Dīn Abū al-'Abbās Aḥmad Ibn Maylaq (or Malyaq) (d. 749/1349) must have been in contact with shaykh Yāqūt as well. ${ }^{76}$

The final verse of al-Yāfi'î's poem refers to 'Abd Allāh Abū Muḥammad alMarjānī (d. 699/1299), a Mālikī jurist and Sufi shaykh who lived in Alexandria and Cairo and eventually moved to Tunis, where he passed away. ${ }^{77}$ The fact that Ibn 'Ațāa' Allāh and Ibn al-Ṣabbāgh both quote from him attests to his connection with the Shādhiliyya, although its exact nature remains unclear. ${ }^{78} \mathrm{Ibn}$ al-Ṣabbāgh relates that al-Marjānī met with Najm al-Dīn when he was in Mecca, which shows once more that there was contact between shaykhs who were in some way associated with the Shādhilī network, even if there was a considerable geographical distance between them.

There are a few other shaykhs not mentioned in the poem that deserve to be added to the current list for the sake of our knowledge of the Shādhili network. First is the son of al-Shādhilī, Shihāb al-Dīn Aḥmad Ibn Abī al-Ḥasan, who appears to have made a name for himself as a Shādhilī master in Alexandria. A letter that he wrote to a disciple of his in Giza, southwest of Cairo, proves that he had followers outside of Alexandria as well..$^{79}$ That he also had a bond with al-Mursī is affirmed in a poem by the latter in praise of Shihāb al-Dīn,

74 Al-Suyūṭī, Husn al-muhạậara, vol. 1, p. 507; see also: al-'Asqalānī, al-Durar al-kāmina, vol. 2, pp. 233-235.

75 Al-Ṣumaydī, Zinat al-nawāzir, p. 22.

76 Al-Sharrānī, al-Tabaqāt al-kubrāa, vol. 2, p. 176. On Ibn Maylaq, see: Ibn Taghrī Birdī, alNujūm al-zāhira, vol. 10, p. 242; al-Yāfi'ì, Mirāât, vol. 3, p. 250; al-Suyūṭī, Husn al-muhạậara, vol. 1, p. 552; al-'Asqalānī, al-Durar al-kāmina, vol. 5, p. 438.

77 Ibn al-Mulaqqin, Țabaqāt al-awlìyā', p. 441; al-Yāfi'ì, Mir'āt, vol. 4, pp. 174-175; Makhlūf, Shajarat al-nūr, vol. 1, p. 277; Șalaḥ al-Dīn Khalīl al-Ṣafadī, A'yān al-'așr wa-a'wān al-nașr, ed. 'Alī Abū Zayd et al (Beirut: Dār al-fikr al-mu'āșir/Damascus: Dār al-fikr, 1998), vol. 2, pp. 719-720.

78 Tāj al-Dīn Ahmad Ibn 'Ațā' Allāh al-Iskandarī, Kitāb al-tanwìr fì isqāt al-tadbīr (Beirut: Dār al-kutub al-ilmiyya, 6002), p. 82, and Ibn al-Sabbāgh, Durrat al-asrār, pp. 157, 162, 164, and 169 .

79 Shihāb al-Dīn Ahmmad b. 'Alī al-Shādhilī, Risālat Sayyidinā al-shaykh al-imām al-'ālim alārif Shihāb al-Dīn Ahmad, MS. Or. 329(7b), Leiden University, fol. 10oa. Ibn 'Ațā̄ Allāh appears to confirm his role as an independent shaykh in Lațäif al-minan, p. 54. 


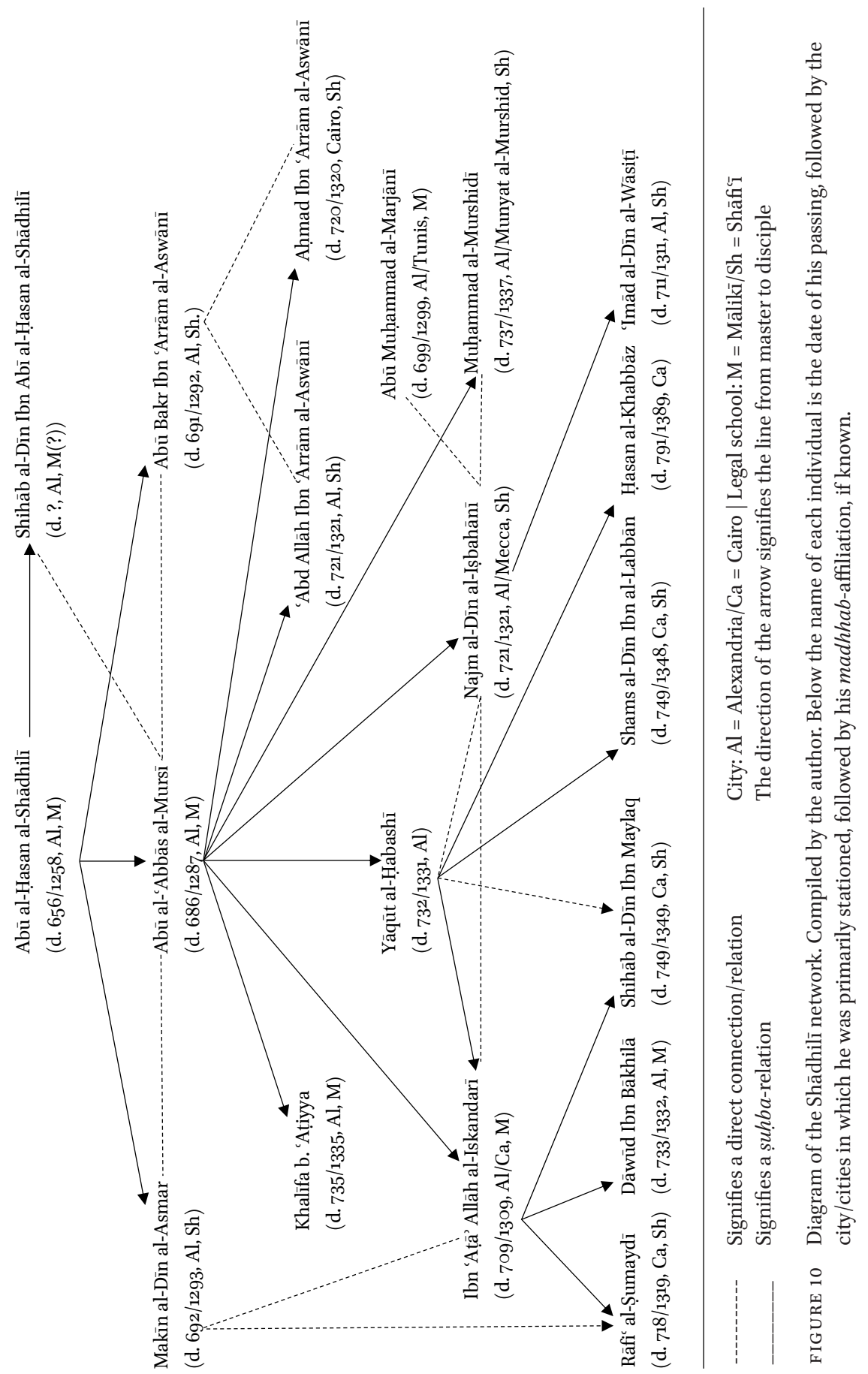


quoted by Ibn al-Ṣabbāgh. ${ }^{80}$ Furthermore, the Sufi shaykh Abū 'Abd Allāh Muhammad al-Murshidī (d. 737/1337) had been a disciple of al-Mursī and also seems to have known Najm al-Dīn. He eventually started his own convent east of Alexandria, in a village currently known as Munyat al-Murshid. ${ }^{81}$ The Alexandrian Shāfiī jurist Zakī al-Dīn Abū Bakr Ibn 'Arrām al-Aswānī (d. 691/1292) had been a disciple of al-Shādhilī and married one of his daughters. According to Ibn 'Ațā' Allāh's Lațāiif al-minan, he also personally knew al-Mursì. ${ }^{82}$ The fact that both his sons, Bahā' al-Dīn Aḥmad Ibn 'Arrām al-Aswānī (d. 720/1320) and 'Abd Allāh Ibn 'Arrām al-Aswānī (d. 721/1321), subsequently became disciples of al-Mursī may indicate that there was already an awareness of a Shādhilī 'Sufi genealogy' during their lifetimes. It can hardly be a coincidence that we have here two sons who followed the successor of their father's shaykh in tașawwuf. ${ }^{83}$ Finally, we find that the otherwise unknown Mālikī jurist Khalīfa Ibn 'Ațiyya (d. 735/1335) is mentioned as a disciple of al-Mursī, too. ${ }^{84}$

In spite of the several blanks in our picture of the network of Shādhili affiliates, the above enumeration enables us to make a diagram (as depicted on page 92) based on which several relevant observations can be made. First, almost all the individuals we have identified as affiliates of the Shādhiliyya were connected to each other by being part of the Shādhilī chain of șụ̣ba, which signifies their master-disciple relationship with one of the shaykhs in the $t \bar{a}$ iffa's network. Second, the diagram shows that there does not appear to have been one clear-cut leader of the Shādhiliyya after al-Mursī. Instead, we find that each city with a Shādhilī community could have one or even several local shaykhs, who each had disciples of their own. Alexandria in particular had several shaykhs who were apparently authorized to train their own pupils in the Shādhili way. This, of course, is not strange in view of the fact that the țầifa was rapidly gaining followers with the rise of its popularity, which is also reflected in the sudden shift away from Alexandria after the death of al-Mursī. Where the majority of the first and second generation Shādhilīs were, at least initially, naturally based in Alexandria, the home-base of al-Shādhilī and al-Mursī, it is seen that many of the $t \bar{a}$ i $i f a^{\prime}$ ' major figures of the generation after that were

\footnotetext{
8 I Ibn al-Sabbāgh, Durrat al-asrār, pp. 155-156.

81 Al-Yāfi'ī, Mir'āt, for al-Mursī being his shaykh: vol. 4, p. 221, for his connection to Najm alDīn: vol. 4, p. 198. See also: al-Suyūṭī, Husn al-muhậ̣̂ra, vol. 1, p. 525; al-Ṣafadī, al-Wāfĭ, vol. 3, pp. 294-295.

$82 \quad$ Al-Iskandarī, Lațāifi al-minan, pp. 65 and 84.

83 For Abū Bakr, see: Ibn al-Mulaqqin, Ṭabaqāt al-awliyā', p. 485; for Ahmad, see: al-Ṣafadī, al-Wāfĭ, vol. 6, p. 168, and Ibn al-Mulaqqin, Țabaqāt al-awliyā', p. 514; for 'Abd Allāh, see: al-Ṣafadī, al-Wäfì, vol. 17, p. 5 \%.

84 Ibn al-Mulaqqin, Țabaqāt al-awliyā', p. $55^{2}$.
} 
based in Cairo. Third, we have seen indications in our sources that several shaykhs of the generations after al-Mursī were in contact with each other, surely on the basis of their affiliation with the Shädhiliyya. There was correspondence via letters and some shaykhs would travel through Egypt to visit other Shādhilī fractions. Some of the affiliates, such as al-Marjānī and al-Murshidī, seemingly operated independently of the țâi ifa, but may have still maintained a connection of some sort with its shaykhs. Last but certainly not least, what is particularly striking is that the diagram shows very clearly that every chain of affiliates from al-Wāsițī's generation goes back exclusively to al-Mursī, who can thus be seen as the common link in the țâaifa. It is this final observation that will be of great significance to our further study of al-Wāsițîs account below.

We have thus far seen that al-Wāsiți obviously viewed the Shādhiliyya as a Sufi ța iffa. As such, I have tried to give an overview of what the network of this țäifa looked like based on other primary sources. While the observations we have thus far made provide some grounds to assume that there indeed existed a network of Shādhilī affiliates in Egypt and beyond that operated as a distinct Sufi group at the time of al-Wāsitịis initiation by Najm al-Dīn, the issue is not yet settled. It will therefore be useful to explore whether there existed something of a common Sufi doctrine within this network of shaykhs. If the teachings al-Wāsiți relates from Najm al-Dīn correspond to what is found in the earliest Shādhilī writings, most notably those of Ibn 'Ațầ' Allāh, this would be a strong indication that a distinct Sufi doctrine existed among the Shädhilīs, the common link of which would have been al-Mursī, in whom all lines of șuḥba come together. This would then mean that it is possible to locate the point at which the Shādhiliyya existed as a distinct Sufi țăi ifa as early as al-Mursī. I will come back to this in the conclusion to the section that now follows, in which we will examine what can be said about the teachings of the Shādhiliyya at the time of our Iraqi Sufi's stay in Alexandria.

\subsection{The Doctrine of the Early Shädhiliyya}

The difficulty with al-Wāsițīs description of the Shādhilīs in his autobiography is that it comes across in itself as an insignificant sequence of spiritual qualities he claims to have witnessed among them. It is only after careful consideration and comparison with other writings of al-Wāsiți that one will find that several passages actually contain references to the Sufi doctrine that he identified as characteristic of the țāiffa. He says, for instance:

One of them considers his own self-direction (tadbir) and choice (ikhti$y \bar{a} r)$ to be among the greatest sins, so that he happily welcomes his Lord's choice and trusts in it, relying on whatever his Lord has designated in His 
pre-eternity ( $f$ i azalihi) according to His divine wisdom and mercy. This comes to the point that it seems as if this one is in the presence of his Lord, seeing Him with the vision of his heart (yarāhu 'iyānan bi-qalbihi). The signs of [God's] majesty, love, and magnificence shine on his face and he submits to His decree $(h u k m)$. I found such signs among them and in their movements, their stillness, and the fluctuations of their hearts (taqallubät). ${ }^{85}$

As I have pointed out before, al-Wāsițīs autobiography makes no mention of names in the section on the Shādhiliyya. Nonetheless, we can almost be certain that the above quote is actually a direct description of Najm al-Dīn, his own Shādhilī mentor in Alexandria. In Q Qácida fì al-tajrìd he provides us with the only explicit reference to his shaykh's teachings that I have come across in his writings, and it clearly overlaps with the above quote:

Shaykh Najm al-Dīn - may God renew his blessing - told me some words that summarize the beginnings and the endings [of the spiritual way], which I only understood after fifteen years. I thus came to know that he never held back any good council from me. He said: "Your reflection on what has passed and your attempt to direct (tadbiruka) what is to come distract you from the state you are in at the moment (al-hâl fi al-waqt). This requires [that you] perfect piety $(\operatorname{taqwa})$ in your inward being and become aware of your passing thoughts (khawātir) out of shame before God (T), which is the beginning of the path of those who are drawn near [to Him] (al-muqarrabin)."

He also told me something that comes down to the following: "God was and there was nothing with Him (kāna Allāh wa-mā shay'ma'ahu), so it is necessary for man that his heart becomes absent in the meaning [of these words]." 86

We find a very similar portrayal of Shādhilī teachings in al-Wāsițīs $Q \bar{a}$ cida fì așnāf al-ta'alluh, where he states that it is characteristic of the order to commence with the spiritual path by renouncing one's choice (ikhtiyār) and desire (irāda), and attaching oneself to al-Shādhilī: "Then will the ecstatic (wājid) find a spiritual taste (dhawq) through the divine attribute of antiquity (sifat al-qidam), since God was and there was nothing with Him, so that he is about to become veiled from all that is not [God] of created things." 87

85 Al-Wāsițī, Riḥla, p. 34.

86 Al-Wāsițī, Qā'ida fì al-tajrīd, p. 256

87 Al-Wāsițî, Qãcida fì aṣnāf al-ta’alluh, p. 151 . 
What is especially noticeable about the way al-Wāsițī summarizes Shādhilī doctrine in these citations is how it seems to be a very condensed form of several core teachings found in the earliest Shādhili writings, most notably those of Ibn 'Ațā' Allāh. It is, therefore, first and foremost through Ibn 'Ațā̄ Allāh that we can appreciate the true significance of al-Wāsițì's remarks here.

The first thing that we may recognize as a distinct aspect of Shādhilī doctrine is the stress that is laid on desisting from any claim to self-direction (tadbir), choice (ikhtiyār), or desire (iräda or shahwa), since it is ultimately God who controls all things. Now, it can be no coincidence that Ibn 'Ațā' Allāh starts his Hikam with several aphorisms that all deal with this in some way:

[1] One of the signs of relying on one's own deeds is the loss of hope when a downfall occurs.... [3] Preceding intentions cannot pierce the walls of predestined decrees (aqdār). [4] Free yourself from self-direction (tadbir), for that which Someone Else has carried out on your behalf you must not yourself undertake to do. [5] Your striving for what has already been guaranteed to you, and your neglectfulness of what is demanded of you, are a proof that your spiritual insight (bașira) is clouded. ${ }^{88}$

As the title indicates, this is also the main concern of Ibn 'Ațā' Allāh's Kitāb altanwīr $f i$ isqät al-tadbīr, which we may render as 'the Book of Illumination through the Elimination of Self-Direction.' In its introduction, Ibn 'Ațā' Allāh states that whoever seeks to arrive unto God (al-wușull ilä Allāh) must necessarily purify himself of having self-direction..$^{89}$ It is worthwhile noting that Ibn al-Ṣabbāgh and Ibn 'Ațā' Allāh relate very similar words from al-Shādhilī, the kernel of which is that living in this world with the assumption that you are the one directing your acts is one of the things that will cut you off from arrival (wuṣla). ${ }^{90}$ The gravity of this matter is such that Ibn 'Ațāa Allāh states in his Kitāb al-tanwìr that the truest miracle (karäma) of the friend of God is when he lives by tafwied, which is to entrust all affairs to God, since human beings cannot have any influence on the divine decree. ${ }^{91}$ Besides several other writings of Ibn 'Ațā' Allāh that expound such teachings, it appears from Rāfi's notes that he actively advocated this during his teaching sessions on Sufism as

88 I follow Nwyia's critical edition and numbering of the aphorisms; see: al-Iskandarī, $I b n$ 'Ațā' Allāh (m. 709/1309) et la naissance, pp. 84-85. I have relied on Danner, Ibn 'Ațāillāh's Süfi Aphorisms, pp. 23-24 for the translation, which I have slightly altered.

89 Al-Iskandarī, Kitāb al-tanwìr, p. 4.

9o Ibn al-Ṣabbāgh, Durrat al-asrār, p. 102; al-Iskandarī, Lațāiif al-minan, p. 135.

$91 \quad$ Al-Iskandarī, Kitāb al-tanwìr, p. 27. 
well. ${ }^{92}$ It is thus clear that it must have been an essential principle in the doctrine of the early Shādhiliyya to strive to eliminate one's self-direction, choice, and desire.

Although not completely straightforward, al-Wāsițī provides us with what appears to be the primary foundation on which this principle was built in his above-cited descriptions of Shādhilì doctrine. In all three of them we can find reference being made to God's pre-eternity, such as the words he says were taught to him by Najm al-Dīn: "God was and there was nothing with Him (kāna Allāh wa-mā shay'ma'ahu)." It is striking that these exact same words are found in the thirty-fourth aphorism of Ibn 'Ațā' Allāh's Hikam, which has added: “... and He is now as He was." ${ }^{93}$ This saying is actually based on a canonical hadīth that is found in al-Bukhārì's al-Jämi' al-șahịh, according to which the Prophet Muhammad said: "God was and there was nothing before Him..." 94 Its significance to the principle of rejecting one's self-direction and choice becomes clear from Ibn 'Ațā' Allāh's following explanation found in Kitāb al-tanwìr:

You should know that God was there for you before you were there for yourself. Now in the same way as He directed $\left(\right.$ mudabbir $\left.^{a n}\right)$ [your affairs] before you existed when there was nothing of your self-direction (tadbir) [to compete] with Him, thus He (ST) directs [your affairs] after you have come into existence. So be to Him as you were to Him [in pre-eternity], and He will be to you as He was to you [in pre-eternity]! ${ }^{95}$

Since God in the sovereignty of His lordship (rubūbiyya) has already directed all affairs in pre-eternity, the Sufi must fully grasp that creatures hold no power or control over anything and that they are all completely dependent on Him. ${ }^{96}$

92 See for instance al-Ṣumaydī, Zīnat al-nawāzir, pp. 252-256, 270, 444, 464, and 499. The significance of tadbīr and ikhtiyār in Rāfi's book was already noted by Denis Gril in his "L'enseignement d'Ibn 'Atâ' Allâh al-Iskandarî, d'après le témoignage de son disciple Râfi' Ibn Shâfi," in Une voie soufie dans le monde: la Shâdhiliyya, ed. Éric Geoffroy (Paris: Maisonneuve et Larose, 2005), pp. 98-99. For other references in Ibn 'Ațā̄' Allāh's writings, see his Tartīb al-sulūk, wa-yalīhā Risāla fì adab al-ilm, ed. Khālid Zahrī (Beirut: Dār alkutub al-'ilmiyya, 2006), p. 57, and his Lațäif al-minan, for example pp. 24 and 91.

93 Al-Iskandarī, Ibn 'Ațā' Allāh (m. 709/ı309) et la naissance, p. 103.

94 Muhammad b. Ismāīil al-Bukhārī, al-Jāmi al-musnad al-ṣahịh al-mukhtaṣar min umūr Rasūl Allāh (șallā Allāh 'alayhi wa-sallam) wa-sunanihi wa-ayyāmihi, ed. Muhammad Zuhayr b. Nāṣir al-Nāṣir (Beirut: Dār țawq al-najāh, 2001), vol. 4, p. 105, and also vol. 9, p. 421.

95 Al-Iskandarī, Kitāb al-tanwìr, p. 14.

96 Ibid. p. 18. 
This principle revolves around the realization of an essential dichotomy between Lord ( $r a b b$ ) and servant ('abd), or between lordship (rubübiyya) and servitude ('ubūdiyya), which the early Shādhiliyya considered the way to reach the station of servitude (maquam al-ubüdiyya). Its prominence in their doctrine is reflected in the very definition of Sufism itself as attributed to alShādhilī by Ibn al-Ṣabbāgh: "Sufism is to train the carnal soul (nafs) to be in accordance with servitude, and to return it to the principles of lordship (ahkām al-rubübiyya). ${ }^{n 7}$ Several references to this dichotomy can be found in Ibn 'Ațā' Allāh's Hikam as well. In the 1ooth aphorism, for instance, he states that it is in carrying out one's servitude that the majesty of God's lordship manifests. ${ }^{98}$ In Kitāb al-tanwīr he explains that the Prophet Muhammad therefore chose servitude when he was made to choose between becoming a servant prophet (nabī 'abd) or a king prophet (nabì malik). For Ibn 'Ațầ' Allāh, this is also the definitive proof that servitude is the most noble of spiritual stations. ${ }^{99}$

Against this background we may understand what is implied by the earlierquoted statement al-Wāsițī related from one of the Shādhilīs (in all likelihood Najm al-Dīn himself) that self-direction and choice are among the greatest sins. Similar statements can in fact be found in several Shādhilī works. Ibn 'Atạa' Allāh phrases it in almost identical words, and Rāfic attributes it to al-Shādhilī as follows: "Beware of self-direction and choice, for they are worse than offenses and sins." ${ }^{100}$ For the early Shādhilīs, the idea behind this notion is that if the servant lays claim to self-direction he is in fact competing with his Lord's decrees. He thereby makes himself an associate with God's lordship (shirk bial-rubūbiyya), which Ibn 'Ațā' Allāh also refers to as an inward form of idolatry. ${ }^{101}$ Therefore, according to the Shādhiliyya, it is only by cleansing the heart of attributing lordship to other things besides God that the servant becomes fit to be in His divine presence. ${ }^{102}$

Another seemingly distinct part of Shādhilī doctrine to which al-Wāsiți alludes three times in his autobiography is the role of God's divine names $(a s m \vec{a})$ and attributes (șifât). In his first mention of these terms he merely states that he found the Shādhilīs discussing experiential knowledge (márifa) of the

\footnotetext{
97 Ibn al-Ṣabbāgh, Durrat al-asrār, p. 90.

98 Al-Iskandarī, Ibn 'Ațā' Allāh (m. 709/1309) et la naissance, p. 129, and for the other references, pp. 121, 137, and 153 .

99 Al-Iskandarī, Kitāb al-tanwìr, p. 25 .

100 Ibn 'Ațā' Allāh makes a similar statement in Kitāb al-tanwīr, p. 27. For al-Shādhilī's quote, see: al-Ṣumaydī, Zīnat al-nawāzir, p. 287.

101 Al-Iskandarī, Kitāb al-tanwìr, pp. 11 and 13; al-Iskandarī, Lațāì al-minan, pp. 88-89 and 142 .

Al-Iskandarī, Miftāḥ al-falāh, p. 37.
} 
divine names and attributes. The second instance provides some more detail and explains that "they enter the presence of the divine names (hadarät alasmä) and achieve spiritual realization (tahaqqaqū) through something from that. The reality of a divine name or attribute is granted to them and they thereby become intimately acquainted with God ('AJ)." 103 In the third instance, he describes that when they have emptied their hearts of all things other than God, they become filled with His love and the unveiling (kashf) of His names and attributes. ${ }^{104}$ While this suggests that the divine names and attributes fulfilled a role in the early țăiifa, al-Wāsițî̀s allusions do not fully convey their significance.

When we turn to Shādhilī sources, we find that their relevance to the spiritual way is a rather complex issue that will require some elaboration here. According to Ibn al-Ṣabbāgh, al-Shādhilī differentiated between the attributes of servitude, which belong solely to human beings, and the attributes of lordship, which belong solely to God. The Sufi must realize his own attributes while perceiving those of God. This principle can also be found in the 117th aphorism of the Hikam, which states: "Be connected to the attributes of His lordship and realize the attributes of your servitude." ${ }^{105}$ The aim is to thereby realize the nature of one's human attributes and their essential difference from God's divine attributes, a spiritual exercise which al-Shādhilī reportedly referred to as "sitting on the carpet of thruthfulness" (al-julūs 'alā bisāt al-ṣidq). ${ }^{106}$ For instance, the Sufi should realize that he is weak ( $d a$ ciff) while God is the Strong (al-qawiyy), that he is lowly (dhalīl) while God is the Almighty (al-aziz), that he is needy (faqïr) while God is the Self-Sufficient (al-ghanī). ${ }^{107}$ In other words, for the Shādhilīs it is through the divine names and attributes that one journeys deeper into the fundamental dichotomy of 'ubüdiyya and rubūbiyya.

The end of that journey, however, is a still deeper realization that people's existence as newly created, temporal beings is like non-existence in view of God's existence in pre-eternity. Ibn 'Ațầ' Allāh hints at this principle in a letter he sent to Alexandria, where he discusses whether it is better for the Sufi to be in a state of neediness (faqr) or a state of sufficiency (ghinā). He concludes that, ultimately, neediness is more perfect because it is an attribute of

\footnotetext{
103 Al-Wāsițī, Rị̣la, pp. 33-34.

104 Ibid. p. 34.

105 Al-Iskandarī, Ibn 'Ață' Allāh (m. 709/1309) et la naissance, p. 137, also hinted at in the 112th aphorism, p. 73 .

106 Ibn al-Ṣabbāgh, Durrat al-asrār, p. 72.

107 Ibid.
} 
servitude, whereas sufficiency is an attribute of lordship. ${ }^{108}$ The true meaning of neediness, he explains, only manifests by fully realizing God's pre-eternity:

The reality of neediness is to be after you have come into existence as you were before your existence, that is, just as [God] directed [your affairs] for you before your existence, without you having any saying in the matter. So be to Him as you were to Him, He will be to you as He was to you. Yet, the reality of neediness is only sound by being absent from it, for otherwise you will [still] be in a state of sufficiency by means of your neediness. ${ }^{109}$

The last sentence alludes to the station of annihilation $($ fan $\vec{a})$ wherein man's attributes become annihilated in God's attributes so that he loses awareness of all that pertains to the created realm. For awareness of one's own neediness would imply that a created, temporal attribute is still present together with the pre-eternal Creator. This process is also referred to in the 122th aphorism of the Hikam, where it is stated that "when [God] wants to make you arrive unto Him, He covers your attribute with His attribute and hides your quality with His quality." ${ }^{\prime 10}$ Ibn al-Ṣabbāgh quotes a like-minded statement from al-Shādhilī:

Just as your vile names can be obliterated by your excellent names, thus your [human] names can be obliterated through [God's] divine names, and your [human] attributes through His divine attributes, for nothing of the temporal being (al-hādith) will remain when he is connected to the Pre-Eternal (al-qadim).... When you call upon Him by His sublime name and pay heed to His sublime attributes existing in His essence, all of your names will be obliterated and your existence will have disappeared. You will have become effaced, having no existence whatsoever. This is the locus of annihilation, and of subsistence $\left(\right.$ baq $\left.\bar{a}^{\top}\right)$ after annihilation. ${ }^{111}$

That is not to say that a human being and God unite and become one, or that God incarnates in him. Ibn 'Ațā' Allāh clarifies that the servant can be adorned by God's names and attributes to the extent that it becomes conceivable that he is described by their good qualities and becomes "lordly" (rabbāniyy ${ }^{a n}$ )

\footnotetext{
108 Al-Iskandarī, Tartīb al-sulūk, p. 58.

109 Ibid. p. 57.

110 Al-Iskandarī, Ibn 'Ațā' Allāh (m. 709/1309) et la naissance, pp. 137-139. A similar saying is quoted from al-Mursī, cf. al-Iskandarī, Lațāîf al-minan, p. 26.

111 Ibn al-Ṣabbāgh, Durrat al-asrār, p. 132.
} 
- though not in the sense that he becomes like God, but rather that he is near to his Lord by his spiritual station (maqām).112

From being unconscious of the created realm in fanā', Shādhilī doctrine turns to the classical Junaydian model wherein perfection is only reached by returning to the creation with the profound consciousness that God is constantly governing it, perceiving that He is always manifest in all created things, which thence become as mirrors for His perfect attributes. ${ }^{113}$ This is the station referred to in the above quote of al-Shādhili as subsistence $\left(b a q \bar{a}^{3}\right)$, which is where the veil of self-direction is said to have fallen and the Sufi witnesses that everything is in the hands of God.114

There is one final aspect of Shādhili doctrine of which we can find hints in al-Wāsițī's autobiography. He characterizes the Shādhilīs twice by the word injidhāb to signify that they are drawn near unto God. ${ }^{115}$ In another passage he uses the word jadhb, which comes from the same Arabic root-letters. He says: "The spiritual states that [the Shādhilīs] have are penetrating, distinguished insights (muțālacatt) that cause the attraction of their spirits (jadhb al-arwāh $)$ unto the domains of divine proximity (mawātin al-qurb)."116 Now, al-Wāsițîs use of these terms is significant for us in view of the distinction that is made in several Shādhili sources between two ways to arrive unto God: that of the sâlik and that of the majdhüb. The former is the traveler on the spiritual path, who struggles through the necessary states and stations to earn his friendship with God. The latter reaches this status unintentionally when he is suddenly overtaken by spiritual attraction (jadhb) from God by which he is drawn unto Him. Rāfi' relates the following explanation of this distinction from Ibn 'Ațā' Allāh:

The likeness of the sălik is that of someone who digs for water, bit by bit, until he feels exhausted - but it is after exertion that it gushes forth to him. The likeness of the majdhüb is that of someone who desires water, and for whom a cloud [suddenly] rains so that he takes from it what he needs without any exertion. ${ }^{117}$

\footnotetext{
112 Tāj al-Dīn Aḥmad Ibn 'Ațā̄' Allāh al-Iskandarī, al-Qaṣd al-mujarrad fì márifat al-ism almufrad, ed. Khālid Muḥammad Khamīs (Cairo: Maktabat al-khānjī, 20o8), p. 48.

113 This process is elaborated upon in al-Iskandarī, Lațāif al-minan, pp. 30-31; God's manifestation in the creation is also mentioned in the $15^{\text {th }}$ aphorism, cf. Al-Iskandarī, Ibn 'Ațā' Allāh (m. 709/1309) et la naissance, p. 91.

114 Al-Iskandarī, Kitāb al-tanwìr, p. 55 .

115 Al-Wāsițī, Riḥla, pp. 33 and 49.

116 Ibid. p. 50.

117 Al-Ṣuwaydī, Zīnat al-nawāzir, p. 272.
} 
In Lațäif al-minan, both paths to God's friendship are said to be described in the Qur'an, with the verse "whoso makes God his friend (wa-man yatawalla Alläh)" [Q. 5:56] being interpreted as a reference to the sālik, and "He [God] takes care of the righteous (wa-huwa yatawallā al-șālihịn)" [Q. 7:196] being interpreted as a reference to the majdhūb. ${ }^{118}$ Ibn 'Ațā' Allāh maintains that the majdhūb has a higher degree of friendship with God because, contrary to the sălik, he achieves the station of arrival right away and then continues to abide by the precepts of the spiritual way. ${ }^{119}$

If we now return to the initial question posed in the preceding section, whether there already existed a distinct Shāhilī țăiifa when al-Wāsiți entered Alexandria, the above study provides solid ground to argue that this was very likely the case. We have seen that all the major characteristics by which our Iraqi Sufi describes the Alexandrian Shādhilīs can also be found expounded upon in early Shādhilī writings, most notably, but certainly not exclusively, those of Ibn 'Ațā' Allāh. While the fact that Ibn 'Ațā' Allāh was the first Shādhilī shaykh to compose books on Sufism ensured that his legacy as a master of the țâifa was preserved in history, this does not mean that its formation must therefore necessarily be placed with him. We must bear in mind that, originally, the teachings of the Shādhiliyya would primarily have been transmitted orally, which was likely a central aspect of the disciple's suhba-relationship with his Sufi master. Hence, it is related that when al-Shādhilī was asked why he never wrote any books, he responded that his pupils are his books, a principle al-Mursī is also said to have lived by. ${ }^{120}$ Since we have noted that the common link between Najm al-Dīn (the source for al-Wāsițīs account of Shādhilī doctrine) and Ibn 'Ațā' Allāh was al-Mursī, we may then conclude that there was already a distinct doctrine and method that was transmitted orally within the latter's circle of disciples. Moreover, when we take into account that alMursī was the common link for the entire network of the Egyptian Shādhilīs that followed after him, the notion that a common doctrine existed among them that can be traced back to him becomes very plausible. All this, I would argue, points to the existence of a distinct țāifa well before the turn of the century, perhaps already under al-Mursī. I would even say that we should not disregard the possibility that it already originated under al-Shādhilī himself, although, admittedly, that will in all likelihood remain an unsolvable mystery.

118 Al-Iskandarī, Lațāi if al-minan, p. 27. Throughout the current study I have mostly relied on A.J. Arberry's translation of the Qur'an, though in several cases with slight alterations.

119 Ibid. p. 129.

120 Ibid. p. 6. 


\subsection{The Success of the Shädhiliyya}

Now that we have identified the Alexandrian Shādhilīs al-Wāsiți joined as a distinct Sufi țäifa with its own particular doctrine, we close his account of them with several observations that will explain to us, first, why he was initially attracted to their method in Sufism, and, second, why he eventually distanced himself from them. As with the Rifāiiyya, I will argue that his views on the Shādhiliyya can tell us something about the normative religiosity that dominated the context in which the țầifa thrived.

The first thing that is clear from al-Wāsițìs autobiography is that he had never seen Sufis like those of the Shädhiliyya before. In fact, of all the Sufi groups he accompanied during his lifetime, they were without a doubt the closest thing to what true Sufism should embody in his vision. He tells us in his autobiography: "By God, I felt intense joy with them and my heart found rest with them and their method (tariq), because I perceived with them something that is the highest degree that can be attained and the utmost limit that can be desired!"121 Moreover, one gets the impression from his choice of words that the Shādhilī shaykhs he met must have been highly charismatic figures. At one point, he even likens them to angels:

Truly - and God knows better the reality of the way I perceived them I likened them to the angels who are in the presence of God surrounding His Throne, even if they do not resemble them in every respect. Do not deem this strange, for their hearts are amidst the host of God's friends (awliy $\vec{a}$ ) surrounding the Throne, so that during most of their spiritual states their character $(t i b \bar{a})$ is transformed from that of a human being into that of an angel. This unique trait (khușussiyya) that they have cannot be denied and only they are able to achieve it. ${ }^{122}$

For al-Wāsițī, it must have been Najm al-Dīn in particular who inspired him, not just during his time in Alexandria, but also afterwards as he continued his journey in search of the pathway to God. He reveres him as a 'knower of God' (al-'ārif) in his autobiography, ${ }^{123}$ and concludes in his Q⿳亠丷⿵ ida fí al-tajrìd that

he (R) summarized for me everything that the seeker [of God] needs during the beginnings and the endings [of the spiritual way], such as vigilant awareness (murāqaba), experiential knowledge (márifa), annihilation 
(fana $)$, love (mahabba), and detachment (tajrid) - although I only understood this after a period of time. ${ }^{124}$

This shows that Najm al-Dīn had a considerable influence on his understanding of the Sufi path, a fact that we will be reminded of in part 2 of our study.

Al-Wāsițīs deep admiration for the Shādhiliyya was for the greater part grounded in what we may identify as the țāiffa's soberness, which manifested in its scholastic and practical approach to Sufism. It is in fact exactly on the basis of this soberness that several scholars have sought to explain the success of the early Shādhiliyya. Both Éric Geoffroy and Nathan Hofer view their sober Sufism as a product of the Malāmatī tradition, the Nishapuri way of blame, which emphasized the importance of keeping one's piety private. Moreover, Geoffroy contends that the Shādhiliyya was able to spread so quickly because its doctrine was formulated in words that were easily accessible to all kinds of people. He also argues that it was thanks to the "orthodoxy" of the early Shādhili masters that the țăiifa was easily accepted by Egypt's 'ulamă ${ }^{\prime}{ }^{125} \mathrm{~A}$ similar line of argumentation is adopted by Hofer, who states that the practical way of the Shādhiliyya created social space for many different strands of people to participate in Sufism. In his reading of Ibn 'Ațầ' Allāh's Lațāi if al-minan, he recognizes an effort to underline the Sunni credentials of the țāiffa's eponymous founder, al-Shādhilī, by constructing his image as a scholar and a jurist. ${ }^{126}$ He argues that, by doing so, Ibn 'Ațâ̄' Allāh aimed to secure the țẩifa's legitimacy within the domain of Sunni Islam - an approach we have also observed in the portrayal of al-Rifāi ì by his followers in the previous chapter. As we will now see, the sober character of the Shādhilīs is more or less confirmed by alWāsițī.

This is first and foremost illustrated by our Iraqi Sufi in terms of their close observance of Islamic law. In his autobiography he writes that he "found them the most strict of people in honoring the revealed law (sharita), the commands and prohibitions." 127 The scholastic background of the early Shādhilī masters is also attested to in several biographical sources. Al-Yāfici relates that besides Najm al-Dīn's knowledge of Sufism, he was also learned in Shāfiī jurispru-

\footnotetext{
124 Al-Wāsițī, Qā'ida fíal-tajrìd, p. 257.

125 Éric Geoffroy, "Entre ésotérisme et éxotérisme: les Shâdhilis, passeurs de sens (Égypte XIIIe - Xve siècles)," in Une voie soufie dans le monde: la Shâdhiliyya, ed. Éric Geoffroy (Paris: Maisonneuve et Larose, 2005), pp. 117-118. See also by the same author, Le Soufisme, pp. 490-491, where he argues that the order's balance between sharía and haqiqa was at the heart of its success.

126 Hofer, The Popularisation of Sufism, pp. 140-141 and 16o.

127 Al-Wāsițī, Rihlala, p. 34.
} 
dence. ${ }^{128}$ This may very well have played some role in his relationship with al-Wāsițī, who would himself still have followed the same madhhab when he was under his spiritual guidance. Furthermore, as we have already seen in the diagram above, practically all the notable members of the early ța $i$ ifa were to some degree trained in either the Mālikī or the Shāfiì school. Ibn al-Ṣabbāgh stresses that the close observance of religious law by following one of the legal schools was actually promoted by al-Shādhilī himself. ${ }^{129}$

With an approach to Sufism that aimed to be grounded in scholastic Islam, there are indications that early Shādhilī shaykhs may have occasionally been critical of Sufis who, in their eyes, did not sufficiently observe the boundaries of law and theology. A good example is the criticism towards the Rifāiiyya alWāsițī reports from Najm al-Dīn, who would have said that "nothing corrupts this religion like two groups: the Ahmadiyya when it comes to women and the Harīiyya when it comes to young boys." ${ }^{130}$ Although the evidence for an actual Shādhilī-Rifāî̀ rivalry is scarce, Geoffroy too has noticed that the two Sufi groups appear to have been quite incompatible and did not always go well together. ${ }^{131}$ According to Geoffroy, the critical attitude towards Sufis who were in some way regarded as transgressing the proper bounds of religious law can be viewed as characteristic of the early Shādhiliyya and was continued by later generations. ${ }^{132}$

Here we must make make note that some of the later Shādhilī shaykhs took a somewhat new direction that al-Wāsițī would not have been appreciative of. I am referring here to the growing influence of what many scholars have labelled 'the Akbarian school of Sufism,' which appears to have entered the Shādhili $t \bar{a}^{\prime} i f a$ somewhere after the turn of the seventh/thirteenth century. ${ }^{133}$

128 According to al-Yāfi'ì, Najm al-Dīn occupied himself with many religious sciences ('ulūm) and his book in jurisprudence (figh) was al-Ghazāli’s Wajizz, see: Mir'āt, vol. 4, p. 198; see also: al-'Asqalānī, al-Durar al-kāmina, vol. 3, p. 86.

129 Ibn al-Ṣabbāgh, Durrat al-asrār, p. 34.

130 Al-Wāsițî, Rihla, p. 24. The Ahmadiyya is, as noted in the previous chapter, one of the

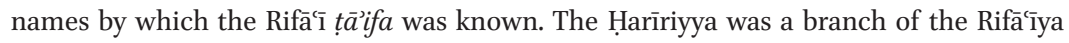
from Damascus, founded by 'Alī b. Abī al-Hasan al-Harīī al-Marwarī (d. 645/1147), cf. Louis Massignon, "Harīî̀ya," in $E I^{2}$ : vol. 3, p. 222.

131 Geoffroy gives an example in Le Soufisme, pp. 278-279, and also in "Les milieux," pp. 175176 .

132 Geoffroy, Le Soufisme, p. 178.

133 This trend among the Shādhiliyya has been studied in some detail by Geoffroy in "Entre ésotérisme," pp. 125-128 and Le Soufisme, pp. 221-222 and 391-392. He observes the increasing influence of Sufis such as Ibn 'Arabī, Ibn al-Fārị̣, and Ibn Sab'īn from the end of the seventh/thirteenth century onwards, and concludes that the Shādhiliyya played an important role in helping the advocates of ' $w a h d a$ ' rise from all-round denial to relative acceptance. He contends that it were in fact Shādhilī shaykhs who became the foremost 
Branded by its opponents as 'monists' (ittihādiyya), the Akbarian school is mostly known for the unity of being/existence (wahdat al-wujüd). It is closely connected to the doctrine of Muhyī al-Dīn Ibn 'Arabī (d. 638/1240), famously known as 'al-shaykh al-akbar' (the greatest master) from which the school derives its name. The latter's teachings were spread and expounded upon by his followers, such as his foremost disciple Șadr al-Dīn al-Qūnawī (d. 673/1274), and the latter's pupil 'Afîf al-Dīn al-Tilimsānī (d. 69o/1291). These figures and several others were increasingly incorporated by later Shādhilīs, a development that may have instigated some debate surrounding the legitimacy of the Shādhili țầifa in view of what some considered as its apparent incorporation of monistic teachings. I do not doubt that this, at least partially, motivated the Egyptian polymath and Shādhilī Suf Jalāl al-Dīn al-Suyūṭi (d. 911/1505) to prove that the early Shädhilī masters had nothing to do with the doctrine of divine indwelling (hulül) and unification (ittihāad). ${ }^{134}$ It is worthwhile noting that both he and Ibn Taymiyya relate a severe condemnation aimed at monistic Sufis that is attributed to al-Mursī, who would have held that "they are unbelievers ( $k u f f a r r)$, because they believe that the creation is the same as the Creator."135 In Ibn Taymiyya's version, this remark is even supposed to have been directed

interpreters of Ibn 'Arabī and Ibn al-Fāriḍ. Richard McGregor studied the considerable influence of Akbarian Sufism on the Wafā’iyya, a Cairene branch of the Shādhiliyya started by Muhammad Wafā’ (d. 765/1363), a disciple of Ibn Bākhilā, cf. "Akbarian Thought in a Branch of the Shâdhiliyya," in Une voie soufie dans le monde: la Shâdhiliyya, ed. Éric Geoffroy (Paris: Maisonneuve et Larose, 2005), pp.107-115. Ibn 'Arabī himself never formed a distinct madhhab or order, but, as Chittick explains, scholars have used the term "school of Ibn 'Arabī", "to refer to the fact that many Muslim thinkers ... took seriously Ibn 'Arabī's title as the "Greatest Master" (al-shaykh al-akbar) and consciously rooted their perspective in their own understanding of his theoretical framework." Cf. William C. Chittick, "The school of Ibn 'Arabî," in History of Islamic Philosophy: Part 1, ed. Seyyed Hossein Nasr \& Oliver Leaman (London/New York: Routledge, 1996), p. 510. It must be noted that some scholars appear to have also regarded those Sufis with monistic tendencies as being part of the Akbarian school, even though they may not have had any concrete relation with Ibn 'Arabī's thought. The poet Ibn al-Fārị, for instance, was a contemporary of Ibn 'Arabī who certainly did not belong to his circle, but whose poetry was so popular among Ibn 'Arabi's followers that he was in that sense incorporated into the Akbarian school by both its followers and its detractors, cf. Homerin, "Sufis and their Detractors," pp. 228-229.

Jalāl al-Dīn 'Abd al-Raḥmān b. Abī Bakr al-Suyūțī, Ta'yīd al-ḥaqīqa al-'aliyya wa-tashyìd al-țarīqa al-Shādhiliyya, ed. 'Āṣim Ibrāhīm al-Kayyālī (Beirut: Dār al-kutub al'ilmiyya, 20o6), pp. 54-55; note that al al-Suyūṭī also defended Ibn 'Arabī against such criticisms.

Jalāl al-Dīn 'Abd al-Raḥmān b. Abī Bakr al-Suyūṭì, al-Hāwī li-al-fatāwā (Beirut: Dār al-Fikr, 2004) vol. 2, p. 162, and Ibn Taymiyya's Haqüqat maddhab al-ittihādiyyīn, MF, vol. 2, p. 245. I believe al-Suyūtī actually cites from this work by Ibn Taymiyya, although he does not give the same title. 
specifically at the Akbarian master al-Tilimsānī and his following. As for alWāsițīs account, since his autobiography tells us that he was only introduced to the Akbarian school (which he termed 'al-ittihädiyya') in Cairo, we can assume that he found no evident traces of its doctrine when he was in Alexandria. That there was indeed a distance between the early Shādhiliyya and the followers of Ibn 'Arabī was also the impression of the late scholar of Sufism Paul Nwyia, who based himself on Ibn 'Ațā' Allāh's writings. ${ }^{136}$ We can thus say that, in all likelihood, distinct Akbarian teachings were still completely absent from the țăiifa as al-Wāsițī witnessed it, and were in all likelihood introduced only after Ibn 'Ațā' Allāh’s time.

Besides its scholastic and critical character, the Sufism of the Shādhiliyya must have also appealed to al-Wāsițī on a practical level. As several scholars have already noted, early Shādhilī shaykhs did not demand of their pupils that they wear a particular dress. This contrasted with many other Sufi groups in Alexandria, especially those with roots in the west, such as the followers of Abū Madyan, who wore the so-called patched Sufi cloak (muraqqa'a) to exhibit their renunciant lifestyle. ${ }^{137}$ Many such groups would also hold $s a m \bar{a}^{c}$ gatherings, a practice that was not undisputed among Muslim jurists as we have seen in chapter $1 .{ }^{138}$ This, too, was not done by the early Shādhiliyya, as attested to not only by the fact that al-Wāsiți makes no mention of it in his

${ }_{136}$ See Nwyia's introduction in: al-Iskandarī, Ibn 'Ațā' Allāh (m. 709/1309) et la naissance, pp. 25-26; I owe this reference to Alexander Knysh, Ibn 'Arabi in the Later Islamic Tradition: The Making of a Polemical Image in Medieval Islam (Albany: State University of New York Press, 1999), pp. 8o-81.

137 Ibn 'Ațā' Allāh states that the Shādhilī way does not promote renunciant clothing because that would draw attention to oneself and give the impression that one is in need of people's donations, whereas the Sufi should only be in need of God, cf. al-Iskandarī, Lațāi if al-minan, p. 134. The wearing of patched cloaks appears to have been practiced in the school of Abū Madyan, proof for which is found in Vincent J. Cornell, The Way of Abu Madyan: Doctrinal and Poetic Works of Abū Madyan Shu'ayb ibn al-Husayn al-Anșārī (c. 509/1115-16-594/1198) (Cambridge: Islamic Texts Society, 1996), pp. 96-67, and al-Tādilī, alTashawwuf, p. 439, where we find that the followers of al-Māghirī wore them.

${ }_{13} 8$ The Rifācī shaykh Abū al-Fath al-Wāsițī would certainly have organized samă $\bar{a}^{c}$ gatherings, given the importance of the ritual in his ță ifa. It is related that the Sufi master al-Shātịi practiced $\operatorname{sam} \bar{a}$, as this was the way of his own master, Abū al-'Abbās al-Ra's, cf. Ibn Abī al-Manșūr, La risāla, p. 108. The sama $\bar{a}^{c}$ was likely also performed in the Alexandrian community of Sufis with origins in the west, since we find that it was part of Abū Madyan's method, although with some caution, as noted by Cornell, The Way of Abū Madyan, pp. 34-35. It must be mentioned that not all Sufis from the west were in favor of the ritual, an example of which is Ibn 'Arabī, who hailed from Murcia, cf. William C. Chittick, The Self-Disclosure of God: Principles of Ibn al-Arabi's Cosmology (Albany: State University of New York Press, 1998), p. 383, and also: Claude Addas, Quest for the Red Sulphur: The life of Ibn 'Arabi, trans. Peter Kingsley (Cambridge: Islamic Texts Society, 1993), pp. 163 and 272. 
account of the țāiffa, but also explicitly by several Shādhilī sources. Both Ibn al-Ṣabbāgh and Ibn 'Ațā' Allāh relate that samā' was not done by al-Shādhilī, and al-Suyūṭi also confirms that it was not part of his method (tarīq). ${ }^{139}$ And thanks to Rāfi 'we know that it had still not integrated into the Shādhilī method of Sufism under Ibn 'Ațā̄' Allāh, who is cited on the issue as follows:

It is not proper for you to attend the sama $\bar{a}$ in this age. That is because the $s a m \bar{a}^{c}$ of the early [Sufis] was done to give rest to their spirits (nufüs), since the process of spiritual disciplining (al-riya $\bar{a} d a)$ is a fire that is extinguished through the $s a m \bar{a}$. But the folk of this age attend the $s a m \bar{a}^{c}$ because they're sick from eating too much food and being overly satiated, so that [the sama] strengthens their worldly desire. Sometimes, their carnal souls and desires are also stimulated because they listen to a beautiful voice. Now if you would say that al-Junayd, Sarrī, and others like them attended the $s a m \bar{a}^{c}$, then we would say to you: Indeed, but they would eat food and subsequently fast, whereas you will eat and not fast. ${ }^{140}$

Finally, the Shādhilī way was also sober in that it did not require from its followers that they renounce the world and live in poverty. On the contrary, the order's second shaykh, al-Mursī, is quoted as having emphasized the importance of having a means of subsistence (sabab), and Ibn 'Ațā' Allāh's Kitāb altanwir contains several passages that elucidate how the practice of Sufism can be combined with making one's daily livelihood. ${ }^{141}$

In view of al-Wāsițî's critical attitude towards what he perceived as a lack of regard for religious law among many Sufis and the acceptance of innovated rituals such as sama $\bar{a}^{c}$ gatherings, his stay among the Alexandrian Shādhiliyya must have seemed as if he had finally reached the destination of his journey, if only for a time. The way he explains it himself, he eventually traded Alexandria for Cairo because he became increasingly dissatisfied with his newfound Sufi companions for two particular reasons.

One of these may be identified as the first clear-cut instance where he displays his conviction that the traditionalist creed is the only correct creed. Although we have seen in chapter 1 that he appears to have denounced Ash'arism in favor of traditionalism in Baghdad already, it is only in the conclusion to his account of Alexandria that we find it formulated unambiguously for the first

139 Ibn al-Ṣabbāgh, Durrat al-asrār, p. 104; al-Iskandarī, Lațā̉if al-minan, p. 61; al-Suyūțī, Ta’yid, p. 73 .

140 Al-Ṣumaydī, Zīnat al-nawāzir, pp. 284-285.

141 Al-Iskandarī, Lațāiif al-minan, p. 97; and by the same author, Kitāb al-tanwìr, pp. 51-55 and 6o-117. 
time. While we should be open to the possibility that his theological criticism of the Shādhiliyya was formulated only later on during his Damascene years, he ascribes it such a central role in his autobiographical writings that it may very well reflect what had been his true sentiment. The Rihla describes his theological disagreement with the Alexandrian Sufis as one of the primary reasons behind his departure from them:

Then I thoroughly examined the foundation of this uppermost level (dhirwa) that [the Shādhilīs] have, in order to see on what it is based in terms of the articles and principles of faith (al-'aqā'id wa-al-ușūl). I found them to be a people who are not conscious of the Sunna, nor the era of the Prophet, the lives of his Companions, or [their] morality (akhlāq). I also found that they believe in something of the tenets of the Jahmiyya (lit. tajahhum); and although I did not find them openly declaring beliefs that strip God of His attributes $(t a t i \bar{l})$, they are nevertheless inclined to refrain from judgment [about them] (wuqūf). Indeed, I do not doubt that they deny some of the divine attributes (șifät), or refrain from judgment aboutthem, asistheschoolofthespeculativetheologians(mutakallimin).$^{142}$ Because of that I found that they are overshadowed by a darkness and that there is a disease in the lights of their faces. ${ }^{143}$

His claim of having detected elements of the Jahmiyya among his Alexandrian shaykhs is a common ploy used by traditionalists to equate followers of the Ash'arī school with a doctrine that is widely regarded as heretical among the majority of Sunni scholars, including the Ash'arīs themselves. ${ }^{144}$ He takes it a

142 The use of the term ' $w u q u \bar{f}$ ' in the context of theology is explained by Ibn Taymiyya in his al-Fatwā al-hamawiyya al-kubrā as follows: He differentiates between two groups who both differ in the way that they abide by the principle of wuqu $f$ with regard to God's divine names and attributes: (1) A group that consists mostly of jurists ( fuqah $\left.\bar{a}^{3}\right)$, who are said to profess that it is possible that the apparent (zāhir) meaning is intended by any particular attribute of God in a way that befits His loftiness (jaläl), while remaining open to the possibility of it not being intended as such. (2) The second group are the speculative theologians who are said to profess that they refrain (yamsikün) from all of this, and do not go beyond the recitation (tilāwa) of the Qur'an or the reading (qiräa) of the hadith, thus turning away from their meanings with heart and tongue, cf. Ibn Taymiyya, MF. vol. 5, pp. 116-117. Al-Wāsițī, Rị̣la, p. 35 .

144 Ibn Taymiyya does this quite often; see for instance his Bayān talbīs al-Jahmiyya fì ta'sīs bida ihim al-kalāmiyya, ed. Yahyā b. Muhammad al-Hunaydī et al (Riyad: Majma' al-malik Fahd, 2005), vol. 1, p. 8, where he states that the Bayān talbīs is a refutation of the Ash'arī theologian Fakhr al-Dīn al-Rāzī, whom he refers to as one of the pseudo-Jahmī theologians (al-mutajahhima al-mutakallimin). 
step further in his Q $\bar{a}^{\prime} i d a f ı$ al-tajrìd, where he seems to be implying that Ash'arī kalām was an integral part of Shādhilī doctrine. After citing the earlier advice of Najm al-Dinn regarding the need to become absent in the meaning of the words "God was and there was nothing with Him," which we have identified as a reference to God's pre-eternity, al-Wāsițī remarks:

This is the key to intimate knowledge (ma'rifa) of God and knowledge of His existence according to the method of the speculative theologians (ahl al-kaläm). However, according to the method of the Ahl al-Sunna, the key to intimate knowledge is knowledge of God's aboveness (fawqiyya) in a way that befits His majesty, and not in a way that it is taken as one of the attributes of created beings. ${ }^{145}$

That is, in al-Wāsițīs vision of Sufism, the sound way to become intimately acquainted with God is built on the affirmation that He is above His creation, in accordance with the traditionalists (referred to here as the Ahl al-Sunna), whereas the way of the Shādhilīs is built on a deep realization of God's preeternity, in accordance with the Ash'arī kalām-scholars.

There are two important claims made by al-Wāsițī here: first, that the issue of pre-eternity is particular to the mutakallimūn (by which he undoubtedly means the adherents of the Ash'ari school); second, that there was a distinct presence of Ash'arī kalām in the early Shādhiliyya. Based on other primary sources, we can find that both claims actually have a historical basis.

Regarding the centrality of God's pre-eternity, there are many examples of works by followers of the Ash'arī school where we find mention being made of the notion that God existed in pre-eternity and that "He is now as He was." One of the earliest instances is found in the epistle on Sufism (al-Risāla) by the Asháaī Sufi al-Qushayrī (d. 465/1072), in a citation from Abū Bakr Muḥammad Ibn Fürak (d. 330/941), his teacher in theology and one of the early leading Ash'arī theologians. ${ }^{146}$ Other examples of important Ash'arīs who refer to this in their creeds are al-Ghazālī and 'Izz al-Dīn Ibn 'Abd al-Salām (d. 66o/1261).147

145 Al-Wāsițī, Qā'ida fì al-tajrìd, p. 256.

146 Abū al-Qāsim 'Abd al-Karīm b. Hūzān al-Qushayrī, al-Risāla al-Qushayriyya, ed. 'Abd al-Ḥalīm Maḥmūd \& Maḥmūd b. al-Sharīf (Cairo: Dār al-Ma'ārif, 1995), vol. 1, pp. 24-25. I owe this reference to Gibril Fouad Haddad's The Refutation of Him [Ibn Taymiyya] Who Attributes Direction to Allāh (al-Raddu 'alā Man Qāla bil-Jiha) (Birmingham: AQQSA Publications, 2008), p. 165-169.

147 For the former see: Abū Ḥāmid Muhammad b. Muḥammad al-Ghazālī, Ihyyā' 'ulūm al-dìn (Beirut: Dār al-ma'rifa, 2011), vol. 1, p. 9o. See also: al-Subkī, Ṭabaqāt al-shāfíiyya, vol. 6, p. 232. For the latter, see: 'Izz al-Dīn Ibn 'Abd al-Salām 'Abd al-'Azīz al-Sulamī, "Al-Mulha fì i'tiqād ahl al-ḥaqq," in Rasā̄il fı al-tawhìd, ed. Iyād Khālid al-Ṭabbā' (Beirut: Dār al-fikr 
It is also explicitly formulated as the creedal position of Ibn Taymiyya's contemporary and Asharī opponent, the qạ ḍ̄ Ahmmad Ibn Jahbal al-Kilābì (d. 733/1333). Upon mentioning God's pre-eternity, he writes: "He was without place - He created place and regulated time - and He is now as He was: this is the school (madhhab) of the Ahl al-Sunna and the creed of the shaykhs of the spiritual path (mashāyikh al-tarīq)."148 It is surely no coincidence that, just as we have found al-Wāsițī do above, Ibn Taymiyya too connects this phrase to the theology of the Jahmiyya. He is surely addressing the Ash'arīs when discussing words very similar to those we have just quoted from Ibn Jahbal:

Such words were spoken by some of the later Jahmī speculative theologians, and this was subsequently learned from them by those who reached the extremity of the tenets of the Jahmiyya (al-tajahhum) which is stripping God of His attributes $\left(t^{t} t \underline{t} l\right)$ and apostacy - although the former would say: "God was, without place and without time, and $\mathrm{He}$ is now as He was," while the latter say: "God was and there was nothing with Him, and He is now as He was."149

Ibn Taymiyya then goes on to explain the importance of this phrase in view of the kalämi argument against the literal interpretation of several attributes by which God describes Himself in the holy texts, such as His sitting (istiwā) on the Throne and His descent $(n u z \bar{u} l)$ to the lowest sphere of the heavens. He comments on this, saying that "[the Ash'arīs] maintain that [God] was not sitting on the Throne in pre-eternity $(a l-a z a l)$; and since He is now as He was, $\mathrm{He}$ will not be upon the Throne [in a literal sense], for that would require [that He underwent] something of a transformation and change."150 This shows that the issue of pre-eternity was of particular importance to the Ash'arī argumentation that God exists beyond time and space, so that the literal value of statements describing Him sitting on a Throne or existing in aboveness cannot possibly be affirmed. ${ }^{151}$

al-mucāṣir/Damascus: Dār al-fikr, 1995), p. 11. See also: al-Subkī, Ṭabaqāt al-shāfíiyya, vol. 8, p. 219.

148 al-Subkī, Țabaqāt al-shāfíiyya, vol. 9, p. 41. Also translated in Haddad, The Refutation, p. 165 .

149 Ibn Taymiyya, Haqüqat maddhab al-ittihāäiyyīn, $M F$, vol. 2, p. 272.

150 Ibid. vol. 2, p. 273 .

151 That is not to say that Ibn Taymiyya, or traditionalists in general for that matter, dismissed God's pre-eternity. The issue here is rather to show that the Ash`arī and Shādhilī use of the notion as identified by al-Wāsițī can indeed be verified as a historical reality. For further notice of the importance of God's eternity in Ash'arī theology, see also: Michel Allard, Le 
As for the distinct presence of Ash'arism in the early Shādhilī way of Sufism, this is exemplified most clearly when we look at Izālat al-shubuhät 'an al-āyāt wa-al-ahāàith al-mutashābihāt, a treatise by Yāqūt's pupil Ibn al-Labbān. Its aim is to refute what he labels the literalism of the traditionalists, whom he accuses of ascribing anthropomorphism (tashbih $)$ and corporeality (tajsim) to God. In accordance with a group of the later Ash'arī scholars he argues for the necessity to apply a metaphorical interpretation $\left(t^{2} w^{2} \bar{l}\right)$ of the so-called mutashābihāt, the ambiguous verses from the Qur'an. He occasionally combines his argumentations with a discussion from the viewpoint of Sufism..$^{152}$

This work may very well be the most clear-cut example of how Shādhili Sufism was intermingled with Ashari theology, which manifests, above all, in the chapter on God's aboveness. Mentioned several times in the Qur'an in such verses as: "They fear their Lord above them (min fawqihim)" [Q. 16:50], Ibn alLabbān argues that the literal meaning cannot possibly be intended when the word 'fawqa' is used, since God is free from being bound by direction. But only those endowed with spiritual insight, who have mastered their hearts (arbāb al-bașāì wa-al-qulüb), can truly comprehend that God's fawqiyya is a highness that is essential to Him rather than one that is relative, he says, for the latter variety is specific to the created world, as either highness in a physical sense or in rank. It is here where Ibn al-Labbān delves deeper into the matter, using clear elements of Shādhilī Sufism. He explains that the manifestation (tajallī) of the light of God's unity through the highness of His fawqiyya comes from God's attribute of omnipotence (qahr). Its veil (hijäb) is pure servitude ( ubüdiyya), which he bases on the verse "He [God] is the Omnipotent over His servants (wa-huwa al-qāhir fawqa ibädihi)" [Q. 6:18].153 Ibn al-Labbān then elaborates upon this as follows:

If you desire to realize that [God's] aboveness is not a spatial aboveness (fawqiyya makāniyya), but that it is rather essential aboveness (al-fawqiyy a al-haqiqiyya) by the omnipotence of [His] lordship in view of [mankind's] servitude (qahr al-rubūbiyya li-al-ubüdiyya), then reflect on the fact that He was and there was nothing with Him. He is not delimited by His creation of the heavens in an upwards direction ('uluw), nor by His creation of the earth in a downwards direction $(n u z \bar{u} l)$, nor by His

problème des attributs divins: dans la doctrine d'al-Ašcarī et de ses premiers grands disciples (Beirut: Imprimerie Catholique, 1965), pp. 231-233.

$15^{2}$ Shams al-Dīn Muḥammad b. Aḥmad Ibn al-Labbān, Izālat al-shubuhāt 'an al-āyāt wa-alahāàith al-mutashābihāt, ed. Ayman 'Abd al-Jābir al-Buhayrī and 'Amr Muṣțafā al-Wardānī (Cairo: Dār al-bayān al-'Arabī, 2002), pp. 31-35.

Ibid. p. 98 (underlining my own). 
creation of the Throne upon which He sits. On the contrary, the entire quantity of created things springs from the manifestation (tajallī) of His divine names and attributes, without physical contact with Him, and without being relative to Him in terms of aboveness, underness, or any other direction. He (T) says: "Magnify the Name of your Lord, the Most High $\left(a l-a^{\imath} l \bar{a}\right)$, Who created and shaped" [Q. 87:1-2]. Here, He is described as 'the Most High,' a status by which He is distinguished from the creation, which indicates that His Highness was established before the creation. ${ }^{154}$

Ibn al-Labbān thus leans on the notion that God existed in pre-eternity before there even was space and time, so that His aboveness can never be spatial. To get around the literal meaning he applies the Shādhilī dichotomy of rubübiyya and 'ubüdiyya by holding that God's pre-eternal fawqiyya concerns His essential omnipotence over His servants.

While I have not come across any other Shādhilī treatise that is of such a theological, kalämī nature as that of Ibn al-Labbān, there are several more indications that Ash'arism was inherent to the tă $i f a$. It is highly likely, for instance, that al-Wāsițī's shaykh Najm al-Dīn was also an adherent of the kalām school. Al-Yāfíì, himself a staunch Ash'arī, hints at this where he relates that the renowned Shāfíi Ash'arī master Ibn Daqīq al-'̄̃d (d. 702/1302) once expressed his amazement at the deviation (shudhüdh) he found in the creed of al-jīlānī regarding the divine attributes, to which Najm al-Dīn replied that the famous Hanbalī Sufi had revoked his traditionalist beliefs at the end of his life. ${ }^{155}$ Besides Najm al-Dīn, al-Yāfi'ì explicitly names al-Shādhilī as one of the great knowers of God ('ārifin ) who followed the school of Abū al-Hasan al-Ash'arī.156 Other known examples of Ash'arī Shādhilī shaykhs are al-Mursī, Ibn 'Ațā' Allah, and the latter's pupils, Ibn Bākhilā and Taqī al-Dīn 'Alī al-Subkī (d. $756 / 1355) \cdot{ }^{157}$ Furthermore, many of the scholarly authorities mentioned in the

154 Ibid. p. 99 .

155 Al-Yāfi'ì, Mir'āat, vol. 3, pp. 272-273. For Ibn Daqīq's Ash'arism, see: Taqī al-Dīn Muhammad

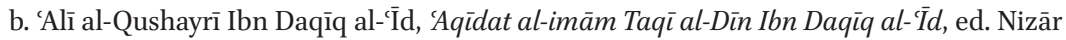
al-Ḥammādī (Tunis: Dār al-imām Ibn 'Arafa, 2012), pp. 22-30, where he discusses God's names and attributes.

156 Al-Yāfi'ì, Mir'āt, vol. 2, p. 228.

157 See: al-Iskandarī, Lațāif al-minan, p. 83, where al-Mursī is mentioned as having studied al-Juwaynī's Irshād. For Ibn 'Ațā' Allāh, see his Miftāh al-falāh, p. 37, where he stresses the importance of having a sound creed ('aqida) that is in accordance with "the school of those who are on the truth (madhhab ahl al-haqq)." That he is actually speaking of the speculative theologians becomes clear on p. 40, where he states that it is the mutakallimūn who protect the declaration of divine unity against innovators (mubtadía). Although Ibn 
sources as having been on close terms with the Shādhiliyya were also Ash'arīs, such as the above-mentioned Ibn Daqiq and his distinguished teacher in jurisprudence, Ibn 'Abd al-Salām;'158 also the renowned mutakallim, qādī Shams alDīn Abū 'Abd Allāh Muhammad al-Iṣbahānī (d. 688/1289), ${ }^{159}$ and the Mālikī jurist, famous for his book al-Madkhal, Muhammad Ibn al-Hājj al-'Abdarī (d. $737 / 1336) \cdot{ }^{160}$

In conclusion to the above observations, I would argue that while the presence of Ash'arī doctrine among the Shādhilīs was one of al-Wāsițìs main reasons for leaving Alexandria, it is precisely in their adherence to the kalām school that we find a significant reason for their success in Alexandria - and perhaps even Egypt in general - that has mostly been overlooked in studies of the early ta $\bar{a}^{3} f a{ }^{161}$ By no means am I claiming that scholars have been unjust in laying emphasis on the Shādhiliyya's sober, sharîa a-minded Sufism to explain

'Ațā' Allāh is not explicitly mentioned as an Ash'arī, al-Ghunaymī shares my conviction that this was the case, cf. Ibn 'Ață' Allāh, p. 66. For Ibn Bākhilā, see Sharaf al-Dīn Dāwūd Ibn Mākhilā al-Iskandarī, al-Lațîfa al-marḍiyya bi-sharh du'ẩ al-Shādhiliyya, ed. Muḥammad 'Abd al-Qādir Nașșār (Cairo: Dārat Karaz, 2011), where he frequently refers to Ash'arī doctrine and scholars, see: pp. 117, 142 for Abū Bakr al-Bāqillānī, 129 for Fakhr alDīn al-Rāzī, 168 for al-Juwaynī, and 193 for al-Ash'arī himself. For al-Subkī’s Ash‘arism, see al-Subkī, Țabaqāt al-shäficiyya, vol. 10, p. 146.

158 On Ibn 'Abd al-Salām, see: al-Subkī, Țabaqāt al-shäfíiyya, vol. 8, pp. 218-238, and also: 'Izz al-Dīn Ibn 'Abd al-Salām 'Abd al-'Azīz al-Sulamī, Tafsìr al-qur'ān, ed. 'Abd Allāh b. Ibrāhīm al-Wahbī (Beirut: Dār Ibn Ḥazm, 1996), vol. 1, pp. 486-487 for the Ash'arī position on of God's sitting on the Throne, and vol. 2, p. 193 on fawqiyya.

159 Al-Ișbahānī took lessons in Sufism from al-Mursī according to al-Iskandarī, Lațāàif al-minan, p. 72. For his Ash`arī background, see: al-Subkī, Țabaqāt al-shäfíiyya, vol. 8, pp. 100-102.

16o Ibn al-Hâjj's relation to the Shādhiliyya is attested to by al-Iskandarī, Lațāaif al-minan, p. 52, and whenever Ibn al-Ḥājj cites al-Shādhilī, he calls him "my master, the venerable shaykh (sayyidial-shaykh al-jalil)," words of respect he only appears to use for scholars he was affiliated with in some way, such as his own shaykh, al-Marjānī, whom he cites throughout al-Madkhal; see: Muḥammad b. Muḥammad Ibn al-Ḥājj al-'Abdarī, alMadkhal (Cairo: Maktabat dār al-turāth, date unknown), vol. 2, p. 189 and vol. 4, p. 29. Furthermore, his Ash'arism is attested to in al-Madkhal, vol. 2, pp. 147-153, where he devotes several pages to the refutation of anthropomorphism. He cites the Māliki authority Ibn Rushd al-Jadd (d. 520/1126) on p. 148, who was known to have promoted the Ash'arī creed in al-Andalus to counter literalism; see: Delfijina Serrano Ruano, "Ibn Rushd al-Jadd (d. 520/1126)," in Islamic Legal Thought: A Compendium of Muslim Jurists, ed. Oussama Arabi, David S. Powers and Susan A. Spectorsky (Leiden: Brill, 2013), pp. 310-314.

161 The relation between the Shādhiliyya and Ash'arism has been noted before, see for instance Kamran Karimullah's dissertation on the Shādhilī shaykh Aḥmad Zarruq (d. 899/1493): Ahmad Zarrūq and the Ash'arite School (dissertation M.A. McGill University, 2007), p. 31, where he notes that: "Zarrūq strongly identified the Shādhilī path with kalām: the formal principles of theology are related to the principles of the particular șüfism of Abū al-Ḥasan al-Shādhilī.” 
its successful expansion. However, the theological dimension of the context in which they thrived is equally deserving of attention. As noted in this chapter's first section, Alexandria was dominated by Shāfi'is and Mālikīs, the majority of whom adhered to the Ash'arī creed. It is, then, not difficult to imagine that, with its scholastic Sufism grounded in Ash'arī theology, combined with its attention for jurisprudence and a seemingly critical stance towards ecstatic Sufis, the Shādhilī way was easily embraced by the learned class of early Mamluk Alexandria. In addition, the țāifa's charismatic shaykhs were able to rapidly earn their place among the city's Sufi audience as well by laying claim to the western spiritual tradition. That way, the large population of Alexandrians with a Maghribi or Andalusi background could easily relate to Shādhilī Sufism. With all this in mind, one could say that the early order fit in neatly with the local normative religiosity of early Mamluk Alexandria, and that this undoubtedly contributed to its rapid growth in this context. However, for our Iraqi Sufi, who presents himself to us as having been a self-proclaimed traditionalist at that time, the distinct presence of Ash'arī theology was naturally not to his liking.

Now, as I have pointed out earlier, there was yet another reason for alWāsițì's separation from the Shādhilīs. Apart from his convinction that some of their theological beliefs were incorrect, their focus on the ta $\bar{a}$ iff's charismatic spiritual leaders also deeply troubled him. He tells us, for instance, that they would refer to al-Shādhilī by such terms as 'the spiritual axis' (al-quṭb) and 'the helper' (al-ghawth), the use of which is indeed attested to in works of early Shādhili authors. ${ }^{162}$ That such reverence bothered him is not surprising in consideration of the previously discussed criticism he had leveled against a similar attitude towards Sufi shaykhs among the Rifāīs. When it came to the Shādhilīs, however, the biggest issue for him was the essential role that the shaykhs played in their own spiritual experiences. In his autobiography he writes:

I also found that they acquire the above-mentioned states that they have from their shaykhs. Hence, they only mention their shaykhs without relying on hadith for these [states], even though there is no contradiction between them. Yet, their substance comes from the breaths (anfās) of their shaykhs, it is to them that their hearts are directed, and to them that they turn concerning their states. They depend on their [shaykhs'] spiritual unveiling (kashf), while only knowing their Lord with respect to His

162 Al-Wāsițī, Qã ida fí aṣnāf al-ta’alluh, p. 151; al-Iskandarī, Lațā̉if al-minan, al-Shādhilī is called the quṭb on p. 51 and al-Mursī on p. 76; Ibn al-Ṣabbāgh calls al-Shādhilī the ghawth and the quțb in Durrat al-asrār, p. 3 . 
antiquity and pre-eternity (qidamuhu wa-azaliyyatuhu), since He was and there was nothing with Him. ${ }^{163}$

We may note that what he viewed as excessive devotion to the shaykh in the Rifāiyya and the Shādhiliyya was most likely the mainstream position among Sufi groups in general in this epoch. There appears to have existed something of a consensus that the shaykh as a spiritual guide was essential to the novice's journey on the Sufi path. The Shādhiliyya was indeed no exception to that rule. This is exemplified most clearly by Ibn 'Ațā' Allāh's 'Unwān al-tawfì , which states that the Sufi seeker is required to find the spiritual axis (quț) of his age, as it is only through him that he may be guided unto God's proximity. ${ }^{164}$ Then, when he actually finds the axis by the grace of God, he must work hard in his service and keep him informed of his spiritual states, because the shaykh is like his spiritual physician. ${ }^{165}$ In Miftāh al-falāh Ibn 'Ațā' Allāh even relates that some Sufis are of the opinion that the disciple should imagine that his shaykh is before him when performing his remembrance of God (dhikr):

During the dhikr, [the novice] should seek the help of the shaykh's spiritual power (himma) with his heart or his consciousness [sic], believing that in doing so he is actually seeking the help of the Prophet (S), since [the shaykh] is his representative $\left(n \bar{a}^{\prime} i b\right) .{ }^{166}$

Thus, as scholastic and sober as the țầifa's Sufi doctrine was, al-Wāsițī had evidently developed his very own ideal image of Sufism that he could no longer consolidate with that of his Shādhilī masters. Their reliance on Ash'arī theology and devotion to their shaykhs were, in his view, serious obstructions on the pure, unadulterated journey towards God. He nevertheless felt a sense of debt to them, which he expresses poetically in the final sentence of his account of Alexandria:

But in spite of this I found something with them - and what a thing indeed! As it is said:

For the likes of Laylā a man may kill himself

Even if I'd completely renounce her! ${ }^{167}$

\footnotetext{
163 Al-Wāsiṭi, Riḥla, p. 35 .

164 Tāj al-Dīn Aḥmad Ibn 'Ațā̄' Allāh al-Iskandarī, 'Unwān al-tawfíq fì ādāb al-țarīq, ed. Khālid Zahrī (Beirut: Dār al-kutub al-'ilmiyya, 2004), pp. 53-54; this is also alluded to in: alIskandarī, Ibn 'Ațâ' Allāh (m. 709/1309) et la naissance, p. 149.

165 Al-Iskandarī, Lațāilf al-minan, p. 114, and by the same author, Miftāh al-falāh, p. 36.

166 Al-Iskandarī, Miftāh al-falāh, p. 21.

167 Al-Wāsițī, Rị̣la, p. 35.
} 
It is not mentioned why he subsequently chose to move to Cairo instead. Since the Shādhiliyya appear to have dominated Alexandria's Sufi scene one can imagine that he may have hoped to once again make a fresh start, this time in the capital of Egypt. However, what he found there among the Sufis was many times more loathsome to him than what he had found among the Shādhiliyya, and would finally push him away from Egypt for good. 


\section{The Final Steps: From Heretics to the Saved Sect}

After what would have been something of a fifteen-day journey, ${ }^{1}$ al-Wāsițī entered Cairo, the place that eventually turned out to be the turning point in his search for spiritual guidance in the sense that it pushed him to his final destination, Damascus. Since these were the last stages of his journey, his experiences in these two cities also comprise the last sections of his autobiography. The current chapter is therefore split into two parts: the first examines his account of the Egyptian capital and the Sufi convents he stayed in there, and the second follows the final years of his life spent in Damascus as a teacher of his own formulation of traditionalist Sufism. As I have noted before, we do not know when he entered Cairo and how long he subsequently stayed there. We do know that he must have already settled in Damascus in 699/1300, so that it is likely that he spent his time in Cairo somewhere during the nineties.

In his autobiography al-Wāsițī differentiates between two categories of Sufis he found residing in Cairo's convents. He calls the first group "sūfiyyat al-rasm," i.e. those who are Sufi only by carrying out the conventions of Sufism, a term that is actually coined by Ibn Taymiyya as well. ${ }^{2}$ The second group may be identified as those Sufis who either adhered to the Akbarian school or were close to it in doctrine, all of whom our Iraqi Sufi considers monists (al-ittihādiyya). Both the Sufis of convention and the Akbarians will be further examined below on the basis of al-Wāsițī's writings and several relevant primary and secondary sources. As we shall see, we are once more confronted with some difficulty in contextualizing what he tells us about both groups due to the meagre information he provides us with. There are nevertheless useful clues to be found in his account that will help us elaborate on the background of these two trends of Sufism that had apparently become successfully established in early Mamluk Cairo.

1 Udovitch, "Alexandria in the 11th and 12th Centuries," p. 102.

2 To my knowledge, Ibn Taymiyya only uses the term once (see: $M F$, vol. 11, p. 19). Whether it was appropriated by al-Wāsițī or the other way around remains impossible to establish. 


\subsection{The Sufis of Convention}

We have previously seen that, as the capital, Cairo was the economic and political center of the Mamluk sultanate. While I have argued that Alexandria may for a part of the seventh/thirteenth century be regarded as the Sufi capital of Egypt, mostly due to the distinct presence and activity of renowned Sufi shaykhs, by no means did I imply that Cairo was not an important center of Sufism as well. On the contrary, it was full of Sufi activity. In all its different, and sometimes opposing, manifestations, Sufism was undoubtedly already a fundamental part of the daily lives of many Cairenes when al-Wāsițī came to the city. When it comes to Cairo's scholars and students of religious knowledge this can be observed by merely looking at the many examples of religious institutions where Sufism was taught as one of the Islamic sciences. ${ }^{3}$ For the common citizen the link with Sufism is evident from the great numbers that flocked to Sufi shaykhs who were widely acknowledged as friends of God, or 'awliya $\bar{a}$ ' Allāh.' Their distinguished position was considered a source of blessing (bara$k a)$ that could be of benefit even after their passing by visiting their graves. ${ }^{4}$ As for the governing powers, their involvement with Sufism in Egypt became manifest most clearly for the first time in Cairo under the Ayyubids. It was then that Șalāh al-Dīn established the Dār Saīd al-su'adā', also known as the Salāhiyya, the first khānqāh of Egypt that served as a center for the so-called "state-sponsored" Sufism. For a considerable time this convent was headed by the country's chief Sufi shaykh, the shaykh al-shuyükh, who was appointed and salaried by the Ayyubids, a practice that the Mamluks continued. ${ }^{5}$ We could thus say that, like Alexandria, Cairo had become an important center of Sufism at the time of al-Wāsițī's travels, so that it was indeed no exceptional decision for a wandering Sufi to have an interest in the city.

Although there are several instances where al-Wāsiți tells us that he had at one point in his life lived in Sufi convents, he never mentions any by name. In the first sentence of the section on the șüfiyyat al-rasm in his autobiography we find him stating rather ambiguously that after his days among the Alexandrian Sufis he settled in 'the convent' (al-ribātt). ${ }^{6}$ It could very well be that his use of

3 On the presence of Sufism in the formal curriculum of Islamic institutions in the Mamluk period, see for instance: Berkey, The Transmission of Knowledge, chapter 3.

4 On the role of Sufism among "ordinary" citizens, see for instance: Shoshan, Popular Culture, chapter 1.

5 On the history of this khānqah, see for instance: Leonor E. Fernandes, The Evolution of a Sufi Institution in Mamluk Egypt: The Khanqah (Berlin: Klaus Schwarz Verlag, 1988), pp. 21-25. On the position of the shaykh al-shuyūkh, see: Nathan Hofer, "The Origins and Development of the Office of the "Chief Suf" in Egypt, 1173-1325." Jss 3 (2014): pp. 1-37.

6 Al-Wāsițī, Rihla, p. 37. 
the term ribät is significant here in view of his Iraqi background. In parts of Iraq, especially west of Baghdad, it was quite common to use the term ribät to refer to the "state-sponsored" Sufi institution, known in Egypt as the khānqāh. ${ }^{7}$ It is perhaps no coincidence that al-Dhahabi uses the word khānqāhs (khawāniq) rather than ribāts (rubuț) when he relates that our Iraqi Suf lived in Sufi convents for some time. ${ }^{8}$ It may very well have been specifically the institutions sponsored by the sultanate that he attended in Cairo, which would certainly have been a logical choice at that time.

There are in fact two indications in al-Wāsiți’s writings that the above-mentioned Sa'ìd al-su'adā was one of them. This khānqāh could house up to 300 people and was primarily meant for Sufis from abroad, particularly those of a Shāfíi-Ash'arī denomination, as attested to by its endowment deed (waqfìya). In practice, it especially attracted Muslims of Persian origin coming from the east, the majority of whom we know adhered to the latter schools of law and theology respectively. ${ }^{9}$ Sufis who traveled to the Saīd al-su'adā would stay for varying lengths of time. Some would come to study with reputable scholars who taught and transmitted books from there, while others simply wanted to find out what Cairo had to offer them. ${ }^{10}$ As an Iraqi Shāfíi and a Sufi in search of guidance, this could thus have been an environment that initially appealed to al-Wāsiți. His own account only very briefly touches upon what it was that convinced him to join the company of the convent's Sufis, where he states that "something of lights shone [with them] so I accompanied them and found [sic] them speaking about the remembrance of God (dhikr), spiritual seclusion (khalwa), the study of religious knowledge, and devotion to worship."11 Nothing more is found in any of his works regarding his motivation.

The first instance where he may be revealing indirectly that it was the Said al-su'adā where he stayed is found in his Talqị̂ al-afhām. In it he mentions that one of the characteristics of the Sufis he encountered in the convent was that "they love to show off their appearance (hay'a) to the common people (al'awāmm) on Fridays and gatherings." 12 Now, according to the Egyptian historian al-Maqrīzì (d. 845/1442), the people of Fusțāt (mișr) would come to Cairo on Fridays especially to watch the Sufis of the Sa'id al-su'adā proceed to the Ḥākimī Jāmic', believing that they obtained blessings therefrom. These Sufis,

$7 \quad$ Homerin, "Saving Muslim Souls," pp. 61-63.

8 Note that in the printed edition the word khawāniq is written as khawānik with the letter kāf instead of $q \bar{a} f$, cf. al-Dhahabī, Dhayl Tärīkh, p. 126.

9 Hofer, The Popularisation of Sufism, p. 69.

$10 \quad$ Ibid. p. 68.

$11 \quad$ Al-Wāsițī, Rihla, p. 37.

12 Al-Wāsițī, Talqūh al-afhām, p. 16o. 
al-Maqrizi continues, "would have an eminent appearance (hay'a fädila) on [these] Fridays." ${ }^{\prime 3}$ It is thus very well possible that it were exactly these processions from the Sa'īd al-su'adā that al-Wāsițī was referring to in Talqūh al-afhām.

The second indication that he stayed in the Sa'ìd al-su'adā is found in his autobiography. In the section on the monistic Sufis he says to have met in Cairo's convents, he attempts to discredit their doctrine through the following example:

When they go to see a king or someone with public authority (șăhib walāya), they address him and implore him as if they are imploring God. That is because, in their view, he is a manifestation of [God's] being (mazhar wujüdihi), so they are in fact addressing the 'divine being' (alwujūd) inside of him. Hence, one of their shaykhs would say to al-Shujāìi, who was a vice-regent known for tyranny and aggression: "You are the supreme name of God (anta ism Allāh al-a'zam)," and other such things! $!^{14}$

The vice-regent he is referring to here is 'Alam al-Dīn Sanjar al-Shujāî̀, a controversial Mamluk amir who was put to death in 693/1293 by supporters of Zayn al-Dīn Kitbughā, a rival amir who later became sultan..$^{15}$ According to the chronicles, he was indeed known among the people as an oppressor. He was in fact so hated that, after he was executed, they beat his severed head as it was paraded around Cairo on a spear. ${ }^{16}$ Now, we know that this amir had friendly relations with one al-Aykī, a shaykh of the Akbarian school to whom we will return shortly in the next section. Al-Shujāî is said to have favored him "to the extent that he would let him sit higher than him (kāna yu'qiduhu fawqa minhu)." ${ }^{\prime 17}$ And it was reportedly thanks to his influence that al-Ayki became head of the Sa'īd al-su'adā' when he was formally appointed shaykh al-shuyükh in $684 / 1285$, a position he held until he was dismissed somewhere between

13 Taqī al-Dīn Aḥmad b. 'Alī al-Maqrīzī, al-Mawāiciz wa-al-ítibār bi-dhikr al-khițaț wa-alàthār (Beirut: Dār al-kutub al-ilmiyya, 1997), vol. 4, p. 283.

14 Al-Wāsițī, Rị̣la, p. 41.

15 Ibn Taghrī Birdī, al-Nujūm al-zāhira, vol. 7, p. 384; al-Maqrīzì, al-Sulūk, vol. 2, p. 226. AlShujāî's bad reputation is also noted by Northrup several times in From slave to sultan, see for instance pp. 121-123, 140, and 218. al-Maqrīzī, al-Sulūk, vol. 2, pp. 254-255. The circumstances leading up to al-Shujāî̀'s execution are studied in detail by Amir Mazor, The Rise and Fall of a Muslim Regiment: The Manșüriyya in the First Mamluk Sultanate, 678/1279-741/1341 (Göttingen, Niedersachs: V\&R unipress, 2015), pp. 86-89.

17 Shams al-Dīn Muhammad b. Ibrāhīm al-Jazarī, Ta'rīkh ḥawādith al-zamān wa-anbā̉ihi wawafayāt al-akābir wa-al-a'yān min abnāihi, ed. 'Umar Tadmurī (Beirut/Șaydā: al-Maktaba al-'așriyya, 1998), vol. 1, p. 403 . 
687/1288 and 692/1292. ${ }^{18}$ With that in mind, it is not farfetched to think that the Sufi shaykh referred to by al-Wāsiți in the above-quoted remark may actually have been al-Ayki. If so, this would indicate that his autobiography's section on the monistic Sufis in the convents of Cairo was in all likelihood at least partially based on what he had witnessed in the Saî̀ al-su'adā'.

Either way, life within the confinements of the Sufi convent confronted alWāsiți once more with what he considered to be major flaws in the practice of Sufism in his age. His criticism towards the convent's inhabitants is reminiscent of what we have seen in his account of the Sufis he accompanied in Baghdad. At the heart of the label 'Sufis of convention' was his conviction that they failed to realize that the practice of Sufism ought to be a means to an end, and not the end itself. The label is perhaps explained most distinctly in Talqị alaftham, where he elaborates on what he means when he says that they are "obsessed with conventions" (al-'âkifün 'alà al-rusūm):

[They are] obsessed with what the group $(t \bar{a} i f a)$ has established, pertaining to conventional habits. They have made conventions regarding entering and leaving, sitting and moving, clothing and turbans. They view anything contradicting [their conventions] as something reprehensible, as if a $\sin .^{19}$

For al-Wāsițī, the supervised, orchestrated communal life in the khānqāh was the crux of the problem, because it resulted in behavior that was not purely for the sake of God. In his autobiography he describes the convents' Sufis as follows:

I found a people who are concerned with outward image, the marks of prostration on their foreheads, their appearance (hay'a), ornaments

The historian Ibn al-Furāt (d. 807/1405) may be implying that al-Aykī was dismissed in 69o/1291 in Tārīkh Ibn al-Furāt, pp. 123-124, while another historian, al-'Aynī (d. 1451/855), seems to imply that this occurred in 692/1292, cf. Badr al-Dīn Mahmūd al-'Aynī, Iqd aljumān fì tārīkh ahl al-zamān ('aṣr salāțīn al-mamālēk), ed. Muhammad Muḥammad Amīn et al. (Cairo: Dār al-kutub wa-al-wathāiiq, 2010), vol. 3, p. 179. It must be noted that neither of these two sources explicitly mention a date, but both discuss al-Ayki's dismissal in the entry of the year I have mentioned. We must also consider that al-Aykìs successor as shaykh al-shuyūkh, Ibn Bint al-A'azz, was deposed of all his positions save one in the year 69o/1291, cf. al-Dhahabī, Tärïkh, vol. 51, p. 55. Secondary sources also differ on the date of al-Ayki's dismissal, with the year 687/1288 mentioned by both Hofer, The Popularisation of Sufism, p. 65 and Homerin, "Saving Muslim Souls," p. 66. However, Hofer gives the year 689/129o in: "The Origins," p. 27. 
(ashkāl), and having their beards combed.... I found that their hearts are filled with the actions of their brothers. ${ }^{20}$

In other words, while they display the poverty of the Sufis (faqr) outwardly, they disregard work on their inner being $(b \bar{a} t \underline{t i n})$. He therefore refers to them in several other writings as "the people of outward appearance" (ahl al-ziyy) and their shaykhs as "Sufi masters in outward appearance only" (mashāyikh alziyy). ${ }^{21}$ For the most part their concern is for worldly matters, he says, for they are bent on preserving their own position and status. His main complaint in that regard is that that they put in sincere effort only to uphold the favor of their Mamluk patrons, who provide them with the stipends (sing. manșab, pl. manāsib) to preserve their life in the convent. ${ }^{22}$

As in most cases thus far, there is a historical reality to these descriptions if we examine other relevant sources. Because the situation of the khānqāh in Mamluk Egypt has been studied in some detail, we may to some degree historicize the picture al-Wāsiți has sketched for us above. We know, for instance, that there were indeed highly ritualized routines in which inhabitants of a khānqāh had to participate. The resident Sufi would have specific religious obligations to fulfill individually in his own cell, imposed by either the establishment's endower (wāqif) or its head shaykh. There were also specific communal practices that were incumbent upon each Sufi, such as the congregational prayers five times a day and their wazi $\bar{f} a$, the daily ritual duty that increasingly consisted of what came to be known as hudür. The latter term signified a gathering during which God would be remembered in a stipulated way, by reciting the Qur'an or through specific invocations, followed by the recital of Sufi poetry. During his visit to Cairo, Ibn Batțūța witnessed such sessions which, according to his Rihla, took place twice a day, once after the morning prayer (al-șubh), and once after the afternoon prayer $\left(a l-{ }^{\prime} a s ̧ r\right) .{ }^{23}$ Al-Wāsițī may very well be referring to this same ritual in his autobiography where he states that a Sufi who lives in the convent is fearful of skipping his afternoon ritual duty (waziffat al-'așr), lest his reputation be ruined, or worse, he be expelled from the convent. ${ }^{24}$ That, as implied here, a close record was being kept of everyone's participation in the daily routines is actually attested to by the fact that

\footnotetext{
$20 \quad$ Al-Wāsițī, Riḥla, p. 37.

21 Al-Wāsițī, Talqūh al-afhām, p. 158; Mīzān al-shuyūkh, p. 232; Mukhtaṣar sīrat rasūl Allāh, f.2b. where he refers to these Sufis as the Rasmiyya in a letter to several of his companions.

23 Ibn Bațtūța, Riḥla, vol. 1, p. 204.

24 Al-Wāsițī, Riḥla, p. 37.
} 
endowers of convents would appoint a so-called kātib ghaybat al-șūfiyya, a scribe who noted those Sufis who were absent during the communal obligations. ${ }^{25}$ Another observation made by al-Wāsiți that has a historical basis is his allusion to the financial dependency of the convents' Sufis on Mamluk officials. In the past, some scholars in Mamluk studies have dismissed such a dependency. However, more recently scholars such as Nathan Hofer and Emil Homerin have convincingly shown that the Sufis of the khānqāh were indeed reliant on the Mamluk sultanate for their livelihood. ${ }^{26}$

Finally, al-Wāsițì's negative depiction of the convents' shaykhs as charlatans who only look like Sufi masters outwardly perhaps reflects that, in practice, it was not required to be a Sufi of great renown to become head of a khānqāh. Since the position was actually quite lucrative, competition for it was fierce. We thus find that it would sometimes be granted to a jurist with no particular Sufi credentials, and that this was often on the basis of a relationship that the appointee had with the wäqif prior to the appointment. ${ }^{27}$

Under these circumstances al-Wāsiți would undoubtedly have felt that his life in Cairo was in no way a step forward from the Shādhiliyya. Matters soon went from bad to worse as he discovered a relatively new trend of Sufism that had gained favor among a group of the Sufis living with him in the convents. This was the Akbarian school of Ibn 'Arabī, whose followers al-Wāsițī viewed as sheer monists. He understood their presence in terms of what was to him the very core of the affliction that plagued the Cairene convents, namely, their focus on conventions:

They [the inhabitants of the convents] have something of the Mongols' disposition, for they accept anyone who upholds the conventions [of Sufism], be it a monist (ittihād $\bar{l}$ ) or heretic. They will not object to him. That is why the followers of Șadr al-Dīn al-Qūnawī and Ibn 'Arabī (al-șadriyya wa-al-arabiyya) are ever in their presence, in spite of the fact that they are aware of their deviancy (inhiräf)! Now, the same goes for the Mongols: they accept anyone who obeys [them], be it a Jew or a Christian. ${ }^{28}$

To judge someone's state as a Sufi merely by appearance or by his or her practice of Sufi rituals, without concern for sound doctrine, was a great threat to pure, unadulterated Sufism in al-Wāsițî's eyes. It was a threat that opened

Fernandes, The Evolution, pp. 54-56.

26 Hofer, The Popularisation of Sufism, p. 78; and: Homerin, “Saving Muslim Souls," p. 69.

27 Homerin, "Saving Muslim Souls," p. 70.

28 Al-Wāsițī, Riḥla, p. 38. 
doors to what he would come to recognize as one of the most dangerous manifestations of the Sufi path.

\subsection{The Heresy of the Ittihādiyya}

After having described the Sufis of convention, al-Wāsițîs autobiography proceeds with a new section to introduce the convents' ittihaddiyya, or monistic Sufis, who are portrayed as a distinct Sufi țăiffa. This section starts right away with setting forth his own understanding of their doctrine:

While living in the convents (al-rubut) I was confronted by a group ( $t \bar{a} i f f a)$ who talk about divine love (mahabba) and divine unity (tawhìd), to which they refer by saying: "This one is a monotheist (muwahhid), but that one understands nothing of [God's] unity." They magnify their level of tawhìd and ask who is able to reach it, then name their own shaykhs, such as Ibn 'Arabī and al-Ṣadr al-Qūnawì.

I stayed for some time to examine this tawhìd that they allude to. I concluded that the gist of it is that they believe the Real (T) to be nondelimited existence, permeating all created things (al-wujūd al-muțlaq $a l-s \bar{a} r \bar{\imath} f \grave{\iota} j a m \bar{\imath}$ al-akwān), and that He constitutes the true essence of all concrete things (haqīqat al-a'yān), whether living or inanimate beings. .... The reality of their creed (mutaqad) is that the Creator $(\mathrm{T})$ is not something separate from the creation, above the Throne. Rather, in their view the Real manifests in the heavens and the earth, and He manifests in all things with His very essence (bi-dhätihi). ${ }^{29}$

This passage is basically an attempt at defining the term wahdat al-wujüd, the unity of being/existence, a concept for which the Akbarian school is mostly known, and interpreted by its censors as pantheism/monism (ittihāad). AlWāsițī clearly makes no attempt to hide that he is one such censor. After the above description of Akbarian doctrine, he concludes that "when I perceived them in this fashion, my heart turned away from them with intense aversion!"30

Now, in reality, wahdat al-wujüd was never used as a technical term by Ibn 'Arabī nor by al-Qūnawī, both of whom are mentioned in the quoted passage. While some disciples of Ibn 'Arabi may have used it, the first to do so explicitly was probably the Sufi philosopher 'Abd al-Haqq b. Ibrāhīm Ibn Sabīn (d. 669/1270). However, it must be noted that Ibn Sab'in was not directly linked to Ibn 'Arabī through any teacher, although he did know al-Qūnawī and became

29 Al-Wāsițī, Rị̣la, p. 40.

$30 \quad$ Ibid. p. 41. 
the second shaykh of the latter's pupil, al-Tilimsānī. Because he was familiar with Ibn 'Arabī's work and his own doctrine was certainly influenced by it, he may nevertheless be identified as an Akbarian Sufi. ${ }^{31}$ As we shall see below, al-Wāsițī certainly considered him as such.

What both Ibn 'Arabī and al-Qūnawī did discuss in their writings, and which al-Wāsițī was clearly conscious of, is the relation between existence and God's oneness. According to their teachings, true existence only belongs to God, since all things that are not God are dependent on Him for their existence. Existence is thus essentially one because God in His essence (dhāt) is also one. Multiplicity is explained through the reality of the names and attributes by which God has described Himself in His revelation. Ibn 'Arabī held that while God's essential being is completely distinct from the phenomenal world and totally beyond its reach, $\mathrm{He}$ is at the same time manifest in it through the projection of His names and attributes in all that He creates. Thus, while concrete things have no existence in themselves - since that would make them independent of God, which they are not - they receive existence through His names and attributes. This means that they are both identical with existence and other than existence at once. From that perspective, Ibn 'Arabī and al-Qūnawī viewed existence in terms of both affirmation and negation. ${ }^{32}$

Al-Wāsitị could not but conclude that the implications of the language and terminology used by the Akbarians to set forth their understanding of God's unity inevitably leads to monism. And because he believed monism to be in contradiction with the very essence of Islam, the affirmation of God's absolute unity, it became clear to him that he was dealing with heretics (zanādiqa). An assertion he makes that demonstrates this conclusion is that, according to Akbarian doctrine, "their god is 'existence' (al-wujūd) that permeates dogs, pigs, rats, and dung beetles," but, he responds, "God is too exalted to be like this, separate by His essence and attributes from all He has created." 33 He contends, moreover, that the Akbarian view of divine reality will lead people to abandon the revealed law, because "to them, the sharīa is [merely] a barrier of regulation (siyaj nizām) to keep the world in proper order. For otherwise, who would be the worshipper and who would be worshipped?" ${ }^{34}$ We will delve deeper into his polemics against the doctrine of the Akbarians in chapter 4.

$31 \quad$ William C. Chittick makes this argument in: "A History of the Term Wahdat al-wujūd," in In Search of the Lost Heart: Explorations in Islamic Thought, ed. Mohammed Rustom, Atif Khalil, and Kazuyo Murata (Albany: State University of New York Press, 2012), p. 81. Chittick gives an excellent overview of the doctrine of Ibn 'Arabī and al-Qūnawī in: "A History of the Term Wahdat al-wujūd," pp. 75-79.

33 Al-Wāsițī, Riḥla, p. 40.

34 Ibid. p. 41. 
For our current purpose it is relevant to add that he appears to have recognized a relationship between monistic teachings and the cultural background of the shaykhs who formulated them. In Talqīh al-afhām he has an interesting remark in that regard when he refers to monists as "those who follow the wicked creed of the people from al-maghrib and al-rūm." ${ }^{35}$ By 'al-maghrib' he means the Islamic west, which includes al-Andalus and North Africa, and by 'al-rüm' he means the Islamic east, in particular Anatolia and perhaps Persianspeaking areas in general. This cultural background is indeed historically related to the individuals he mentions by name in his writings as the leaders of the ittihädiyya. Those with a western background among the names he mentions are the shaykh al-akbar himself, Ibn Sabiinn, the latter's pupil Ibn Hūd, and al-Tilimsānī. ${ }^{36}$ Those with an eastern background among the names he mentions are al-Qūnawī, Yūnus b. Yūsuf (or Yūnus) b. Musāid al-Shaybānī (d. 619/1222), and the rather obscure figure of Awḥad al-Dīn 'Abd Allāh al-Balyānī (d. 686/1288). ${ }^{37}$ If there was indeed a certain relationship between doctrine and the cultural background of these shaykhs, we may ask how, as al-Wāsitịi claims, they were able to reach a degree of success in the convents of Cairo.

Before we further elaborate on this topic, it is necessary to examine the history of Ibn 'Arabī's school in Cairo prior to al-Wāsițî̀'s arrival there so we can judge the extent to which they were indeed able to earn a notable place among the city's Sufis. We know that followers of Ibn 'Arabī were already present in Cairo several decades earlier. They appear to have experienced varying degrees of success in establishing themselves in the city's religious landscape. Ibn 'Arabī visited Cairo twice during his lifetime and had stayed in the Sa'îd alsu'adā at least during his first stay. It is unclear, however, to what extent something of an Akbarian circle remained after he left. ${ }^{38}$ The first real establishment

35 Al-Wāsițī, Talqūh al-afhām, p. $15^{2}$.

36 Ibn 'Arabī, Ibn Sab'īn, and Ibn Hūd came from al-Andalus; for Ibn Hūd, cf. al-Ṣafadī, A'yān al-'așr, vol. 2, p. 202. It is unclear whether al-Tilimsānī was born in Tlemcen or in Damascus. He descended from the Berber tribe Kūmiya, which is based near Tlemcen, cf. Fritz Krenkow, "Al-Tilimsānī," in $E I^{2}$ : vol. 10, p. 500.

37 Al-Qūnawī came from Konya, Turkey. Al-Shaybānī came from al-Qunayya near Mardin, Turkey. According to al-Dhahabī, the latter was a "mad" (majdhūb) shaykh who had no real knowledge and whose poetry contains monism (ittihâd), cf. Tärīkh, vol. 44, pp. 471473. See also: Trimingham, The Sufi Orders, p. 15. Al-Balyāni came from Shiraz, Iran, and is noted by Chittick as a member of the Akbarian school, cf. "The school of Ibn 'Arabī," p. 519. For the instances where al-Wāsițī presents us with the names of the above mentioned Akbarian shaykhs, see his: Risālatuhu ilā al-shaykh Ahmmad al-Maghrib̄̄, p. 113, where he refer to al-Qūnawī as "al-Rūmī"; 'Umdat al-țullāb, p. 214; al-Tadhkira wa-al-ítibār, p. 34 .

38 Ibn 'Arabī's first visit to Egypt was in 598/1202 and his second in 6o3/1207, cf. Addas, Quest for the Red Sulphur, pp. 196 and 302-305. 
of Akbarian Sufis in the Egyptian capital probably occurred under his disciple al-Qūnawī, who settled there in 643/1245, some five years after his master's passing. As someone who understood Ibn 'Arabī like no other and who had been granted ijāzas in all of his major works, al-Qūnawīs coming to Cairo would have contributed greatly to the spread of his shaykh's teachings there. ${ }^{39}$ And apart from Mu’ayyad al-Dīn al-Jandī (d. 70o/130o), all of al-Qūnawì's major disciples who would one day become important transmitters of the Akbarian school in their own right were also with him when he lived in Cairo. ${ }^{40}$ His most renowned pupil and close friend al-Tilimsānī resided in the Sacìd alsu'adā at that time. ${ }^{41}$ Other important Akbarians who studied under al-Qūnawī in Cairo were Sacìd (or Sađd) al-Dīn Muḥammad al-Kāsānī al-Farghānī (d. 699/1300), ${ }^{42}$ the above-mentioned Shams al-Dīn Muhammad al-Aykī (or al-Īkī) (d. 697/1298),43 and Fakhr al-Dīn Ibrāhīm b. Buzurgmihr al-'Trāqī (d. 688/1289), ${ }^{44}$ all of whom, we may observe, were of Persian origin. Although it is unknown when exactly al-Qūnawī and his disciples left Cairo, we do know that he was back in Konya by $652 / 1254.45$

The time these representatives of Ibn 'Arabī's school spent in Cairo would undoubtedly have left something of a mark on the city's Sufi community. In all likelihood, it signified the starting point from where the Akbarian movement was able to slowly flourish in Egypt's capital, to eventually achieve what alWāsitị has described to us as a notable presence in several of its convents before the turn of the century. That this was indeed the case is best exemplified by the case of al-Aykī, who we have seen became Egypt's shaykh al-shuyūkh in 684/1285. This formally made him head of all Sufis in the Mamluk domains and put him in charge of not only the Sa'ìd al-su'adā', but also the al-Fayyūm

39 Richard Todd, The SufiDoctrine of Man:Șadral-Dīnal-Qūnawı̈’ Metaphysical Anthropology (Leiden: Brill, 2014), p. 2o. On al-Qūnawī’s ijāzas, see: Gerald Elmore, "Ṣadr al-Dīn alQūnawì's Personal Study-List of Books by Ibn al-'Arabī, JNES, vol. 56, No. 3 (Jul., 1997): pp. $161-181$.

40 Al-Jandī was initiated by al-Qūnawī in Konya at a later stage in the latter's career, cf. alJāmī, Nafahăt al-uns, vol. 2, p. 739, and: Todd, The Sufi Doctrine, pp. 23-25.

41 Al-Ṣafadī, al-Wäfi, vol. 15, p. 250, and: Todd, The Sufi Doctrine, p. 17.

42 Ibn al-'Imād, Shadharāt, vol. 7, pp. 782-783; Al-Ṣafadī, al-Wäfì, vol. 2, p. 99; Todd, The Sufi Doctrine, p. 19.

43 Ibn al-Imād, Shadharāt, vol. 7, p. 767; al-Ṣafadī, Áyān al-'așr, vol. 4, pp. 351-353; Taqī alDīn Aḥmad b. 'Alī al-Maqrīzī, Kitāb al-muqaffā al-kabīr, ed. Muḥammad al-Ya'lāwī (Beirut: Dār al-gharb al-islāmī, 1991), vol. 5, pp. 447. Acording to al-Jāmī, al-Aykī belonged to the elite (khawāṣṣ) of al-Qūnawī's followers, cf. Nafahāât al-uns, vol. 2, p. 629.

44 William C. Chittick, "Erāqī, Faknr-al-Dīn Ebrāhīm," EIr, vol. viıI, Fasc. 5, pp. 538-540.

45 Todd, The Sufi Doctrine, p. 2 o. 
khānqāh and the al-Mashțūb khānqāh. ${ }^{46}$ As previously noted, he was able to get this position thanks to his friendly relations with the controversial amir alShujāīì.

Besides Cairo's most important khānqāh run by the sultanate, there were at least two more convents that housed Sufis who were labelled monists by alWāsitị. The first of these is the convent of the Yūnusiyya, the Sufi țăifa of the earlier-mentioned Yūnus al-Shaybānī, which was located at Bāb al-Lūq in the city's southeast. ${ }^{47}$ Al-Wāsiți mentions the Yūnusiyya in relation to the ittihàdiyya at least twice in his writings, indicating that he must have been exposed to followers of shaykh Yūnus. The second convent is that of the shaykh Abū al-Fatḥ Naṣr b. Sulaymān al-Manbijī (d. 719/1319), who would later turn out to become one of Ibn Taymiyya's most fierce opponents from among the Sufis. According to al-Maqrīīi, himself by no means fond of the Akbarians, al-Manbijī would go too far in his love for Ibn 'Arabī. The shaykh's zäwiya was located at Bāb al-Nașr in the city's northeast, not far away from the Sa'īd al-su'adā'. ${ }^{48} \mathrm{Al}$ though no mention is made of the date it was established, given the fact that al-Manbijī would already have been a shaykh in his fifties when al-Wāsițī was in Cairo, it is certainly possible that it was open and running at that time. ${ }^{49}$ There is also a remote hint at a possible link between al-Manbijī and al-Wāsițī in a letter Ibn Taymiyya sent to the Cairene Sufi shaykh in $704 / 1304 \cdot{ }^{50} \mathrm{In}$ it Ibn Taymiyya actually mentions al-Wāsițī, referring to him only as "our master shaykh 'Imād al-Dīn," which suggests that he expected al-Manbiji to know of whom he was speaking. ${ }^{51}$ If that was indeed the case, then the two would surely have made each other's acquaintance in Cairo.

Of course, Sufis with Akbarian leanings did not merely occupy the above convents, but also used them as platforms to disseminate their own teachings. This is attested to by al-Wāsiți’s autobiography in the section on the Akbarians he met in Cairo, where he implies that it was in the convents that he was exposed to their writings for the first time. We are told that it was only when he learned about the contents of Ibn 'Arabī's Fuṣuṣ al-hikam that he became fully convinced of the heretical nature of their doctrine: "This clarified their school

46 According to his document of investiture (taqlīd), preserved in by Nāșir al-Dīn Muhammad b. 'Abd al-Rahīm Ibn al-Furāt, Tärīkh Ibn al-Furāt, volume 8, ed. Qusțanținn Zurayq (Beirut: al-Mațba'a al-amīrkāniyya, 1939), p. 31; see also: Fernandes, The Evolution, p. 52. Al-Maqrizi, al-Mawā'iz, vol. 4, pp. 314-315.

48 Al-Maqrizi, al-Mawāi iz, vol. 4, p. 310.

49 Al-Manbijī was born in 638/1241 and died in 719/1319, cf. Ibn Taghrī Birdī, al-Nujūm alzāhira, vol. 9, pp. 244-245.

50 Taqī al-Dīn Aḥmad Ibn Taymiyya, Majmūáat al-rasā̉il wa-l-masā̉il, ed. Muhammad Rashīd Riḍā (Cairo: Lajnat al-turāth al-'arabī, 1976), vol. 1, p. 161. Ibid. vol. 1, p. 170. 
(madhhab) [for me], so that I came to know the true nature of their objectives. I subsequently became weary of them for a long time." ${ }^{52}$ In all likelihood he was exposed to several more titles by Akbarian Sufis in Cairo, such as Ibn 'Arabī's magnum opus, al-Futūhāt al-makkiyya, his al-Amr al-muhkam almarbüt, Ibn Sab'īn's Budd al-ārif, and al-Qūnawī's Kitāb al-fukūk, all of which he mentions in other writings where he discusses their doctrine. ${ }^{53}$

Besides these titles, we know for sure that the Sufi poetry of Sharaf al-Dinn 'Umar Ibn al-Fāriḍ (d. 632/1235) was taught by Akbarians in the convents of Cairo. His Nazm al-sulük, a didactic poem on the spiritual way, was particularly popular among them. It is in fact due to their frequent use of this poem that its author was in a sense claimed by them as a member of their school. ${ }^{54}$ This trend started with al-Qūnawī, who greatly admired Ibn al-Fāriḍ and gave discourses on the poem in Persian when he was in Cairo. ${ }^{55}$ Al-Ayki, too, was greatly fond of Ibn al-Fāriḍ's poetry, especially the Nazm al-sulük, which he is known to have often recited and propagated among the Sufis of Cairo. ${ }^{56}$ Several notable early Akbarians also composed commentaries on it. The first of these were by two of al-Qūnawīs students, al-Tilimsānī and al-Farghānī. The latter actually wrote one in Persian, Mashāriq al-darārī, and one in Arabic, Muntahä al-madārik, which were reportedly taught in Cairo in $670 / 1271 .{ }^{57}$ This tells us that the Nazm al-sulük not only continued to be a celebrated poem within the Akbarian school from al-Qūnawī onwards, but that it was also

53 These titles are not mentioned in the Rị̣la but in three other of al-Wāsitịis treatises: Qāंida fi al-farq bayna mushāhadat al-qayyūmiyya wa-al-tahaqquq bihā, pp. 265-266, Bāshūrat al-nușūṣ, p. 31, and: Risālatuhu ilā al-shaykh Aḥmad al-Maghribū, p. 113.

Th. Emil. Homerin, who has done much work on Ibn al-Fāriḍ's poetry, has noted this as well in his book From Arab Poet to Muslim Saint: Ibn al-Fārid, His Verse, and His Shrine (Cairo, Egypt: American University in Cairo Press, 2001), pp. 28-30. Al-Jāmī, Nafahăt al-uns, vol. 2, p. 721; Todd, The Sufi Doctrine, p. 19.

56 Homerin, From Arab Poet, p. 40. See also: al-'Aynī, Iqd al-jumān, vol. 3, p. 179, where it is related that al-Aykī recited particular verses of Ibn al-Fāriḍ, which are in fact from the Nazm al-sulūk, as found in: Sharaf al-Dīn 'Umar b. 'Alī Ibn al-Fāriḍ, Dīwān Ibn al-Fārị̣ (Beirut: Dār Șādir, 1962), p. 73.

Al-Ṣafadī, al-Wäfì, vol. 2, p. 99. On these commentaries, see: Giuseppe Scattolin, "The Key Concepts of al-Farghānī's Commentary on Ibn al-Fāriḍ's Sufi Poem, al-Tā’iyyat al-Kubrā," JMIAS 39 (2006): pp. 33-83; also: Chittick, "The school of Ibn 'Arabī," p. 512. From the following generation of Akbarians there is a commentary by Kamāl al-Dīn 'Abd al-Razzāq al-Kāshānī (or Qāshānī) (d. 73o/133o), a disciple of al-Jandī mentioned earlier as a member of al-Qūnawī's inner-circle. Al-Kāshānī's most eminent pupil, Sharaf al-Din Dāwūd al-Qayṣarī (d. 751/1350), also joined the list of commentators with his Sharh tā’iyyat al-sulūk; see: Mușțafā b. 'Abd Allāh Hājjī Khalīfa, Kashf al-žunūn 'an asāmī alkutub wa-al-funūn (Baghdad: Maktabat al-muthannā, 1941), vol. 1, p. 266. 
continuously assigned a practical function by its adherents, in the sense that it was used as a base text from which to expound upon the Sufi way.

It is thus not unthinkable that it was in these convents that al-Wāsiți himself was exposed to Ibn al-Fāriḍ's poetry. Although he never mentions the Sufi poet by name, on two separate occasions he presents us with an anonymous citation of verses by his hand, one of which actually comes from the Nazm alsulūk. ${ }^{58}$

In spite of their influence in the convents, Sufis with Akbarian leanings were not on the whole without controversy in Cairo. According to Alexander Knysh, who extensively studied the history of the polemics against Ibn 'Arabī, the earliest condemnation of the shaykh al-akbar came from Ibn 'Abd al-Salām upon his arrival in Cairo in 639/1241. ${ }^{59}$ Knysh's second most notable example of an anti-Akbarian scholar who settled in Cairo is Quṭb al-Dīn (Ibn) al-Qasțallānī (d. 686/1287). ${ }^{60}$ The latter already recognized the ittihaddiyya as a distinct Sufi țāifa whose interpretation of Sufism he considered heretical. Al-Ṣafadì makes note of this in his biographical dictionary, saying that al-Qasțallānī "wrote against the [Sufi] group (tă $i f a)$ whose way was followed by Ibn Sabinn, which was started by al-Ḥallāj and closed by al-'Afïf al-Tilimsānī." ${ }^{\prime 1}$ Al-Qasțallānī's polemics against the Akbarians later influenced Abu Ḥayyān al-Gharnați (d. 745/1344), who quotes his predecessor in that regard in his well-known commentary on the Qur'an. ${ }^{62}$ Furthermore, the same Abū Hayyān shared his hostile attitude towards the Akbarian shaykh al-Aykī with Taqì al-Dīn 'Abd

$5^{8} \quad$ Al-Wāsițī cites Ibn al-Fāriḍ's poem 'Qalbī yuhaddithunì in his Qawā'id al-nubuwwāt: Qā'ida nabawiyya, p. 301. The lines he cites can be found in: Ibn al-Fāriḍ, Dīwān, on separate pages, namely, pp. $15^{1}$ and ${ }_{152}$. For the quote from the Nazm al-sulūk, see al-Wāsițī's Qã ida fí al-ḥubb fí Allāh haqüqat ${ }^{a n}$, p. 54. The lines he cites can be found in: Ibn al-Fāriḍ, Dīwān, p. 51 .

59 Knysh, Ibn 'Arabi in the Later Islamic Tradition, pp. 61-85. I will only mention the scholars that are relevant to the Cairene context here. There were, however, several other scholars in the century we are dealing with who attacked Akbarian Sufis. Besides Knysh's book, a few more names he makes no mention of can be found in the study of Daghash b. Shabīb al-Ajmī, although this work should be used with caution due to its polemical nature: see: Ibn 'Arabī: 'Aqüdatuhu wa-mawqif 'ulamā' al-muslimīn minhu. Min al-qarn al-sādis ilā alqarn al-thälith 'ashr (Kuwait: Maktabat ahl al-athar, 2011), in particular pp. 255-273, where names of scholars from the seventh/thirteenth century are listed.

6o Knysh, Ibn 'Arabi, pp. 44-45, 169, and 359n2. At one point in his life al-Qasțallānī became the head of the Dār al-Ḥadīth al-Kāmiliyya in Cairo, cf. Subki, Țabaqat al-shāfíiyya, vol. 6, p. 44.

61 Șafadī, al-Wāfì, vol. 2, p. 95. See also: al-Yāficì, Mir’āt, vol. 4, p. 129.

62 Abū Ḥayyān Muhammad b. Yūsuf al-Andalusī, al-Baḥr al-muhīt fì al-tafsīr, ed. Șidqī Muḥammad Jamīl (Beirut: Dār al-fikr, 1992), vol. 4, p. 210, and vol. 5, p. 404; also mentioned by Hofer, The Popularisation of Sufism, p. 66. 
al-Raḥmān Ibn Bint al-A'azz (d. 695/1296), the vizier of Sultan Qalāwūn. But while Abū Hayyān only expressed this in writing, Ibn Bint al-A'azz took it a considerable step further and made sure that al-Ayki got dismissed from the post of shaykh al-shuyūkh. ${ }^{63}$ Another Sufi who got in trouble in Cairo for his supposed monistic teachings was Ibn Sabinn. He had reportedly fallen into the disfavor of Sultan Baybars I, who was notified of his disputed Suf teachings. The shaykh eventually left the city as he was unable to find peace there. ${ }^{64}$ These examples show that those individuals whom al-Wāsiți labelled monists did at times experience opposition over the course of the seventh/thirteenth century in Cairo, which tells us that their Sufi doctrine was not necessarily considered mainstream there.

Nevertheless, it would be an exaggeration to say that the city was a particularly hostile environment for them when al-Wāsiți visited it. The tradition of heresiography against Akbarian Sufism really only took off in the early eighth/ fourteenth with Ibn Taymiyya, who is generally considered the first to formulate a coherent polemical strategy that proved effective. ${ }^{65}$ And even then, it was Damascus in particular where the Akbarians and those close to them in doctrine were looked upon with suspicion. Cairo remained much more open to Ibn 'Arabī and his ilk. ${ }^{66}$

Having said that, we may now return to our initial question: How were the Sufis with Akbarian leanings able to reach a degree of success in the convents of Cairo? In his conviction that their heresy was decidedly evident, this appears to have been a question that bothered al-Wāsiți as well. An answer is perhaps found in the cultural sphere. We may note that the Turco-Persian context seemed to have been much more open to Akbarian doctrine than the Arab context. This would certainly explain why, as Claude Addas has shown, the

63 Some sources relate that this came to pass because al-Aykī did not grant Ibn Bint al-A'azz the customary honor of standing up when the vizier visited the Sa'īd al-su'adā'. Al-'Aynī, on the other hand, reveals that the dispute between the two was rooted in al-Aykīs love for the poetry of Ibn al-Fāriḍ, see: Ibn al-Furāt, Tārīkh Ibn al-Furāt, p. 124; al-Maqrizi, Kitāa al-Muqaffā, vol. 5, p. 447; al-'Aynī, Iqd al-jumān, vol. 3, p. 179; on this episode, see also: Hofer, The Popularisation of Sufism, pp. 65-66.

64 Al-Sha'rānī, al-Ṭabaqāt al-kubrā, vol. 1, p. 35; Faure, Adolph. "Ibn Sab'īn," in $E I^{2}$ : vol. 3, pp. 921.

65 Cf. Michel Chodkiewicz, "Le procès posthume d'Ibn 'Arabī," in Islamic Mysticism Contested: Thirteen Centuries of Controversies and Polemics, ed. Frederick de Jong \& Bernd Radtke (Leiden, Netherlands: Brill, 1999), pp. 98-99. Also the observation of Th. Emil Homerin, "Sufis and their Detractors in Mamluk Egypt," in: Islamic Mysticism Contested: Thirteen Centuries of Controversies and Polemics, ed Frederick de Jong \& Bernd Radtke (Leiden, Netherlands: Brill, 1999), p. 234.

66 Geoffroy, Le Soufisme, p. 459. 
students of al-Qūnawī were especially successful in spreading their school of Sufism in Turkey and Iran.$^{67}$ Now, when it comes to Cairo, we saw in the previous section on the Sufis of convention that the Saìd al-su'adā' was dominated by Persians from the east, which was in fact more or less the situation in all the Cairene khānqāhs sponsored by the sultanate. ${ }^{68}$ This presence of Persian immigrants is undoubtedly why al-Qūnawī gave classes on Ibn al-Fāriḍ's Nazm al-sulük in Persian rather than in Arabic when he lived in the Egyptian capital. So even though seventh-/thirteenth-century Cairo was not necessarily sympathetic towards the Akbarians as we have seen, I would argue that their doctrine was likely much more easily accepted as normative in the context of the city's "state-sponsored" convents due to the distinct presence of Sufis with a Persian background. Needless to say, the current study alone is not enough to confirm this hypothesis as a historical fact. Further inquiry is certainly needed.

As for al-Wāsițī, his conclusions regarding the Akbarians he met in Cairo was a serious setback in his search for the pathway to God, leading him to conclude that he had thus far only benefited from two groups. The first were the Shāfi'i jurists, from whom he learned God's commandments and prohibitions. The second were the Alexandrian Sufis, the Shādhiliyya, from whom he learned the goal of the spiritual journey (al-mațiub), the properties of servitude (a hkām $a l$ - ubüdiyya), and the marks of the different states and stations that the seeker attains along the spiritual path. Thus, he says, the way of the jurists became like his physical form (al-qālab al-jismì), and the way of the Shādhilīs became like his inward spirit $(a l-r u ̄ h) .{ }^{69}$

But I remained like a destitute who has attained the first of degrees (darajāt) while the highest of them is visible to him, so that he is in need of the degree that is in between them. At that point I was nevertheless satisfied with this, for it stilled my heart's hunger - surely, the starved person will be nourished by anything there is $!^{70}$

Looking for the last piece of the puzzle, he was perhaps drawn to Damascus by its status as a Hanbalī stronghold. We have seen that he claims to already have had noticeable traditionalist leanings in Alexandria. It was indeed Damascus where he found what he believed to be the final ingredient to perfect his vision of Sufism.

\footnotetext{
67 Addas, Quest for the Red Sulphur, p. 233.

68 Geoffroy, Le Soufisme, p. 168.

69 Al-Wāsițī draws the same conclusion on two occasions in his autobiography, cf. Rihla, pp. $35^{-36}$ and 44 . 
Al-Wāsițī arrived in Damascus towards the end of the seventh/thirteenth century. Before he became a follower of Ibn Taymiyya, he may have made one final attempt at attaching himself to a Sufi shaykh when he asked the Sufi Ibn Hūd to guide him on the spiritual way. However, this could very well have been motivated by a desire to expose him as a fraud. ${ }^{71}$ Either way, as he joined the city's traditionalist community al-Wāsiți would soon enter Ibn Taymiyya's circle and become convinced that, as the only group that truly followed the way of the Salaf in belief and practice, they were the saved sect of Islam.

The remainder of the current chapter will follow this last step of his journey in the city where he spent his final years. It is divided into three sections. The first of these will focus on context and provide background to the traditionalist community of Damascus and the role of Sufism in it. Here we will also briefly discuss Ibn Taymiyya's often-mentioned supposed link with Qādirī Sufism. The second section will provide a study of al-Wāsițīs account of the early years he spent among Ibn Taymiyya's circle. In the final section we will elaborate upon al-Wāsițìs own position as a Sufi shaykh in relation to Ibn Taymiyya and the members of his inner circle, and what can be said about how they operated as a group in early eighth-/fourteenth-century Damascus.

\subsection{Sufism and Hanbalì Piety in Damascus}

The Hanābila experienced their heyday in Baghdad, the city of their eponymous founder Ahmad Ibn Hanbal (d. 241/855). Here they became especially notorious during the fourth/tenth and fifth/eleventh century due to their activist stance in publically commanding right and forbidding wrong. Hanbali mobs would go around Baghdad to harass wine sellers, brothels, musicians, or any other activities they considered to be in contradiction with proper religious morality. At times they could even afford to openly criticize and confront the powers that be. They were partially able to get away with this thanks to

$71 \quad$ Al-Dhahabī relates that al-Wāsițī described his meeting with Ibn Hūd as follows: "I went to him and asked him: 'I want you to guide me along the spiritual way (tusallikunī),' to which he replied: 'By which of the paths do you wish to travel; by that of Moses, that of Jesus, or that of Muhammad?' - and he meant that every religion leads to God!" cf. alDhahabī, Tārīkh, vol. 52, p. 401, and: Ibn al-'Imād, Shadharāt, vol. 7, p. 780. It is worth mentioning in this regard that Ibn Hūd was known as a controversial figure in Damascus, in part because he had many Jews among his disciples with whom he apparently studied Maimonides. If al-Wāsițī was aware of this, it could be that he simply wanted to see how Ibn Hūd would respond to his question. On Ibn Hūd's relation to Jews, see for instance: Joel L. Kraemer, "The Andalusian Mystic Ibn Hūd and the Conversion of the Jews," in Israel Oriental Studies XII (1992): pp. 59-73. 
their popularity among the city's populace. But as Hanbali scholars became closer connected to the authorities with the passing of time, accepting positions that they had hitherto denied out of piety, their activism started to decline. By the time the 'Abbāsid caliphs became autonomous again in the sixth/ twelfth century - having previously operated under Būyid and Seljūq rule respectively - Hanbali activism had been permanently replaced by quietism under the patronage of government officials. ${ }^{72}$ As noted in chapter 1, after Baghdad had fallen to the Ilkhanids, the Hanbalīs were unable to retain their position. Therefore, al-Wāsițī will probably not have found a strong Hanbalī center when he visited the city.

It was only when he migrated to Damascus that he found what had by then become the capital of the Hanbalī school in his age. But as a city dominated by Shāficiss, most of whom were Ash'arī in theology, Damascus never provided the security of official protection that the Hanbalis had once enjoyed in Baghdad. ${ }^{73}$ They nevertheless managed to grow quite powerful there. By the end of the seventh/thirteenth century the Hanbalīs came to dominate certain quarters of Damascus, organized around the leadership of notable Hanbali families and their shaykhs. In these quarters they were able to finance the construction and management of their own mosques and madrasas independently of the Ayyubid, and thereafter Mamluk, sultanate. ${ }^{74}$ It was their influence in Damascus in this epoch which ensured that the mastership of hadith switched to Greater Syria after having been based in Iraq for practically all previous centuries. ${ }^{75}$

It will be useful to have a closer look at the overall course of this development, in order to get a clearer image of the context of Damascene Hanbalism as al-Wāsițī encountered it. The first influential Hanbalī family, the Banū alHanbalī, entered Damascus somewhere by the end of the fifth/eleventh century. In the century that followed, Hanbali activity intensified rapidly. The Banū al-Hanbalī opened the first school dedicated solely to their madhhab, al-Madrasa al-Hanbaliyya al-Sharifiyya, located within the confinements of the city walls. Not long after the Banū al-Munajjā, another Hianbalì family, which had established itself in the old city, set up a second madrasa by the

72 Michael Cook, Commanding Right and Forbidding Wrong in Islamic Thought (Cambridge: Cambridge University Press, 200o), see chapter 6 for a detailed study of this development.

73 Laoust, "Le Hanbalisme," p. 128; Cook, Commanding the Right, pp. 146-147.

74 Ira M. Lapidus, Muslim Cities in the Later Middle Ages (Cambridge: Harvard University Press, 1967), p. 86, and: Joan E. Gilbert, "Institutionalization of Muslim Scholarship and Professionalization of the 'Ulamā' in Medieval Damascus," Studia Islamica, No. 52, (1980): p. 130.

75 Scott C. Lucas, Constructive Critics, Hadith Literature, and the Articulation of Sunnī Islam: The Legacy of the Generation of Ibn Sa'd, Ibn Main, and Ibn Hanbal (Leiden: Brill, 2004), p. 109, and also: Pouzet, Damas au viIe-XIIIe siècle, p. 85. 
name of al-Mismāriyya. In the same age a third Hanbali family, the Palestinian Maqdisīs of the Banū Qudāma, emigrated to Damascus to flee from Crusader invaders. They soon dominated the Damascene suburb on the slopes of Mount Qāsyūn, which was subsequently dubbed 'al-Ṣalihịyya' after the mosque of Abū Șālih where the Qudāma family had lived when they first arrived in the capital of Shām. ${ }^{76}$ By the end of the sixth/twelfth century they managed to open the Hanbalī cathedral mosque al-Jāmi' al-Muzaffarī and the 'Umariyya madrasa. Over the course of the next century they founded two more madrasas - both named al-Diyā̉iyya - and took over the Șāhibiyya madrasa and the Dār al-Hadīth al-Ashrafiyya al-Barrāniyya, all located in the Ṣalihịiyya suburb. ${ }^{77}$

The Hanbali expansion continued with two other families that settled in Damascus. In the middle of the seventh/twelfth century many Hanbalis from Harrān, a city in present-day Turkey, were seeking safety in Damascus from the Ilkhanid advance in their homeland. Among them the most notable were the Banū Taymiyya, who arrived in 667/1269 under the leadership of the shaykh of Harrān, Shihāb al-Dīn 'Abd al-Halīm (d. 682/1284), the father of Ibn Taymiyya. Shihāb al-Dīn and his family ended up in the Qaș̣āâin quarter of the old city near the western gate, Bāb al-Jābiyya, where they took up residence in the Dār al-Hadith al-Sukkariyya, over which the shaykh had acquired directorship (mashyakha). ${ }^{78}$ Last is the Banū al-Jawzī, the family of the well-known Baghdadi scholar Abū al-Faraj 'Abd al-Raḥmān Ibn al-Jawzī (d. 597/1201). In 63o/1233 a son of the latter founded the Jawziyya madrasa south of the Umayyad Mosque, which often served as the seat of the Hanbali judge ( $q \bar{a} d \bar{\imath})$ for the old city. ${ }^{79}$ Needless to say, al-Wāsițī would have found Damascus to be a place with plenty of opportunities for a traditionalist seeker of knowledge, both in the old city and in al-Ṣâliḥiyya. ${ }^{80}$

But what did Damascus have to offer in terms of Sufism for a traditionalist? There are some elements that may be viewed as characteristic of Damascene spirituality in al-Wāsiți’s context that would surely have appealed to him. As we remarked in the previous section, Damascus was not as open to Ibn 'Arabī's school as Cairo. We find, for instance, that by the eighth/fourteenth century Ibn 'Arabī's grave - located in the Hanbalī suburb of al-Ṣâlihịya - had turned

76 Stefan Leder, "Charismatic Scripturalism: The Ḥanbalī Maqdisīs of Damascus," Der Islam, volume 74, Issue 2 (Jan 1997): p. 283.

77 Pouzet, Damas, pp. 81-83.

78 'Abd al-Q̄ādir b. Muhammad al-Nu'aymi al-Dimashqī, al-Dāris fìt tārīkh al-madāris (Beirut: Dār al-kutub al-'ilmiyya, 1990), vol. 1, p. $5_{6}^{6 .}$

79 Pouzet, Damas, pp. 83-85.

$80 \quad$ For a map with the locations of the abovementioned mosques and madrasas, see p. 167 . 
into something of a garbage dump. ${ }^{81}$ While certainly not hostile to tașawwuf itself, it may be that the strong presence of the traditionalist camp in the city also had its effect on the trends of spirituality that were able to thrive there. That is not to say that Damascus was void of Sufis with Akbarian leanings or who displayed ecstatic behavior. There certainly were fractions of Akbarians there at the time of al-Wāsițīs arrival, the most vibrant of which was perhaps Ibn Sab'īn's Sab'inniyya, by then under the leadership of Ibn Hūd. Other examples of Sufi țäifas that were occasionally regarded with distrust by the city's Sunni jurists were the aforementioned Yūnusiyya, the Rifăciyya, their sub-fraction the Hariiriyya, and a group that was referred to as 'those captivated by God,' al-muwallahün. As opposed to the former groups, the muwallahūn were mainly attacked for their practices rather than their theological beliefs, and in most cases this had to do with their disregard for ritual purity..$^{82}$ Again, it was not that such groups were systematically opposed, but we do find that they were not quite as popular in Damascus as they were in other places of the Muslim world. It thus seems that al-Wāsiți’s journey had finally taken him to a land where the local religiosity was possibly more in line with his own preferences than what he had witnessed in Iraq and Egypt. ${ }^{83}$

Popular in Damascus was the moralistic, ascetic spirituality of the Hanbalīs, referred to in most cases as zuhd (renunciation) rather than tașawwuf. Indeed, in biographical dictionaries from around the era that concerns us we hardly find the label 'șūfi being attached to Hanbalī authorities. There are, however, numerous cases where 'zāhid' (renunciant, pl. $z u h h \bar{a} d$ ) is used instead. A wellknown example is the Hanbalī scholar al-Jīlānī, who undoubtedly viewed himself as a Sufi, but is nevertheless labelled a $z \bar{a}$ hid instead of a Sufi by Ibn Rajab. ${ }^{84}$ George Makdisi has therefore opted that these two terms were possibly used interchangeably. ${ }^{85}$ The reality is that it remains very difficult to say how the zuhd-practicing Hanbalīs of Mamluk Damascus would have felt if someone described them as Sufis. There is probably truth in Geoffroy's suggestion that the Hanbalīs' strict rejection of innovation (bid'a) may have made them wary of an epithet that was being widely used by individuals they thoroughly dis-

\footnotetext{
$81 \quad$ Geoffroy, Le Soufisme, p. 459.

82 Pouzet, Damas, pp. 216-226, and 227-230.

83 Geoffroy also notes that the saintly hierarchy inherent to the more ecstatic currents of Sufism was far more prominent and important in Egypt than in Syria, which leads him to conclude that "the ecstatic Syrians unquestionably had a lesser role in society," cf. Le Soufisme, p. 138 .

84 Ibn Rajab, Dhayl, vol. 2, p. 188. That al-Jīlānī occupied himself with Sufism is first and foremost attested to by the sections on tașawwuf found in his al-Ghunya, pp. 269-336.

85 Makdisi, "The Hanbali School and Sufism," p. 63.
} 
agreed with. He hypothesizes that the close relationship between zuhd and Hanbalism may even have been a Syrian specificity. ${ }^{86}$ Whatever the case may be, it cannot be denied that in seventh-/thirteenth-century Damascus the scrupulous observance of zuhd as practiced by many Hanbalīs was commonly viewed as the raison d'être for them being able to perform the kind of miraculous feats - karāmāt - one would expect from Sufi shaykhs.

Al-Ṣālihiyya in particular had grown notorious in this period as home to the line of respected men from the Banū Qudāma, who were widely famed for their extreme piety. In fact, one of the key figures in shaping the Damascene zuhd-tradition was Abū 'Umar Muhammad al-Maqdisī (d. 607/1210). Commonly known as 'the shaykh of the Mountain' (i.e. Mount Qāsyūn), he was popular outside of Hanbalī circles as well. After his passing, his legacy was more or less inherited by his brother, Muwaffaq al-Dīn 'Abd Allāh (d. 620/1223), a respected Hanbalījurist and author of the encyclopedic figh work al-Mughnī.87 Their zuhd consisted of such practices as the consistent performance of supererogatory prayers, especially during the night (i.e. qiyam al-layl, or tahajjud), giving away their worldly possessions to the point of poverty, frequent fasting, and the daily recital of specific portions of the Qur'an. It also included an active commitment to the Muslim community and support during campaigns of holy war (jih $\bar{a} d) .{ }^{88}$ If we are to believe the biographical dictionaries, this kind of piety was indeed the rule among all family members of the Banū Qudāma. It has been argued that, because they were able to combine their traditionalist religious orientation with charismatic leadership, their religiosity quickly became popular in Damascus. ${ }^{89}$ Their public readings of religious texts and tales of pious individuals (akhbār al-sālihịn), attended by people from all classes of society, also contributed to their popularity. Hilyat al-awliy $\bar{a}^{3}$ wa-țabaqāt alasfy $\bar{a}$, the biographical dictionary of the friends of God by the Persian Sufi and hadìth master Abū Nu'aym al-Ișbahānī (d. 430/1038), was likely an important source for them in that regard. ${ }^{90}$ As for their own status as friends of God, this

86 Geoffroy, Le Soufisme, pp. 290-291.

87 Pouzet, Damas, p. 209.

88 For Abū 'Umar, see: Ibn Rajab, Dhayl, vol. 3, pp. 112-119, for Muwaffaq al-Dīn, see: al-Dhahabī, Siyar, vol. 22, p. 167 and: al-'Ulaymī, al-Manhaj al-ahmad, vol. 4, pp. 149-15o. These characteristics were already noted by Leder in his article "Charismatic Scripturalism," in which he connects them to other members of the Banū Qudāma as well.

89 Leder, "Charismatic Scripturalism," p. 303.

9o Leder, "Charismatic Scripturalism," pp. 288-289. Although Abū Nu'aym himself had been in conflict over his beliefs with several of his traditionalist colleagues, it appears that the Hilya became an important and respected work in later traditionalist circles. The Hanbalī hadīth master of Baghdad, Muhammad b. Nāṣir al-Salāmī (d. 550/1155), a contemporary of al-Jīlānī, transmitted it in Baghdad. On al-Salāmī, see: Ibn Rajab, Dhayl, vol. 2, pp. 51-63, 
was enforced not only through their pious deeds performed in public, but also through the composition of their hagiographies, such as those by the family chronicler Diyā' al-Dīn Muḥammad b. 'Abd al-Wāḥid al-Maqdisī (d. 643/1245). The latter recorded the stories of the lives of the Banū Qudāma and the miracles they performed, which served as source material for the later Hanbalī biographer Ibn Rajab. ${ }^{91}$

There was yet another important trend of Hanbalī-linked spirituality present in seventh-/thirteenth-century Damascus that also involved the Banu Qudāma, but whose exact nature is unclear: the influence of 'Abd al-Qādir alJīlānī's Baghdadi Sufism. I have already stressed in chapter 1 that we still understand very little of the development of the early Qādiriyya as a Sufi țăi ifa. While the sources do confirm the existence of an intellectual - and perhaps spiritual - link between al-jīlānī and several Damascene Hanbalīs, we do not know how this manifested itself in practice. There is evidence that the Sufi cloak (khirqa) of the Baghdadi shaykh was being passed on in Greater Syria, but with no clear-cut indication that this went hand in hand with the kind of spiritual master-disciple relationship such as we find among institutionalized Sufi groups of the era. Likewise, biographical dictionaries that deal with our context hardly make mention of the appellation 'Qādirì' as an indication of someone's Sufi affiliation with the țāilfa linked to al-Jīlānī. In light of its relevance to Hanbalī spirituality, we shall briefly elaborate on the lack of clarity surrounding alJīānīs influence in Damascus.

The spiritual link between the Banū Qudāma and al-Jīlanī was first brought to light in George Makdisi's famous article on Ibn Taymiyya's possible affiliation with the Qãdiriyya. Makdisi based himself on three unpublished manuscripts, all of which state that al-Jilānī invested the Maqdisī brothers Abū 'Umar and Muwaffaq al-Dīn with the khirqa, and that both passed it on to the former's son, Shams al-Dīn Ibn Abī 'Umar 'Abd al-Raḥmān (d. 682/1283). It was the latter Ibn Abī 'Umar who allegedly passed it on to Ibn Taymiyya, who in his turn passed it on to his own pupil, Ibn Qayyim al-Jawziyya. It is also claimed in one of the manuscripts that Ibn Taymiyya had once held that al-Jīlānīs țaríqa

and on his transmission of the Hilya: vol. 3, p. 91. Abū 'Umar himself was known to copy the Hilya for the people purely to receive God's blessings, cf. Ibn Rajab, Dhayl, vol. 3, p. 112. Leder, "Charismatic Scripturalism," p. 294. Some of Ḍiyā’ al-Dīn's biographical material on the Banū Qudāma has been studied by Daniella Talmon Heller in "The Shaykh and the Community: Popular Hanbalite Islam in 12th-13th Century Jabal Nablus and Jabal Qasyūn," Studia Islamica, No. 79 (1994): pp. 103-120. For Abū 'Umar's alleged miracles, see for instance: Ibn Rajab, Dhayl, vol. 3, p. 118, and for Muwaffaq al-Dīn, see for instance: al-'Ulaymì, al-Manhaj al-ahmad, vol. 4, pp. 153-154. 
is the greatest of the known brotherhoods. ${ }^{92}$ Even though there is some evidence in support of Makdisi's hypothesis, it still remains highly problematic in view of other primary literature.

First off, according to the relevant biographical sources it was only Muwaffaq al-Dīn who had been a student of al-Jīlānī, and not Abū 'Umar. In 561/116 the former traveled with his cousin, Taqī al-Dīn 'Abd al-Ghanī (d. 6oo/1203), to Baghdad to study under al-Jīlānī, only to spend forty or fifty days with the Hanbali Sufi in his madrasa before he passed away. Perhaps surprisingly, it is related that the two cousins managed to take figh and hadīth from al-jīlānī, with no mention at all of tașawwuf or zuhd.${ }^{93}$ We nevertheless find that three of Muwaffaq al-Dīn's writings on the subjects of good traits ( $\left.f a d \bar{a}^{2} i l\right)$, renunciation (zuhd), and spiritual subtleties (daqāi iq) do contain quotations of traditions that al-jillānī himself had transmitted to him, which may indicate that he did receive something of spiritual instruction from the shaykh. ${ }^{94}$ Besides Muwaffaq al-Dīn's acquaintance with al-Jīlānī, I have come across three instances in two separate sources where he is found in a silsila of the Qādirī khirqa. Out of these three, the two most interesting ones are related by Ibn al-Mulaqqin, who was himself a Qādirī Sufi. ${ }^{95} \mathrm{He}$ relates that Muwaffaq al-Dīn had initiated his own cousin, Shams al-Dīn Muhammad b. Ibrāhīm al-Maqdisī (d. 676/1277), and Taqī al-Dīn Ibrāhīm b. 'Alī al-Wāsițī (d. 692/1293). ${ }^{96}$ Ibn Rajab confirms that this al-Wāsiṭi indeed studied under Muwaffaq al-Dīn and, interestingly, also under Ḍiyā' al-Dīn Mūsā (d. 618/1221), one of al-Jīlānī's sons who had settled in Damascus. ${ }^{97}$ However, he makes no mention of any Sufi affiliation. That there was nevertheless indeed a close bond between al-Wāsițī and Muwaffaq al-Dinn, reminiscent of the Sufi's master-disciple relationship, is attested to by the fact that the former was buried in the latter's mausoleum. ${ }^{98}$ But is this enough to say that Muwaffaq al-Dīn was a Sufi master? The above still leaves us

92 Makdisi, "Ibn Taymīya: A Șūfĩ of the Qādiriyya Order," pp. 123-124.

93 Al-Dhahabī, Siyar, vol. 22, p. 166; al-'Ulaymī, al-Manhaj al-ahmad, vol. 4, p. 54.

94 Cf. al-'Ulaymī, al-Manhaj al-ahmad, vol. 4, p. 155. The works in question are: Kitāb altawwābīn (Beirut: Dār Ibn Ḥazm, 2003), p. 36; al-Mutahạabbìn fí Allāh (Damascus: Dār alțibāc, 1991), pp. 92 and 41; al-Riqqa wa-al-bukā', ed. Muhammad Khayr Ramaḍān Yūsuf (Damascus/Beirut: al-Dār al-shāmiyya, 1994), p. 98.

For the third instance, see: al-'Asqalānī's al-Durar al-Kāmina, vol. 6, p. 25o: here we find that Jamāl al-Dīn Yūsuf al-Mádinī (d. 745/1344), a Ḥanbalī ḥadīth scholar who passed away in Cairo, was invested (albasanī) with the khirqa by one Abū Bakr b. al-'Imād (whom I was unable to identify), who had received it from Muwaffaq al-Dīn, who had received it from al-Jìlānì.

96 Ibn al-Mulaqqin, Țabaqāt al-awliyā', pp. 494-495, and p. 500.

97 Pouzet, Damas, p. 226.

98 Ibn Rajab, Dhayl, vol. 4, pp. 254-266. 
with very little to hold on to and keeps us in the dark as to what the investment of the khirqa - if this was indeed practiced by him - may have actually signified to him.

As for Ibn Taymiyya's investment with the Qādirī khirqa, here too we are left with several obscurities. The first of these concerns the person who is said to have initiated him, Ibn Abī 'Umar. Apart from the fact that Ibn Abī 'Umar's uncle Muwaffaq al-Dīn is mentioned as one of his teachers, I have not found anything that points to his affiliation with any silsila. He is simply described by Ibn Rajab as a $z \bar{a} h i d$, along with many other characteristic elements of piety found in the biographies of members of the Banū Qudāma. ${ }^{99}$ What is certain is that he was one of Ibn Taymiyya's shaykhs, and that the latter held him in high esteem. ${ }^{100}$ Furthermore, Ibn Taymiyya also clearly had an immense respect for al-Jīlānī, both as an authority in the Hanbalī madhhab and as one of the greatest shaykhs among the later Sufis. ${ }^{101}$ When we look at his juridical opinion regarding the bestowal of the khirqa, Ibn Taymiyya held that it should not be seen as an act of the Prophetic Sunna, as there is no foundation in the Islamic texts that supports it, and the different chains of transmission that trace back khirqas to the Prophet's Companions are all false. Even so, he still considered it to fall under the category of permissible acts (mubāhāt) that can be regarded as good (hasan), provided that it is done with a sound intention. ${ }^{102}$ $\mathrm{He}$ also hints that he himself at one point had some affiliation with certain chains of transmission of a khirqa, although he does not specify which one(s). ${ }^{103}$

$99 \quad$ Ibid. pp. $172-185$.

100 As is clear from the eulogy Ibn Taymiyya wrote for Ibn Abī 'Umar, cf. Ibn Rajab, Dhayl, vol. 4, p. 181 .

101 There are over thirty references to al-Jīlānī in the printed edition of Ibn Taymiyya's $M F$. He often extols him when he mentions him in relation to correct Sufism, and acknowledges him as a knower of God ('ârif). He also quotes him several times as a spokesperson of the Hanbalī position in theological discussions; See for instance: MF: vol. 3, p. 222, and p. 264, vol. 27, p. 12; see also his al-Jawāb al-bāhir fì zuwwār al-maqābir (Riyad: al-Maktaba al'arabiyya al-sa'ūdiyya, 1984) p. 66. He quotes portions of al-Jīlānī's creed in al-Fatwā alhamawiyya al-kubrā (Beirut: Dār al-kutub al-'ilmiyya, 1985) pp. 50-51. Ibn Taymiyya also has a commentary on several sections from al-Jīlānīs Futūh al-ghayb (MF, vol. 10, pp. 455$55^{2}$ ). However, it has been noted that this commentary seems to be a revision rather than a complementary text, so that it does not add much to the possibility of his affiliation with al-Jillānī, cf. Michel "Ibn Taymiyya's Sharh," p. 6.

Ibn Taymiyya, $M F$, vol. 11, p. 511; and also his Minhāj al-sunna al-nabawiyya fì naqd kalām al-shĩa al-qadariyya, ed. Muḥammad Rashād Sālim (Riyad: Jāmi'at al-imām Muhammad b. Sacūd al-islāmiyya, 6891), vol. 8, pp. 43-47. This attitude was already noted by Schallenbergh, "Intoxication and Ecstasy," pp. 459-46o.

103 See: Ibn Taymiyya, Minhāj al-sunna, vol. 8, p. 47: "wa-qad katabtu asānīd al-khirqa, liannahu kāna lanā fìhā asānìd, fa-bayyantuhā li-yu'raf al-ḥaqq min al-bāțil." 
Thus, like Muwaffaq al-Dīn, Ibn Taymiyya's exact relationship with al-Jīlānī's line of Sufism remains a puzzle.

We do find several hints that some form of Qādirī Sufism was present in his direct surroundings. In his Wașiyya, Ibn Taymiyya forbids the misuse of any epithet that indicates one's affiliation with a particular group, and names 'alQādirī' among several others as an example. ${ }^{104}$ Elsewhere, in a fatwa, we find that he was once asked whether it is permissible to say that al-jīanni is the best of (Sufi) shaykhs and Ibn Hanbal the best of imams, to which he replies that this is forbidden when such claims are made without proof and give rise to division among the people. ${ }^{105} \mathrm{~A}$ very similar issue is addressed in Ibn Taymiyya's Bughyat al-murtād, in a passage where he attacks the exaggeration that exists among some people in their praise of Ibn Hanbal and al-Jīlānī. ${ }^{106}$ Now, it will not have been by chance that Ibn Hanbal and al-Jīannī are mentioned together in two separate works. We may take this as an indication that some kind of Hanbalī-Qādirī affiliation did exist in Damascus around the beginning of the eighth/fourteenth century, and that its visibility was thus that Ibn Taymiyya felt compelled to express his own views about it on paper. Moreover, this also casts a shadow of doubt over the above-mentioned claim attributed to Ibn Taymiyya in one of the manuscripts used by Makdisi regarding the superiority of the Qādirī path.

An important concluding observation to be made, then, is that while Makdisi's article that links Ibn Taymiyya to al-jīlānī is still talked about to this day, it is not likely that al-Wāsițī would have found some sort of Qādirī Sufi shaykh in his Hanbali master. What he did find was a shaykh who walked in the footsteps of the Hanbali zuhhād of Damascus. As we shall see, it was, above all, the mixture of traditionalist theology and charismatic leadership, the same ingredients that had made the Maqdisiss of the Șalihịiyya so successful, that attracted him to Ibn Taymiyya.

\subsection{In the Company of Ibn Taymiyya: Șụba under the Shaykh al-Islām}

Speaking of himself in the third person, al-Wāsiți sums up his life's journey leading up to Damascus as follows in his Mukhtașar sìrat Rasül Allāh:

Someone in whom God (ST) aroused the resolution to taste something of the spiritual stations (maqāmāt) to which the [Sufi] folk (al-qawm) allude maintained a state of renunciation $(z u h d)$ for period of time in order

104 Ibn Taymiyya, $M F$, vol. 3, p. 416.

105 Ibid. vol. 20, p. 291.

106 Ibn Taymiyya, Bughya, p. 493. 
to seek a path through which he may reach something of these lofty states $(a h w \bar{a} l)$ and sublime tastes $(a d h w \bar{a} q)$ - such as love for God (T), longing for Him, fearing Him, being patient with His commands and decrees, trusting in Him, being content with Him, and other such things; and also their elevated branches - such as divine manifestation (tajalli $)$ and concealment (istitār), annihilation ( fana $\left.\bar{a}^{3}\right)$ and subsistence (baqa $\left.\vec{a}^{\prime}\right)$, intoxication (sukr) and sobriety (sahw $)$, and other such things. His travels in search of that became long and his hope and expectation became strained after almost fifteen years of ill luck, not finding any gleam of light; being eager, but not seeing a beginning nor a ray of sunlight; persevering in whatever the seekers [of God] persevere by different kinds of spiritual struggles (mujāhadāt) and different ways to remember God and draw near unto Him (al-adhkār wa-al-taqarrubāt). Until he came to a point that he felt disgusted by his desperate resolution to deviate on the path of those who are shaykhs by outward appearance only among the people. But God (ST) was kind to him, for He made him meet a murshid who was a refuge of succor for him. ${ }^{107}$

This murshid - a guide on the spiritual path in Sufi terminology - was none other than the Hanbalī shaykh al-Islām Taqī al-Dīn Aḥmad Ibn Taymiyya. By then well into his thirties, he was some four years younger than al-Wāsiți. Yet, our Iraqi Sufi soon recognized him as the shaykh he had been seeking ever since he departed from his homeland. How exactly al-Wāsițī ended up finding him when he came to Damascus is never disclosed, but one can imagine he would not have been difficult to miss. Ibn Taymiyya had by then already made a name for himself as a talented Hanbali jurist and theologian. Below we will go through the final pages of al-Wāsițīs autobiography to see what his first impressions of Ibn Taymiyya and his circle can tell us about them.

Before we start, it must be noted that the information we are provided with here must, strictly speaking, specifically be situated within the time frame of the ending of the seventh/thirteenth century until 705/1306, when Ibn Taymiyya went to Egypt. ${ }^{108}$ Several studies have shown that over time the Taymiyyan circle became somewhat divided, in part due to the many tribulations the group's leader had to endure, but perhaps also due to conflicting opinions

107 Al-Wāsițī, Mukhtașar sīrat rasūl Allāh, f.2b.

108 Al-Wāsiṭi stayed in Damascus and would never again see his shaykh. Also worth mentioning is the fact that al-Wāsițī would have been a witness to the Mongol attacks on Damascus around this period of time, though he makes no mention of this anywhere. 
regarding his rational approach to theology and some of his legal opinions. ${ }^{109}$ While this is an important development for the study of their dynamics, the remainder of the current chapter will focus on a period of time when these issues did not yet give rise to the kind of fragmentation that appears to have afflicted the group later on - especially after al-Wāsițî's passing.

Since our Iraqi Sufi wrote his autobiography at the beginning of the eighth/ fourteenth century, we can be certain that he entered a master-disciple relationship (suhba) with Ibn Taymiyya rather soon after his arrival in the capital of Shām. ${ }^{110}$ The Hanbalī shaykh al-Islām was at that time head of the Dār alHadīth al-Sukkariyya and teacher at al-Madrasa al-Hanbaliyya al-Sharīfiyya. On Fridays he also gave Qur'anic exegesis from the Hanbalī chair in the Umayyad Mosque. ${ }^{111}$ His activities were thus largely concentrated within the walls of the old city. Al-Wāsiṭi in all likelihood took up residence in al-Hanbaliyya alSharīfiyya, which may very well have been catered for by Ibn Taymiyya. ${ }^{112}$

We can get a glimpse of what al-Wāsițīs daily life under his shaykh's guidance may have looked like thanks to the account of Sirāj al-Dīn 'Umar b. 'Alī al-Bazzār (d. 749/1349), who had likewise been a student of the Damascene scholar. ${ }^{113}$ He relates that after sunrise Ibn Taymiyya would sometimes leave his mosque - likely the Sukkariyya madrasa where he lived - with his companions (ma'a man yașhabuhu) to attend an audition of prophetic traditions (samā' al-hadith). Upon return the shaykh al-Islām would issue fatwas and see to the needs of people until the break of midday prayer (al-zuhr), and then

109 On this, see in particular: Bori, "The collection and edition of Ibn Taymiyah's works," pp. 56-59; and also by Bori: Ibn Taymiyya wa-Jamāeatuhu," p. 43.

110 Al-Wāsițī, Rị̣la, p. 49, where al-Wāsiți explicitly says that his age is the beginning of the eighth century of the Prophetic Hijra (fì 'așrī hädhā fì ra's al-sab'imia min al-hijra alnabawiyya).

111 When his father passed away in 683/1284 Ibn Taymiyya took over directorship of the Sukkariyya. He retained this position for the remainder of his life, even during his absence from Damascus, cf. al-Dimashqī, al-Dāris, vol. 1, pp. 57-59. About a year later Ibn Taymiyya also took over his father's chair at the Umayyad Mosque, cf. Ibn Rajab, Dhayl, vol. 4, p. 495. In 695/1296 Ibn Taymiyya's shaykh Zayn al-Dīn al-Munajjā passes away and he takes over his position as head teacher at al-Hanbaliyya al-sharifiyya, which he retained until 716/1317, when he was replaced, cf. al-Dimashqì, al-Dāris, vol. 2, pp. 57-58.

112 Neither the relevant chronicles nor al-Wāsiți’s own works explicitly mention where the latter lived in Damascus. However in a manuscript on $s a m \bar{a}^{c}$ al-Wāsițī writes in the colophon that he finished it in the early morning of a Friday, in al-Madrasa al-Hanbaliyya, which suggests that he lived there; cf. al-Bulgha wa-al-iqnā' fi hall shubhat mas'alat al$s a m \bar{a}$, The National Library of Israel, JER NLI AP Ar. 158/7: f. 72b.

113 Al-Bazzār claims he was a witness to Ibn Taymiyya's daily routine, as he would stay by his shaykh's side for the entirety of the day and the majority of the night, cf. Sirāj al-Dīn 'Umar b. 'Alī al-Bazzār, al-A'lām al-'aliyya fì manāqib shaykh al-islām Ibn Taymiyya, ed. Ṣalāḥ al-Dīn al-Munajjid (Beirut: Dār al-kutub al-jadīd, 6791), p. 38. 
continue like that until the sunset prayer (al-maghrib). The final hours of the day were reserved for his companions. He would have a class during which someone would read passages from his writings out loud, and he would give commentary and inform them of the curiosities and subtleties of the subject under consideration. Thus they would go on until the evening prayer $(a l-i s h \bar{a})$, after which they proceeded in like manner, treating the religious sciences ( $a l-$ 'ulüm) late into the night. ${ }^{114}$

As al-Wāsiṭī accompanied Ibn Taymiyya, his entire perspective on religion was soon engrossed in the way of the Hanābila. This compelled him to devote himself to the study of a variety of texts from the traditionalist curriculum, and before long he made his definite conversion to the Hanbali madhhab. In jurisprudence he read Muwaffaq al-Dīn's al-Käfi under Majd al-Dīn Ismāîl b. Muhammad al-Harrānī (d. 729/1329), possibly in the Jawziyya madrasa. ${ }^{115}$ As befits a traditionalist, he also occupied himself with hadith, although it is unclear how far he delved into the subject. ${ }^{116}$ Under Ibn Taymiyya's guidance he was directed to focus on the Prophet's biography (al-Sìra) of Ibn Hishām (d. 218/833) and its revision by Ibn Isḥāq (d. 150/767). Al-Wāsițī would later compose a summary of this well-known book, from which I have quoted at the

114 Ibid. p. 39.

115 For al-Wāsițī's study of al-Kāfí, see: Ibn Rajab, Dhayl, vol. 4, p. 382. Majd al-Dīn al-Ḥarrānī was considered a specialist in this particular work and one of the chief shaykhs of the Ḥanbalīs in Damascus, see: Ibn Kathīr, al-Bidāya, vol. 14, p. 168, and Ibn Rajab, Dhayl, vol. 4, pp. 532-535, where we also find that he passed away in the Jawziyya madrasa, on which I base my assumption that he would have taught there.

116 Cf. Ibn Rajab, Dhayl, vol. 4, p. 381. As would be expected of a traditionalist, al-Wāsițī refers to the six canonical collections of hadith and Ibn Hanbal's Musnad several times in his writings. These would certainly have been studied in the Taymiyyan circle; see al-Wāsițīs Miftāh al-márifa wa-al-ibāda, p. 258; Qāंida fı ítibār ahl al-khayr wa-ghayrihim, p. 135; 'Umdat al-tullāb, p. 195. In the latter treatise he also mentions the following other works in this genre: the Muwațtá of Mālik (d. 179/795), the Șaḥị̣ works of Abū Bakr al-Ismāî̀lī (d. 371/981), Abū Bakr al-Burqānī (d. 425/1033), Abū Ḥātim Ibn Ḥibbān al-Bustī (d. 354/965), al-Hākim al-Nīsābūrī (d. 405/1014), Abū Bakr al-Jawzaqī (d. 388/998), Abū Nu'aym alIṣbahānī, and al-Baghawī (d. 516/1122). Also, the Musnad works Isḥāq Ibn Rāhwayh (d. 238/852), Ibn Abī Shayba (d. 235/849), 'Abd b. Ḥamīd al-Kashshī (d. 249/863), Muhammad b. Hārūn al-Rūyānī (d. 307/919), 'Abd Allāh b. 'Abd al-Raḥmān al-Dārimī (d. 255/869), Abū Ya'lā al-Mawșilī (d.307/919), Abū Dāwud al-Ṭayālisī (d. 204/818), Mūsā Abū Qurra al-Zabīīi (d. unknown). Also, abridgments of such compilations, such as Jam' bayna alȘahịhayn by al-Ḥumaydī (d. 488/1095), Jāmi` al-ușūl by Ibn al-Athīr (d. 6o6/1210), and al-Mașābīh by al-Baghawī. And, finally, the Aḥkām works of hadīth by 'Abd al-Haqq alIshbilī (d. 581/1185), 'Abd al-Ghanī al-Maqdisī (d. 6oo/1203), Majd al-Dīn Ibn Taymiyya (d. 653/1255), and Ḍiyā' al-Dīn al-Maqdisī (d. 643/1245). 
beginning of the current section. ${ }^{117}$ That he took his shaykh's advice to heart is apparent from the many titles he was familiar with from the Sira-genre. ${ }^{118}$ And as we shall see in the next chapter, this would later inspire him to allot a crucial role to the Prophet in his own teachings on Sufism.

Another subject he studied in Damascus that deserves special attention due to its tremendous influence on his formulation of Sufism is theology. Al-Wāsițî̀s writings contain references to several theological works that he was presumably introduced to among the Hanbalīs. The Kitāb al-tawhìd of Muhammad b. Ishāq Ibn Khuzayma (d. 446/1054) and the Kitāb al-naqd of 'Uthmān b. Sa'ìd al-Dārimì (d. 28o/894) are recommended by him on two separate occasions as reliable books on the doctrines (madhähib) of the Salaf. ${ }^{119}$ Biographical sources show that both books were indeed popular among traditionalists of the period that concerns us. It is known that the Kitāb al-tawhid was in fact transmitted by Jamāl al-Dīn Yūsuf al-Mizzī (d. 742/1341), a renowned Shāfíi traditionalist from Ibn Taymiyya's Damascene circle. ${ }^{120}$ Ibn Taymiyya was also

117 Ibn Rajab, Dhayl, vol. 4, p. 381. In the introduction to this Sïra's summary al-Wāsitī implies indirectly and without mentioning his name that it was indeed Ibn Taymiyya who had directed him to the study of it, cf. al-Wāsițī, Mukhtașar sìrat rasūl Allāh, f.2b-3a.

118 Al-Wāsițī mentions the Maghāzī of Mūsā b. 'Uqba (d. 141/758) and the Sirra works of al-Wāqidī (d.207/823), Yahya b. Sa'īd al-Umawī (d. 194/809), and Muhammad Ibn 'Ā'id (d. 232/847). On Daläil al-nubuwwa, a subgenre of Sīra, he was familiar with the works of Abū Nu'aym al-Iṣbahānī, Abū Bakr al-Bayhaqī (d. 458/1066), Abū al-Ḥasan 'Alī al-Māwardī (d. 434/1043), 'Abd al-Jabbār al-Hamadhānī (d. 415/1024), and the Ithbāt nubuwwa Muhammad by Abū al-'Abbās Aḥmad al-Qurțubī (d. 656/1258). On the virtues of the Prophet he names: Ikhtișār sharaf al-Muștafā by Qādī 'Iyāḍ (d. 544/1149) and al-Wafā’ bi aḥwāl al-Muștafā by Abū al-Faraj b. al-Jawzī. In addition, on the prophets in general he mentions Qișaș al-anbiyä’ by al-Kisā'ì (d. unknown) and on the Prophet's Companions al-Ṭabaqāt al-kubrā of Ibn Sa'd (d. 168/784) and the Isti'āb fì ma'rifat al-așhāb of Ibn 'Abd al-Barr (d. 463/1071). For this list, see al-Wāsițì's 'Umdat al-țullāb, p. 195, and his Miftāh al-márifa wa-al-ibāda, p. $25^{8}$.

119 For al-Wāsițî's mention of both works, see: Wașiyya ilā ba'd quḍāt al-Shām, p. 141, and Qã ida fì al-umūr allatì yanbaghī an takūn hamm al-sālik, p. 192. Also, both in al-Wāsițīs Risāla fì ithbāt, p. 40 and in the Wașiyya ilā ba'd qudāt al-Shām, p. 143 he cites from 'Uthmān b. Sa'īd al-Dārimī, Naqụ al-imām Abì Sa'ìd 'Uthmān b. Sa'ìd 'alā al-Marīsīal-Jahmī al-'anìd fìmā 'ftarā 'alā Allāh ('azza wa-jalla) min al-tawhìd, ed. Abū 'Āṣim al-Shawāmī al-Atharī (Cairo: al-Maktaba al-islāmiyya li-al-nashr wa-al-tawzī', 2012), p. 67.

An important source is Aḥmad Ibn Ḥajar al-Asqalānī: in his al-Mujam al-mufahras awtajrìd asānīd al-kutub al-mashhūra wa-al-ajzāò al-manthūra, ed. Muhammad Shakkūr Maḥmūd al-Ḥājī Amrīr al-Mayādīnī (Beirut: Mu’assasat al-risālah, 1998), p. 55 we find that the Kitāb al-naq d़ was transmitted to him via the Iraqi Ḥanbalī, Muhammad b. 'Abd alMuḥsin al-Dawālībī (d. 728/1328) (on him, see: al-Ṣafadī, al-Wafì, vol. 4, p. 23). On p. 52 of the same work Ibn Hajar relates that the Kitāa al-tawhìd was transmitted to him via alMizzī. Furthermore, we find proof that the latter work was already popular in Hanbalī 
thoroughly familiar with both the Kitäb al-tawhìd and the Kitāb al-naqd.. ${ }^{121}$ Another treatise of theology that must have been at al-Wāsițī's disposal in Damascus is the creed of the Hanbali hadìth-scholar 'Abd al-Ghanī al-Maqdisī, the aforementioned cousin of Muwaffaq al-Dīn. ${ }^{122}$ Finally, there is al-Aqìda alWäsitiiyya, a creedal text composed by Ibn Taymiyya in 698/1298-1299, which he will evidently have heard directly from the Hanbalī shaykh himself. ${ }^{123} \mathrm{Al}-$ Wāsițī mentions this creed in his Umdat al-țullāb, where he comments that it is sufficient for someone who seeks guidance (al-mustarshid), as it provides the essential knowledge of religion that is required to hopefully reach the final station of arrival unto God and spiritual stability ( maqām $^{a n}$ min al-wușūl wa-altamkin). ${ }^{124}$

For al-Wāsiți there was thus an indissoluble bond between theology and spirituality, and it is herein that we find one of the main reasons why he ultimately came to value Ibn Taymiyya so greatly. His 'Umdat al-țullāb once more provides us with a notable illustration in that regard, in a passage where he discusses how under the influence of philosophy and kaläm the Muslim world of his time has become dominated by erroneous views in the field of doctrine:

But God has bestowed His blessing upon the Muslims in this age through the appearance of our shaykh and imam, the master of Islām, the lamp in the darkness (miṣbāḥ al-zalām), Taqī al-Dīn Abū al-Abbās Aḥmad Ibn Taymiyya - may God make the people profit by preserving him! - for he clarifies to the Muslim community (umma) their original path (minhajjahā al-awwal) with regard to their religion and articles of faith ('aqā'id). ${ }^{125}$

Without mentioning Ibn Taymiyya by name, but certainly intended as an indirect reference to him, al-Wāsițī makes a complimentary statement in his Mìzān al-shuyūkh:

circles well before our period under consideration, as it was studied among them in fifth/ eleventh century Iraq, cf. Ibn Rajab, Dhayl, vol. 1, p. 66.

121 Ibn Taymiyya has extensive and often lengthy quotations from both doctrinal works in his Bayān talbiss al-Jahmiyya, see for instance: vol. 2, pp. 64-65 for al-Dārimī, and vol. 4, p. 490 for Ibn Khuzayma.

See: al-Wāsițī's Risāla fì ithbāt, p. 34, where he cites 'Abd al-Ghanī concerning a hadīth, as found in the latter's al-Iqtișād fí al-i'tiqād, ed. Aḥmad b. 'Ațiyya b. 'Alī al-Ghāmidī (Medina: Maktabat al-'ulūm wa-al-hikam, 1993), p. 42.

123 For the date of composition, see Ibn Taymiyya's $M F$, vol. 3, pp. 163, 194 \& 203.

124 Al-Wāsițī, 'Umdat al-țullāb, p. 203

125 Ibid. 
Every century God saves the Muslim community by electing distinguished men to be assistants (anșār) of His religion. They warn the people about the newly invented things and innovations that have come into being. They succeed one another, rectifying what the people have corrupted of the [Prophet's] Sunnas. ${ }^{126}$

It was, above all, the Damascene shaykh's fearless and outspoken stance as an activist of the traditionalist creed that convinced al-Wāsiți of his high rank as one of the revivers of the Sunna. ${ }^{127}$ In his view, God had appointed Ibn Taymiyya for this cause by having blessed him with the intellectual capabilities that enabled him to effectively combat the innovations that had crept into the original doctrine of the Prophet and the righteous predecessors (al-Salaf al-șalih).

But it wasn't Ibn Taymiyya's theological competence alone that will have earned him al-Wāsițīs loyalty. He was seen by his disciples as someone who emanated a pious charisma in his bearing and daily routines. His student alDhahabì describes him as a man of medium height who inspired reverence ('alayhi mahāba), with fair skin, striking eyes, short black hair, and a round beard. ${ }^{128}$ Both he and several other biographers concur that he dressed moderately, wearing cheap sandals, a jurist's cloak, and a turban, and that he was content living in poverty, having but few possessions and receiving only a small stipend for his work. ${ }^{129}$ According to al-Bazzār, the Ḥanbalī shaykh would spend his nights in solitude, reading from the Qur'an until it was time for morning prayer (al-fajr). Before joining the congregation to lead the prayer he would first perform two cycles of voluntary prayer by himself, which he followed up with invoking God forty times with His divine names al-Hayy (the Living) and al-Qayyūm (the Sustainer). ${ }^{130}$ After concluding the communal

126 Al-Wāsițī, Mīzān al-shuyūkh, pp. 229-23o. A very similar statement is made by al-Wāsițī in al-Tadhkira, p. 40.

127 Note that al-Wāsițī's description of Ibn Taymiyya bears close resemblance to the concept of the 'reviver of the religion' (mujaddid al-dìn). According to a prophetic tradition, every century will know such a mujaddid, sent by God to revive and purify His religion. On this, see for instance: Emeri van Donzel, "Mudjaddid." In EI2: vol. 7, p. 29 o.

128 I refer to the summarized biography of Ibn Taymiyya, composed by al-Dhahabī, which is edited and translated by Caterina Bori in "A New Source for the Biography of Ibn Taymiyya." BSOAS, vol. 67, no. 3 (2004): p. 334 for the Arabic, and pp. 343-344 for the translation.

129 For al-Dhahabī, see: Bori, "A New Source," p. 346. For others, see: al-Bazzār, al-A'tām, pp. 47-48, and 51; Ibn Rajab, Dhayl, vol. 4, p. 5 o9.

130 Ibn Taymiyya's invocations between the voluntary and the obligatory morning prayer are not mentioned by al-Bazzār, but can be found in: Shams al-Dīn Muḥammad Ibn Qayyim al-Jawziyya, Madārij al-sālikīn bayna manāzil iyyāka naçbudu wa-ikkāka nastaìn, ed. Muḥammad al-mu'tașim bi-Allāh al-Baghdādī (Beirut: Dār al-kitāb al-'arabī, 1996), vol. 1, p. 446, and again in vol. 3, p. 248. 
prayer he again recited specific invocations and supplicated to God in accordance with the Sunna, and then continued with the remembrance of God (dhikr) until the sun rose, not speaking with anyone except out of absolute necessity. ${ }^{131}$ This routine reflects the kind of piety characteristic of the Hanbali zuhhād of the Banū Qudāma. The same goes for the hagiographic tales that we find attributed to Ibn Taymiyya by his followers, indicating that he was no ordinary man in their eyes. They for instance relate that his supplications to God would be answered and that he was granted miracles (karāmāt), such as the gift to foresee what would come to pass. ${ }^{132}$ We can assume that it were these kind of qualities that made Ibn Taymiyya popular and earned him the recognition of his admirers as a complete master in whom traditionalist learning and piety came together. To al-Wāsițī, and to his companions in general, he was indeed that.

As Ibn Taymiyya rose to fame, there formed an intimate circle (jama $\left.\bar{a}^{c} a\right)$ of predominantly Hanbalīs and Shāfi'is who followed him, most likely on the basis of his erudition, charisma, and competence as a leader. Caterina Bori has observed that while he will surely have had numerous students studying under him in the madrasas where he taught, this inner circle appears to have been a rather small group of men who shared a strong sense of loyalty and elitism among themselves. ${ }^{133}$

Bori argues furthermore that their support of Ibn Taymiyya should be read beyond the framework of madhhab, though I would add that this only goes for jurisprudence. ${ }^{134}$ When it comes to theology, it is exactly in the madhhab that we find the common ground between all members of his jama $\bar{a}^{c} a$. Both the Hanbalīs and the Shāfi īs who followed Ibn Taymiyya probably did so because they believed in his ability to support the cause of the traditionalist school, the Ahl al-Hadīth. In his autobiography, al-Wāsiți explicitly notes their shared affiliation with traditionalism as a characteristic element of the group:

Their principles of faith $(u s \bar{u} l)$ are not those of the speculative theologians (mutakallimin). Rather, the principles of their beliefs are based on Qur'anic verses and authentic reports (al-akhbār al-șahịha). They take the divine attributes (șifāt) as they are mentioned, without metaphorically interpreting them $\left(t a^{\prime} w \bar{l} l\right)$, stripping them of their meanings $\left(t a^{t} t \bar{l} l\right)$, or assimilating them to those of creatures (tashbih). They affirm that

\footnotetext{
131 Al-Bazzār, al-Aֹ⿳亠̄m, pp. 37-38.

132 Ibn 'Abd al-Hādī, al-'Uqūd, pp. 191-193; Ibn Qayyim al-Jawziyya, Madārij al-sālikīn, vol. 2, p. 458; al-Bazzār, al-A'ām, pp. 56-62.

133 Caterina Bori, "Ibn Taymiyya wa-Jamā'atuhu," pp. 30-33.

134 Ibid. p. 43.
} 
their concrete realities (haqūiqahā) relate to God in a way that befits Him, such as His sitting [on the Throne] (istiw $\bar{a}$ ) or descent [from the heavens] (nuzül), and all other attributes.... They know that their Lord is above them (min fawqihim) and thus worship Him as it has come down in the holy texts (nușuṣs), since these demonstrate that He is above the Throne with His divine essence and attributes with an aboveness (fawqiyya) that befits His majesty and magnificence. ${ }^{135}$

And not only did they adhere to the same theological school, but as is evident from a letter al-Wāsiți sent to several members of Ibn Taymiyya's jamãa $a$, they were also willing to join their leader in his activism for its sake. After summing up all the deviating groups of his age he had come across, our Iraqi Sufi tells them: "I have traveled the world, but I have not come across anyone who stands up against their ilk save you."136 Evidently, he valued their joint effort to strive for the traditionalist cause by censuring all those who deviated from their notions of normativity as one of the group's key features.

There is little doubt that their activism emerged from the genuine conviction that the traditionalists were the last group that truly represented the original doctrine of the Ahl al-Sunna wa-al-Jamã a, and were, as such, 'the saved sect' (al-firqa al-näjiya), or 'the victorious group' (al-țāiffa al-manșūra). This concept of the saved sect is based on several hadiths wherein the Prophet is supposed to have predicted the splitting up of the Muslim community into a number of sects, only one of which will still follow the pure, unadaltered religion of God. ${ }^{137}$ That Ibn Taymiyya was not shy to lay claim to this status for his own theological school is evident from his aforementioned creed, al-Wäsitịyya. In its introduction he calls it "the creed of the saved, victorious sect (itiqa a d alfirqa al-näjiya al-manșūra)," that being "the Ahl al-Sunna wa-al-Jama'a," by

135 Al-Wāsițī, Riḥla, pp. 45-46.

136 Al-Wāsițī, al-Tadhkira, p. 38.

137 A well-known hadith in that regard tells that the Muslims will split up into seventy-three sects, only one of which will be on the truth, that being 'the community' (al-jamā'a), see for instance: Aḥmad b. Muḥammad Ibn Ḥanbal, Musnad al-imām Aḥmad b. Hanbal, ed. Shu'ayb al-Arna'ūț, 'Ādil Murshid, et al. (Beirut: Mu’assasat al-risāla, 2001), vol. 28, p. 135. According to another hadith the Prophet said: "There will continue to be a group (țāifa) in my community (ummatī) who are manifestly upon the truth. They will not be harmed by those who forsake and oppose them until the coming of the [final] hour," see for instance: Abū al-Ḥasan b. al-Hajjāj Muslim, al-Musnad al-șaḥịh al-mukhtașar bi-naql al'adl 'an al-'adl ilà Rasūl Allāh (șallā Allāh 'alayhi wa-sallam), ed. Muhammad Fu'ād 'Abd al-Bāqī (Beirut: Dār iḥyāà al-kutub al-'arabiyya, 1955), vol. 3, p. 1523. 
which we know he actually means the Ahl al-Hadīth. ${ }^{138} \mathrm{Al}$-Wāsițī takes it a step further than his Damascene master and seems to have been convinced that their jamāa $a$ itself was the saved sect. In the same letter from which we have quoted above he tells his Taymiyyan companions: "If God wills it, I hope that you will be the victorious group (al-țăifa al-manșüra), who will not be harmed by those who forsake and oppose them, and who will be in Greater Syria (alshām)."139

Al-Wāsițīs depiction of the jamā'a also tells us that it included a number of other authoritative and charismatic figures besides Ibn Taymiyya. Indeed, as will become apparent in the last section of this chapter, the Taymiyyan circle was not a mere gang of slavish disciples, but comprised individuals who were themselves climbing the ladder of the scholarly scene of Damascus. It is perhaps for that reason that his autobiography neither mentions Ibn Taymiyya by name nor alludes to his person indirectly. Instead al-Wāsiți only speaks of the ța $i$ ifa he found in Damascus and then continues to refer to them as "our shaykhs" (mashāyikhunā). The following passage in particular indicates that he must have been immensely impressed not only by the circle's leader, but by all its members:

I found that they are men who possess intimate knowledge of the days of Prophethood ('ärifin bi-ayyām al-nubuwwa), the biographies of the Companions, the meanings of the revelation, and the principles of beliefs (ușūl al-'aqā'id) as derived from the Book and the Sunna. They possess intimate knowledge of the tastes of the spiritual travelers [unto God] ('ârifin bi-adhwāq al-sālikīn), their beginnings, and the particulars of their spiritual states $(a h w \bar{a} l)$ which they regard as part of religious perfection (kamāl al-dīn), since the religion is incomplete without them. Their breaths (anfās) are incomparable to those of their contemporaries, whether jurist or Sufi. Their breaths can only be compared to those of the first three centuries [after Hijra] in the time of the Companions, the Followers (täbi ìn), and those who followed after them. By being together with them and seeing them it was as if I was meeting with Abu Bakr, 'Umar, 'Uthmān, and 'Alī, and with Followers such as Sa'īd b. al-Musayyab, al-Ḥasan al-Bașrī, al-Rabī' b. al-Khuthaym, Thābit al-Bunānī, and others like them. By seeing them, it was as if I was meeting with Mālik, al-Shāfi 'ì, the two Sufyāns [Ibn 'Uyayna and al-Thawrī], the two Ḥammāds

138 Ibn Taymiyya, al-'Aqïda al-wāsitiiyya, in $M F$, vol. 3, p. 129, and he makes another reference to it on p. 159 .

139 Al-Wāsițī, al-Tadhkira, p. 41. 
[Ibn Zayd and Ibn Salama], Ibn al-Mubārak, Ishāa [Ibn Rāhwayh], Aḥmad Ibn Hanbal, and their peers and equals. ${ }^{140}$

In al-Wāsitị̂s comparison of his Damascene shaykhs to Muslim authorities from the first centuries of Islam we may recognize a way of showing deep reverence that is typical of the classical traditionalist scene. ${ }^{141}$ By connecting them to the time of the Salaf, which they themselves regarded as the most sound and glorious period for Islam, he meant to distinguish them from the majority of his contemporaries who were at odds with the traditionalist school. This may explain the sense of elitism among them of which Bori has made note, which may very well have been the trend among Damascene traditionalists in general as proponents of what was by then a minority position in theology.

No less striking in the above quote is al-Wāsiți’s use of Sufi terminology in relation to his newly found companions. He calls them "men who possess intimate knowledge" ('arifín), and specifically of the "tastes of the spiritual travelers" (adhwāq al-sālikin), by which he seems to imply that they have been exposed to something of the spiritual experiences of the Sufis. He also states that their "breaths" (anfās) are unique in their age, which seems to imply that their sincere devotion to God is peerless. In Sufi terminology, 'breath' is sometimes used in relation to the notion that the Sufi is constantly aware of God. It is related from al-Junayd, for instance, that the servant's every breath should be devoted to God, and a Sufi poet reportedly said: "To God belong those breaths that are breathed for Him.."142 The use of these terms indicates that, unlike the Shāfi'i fuqahā' al-Wāsiṭi had accompanied earlier in his journey, these Damascene shaykhs were not merely dry jurists whose profession was nothing more than an intellectual exercise. Their knowledge actually served a deeper purpose.

140 Ibid. p. 45 .

141 We find several examples in Hanbalī sources where scholars of repute are being compared to the early generations of the Salaf. See for instance: al-'Ulaymī, al-Manhaj al-ahmad, vol. 4, pp. 149-150, where it is related with regard to Muwaffaq al-Dīn that "when you saw him, it was as if you saw one of the Companions." In Ibn Rajab's Dhayl, vol. 4, p. 180, it is related that al-Birzālī described Ibn Abī 'Umar as "a successor of the righteous predecessor in the majority of his states $(a h ̣ w a \bar{l})$." And another member of the Banū Qudāma, 'Imād al-Dīn Ibrāhīm (d. 614/1218), was reportedly compared to Sufyān al-Thawrī, cf. Leder "Charismatic Scripturalism," p. 302.

142 'Abd Allāh b. 'Alī al-Sarrāj, Kitāb al-luma'fi al-tașawwuf, ed. Reynold A. Nicholson (Leiden: Brill, 1914), pp. 347-348. See also for instance: al-Qushayrī, al-Risāla, for the term 'anfās,' vol. 1, p. 196, and for the term 'dhawq,' see vol. 1, pp. 177-178. 
While he certainly does not name them Sufis anywhere in his writings either, he did find that a certain spiritual disposition was inherent to their preoccupation with upholding God's religion and their embodiment of the way of the Salaf. This, he says, "is a magnificent task for the sake of their Lord through which their hearts have become enraptured out of bewilderment, awe, and

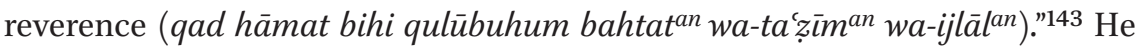
even admits that they do not reach the kind of self-effacement (iștiläm) in God that he had witnessed among the Shädhiliyya, and which he clearly greatly admired. However, he states in their defense, "it does not befit someone who is concerned with upholding the religion and disseminating its laws and rites to be self-effaced in the way of these [Shādhilīs] who only have room for their Creator." ${ }^{144}$ He explains later on in his autobiography that this is why someone who seeks the realities of Sufism (haqä̉iq al-tașawwuf) should do so among its specialists rather than among the jurists. ${ }^{145}$ It is thus obvious that he differentiated between his shaykhs from Alexandria as specialists in Sufism and his shaykhs from Damascus as qualified traditionalist scholars.

This eventually leads al-Wāsiți to a surprising conclusion that marks the end of his autobiography. In his final reflections he writes that those who love his Damascene shaykhs (muhibbì mashāyikhinā) may notice that he credits both them and his Shādhilī masters with intimate knowledge (ma'rifa). He imagines that they may subsequently wonder what special trait (khusūssiyya) the Shādhilīs have that cannot be found among his traditionalist shaykhs. He replies as follows:

My response is that this special trait [of the Shādhiliss] is a penetrating mode of being (kayfryya ha a dda): by merely seeing and hearing them they induce in the seeker (al-tâlib) love for God, divine attraction towards Him (injidhāb ilayhi), desire for Him, and obliviousness to all things save Him. This is the special trait they have that is for them alone.

A second signification is that they remind [people] of God when they are seen, which causes His light to come to the viewer's heart with vigor and severity, while when our [Damascene] shaykhs are seen they remind [people] of the religion, the Sunna, and the revealed law (al-shari $a)$. As for the former group, the sharía is embodied in their inner state $(h \bar{a} l)$ so that their outward appearance is enveloped by the mode of ma'rifa. As

143 Al-Wāsițī, Riḥla, p. 48.

144 Ibid.

145 Ibid. p. 51. His words are "shuyūkhina al-fuqahä,", which in the context of the point he is making undoubtedly refers to his shaykhs from Damascus. 
for the latter group, ma'rifa is embodied in their inner state so that their outward appearance is enveloped by the mode of sharîa. ${ }^{146}$

Even though al-Wāsițīs elucidation here bears witness to a profound appreciation for both groups, the distinctive criterion between them remained, of course, theology. He argues that, without the theological foundations ( $q a w \bar{a} \bar{a}^{\mathrm{i}} \mathrm{d}$ ) of his Damascene shaykhs, the Sufi mode of being (al-kayfiyya al-șuffiyya) of his Shādhilī brethren continues to be incomplete and baseless (maqțúa ${ }^{u n}$ là asās lah $\bar{a}){ }^{147}$ It is in the conclusion on the final page of his autobiography that he then makes a fascinating plea to God:

I hope that, out of His kindness, God (T) will accommodate me to travel the path of these [Damascene] scholars with regard to the principles and

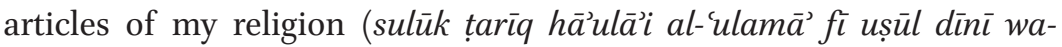
'aq $\bar{a} i d i h \bar{a}$ ) and its outward works and inward states, and that He will bring me to spiritual realization through the realities of my Sufi brothers (wa-an yuhaqqiqanī bi-ḥaqāiq ikhwānī al-șūfiyya). ${ }^{148}$

In other words, instead of disavowing the Shādhilīs on the basis of their theological affiliation, he expresses a genuine desire for divine guidance to synthesize their method of Sufism with the teachings of his Damascene shaykhs. In this final paragraph it is as if he realizes that his experience in the field of Sufism and his acquaintance with the traditionalist school placed him in a unique position. I believe that the above prayer should be read as a plea for help in the task that he now saw before him: to reformulate what he had learned of Sufism so that it could appeal to the traditionalist community of Damascus and conform to their doctrine.

This is where al-Wāsițîs autobiography ends. We must therefore rely on other sources for information regarding the remainder of his life from the beginning of the eighth/fourteenth century onwards. In doing so we find that our Iraqi Sufi would have eventually adjusted the above conclusion as his opinion of the Shädhili țăiifa changed for the worse. Although he continued to extoll Abū al-'Abbās al-Mursī as the teacher of his own shaykh, Najm al-Dīn, he became increasingly critical of Abū al-Ḥasan al-Shādhilī. ${ }^{149}$ In the latter's entry in al-Dhahabī's Tärïkh we find the following statement in that respect:

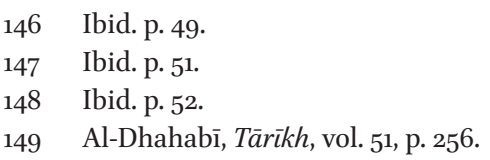


He [al-Shādhilī] has poetry and prose that contain some doubtful matters and expressions ( $i b \bar{a} r \bar{r} t$ ) that would prove difficult for him to plead in defense of. I saw that our shaykh Imād al-Dīn [al-Wāsițī] had become tepid about him towards the end [of his life] (qadfatara 'anhu fial-äkhir). He became aware of these expressions, which made him confused about the man because he had taken the Sufi path according to his method (tașawwafa 'ala țaríqatihi). ${ }^{150}$

In his biographical dictionary Ibn Rajab likewise appears to be hinting at alWāsițî's increasing distance from the Shādhiliyya, stating that he eventually abandoned all of his Sufi ways after he had decided to focus solely on the example and guidance of the Prophet. ${ }^{151}$ This development is in fact clearly expressed in one of al-Wāsițī's own works as well, which we will examine in more detail in the first section of the next chapter.

We can thus recognize two stages in the development of al-Wāsiți's conversion to Hanbalī traditionalism during his time in Damascus. His early years were distinguished by a deep-rooted conviction that Ibn Taymiyya was the shaykh of his age, appointed by God as the greatest representative of Sunni doctrine as defined by the traditionalists. In addition, we find that other scholars from the shaykh al-Islām's tă âifa also played a significant role in al-Wāsițîs vision of Islam and thus contributed to his perception of Damascus as the final destination of his journey. At this time he was profoundly influenced by the traditionalist curriculum he studied, especially in theology. This brought him to the first stage of his conversion, where he concluded that the way of the Shādhiliyya, the only manifestation of Sufism he had come to appreciate, was of no avail if it was not anchored in the theology of the Ahl al-Hadith. We may recognize the second stage as his definitive conversion to pure traditionalism, when his strong inclination towards its theology as he understood it eventually even led him to question some of the teachings he had been exposed to among the Shādhiliyya. Was he still a Sufi then?

\subsection{A Shaykh of Sufism for the Taymiyyan Circle}

As we shall now see, it is evident that al-Wāsiți eventually brought to fruition that for which he entreated God in the final paragraph of his autobiography: he formulated his own interpretation of a traditionalist Sufism that he taught to

$150 \quad$ Ibid. vol. 48, p. 274 .

151 Ibn Rajab, Dhayl, vol. 4, pp. 381-382, where he describes al-Wāsițì's abandonment of his Sufi ways in the following words: "wa-takhallā min jamīi țarāiqihi wa-aḥwālihi wa-adhwāqihi wa-sulūkihi." 
spiritual seekers of God with a traditionalist background. This is confirmed in several relevant chronicles. According to al-Dhahabī, for instance, "a group of people accompanied him (jamā'at us șahabūhu)"152 and "took the spiritual way through him (tasluku bihi)." ${ }^{153}$ And Ibn Rajab concurs that "a group of our shaykhs and others have learned [Sufism] from him."154 Below we will elaborate on this role of Sufi shaykh to see what can be said regarding his position in the inner circle of Ibn Taymiyya and the way its members operated as a group.

Now, in the previous two sections we have made several observations in light of which al-Wāsițīs activity as a teacher of Sufism among Damascene traditionalists seems conspicuous. First of all, we have concluded that there is very little to be found in the relevant primary sources of the period under consideration that points to a distinct presence of Sufism among the Hanbalīs of Damascus. However, we did find that there was a tradition of a particular form of zuhd among them. Secondly, even though there appears to have been a link between al-Jīlānì and several of the city's prominent Hanbalì scholars, there remains a great deal of obscurity as to whether they actually manifested some conscious form of Qādirī Sufism. Very much in line with this is our third observation, namely, that al-Wāsiți's autobiography has unmistakably conveyed to us that he did not regard his shaykhs from the Taymiyyan circle as Sufis. All of this implies that during the time our Iraqi Sufi studied under the Hanābila of Damascus, he most likely did not receive any additional training in the Sufi way. This would mean that he himself was the architect of the Sufi doctrine he went on to actively propogate.

Based on his written works we can make a rough estimation of the years he was active as a teacher and spiritual guide. Although it is impossible to say whether he first started with penning his conceptualization of Sufism on paper or with conveying it orally, both modes of transmission were surely interconnected. The majority of his works are of a pedagogical nature, and take the reader by the hand through a step-by-step description of the different stages on the spiritual path towards God. This is especially so for the great number of precepts (sing. qāंida, pl. qawā $i d$ ) he wrote, which are mostly very brief and display a considerable degree of overlap among themselves. ${ }^{155}$ Reading

\footnotetext{
152 Ibn Rajab, Dhayl, vol. 4, p. 383 .

153 Al-Dhahabī, al-Dhayl, p. 126; see also: al-'Asqalānī, al-Durar al-kāmina, vol. 1, p. 103.

154 Ibn Rajab, Dhayl, vol. 4, p. 383.

155 I have provided a list of the published works of al-Wāsițī in the bibliography on pp. 284287. The titles in themselves display the variety of subjects pertaining to Sufism he dealt with. The pedagogical nature of the qawā id was also observed by Geoffroy, "Le traité de soufisme," p. 85. It is possible that the original manuscript of al-Wāsițīs qawā'id was written as one book, with each $q \bar{a} c i d a$ meant as a chapter (which appears to have been
} 
through his corpus of precepts often gives the impression that he may very well have taught from them during his classes, or perhaps wrote them as complimentary study material for his disciples. The relation between the role of teacher and author is, moreover, evident from a few treatises that were actually written after the request of someone, possibly a student. ${ }^{156}$ Taking this into consideration, my study of al-Wāsiți’s oeuvre has led me to believe that, in line with the dating of his autobiography, his teaching activity will have taken off in the early years of the eighth/fourteenth century. We know of at least five of his other treatises that similarly allude to their time of composition as the beginning of the century, and of one work on sama $\bar{a}^{c}$ that is dated 703/1304. ${ }^{157}$ Furthermore, I have not come across any treatise by his hand that contains even a remote allusion to an earlier date of composition. It was thus roughly during the final ten years of his life that he would have been active as teacher and author in the field of Sufism.

We may get an impression of how his role as a Sufi shaykh at that time influenced his position in the Taymiyyan jamác $a$ by looking at several references to his relationship with Ibn Taymiyya. It is obvious from the few instances in our sources where the latter is found referring to al-Wāsiți that he came to regard him as an authority in Sufism rather than simply as one of his followers. We quoted above a letter by Ibn Taymiyya from 704/1304 in which he calls him "our master (sayyidunā) shaykh 'Imād al-Dīn." 158 In the heading of a another letter, which Ibn Taymiyya sent to al-Wāsiți from Cairo between 705/1306 and 711/1311, he addresses him as follows: "To our shaykh, the imam, the knower (al-ärif), the model $(a l-q u d w a)$, the spiritual traveler $(a l-s \bar{a} l i k) . . . " 159$ Another instance is found in Ibn Taymiyya's Dar' ta'ärud al-'aql wa-al-naql, which he wrote over the course of the years $710 / 1313-717 / 1317$. In a section likely to have been com-

Geoffroy's impression, who discusses the original manuscript in "Le traité de soufisme" and treats it as a single title rather than a collective volume). However, having gone through the printed edition, It appears to me that the occasional reference of one $q \bar{a}$ cida to another rather indicates that he wrote it as teaching material as he proceeded with his

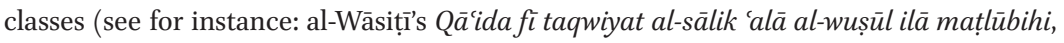
p. 119). In most cases, the qawā $i d$ are clearly separate treatises, written almost like fatwas on particular aspects of the spiritual way.

156 This is mentioned explicitly in al-Wāsițī's al-Sirr al-mașūn wa-al-ilm al-makhzūn, p. 40, Qāida fì al-umūr al-muwașșila, pp. 215-216, Q̄àida mukhtașara fì țarīq al-faqr, p. 24.

157 For the references to the early eighth/fourteenth century, cf. al-Wāsițī's Qā'ida fì așnāf alta'alluh, p. 151; Miftāh al-ma'rifa wa-al-ibāda, p. 253; al-Tadhkira wa-al-i'tibār, pp. 36, 40, \& 49; Mizzän al-shuyūkh, p. 229; and 'Umdat al-țullāb, p. 202. The treatise that is dated is alBulgha, f. $72 \mathrm{~b}$.

$15^{8}$ Ibn Taymiyya, Majmū'at al-rasā̉il, vol. 1, pp. 161 \& 170.

159 Cited by Ibn Rajab, Dhayl, vol. 4, p. 382. 705/1306 is the year Ibn Taymiyya arrived in Cairo, and $711 / 1311$ is the year al-Wāsiți passed away. 
posed at an earlier date, he discusses a quotation from a traditionalist Mālikī Sufi by the name of Abū Muḥammad b. 'Abd al-Bașrī. He then cites our Iraqi Sufi to explain a difficult passage from this quote, referring to him as "our companion (ṣāhibūna) shaykh Abū al-'Abbās al-Wāsiṭ̂." ${ }^{60}$ A final instance comes from Ibn Rajab's Dhayl in the entry on al-Wāsițī, where we find that "shaykh Taqī al-Dīn Ibn Taymiyya would extol and praise him, and say about him that he is the al-Junayd of his time." 161 It is especially the latter comparison to alJunayd, considered by Ibn Taymiyya as a knower of God and an archetype of the authentic Sufis, which tells us that al-Wāsiți was in his eyes one of the great spiritual masters of his age. ${ }^{162}$

At the same time there is no clear-cut indication that al-Wāsiṭi was systematically instructed by Ibn Taymiyya when it came to the science of tașawwuf. This may in part have to do with the fact that the shaykh al-Islām was not himself a Sufi master in the strictest sense of the word, as previously noted. His oeuvre, more often than not, demonstrates that his primary concern in this field was of a polemical or theological nature - not because he disliked Sufism, but because he disliked certain concepts that, in his view, had unrightfully infiltrated it and (potentially) led to doctrinal errors, or even heresy. ${ }^{163}$ It is thus unlikely that there was any personal interpretation of Sufism that the Hanbali

16o For the citation of al-Wāsițī, see: $\operatorname{Dar}^{\prime} t^{\prime}{ }^{`} a \bar{r} u d$, , vol. 8, p. 507. I have not been able to identify this al-Bașrī, but Ibn Taymiyya describes him in vol. 8, p. 502. The exact date that Ibn Taymiyya commenced writing Dar' ta'ārud is not known. In vol. 1, p. 9 the editor Muhammad Rashād Sālim argues that it was most likely composed over the course of the years $713 / 1313$ up to $717 / 1317$. He bases this on a passage where Ibn Taymiyya reflects on the time when, as he says, he was in Egypt, which shows that he would have started with the book only after he returned to Damascus in 712/1313. However, as Sālim also notes in vol. 1, p. 8, there is the possibility that work on Dar'ta'ärud started in 710/1310 already. This was likely the case, since Ibn Taymiyya refers to al-Wāsiți without the usual invocation for a deceased person, which would mean that a beginning with Dar'ta'ärud was made when the shaykh was in Egypt, when our Iraqi Sufi was still alive.

$161 \quad$ Ibn Rajab, Dhayl, vol. 4, p. 382.

162 On Ibn Taymiyya's respect for al-Junayd, see for instance his Kitāb al-Șafadiyya, ed. Muhammad Rashād Sālim, 2 vols. (Cairo: Maktabat ibn Taymiyya, 1986), vol. 1, p. 266.

163 As mentioned earlier, we will closely examine al-Wāsiți’s Sufism in the following two chapters. Examples of Ibn Taymiyya's approach to Sufism are found, for instance, in his Kitāb al-istiqāma and in his treatises on tașawwuf and sulük published in volumes ten and eleven of MF. The majority of the treatises found in these volumes are critical, academiclike evaluations of matters pertaining to Sufism. There are only a few exceptions, such as his Amrā d al-qulüb wa-shifäuhä, in $M F$, vol. 10, pp. 138-148, which seems more practical than academic. On this issue, Elliott A. Bazzano gives a good overview of the academic discussions surrounding Ibn Taymiyya's relationship with Sufism and his polemics, cf. "Ibn Taymiyya, Radical Polymath. Part 2: Intellectual Contributions," Religion Compass 9.4 (2015): pp. 117-120. 
master taught amongst his followers. As the true specialist in that regard, alWāsițī was therefore probably largely self-reliant when he taught Sufism in Damascus.

As such, there are indications that he would have sometimes fundamentally disagreed with Ibn Taymiyya's opinions, especially with regard to certain Sufi authorities. Ibn Rajab relates that "[al-Wāsițī] and a group of the elite of [Ibn Taymiyya's] companions would sometimes criticize the shaykh for his [negative] remarks about some of the great and eminent imams or the folk of withdrawal and isolation (ahl al-takhallī wa-al-inqițā $)$."164 The latter category is undoubtedly meant as a reference to those Sufis who in spite of their respected status among traditionalists were nevertheless censured by Ibn Taymiyya. One such Sufi al-Wāsițī will surely have defended against his shaykh's sharp tongue is the Hanbalī master 'Abd Allāh al-Anșārī al-Harawī (d. 481/1089). While Ibn Taymiyya used to extol this Sufi sage earlier in his career, he later came to censure him for his system of stages on the Sufi way, which he considered baseless. ${ }^{165} \mathrm{Al}-W a \bar{s} i t \underline{1}$, on the other hand, appears to have consistently viewed al-Harawi as one of the great Sufis of his respective age. ${ }^{166}$

The observations we have thus far made throw a whole new light on the spiritual side of Ibn Taymiyya's leadership in his jamā'a. While it has been argued by Éric Geoffroy that al-Wāsițīs work testifies that the Hanbalī shaykh al-Islām must have fulfilled the role of spiritual guide for Sufis, our study has offered no conclusive evidence to support this assumption. ${ }^{167}$ On the contrary, we have come across several indications suggesting that it would rather have been al-Wāsitị who fulfilled this role, clearly with the approval of Ibn Taymiyya himself. I must stress that I am not thereby claiming that spiritual counseling and guidance was absent from Ibn Taymiyya's function as the leader of their Damascene jamāa $a$. We have already noted that his daily routine reflected the lifestyle typical of the Hanbali zuhhäd. But it was precisely his ability to com-

\footnotetext{
164 Ibn Rajab, Dhayl, vol. 4, p. 505 .

165 Al-Dhahabī, Tärīkh, vol. 33, p. 55. For Ibn Taymiyya's censure of al-Harawī, see for instance his commentary on al-Jīlānīs Futūh al-ghayb, in MF, vol. 10, p. 487; and also his al-Radd 'alà al-Shādhilī fì Hỉzbayhi wa-mā șannafahu fì ādāb al-țarīq, ed. 'Alī b. Muhammad al'Imrān (Mecca: Dār al-'ālam al-fawāìd li-al-nashr wa-al-tawzī', 2009), p. 120.

166 Al-Wāsițī, Madkhal ahl al-figh, p. 52; Mìzān al-shuyūkh, p. 235; Qā'ida fì sulūk al-awliyā', p. 168. It is worthwhile noting that it has since long been established that al-Wāsițī was not the only one of Ibn Taymiyya's inner circle who had a dislike for his shaykh's harsh attitude towards those he criticized. Al-Dhahabī, too, on numerous occasions expresses his annoyance with Ibn Taymiyya's habit to occasionally degrade his opponents in matters of religion. On this, see: Bori, "A New Source," pp. 326-328; and: Donald P. Little, "Did Ibn Taymiyya Have a Screw Loose?” Studia Islamica, No. 41 (1975): pp. 107-109.

Geoffroy, "Le traité de soufisme," p. 101.
} 
bine scholarly erudition with a profound consciousness of the deeper spiritual implications of his knowledge that led al-Wāsiți to recognize him as a complete master of the inward and outward dimension of Islam - though never as a Sufi master. ${ }^{168}$ The fact that he referred to Ibn Taymiyya as his spiritual guide (murshid), and to himself and the other members of their jama'a as the shaykh's aspirants (murieds), should therefore be understood against the background of his own identity as a Sufi, in light of which it was only natural to use such terminology to describe their relationship. ${ }^{169}$ It is not enough to assume that Ibn Taymiyya himself would have used these terms to describe his position vis-à-vis his disciples.

Having established what role al-Wāsițī had taken upon himself in Damascus, we will now seek to establish what can be said of the jamáa $a$ in which he fulfilled this role. We will do this through a brief study of what the relevant primary sources tell us about each individual member of Ibn Taymiyya's circle who is known to have been connected to our Iraqi Sufi, at least five of whom evidently took him as their shaykh in Sufism. This will allow us to recognize several more characteristics of their group identity and get an image of the nature of their relationships.

Seven of al-Wāsițîs Taymiyyan companions can be identified through a letter he had sent them (from which we have quoted before) ${ }^{170}$ and four others can be identified on the basis of biographical dictionaries and/or their own writings. ${ }^{171}$ The list of individuals from Ibn Taymiyya's circle is then as follows:

1. Taqī al-Dīn Aḥmad Ibn Taymiyya (661-728/1263-1328)

2. 'Imād al-Dīn Aḥmad al-Wāsițī (657-711/1259-1311)

3. 'Alam al-Dīn (or Bahā' al-Dīn) al-Qāsim b. Muḥammad al-Birzālī (665739/1267-1339)

4. Taqī al-Dīn 'Umar b. 'Abd Allāh b. Shuqayr al-Ḥarrānī (666-744/12681343)

168 Al-Wāsițī, al-Tadhkira, p. 47.

169 Al-Wāsițîs view of Ibn Taymiyya as a complete shaykh and his use of Sufi language in relation to Ibn Taymiyya has been noted by Bori, "Ibn Taymiyya wa-Jamāatuhu," pp. 27-28. See also Geoffroy, "Le traité de soufisme," p. 101. Both base themselves on al-Wāsiți’s alTadhkira, p. 45 .

170 Al-Wāsițī probably sent this letter to these individuals when they were in Egypt with Ibn Taymiyya, who had been summoned to Cairo by Sultan al-Nāșir in 705/1306. We know that when the shaykh returned to Damascus seven years later, about a year after al-Wāsițīs passing, he was accompanied by his brothers and a group of his companions (jamāc $\mathrm{a}$ min așhābihi), cf. Ibn Rajab, Dhayl, vol. 4, p. 518.

171 This list consists exclusively of members of the Taymiyyan jamāa $a$ who are known to have been linked to al-Wāsițî. It thus omits those individuals for whom I have not been able to establish a link with him (such as al-Mizzī, for instance). 
5. Shams al-Dīn Muhammad b. 'Abd al-Ahad al-Āmidī (661343-8621/743-6)

6. Shams al-Dīn Abū 'Abd Allāh Muhammad al-Dhahabī (673-748/ 12741348)

7. Fakhr al-Dīn Muḥammad b. Muḥammad Ibn al-Ṣāigh (674-748/12751347)

8. Sharaf al-Dīn Muhammad Ibn al-Munajjā al-Tanūkhī (675-724/12761324)

9. Zayn al-Dīn Abū Muḥammad 'Abd al-Raḥmān al-Ba'labakkī (675734/1276-1333)

10. Nūr al-Dīn Muhạmmad b. Muḥammad Ibn al-Șā̄igh (676-749/1277-1348)

11. Ibrāhīm b. Muḥammad al-Qawwās al-Dimashqī (677-761/1278-136o)

12. Shams al-Dīn Muhammad b. Abī Bakr Ibn Qayyim al-Jawziyya (691751/1292-1350)

13. Sharaf al-Dīn Muhammad b. Sacd Allāh al-Harrānī (d. 723/1323)

We will begin by looking at the activities of the above individuals and see whether these can be connected to specific localities within Damascus. Of the eleven companions and disciples of al-Wāsițī, at least eight attended hadìth auditions under one or more of the shaykhs also attended by Ibn Taymiyya, as depicted in the following table. ${ }^{172}$

Ibn Taymiyya's shaykhs of hadith

\begin{tabular}{|c|c|c|c|c|c|c|c|}
\hline Members of Ibn Taymiyya's circle & $\frac{1=}{3}$ & 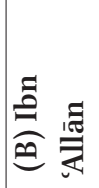 & 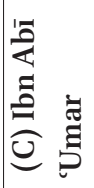 & 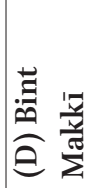 & (ี己 & 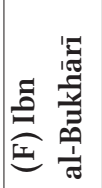 & 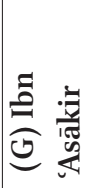 \\
\hline (3) al-Birzālī & $\mathrm{x}$ & $\mathrm{x}$ & $\mathrm{x}$ & & & $\mathrm{x}$ & $\mathrm{x}$ \\
\hline (4) Taqī al-Dīn al-Harrān̄̄ & $\mathrm{X}$ & & & $\mathrm{x}$ & $\mathrm{X}$ & $\mathrm{X}$ & \\
\hline (6) al-Dhahabī & $\mathrm{X}$ & $\mathrm{X}$ & $\mathrm{x}$ & & & $\mathbf{X}$ & $\mathrm{X}$ \\
\hline (7) Fakhr al-Dīn Ibn al-Ṣā'igh & & & $\mathrm{X}$ & & $\mathrm{x}$ & $\mathrm{X}$ & \\
\hline (8) Ibn al-Munajjā & & $\mathrm{x}$ & $\mathrm{x}$ & & & $\mathrm{X}$ & \\
\hline (10) Nūr al-Dīn Ibn al-Ṣāigh & & & & & & & $\mathrm{X}$ \\
\hline (11) Ibrāhīm al-Qawwās & & & & $\mathrm{x}$ & & $\mathrm{X}$ & $\mathrm{x}$ \\
\hline (13) Sharaf al-Dīn al-Ḥarrānī & & & & $\mathrm{x}$ & & $\mathrm{x}$ & \\
\hline
\end{tabular}

172 For a brief biographical notice on each of these hadith masters, see appendix 2, pp. 169170. For a list of Ibn Taymiyya's shaykhs, see: Ibn 'Abd al-Hādī, al- Uqūd, p. 19; Ibn Rajab, Dhayl, vol. 4, p. 493, and Ibn Taymiyya's $M F$, vol. 18, pp. 97-98, where he mentions Ibn 'Allān, saying that he heard hadīth from him in 68o/1281. 
If we recall the earlier-mentioned daily schedule of Ibn Taymiyya, where we saw that he would go to hadith auditions after sunrise with his companions, we should be open to the possibility that they attended at least some of the above shaykhs as a group. If this was indeed the case and we look at the locations where a few these shaykhs are said to have been based (as indicated in figure 19, p.167), then Ibn Taymiyya's jamā'a may have jointly frequented the Muzaffarī Mosque, the 'Umariyya madrasa, and the Dār al-Hadìth al-Ashrafiyya in alȘālihiyya, and the Dār al-Ḥadìth al-Ashrafiyya and the Hanbaliyya madrasa in the old city. If we then look at the locations where they themselves acquired teaching positions (also indicated in figure 19), we find that, with the exception of al-Āmidī, they were all based in the old city (the Umayyad Mosque, the Dār al-Hadìth al-Nūriyya and al-Sukkariyya, and the Hanbaliyya, Mismāriyya, Nafisiyya, and Dimāghiyya madrasas). We can thus observe that while they were certainly prepared to roam around Damascus for the sake of religious knowledge, they were primarily concentrated in the western part of the old city.

By Analyzing the biographical information provided in appendix 3 (pp. 170174), there are several more relevant observations to be made regarding the relationships between the members of the jama $\bar{a}^{c} a$. We can see that three of them were born in the mid-sixties and six in the mid-seventies, and therefore not much younger than Ibn Taymiyya, who was born in 661/1263. With the exception of Ibn al-Qayyim, who was born in the nineties, there was thus not a considerable age difference among them. In addition to the several shaykhs of hadith they probably attended as a group, they also appear to have taken knowledge from each other, and certainly not exclusively from Ibn Taymiyya. A case in point is al-Dhahabī, who heard hadìth from at least four other members of the jamā'a besides the shaykh al-Islām, and credits three of them with being his shaykhs, even though they were most likely peers. Another testament to that reality is, of course, al-Wāsiți himself, who, in spite of his role as their Sufi teacher, displays a deep sense of appreciation and reverence in the way he speaks of the Taymiyyan disciples he taught, indicative of mutual respect rather than strictly a master-disciple relationship. ${ }^{173}$ Add to that the fact that the biographical information on the members of the jamã $a$ shows that they all reached a certain degree of success as scholars in their own right, with some

173 I have added the titles of respect by which al-Wāsițīs earlier mentioned letter refers to seven of his companions from the jama $\bar{a}^{c} a$ in their respective biographies in appendix 3 . For the original Arabic, see: al-Wāsițī, al-Tadhkira, pp. 21-23. While it may be argued that the way he addresses them is purely rhetorical convention, I believe our study in the previous section has convincingly shown that al-Wāsițī did genuinely revere his Damascene companions. 


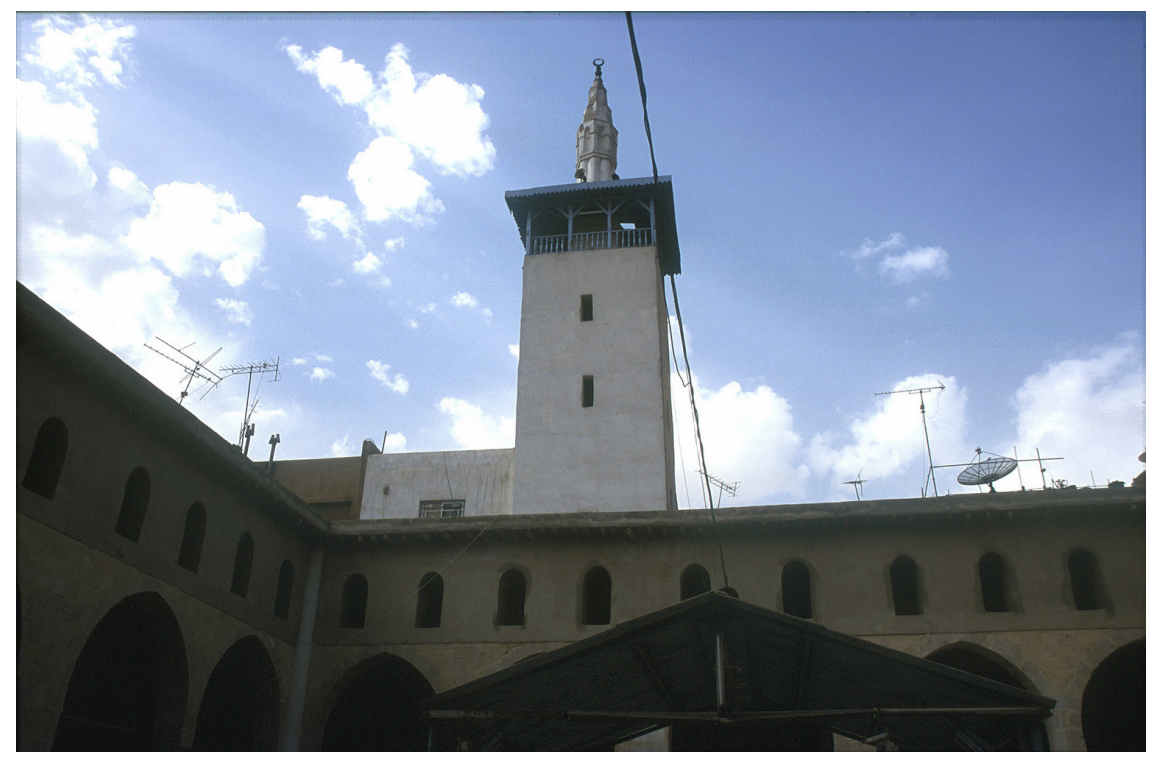

FIGURE 11 The great Muẓaffarī Mosque (a.k.a. Jāmi` al-Ḥanābila) in al-Ṣaliḥiyya, Damascus (number 1 on the map on p. 167).

(C) ROSS BURNS, <HTTP://MONUMENTSOFSYRIA.COM>

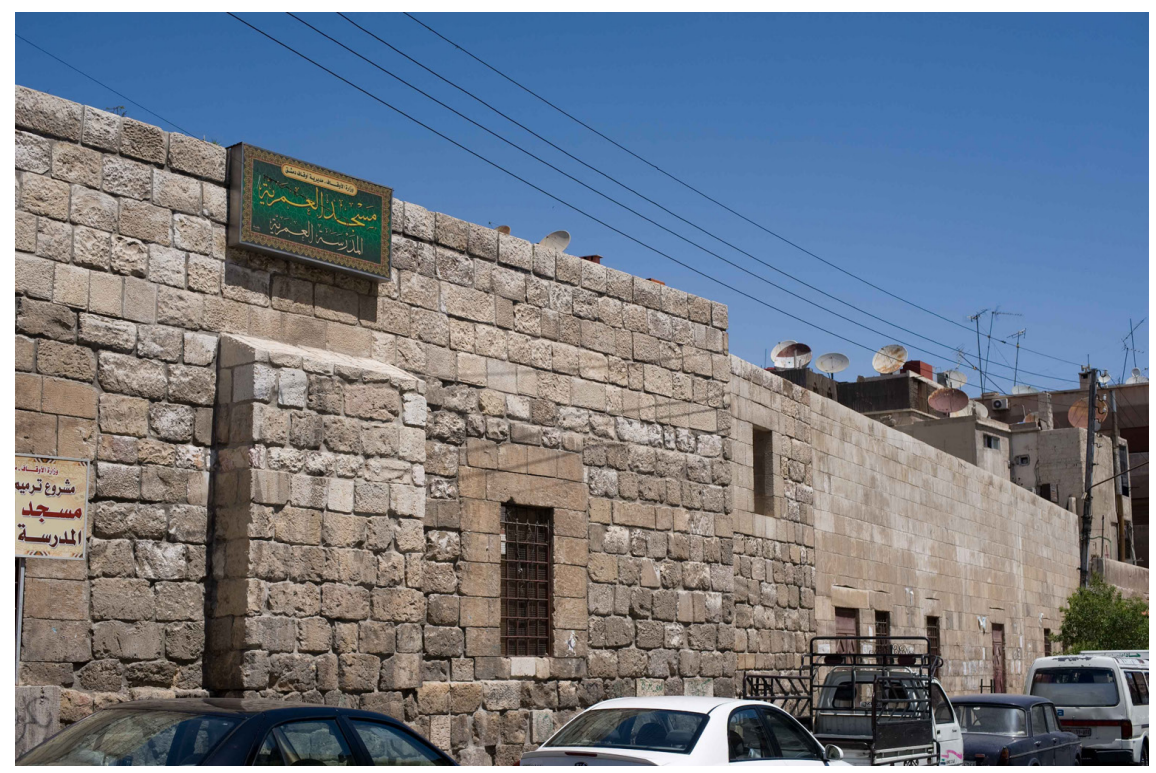

FIGURE 12 Al-Madrasa al-'Umariyya in al-Ṣālihiyya, Damascus (number 2 on the map on p. 167).

(C) ROSS BURNS, <HTTP://MONUMENTSOFSYRIA.COM> 


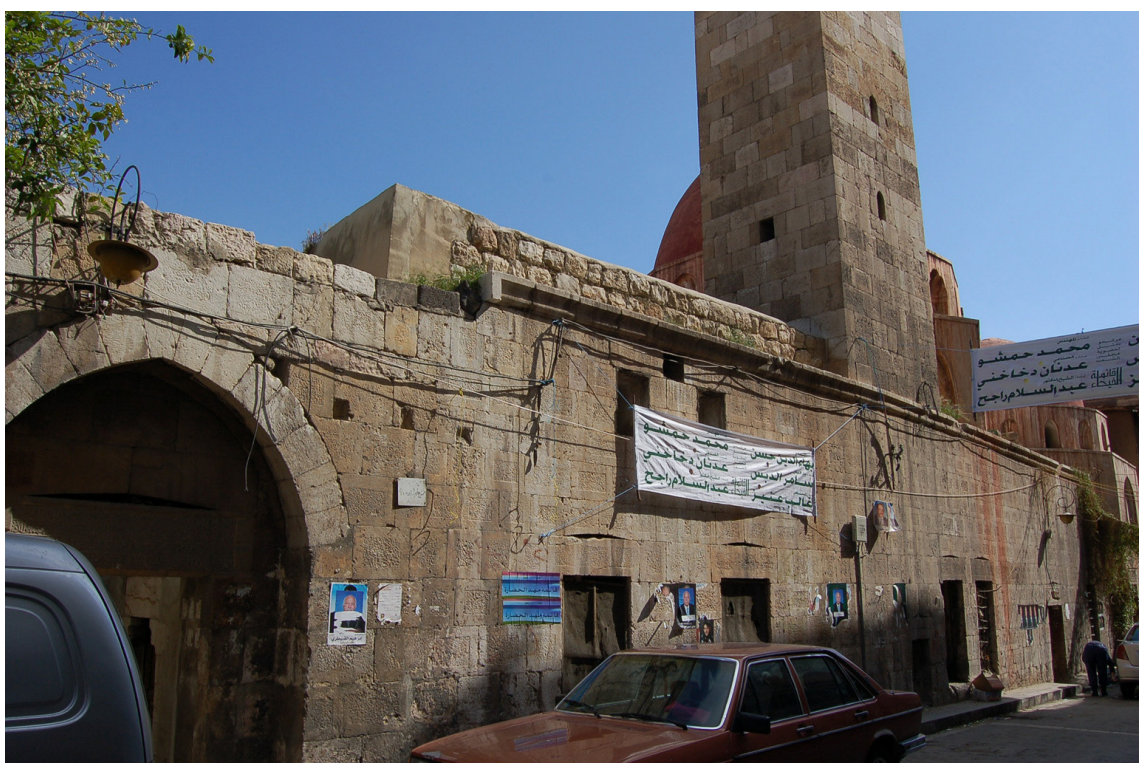

FIGURE 13 On the left is the gate of Dār al-Hadīth al-Ashrafiyya al-Barrāniyya with al-Madrasa al-Murshidiyya to its right, in al-Ṣālihịyya, Damascus (number 5 on the map on p. 167).

(C) ROSS BURNS, <HTTP://MONUMENTSOFSYRIA.COM>

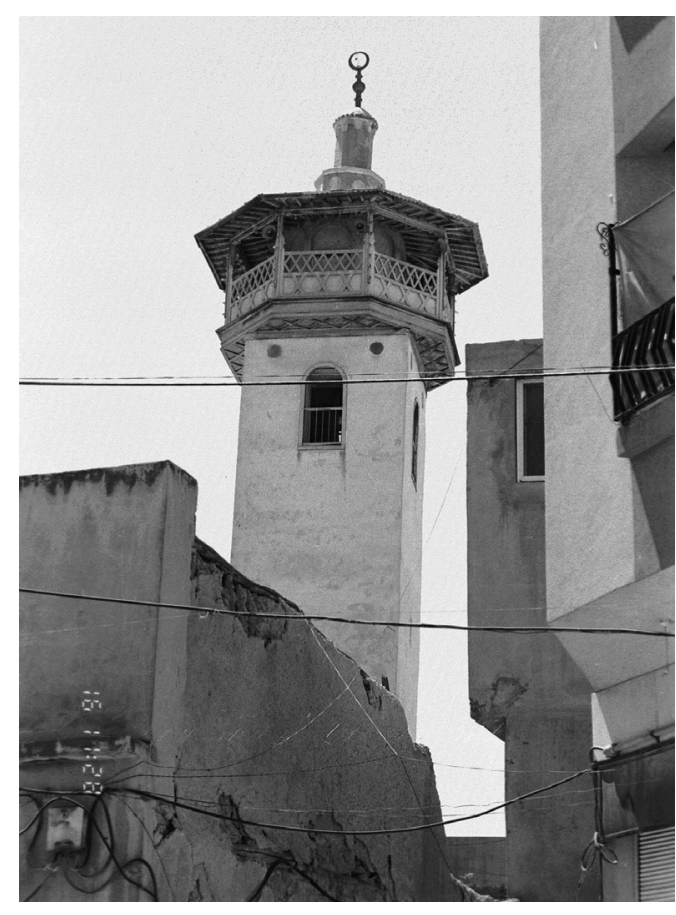

FIGURE 14

Minaret of the Karīmī Mosque in the Qubaybāt quarter of Damascus (number 16 on the map on p. 167). (C) ROSS BURNS, <HTTP://MONU MENTSOFSYRIA.COM $>$ 

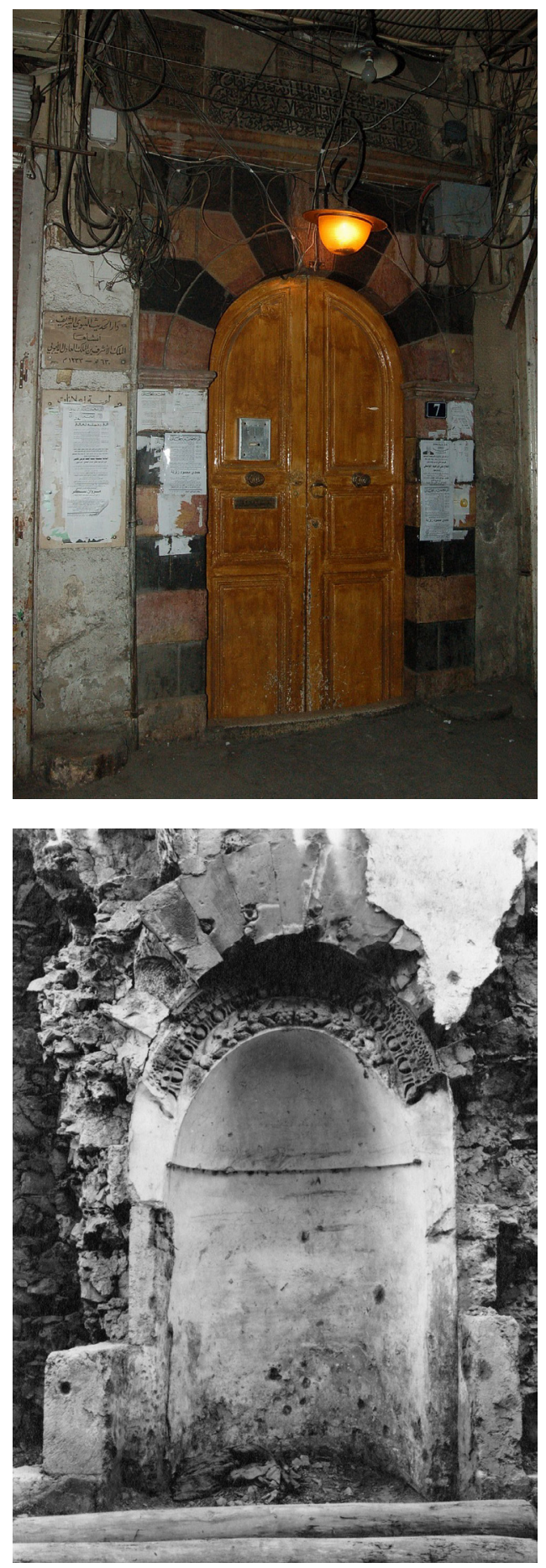

FIGURE 15

The gate of Dār al-Ḥadìth al-Ashrafiyya in the old city of Damascus (number 7 on the map on p. 167).

(C) ROSS BURNS, <HTTP://MONUMENTSOFSYRIA.COM $>$

\section{FIGURE 16}

The remains of the carved mihrāb of Dār al-Ḥadīth al-Nūriyya in the old city of Damascus (number 12 on the map on p. 167).

(C) ASHMOLEAN MUSEUM, UNIVERSITY OF OXFORD. IMAGE COURTESY OF SPECIAL COLLECTIONS, FINE ARTS LIBRARY, HARVARD UNIVERSITY 

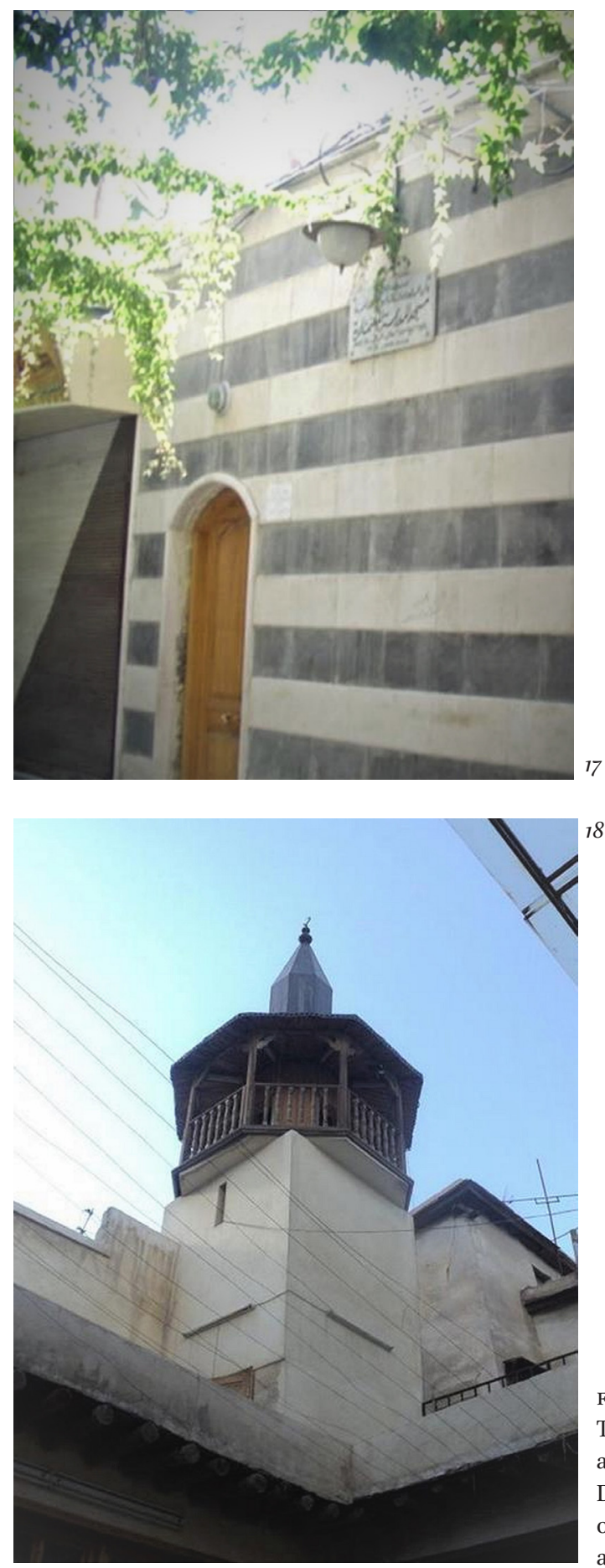

\section{8}

FIGURES 17 AND 18

The gate and minaret of al-Madrasa al-Mismāriyya in the old city of Damascus. (number 10 on the map on p. 167). Pictures courtesy of 'Imād al-Armashī 


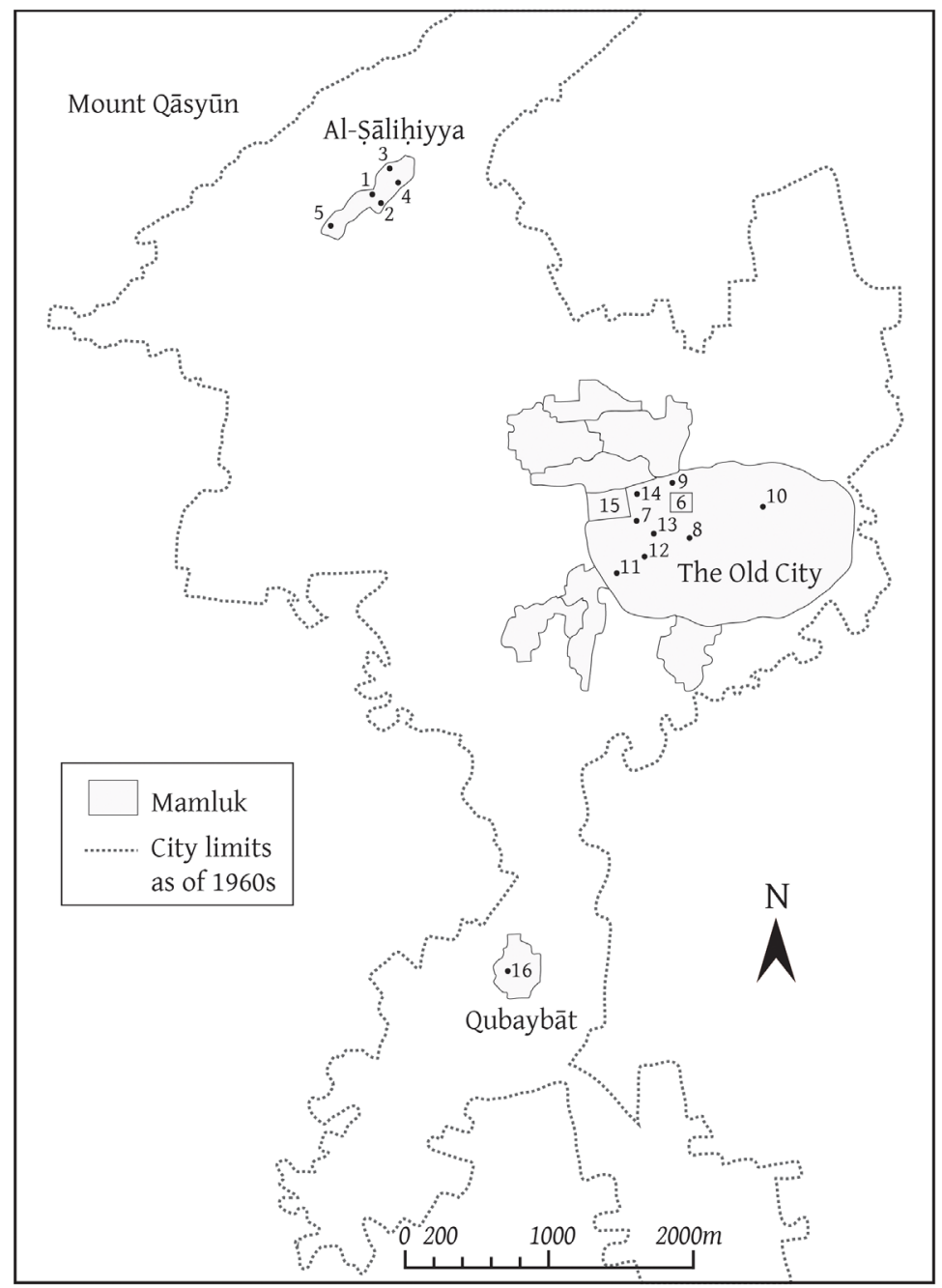

FIGURE 19

Above: A map of Mamluk Damascus with the mosques and madrasas ran and/or attended by traditionalists. Map adapted from Ross Burns, Damascus: A History (London/New York: Routledge, 2007), p. 310. Below: The names of the institutions followed by references between brackets: with the numbers referring to members of Ibn Taymiyya's circle, and the letters referring to the scholars they themselves attended to hear hadith (numbers and letters are in accordance with the sequence as found above and in appendix 2 and 3 )

\section{al-Ṣāliḥiyya:}

1. al-Jāmi` al-Muẓaffarī (C)

2. al-Madrasa al-'Umariyya (F)

3. al-Madrasa al-Diyāiiyya

4. al-Madrasa al-Ṣaḥibiyya

5. Dār al-Ḥadīth al-Ashrafiyya al-

Barrāniyya $(\mathrm{C})$

Old City:

6. Umayyad Mosque (1)

7. Dār al-Ḥadīth al-Ashrafiyya (A)
8. al-Madrasa al-Jawziyya

9. al-Madrasa al-Hanbaliyya al-Sharīfiyya (D/1, 2)

10. al-Madrasa al-Mismāriyya (D/8)

11. Dār al-Hadīth al-Sukkariyya $(1,6)$

12. Dār al-Hadīth al-Nūriyya (3)

13. al-Madrasa al-Nafìsiyya (3)

14. al-Madrasa al-Dimāghiyya (10)

15. Citadel

Qubaybāt:

16. al-Jāmi` al-Karīmī (5) 
even acquiring considerable fame, we begin to get the impression that perhaps Ibn Taymiyya was not some figure that towered over them, but that we are dealing with a group of men who were first and foremost kindred spirits.

As I have argued earlier, I believe that it was their shared passion for traditionalism as the purest form of Islam that brought them together. They chose to do so under the leadership of Ibn Taymiyya because they recognized in him the traditionalist (Hanbalī) ideal of a complete master, who combined scholarship and piety. As a group they strove to attend auditions of hadith among the renowned shaykhs of Damascus together, they followed their leader wherever they could together, and they were willing (at least initially) to jointly suffer the consequences of his activism for the traditionalist cause.

To conclude, we will once more draw attention to the way normativity may be related to context. Our overview in section 2.1 of the situation in Damascus shortly before and during al-Wāsițī's lifetime has shown us that the traditionalist Hanbalīs had claimed it as their new capital. Although they certainly did not dominate the city, and there was occasional tension between them and scholars from other schools of law/theology, they did successfully establish themselves in its religious landscape. We may recall, for instance, that the combination of scholarship and piety of the Maqdisīs appears to have greatly appealed to many Damascenes. In such a setting it seems quite natural that a group such as that of Ibn Taymiyya could emerge and gain a following. After all, in the traditionalist community of Damascus, their religiosity would have been considered quite normative and admirable, even. ${ }^{174}$ It is therefore not surprising that, as a self-proclaimed traditionalist, al-Wāsiți considered his assimilation into the jamác $a$ a shot from his nadir in Cairo to the zenith he had been pursuing most of his adult life. For him, it marked the end of his physical journey.

Since we have constantly considered how the Sufism of the previous groups he had accompanied may be related to notions of normativity of the respective context in which they operated, we should likewise consider how this is the case for the formulation of Sufism he himself preached amidst the Taymiyyan circle. This will require a thorough examination of his own Sufi doctrine, for which we now turn to part 2 of our study.

174 I am aware of the later controversies in traditionalist circles surrounding some of Ibn Taymiyya's teachings, which Caterina Bori has covered in her article "Ibn Taymiyya waJamā'atuhu," pp. 23-43. However, it should be noted - as Bori also does - that this was a later development in Ibn Taymiyya's career. During the years al-Wāsițī spent with him he was in all likelihood still very much a rising star in the city's traditionalist community. 


\section{Appendix 2: The Hadith-Scholars Attended by the Taymiyyan Circle}

A. Amìn al-Dìn al-Qāsim b. Abì Bakr al-Irbilī (d. 680/1281): A muhaddith rank hadìthscholar, ${ }^{175}$ who taught at the Dār al-Hadīth al-Ashrafiyya in the old city of Damascus. ${ }^{176}$

B. Shams al-Dìn Abū al-Ghanāim al-Muslim Ibn 'Allān (d. 1282/o86): A Damascene musnid rank hadïth-scholar ${ }^{177}$ and traditionalist in creed who taught in Baalbek and Damascus. ${ }^{178}$

C. Shams al-Dīn Ibn Abī 'Umar 'Abd al-Raḥmān al-Maqdisī (d. 682/1283): The earliermentioned cousin of Muwaffaq al-Dīn. He was considered the most knowledgeable of his time in the Hanbali school. He was Friday preacher of the Muzaffarī Hanbalī Mosque and attained directorship over the Dār al-Ḥadìth al-Ashrafiyya al-Barrāniyya of the Șālihịyya, where he functioned as teacher and judge. ${ }^{179}$

D. Zaynab Bint Makkī b. 'Alī al-Harrānī (d. 688/1289): A Hanbalī zāhida and musnida rank hadith-scholar who appears to have taught at the madrasa al-Hanbaliyya al-sharīfiyya and al-Mismāriyya, both in the old city.180

E. Badr al-Dìn Abū al-'Abbās Aḥmad Ibn Shaybān (d. 689/129o): A musnid rank hadìth-scholar who lived in the Șāliḥiyya, from where he transmitted Ibn Hanbal's Musnad. 181

175 A muhaddith is a specialist who has reached the second rank in hadith scholarship. This is someone who is knowledgeable in the hadith's strengths and weaknesses when it comes to isnād and text, and who is familiar with the six canonical collections and has memorized at least a thousand of their hadiths, cf. Mohammed Hashim Kamali, A Textbook of Hadìth Studies: Authenticity, Compilation, Classification and Criticism of Hadith (Markfield, Leicestershire: Islamic Foundation, 2005), pp. 63-64.

176 On him, see: al-Ṣafadī, al-Wāfì, vol. 24, p. 86; Ibn al-'Imād, Shadharāt, vol. 7, p. 641. Note that there were two schools with the name Dār al-Ḥadith al-Ashrafiyya, one in the old city and one in the Șālihiyya. For al-Irbilī’s teaching activity at this institution, see: alDimashqī, al-Dāris, vol. 1, p. 21.

177 A musnid is a specialist who has reached the first rank in hadith scholarship. This is someone who transmits hadïth, even though he may not be knowledgeable in its isnäd or its meaning, cf. Kamali, $A$ Textbook, p. 64.

178 He was probably a Shāfi īi I base his traditionalism on al-Dhahabỉ's entry on him, where it is stated that he loved the Ahl al-Hadìth, cf. al-Dhahabī, Tārīkh, vol, 5o, p. 373; and also al-Ṣafadī, al-Wāfì, vol 25, pp. 326-327.

179 Al-Dimashqī, al-Dāris, vol. 1, pp. 36-37; Ibn Rajab, Dhayl, vol. 4, pp. 179-180.

180 Al-Șafadī, al-Wāfì, vol. 15, pp. 42-43; al-Dhahabī, Tārīkh, vol. 51, pp. 327-328. For her teaching activity, see: al-Dimashqīi, al-Dāris, vol. 2, p. 58, and: Stefan Leder, Yāsīn Muhammad al-Sawwās, and Ma’mūn Șāğarğī, Mu'ğam al-samāāàt al-dimašqiyya 550-750 h. / Les certificats d'audition à Damas: 1155-1349 (Damascus: Institut français de Damas, 1996), p. $5^{\circ}$. She is listed as a Ḥanbalī scholar by Bakr b. 'Abd Allāh Abū Zayd, 'Ulamā’al-ḥanābila (Riyad: Dār Ibn al-Jawzī, 2001), p. 508.

181 Al-Dhahabī, al-Tbar, vol. 3, p. 358; Ibn al-Imād, Shadharāt, vol. 7, p. 681; Ibn Kathīr, alBidāya, vol. 13, p. 361 . 
F. Fakhr al-Dìn 'Al̄̄ Ibn al-Bukhārī al-Maqdisī (d. 69o/1291): A zāhid, Hanbalī jurist, and muhaddith rank hadith-scholar who taught at the 'Umariyya Hanbali madrasa in the Șālihiyya. ${ }^{182}$

G. Sharaf al-Dīn Ahmad b. Hibat Allāh Ibn Asākir (d. 699/130o): A musnid rank hadith-scholar who taught in the old city. He was from the famous Damascene Banū 'Asākir, a Shāfīì-Ash'arī family. ${ }^{183}$

\section{Appendix 3: Biographies of al-Wāsițîs Companions from Ibn Taymiyya's Circle}

3. 'Alam al-Dīn (or Bahā' al-Dìn) al-Qāsim b. Muhammad al-Birzālī (665-739/12671339): A Damascene historian, traditionalist Shāfi '̄, and hadìth specialist who reached the rank of haffiz. ${ }^{184}$ When he was approximately eight years old he began studying under his father. He soon sat with the distinguished hadith-scholars of Damascus, such as Ibn 'Allān, Ibn al-Bukhārī, al-Irbilī, Ibn 'Asākir, and Ibn Abī 'Umar. ${ }^{185}$ Although he credited Ibn Taymiyya with being one of his shaykhs, the two would probably have been closer to peers. ${ }^{186}$ In his dictionary of the shaykhs he studied with, al-Birzāli describes al-Wāsițī as follows: "He was a pious man and a knower [of God] (rajulun șăliḥun 'ärifun), given to asceticism and worship, who abstained from this world. He has solid words about authentic Sufism (al-tașawwuf al-șahịh)." ${ }^{187}$ Al-Birzālī made a good career for himself, teaching hadìth at several madrasas in the old city and eventually attaining directorship over the Dār al-Hadīth al-Nūriyya and the Nafisiyya madrasa. ${ }^{188}$

4. Taqì al-Dìn 'Umar b. 'Abd Allāh Ibn Shuqayr al-Harrānī (666-744/1268-1343): A Hanbali jurist and hadìth-scholar from Damascus who is mentioned as one the elite

182 Ibn Rajab, Dhayl, vol. 4, pp. 242-249.

183 Al-Dhahabī, Tārīkh, vol. 52, pp. 389-39o; Ibn al-'Imād, Shadharāt, vol. 7, p. 778.

184 A hăfiz is a specialist who has reached the third rank in hadith scholarship. It is someone with a yet even wider knowledge of hadith than the muhaddith. Cf. Kamali, A Textbook, p. 64 .

185 Al-'Asqalānī, al-Durar al-kamina, vol. 4, pp. 277-279; al-Subkī, Ṭabaqāt al-shāfíìya, vol. 10, pp. 381-383; Ibn Kathīr, al-Bidāya, vol. 14, pp. 216-217; Ibn Rajab, Dhayl, vol. 4, p. 181; al-Dhahabī, Tārīkh, vol. 52, p. 38o; Ibn Qāḍī Shahba, Țabaqāt, vol. 2, pp. 279-28o.

186 Al-Birzālī mentions Ibn Taymiyya in his Mujam al-shuyūkh, a work that is unfortunately lost. However, the shaykh al-Islām's entry is preserved in Shams al-Dīn Muhammad alQaysī Ibn Nāșir al-Dīn, al-Radd al-wāfir, ed. Zuhayr al-Shāwīsh (Beirut: al-Maktaba alislāmī, 2010), p. 121. Ibn Taymiyya appears to have valued al-Birzālī's evidently superior talent in the field of hadìth. Ibn Kathīr relates that the Hanbalī shaykh alluded to his sharp memory, saying: "al-Birzālì's transmission [of hadìth] is engraved in stone" (naqlal-Birzāale naqrun fi hajar), cf. al-Bidāya, vol. 14, p. 217.

187 Ibn Rajab cites the entry of al-Wāsiți from al-Birzālī’s Mujam al-shuyūkh in:Dhayl, vol. 4, p. 382 .

188 Al-Dimashqī, al-Dāris, vol. 1, pp. 83 \& 85 . 
members of Ibn Taymiyya's circle. He is the first disciple to be mentioned in al-Wāsiți’s letter, where he is addressed as "the most outstanding notable, the eminent scholar, the pride of the hadith specialists, the light of those devoted to God, the one who has turned himself to God ..."189 In jurisprudence he memorized al-Muharrar fi al-fiqh by Ibn Taymiyya's grandfather Majd al-Dīn, and in hadìth he sat with al-Irbilī, Zaynab Bint Makkī, Ibn Shaybān, and Ibn al-Bukhārī. ${ }^{190}$

5. Shams al-Dīn Muhammad b. 'Abd al-Ahad al-Āmidī (661343-8621/743-6): Also referred to in the sources as Ibn al-Zarīr and Ibn al-Razīz. He is the second disciple to be mentioned in al-Wāsițī's letter, where he is addressed as "the most outstanding shaykh, the eminent scholar, the ascetic traveler of the spiritual way (al-sālik al-nāsik), who combines knowledge with practice. Due to his praiseworthy qualities he is dressed in the most beautiful of garbs ..." ${ }^{191} \mathrm{Al}-\bar{A}$ midī was born in the city of Amida (present-day Diyarbakır, Turkey) and settled in Damascus, where he became one of Ibn Taymiyya's companions. He was regarded as one of the elite members of his circle. Apart from his function as preacher $(k h a t ̦ i ̄ b)$ of the Jāmic al-Karīmī in the Qubaybāt quarter south of Damascus, little more is known of him. ${ }^{192}$

6. Shams al-Dīn Abū 'Abd Allāh Muḥammad al-Dhahabì (673-748/1274-1348): By now we have come across al-Dhahabī's name numerous times. Like al-Birzālī, he was a Damascene historian, Shāfiì jurist, and hadìth specialist who reached the rank of hăfiz. According to his student al-Subkī, he was strongly inclined towards the theological opinions of the Hanbalīs, with great disregard for the Ash'arīs, of whom he would speak well reluctantly. ${ }^{193}$ This attitude is indeed reflected in many of his own writings, which are full of praise for traditionalist theology (often simply referred to as the method of the Salaf) and negative remarks towards kaläm. ${ }^{194}$ He took hadith from Ibn al-Bukhārī, Ibn Abī 'Umar, Ibn 'Allān, al-Irbilī, and Ibn 'Asākir, and in Ibn Taymiyya's circle from the shaykh al-Islām himself, al-Birzalī (who had guided him to the study of hadìth), Sharaf al-Dīn al-Ḥarrānī, Sharaf al-Dīn Ibn al-Munajjā, and perhaps also Nūr al-Dīn Ibn al-Ṣā’igh. ${ }^{195}$ He had a successful career in Damascus, and after the passing of

189 Al-Wāsițī, al-Tadhkira, p. 21.

190 Taqī al-Dīn Muḥammad Ibn Rāfí, al-Wafayāt, ed. Șāliḥ Mahdī 'Abbās \& Bashshār 'Awwād Márūf (Beirut: Mu’assasat al-risāla, 1982), vol. 1, pp. 461-462; Ibn Nāṣir al-Dīn, al-Radd alwäfir, p. 115; Al-Dhahabī, Tärīkh, Vol. 49, p. 233.

191 Al-Wāsițī, al-Tadhkira, p. 21.

192 Al-Asqalānī, al-Durar al-kāmina, vol. 5, p. 237; Ibn Kathīr, al-Bidāya, vol. 14, p. 239.

193 al-Subkī, Țabaqāt al-shäficiyya, vol. 9, pp. 100-103.

194 See for instance al-Dhahabī's Siyar, vol. 18, p. 514 where he compliments al-Harawì's Kitāb al-fārū $q$ for its chapter on the Hanbalī position regarding the divine attributes, and p. 510 where he defends al-Harawī as "a traditionalist man (rajulun athariyyun) devoted to affirming the texts on the divine attributes, very averse to kaläm and its practitioners."

195 For his shaykhs, see: al-Subkī, Ṭabaqāt al-shäfíiyya, vol. 9, pp. 101-102; al-Dhahabī's dictionary of his shaykhs, Mujjam al-shuyūkh al-kabìr, ed. Muḥammad al-Ḥabīb al-Hīla 
Ibn Taymiyya he obtained directorship of the Dār al-Hadīth al-Sukkariyya. ${ }^{196}$ Interestingly, al-Dhahabì was initiated into the Suhrawardiyya in Cairo by the hadith-scholar and Sufi Ḍiyā' al-Dīn 'Īsā al-Anșārī, who passed away in 696/1297. ${ }^{197}$ This means that he must have already been something of a Sufi before he sat with al-Wāsițī. As for our Iraqi Sufi, al-Dhahabī was evidently impressed by him, stating that he had benefitted from his classes in Sufism and did not know of anyone in Damascus who could equal him in this field. ${ }^{198}$

7. Fakhr al-Dīn Muhammad b. Muhammad Ibn al-Ṣāigh (674-748/1275-1347): A traditionalist Shāfíi jurist from Damascus who is mentioned as an elite member of Ibn Taymiyya's circle. He is the sixth disciple to be mentioned in al-Wāsițì's letter, where he is addressed as "the notable, the brother, the devout, righteous, and reliable scholar, excelling in his trustworthiness, endowed with good manners and faith, firm in following the Sunna ..."199 Among others, he took hadìth from Ibn Abī 'Umar, Ibn Shaybān, and Ibn al-Bukhari. In 742/1341 he was invested with the jurisdiction over the Mamluk troops ( $q a d \bar{a}^{\prime}$ al-'așākir), most likely in Damascus, where he also passed away some six years later. ${ }^{200}$

8. Sharaf al-Dīn Muhammad Ibn al-Munajjā al-Tanūkhī (675-724/1276-1324): A Hanbali jurist and hadith scholar from Damascus who is mentioned as an elite member of Ibn Taymiyya's circle. He is the third disciple to be mentioned in al-Wāsiți's letter, where he is addressed as "the notable, the brother, the eminent scholar, the ascetic traveler of the spiritual way, the righteous devout servant, whose feature is that his

(al-Ṭāiif, Maktabat al-ṣiddīq, 1988), vol. 2, pp. 13-14 (Ibn al-Bukhārī), vol. 1, pp. 374-375 (Ibn Abī 'Umar), vol. 2, p. 340 (Ibn 'Allān). Al-Birzālī had encouraged al-Dhahabī to study Prophetic tradition, telling him that he has the handwriting of a hadith scholar, cf. alDhahabī, Mújam, vol. 2, pp. 115-117. In his al-Mucjam al-mukhtașs, p. 23o, al-Dhahabī relates that Sharaf al-Dīn al-Harrānī was a companion of his (șăhibī $)$ who transmitted hadiths to him on the authority of Ibn al-Bukhārī. In his Mújam al-shuyūkh, vol. 2, pp. 289-29o, al-Dhahabī mentions Sharaf al-Dīn b. al-Munajjā as one of his shaykhs from whom heard hadìth. In his al-Tbar, vol. 4, p. 150, al-Dhahabī refers to Nūr al-Dīn Ibn alṢāiigh as "our shaykh."

196 Al-Dimashqī, al-Dāris, vol. 1, p. 59.

197 As attested to by al-Dhahabī himself in: Mujam al-shuyūkh, vol. 2, pp. 87-88, and: Siyar, vol. 22, p. 377 .

198 Al-Dhahabī always refers to al-Wāsițī as "our shaykh," often accrediting him as an 'ārif, cf. his Kitāb tadhkira, vol. 3, p. 130 \& vol. 4, 191; Dhayl Tärīkh, p. 126; Tärīkh, vol. 44, p. 393, vol. 48, p. 274, vol. 51, p. 256, \& vol. 52, p. 401; Mújam al-shuyūkh, vol. 1, pp. 29-30; al-Tibb alnabawī, wa bi-ākhirihi fașl fì al-samā', ed. Muhammad 'Abd al-Raḥmān al-Mar'ashlī (Beirut: Dār al-Nafāì li-al-țibā'ah wa-al-nashr wa-al-tawzī', 2004), p. 228; Ibn Rajab, Dhayl, vol. 4, p. 383 .

199 Al-Wāsițī, al-Tadhkira, p. 22.

200 Ibn Rāfí, al-Wafāyāt, vol. 2, pp. 42-43; Ibn Kathīr, al-Bidāya, vol. 14, p. 229; al-Dhahabī, Tärīkh, vol. 5o, p. 175 . 
heart's light shines on the surface of his face ..." ${ }^{201}$ His father, Zayn al-Dīn, was greatly impressed by Ibn Taymiyya, who had been one of his students. ${ }^{202}$ It is therefore perhaps not surprising that Sharaf al-Dīn attached himself to the shaykh al-Islām and became one of his loyal followers. He is known to have stood by his side and accompanied him on his travels. Among his shaykhs in hadìth were his own father, Ibn 'Allān, Ibn Ab̄̄ 'Umar, and Ibn al-Bukhārī. He heard the six canonical books of hadìth and the Musnad of Ibn Hanbal. Eventually he reached the degree of mufti and became teacher at the Mismāriyya madrasa of his family. ${ }^{203}$

9. Zayn al-Dīn 'Abd al-Raḥmān al-Ba labakkī (or al-Ba'lī) (675-734/1276-1333): A specialist in Hanbalī jurisprudence, a scholar of hadìth, and a Sufi, who is mentioned as an elite member of Ibn Taymiyya's circle. He is the fourth disciple to be mentioned in al-Wāsițī's letter, where he is addressed as: "the notable, the brother, the jurist, the outstanding eminent scholar, the pride of those who comprehend (fakhr al-muhas silin)..." 204 Although he was originally from Baalbek and passed away there as well, it is likely that he spent the majority of his scholarly career in Damascus. He accompanied al-Wāsiți in Sufism and mastered jurisprudence under the guidance of Ibn Taymiyya, until he became proficient in it and was permitted to issue fatwas. He taught at several madrasas and authored books in the fields of figh, hadith, and tașawwuf. ${ }^{205}$

10. Nür al-Dīn Muhammad b. Muhammad Ibn al-Șāigh (676-749/1277-1348): The younger brother of the earlier-mentioned Fakhr al-Dīn Ibn al-Ṣāigh and the fifth disciple to be mentioned in al-Wāsițī's letter, where he is addressed as "the notable, the brother, the eminent scholar, the ascetic traveler of the spiritual way, endowed with an excelling intellect, righteous works, ample tranquility, and abundant virtues ..."206 $\mathrm{He}$ studied under Ibn 'Asākir and is mentioned as an elite member of Ibn Taymiyya's circle. In Damascus he was invested with the jurisdiction over the Mamluk troops, with whom he traveled to Cairo. He later returned to Damascus and became a teacher at the Dimāghiyya madrasa, until he was appointed chief judge ( $q a \bar{a} d \bar{\imath} a l-q u d \bar{a} t)$ of the Shāfīis in Aleppo in 744/1343, an office he held until he passed away. ${ }^{207}$

\footnotetext{
201 Al-Wāsițī, al-Tadhkira, p. 22.

202 Ibn Rajab, Dhayl, vol. 4, p. 273.

203 Al-Dhahabī, Mújam, vol. 2, pp. 289; Ibn Rajab, Dhayl, vol. 4, pp. 456-459; al-'Asqalānī, alDurar al-kāmina, vol. 6, p. 18; Ibn Kathīr, al-Bidāya, vol. 14, pp. 133-134.

204 Al-Wāsițī, al-Tadhkira, p. 22.

205 Ibn Rajab, Dhayl, vol. 5, pp. 50-52, Ibn Kathīr, al-Bidāya, 14:194. For a more detailed biography, I refer the reader to the introduction to my article: "A Glimpse of Sufism," pp. 163166.

206 Al-Wāsițī, al-Tadhkira, p. 22.

207 Al-'Asqalānī, al-Durar, vol. 5, p. 495; note that al-Ṣafadī gives an incorrect date of birth in al-Wāfi, vol. 1, p. 249; al-Ṣafadī also offers a biography in Áyān al-'aṣr, vol. 5, pp. 199-200. For the Dimāghiyya, see: al-Dimashqī, al-Dāris, vol. 1, pp. 177-182.
} 
11. Ibrāhìm b. Muhammad al-Qawwās al-Dimashqī (677-761/1278-1360): His madhhab-affiliation is unknown, but he was a Sufi and a musnid rank hadīth-scholar. He took hadīth from Zaynab Bint Makkī, Ibn al-Bukhārī, and Ibn 'Asākir, and he also transmitted himself. Initially he had been a close disciple of Ibn Hūd, but he later renounced him and started following Ibn Taymiyya. In Sufism he accompanied (șahiba) al-Wāsițī, from whose guidance he is reported to have benefited. ${ }^{208}$

12. Shams al-Dìn Muhammad b. Abī Bakr Ibn Qayyim al-Jawziyya (691-751/1292-1350): A Damascene Hanbalī scholar and perhaps the most talented of Ibn Taymiyya's disciples. As seen from his date of birth, he was by far the youngest of al-Wāsiți's known students. If we are to believe Ibn Kathīr, Ibn al-Qayyim only started following Ibn Taymiyya upon the shaykh's return from Egypt in $712 / 1313 .{ }^{209}$ This would mean that he probably joined al-Wāsițī's classes on Sufism somewhere after the shaykh al-Islām left Damascus for Egypt in 705/1306. Of all the individuals we have thus far discussed, Ibn al-Qayyim became by far the most prolific author in the field of Sufism. Although little to nothing is known of his relationship with our Iraqi Sufi, he appears to have inherited his unfinished manuscript of a commentary on al-Harawīs Sufi treatise Manāzil alsäirìn. He quotes from it in his Shifä’ al-'alîl, wherein he refers to al-Wāsiți as "our shaykh."210

13. Sharaf al-Dīn Muhammad Ibn Najịh al-Harrānī (d. 723/1323): A Damascene Hanbali jurist and mentioned as an elite member of Ibn Taymiyya's circle. He is the seventh and final disciple to be mentioned in al-Wāsițīs letter, where he is addressed as "the dear and righteous brother, who seeks the path of His Lord and desires His contentment and love, the eminent scholar ..." ${ }^{211}$ He heard hadìth from Ibn al-Bukhārī, Zaynab Bint Makkī, and others, and also studied by himself. In jurisprudence his main teacher was Ibn Taymiyya, who also granted him the authority to give fatwas. Ibn Najị partook in many of his shaykh's trials and was at one point jailed with him.212

208 Al-'Asqalānī, al-Durar, vol. 1, p. 8o; Ibn Rāfic, al-Wafayāt, vol. 2, pp. 233-234.

209 Ibn Kathīr, al-Bidāya, vol. 14, p. 270; see also: Ibn Rajab, Dhayl, vol. 5, pp. 170-171.

210 Ibn Qayyim al-Jawziyya, Shifä’ al-'alïl fì masā'il al-qadăà' wa-al-qadar wa-al-hikma wa-alta'lïl (Beirut: Dār al-ma'rifa, 1978), p. 16. See also: Ibn Rajab, Dhayl, vol. 5, p. 383, and also: al-Dhahabī, al-Dhayl, p. 126.

211 Al-Wāsițī, al-Tadhkira, pp. 22-23.

212 Ibn Rajab, Dhayl, vol, 4, pp. 453-454. Ibn Nāșir al-Dīn, al-Radd al-wāfir, p. 45; al-'Asqalānī, al-Durar, vol. 5, p. 185; Ibn Kathīr, al-Bidāya, vol. 14, p. 127. 
PART 2

The Spiritual Journey (al-Sulūk) 
Arjan Post - 978-90-04-37755-4

Downloaded from Brill. com $04 / 26 / 2023$ 03:36:10PM via free access 


\section{Sulūk as Sufism}

He who traveled during the darkness of night, The stars he observed, his lamp he ignited

Until when guided by the moon's light, He looked for the morning and left the stars behind Until when the darkness completely expired He saw from the horizon: morning's come in sight So lamps, stars, and moon, all he left behind While he waited for the radiance to shine POEM ON $S U L \bar{U} K$, 'IMĀD AL-DĪN AHMAD AL-WĀSIṬ $\bar{I}^{1}$

The second half of the present book, consisting of chapters 4 and 5 , aims to provide a comprehensive overview of al-Wāsițīs interpretation of Sufism. For this endeavor I have studied all his writings that have been available to me. ${ }^{2}$ It must be mentioned that, while the vast majority of these deal with tașawwuf, there are a few titles that are concerned with either traditionalist theology or the Prophethood of Muhammad. Nonetheless, as will become apparent in chapter 4, even these two topics have a direct relationship to his vision of $\mathrm{Su}$ fism and have therefore been of relevance to the following study. So, if the previous chapter has not yet convincingly shown that al-Wāsitị's main role in the Taymiyyan circle was that of a Sufi guide on the spiritual way, then his corpus clearly attests to that fact. Before we proceed to investigate what it is that he taught his disciples, there remain a few clarifying remarks that ought to be

1 Al-Wāsițī, al-Sirr al-mașūn, p. 67; And also in: 'Umdat al-țullāb, p. 213, where he states that these verses are on the beginnings and the endings of sulük and he provides a commentary on each line. Although he does not state that he wrote these verses himself, we know this to be the case thanks to Shams al-Dīn Muhammad al-Qaysī Ibn Nāṣir al-Dīn, Taw dịh al-mushtabah fí dabț asmā' al-ruwāt wa-ansābihim wa-alqābihim wa-kunāhum, ed. Muhammad Naīm al-'Irqsūsī (Beirut: Mu'ssasat al-risāla, 1993), vol. 3, pp. 166-167.

2 Besides all of al-Wāsițī's writings that have been published, I have had access to three unpublished manuscripts from his oeuvre. For a list of the titles I have consulted, see the bibliography, pp. $284-287$. 
made concerning some of the particularities of the style he maintains throughout his writings.

Here we must address briefly how he conceptualizes Sufism. For besides the fact that he only rarely uses the terms 'tașawwuf' or 'șüfi', he occasionally expresses severe criticism towards Sufis, even seemingly disassociating himself from them altogether on some occasions. Most often he names the discipline he is concerned with 'al-sulük,' which may be rendered as the spiritual way, or path towards God, treaded by the sălik, the spiritual traveler. Sometimes he uses sayr as a synonym of sulük, and säir as a synonym of sālik. He understands sulük as the effort to progress on the spiritual way by applying the method of the Prophetic way, with the goal to arrive unto God spiritually. When we look at what several medieval Muslim biographers say with respect to alWāsițī's writings, we find that al-Dhahabī, Ibn Rajab, and Ibn Ḥajar al-'Asqalānī all state that they fall under the category of al-sulük. ${ }^{3}$ Ibn Rajab even specifically categorizes them under the topic "al-sulük al-atharĭ," the traditionalist spiritual way, clearly to emphasize that al-Wāsițị's method of spirituality was anchored in the school of the Ahl al-Hadith. ${ }^{4}$ On that basis, it may be tempting to think that our Iraqi Sufi sought to distance himself from Sufism with the term sulūk. However, his Mìzān al-shuyūkh undisputedly proves that this was not the case, as he states therein that "the master of sulük is the Sufi" (washaykh sulük huwa al-șüfì). ${ }^{5} \mathrm{He}$ evidently viewed the sālik and the Sufi as one and the same. Why, we may then ask, does his work frequently display a degree of caution in presenting himself as a Sufi, and the discipline he teaches as $\mathrm{Su}-$ fism?

To answer this question, we must take into account the traditionalist community in which he operated. In the section on the Damascene Hanbalīs from the previous chapter we have already observed that it is difficult to pinpoint the exact relationship they had with Sufism. As mentioned, the sources of the era under consideration more often speak of Hanbali zuhhād than of Hanbali Sufis, perhaps because the Hanbalīs were wary of an epithet that was surely not always without controversy. This may in part have been motivated by their strict rejection of innovation (bid'a), an attitude that is also reflected in alWāsițîs style of writing. In the final section of the next chapter, for example, we will find that he evidently tried to live up to the Hanbali stereotype, attacking innovations he found prevalent among certain contemporary Sufi groups

3 Al-Dhahabī, Dhayl, p. 126; al-'Asqalānī, al-Durar al-kāmina, vol. 1, p. 103; Ibn Rajab, Dhayl, vol. 4 , p. 383 .

4 Ibn Rajab, Dhayl, vol. 4, p. 382.

5 Al-Wāsițī, Mīzān al-shuyūkh, pp. 234. 
- though never to censure Sufism in itself, but to purify it of what he believed were perversions of the true Prophetic spiritual way. His preference for the term sulūk may thus in part be understood against the background of the Hanbalī/traditionalist community he was preaching Sufism to.

It must be noted that the connotation of sulük as the discipline of striving on the spiritual way towards God was not exclusive to traditionalist circles. We may recall from chapter 2, for instance, that it was also used as such by the Shādhiliyya. It is possible that the traditionalists' inclination towards the term had to do with the fact that its verbal form occurs several times in the Qur'an. ${ }^{6}$ However, I have not been able to verify this in any of the sources I consulted.

Apart from al-Wāsițīs preference for the term sulūk, it is, above all, clear from his writing style that he was in the first place addressing a traditionalist audience. By that I am not only referring to the often-recurring discussions on and allusions to traditionalist theology, a topic that is very neatly intertwined with his formulation of Sufism as the next chapter will reveal. His traditionalist style is also very much visible in the source material he relies on.

Anyone familiar with the writings of classical traditionalist scholars will have observed that they give precedence to two sources: the Qur'an and the Sunna (mostly in the form of hadith). Although they certainly valued the opinions and sayings of renowned scholars and pious individuals, it weighed heavier for them to make an argument on the basis of the nușuss - the holy texts - than on the basis of "qäla fulān" - "so-and-so said." Of course, generally, most Sufis would also claim that their spiritual teachings are purely based on the texts of revelation; but reading Ibn Taymiyya's al-Tuhfa al-Irāqiyya, a work of considerable length on the spiritual states of the heart, one cannot help but notice his heavy reliance on citations from the Qur'an and hadith, while only rarely referring to the sayings of scholars. In contrast, one would find most Sufi books of a similar length from around the same period filled with the sayings of pious figures and Sufi authorities.

When we look at al-Wāsiți’s writings, one quickly notices that, like his Hanbali shaykh, he mostly relies on the Qur'an and the hadith, and only sporadically refers to Sufi authorities, or any scholarly authority for that matter. $^{7}$ The few examples of quotes from Sufis I have come across are once from Sahl al-Tustarī (d. 283/896), once from Abū Yazīd al-Basțāmī (d. 234/848 or

6 Most fittingly in verse 69 of Sürat al-Nahl, where God enjoins the bees to "... travel the paths of your Lord" (fa-'sluki subula rabbiki). We must note that all other uses of the verb "salaka" in the Qur'an do not appear to fit the concept of traveling towards God.

7 This characteristic element of his writing style was also noted by Geoffroy, "Le traité de soufisme," p. 87 . 
$261 / 875),{ }^{8}$ and several times from al-Junayd (d. 289/910), thought mostly anonymously. ${ }^{9}$ In fact, the majority of the few citations from Sufi shaykhs in his work are made uncredited. ${ }^{10}$ We must bear in mind that part 1 of our study has shown that al-Wāsiți was, of course, intimately familiar with the teachings of a wide variety of Sufi scholars. I would therefore argue that the fact that his own writings contain so few references is not because he did not rely in any way on the teachings of other Sufis and scholars, but rather because he wrote in the style of his traditionalist teachers.

To return to our initial point, we can safely say that al-Wāsițī never explicitly breaks with Sufism, but rather operates carefully within the lines of traditionalism to define how it should be given form. Indeed, the foremost concern in his writings is this spiritual dimension of religion that he most certainly regarded as 'the science of tașawwuf,' precisely because he acknowledged the dire need to have an inward experience complementing one's outward acts. At one point he even explicitly argues that, without seeking the spiritual realities (haqā'iq) of faith from the Prophet's Sunna, people will remain veiled from intimate, spiritual knowledge of God (marifa) and the taste of His love (mahabba); and that without witnessing God (shuhūd) during such acts as the ritual prayer (șalāt), the remembrance of Him (dhikr), Qur'anic recitation (tilāwa), or any other form of worship, people will inevitably be overcome by boredom and laxity. ${ }^{11}$ For al-Wāsițī, it is Sufism in its pure, legitimate form that

For al-Tustarī, see: al-Wāsițī, Madkhal ahl al-figh, p. 84; for al-Basțāmī, see: al-Wāsițī, alSirr al-mașūn, p. 67.

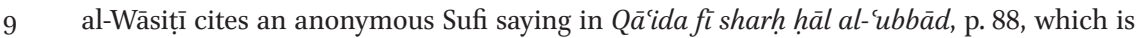
attributed to al-Junayd by Ibn Taymiyya, $M F$, vol. 7, p. 186. There is a poem by Junayd cited anonymously in Qawā'id al-nubuwwāt, p. 3oo, cf. Abū Țālib Muḥammad b. 'Alī al-Makkī, Qùt al-Qulūb fì mu'āmalat al-Maḥbūb wa-wasf al-țarìq al-murìd ilā maqām al-tawhìd, ed. 'Așim Ibrāhīm al-Kayyālī (Beirut: Dār al-kutub al-ilmiyya, 2009), vol. 2, p. 97. There is also poem related by Junayd from a female slave, quoted anonymously in al-Wāsițīs Miftāh al-ma'rifa wa-al-ibāda, p. 268 and likewise 'Umdat al-țulāa, p. 212, cf. Ibn al-'Imād, Shadharāt al-dhahab, vol. 3, p. 418.

10 In the previous chapter I have made note of two nameless citations of Ibn al-Fāriḍ. AlWāsițī cites two poems by Dhū al-Nūn al-Mișrī in Miftāh al-márifa wa-al-ibāda, p. 251. One is found in Abū Nu'aym Aḥmad b. 'Abd Allāh al-Iṣbahānī, Hilyat al-awliyā'wa-țabaqāt al-asfiya '’ (Cairo: al-Sa'āda, 1974), vol. 9, p. 368, the other in: Abū Bakr Muhammad alKalābādhī, Al-Ta'arruf li-madhhab ahl al-tașawwuf (Beirut: Dār al-kutub al-ilmiyya, 1993), p. 26. Al-Wāsițī cites al-Ḥallāj in Qā'ida fì bayān al-țarīq ilā Allāh táăla min al-bidāya ilā al-nihāya, p. 182; Qã̄ida fí al-wișāl, p. 269; Qawā'id al-nubuwwāt, p. 30o. Al-Wāsițī cites alShādhilī in Miftāḥ al-márifa wa-al-ibāda, p. 270 (cf. Ibn al-Ṣabbāq, Durrat al-asrār, p. 137), and again in his Qāंida fi hạs al-nafs wa-al-uküf 'alä al-hamm, p. 9o (cf. al-Iskandarī, Lațāiff, p. 38).

11 Al-Wāsițī, Qā'ida fi al-farq bayna al-ābid wa-al-mushāhid, p. 258; Madkhal ahl al-figh, p. $5^{\circ}$. 
facilitates this spiritual dimension, with the ultimate goal to reach perfection in one's religion. ${ }^{12}$ That is why, on rare occasions, he does not shy away from extolling the Sufis as the folk of God (ahl Alläh) who obtain His friendship, intimacy, and nearness. ${ }^{13}$ In one treatise on the exalted status of the Sufis, he describes them as those who

love friendship with the Real in the unseen realm (al-ghayb), and force themselves to uphold whatever is possible for them of what is due to this Friend from their breaths, hearts, and spirits, through works of love and reverence and preferring Him over everything else ... They do not act with Him in the manner of the absentminded, but rather as one who is present [with Him] and witnesses [Him] - for although He is absent from their eyesight, He is never absent from their inner vision (bașäir)! $!^{14}$

Such is the outcome of true Sufism, which in the eyes of our Iraqi Sufi may be reached by traversing all the steps of sulūk as set out it in his writings. What these steps entail we will explore in the following two chapters. The first of these is concerned with the foundations of his teachings, the second with the stages of witnessing God's attributes that are meant to lead to the utmost degree of friendship with Him.

12 For al-Wāsițī it is through Sufism that one may become an 'insān kāmil,' or perfect human being; see for instance: Qā'ida fi habs al-nafs wa-al-ukūf'alä al-hamm, pp. 83 \& go.

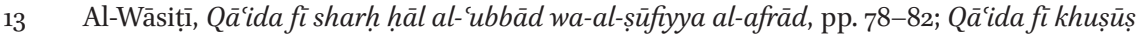
țăiffat al-șüfiyya, pp. 129-130. Note that, sometimes, al-Wāsiți speaks of the Sufis by referring to them as "the folk" (al-qawm), cf. Qã'ida fí al-musta'idd li-al-tașawwuf, p. 125; al-Sirr al-mașūn, p. 59; Madkhal ahl al-figh, p. 64; Mukhtașar sīrat rasūl Allāh, f.2b; Qāंida ya'rifu al-'abd fìhā nașībahu min rabbihi wa-bu'dahu min huzūuz nafsihi, p. 212; he calls the Sufis 'qawm al-sulūk,' in: Qā'ida fì al-jidd wa-al-ijtihād, p. 251. 


\section{Traditionalist Sufism: Outlining the Foundations of the Journey}

\section{Introduction}

In this chapter we commence with a study of al-Wāsițîs method of sulūk by expounding upon a set of recurring elements in his writings that we may identify as its foundations. Although I do not mean to claim that this endeavor will convey the full spectrum of the foundations of Sufism as he envisioned it, I believe that the themes we will focus on were, in his view, essential to the further continuation on the pathway towards God. It is those elements that can either make or break one's sulūk, so to speak. Whatever the sālik seeks to attain through Sufism without them, or with a faulty understanding of them, will prove fruitless in his view.

This chapter is divided into three sections. The first of these deals with knowledge of the Prophet, the second with knowledge of God. These two sections very much stand together as consecutive steps that are supposed to firmly set the sālik on his path. The third section is concerned with al-Wāsiṭ̂'s negative definition of Sufism. It aims to give an overview of the polemical side of his writings, by which he intended to provide a solid argumentation against practices and doctrines that he felt will thwart the sālik's journey. We will thus find that the foundations of Sufism are not only defined in terms of what constitutes the correct path, that is, 'selfing,' but also in terms of what leads astray from it, that is, 'othering.'

I will argue that the common thread that connects each of the subjects under consideration is traditionalism. Even when we can clearly distinguish alWāsițīs own creative thought at work, he was, in his own mind, constantly anchored in the scholarly tradition of the Ahl al-Hadith. For as he saw it, to deviate from it would be to deviate from the pure path of the righteous predecessors, the Salaf. As we have seen, he held that out of all Muslim fractions that have come into existence since the beginning of Islam, only the traditionalists continued to represent the true Ahl al-Sunna wa-al-Jamā'a. And as many traditionalists had done before him, he regularly reminds us in his corpus that this title belongs solely to the partisans of hadith by rendering it as 'Ahl alSunna wa-al-Hadith,' and various other modifications of the label, in order to 
emphasize that to be a Sunni Muslim is to be a traditionalist. ${ }^{1}$ Moreover, he often buttresses his school's authority by counting amongst its ranks such early renowned scholars as Mālik b. Anas (d. 179/795), 'Abd Allāh b. al-Mubārak (d. 181/797), Ibn Idrīs al-Shāfiī (d. 204/819-820), Aḥmad Ibn Ḥanbal (d. 241/855), and the well-known compilers of hadìth collections, such as al-Bukhārī (d. 256/870) and Muslim (d. 261/875). ${ }^{2}$ By laying claim to such figures, he effectively presents the Ahlal-Hadith movement as the sole representatives of their legacy - or rather, the legacy of the Prophet, which they conveyed most soundly.

When it comes to the way he defined the foundations of Sufism, the current chapter will demonstrate that he very explicitly aimed to build on a traditionalist basis. Each of the following three sections will illustrate how this is apparent in his teachings. We will first and foremost draw attention to his reliance on the nușuss, the Qur'an and the Sunna, as the primary sources of spiritual knowledge, and to his use of traditionalist hermeneutics to understand them. Secondly, we will occasionally point to instances of overlap between him and Ibn Taymiyya, not to prove that al-Wāsițîs teachings were directly influenced by his shaykh per se, but rather to highlight that both scholars appear to have operated within the same traditionalist framework. Finally, the third section will demonstrate how al-Wāsițī worked from a traditionalist framework to exclude from Sufism those Sufis whom he polemicized against.

\section{The Muhammadan Way (al-Tarīqa al-Muḥammadiyya)}

He said: "The Lord came from Sinai, and dawned over them from Seir;

He shone forth from Mount Paran."

(Book of Deuteronomy: 33:2)

These words from the Torah and the Old Testament are quoted in Arabic in alWāsițìs Talqīh al-asrār, where he comments that the first line is an allusion to the coming of Moses, the second to the coming of Jesus, and the third to the

1 Al-Wāsițī, Risalatuhu ilā al-shaykh al-Maghribī, p. 108; other variations of the label al-Wāsițī mentions are: 'Ahl al-Hadith wa-al-Sunna,' 'Ahl al-Sunna wa-al-Athar,' and 'Ahl al-Sunna wa-

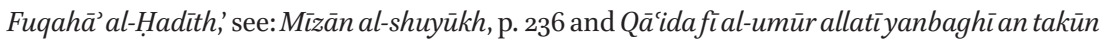
hamm al-sālik, p. 192.

2 Al-Wāsițī, Madkhal ahl al-fiqh, p. 51; Risāla fi ithbāt, p. 40; Qāida fì tasfiyyat al-akhlāq, p. 93; Qā'ida fì al-umūr allatì yanbaghì an takūn hamm al-sālik, p. 192; 'Umdat al-țullāb, p. 202; Risālatuhu ilā al-shaykh al-Maghribì, p. 108. 
coming of Muhammad. ${ }^{3}$ He will undoubtedly have taken this interpretation from 'the Proofs of Prophethood' (daläil al-nubuwwa), one of the subcategories of literature on the Prophet Muhammad into which he had immersed himself. As we have seen in the previous chapter, he took this direction under the guidance of Ibn Taymiyya. However, we have yet to see the far-reaching impact that this had on his spiritual life. In the current section we will explore the result of his endeavor to formulate a form of Sufism in which the Prophet is allotted a central role. As we shall see, one of the primary foundations of Sufism he describes is centered around acquainting oneself with the Prophet and, eventually, establishing a relationship with him.

\subsection{The Origins of the Țarīqa Muhammadiyya}

From the perspective of our Iraqi Sufi, true Sufism was nothing other than the pure inward dimension - the ba țin - of the Prophet Muhammad's Sunna. He sometimes conceptualizes his method of sulūk as the Muhammadan way (altariqa al-Muhammadiyya), ${ }^{4}$ the guidance of the Muhammadan light (al-nūr al-Muhammadī $),{ }^{5}$ and the path of Muhammadan poverty (taríqat al-faqr alMuhammadī ${ }^{6}{ }^{6}$ To characterize the effects of this particular path as opposed to the paths of those Sufis whom he rejects for straying from it, he occasionally likes to use Sufi terminology with the adjective 'Muhammad $\vec{\imath}$ added to it. He speaks, for instance, of the Muhammadan taste (al-dhawq al-Muhammadī $)^{7}$ and the Muhammadan state (al-hâal al-Muhammadī). ${ }^{8}$ As we will see, he was thereby separating himself from other trends of Sufism that were at variance with the principles of traditionalism he adhered to. ${ }^{9}$ His writings convey again and again that to deviate from the path of the Ahl al-Hadith is to deviate from the Muhammadan way.

3 Al-Wāsițī, Talqịh al-asrār, p. 54.

4 Al-Wāsițī, Qā'ida fì bayān 'amal yawm wa-layla li-al-abrār, p. 27; Qā'ida fí aṣnāf al-ta’alluh, p. 151; and in the title of his Miftāh al-márifa wa-al-ibāda li-ahl al-țalab wa-al-irāda al-rāghibìn fì al-dukhūl ilā dār al-sa'āda min al-țarīqa al-muhammadiyya allatī laysat munharifat ${ }^{a n}$ 'an al-jädda (The key to intimate knowledge and worship for those who seek and desire [God], who wish to enter the Abode of Happiness through the Muhammadan way, which never deviates from the right course).

5 'Umdat al-țullāb, p. 198; al-Tadhkira, p. 40.

6 al-Wāsițī, Qã'ida mukhtașara fì țarīq al-faqr 'alā minhāj al-rasūl; the whole treatise is about Muhammadan poverty, which is referred to as a distinct țariqa, or path, on p. 25. In his Mìzān al-shuyükh, p. 247, he explains that spiritual poverty, or faqr, signifies the effort to remain constantly connected to the Prophet and to God.

7 Al-Wāsițī, Qā'ida fíașnāf al-ta’alluh, pp. 153-154; al-Bulgha, f. 69 a.

8 Al-Wāsițī, Qã ida fíașnāf al-ta’alluh, p. 153; Qā'ida tatimma li-hādhihi al-qā'ida fì al-ta'alluhāt, p. 156 .

9 A similar observation was made by Geoffroy, "Le traité de soufisme," p. 95. 
In the field of Sufi studies, the term 'taríqa Muhammadizya' is mostly known as a concept that is characteristic of a distinct type of reformist Sufi movement that emerged during the late eighteenth and early nineteenth century, which scholars have referred to as neo-Sufism. Bruce B. Lawrence, for instance, has observed that

the nineteenth century witnessed a more explicit, and more openly public, awareness of the Prophet as the crucial link between God and humankind. It has been etched in the phrase al-tarīqa al-Muhammadiyya. What underlies al-tariq a al-Muhammadiyya ... is not just loyalty to the Prophet but connection to his reality (al-haqiqa al-Muhammadiyya) and to his light (al-nūr al-Muhammadī)..$^{10}$

The 'Muhammadan way' as a Sufi concept with a much longer history has already been established by Vincent J. Cornell, who thought to have found "the apparent originator of the term" in 'Abd Allāh al-Ghazwānì (d. 935/1528-1529), a Moroccan Sufi shaykh of the Jazūliyya order. ${ }^{11}$ The latter coined it as the title for his doctrine that based the "authority of the Sufi shaykh ... on an explicit analogy between the saint and the Prophet Muhammad."12 Evidently, the term actually goes back at least two more centuries before al-Ghazwānī, as it can be found in the writings of al-Wāsiți and, perhaps surprisingly, also in those of Ibn Taymiyya.

FritzMeieralreadynoted thatIbn Taymiyya coined the term 'Muhammadiyya,' and overlooked that he actually used the term 'țariqa Muhammadiyya' as well. Ibn Taymiyya adopts it in two treatises as something of an umbrella term for

$10 \quad$ Bruce B. Lawrence, "Sufism and neo-Sufism," in The New Cambridge History of Islam Volume 6, ed. R. Hefner (Cambridge: Cambridge University Press, 2010), p. 356, where he specifically identifies the concept with the North African movement of Muhammad alSanūsī (d. 1859) and the north Indian movement of Sayyid Ahmmad Barelwī (d. 1831). Note that the early proponents of the neo-Sufism theory have mistakenly understood the țariqa Muhammadiyya as an effort to develop a concept of union with the Prophet in order to replace the concept of union with God. This understanding has been criticized by Rex S. O'Fahey \& Bernd Radtke, "Neo-Sufism reconsidered," Der Islam, 70 (1973): pp. 64-71; for a response to this criticism, see: John O. Voll, "Neo-Sufism: Reconsidered Again," Canadian Journal of African Studies Vol. 42, No. 2/3 (2008): pp. 322-324. Cornell, Realm of the Saint, p. 219; see also pp. 226-227. Fritz Meier also discussed the history of the term taríqa Muhammadiyya, and traced back its earliest use to the Ottoman scholar Muḥammad b. Pīr 'Ali al-Birkawī (d. 981/1573); cf. Nachgelassene Schriften, pp. 335-346, where he also discusses the further history of the term after al-Birkawì. Ibid. p. 157 . 
the entirety of the traditionalist path towards God. ${ }^{13} \mathrm{He}$ mentions it in his earlier-quoted letter to the Sufi shaykh al-Manbiji, referring to the tariqa Muhammadiyya as the sound religious path that maintains a perfect equilibrium between the law and the spiritual. ${ }^{14}$ Its second mention is in a treatise that addresses al-Ghazâli's claim that the Sufis are the best of all Muslim groups he had studied (the 'groups' being the mutakallimūn, the Ismāiliyya Shi'ites, the philosophers, and the Sufis). Ibn Taymiyya's response is that "he [alGhazāili] was not aware of the path of the Ahl al-Sunna wa-al-Hadith from among the knowers [of God] ('ärifin) and thus makes no mention of it, even though this is the pure Muhammadan way (al-taríga al-muhammadiyya almahḍa)..."15 What is interesting here is that, like al-Wāsițī, Ibn Taymiyya equates the Muhammadan way with the path of the Ahl al-Hadith.

This raises the question as to whether it could have been al-Wāsițī who had first coined the term, or whether he took it from his master. ${ }^{16}$ Initially, I had deemed the latter option more plausible, since it was, after all, the Hanbali shaykh al-Islām who guided al-Wāsițī to focus on the Prophet's biography.

13 For Fritz Meier's mention of Ibn Taymiyya in this regard, see Fritz Meier's Nachgelassene Schriften. Band 1. Bemerkungen zur Mohammedverehrung. Teil 2. Die täșliya in Sufischen Zusammenhängen. Herausgegeben von Bernd Radtke (Leiden: Brill, 2005), pp. 333-334. Ibn Taymiyya, $M F$, vol. 2, p. 452 .

15 Ibid. p. 57.

16 It is necessary to mention that Éric Geoffroy (in "Le traité de soufisme," p. 93) discusses several of the particularities of al-Wāsițī's concept of the Muhammadan way, among which the method of connecting to the Prophet's incorporeal presence, which we will elaborate on below. In this method Geoffroy recognizes what he calls an "Akbarian heritage." He argues that it was due to al-Wāsițî's choice to settle in Damascus that he practiced caution in the formulation of his teachings, which would have been why he only referred to certain doctrines "in an allusive way without naming them." Thus, Geoffroy, continues, "he does not literally use the expression nūr muhammadī or haquiqa muhammadiyya, for this would be equivalent to validating the Akbarian doctrine of 'the perfect man' (al-insān al-kāmil), reproved by Ibn Taymiyya." It is certainly not impossible that our Iraqi Sufi was in some way influenced by Ibn 'Arabī's school in his formulation of the Muhammadan way, since he was familiar with its teachings as we have seen in the previous chapter. However, his elaboration on the concept is so different from what Ibn 'Arabī's doctrine says regarding the Muhammadan reality (al-ḥaqiqa al-Muhammadiyya) that this seems farfetched to me; cf. for instance: Addas, Quest for the Red Sulphur, p. 7677; Michel Chodkiewicz, "Towards Reading the Futûhât Makkiyya," in The Meccan Revelations Volume II, ed. Michel Chodkiewicz (New York: Pir Press, 2004), pp. 30-34. Moreover, we may note that the concept of the Muhammadan light (al-nūr alMuhammadī) can actually be traced back to the ninth century already, cf. Vincent J. Cornell, Realm of the Saint: Power and Authority in Moroccan Sufism (Austin: University of Texas Press, 1998), p. 218. So, at first sight, I would argue that there is no explicit indication that the Muhammadan way contains purely Akbarian influences. 
However, as the following study of al-Wāsițìs writings will show, there are indications that it may in fact have been the other way around.

In order to understand the roots of the tariq a Muhammadiyya we must return to the moment al-Wāsiți had started following the Damascene traditionalists, right before he renounced the Shādhiliyya. We may recall that he closed his autobiography with the conclusion that the best path towards God is to combine the theological foundations of the traditionalists with the Sufism of the Shādhiliyya. His story appears to continue in Qã'ida fı̀ așnāa al-ta'alluh wakhușussịyyat ta'alluh kull țāiifa min al-țawäì (Precept on the Ways to Exercise Devotion to God and Every Group's Particularity in [Their] Exercise of Devotion), a treatise that clearly postdates his autobiography. Here he mentions that he increasingly noticed that the tastes $(a d h w \bar{a} q)$ of the Sufis he had accompanied were at odds with the essentials of the traditionalists he now aspired to follow. He observed, for instance, that the latter group's affirmation of God's highness and aboveness over His Throne (al-uluw wa-al-fawqiyya 'alä $a l$-'arsh) has an illuminating effect on the heart, so that their taste (dhawq) conforms to the verses of the Qur'an, exactly as revealed to the Prophet. But when occupied with his spiritual state during the tastes of the Sufis, al-Wāsitị says that his heart would experience constraint $(d \bar{l} q)$ during the recitation of the Qur'an. While he had initially thought that this was simply due to the triumph of this spiritual state, he gradually became convinced that this only occurred when he turned away from the Prophet's rühāniyya - his spiritual presence - in favor of the rūhanniyya of certain Sufi shaykhs. ${ }^{17}$ It was only among the traditionalists that he was able to connect to the Prophet's rühāniyya. Thus, he claims his heart became illuminated by the lights of prophethood, the hadith, and the sir a, all subjects he was now closely studying under the guidance of his newly found shaykhs. Nonetheless, he could not help feeling that the traditionalist path was incomplete without the intensity he experienced in the nearness (qurb) and intimacy (uns) that he found through the rūhāniyya of the Sufis he so greatly admired. ${ }^{18}$ Referring to himself in the third person, he reflects upon this episode as follows:

17 We have come across the term rūhäniyya several times now. Due to its significance to the subject at hand, it is in place to provide a brief explanation of it here. Al-Wāsiți clearly expected his reader to know what it is he is speaking of, as he never explains what he exactly means by the term. Éric Geoffroy translates it as "présence spirituelle," and explains that it often means something's spirituality as opposed to its corporeality. When it comes to the rūhanniyya of a deceased Prophet or saint, he says, it refers to their spiritual impulse, or even his subtle body, cf. "Le traité de soufisme," pp. 89-9o. In light of alWāsiți’s use of the term, I agree with Geoffroy that this is indeed the term's signification in his works.

18 Al-Wāsiți, Qā'ida fíașnā al-ta’alluh, pp. 151-152. 
O dear God! Would that he knew that it is an incorrect view to hold that the Muhammadan taste (al-dhawq al-Muhammadī) is lacking until it is completed by this other taste [of the Sufi shaykhs]! On the contrary, the Muhammadan taste is perfect and complete and, hence, all good that these [other] paths contain only branches from it, despite their deviation from it. All good that they contain comes from the Muhammadan taste, while any gloom and darkness that they have comes from their deviation from it. Thus this man fell into a state of confusion, which only God knew, and so he sought His help and appealed to Him to guide him. ${ }^{19}$

In short, as the contradictions between the way of the Sufis and that of the traditionalists became clear to him, he could not but turn to God for guidance.

And guidance he received, so he tells us. God facilitated the withdrawal of all other tastes from the core of his heart (sirr), he writes, enabling him to focus completely on the rühanniyya of the Prophet without interference from the rühāniyya of any shaykh or Sufi master. In doing so he was provided with the definite way out of his state of confusion, which he shares with his readers in the following anecdote, again written in the third person:

When he did this, God disclosed an idea to his insight (bașira) that alludes to a sublime point, of great significance to those who recognize its worth. It was an inspiration (ilhām ${ }^{a n}$ ) that came from God's grace upon this weak and confused servant, whose state of affairs had brought him into a depression. This [inspiration] was that it is this rūhanniyya of the Messenger (Ș) that is linked [directly] to the Lord ('AJ), in the sense that it is His law and His path, and the very Book that He revealed, and His spirit $\left(r \bar{u} h\right.$ ) which He bestowed upon His servant and Messenger. ${ }^{20}$ It is this [rühāniyya ] that He loves and is pleased with, and it is this [rühāniyya ] that contains no deviation between it and Him. On the contrary, it corresponds with Him in every respect! When this point became firmly established in his innermost secret (sirr), and his heart drank from it in certainty of it, and his soul became convinced of its correctness - then the Abrahamic-Muhammadan state of intimate friendship made it clear

$19 \quad$ Ibid. p. 152.

20 A reference to the Qur'an, where we often find that there is a particular rūh that would serve as a vessel of the revelations God sent to the Prophets. With regard to the Prophet Muhammad's contact with this rüh, see for instance Q. 26:192-194: "Truly it is the revelation of the Lord of all Being, brought down by the Faithful Spirit (al-rūh al-aminn) upon your heart [Muhammad], so you would be one of the warners." 
to him that, in many respects, what he used to find during the Sufi taste was [actually] the opposite of what he thought it was! ${ }^{21}$

This is perhaps one of the most significant passages on our current topic in alWāsițî's writings, because it presents us with the first-hand account of the way in which the tariqa Muhammadiyya was conceived. We will therefore briefly recount what it is that we are being told here.

The first matter of import is that while his step towards the establishment of the taríqa Muhammadiyya was certainly deeply influenced and, in a sense, even provoked by Ibn Taymiyya (and perhaps also other members of the Taymiyyan circle), it was in the end al-Wāsiți himself who gave it form. The above anecdote gives the impression that what we are dealing with here is a key aspect of his method in sulük that was very much his own conception.

The realization al-Wāsiți claims to have reached through divine intervention was that the purest link between man and God is not found through any Sufi shaykh, but only through the incorporeal presence of the Prophet, his rühāniyya, as his corporeal being has passed away from the material world. But since the Prophet was the vessel of God's speech on earth and, as such, the embodiment of the Qur'an, his spiritual presence continues to be mankind's guide to God.2 ${ }^{22}$

Another point of interest is found in the last sentence of our quote, where al-Wāsiți makes mention of the Abrahamic-Muhammadan state of intimate friendship, 'al-hāal al-Ibrāhìmì al-khalìlı̀ al-Muhammadì', which later in the same treatise he calls the only correct spiritual state. ${ }^{23}$ We must take note that he is by no means implying that the tariqa Muhammadiyya is mixed with the ways of other Prophets, such as that of Abraham in this case. It is to him wholly Muhammadan. However, for our Iraqi Sufi the bond between these two Messengers, Abraham and Muhammad, is particularly significant in that God took both of them as His khalīl, or intimate friend (hence the added adjective "alkhalïlı" in the quoted passage) ${ }^{24}$ While this state of intimate friendship with God (khulla or khilla) was particular to their status as Prophets, al-Wāsiți holds that the wali, or 'friend of God,' can also attain a share of it, which he refers to

21 Al-Wāsițī, Qā'ida fì așnāf al-ta'alluh, p. 153. The last sentence reads: "akasa 'alayhi al-ḥàl

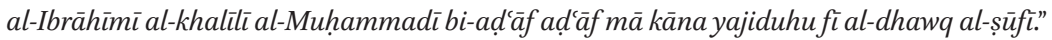

22 Ibid.

23 Ibid. pp. 153-154.

24 In his Qā'ida tatimma li-hādhihi al-qā'ida fì al-ta’alluhāt, p. 156 al-Wāsițī specifically addresses this issue, and cites a canonical hadìth in which Muhammad reportedly said that, like Abraham, "your companion," that is, Muhammad, "is the intimate friend of God." For this tradition, see for instance: Muslim, al-Musnad al-ṣaḥịh, vol. 4, p. 1855. 
elsewhere as the station of Abrahamic-Muhammadan friendship (maqām alkhulla al-Ibrähimiyya al-Muhammadiyya). ${ }^{25}$ As we shall see in chapter 5 , the final stage in al-Wāsițī's Sufism is precisely the point at which God takes the sălik as His beloved (mahbūb), which we may take as an indication that he viewed the terms khalïl and mahbüb as synonyms in that regard. If we return, then, to our passage from Q $\bar{a}$ ida fi aṣnăf al-tảalluh, we may conclude that it was the above divine inspiration he claims to have experienced that compelled him to connect the entirety of his spiritual journey, from its beginning to its highest peak, to the example of the Prophet Muhammad.

What we learn from this is that, as suggested in the beginning of this section, al-Wāsiți aimed to distinguish his sulūk from that of other Sufis. By laying claim to the Prophet as the main source for spiritual guidance he effectively granted Prophetic authority to his teachings, which now represented the authentic inward Sunna rather than the conceptions of some Sufi master. We may understand this in light of his effort to formulate a Sufism that is compatible with the puritan, nușuss-based principles of the Ahl al-Hadith. With this background in mind we now turn to his other writings to study how exactly the Prophet should function as a guide on the Muhammadan way.

\subsection{How to Practice the Muhammadan Way}

One of the first steps in the Muhammadan way that is repeatedly mentioned throughout al-Wāsițīs works is that the sālik should take the Prophet as his shaykh and stick to his guidance, inwardly and outwardly. ${ }^{26}$ The proof for that, he says, is found in the Qur'an, where God commands the Prophet to say to his followers: "If you love God, follow me, and God will love you and forgive you your sins" [Q. 3:31].72 Several times al-Wāsiți compares this relationship with the Prophet to the loyal devotion that the Sufis display towards their shaykhs, concerning which he says: "stick to him like the fuqarä' in our age stick to their shaykhs." 28 Beneath the surface of this remark, and others like it, clearly lays his frustration with the way he had often witnessed the Sufis he met during his travels putting far too much emphasis on their shaykhs. By allowing their hearts to be filled with the secrets $(a s r \bar{a} r)$ and authority (rabbāniyya) of their shaykhs, he argues, they have become veiled from the guidance

\footnotetext{
25 Al-Wāsițī, Qā'ida fíaṣnāf al-ta’alluh, p. 154; and his Qã'ida fíal-jidd wa-al-ijtihād, pp. 250251.

26 See al-Wāsițī's 'Umdat al-țullāb, p. 198; Qā'ida mukhtașara, p. 25; Miftāh țarīq al-muhibbīn, p. 279; Wașiyya ilā ba'd al-quḍāt, p. 141.

27 Al-Wāsițī, Qã̄idat al-rūhāniyyāt wa fìhā bayān li-mā qabluhā, p. 297.

28 Al-Wāsițī, Wașiyya ilā ba'̣̂l al-quḍāt, p. 141; For similar statements, see his: Qā'ida mukhtașara, p. 25; Miftāh al-márifa wa-al-ibāda, p. 264; al-Bulgha, f. 7ob-71a.
} 
and supervision of the Messenger, and thus deviate from the path of arrival $(w u s ̦ u \bar{l})$. He believes that the true reason why the Sufis fail in that regard is because they are unable to extract the secrets of spiritual knowledge (asrār alma'rifa) from the Sunna themselves, thinking that their shaykhs have already done this for them: "They thus allow the Sunna to take direction over their outward being, while turning towards their shaykhs when it comes to the divine secrets and realities (al-asrār wa-al-haqāìq)." ${ }^{29}$ But as he explains in a metaphor, the Prophet is like the pure beginning of a spring; if you fail to drink Muhammadan fagr directly from him, you will be taking water that has been mixed with salty earth, whose colors have turned yellow due to its distance from the source. ${ }^{30}$

The main drive behind attaching oneself to the Prophet ought to be love, which he divides into two categories. The first of these is an obligatory (fard) expression of love, the second a commendable (sunna) one. Obligatory love is to accept what the Prophet has brought in the way of worship for the sake of God's love, to abide by the commands and prohibitions as revealed to him by God, and to strive for the victory of God's religion in jihād with one's life and wealth. ${ }^{31}$ To perfect the former, the sālik has to practice the second category of love for the Prophet, which is to closely follow him. This is realized in two ways.

First, one is to excel in imitating his example and to constantly remember him and hold him in great awe, to the degree that the heart trembles at his mention. He explains that one of the methods to reach this is to incorporate praise for the Prophet in one's daily litany (wird). Litanies were employed by practically all Sufi groups of his age, and mostly consisted of a specific set of Qur'anic verses and invocations put together by a shaykh for the purpose of recital at fixed times. While it is not mentioned whether al-Wāsiți himself ever composed one for his disciples, we know from his writings that he strongly encouraged them to take a litany to recite during the last third of the night, and that this should include a multitude of prayers for blessings upon the Prophet (kathrat al-șalät 'alayhi), commonly known as the tașliya. ${ }^{32}$

29 Al-Wāsițī, 'Umdat al-țullāb, pp. 198-199.

$30 \quad$ Al-Wāsițī, Qā'ida mukhtașara, p. 24.

31 Al-Wāsiți, al-Sirr al-mașūn, p. 46, and this is mentioned as the third necessary aspect of love for the Prophet in Qawā'id al-nubuwwāt, p. 3oo. It must be noted that the necessity of adhering to God's commands and avoiding His prohibitions is a catchphrase repeated endlessly by al-Wāsițī throughout his writings.

Remembering the Prophet's attributes and closely following him is the second necessary aspect of love for the Prophet in al-Wāsițìs Qawā'id al-nubuwwāt, p. 3oo. For his mention of the tașliyya in the wird, see: al-Sirr al-mașūn, p. 46 where he names it as an aspect of

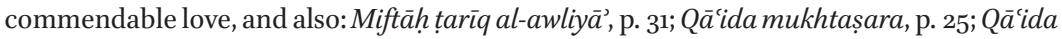


A second way to realize commendable love for the Prophet is to acquire intimate knowledge (márifa) of him. ${ }^{33}$ What is interesting here is that al-Wāsiți does not appear to define the term ma'rifa as some purely spiritual, God-inspired form of knowledge, as is its usual connotation in Sufism. He holds that there are degrees to ma'rifa, with ma'rifa of the Prophet being the first essential foundation. ${ }^{34}$ As he explains it, this particular form of knowledge is the accumulation of as much detailed information about the Prophet's biography and Sunna as one can acquire, leading to a profound and, indeed, spiritual insight into his being. This is only achieved by reconstructing all facets of his life, from its beginning to its end, through a study of the nușuṣs. Of particular importance is the genre of Prophetic biography (sing. sirra, pl. siyar) and its subcategories, such as the accounts of his military expeditions (maghāzi ) and the aforementioned proofs of Prophethood (daläil al-nubuwwa), wherein special focus is laid on the Prophet's character and the stories of his miracles and predictions. A crucial role is also allotted to a study of the hadith collections: first and foremost the Sahịh books, followed by the Sunan and Musnad categories to acquire more detail. ${ }^{35}$

In al-Wāsițīs view, any reasonable person who devotes himself to márifa of Muhammad's Prophethood with an unbiased, rational approach should become convinced that he was indeed God's Messenger. He argues that since his Prophethood is the pillar of sound faith upon which the religion is built, it is essential for the sālik's heart to reach certainty about him and that all doubts are cast away. ${ }^{36}$ The importance of this ma'rifa to the early stages of sulük is undoubtedly also what motivated our Iraqi Sufi to himself compose several books on the Prophet's life. ${ }^{37}$

fí bayān 'amal yawm wa-layla li-al-abrār wa-'amal yawm wa-layla li-al-sāirī̄n ilā țarīq almuqarrabin jaialnā Allāh minhum, p. 70. On the practice of taking a wird, see also: Madkhal ahl al-figh, p. 83. On the use of the tașliya in the litanies of the Sufis, see: Meier, Nachgelassene Schriften, pp. 290-302.

Al-Wāsițī, al-Sirr al-mașūn, p. 46. Gaining ma'rifa of the Prophet's time and biography and studying his miracles and distinguished status is mentioned as the first necessary aspect of love for the Prophet in Qawāid al-nubuwwāt, p. 299.

34 Al-Wāsițī, Miftāh al-márifa wa-al-'ibāda, p. 265; 'Umdat al-țullāb, p. 206.

35 Al-Wāsițī, Wașiyya ilā ba'ḍ al-quḍāt, p. 141; and also: Madkhal ahl al-figh wa-al-lisān, pp. 49-50; and Qã̄ida fì taqwiyat al-sālik 'alā al-wușūl ilā mațlūbihi, p. 121.

36 Al-Wāsițī, Talqūh al-asrār, pp. 54-55; Qā'ida fì nafȳ̄ al-khawāṭir, p. 241; Qã̄ida fì bayān alțarìq ilā Allāh ta ālā min al-bidāya ilā al-nihāya, p. 181; Qã̄ida fì al-umūr al-muwașșila waal-umūr al-qātitia, pp. 216-217. 
With the above ma'rifa acquired, al-Wāsiți takes a fascinating turn when it comes to its further application. There are several instances where he states that the sālik's knowledge of the Prophet's life and times enables him to meet with him:

If, my brother, you yearn for something of these realities of faith (alhaquāiq al-ìmāniyya) and tastes of spiritual knowledge (al-adhwāq alirfanniyya), then think of yourself as if you are in the time of ignorance ( fa-j'al nafsaka ka-annaka fi zaman al-jāhilizya) and travel to the Messenger of God (S) so that you can meet him. Then believe in him and become Muslim at the hands of him. Your journey to him and meeting with him is [done through] your study of his biography (sira) and all that has been narrated from him about his life and normative practice (sunna), and the biographies of his Companions and the elite of his followers. ${ }^{38}$

In similar statements made in other treatises we find al-Wāsiți explaining that ma'rifa of the Prophet enables you to "imagine him in Medina as if seeing him,"39 that "you ought to be present [with him] as if you are seeing him,"40 and that, consequently, "the Prophetic days become such that it is as if they are perceived with the eye."11 In what is arguably his most detailed account on the way to see the Prophet by means of one's acquired knowledge of him, we find that this actually pertains to meeting him and establishing a șuhba relationship with him in a literal sense:

Whoever seeks the greatest bliss, the perfect annihilation $\left(f a n \bar{a}^{3}\right)$ in this world and the Afterlife ... and the unseen treasure ... he must meet the Messenger of God (S) and accompany him. This is achieved by means of those lights [the servant] has within himself that hold fast to his Sunna

..." Other treatises about the Prophet are Qã ida min daläil al-nubuwwa, pp. 302-309, and his Hayāt al-qulüb, pp. 74-88, which both deal with the proofs of his Prophethood in particular.

38 Al-Wāsițī, Lawāmi al-istirshād fi al-farq bayna al-tawhìd wa-al-ittihāad, p. 94. For the translation, I cite my article: Arjan Post, "A Taymiyyan Sufi's Refutation of the Akbarian School: 'Imād al-Dīn Aḥmad al-Wāsițī's (d. 711/1311) Lawāmic l-istirshād," in CHESFAME proceedings $I X$, ed. K. D’Hulster, G. Schallenbergh, \& J. van Steenbergen (Leuven, Paris, Bristol: Peeters, 2019), p. 322.

"Yatașawwarahu fìl-Madīna... ka-annahu yarāhu," cf. al-Wāsițī, Qã̄ida fì taqwiyat al-sālik 'alà al-wușūl ilā mațlūbihi, p. 121.

40 “Wa-anta hạạdir ${ }^{u n}$ ka-annaka tarāhu," cf. al-Wāsițī, Miftāh țarīq al-awliyā’, p. 31.

41 "Wa-tașìru al-ayyām al-nabawiyya ka-annahā bi-manżir al-'ayn," cf. al-Wāsițī, Qāंida fì alumūr allatìyanbaghī an takūn hamm al-sālik, p. 193. 
and the external aspects of his law (sharîatihi). These lights are produced amidst the sparks of [the servant's] endurance in adhering to the narrated traditions (al-ittib $\bar{a}^{c}$ li-al-äthār), manifestly with his outward body parts, and inwardly with his intentions. Now, meeting [the Prophet], visiting him, and witnessing him is not conceived with one's external sensory perception (al-hiss al-zähir), for he has passed on from the world of manifestation to the world of the unseen. Accompanying him and witnessing him can only occur while being absent in the unseen realm (ghayb ${ }^{a n}$ fighayb), and inwardly in one's innermost secret (sirran fi sirr).

When the servant knows [the Prophet's] biography, his times, his Sunna, his distinguishing marks, his supernatural abilities (khawäriqahu), his miracles (mujizātahu), his signs, and his marks of honor, and knows the relationship between him and the Prophets who preceded him - he has then come to know him, arrived unto him with his heart, and witnessed him in the unseen (fial-ghayb), provided that he loves him at that point.

An indication of love for him is [the servant's] concern for intimate knowledge (ma'rifa) of [the Prophet's] Sunna after [having acquired] intellectual knowledge ( $\mathrm{ilm}$ ) of his biography. He must then clothe himself with this [love], witnessing the lights of his splendor as if he is with him in his age, neither separating himself from him inwardly nor manifestly! ... As it is said:

Although you are in the unseen, veiled from my gaze

The heart looks at you from a distance, far away. ${ }^{42}$

Whoever at one point during his lifetime is overtaken by this state, he has arrived unto the Messenger (Ṣ) and his șuḥba $!^{133}$

To place the above passage in al-Wāsițīs overall narrative on the Muhammadan way, let us reiterate what we have thus far seen. We began with the path towards love for the Prophet, which requires conforming to the religion that God revealed to him, imitating and remembering him, and acquiring ma'rifa of him through a study of the nușuss. It is then through the combination of all these steps and the love that is thereby realized that the doors to meeting him and accompanying him are opened. This occurs in the unseen realm, al-ghayb, perceived by the human being with his innermost secret, al-sirr, which al-Wāsițī

42 Interestingly, this line comes from a poem by the controversial Sufi al-Ḥusayn b. Manșūr al-Ḥallāj (d. 309/922), see his Dīwān al-Ḥallāj, ed. 'Abduh Wāzin (Beirut: Dār al Jadīd, 1998), p. 8 o.

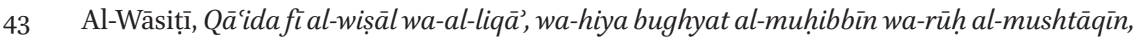
pp. 268-269. 
defines as the heart's kernel (habbat al-qalb) ${ }^{44} \mathrm{He}$ describes this process on different occasions as seeing the Prophet with the eye of one's heart (bi-'ayn qalbihil'aynay fu'ädika) ${ }^{45}$ one's insight (bașīra), ${ }^{46}$ or one's inner vision ('iyān) ${ }^{47}$ all of which he uses as synonyms. In one treatise he calls it 'the witnessing of Prophethood' (mashhad al-nubuwwa), wherein the sālik witnesses the possessor of Prophethood (șâhib al-nubuwwa). ${ }^{48}$

Although he only rarely attempts to elaborate on the nature of this vision, it clearly had to do with connecting to the Prophet's rühanniyya. In one treatise he writes that the above-mentioned trajectory of love is aimed at reaching a state wherein one's spirit becomes intermingled with that of the Prophet (mam$z$ ujat ${ }^{a n}$ bi-al-arwāh $) .{ }^{49}$ In a precept on Prophethood he delves deeper into what he means by that. He explains that when the servant has realized love for the Prophet and clothed himself with it, he obtains the realities of his mysteries from the light of Prophethood; through his bașira he will know the link between Muhammad and the Messengers who preceded him, and acknowledge that their lights come from one and the same niche (mishkāt). He will then find unification (ittiha a d) with his Prophet, and he will be invested with a garment (kiswa) from his clothing. This, al-Wāsițī says, "results in a connection (ittișāl) between their spirits, of which [the servant] will be conscious during his [everyday] conduct (fimu'ämalatihi). ${ }^{.50}$

Based on the above, it becomes clear that al-Wāsiți did not regard the sālik's attachment to the rühanniyya of the Prophet as a mere symbolic act to oppose the Sufis' exaggerated focus on their shaykhs. He conceived it as an actual master-disciple relationship with the Prophet, who in spite of his absence from the material world could still exercise his influence upon the sālik. Since it is the Prophet's rüh, his spirit, that remains accessible in the spiritual world, the connection with him is necessarily one of the spirit as well.

Besides the Prophet himself, we find occasional hints that the elite of his Companions (șahāba) are also allotted a role in the țariqa Muhammadiyya. In al-Wāsițîs view, their guidance is indispensable because they were present as the sira unfolded and God's revelations to their Prophet progressed, and they were, in Qur'anic terms, al-sābiqūn al-awwalūn, the First and Foremost in

Al-Wāsițī, Qāida fì al-umūr al-muwașșila, pp. 221-222.

Al-Wāsițī, Qā'ida fì al-wișāl wa-al-liqä’, p. 269; Qã̄ida mukhtașara, pp. 25-26; 'Umdat alțullāb, pp. 198 \& 206; Qã ida fì taqwiyat al-sālik 'alā al-wușül ilā mațlübihi, p. 121.

46 Al-Wāsițī, al-Tadhkira, p. 29; Qawāìid al-nubuwwāt, p. 300.

47 Al-Wāsițī, al-Tadhkira, p. 29.

48 Al-Wāsițī, Talqūh al-afhām, p. 156.

49 Al-Wāsițī, Q̄ं'ida fì ta'arruf al-nubuwwa ayḍan, p. 313.

50 Al-Wāsițī, Qawā id al-nubuwwāt, p. 300.
} 
following him. ${ }^{51}$ Although he never explicitly says so, he characterizes them as archetype Sufi masters who, due to their proximity to the Prophet, were able to reach utmost perfection in acquiring a set of spiritual qualities that we may recognize as distinct Sufi terms:

They [the elite of the Companions] were the people most immersed in spiritual states, such as renunciation (zuhd), trust (tawakkul), contentment (ridā), love (hubb), longing (shawq), annihilation (fanā), and subsistence $(b a q \bar{a})$. But due to the strength of their faith and the exaltedness of their ranks, the effects of intoxication (sukārā) that these states bring about were not visible on them. On the contrary, they were strengthened by the light of Prophethood so that they applied these states in [their] deeds and strove on the path of God through long, dark nights. This is the utmost degree of perfection! Do not wonder at this as you would at someone who is sober and drunk at the same time, for the divine gift contains an abundance of Muhammadan traits that continued through the elect of the Companions, giving them spiritual strength and stability (al-quwwa wa-al-tamkin), and a state of separation while being united (al-farq fi $a l$-jam ${ }^{\prime}$ ), and of sobriety while being intoxicated (al-șahı fi al-sukr)!52

The last sentence in particular reflects al-Wāsițīs sentiment that the Companions had reached spiritual perfection. What is implied is that even as they were completely absorbed in their awareness of God, they always had their feet firmly planted in the material world. And since the elite of the Companions cannot possibly be surpassed by anyone after them,

it is from what remains of their milk (rid̄a ihim) that those [who come after them] will have to be nurtured, and on them that they have to rely for the spiritual realities (al-haqāiq). For they had a certain drink $\left(\operatorname{shara} b^{u n}\right)$ that they would take, of which there [still] remain drops that will quench the thirst of the people who follow them. ${ }^{53}$

The title al-säbiqūn al-awwalūn comes from the Qur'an, 9:100: "And the Foremost, the first of the Emigrants and the Helpers (al-sābiqūn al-awwalūn min al-muhājirīn wa-al-anșār ) and those who followed them in good-doing." See also: al-Wāsițī, 'Umdat al-țulāab, pp. 207-208.

$5^{2}$ Al-Wāsițī, Lawāmic al-istirshād, pp. 91-92; Post, "A Taymiyyan Sufi's Refutation," p. 319.

53 Al-Wāsițī, Lawāmi` al-istirshād, pp. 94-95. 
As with the Prophet, al-Wāsiți held it possible to enter into their presence and perceive them with the eye of the heart through a study of their biographies. ${ }^{54}$ For although they have passed away, he says, "for those whose hearts are opened to their guidance, they are, in reality, alive with God!"55

\subsection{The Role of the Shaykh in the Muhammadan Way}

Based on the above, the question arises whether al-Wāsiți saw any need for a living shaykh as a spiritual guide for those who follow the Muhammadan way. He often gives the impression that the Prophet suffices as one's shaykh. This, however, is not entirely so. At times he reveals that in the beginning of the path there is in fact a dire need to enter a master-disciple relationship with a teacher who is a knower of God (ustāadh un 'arrifun), because the spiritual novice (murid) may be susceptible to all kinds of excesses under the guise of Sufism. Constant fasting, for instance, may appear as a pious deed that brings about proximity to God, but in the long term it can do more harm than good to his spiritual state, and eventually even cause him to deviate. ${ }^{56}$ It is one of the tasks of a spiritual teacher to guide him through any such pitfalls. In light of its necessity in the Muhammadan way, it is thus necessary to briefly scrutinize how al-Wāsițī envisioned this master-disciple relationship.

First, there was, in his view, only one kind of shaykh who is truly fit for tarbiyat al-sälikin - the spiritual training of the travelers unto God - and that is someone who has successfully traversed the entire path himself. From alWāsițî's perspective, this means that he must have gone through all the steps of sulūk (which will be discussed in the next chapter) and has thereby arrived unto God spiritually. In the terminology of the Sufis he explains that such a person has returned from intoxication $(s u k r)$ to sobriety (șahw), from annihilation $($ fan $\bar{a})$ to subsistence $\left(b a q \bar{a}^{\prime}\right)$, and attained the station of stability (tamkin) - though none of this is on his own accord, for a master of this degree has been chosen by God to become a guide (murshid) for the murid. ${ }^{57} \mathrm{God}$ desires the existence of such men, al-Wāsițī says, to serve as proofs for Him, to cure mankind's spiritual diseases, take charge over them and govern them, and lead

\footnotetext{
54 Al-Wāsițī, 'Umdat al-țullāb, p. 207, and: Lawāmi' al-istirshād, p. 94.

55 Al-Wāsițī, Lawāmi' al-istirshād, p. 95.

56 Al-Wāsițī, Qã̄ida fì al-umūr allatī yanbaghī an takūn hamm al-sālik, p. 191; Qā'ida fì alumūr al-muwașșila, p. 222; Qāida fì tajrìd, pp. 254-255; Miftāh țarīq al-muḥibbīn, pp. 28o281.

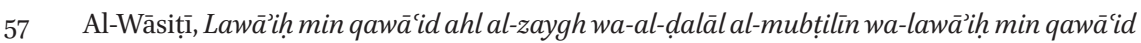
țarīq al-șādiqīn, p. 131; Madkhal ahl al-fiqh, p. 50; Mìzān al-shuyūkh, p. 241.
} 
them unto the path of the revealed law (sharîa), away from falsehood. They are, in short, the successors of God's Messengers (khulafä'al-rusul). ${ }^{58}$

On rare occasions al-Wāsițī reveals that he ideally envisioned Sufism being practiced in a group structure wherein murids are organized around the guidance of such a shaykh. This is attested to most evidently in his treatise on the way of Muhammadan faqr, where he makes mention of specific rules of etiquette for Sufi aspirants to observe, not only towards their shaykh, but also towards one another. Among these etiquettes we find that the murid should accompany his fellow fuqara $\overrightarrow{3}$ with admiration, renown, and reverence, and prefer them over himself. ${ }^{59}$ However, if one of them displays insolence towards their shaykh, by for instance shouting at him with harsh words and mentioning his shortcomings, al-Wāsiṭi maintains rather serious repercussions. His verdict is that such an aspirant

should no longer be accompanied after this, for there is no penance for the disobedience of a murìd among the fuqara $\bar{a}$. That is because that subtlety of the heart (al-latîfa al-qalbiyya) that is pursued by means of his spiritual training (tarbiya), through which a share of the Divine may reach him, has been disrupted [by his actions]. Indeed, this share only reaches the murìd when he reveres his shaykh, respects him, honors him, and loves him! ${ }^{60}$

Our Iraqi Sufi puts so much emphasis on observing due propriety ( $a d a b)$ with one's shaykh because this is, in his view, directly linked to the propriety that is due to God and the Prophet. After all, as we noted above, he considers the true Sufi shaykh a successor of the Messengers, so to revere him is to revere God and the Prophet. For that reason, the aspirant should pay close attention to his shaykh, refrain from disagreeing or arguing with him, and carefully inquire into his spiritual expressions ('ibāa $\bar{a} t)$ and states $(a h w w \bar{a} l)$ with polite words when there is something obscure in them. ${ }^{61}$ In return, the shaykh should teach the aspirant how to be rid of the veils that cover his heart, until the utmost end of his guidance is reached.

Al-Wāsiți maintains that spiritual guides are essentially intermediaries (wasä $\vec{i}$ ) between this world and the Prophet. ${ }^{62}$ There thus comes a degree in

$5^{8} \quad$ Al-Wāsițī, Mìzān al-ḥaqq wa-al-ḍallāl, p. 223; this treatise is identical with his Qā'ida fi sifat al-'ubüdiyya, pp. 47-48.

59 Al-Wāsițī, Qāंida mukhtașara, p. 35.

6o Ibid. pp. 34-35.

$61 \quad$ Al-Wāsițī, Madkhal ahl al-figh, pp. 48-5o.

62 Al-Wāsițī, Madkhal ahl al-figh, p. 49; Mìzān al-shuyūkh, p. 241. 
the sălik's journey where he arrives unto the Prophet, and his shaykh's mediating role is no longer required. This occurs when the earlier-mentioned Muhammadan state is acquired, for then

the vision of his own shaykh who brought him to the Prophet (Ș) vanishes before him, and he sees the Prophet (Ș) from the niche (mishkāt) of his own self (nafs) rather than from the niche of his shaykh. In the beginning [of the path], the murid may perceive the Messenger through the $\operatorname{arch}(t \bar{t} \bar{q} q)$ of his shaykh, until the Messenger (Ș) may at times take shape within his innermost secret (sirrihi) through his shaykh's instruction (kayfiyya). When he ascends to this rank, he rises from the intermediaries (wasāit ț) to the Messenger (Ș), from whom he then receives distinguished love (al-hubb al-khāṣs ), and his spirit will truly be united with his spirit!63

This is a unique passage in that it is perhaps the only instance where al-Wāsiṭi explicitly shares with us how he envisioned the role of the shaykh in the tariqa Muhammadiyya. The shaykh's niche through which he sees the Prophet is likely in reference to the shaykh's spiritual connection with the Prophet. What seems to be intended is that the shaykh thereby provides guidance through all the steps we have gone through, from the beginning of this chapter up to the point where the aspirant, too, becomes connected to the Prophet by his spirit, and subsequently perceives him in the unseen. What the sālik reaches at that point is required for his further advancement towards intimate knowledge of God, which is the topic of the next section.

Up till now we have followed all the basic steps of the Muhammadan way that can be found scattered throughout al-Wāsițīs writings. If we go back to the beginning of the current section, and question once more to what degree we may discern a Taymiyyan influence with all the ground we have now covered, our initial hypothesis that al-Wāsițin himself had developed the concept of the tariqa Muhammadiyya as the way to connect to the Prophet and his Companions becomes all the more plausible. ${ }^{64}$ This does not detract from the fact that Ibn Taymiyya's influence is visible in the role our Iraqi Sufi allots to the study of hadith and the biographical sources on the Prophet and his Companions - after all, it was the Hanbalī shaykh himself who pointed al-Wāsițī in this direction. Herein we may recognize a distinctly traditionalist, nuṣuṣs-based

63 Al-Wāsițī, Qã ida fì al-ḥubb fì Allāh ḥaqūqat ${ }^{a n}$, p. 54.

64 Geoffroy has also noted the originality of al-Wāsițīs take in that regard in: "Le traité de soufisme," p. 88. 
spirituality, an approach that extends even more visibly to the topic we will cover in the next section.

While the effort to harmonize traditionalism with Sufism is thus clearly visible, we may also observe that al-Wāsiți occasionally tilts the balance more towards Sufism in his doctrine. This is especially apparent in the method of connecting to the Prophetic rühanniyya and some of the Sufi terminology he uses to describe this process, but also in the way he envisioned Sufism being practiced in a group structure around the guidance of a complete Sufi master. In view of his position as the teacher of Sufism in the Taymiyyan circle, we may take this as an indication that there was apparently a crowd for such teachings among the traditionalists of Damascus. The same can be said for the masterdisciple structured practice of Sufism: The mere fact that al-Wāsiți deals with the topic seems to imply that such was the nature of the relationship he himself had with his disciples as their shaykh al-sulūk. We may rightfully question whether he would have chosen to express himself through such language and statements if this would have met with the disapproval of the traditionalists who sat at his feet. Since we know he was a respected member of the Taymiyyan circle, this tells us that in all likelihood they generally regarded his teachings as quite normative.

If the shaykh is the intermediary between the sālik and the Prophet, then the Prophet is the intermediary between the sālik and God. It is, after all, by means of the Prophet that God has made Himself known to mankind;65 as al-Wāsiți puts it: "Prophethood is a stairway and an ascension unto knowledge and ma'rifa of God by which God is known and served." ${ }^{6}$ We have already noted that, according to al-Wāsițīs conception of the Muhammadan way, intimate knowledge of the Prophet is but the first of the degrees of ma'rifa. It ultimately serves as the required foundation for the branches of ma'rifa of the Divine. In other words, when the sālik has mastered intimate knowledge of the Rasül, the Messenger, he is ready to ascend to intimate knowledge of the Mursil, the Sender, that is, God. This is done first through God's risāla, the message He sent to Muhammad in the form of the Qur'an. In addition, knowledge of God is obtained by studying the Sunna in the form of hadith $6{ }^{67}$ Our Iraqi Sufi thus

65 Al-Wāsițî, Miftāḥ al-ma'rifa wa-al-ibāda, p. 265; 'Umdat al-țullāb, p. 206; Qã̄ida fì sulūk al-tahqūq ilā ghāyat al-mațālib li-al-sā̉ir ilà rabbihi al-dhāhib, p. 199.

66 Al-Wāsițī, Talqụ̄̆ al-asrār, p. 55.

67 Al-Wāsițī, Miftāḥ al-márifa wa-al-ibāada, p. 265; Miftạh țarīq al-muhibbìn, p. 28o. 
proceeds from a study of the nuṣuṣs on the Prophet to a study of the nuṣūs on God. The first steps in acquiring ma'rifa of God are thus very similar to what we have already seen regarding the acquisition of Prophetic márifa.

\subsection{What is Marifa of God?}

Again, rather than being described as knowledge that is the product of a spiritual, God-inspired experience, it is the nușuss themselves that contain the concrete details about God that, when accumulated, provide the sālik with ma'rifa of Him. In this approach al-Wāsițī expresses a note of caution for the Sufis that we have come across several times already in the previous chapters: Sufism ought to be a means to an end, not the end itself. While he accepts Sufism as a legitimate Islamic science that serves to extract spiritual knowledge from the Qur'an and the Sunna, he stresses that it should always be restricted by what the holy texts themselves say. Sufis can never claim to get to know God without the facts of scripture:

Whoever makes the science of the Sufis into the direction (qibla) of his heart, he will be accorded a general state ( $h \bar{a} l^{a n}$ mujmalan $)$ that contains no completeness of detail $(\operatorname{tafṣil})$. But whoever makes it his pathway until he thereby draws the spiritual realities (al-haqä'iq) from the Book and the Sunna to which the sciences of the [Sufi] community ('ulüm al-țäifa) allude, he has been granted success and he has been guided unto a straight path. Indeed, the only perfect, comprehensive, straight path, which contains neither distortion nor deviation, is to seek intimate knowledge of God from whence He has made Himself known to us (ma'rifat Alläh min haythu ta'arrafa ilaynā), through His exalted names and majestic, beautiful attributes, which are articulated in the Mighty Book and stipulated by the Messenger (Ṣ) through the [Prophetic] reports $(a k h b \bar{a} r)$ and the [Qur'anic] verses $(\bar{a} y \bar{a} t)$ on the divine attributes. Now, each of these reports leads to one of the sublime secrets of ma'rifa [of God] and one of the eminent qualities of [His] magnificence by which the gates of spiritual knowledge (al-ma'ärif) are opened to the seekers ... ${ }^{68}$

The essential point that is made in this passage is a recurring rule in al-Wāsițīs formulation of Sufism, echoed throughout his writings, namely, that ma'rifa of God begins with knowledge of the way He describes Himself in the revelation He sent down unto His Prophet. This was in fact a classical position in 
traditionalist theology. ${ }^{69}$ In al-Wāsițī's view, every word spoken by the Prophet about God is a piece of the puzzle of knowledge of God, whether from the Qur'an or from his sayings transmitted in the hadith literature. ${ }^{70}$ The entirety of the descriptions found in the nușuss results in a list of names (asmā’) and attributes (sifāt) by which God wants His servants to know Him, for otherwise He would not have revealed them to His Prophet. So, simply put, for al-Wāsiți the first essential means to marifa of God is to know all of His names and attributes as found in the Qur'an and the Sunna.

However, knowledge of them alone is not sufficient, for it must necessarily be followed by a correct understanding of their meanings. In al-Wāsițìs sulūk this is tightly interwoven with traditionalist theology. In the previous chapter I have already made note of the indissoluble bond between spirituality and theology that his writings display. It is therefore imperative that we first identify and elaborate upon the specific theological discussions that are connected to his views on ma'rifa.

Upon studying al-Wāsițīs oeuvre, one will find that in most instances this endeavor takes us to the very beginning of his sequence of sulük, where the sālik is told that a sound creed (șihhat al-itiqa $\bar{a}$ ) is a condition for undertaking his spiritual journey. For our Iraqi Sufi this means nothing other than abiding by the traditionalist creed of the Hanbali school. ${ }^{71}$ In a Sufi poem preserved by al-Dhahabī he writes accordingly:

And constantly remember [God] after [belief in] the creed based on the Sunna, The creed of Ibn Ḥanbal, which cures the deceases [of the heart]. ${ }^{72}$

As we shall see below, theology is, above all, crucial to the way one ought to deal with the so-called mutashäbihāt, the ambiguous descriptions of God found in the holy texts. Al-Wāsiți argues on several occasions that if the sālik's beliefs in their regard are corrupted this will have disastrous consequences, as

69 For the importance of knowing God as He describes Himself in traditionalist theology, see or instance: Hoover, "Hanbalī Theology," p. 633.

$70 \quad$ Al-Wāsițī, Risāla fì ithbāt, p. 45; Lawāmi' al-istirshād, pp. 94 \& 96; 'Umdat al-țullāb, p. 203; Miftāh țarīq al-muhibbìn, p. 280; Madkhal ahl al-fiqh, p. 50; Hayāt al-qulūb, p. 88; Qāंida fí

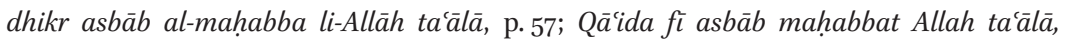
ma'rifatihi, wa-asbāa ma'rifatihi, pp. 61-62; Q̄̄ंida fì taqwiyat al-sālik, p. 122; Qāंida fì bayān al-țarīq ilā Allāh tạầā min al-bidāya ilā al-nihāya, p. 181.

$71 \quad$ This has also been noticed by Geoffroy, "Le traité de soufisme," pp. 85-86.

72 Al-Dhahabī, Mujam al-shuyūkh, vol. 1, p. 3 o. 
the degrees of witnessing God (al-mashähid) he must pursue in the later stages of his journey will necessarily be corrupted as well. ${ }^{73}$

For the roots of the influence of theology on al-Wāsiți's Sufism we again return briefly to his life's story. In the first chapter we have observed that he may have initially followed the Ash'arī school in theology, and at some point became inclined towards traditionalism. And as noted in chapter 3 , at least by the time he fulfilled the task of shaykh in sulük in the Taymiyyan circle, he had clearly reached a degree of proficiency in his newly adopted creed. A closer look at the process of this transition towards traditionalism as described in one of his creedal works reveals that this occurred during a period of confusion and restlessness that plagued him regarding the descriptions of God from the nuṣuṣs whose literal significations are analogous to the attributes of creatures. Does God exist in elevation ( 'uluw) and aboveness (fawqiyya), seated (istiwa $\vec{a}$ ) on His Throne? And should such terms as 'descent' (nuzūl), 'two hands' (yadayn), 'face' (wajh), and others that can be found in the Qur'an and/or hadith in relation to God be considered as actual attributes (șifât) of Him according to their apparent meanings or not?

The way al-Wāsiți saw it, the theological schools he had studied offered four approaches to these issues: The first is to dismiss their concrete realities by applying $t a^{\prime}$ will, a metaphorical interpretation, which was probably the method observed by many of his former Shāfi'î-Ash'arī teachers, and as it seems initially by himself as well. ${ }^{74}$ The second option is to read over them without comment (imrär), which was a position that existed among certain traditionalists. ${ }^{75}$ The third option is to refrain from passing any judgment about them (wuqūf), a position that existed among certain Ash'arīs as we have seen in chapter 2 . While this approach seems very similar to the preceding one, alWāsițī never elaborates on the actual difference between them as he understood them. The fourth option is ithbät, the position he will have found in Ibn Taymiyya's circle, and which he understands as the affirmation of the attributes with their apparent meanings. ${ }^{76}$ After a careful study of the arguments

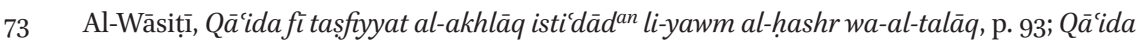
fì bayān al-țarīq ilā Allāh táālā min al-bidāya ilā al-nihāya, p. 182; Qã̄ida fì al-umūr allatī yanbaghī an takūn hamm al-sālik, p. 192; Qã̄ida fì al-umūr al-muwașșila wa-al-umūr alqātíia, p. 217; Qã̄ida fì nafȳ̄ al-khawāttir, p. 241; Wașiyya, p. 137; 'Umdat al-țullāb, p. 202; Miftāh țarīq al-muhibbīn, p. 279; al-Sirr al-mașūn, p. 55; Madkhal ahl al-fiqh, pp. 51 \& 53 .

74 For his initial inclination towards ta'wül, see: al-Wāsițī, Risāla fì ithbāt, p. 26.

75 Imrār was for instance advocated by Ibn Qudāma al-Maqdisī, cf. Hoover, "Hanbalī Theology," p. 633 .

76 Al-Wāsițī, Risāla fì ithbāt, pp. 25-26. It must be noted that although Ibn Taymiyya viewed his theology as being grounded in the tradition of the Ahl al-Hadith, it was quite complex and innovative; on this, see: Hoover, "Hanbalī Theology," pp. 637-638. A good example of 
put forth by the different schools, al-Wāsiți claims to have received an unveiling (kashf) from God that opened his heart to ithbāt and made him turn away from $t a^{\prime} w \bar{l}$ - a claim we may take as indication that he did indeed at one time adhere to the latter position. ${ }^{77}$ This switch would, in effect, have been a turn from the kalam theology of the Ash'aris to the traditionalist theology adhered to by Ibn Taymiyya and his circle.

\subsection{Affirmation versus Metaphorical Interpretation}

This conversion should not be taken lightly, as adherents of both positions had been diametrically opposed to one another for several centuries. In the new traditionalist capital of Damascus, too, dissension (fitna) between Hanbalīs and Ash'arīs (especially the Shāfi'is) was frequently noticeable, both before and after al-Wāsițī settled there. ${ }^{78}$ The Ash'arīs' main criticism towards traditionalists who affirmed the apparent meanings of the above descriptions from the nușus as attributes of God was that this inevitably leads to understanding them in an anthropomorphic sense (tashbih $)$ and likening God to His creation (tamthill). This, they held, contradicts reason and revelation, which both demonstrate that God is utterly transcendent (munazzah) and nothing like His creation. More or less in line with al-Wāsițīs overview discussed above, the Asharīs were roughly divided into two camps when it came to the preferred solution to the problem of the divine attributes. Some preferred to simply delegate the true meanings of such ambiguities from the holy texts to God (tafwied), while another group would resort to $t a^{3} w \bar{l} .^{79}$ Although our Iraqi Sufi disap-

Ibn Taymiyya's argumentation for ithbāt as the affirmation of the apparent meanings of the attributes, and against the use of $t a^{\prime} w \bar{l} l$ - most notably that of the Ash'arīs - is his alFatwa al-Hamawiyya al-kubrā, MF, vol. 5, pp. 5-120. In some respect the approach to the divine attributes appears similar to that of al-Wāsițī, which we will set forth in the following pages of our study.

77 Al-Wāsițī, Risāla fì ithbāt, pp. 40 \& 43.

78 On their fitna in Damascus, see especially: Michael Chamberlain, Knowledge and Social Practice in Medieval Damascus, 1190-1350 (Cambridge: Cambridge University Press, 1994), pp. 169-173.

79 I am indebted to Jon Hoover for sending me his forthcoming article: "Early Mamlūk Ash'arīs against Ibn Taymiyya: on the nonliteral reinterpretation ( $\left.t a^{\prime} w \bar{l} l\right)$ of God's attributes," to be published in: Philosophical Theology in Islam: The Later Ash'arite Tradition, ed. Jan Thiele and Ayman Shihadeh (Leiden: Brill). This article gives a useful and concise overview of the different approaches to the divine attributes among the early Mamluk Ash'arīs. Hoover notes that some of those who resorted to ta'wïl considered this method to be for trained scholars only, whereas others felt this should be the general method for all Muslims. We may also note that safeguarding God's tanzìh has always been at the center of Asharism, see: Richard M. Frank, "Elements in the Development of the Teaching of al-Ash'arī.” Le Muséon 104 (1991), pp.163-164. For the textual proof for God's utter 
proved of both options, his objection to those who practiced ta'wil was much stronger. Let us therefore briefly consider the line of argumentation of the latter group of Ash'arīs before we turn to al-Wāsițî’s own discussions on the matter.

According to the Ash'arīs who made $t a^{\prime}$ wìl, logic dictates that if God exists in an upward direction, seated on His Throne, He is necessarily confined and limited by space. Whenever such is the apparent meaning of statements from the holy texts, they believed that this requires a metaphorical interpretation so as to avoid the attribution of limitation to God. Hence, they interpreted God's sitting on the Throne as His subjugation ( $q a h r$ ) of the Throne. ${ }^{80}$ The same principle applies to corporeal terms in the Qur'an, as found, for instance, in the verse "What prevented you prostrating to what I created with My own two hands (bi-yadayya)?" [Q. 38:75]. They argued that if the term '(two) hands' is taken literally, this means by reason that God has a body and a form. Again, because this is in contradiction with God's utter transcendence, they interpreted the 'hands' as God's creative power (qudra). ${ }^{81}$ It must be noted that al-Wāsițī was not unaware of this line of reasoning. He reveals in several works that he knew very well how such Ash'aris interpret terms from the revelation that they viewed as ambiguous. ${ }^{82}$

However, from his understanding as a traditionalist, there was an intrinsic fallacy to $t a^{\prime}$ wìl in such cases. His argumentation is as follows: Whenever the Prophet intended a certain word or phrase from the revelation as a metaphor, this is either clear through the linguistic context of the wording, or because he explicitly added a statement indicating that a change of the apparent meaning to a metaphorical one is required. ${ }^{83}$ If the Prophet made no indication of $t a^{3} w \bar{l} l$

transcendence, reference is often made to the Qur'anic verse "There is nothing like unto Him" [Q. 42:11]. The diversity of opinions among Ash'arī scholars regarding the divine attributes has since long been noted; see for instance: Allard, Le problème, p. 427.

8o See for instance the well-known Ash'arī authority, 'Abd al-Malik b. 'Abd Allāh al-Juwaynī (d. 478/1085), who is an excellent example of someone who rigorously applies ta'wïl in his Kitāb al-Irshād ilā qawāți al-adilla fì ușūl al-ítiqād, ed. Muḥammad Yūsuf Mūsā \& 'Alī 'Abd al-Mun'im al-Ḥamīd (Cairo: Jamā'at al-Azhar li-al-nashr wa-al-ta'liff, 1950), see on God's aboveness, pp. 39-40, and on His sitting on the Throne, pp. 40-41.

$81 \quad$ Ibid. p. 156.

82 Al-Wāsițī, Risālatuhu ilā al-shaykh al-Maghribī, pp. 105-106; Wașiyya, p. 139; Talqūh alafhām, p. 154; Risāla fì ithbāt, pp. 26.

83 This approach suggests two methods of Qur'anic exegesis: tafsir of the Qur'an through the Qur'an, and 'tafsìr bi-al-ma'thür,' i.e. exegesis on the basis of the Sunna. This hermeneutical approach was also applied by Ibn Taymiyya, see for instance: Walid Saleh, "Ibn Taymiyyah and the Rise of Radical Hermeneutics: An Analysis of "An Introduction to the Foundation of Quranic Exegesis"," in Ibn Taymiyyah and His Times, ed. Shahab Ahmed and Yossef Rapport (Lahore: Oxford University Press, 2010), pp. 144-145. 
by means of either of these two ways, then that is enough to know that the apparent meaning is intended. After all, during the Prophet's teaching sessions both intellectually gifted and deficient individuals would be present, so he will surely have guarded them against any form of misunderstanding when it comes to the revelation. ${ }^{84}$ As an example, al-Wāsiți takes the following words from the Qur'an: "Are you not aware that God knows all that is in the heavens and all that is on earth? Never can there be a secret confabulation between three persons without His being the fourth of them ..." [Q. 58:7]. Here, he says, it is clear that God is not with mankind with His essence, since the context of the verse indicates that it is rather God's knowledge that is with them. In other words, al-Wāsițīs ta'wīl of this particular verse is that they cannot hide from God's knowledge, for He is ever aware of what they do. For an example where ta'will is not allowed, he refers to the earlier example of the Qur'anic words "My (two) hands" (yadayya). While we have noted that a branch of Ash'arīs would interpret 'hands' as God's creative power (qudra), al-Wāsiți contests that there is no indication that a metaphor is intended, because in the Arabic language the word 'hand' that bears the meaning of qudra does not come in pairs. In order for it to be taken metaphorically, it would had to have read the singular form yadī, 'my hand,' instead of the dual form yadayya, he says. ${ }^{85}$ The conclusion is, then, that the attribute of 'hands' is not ambiguous, because it is clear that there is no explicit or implicit proof to view it as such. As a consequence, to make $t a^{\text {'wi }} \bar{l}$ of it would be to strip it of its apparent meaning and subsequently deny it as an attribute by which God describes Himself in the revelation. Besides straying from the method of the Prophet, one would thereby deprive oneself of a piece of the puzzle of ma'rifa and fall short in knowledge of God.

As for the argument of the Ash'aris that affirming such attributes according to their apparent meanings necessarily results in anthropomorphism, al-Wāsiṭ̂̄ replies that this is only from the viewpoint of their inconsistent line of reasoning. Like Ibn Taymiyya, he holds that ithbät is in fact the golden mean between ta'țil, denying God by stripping Him of His attributes, and tashbih, anthropomorphism by assimilating God's attributes to those of creatures. ${ }^{86}$ To underline that He is definitely exempted of the latter, al-Wāsițī frequently states that all of God's attributes ought to be affirmed in a way that befits His majesty and

84 Al-Wāsițī, Risālatuhu ilā al-shaykh al-Maghribī, p. 105; Risāla fì ithbāt, pp. 36; Wașiyya, pp. 138-139; 'Umdat al-țullāb, p. 203.

85 Al-Wāsițī, Risālatuhu ilā al-shaykh, pp. 105-106.

86 Al-Wāsițī, Wașiyya, p. 137. On Ibn Taymiyya's utilization of the middle way, al-wasat, as an argument, see: Jon Hoover, Ibn Taymiyya's Theodicy of Perpetual Optimism (Leiden: Brill, 2007), p. 173. 
magnificence, without imagining them to be in any way similar to those of His creation (bi-lā tamthïl) or in an anthropomorphic sense (bi-lä tashbïh), and without inquiring into their modality $(b i-l \bar{a} t a k y \bar{c}) .{ }^{87}$ Like the Ash'arīs, he considers the basis for God's dissimilarity from His creation to be the Qur'anic verse "There is nothing like unto Him" [Q. 42:11]. ${ }^{88}$ The mistake of the Ash'arīs here, he argues, is that they effectively deny those attributes that they consider ambiguous because they cannot but understand them in a way that befits created beings. He thereby turns the accusation around, implying that it is actually the Ash'aris themselves who are guilty of anthropomorphism - a classical Hanbali counterargument we may note, that was also utilized by Ibn Taymiyya. ${ }^{89}$ Furthermore, al-Wāsițī points to the fact that the Ash'arīs do affirm seven basic attributes of God, namely, life (hayāt), hearing (sam), sight (bașr), knowledge ('ilm), power (qudra), express will (iräda), and speech (kalām). ${ }^{90}$ He argues that, even though any of these could be understood as an accident ('arad) that exists in a corporeal body, they do affirm these as attributes in a way that befits God. To this he objects that

it is not fair that they are only able to understand [God's] sitting, descent, face, and hand as attributes of created beings and thus feel the need to interpret [them] metaphorically and alter [their meanings]. For if that is how they understand these attributes, that should compel them to [also] understand the seven attributes [that they do affirm] as attributes of created beings resulting from accidents! ${ }^{91}$

If the Ash'aris reply that the seven attributes are certainly not accidents but apply to God in a way that befits Him, al-Wāsițī replies that, likewise, God's sitting on the Throne applies to God without limitation (hașr) but in a way that befits Him. ${ }^{92}$

87 Miftāh al-ma'rifa wa-al-ibāda, p. 26o; Miftāh țarīq al-muhibbīn, p. 279; al-Sirr al-mașūn, pp. 55-56; Risāla fì ithbāt, p. 44; 'Umdat al-țullāb, p. 211.

88 Al-Wāsițī, Qā'ida fì dhikr asbāb al-mahabba, p. 57; Wașiyya, p. 140.

89 Al-Wāsițī, Risāla fì ithbāt, p. 44. For Ibn Taymiyya, see Hoover, Ibn Taymiyya's Theodicy, p. 5o. For an example of an earlier Hanbalī authority who used this argument, see: Muhammad b. al-Ḥusayn b. al-Farrā' Abū Ya'lā (d. 458/1066), Ibțāl al-ta’wìlāt li-akhbar alșifāt, ed. Abū 'Abd Allāh Muḥammad b. Ḥamad al-Maḥmūd al-Najdī (Maktabat Dār alimām al-Dhahabī, 199o), pp. 45 \& 49.

9o Al-Wāsițī, Risāla fí ithbāt, p. 44. These seven basic attributes can be traced back to alAsh'arī himself, who considered belief in them to be one of the fundamental theological truths, cf. Frank, "Elements in the Development," p. 154.

$91 \quad$ Al-Wāsițī, Risāla fì ithbāt, p. 45.

92 Al-Wāsițī, Risāla fì ithbāt, p. 45; 'Umdat al-țullāb, p. 204. 
As a consequence of having embraced the traditionalist position against ta'wīl in favor of ithbāt, the nuṣūṣ now offered al-Wāsiți a considerable number of divine names and attributes that he would hitherto have rejected as such. This naturally meant that whatever his former Ash'arī-Sufi colleagues had claimed of ma'rifa of God was by reason of their theological affiliation incomplete and deficient. It is therefore that al-Wāsiți often emphasizes the gravity of the aforementioned rule, that a sound creed is a condition for one's sulūk. As a firm traditionalist, it was his understanding that any mistake in this discipline will have dire consequences for one's knowledge of God.

\subsection{The Critical Importance of Direction}

Here, we must take note that, within the subject of the sifāt, the previous example of God's position vis-à-vis His creation (His aboveness and elevation and sitting on the Throne) is repeated most frequently by al-Wāsiți in relation to ma'rifa. Without a doubt, he considered this the most important aspect of creed that ought to be verified by knowledge and assent (tașdiq $).{ }^{93}$ That is so, he states, because it serves as the foundation (așl) and basis (asās) for the sālikin and their starting point of spiritual knowledge (mabda' al-ma'ārif). ${ }^{94}$ He therefore puts in extra effort to convince his audience of the necessity to affirm these as attributes of God. Fully aware of the heated debates on the matter (especially from the side of the Ash'arīs, as noted above), he admits that the sälik may initially be reluctant to do so out of fear that God is thereby restricted by direction, which would violate His transcendence. ${ }^{95}$ He argues that its correctness can nonetheless be confirmed based on both revelation and reason, and that to do so is imperative for one's further sulük, as we shall soon see.

When it comes to the Qur'an and the hadīth literature, al-Wāsiți tries to demonstrate on numerous occasions that they are filled with evidence for his creedal position on this matter. He cites at least fourteen verses that, in his opinion, support the reality of God's aboveness and elevation - such as: "They fear their Lord above them (min fawqihim)" [Q. 16:50] - and he cites two verses in support of God's sitting on the Throne - such as: "The All-Merciful, sat on the Throne ('alā al-'arsh istawā)" [Q. 20:5]. ${ }^{96}$ As for proofs from the hadith

93 Al-Wāsițī, Miftāh al-ma'rifa, p. 261; 203; al-Sirr al-mașūn, p. 55.

94 Al-Wāsițī, Miftāh al-ma'rifa, p. 261; 'Umdat al-țullāb, pp. 203 \& 205; al-Sirr al-mașūn, p. 55; Madkhal ahl al-figh, pp. 53-54; Qāida fì al-umūr al-muwașșila, p. 218.

95 Al-Wāsițī, Risālatuhu ilā al-shaykh al-Maghribī, p. 108.

96 The Qur'anic references to fawqiyya given by al-Wāsițī are: Q. 3:55, 4:158, 6:18, 16:50 \& 102, 35:10, 40:36-37, 67:16-17, 70:3-4, and 87:1. The Qur'anic references to istiw $\bar{a}$ ' are: Q. 10:3 and 20:5. See: al-Wāsițī, Risālatuhu ilā al-shaykh al-Maghribī, pp. 104-105; 'Umdat al-țullāb, pp. 204-205; Miftāh al-ma'rifa, p. 26o; Risāla fì ithbāt, p. 27. 
literature, he often refers to a report popular among traditionalists, wherein the Prophet asks a slave girl where God is, to which she replies that He is in heaven $(f \grave{\imath} a l-s a m \vec{a})$ while pointing towards the sky. The Prophet then validated her answer and rejected none of it, al-Wāsițī adds. ${ }^{97}$ His argumentation also draws from the well-known tale of the heavenly journey, the mira $\bar{a}$, during which the Prophet reportedly ascended through the seven heavenly spheres until he reached a distance of two bows or less from God. This, too, is in his eyes a clear confirmation that God exists over His creation. ${ }^{98}$

While such proofs would have sufficed for the classical traditionalist, alWāsițī also deploys logic to defend his position against the accusation of attributing limitation to God. This approach was perhaps inspired by his master, Ibn Taymiyya, himself an advocate of harmonizing reason and revelation. There is, however, some irony in the fact that to absolve God from any limitation by direction and space, our Iraqi Sufi turns to a typical Ash'arī argument. He first tries to solve the supposed contradiction between God's transcendence and the attributes of aboveness and sitting by admitting that it would indeed be unbelief and anthropomorphism to assert that God is restricted and enclosed by any direction, or that He is carried by any place: "He [God] was and there was nothing with Him in His antiquity and pre-eternity"99 (kāna wa-lā shay' ma'ahu fi qidamihi wa-azaliyyatihi). God existed before the creation of boundaries (hudūd) and directions (jihāt), and since nothing new befalls Him in His essence or His attributes, "He is now as He was (huwa al-än kamā kāna)."100 If we refer to chapter 2, we may recall that the words "He was and there was nothing with Him" were actually taught to al-Wāsiți as a fundamental spiritual maxim by his Shādhilī shaykh, Najm al-Dīn al-Ișbahānī, in relation to the vanity of self-direction (tadbir). We may also recall that the notion of God's preeternity was similarly used by the Ash'arī-Shādhilī Sufi Ibn al-Labbān to denounce literal aboveness as a divine attribute, arguing that God is now as $\mathrm{He}$ was without any direction and, consequently, without aboveness. It thus seems that al-Wāsițīs line of reasoning against limitation and anthropomorphism

97 Al-Wāsițī, Risālatuhu ilā al-shaykh al-Maghribī, p. 104; 'Umdat al-țullāb, p. 205, Risāla fì ithbāt, pp. 40-41.

98 Al-Wāsițī, Miftāḥ al-márifa, p. 26o; Risāla ilā al-shaykh al-Maghribī, p. 108; 'Umdat alțullāb, p. 205, Risāla fì ithbāt, p. 27.

99 Al-Wāsițī, Risālatuhu ilā al-shaykh al-Maghribī, p. 109.

100 Al-Wāsițī, Risālatuhu ilā al-shaykh al-Maghribì, p. 109; Risāla fì ithbāt, p. 41, where he says that, before the creation "God was and there was no place, Throne, water, space, air, void,

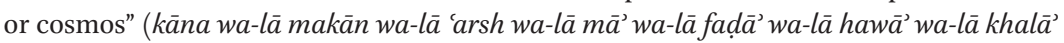
wa-lā malà'). 
here may actually be adapted from his knowledge of Shādhilī doctrine rather than Ibn Taymiyya's formulation of traditionalist theology.

Having acquitted himself of tashbih, our Iraqi Sufi proceeds to make his argument for fawqiyya and istiwa $\bar{a}$ ' as follows. He states that when God's express will (iräda) decreed the existence of creatures restricted by direction, who by necessity require aboveness, underness, rightness, and leftness, He decreed that they exist in locality (mahall). ${ }^{101}$ Being created in this fashion,

the judgment of [God's] magnificence of lordship (hukm 'azamat alrabbāniyya) required that He be above His kingdom, and that the kingdom be under Him - which is in terms of the temporality (al-hudūth) inherent to the creation, not in terms of the pre-eternity inherent to the Creator. So when I refer to Him, it is impossible that this be done by a downward direction, a right direction, or a left direction. Rather, it is only fitting to refer to Him by the direction of elevation ('uluw) and aboveness (fawqiyya). Again, such reference is from the viewpoint of [created] existence, its temporality, and its downward direction. ... When this is known, then [understand that] sitting $($ al-istiw $\vec{a})$ [too] is an attribute of Him that existed in His antiquity ( $f_{\imath}$ qidamihi), although its property only manifested upon the creation of the Throne, in the same way as the reckoning (hisāb) is a pre-eternal attribute of Him whose property will only manifest in the Afterlife. ${ }^{102}$

Al-Wāsiți thus assumes that the only appropriate mode of existence for the creation is in a downward direction (jihat al-taht); God directs us from above, ever remaining unbounded by any physical boundary or restriction as He has always been in His pre-eternity. This he connects to the Qur'anic verse "Surely your Lord is God, Who created the heavens and the earth in six days, then sat on the Throne, directing the affair" [Q. 10:3]. ${ }^{103}$ Due to mankind's reality as temporal, created beings bounded by direction and space, we can never truly comprehend the notion of 'directionlessness' (ghayr-jihāt), al-Wāsițī argues. We therefore refer to God by fawqiyya, the highest part of the created realm as we understand it, because it is the most appropriate point of reference for Him. ${ }^{104}$ When the sălik understands this, he will know that there is no anthropomorphism in affirming fawqiyya and istiw $\bar{a}$ : "Whoever verifies this in his

\footnotetext{
101 Al-Wāsițī, Risāla fì ithbāt, pp. 40-41; Risālatuhu ilā al-shaykh al-Maghribū, p. 109.

102 Al-Wāsițī, Risāla fì ithbāt, p. 41.

103 Al-Wāsițī, Risālatuhu ilā al-shaykh al-Maghribī, p. 109; Risāla fì ithbāt, p. 41; Riḥla, p. 46.

104 Al-Wāsițī, Risālatuhu ilā al-shaykh al-Maghribī, p. 109.
} 
creed firstly, then in his spiritual taste (dhawq) and unveiling (kashf) secondly, his heart will be freed from the resemblance [it has] to attributing limitation [to God] and the discomfort experienced at referring to the direction [of aboveness]."105

Although al-Wāsiți considered this sufficient as an explanation, if we further inquire into his reliance on traditionalist cosmology, we may better grasp how he really understood God's existence in literal aboveness, seated on the Throne. As he puts it, there is a boundary where the created realm stops and God's mode of existence without directions (jihät), distances (masāfät), boundaries (hudūd), and dimensions (aqțār) starts: "[God] is bounded by a boundary (hadd) that distinguishes His magnificence and essence (dhät) from all that He created." ${ }^{106}$ God does not become part of the creation's restrictions by entering it - which would be incarnation $(h u l \bar{u} l)$ - but is rather ever separate $(b \bar{a} \imath i n)$ from it. Our Iraqi Sufi thus differentiates between existence inside the created world (dākhilal-'ālam) and existence outside of it(khārijal-'ālam).107 The former applies to creatures, the latter to God. From the viewpoint of human beings existing inside the created world, it would require an ascension from earth through the seven heavenly spheres to reach the boundary of 'the outside,' al-khärij, which starts from God's Throne. What lays beyond the Throne neither reason nor imagination can comprehended, for it is the unfathomable reality where God exists in His essence. ${ }^{108}$ In other words, the only way to reach the realm where space and direction cease to exist is to go upwards, and it is from there that the creation located under it is governed by God.

Why is this so important to al-Wāsiți? In full acknowledgment of mankind's limited nature, he holds that we are inherently in need of a qibla: a direction to face towards during our acts of worship. That is so, he argues, "because we are temporal beings (muhdathün), and a temporal being cannot get around direction when it turns itself towards [God]."109 And since the revelation makes it very clear that God exists in an upwards direction from the viewpoint of His creation, that should naturally be our qibla. ${ }^{110}$ However, most Sufis literally miss the mark here, he says, due to their disavowal of aboveness:

\footnotetext{
105 Ibid.

106 Al-Wāsițī, Risāla fì ithbāt, p. 41.

107 Al-Wāsițī, Wașiyya, p. 143; Miftāḥ al-márifa, p. 261; Risāla fì ithbāt, p. 42.

108 Al-Wāsițī, Risāla fì ithbāt, pp. 41-42.

109 Ibid. p. 49.

110 Al-Wāsițī, 'Umdat al-țullāb, pp. 204-205; Qācida fì al-umūr allatīyanbaghī an takūn hamm al-sālik, p. 197; Wașiyya, p. 142; al-Sirr al-mașūn, p. 55; Madkhal ahl al-figh, pp. 53-54; Risāla fì ithbāt, p. 49.
} 
More numerous are those who deviate from spiritual realization (tahqi $q$ ) due to their ignorance in this regard. Indeed, I found that the majority of the sālikin and seekers I have come across do not have a qibla that they turn themselves towards, because they have not verified that their Lord is above all things, separate from His creation, and are thus confused about this. Among them are those who believe that there is no 'inside' to the [created] world nor an 'outside,' that it has no 'above,' nor an 'under,' and among them are those who say that [God] is everywhere. It is certain that their hearts will never reach the reality of this affair ....

Hence, the foremost concern of the truthful ones (al-șädiqin) is their ma'rifa that their Lord is above all things. For those among them who acknowledge this, it becomes their heart's qibla whenever they direct themselves towards Him and supplicate Him, in the same way as someone who performs the ritual prayer takes the Ka'ba as his qibla when he prays: he turns himself in its direction, and this is of the same nature [as turning towards the Throne]. Now, when the aspiring seeker (al-tălib almurid) becomes certain of this, the Throne becomes his heart's qibla whenever he turns himself towards God and desires Him, and it will be from this elevated place (al-mahall al-ulwī) [of the Throne] that blessings descend upon him and the realities of divine openings (futūhāat) are revealed to him - by the will and volition of God!111

Evidently, al-Wāsițī envisioned the heart's qibla being upwards as more than a mere direction to focus on during worship. For him it is the only way to become connected to the Throne, which he considers the required gateway to God for one's further sulük. The sālik should therefore aspire to have his heart constantly directed upwards in all deeds performed for the sake of God, so that it ultimately becomes connected to the Throne. By doing so, he states in a letter: "The heart ascends upwards (ilä al-uluw), one heavenly sphere after another, until it ends up at the Throne. When it ends up at the Throne, directions, distances, limits, and dimensions are nonexistent, and all that remains is $\mathrm{He}$ who has no likeness and is not restricted by any limit."112

What becomes clear from the above is that the role of fawqiyya in al-Wāsiți's Sufism leaves no room for any other theological denomination to lay claim to ma'rifa. In his view, only the adherents of the Ahl al-Sunna - which we know he considers a synonym for the Ahl al-Hadith - can make the Throne into their

111 Al-Wāsițī, Miftāh al-ma'rifa, pp. 261-262. A very similar description is given in 'Umdat al-țullāb, p. 204.

112 Al-Wāsițī, Risālatuhu ilā al-shaykh al-Maghrib̄̄, p. 112. 


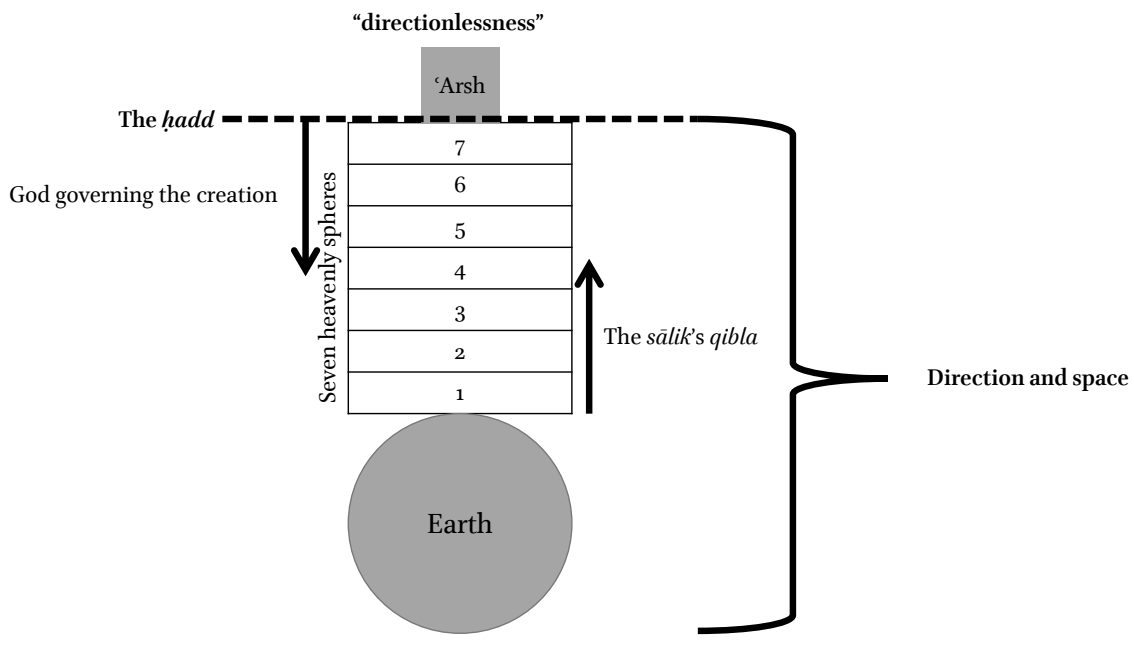

FIGURE 20 A schematic representation of al-Wāsițīs traditionalist Sufi cosmology. Compiled by the author

hearts' qibla, whereas those who strip God of His attributes (ahl al-tațill) a typical traditionalist label for the Ash'aris - are unable to experience this. In light of that, his mention of the sālikin who fail to verify God's aboveness in the earlier quote will surely have been chiefly directed at those who ascribe to the Ash'arī school. He contests that, although they may know God by such attributes as hearing, sight, and pre-eternity, their ma'rifa is incomplete because they remain lost in their ignorance of the direction of their object of worship. ${ }^{113}$

After the sālik has acquired a sound theological understanding of the divine attributes, the next step of ma'rifa in al-Wāsițîs Sufism is to recite the Qur'an and reflect on it as if hearing it directly from its original Speaker (min mutakallimihi) from above the Throne. While the sâlik would previously only recite the Qur'an for the sake of God, he now ascends to a degree in which he perceives God's Self-manifestations (tajalliyyāt) in the words of revelation through the divine names and attributes. ${ }^{114}$ For the time being we must pause here, as it is from this point that al-Wāsițīs doctrine takes the sālik from theory to practice by means of his acquired márifa of the attributes, ultimately leading to what

113 Al-Wāsițī, Risāla fì ithbāt, p. 49; Wașiyya, p. 142.

114 Al-Wāsițī, Qā'ida fì mazāhir al-shuhūd wa-al-ma'rifa, p. 140; Qã̄ida fì dhikr asbāb al-ma-

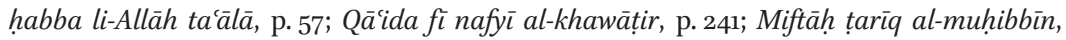
pp. 280 \& 283; Miftāh al-márifa, p. 265. 
he calls 'the witnessing of divinity,' mashhad al-ilähiyya, a degree in his sequence of sulük that belongs in the next chapter.

What this tells us is that while the current section has led us through a complex set of theological principles that may at first sight appear to have little to do with Sufism, al-Wāsitị envisioned them as the very basis from which the sălik proceeds to traverse the required degrees of witnessing (mashähid) that should eventually lead to the apex of the spiritual path. Thus, if we were able to recognize a distinctly traditionalist, nușuṣs-based spirituality in the previous section on the Muhammadan way, then this is all the more so when it comes to his treatment of ma'rifa of God. Not only does it revolve around basing one's knowledge of God solely on the Qur'an and the Sunna - that is, "knowing God as He describes Himself" - but it actually leans directly on the notion that adherence to the traditionalist creed is an essential requirement for one's sulük. Without affirming all of God's attributes from the nușuṣ, one falls short in ma'rifa of Him; and without affirming the literal meanings of God's aboveness and sitting on the Throne, one is left worshipping God without direction, and it becomes impossible to connect one's heart to God's Throne.

It isn't hard to fathom that such a traditionalist approach to the concept of ma'rifa will have met with the approval of Ibn Taymiyya and the members of his circle. I would therefore argue that the teachings of al-Wāsitị we have analyzed in the present section should be understood against the background of their shared activism for the traditionalist cause. His doctrine of ma'rifa sets an unmistakable course for a full rejection of any kalāmī - and especially Ash'arī - inspired form of Sufism, a topic we will further elaborate upon in the following section.

\section{What Sufism is Not: Refuting the Deviations of Sufis}

The misconception that Ibn Taymiyya saw no place for Sufism in Islam is still surprisingly strong today. For the most part, this is because much of his written effort on the subject was aimed at attacking and refuting those practices and/ or doctrines of Sufis which he thought contradict the original religion of the Prophet. From his perspective, however, rather than refuting tașawwuf, he was cleansing it of incorrect and heretical notions by pointing out what Sufism is not, or should not be. ${ }^{115}$ Occasionally, his pupil al-Wāsiți displays a similar attitude in the polemical side of his writings. While he certainly never reaches

115 It has been said that this is in fact Ibn Taymiyya's approach to religion in general: to show what Islam is by pointing out what Islam is not. See for instance: Bazzano, "Ibn Taymiyya, 
the depth and intensity of his master's polemics, we can find many examples where he tries to argue what true Sufism is by 'othering' those interpretations he disagrees with.

It will not come as a surprise that his critiques in the field of Sufism are conditioned by his experiences described in the previous three chapters. We will therefore focus on the three most significant recurring issues from his polemics, according to the chronological order of his journey. We will start with his refutation of $s a m \bar{a}^{c}$, the Sufi audition, which he often connects specifically to the Rifā̄iss. Then, following on from the Ash'arī-traditionalist divide discussed in the previous section, we turn to al-Wāsițî's staunch opposition to the influence of philosophy and kalām on Sufism. Here, special attention will be given to an isolated instance where he expresses harsh criticism towards Abū alḤasan al-Shādhilī, the eponymous founder of the Shādhiliyya. Finally, we turn to his most fierce polemics, which are reserved for Ibn 'Arabī and his followers, whom he regarded as the most dangerous Suf group in his age. Throughout these topics, I will occasionally make note of the overlap he displays with the spirit of Ibn Taymiyya's polemical thought. As stated before, this is not to prove that he was necessarily directly influenced by him or copied his arguments, but rather to stress once more that he was working from the same Ahl al-Hadith framework as his shaykh. In the conclusion to this chapter, we will discuss how al-Wāsițī's polemics may be linked to our analysis of the tarīqa Muhammadiyya and ma'rifa of God.

\subsection{SufiAudition (Samāc)}

Although al-Wāsițī had found that $\operatorname{sama}^{c}$ was also practiced by the Sufis of Baghdad and the Akbarians of Cairo, he was evidently most troubled by the manner in which it manifested amongst the fuqară $\bar{a}^{\prime}$ of the Rifā'ī order of Wāsit and its surroundings. ${ }^{116}$ There are several instances in his writings where he cautions against $s a m \bar{a}^{c}$ by specifically calling attention to their practice of the ritual, which he clearly considered its most extreme form. ${ }^{117}$ That this was no

Radical Polymath. Part 2," p. 119. I have also made note of this in my article, Post, "A Glimpse of Sufism," p. 162.

116 In the previous chapter I have made no mention of the $s a m \bar{a}^{c}$ amongst the Akbarians, as al-Wāsițī's primary focus in his account on them is not their practice but rather their doctrine. He does, however, refer to their sama $\bar{a}^{c}$ in his Rihla, p. 42, where he says that "to them, the $s a m \bar{a}^{\mathrm{r}}$ is the most desirable thing that incites their impulses, during which spiritual knowledge of non-delimited existence (ma'ärif al-wujūd al-muțlaq) is aroused."

117 al-Wāsițī, Wașiyya, pp. 145; Mīzān al-shuyūkh, p. 244-245; and possibly in Qã ída fí ítibār ahl al-khayr wa-ghayrihim, pp.134-135. In Qã ida mukhtașara, p. 38 it is clear that, although he does not explicitly name the Rifāiiyya, his description of those who perform sama $\bar{a}$ ' is without a doubt in reference to them. He states: "we ought to cry over ourselves, 
trivial matter, in his view, is evident from his Mīzān al-shuyūkh, where he puts forth the same characteristic descriptions of their sama $\bar{a}^{c}$ rituals that we have come across in his autobiographical account in chapter 1: They are once more depicted as innovators who dance during $s a m \bar{a}^{c}$, allow men and women to associate with one another, and eat live snakes and other forbidden things. AlWāsițī then testifies by God that if the Prophet, the first four caliphs, the emirs of the Companions, or the Umayyads would see them in such a state, "they would call them to God; and if they'd refuse, they would wage holy war against them (jähadūhum) with their swords ..."118 Although this statement is not solely directed at the Rifấi $s a m \bar{a}^{c}$, he considered this particular issue to be at the heart of many of the immoralities he saw them practice under the guise of Sufism.

Needless to say, the $s a m \bar{a}^{c}$ was a matter that he found deserving of critical attention, perhaps even more so because it was such a widespread practice among the Sufis of his age. It is likely that his critical attitude resonated well with the community of traditionalists in early Mamluk Damascus, among whom there probably existed something of a general dislike towards the practice. The Hanbalī master Ibn Qudāma al-Maqdisī had already issued a fatwa against it, and Ibn Taymiyya also launched attacks against it in several of his writings. ${ }^{119}$ In his aim to keep Sufism compatible with traditionalism, al-Wāsițī may thus have regarded it as something of an obligation to formulate why, from the perspective of a Sufi, sama $\bar{a}^{c}$ has no place in the pure Sufism of the Muhammadan way. This he tries to do, above all, in al-Bulgha wa-al-iqnā fi hall shubhat mas'alat al-sama $\bar{a}^{c}$ (The Sufficiency and Convincement to Solve the Obscurity on the Issue of $S a m \bar{a}$ ), a treatise dedicated solely to the subject. We will therefore go through his main arguments found therein, and supplement it with references from his other writings that are of relevance.

for we are tested today by [Sufi] groups (tawāiff) who concern themselves with eating what is forbidden .... They lay claim to spiritual states, but they do not smell the distinguished flavor of Islam in their exterior, nor the penetrating flavor of faith in their interior. They perform auditions ( $s a m \bar{a}(\bar{a} t)$ and dance to it the entire night, and when they perform the ritual prayer they peck like crows!" The last words concern the act of bowing in the Muslim ritual prayer, and indicate that they hastily perform the prayer. Note that in his Riḥla, p. 18, al-Wāsițī describes the Rifāiiyya in very similar words.

118 Al-Wāsițī, Mīzān al-shuyūkh, p. 246.

119 For Ibn Qudāma's fatwa, see his Dhamm mã 'alayhi mudda'ū al-tașawwuf (Beirut/Damascus: al-Maktab al-Islāmī, 1983). For Ibn Taymiyya, see $M F$, vol. 11, pp. 557-586 and pp. 587649 for two fatwas against samā'; he also deals with the topic in his al-Tuhfa al-Irāqiyya fi al-a'māl al-qalbiyya, ed. Yahyyā b. Muḥammad b. 'Abd Allāh al-Hunaydī (Riyad: Maktabat al-Rushd, 200o), pp. 430-443. 
First, it is interesting to note that al-Wāsițī was able to see why one could easily be confused regarding the impermissibility of $s a m \bar{a}^{c}$. He clearly appreciates some of the effects the $s a m \bar{a}^{c}$ may have on its listener, admitting that it is not altogether void of good. He writes, for instance, that one's inward being (al-bäțin) can be positively affected by the melody, vocals, and tones of the beautiful, spiritual poems that are recited. This may aid in casting out concern for all that is not God (al-aghyār) and put to rest distracting whispers (wasāwis), ease the carnal soul (nafs), and stimulate the heart in what it requires of spiritual states $(a h w \bar{a} l)$ such as love for God (mahabba), longing for Him (shawq), intimacy with Him (uns), and nearness to Him (qurb). ${ }^{120}$ On top of that, alWāsiți acknowledges that Muslim scholars differ on the legal status of the $s a m \bar{a}$. Some jurists hold it to be permissible, while others hold it to be forbidden. Even among the Sufis, he says, there are some of the later knowers of God (al-ärifin al-muta'akhkhirin) who practiced it, some who did not, and still others who used to do it and then later repented from it. ${ }^{121}$

His own verdict is simply that the evil of $s a m \bar{a}^{c}$ outweighs its good, and that this is why it was never ordered by the Prophet. If the performance of $s a m \bar{a}^{c}$ would increase us in virtue and nearness to God, or if it would be a path towards God's contentment, then the Prophet would not have concealed it from us, he argues. The truth of the matter is that it does result in evil, such as unlawful love, unlawful assemblies, and unlawful gazing. Under the pretext that it is a gathering of the pious it becomes, in the end, a gathering of the corrupt. ${ }^{122}$ For the most part, this depiction of the effects of sama $\bar{a}^{c}$ appears to be based on what he himself claims to have observed during the sessions of the Rifāiss, wherein handsome young boys and women would supposedly participate, as seen in chapter 1.

In the knowledge that $\operatorname{sam}^{\mathrm{c}}$ was not prescribed by the Prophet nor by the first four caliphs, al-Wāsiți makes it plain that it is essentially an innovation (bid'a). Going for the typical Hanbali argument, he stresses that we ought to be on our guard against innovations, since the Prophet said that "every newly invented thing is an innovation (bid'a), every innovation is an error, and every error belongs in the hellfire."123 He believes that this is also why it would not be sufficient to defend sama $\bar{a}^{c}$ on the basis of its acceptance by some of the wellknown Sufis. He simulates a discussion on the matter as follows:

\footnotetext{
120 Al-Wāsițī, al-Bulgha, f. 64b and 66a.

121 Al-Wāsițî, Mas'alat fi al-samāc , The National Library of Israel, JER NLI AP Ar. 158/7: f. 62b.

122 Al-Wāsițī, al-Bulgha, f. 66b-67a.

123 Al-Wāsițī, al-Bulgha, f. 67a. This well-known hadìth can be found in: Abū 'Abd al-Raḥmān Aḥmad b. Shu'ayb al-Nasā'ì, al-Sunan al-șughrā, ed. 'Abd al-Fattāḥ Abū Ghudda (Aleppo: Maktab al-mațbū'āt al-Islāmiyya, 1986), vol. 3, p. 188.
} 
Someone may argue: This $s a m \bar{a}^{c}$ was practiced by a group of the friends [of God] (awliy $\left.\bar{a}^{\prime}\right)$ whose high station with God we do not doubt, such as the generations of Sufis [sic] of Junayd and his companions, al-Shibli and his like, Yūsuf b. al-Ḥusayn al-Rāzì, and those before him such as Dhū alNūn al-Mișrī, and others like them. Then how can it be acceptable to us that you disregard them?

It is said [in response]: Even if it was practiced by a thousand renunciant, worshipful, pious individuals - or more or less [than that] - it has still been omitted by the generality of the Companions of the Messenger of God (Ṣ), and they were on intimate terms with him! If Dhū al-Nūn had [indeed] done it, then it was still omitted by Abū Bakr al-Ṣiddīq. Or even if it was attended by Junayd, it has been established on his own account that he repented from the $s a m \bar{a}^{c}$ and renounced it before he passed away. ${ }^{124}$

As we have noted before, a core aspect of al-Wāsițīs sulūk is the premise that the religion is perfectly complete as it was taught by the Prophet, and that there is no need to go beyond the nuṣuṣ. Just as this applies to the way God describes Himself in the revealed texts, this also holds true for the rituals of worship by which one means to draw closer to God. Based on this premise, alWāsiți holds that there are no grounds for practicing the kind of $s a m \bar{a}^{c}$ that involves dancing, singing, and the beating of drums, since neither the Prophet nor the Companions ever did this. ${ }^{125}$

He does offer an alternative, however, by differentiating between two types of $s a m \bar{a}^{c}$. On the one hand, there is the variety we have thus far been discussing, for which he says the word 'sama $\bar{a}^{\circ}$ has become the technical term agreed upon by the people of his age, thus labeled 'al-samā' al-isțilăhï.'126 On the other hand, there is the variety that is rightful by the revelation, thus labeled ' $a$ samā'al-mashrü.' He argues that it ought to be realized that the former variety is made up of doubt (shubha) and worldly appetite (shahwa). Doubt, he explains, is the uncertainty concerning the truth of what one experiences during the $s a m \bar{a}$ 'gathering, as the references to God's love in the poetry that is recited therein may at times lead one to find a share of the spirits (nașīb al-arwāh h). Worldly appetite, on the other hand, is the share of the carnal souls (nașīb alnufüs) that is intermingled with the share of the spirits, which eventually causes the $s a m \bar{a}^{c}$ to become something that is done for the Devil rather than for God. As for the rightful samác, in accordance with the covenant ('ahd) of

124 Al-Wāsițī, al-Bulgha, f. 67a.

125 Al-Wāsițī, Mìzān al-shuyūkh, p. 244.

126 Al-Wāsițī, Mas'alat fì al-samā', f. 62b, where he says: "isțalaḥa 'alayhi ahl hādhā al-zamān." 
the Prophet, the rightly guided caliphs, and the Followers (tābi inn), that is to listen closely to the Qur'an. As opposed to samā' ișțilāhī, al-Wāsiți holds that this variety is purely for the spirit, so that neither the carnal soul nor the Devil can have a share in it. ${ }^{127}$

He then tries to demonstrate that the two varieties of $s a m \bar{a}^{c}$ are in truth irreconcilable by highlighting the essential differences between them. He states that those Sufis who practice samác iștilāḥi supposedly argue that the Qur'an does not behoove the innate nature of man (țibä al-bashar), so that one will not find ecstasy (wajd) when listening to its audition. They are said to believe that poetry does behoove man and softens the heart, so that one ought to listen to that instead. ${ }^{128}$ As to be expected, al-Wāsițī rejects this as a vile argument, stating that as a consequence of this erroneous claim, such Sufis are unable to find any spiritual sensation - or dhawq, 'taste,' as he calls it - in the recitation of the Qur'an (tilāwa) and the ritual prayer (șalät):

The realizers (muhaqqiqūn) have verified that the taste of $s a m \bar{a}^{c}$ conflicts with the taste of ritual prayer. Hence, anyone who is enraptured during the samác iștilāhī and finds therein the perfection of his taste will not find the taste of Qur'anic recitation and ritual prayer. In all likelihood, the one who tastes sama $\bar{a}^{c}$ will never find the taste of ritual prayer, because there is a conflict between these two tastes that is known by those who know the distinguished taste of Islam. ${ }^{129}$

By the word 'realizers' al-Wāsiți likely means the true Sufis, those who have attained to haqiqa, the deeper, spiritual reality of things. He continues his argumentation, emphasizing how curious it is that the hearts of some Sufis who claim to love God have no room for the sama $\bar{a}^{c}$ of God's Speech, and are instead filled with the $s a m \bar{a}^{c}$ of poetry and hand-clapping. ${ }^{130}$ As we have alluded to in the previous section, he holds that it is in the Qur'an that the sälik finds tajalliyya $\bar{t}$ : those verses wherein God manifests Himself to His servants through His divine names and attributes. He therefore considers it essential to listen attentively to the recitation of God's verses and reflect on their meanings, as they are a gateway to intimate knowledge of Him (ma'rifa). ${ }^{131}$

Such is, in his view, the only true and rightful $s a m \bar{a}^{c}$ as practiced by the Salaf and the righteous Sufis of old and, as such, a trademark of those who stick to

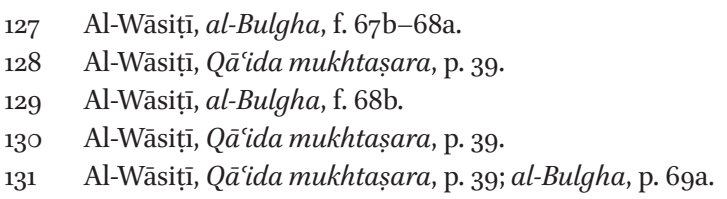


Muhammadan poverty (ahl al-faqr al-Muhammadī). ${ }^{132}$ He claims that among those who adhered to it were Fuḍayl b. 'Iyāḍ, Ibrāhīm b. Adham, Wahb b. alWard, Wahb b. al-Munabbih, Ḥudhayfa b. al-Mar'ashī, Sufyān al-Thawrī, Dhū al-Nūn al-Mișrī, Shaqīq al-Balkhī, Ḥātim al-Așamm, Sahl al-Tustarī, Ma'rūf alKarkhī, Sarī al-Saqațī, Abū al-Qāsim al-Junayd, and others like them. ${ }^{133}$ In laying claim to these names, he creates the image that the sama $\bar{a}^{c}$ that is rightful by revelation was in fact part of the tradition of the early models of authentic Sufism, sadly abandoned by the majority of the later Sufis.

Interestingly, Ibn Taymiyya has the exact same argumentation concerning $s a m \bar{a}$. He, too, differentiates between what he views as the newly invented $s a m \bar{a}^{c}$ of the later Sufis and the Qur'anic sama $\bar{a}^{c}$. Likewise, he claims that the latter variety of $s a m \bar{a}^{c}$ was originally practiced by the very same list of early Sufi authorities also mentioned by al-Wāsițī. ${ }^{134}$ Although such arguments may very well predate both Ḥanbalī scholars, I have yet to find earlier examples wherein Qur'anic sam $\bar{a}^{c}$ is similarly linked to the first generation of the Sufi figures. If this notion was actually brought into being by either al-Wāsiṭi or Ibn Taymiyya, it remains impossible to say whether one had appropriated the arguments of the other, or whether they simply shared a method that coincidentally led to the same conclusions on this issue.

\subsection{Philosophy and Kalām}

Moving on to the second object of al-Wāsițī's polemics, he held that the majority of the fallacies and heresies he found in the words and deeds of his fellow Sufis can be traced back to foreign influences that entered Islam. He names the books of the ancient philosophers (al-falāsifa) and sages (al-hukamä), in particular, as the main source of deviation that slowly poisoned the pure religion (al-sharîa al-khālișa) by inspiring the establishment of such sciences as logic (manțiq) and speculative theology (kalām) within the domain of Islam. ${ }^{135}$ Again, he leans on the traditionalist premise that the pathway unto God can only be known by what God Himself has revealed, so that the faculty of reason (quwwat al-'uqūl) should not be allotted any role therein. Because God was the source of knowledge for the Prophets, only they proclaimed absolute truths, he contends. The philosophers, on the other hand, rely on reason, which can be flawed. Therefore, he argues that in its utter perfection and completeness,

132 Al-Wāsițī, Qācida mukhtaṣara, pp. 39-40.

133 Al-Wāsițì, Mìzān al-shuyūkh, p. 245.

134 Ibn Taymiyya, $M F$, vol. 11, p. 592; and also his al-Tuhfa, pp. 430-431 \& 439-440.

135 Al-Wāsițī, 'Umdat al-țullāb, p. 202. 
God's religion should not be intermingled with sciences that are the product of mankind's own reasoning. ${ }^{136}$

He claims, however, that this is exactly what many Muslims have done since they have gradually turned to kaläm. He places the beginning of this development around the third and fourth century after Hijra, not long after the end of the age of the Salaf, we may note. ${ }^{137}$ In Talqĭh al-asrär, he specifically names the reign of the 'Abbāsid caliph Abū Ja'far Abd Allāh al-Ma'mūn (r. 198-218/813833 ) as the turning point from which the religion began to become weak and disunited. Now, al-Ma'mūn was the caliph responsible for instigating the famous Mihna, the inquisition known especially for enforcing the doctrine that the Qur'an is created, which was officially adopted by the 'Abbāsid caliphate. Since this Mihna was perhaps the greatest clash between the rationalist partisans of kaläm and the traditionalist partisans of hadith, it is unsurprising that al-Wāsițī mentions this particular caliph when he speaks of what he views as the decay of pure religion. It is often disregarded that this episode did not revolve solely around the createdness of the Qur'an, but also meant to censure the traditionalists' affirmation of the apparent meanings of the ambiguous descriptions of God from the nușuș, which was considered anthropomorphism from the kalämı point of view. The Mihna resulted in the persecution and flogging of the eponymous founder of al-Wāsițìs own madhhab, Aḥmad Ibn Hanbal, and demonstrated more clearly than ever before that the mutakallimün were a force to be reckoned with. ${ }^{138}$

I have argued several times before that, although never stated explicitly, alWāsițî's allusions to the presence of kalām theology in the religious landscape of his own context would, above all, have been made in relation to the Ash'arīs. ${ }^{139}$ They had by then become the most authoritative mutakallimūn in Sunni Islam, having triumphed over practically all opposing theologies of the other kaläm schools. ${ }^{140}$ In Miftāh țaríq al-awliya $\bar{a}$, al-Wāsiți even directly admits that the true traditionalists have become a minority in his age when he adjures his

136 Al-Wāsițī, Hayāàt al-qulūb, p. 74 .

137 Al-Wāsițī, Risālatuhu ilā al-shaykh al-Maghribī, p. 105; Wașiyya, p. 139.

138 On the clash between rationalism and traditionalism during the Mihna, and Ibn Hanbal's story in that regard, see for instance: Nimrod Hurvitz, "Mihnna as self-defense," Studia Islamica, no. 92 (2001): pp. 93-111; Christopher Melchert, "The Adversaries of Ahmad Ibn Hanbal," Arabica 44:2 (1997): p. $25^{2}$.

139 Speaking of kalām in his age, al-Wāsiți mentions how the kind of $t a^{\prime}$ wül we have treated in the previous section has come to dominate Muslim theology. This, as we have noted, was also the position of a branch of the Ash'arīs. See his Risālatuhu ilā al-shaykh al-Maghribī, p. 105; Wașiyya, p. 139.

140 Makdisi, "Hanbalite Islam," pp. 220 \& 228; Ignaz Goldziher, Introduction to Islamic Theology and Law (Princeton: Princeton University Press, 1981) pp. 94-95. 
reader to follow the jurists, fuqara $\overline{\text {, }}$, and Sufis of the Ahl al-Sunna wa-al-Hadith, "who base themselves on the science of hadith and athar," and adding that "they are but few." ${ }^{141}$

When it comes to Sufism, he holds that the majority of the Sufi masters of old would have adhered to the traditionalist creed, and that kaläm - again, most likely in the form of Ash'arism - only infiltrated the ranks of the later ones. Among the early traditionalist Sufis who would have affirmed God's aboveness he specifically names al-Muhāāibī, al-Tustarī, 'Amr b. 'Uthmān al-Makkī, al-Junayd, and perhaps surprisingly, al-Ḥakīm al-Tirmidhī, a proto-Sufi reproached by Ibn Taymiyya on several occasions. ${ }^{142}$ Among the increasingly rare examples of traditionalist Sufis from the generations that followed after them al-Wāsițī only names 'Abd Allāh al-Anșārī and 'Abd al-Q̨ādir al-Jīlānī, both Hanbalī Sufis we may recall. ${ }^{143}$

A noteworthy observation is that while he is frequently critical of the influence of kaläm on later Sufism, he hardly ever sees the need to do so in connection to any particular individual or group. One of the rare instances where he attaches a name to his criticism is an isolated mention of Abū al-Qāsim alQushayrì (d. 465/1072), whom he says "would fanatically cling to the school (madhhab) of those who make ta'will and negate direction," a remark that is clearly directed at al-Qushayrì's Ash'arī affiliation. Apart from al-Qushayrī, I have only found him explicitly mention kaläm in relation to the Shādhiliyya.

Despite his claimed dislike for kalām well before his entry in Damascus, his changing views on the Shādhiliyya after he had settled there suggest that his

141 Al-Wāsițī, Miftāh țtarīq al-awliyà̃ , p. 35 .

142 Al-Wāsițī, Risālatuhu ilā al-shaykh al-Maghribī, p. 108, where he says that "even al-Hakīm al-Tirmidhī - may God have mercy on him - states in his writings that the hearts ascend to the heavens, until they eventually end in al-malaq, which is a place in the Throne where the hearts of the friends [of God] who have reached nearness are suspended: they are the gathered hosts of them, the ones set above the others." This shows that al-Wāsitị was probably familiar with al-Tirmidhì's famous Sirat al-awliy $\bar{a}^{\prime}$ (better known as Kițab khatm al-awliy $\bar{a}^{\prime}$ ), a book that was severely criticized by Ibn Taymiyya (see for instance: $M F$, vol. 11, pp. 373-382). Compare al-Wāsițîs quoted words with the critical edition of Sìrat al-awliyā', in: al-Ḥakīm Muhammad b. 'Alī al-Tirmidhī, Thalāțat muṣannafāt li-alHakim al-Tirmidhī, ed. Bernd Radtke (Beirut/Stuttgart: In Kommission bei Franz Steiner Verlag, 1992), p. 18; and in translation, see: Bernd Radtke \& John O'Kane, The Concept of Sainthood in Early Islamic Mysticism: Two Works by al-Hakim al-Tirmidhï; an Annotated Translation with Introduction (Richmond, Surrey: Curzon Press, 1996), p. 68; Interestingly, on pp. 64-65 Radtke also makes note of al-Tirmidhì's more traditionalist hadith-based understanding of Islamic cosmology, which he says had not yet been influenced by the ancient Greek philosophical world model.

143 Al-Wāsițī, Risālatuhu ilā al-shaykh al-Maghribī, pp. 107-108; Madkhal ahl al-fiqh, pp. 5153 . 
comments in censure of rationalist theology within the domains of Sufism were to some degree influenced by his membership of Ibn Taymiyya's circle. Clearly, his stance towards his fellow Sufis became more and more defined in accordance with the principles of traditionalism as he lived amongst the Taymiyyans. In chapter 2 we have already seen that he had addressed his disappointment with the Shādhilīs' reliance on kalām quite carefully in his autobiography; for although he strongly disapproved of it, he still found much good in their spiritual teachings. However, his attitude is markedly different in Qā'ida fi așnäf al-ta'alluh. In this treatise he states that there is in some ways a distance between the Shādhilī way and the Muhammadan way, only known to those who know the tariqa Muhammadiyya. His main argument against the Egyptian Sufi țăifa is that al-Shādhili had "associated with the sciences of the philosophers ('ulüm al-falāsifa), because he refers to the universal intellect (al'aql al-kullī) in his discourse."144 Al-Wāsiți then goes on to say that whoever attaches himself to the Moroccan shaykh will therefore be molded by some precepts that are correct, and some that are not.

We may perceive this change of tone as an indication of his increasingly hardened stance towards non-traditionalist Sufis. As we have noted in chapter 3 , this occurred against the background of his growing rigor in adhering to the principles of traditionalism from the moment he had settled in Damascus onwards. This left no room for elements that were not in some way based on the $n u s ̦ u s$, at least from his point of view. It seems that, more than before, traditionalist theology had become the balance to measure which Sufis were part of the Ahl al-Sunna and which ones were not, and thus ought to be avoided.

There is reason to believe that Ibn Taymiyya's teachings played some role in this development. The Ḥanbalī shaykh al-Islām displays a very similar outlook on the influence of philosophy and kalām on Sufism in his writings. Like alWāsițī, he claims that the early Sufis belonged to the Ahl al-Hadìth and affirmed all of God's names and attributes. And again, apart from al-Hakīm al-Tirmidhī, he names the exact same authorities to give examples of Sufis he accepts as traditionalists. Only among the later shaykhs does he start to distinguish roughly between two categories of deviating Sufis: those who were influenced by the kalām theology of the Jahmiyya, such as the Ash'ari Sufi al-Qushayrī and his ilk, and those who were influenced by Greek philosophy, such as the Sufis of Ibn 'Arabī's school of ittihād.145

144 Al-Wāsițī, Qā'ida fì aṣnāf al-ta’alluh, p. 151.

145 Ibn Taymiyya, Kitāb al-șafadiyya, vol. 1, p. 267; Dar' ta'ārud, vol. 5, pp. 4-7, vol. 6, p. 266, vol. 7, p. 145; al-Radd' 'alā al-Shädhilī, p. 39. 
The influence of Ibn Taymiyya on al-Wāsiți in measuring Sufism according to the balance of traditionalism was likely also what caused the latter's change of heart regarding the Shādhiliyya. In fact, he may have borrowed the abovementioned argument against al-Shādhilī from his Hanbalī master. Although relatively unknown, Ibn Taymiyya composed a refutation of the Moroccan Sufi, which goes into considerable detail to censure some statements of his in the field of Sufism. The second half of the book deals exclusively with a lengthy passage quoted from a treatise that is attributed to al-Shādhilī, wherein the latter makes mention of the primordial intellect (al-'aqlal-așlì) and the necessary intellect (al-'aql al-darūrì). ${ }^{146}$ Ibn Taymiyya, who was without a doubt much more knowledgeable in philosophy than al-Wāsițī, then goes to great lengths to show that these two terms originate from philosophy and have nothing to do with the pure religion of the Prophets. What is interesting is that, contrary to al-Wāsițīs claim, to my knowledge the eponymous founder of the Shādhiliyya never uses the term 'universal intellect' (al-'aql al-kullī) in the writings attributed to him. However, commenting on the two intellects that are indeed mentioned by al-Shādhilī, Ibn Taymiyya says in his refutation that the philosophers view 'the active intellect' (al-'aql al-fa ' $\bar{a} l$ ) as the intellect that is closest to us "and [that] they say that the scriptures that came down unto the hearts of the Prophets come from it, and that [God's] words that reached Moses came from it."147 In other words, Ibn Taymiyya apparently understood one of the terms used by al-Shādhilī as a reference to the 'active intellect.' Because the 'universal intellect' mentioned by al-Wāsițī and the 'active intellect' mentioned by Ibn Taymiyya happen to be synonymous, it becomes very plausible that the former may have taken his argument against al-Shādhilī from the latter. ${ }^{148}$ If this is indeed the case, then we have here another clear indication that al-Wāsiți’s hardening attitude towards Sufis who did not operate strictly within the boundaries of traditionalism was, at least to some degree, influenced by Ibn Taymiyya. Whether the same can be said of our next and final topic, his polemical activity against the Akbarian Sufis, is not so clear-cut as we will now see.

\footnotetext{
146 Ibn al-Ṣabbāgh, Durrat al-asrār, p. 134.

147 Ibn Taymiyya, al-Radd' 'alà al-Shādhilī, p. 132.

148 While al-'aql al-kullī is more commonly known as al-'aql al-fa'call, its use can be traced back to the Brethren of Purity (ikhwān al-șafă'), see for instance: Ismail K. Poonawala, "Humanism in Ismāìīi Thought: The Case of the Rasā̉il Ikhwān al-Ṣafă’ (The Epistles of the Sincere Brethren and Faithful Friends)," in Universality in Islamic Thought, ed. M. Morony (London: I. B. Tauris, 2014), p. 71.
} 


\subsection{The Monistic Akbarians}

Based on our study in the previous chapter, it appears that al-Wāsițīs severe animosity towards the monism (waḥda), unification (ittiḥa d), and incarnation ( hulül) supposedly professed by the Akbarians had sprung forth from his own experiences among them in Cairo rather than under the influence of Ibn Taymiyya's polemics. It remains difficult to assess whether the latter's writings and arguments against their teachings did inspire the refutations al-Wāsiți subsequently composed himself against the Akbarian school, as there certainly are parallels that can be drawn between them. However, it is also true that Ibn Taymiyya is much more elaborate in his argumentation, and also delves into philosophy when discussing Ibn 'Arabī and his doctrine, a field al-Wāsițī never really quite dares to engage with. ${ }^{149}$ I have not found the latter ever bring up philosophy in relation to the Akbarians, whereas we have noted above that his Hanbalī shaykh specifically linked the roots of monistic Sufism to it. This, I would argue, indicates that the arguments al-Wāsițī sets forth in refutation of Akbarian Sufis were rather the fruits of his own labor.

It is important to note that by far the bulk of his polemical effort in the field of Sufism is directed against Ibn 'Arabī and his followers. He authored at least three refutations that deal solely with the heresies he found in their doctrine, two of which have been at my disposal. These are: Lawāmi al-istirshād fi alfarq bayna al-tawhìd wa-al-ittiḥād (Flashes of Guidance to Differentiate Between Divine Unity and Monism) and Ashi'at al-nușūṣ fi hatk astār al-Fuṣūṣ (Rays of Statements to expose 'the Fușūs'). ${ }^{150}$ The former is meant as a rather elementary and general warning against monistic Sufism, while the latter is specifically written as a step-by-step rebuttal of Ibn 'Arabī's treatise Fușūṣ alhikam. Besides these two titles and the section on the Akbarians from alWāsițīs autobiography, there are at least seven more works that contain passages in which he attacks them and their teachings. ${ }^{151}$

149 Below I will give a summary of al-Wāsițī's argumentation against the Akbarians. For Ibn Taymiyya's detailed refutation of them, see for instance his Haqüqat madhhab al-ittihādiyyin, in $M F$, vol. 2, pp. 134-284.

150 Unavailable to me has been al-Bayān al-mufìd fì al-farq bayna al-ittihäd wa-al-tawhìd (The Beneficial Elucidation on the Differentiation between Monism and Divine Unity), which al-Wāsițī mentions in Risālatuhu ilā al-shaykh al-Maghribī, p. 114. Note that I have consulted two editions of Ashi'at al-nușūs, one of which is published in al-Imādiyyāt (pp. 5385). The other edition is published under the variant title Bāshürat al-nușūs fì hatk astār al-Fușuss and misses certain words and phrases found in the former, which sometimes make the text less clear. I have therefore chosen to rely on the former rather than the latter.

151 Talqüh al-afhām, pp. 152-153; Lawāiḥ min qawāid, pp. 124-128; al-Tadhkira, pp. 35-36; Miftāh al-ma'rifa, p. 253; Risālatuhu ilā al-shaykh al-Maghribī, pp. 113-117; 'Umdat alțullāb, pp. 214-215; Qā'ida fì bayān al-sulūk, p. 163. 
Below will follow a summary of the main arguments directed against them and the doctrine of wahdat al-wujüd, the unity of being. In the previous chapter we have already been given a taste of al-Wāsitị̂s problem with the latter concept, which revolves around the Akbarian conception of existence in relation to God's unity. However, since his autobiographical account does not convey the full depths of his argumentation, there is still more to be said in that regard.

If one undertakes to study what it is al-Wāsițī says about Ibn 'Arabī and his followers in his other writings, it soon becomes apparent that his most vicious slander is directed against them. This should not come as a surprise, as we have seen that of all the Sufi groups he had come across he was evidently most troubled by them. We may thus presume that, as with the subject of $s a m \bar{a}^{c}$, he saw it as something of a necessity to distance himself and the science of tașawwuf from their doctrine in unequivocal terms - and this he indeed does. He displays no reluctance to openly declare that those with Akbarian leanings are outside the pale of Islam, and on several occasions even calls upon God to eradicate them from the face of the earth. ${ }^{152}$ In one letter, he argues that it is forbidden to say the customary invocation for a deceased Muslim, "may God have mercy on him," after mentioning the names of Ibn 'Arabī, Ibn Sabīn, alQūnawī, Ibn Hūd, al-Balyānī, al-Tilimsānī, and their ilk. ${ }^{153}$ At times, their deviant nature is emphasized by comparing their heresy to that of the Bătiniyya and Qarāmița Shi'ites, and by linking their doctrine to the eponymous founder of the Jahmiyya, Jahm b. Safwān (d. 128/745), and to the Murji'î theologian Bishr b. Ghiyāth al-Marīsī (d. 218 or $219 / 833$ or 834 ). ${ }^{154}$

It would nevertheless be wrong to assume that al-Wāsițī's treatment of the Akbarians does not surpass mere name-calling. As we have seen in the previous chapter, he appears to have become well familiar with Ibn 'Arabì's madhhab (school or doctrine) when he stayed in Cairo. This is indeed substantiated by his analysis of their teachings as found throughout his writings.

Because he was convinced that anyone who desires to know the true doctrine of Ibn 'Arabī should consult the Fușūs al-hikam, the majority of his polemical attention is devoted to this book. ${ }^{155}$ When he brings forward proofs for what he considers the heresy in Akbarian teachings, he almost exclusively does so by referring to or quoting from the Fușuss. A typical example is the following passage from his Ashicat al-nușūṣ:

\footnotetext{
$15^{2}$ Al-Wāsițī, 'Umdat al-țullāb, p. 214; Ashi'at al-nuṣūṣ, pp. 30 \& $5^{8}$.

153 Al-Wāsițī, Risālatuhu ilā al-shaykh al-Maghribì, p. 113.

154 Al-Wāsițī, Lawāmi', p. 94; Talqüh al-afhām, p. 153.

155 Al-Wāsițī, Risālatuhu ilā al-shaykh al-Maghribì, pp. 114.
} 
O people of intelligence, ponder over these words and you will understand their intent; [Ibn 'Arabī] says [in the Fușūṣ al-ḥikam]: "[God] is your mirror in which you see yourself ..." Do you understand what this means? It means that, since His essential existence emanated upon you, He is like a mirror in which you see that your immutability in non-existence exists. Thus, the existence of the Real is your mirror in which you see yourself.

Then he says: "... and you are His mirror in which He sees His names and perceives their properties (ahkām)." This means that if you did not exist, His names would not be manifest. Hence, you are a mirror for Him, so that His names can manifest, in the same way as He is your mirror in which you yourself manifest. 156

In al-Wāsițị's view, such lines from the Fuṣuṣ he quotes here perfectly exemplify what the doctrine advocated by Ibn 'Arabī entails. Let us therefore elaborate on this passage.

In his introduction to Ashi"at al-nuṣuṣ, al-Wāsiți tells us that the Akbarians believe that existents only come into being after God's essential existence (wujūdahu al-dhātī) emanates upon what they call either 'quiddities' (māhiy$y \bar{a} t)$ or 'concrete things' ( $a^{\prime} y \bar{a} n$ ). These are immutably fixed in non-existence (thäbitat ${ }^{a n} f i$ al-'adam) until they receive existence through this emanation (fayd) in accordance with their predisposition (istic $d \bar{a} d$ ) to do so. This, the Akbarians are said to believe, is the only way they become existents. When this occurs, God's own existence enters the perceptible realm (fi al-zähir), in which the properties (ahkām) of His names and attributes then manifest. ${ }^{157}$ These names and attributes are not other than Him, but in truth identical with Him. Hence, unity (wahda) becomes manifest in multiplicity (kathra) without thereby becoming manifold, as God's essence ever remains one. As an example, al-Wāsițī considers a creature that is granted provision, 'al-marzūq' in Arabic. He explains that the Akbarians would say that this creature remains immutably fixed in non-existence until God's existence emanates upon it. Only then can it be perceived as al-marzu $\bar{q}$, whereby God's divine name alRazzāq, the Provider, simultaneously becomes manifest. According to our Iraqi Sufi, the Akbarians hold that this Self-manifestation of God (al-tajalli $)$ is motivated by His desire to become acquainted with Himself through Himself, since

156 Al-Wāsițî, Ashicat al-nușūṣ, p. 63. A very similar analysis of the same passage from the Fuṣuṣs is provided by al-Wāsițī in his Risālatuhu ilā al-shaykh al-Maghribī, p. 116.

157 In Ibn 'Arabī's terminology, the properties (ahkām, sing. hukm), refer to "the ruling power or the governing control of the divine names in the cosmos," cf. Chittick, The Sufi Path of Knowledge:Ibn Al-'Arabi's Metaphysics of Imagination (State University of New York Press, 1989), p. 39 . 
$\mathrm{He}$ is able to see Himself in the quiddities/concrete things at the moment $\mathrm{He}$ reveals Himself to them. ${ }^{158}$

Al-Wāsițī observes several elemental problems here, which, in his view, contradict the very tenets of Islam. First, if the quiddities/concrete things only receive existence from God in accordance with their predisposition, that would mean that they have a degree of free disposal, independent of God. While God may decide to emanate existence or not, He has no choice when it comes to the measure in which they are predisposed to receive it from Him. Second, if nothing of His existence emanates on them, that would mean that He has no name or attribute in a state of manifestation at all, so that, as a consequence, He becomes something non-delimited (muțlaq) without existence. Third, if God is dependent on them for His Self-manifestation, that would mean He is in need of them - for whoever is sustained by something is in need of it. As long as they do not receive existence from Him, neither God's own existence nor His names and attributes manifest in the perceptible realm. In that sense, they are thus His source of sustenance. The same goes the other way around: The quiddities/ concrete things are in need of God for their existence, for without it they remain non-existent, immutably fixed in their non-existence. Hence, as al-Wāsițī understands it, Akbarian doctrine comes down to the notion that there is a mutual dependency here: God serves the creation, and the creation serves God. ${ }^{159} \mathrm{He}$ argues that this is in complete disagreement with the doctrine of the Muslims, according to which God's essence and His names and attributes are in continuous existence since pre-eternity. There is nothing newly added to God by what is brought forth from what He creates that has not already been a part of Him in His pre-eternity. God's creation, on the other hand, only comes into being by His will and is ever utterly dependent on its Creator. ${ }^{160}$

In Lawāmic al-istirshād al-Wāsiți explains that the roots of this heresy are deviation from the traditionalist premise of upholding the way God describes Himself and not going beyond what the nușuṣs explicitly state. It is in essence due to the Akbarians' exaggeration in affirming God's unity (al-tawhìd) that they have ended up practicing what al-Wāsiți calls the worst form of polytheism. He contends that while the polytheists of the pre-Islamic era (al-jähiliyya) ascribed equals to God by worshipping false idols, stones, stars, trees, and other similar vile objects of worship, the Akbarians actually make all existents into associates with God by affirming that they are identical with Him. To them,

\footnotetext{
$15^{8}$ Al-Wāsițī, Ashi'at al-nușūs, pp. 57-58; Talqūh al-afhām, pp. 152-153; Lawā̉iḥ min qawā'id, pp. 124-126; Risālatuhu ilā al-shaykh al-Maghribī, pp. 114-115.

159 Al-Wāsițī, Ashicat al-nușūṣ, pp. 58-6o; Talqüh al-afhām, pp. 152-153; Lawā̉ih min qawāid, pp. 124-126; Risālatuhu ilā al-shaykh al-Maghribì, pp. 114-115.

16o Al-Wāsițī, Ashi"at al-nușūṣ, p. $5^{8}$ and again on p. 81.
} 
"every created thing is a locus of manifestation in which the Real manifests with His very essence (bi-haqiqatihi) and [in which] He discloses Himself with His existence and 'I'-ness (bi-wujüdihi wa-aniyyatihi). They thereby reach the essential meaning of polytheism."161 With this doctrine, al-Wāsițî says, it becomes possible to assert that worshipping idols is in reality no different from worshipping God, something Ibn 'Arabī himself actually dared to utter in the Fușūss, he points out. ${ }^{162}$ Such beliefs come down to incarnation and unification (al-hulül wa-al-ittihăd) - although, he acknowledges, the Akbarians themselves would deny that, saying that for one thing to become incarnate in something else requires duality; and this can never be the case as everything is one in their view. ${ }^{163}$

While for al-Wāsiți the heresies inherent to this doctrine were apparent, he still felt it posed a very real threat to the Muslim community due to its strong potential to misguide people through its manipulation of allusions ('ibārāt) and terminology of the true Sufis from among the Muslims (șüfyyat ahl alIslām). His genuine concern appears to have been that if those who are heedless of the objectives of the Akbarians hear such teachings as related above, phrased in the language of the Sufis, they may think that it refers to the Sunni creed of tawhìd and the truthful witnessing of God's actions (shuhüd al-af'äl) to which the Sufis allude. That, he says, is because their words resemble the actual truth, namely, that everything in existence only exists by God's express will. ${ }^{164}$ In Lawäih min qawā id ahl al-zaygh he sketches the following picture to exemplify how people may be misguided by Akbarian teachings:

If someone from them studies these [Akbarian] fundamentals (qawāid), writes them down, believes in them, and then enters a spiritual retreat (khalwa) with an empty belly, invoking God with the profession of His unity for some time, ${ }^{165}$ it will not take long before this illusion (wahm) [of wahdat al-wujüd] becomes strong in him. It is very well possible that he becomes deluded by it through a state that hits him, or some inspiration (wārid) that comes over him. He will then depart from his retreat, imagining that he has become reality itself, saying: "glory be to me!"166

\footnotetext{
161 Al-Wāsițī, Lawāmic, p. 93; Post, "A Taymiyyan Sufi's Refutation," p. 320.

162 Al-Wāsițī, Ashi“'at al-nuṣūs, 67.

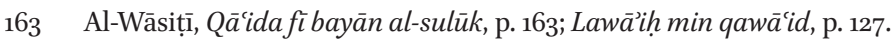

164 Al-Wāsițī, Lawāmic pp. 95-96; Lawā̄ị min qawā'id, p. 124.

165 Literally: “... invokes 'there is no deity but God' for some time" (wa-yadhkuru "lā ilāha illā Allāh" muddat $\left.{ }^{a n}\right)$.

166 Al-Wāsiṭī, Lawā̄ị̣ min qawā'id, p. 127.
} 
What al-Wāsitī speaks of here is what he regards as an example of the way Akbarians manipulate the Sufi concept of annihilation in God $\left(\right.$ fan $\left.\bar{a}^{\prime}\right)$, and render it into a spiritual state of intense awareness of the unity of existence. Hence the expression "glory be to me!" which is actually meant in glorification of God, in their eyes is the only true reality of existence. He contends, however, that "this is not the fana $\bar{a}$ of the lovers [of God] from the Sufis (al-muhibbin min alsüfyya), who are annihilated through the One they love so that they become absent from their own 'selves."'167 But, he concludes, someone who is not aware of the Akbarians' heresy will not be able to differentiate between their fan $\vec{a}^{\text {' }}$ and that of "the folk of truth."168

With this line of argumentation, al-Wāsiți once more differentiates between true Sufis and impostor Sufis. Leaning on the notion that the true Sufis acted in accordance with the principles of traditionalism, and were indeed themselves traditionalists, Ibn 'Arabī and his followers are by reason of their monistic doctrine automatically excluded from their ranks. He makes the same point in Lawāmi`al-istirshād, where he writes:

We, the people of reason, should not exceed the tawhid that [God] has made plain to us, but only seek intimate knowledge [of Him] (ma'rifa) by means of what He has revealed to us. We should not be greedy in seeking tawhìd and adopt everything as a divinity, thus exaggerating in the confession of His unity. By acknowledging that only God has existence we would be making Him identical with everything. We would thereby fall into religious laxity and neglect the obligations, pertaining to what is forbidden and what is permitted, break down the barrier of the revealed law, and exceed the guidance of those who preceded us from our Prophet's Companions and the shaykhs of our [Sufi] community (țäifatinā ), such as Sahl [al-Tustarī], al-Junayd, al-Sarī [al-Saqaṭī], 'Amr b. 'Uthmān [alMakkī], Abū Sa'̄ìd al-Kharrāz, Ibn 'Ațā', and their generations. ${ }^{169}$

The aim of this passage is, of course, to belittle the Sufi credentials of the Akbarians by laying claim to several of the same respected early Sufi authorities we have come across in the previous discussions on samā' and philosophy. AlWāsiṭi alludes to these Sufis as 'țẩifatinā' to single them out as representatives of traditionalist Sufism, who, in his view, never dared to profess the likes of

167 Al-Wāsițī, Risālatuhu ilā al-shaykh al-Maghribī, p. 117.

168 Al-Wāsițī, Lawāì min mawā'id, p. 126.

169 Al-Wāsițī, Lawāmic', p. 96; Post, "A Taymiyyan Sufi's Refutation," pp. 324-325. 
wahdat al-wujüd. He thereby once more tries to emphasize the 'otherness' of Ibn 'Arabī and his followers.

As we have now reached the final word on al-Wāsițīs polemics against Akbarian doctrine, our concluding topic, it will be useful to briefly reflect on the pattern we may recognize throughout the sections of the present chapter in order to tie them all together. As a general observation, we can say that we have been able to discern a distinct presence of Hanbali traditionalism in each of the subjects that we identified as one of the foundations of al-Wāsițî̀s Sufism. It is therefore not unfitting to speak of it as 'al-sulūk al-atharĭ', the traditionalist spiritual way, as it was called by Ibn Rajab. This is a label our Iraqi Sufi in all likelihood would not have been unappreciative of.

To start at the beginning, in the first section of this chapter we found that al-Wāsițī spoke of his way of sulūk as the tariqga Muhammadiyya to highlight that he envisioned it as being based solely on the inner dimension of the Prophet's Sunna. Therefore, rather than connecting spiritually to any Sufi shaykh, he taught a method of spiritually connecting to the Prophet's incorporeal being, which could be established through one's love for him on the basis of intimate knowledge (ma'rifa) of his life and times. Thus, the first foundation of his Sufism was primarily a textually based method that revolved around a close study of the nușuss in order to become acquainted with the Prophet and his Companions. The second foundation was very similar in that it also started with a close study of the nuṣuss, only this time to gain ma'rifa of God and connect to Him by becoming intimately acquainted with Him "as He describes Himself" in the revelation. For al-Wāsițī, this could only be reached through a traditionalist understanding of what the nușuṣ say regarding the divine names and attributes, especially when it comes to God's aboveness and sitting on the Throne. Thus, the second foundation of his Sufism was first and foremost a matter of studying the descriptions of God from the Qur'an and the Sunna in accordance with the traditionalist creed.

This reliance on traditionalist theology was also the common thread in his polemics. We have seen that, whether it concerned the practice of $s a m \bar{a}^{c}$, the presence of philosophy and kalām in Sufism, or Akbarian doctrine, he considered them all illegitimate on more or less the same grounds. In his view, they all lacked any explicit basis in the texts of the Qur'an and the Sunna, so that their existence essentially depended on deviation from the nușuṣ. Of course, what constitutes deviation is in the eye of the beholder, and the way al-Wāsiți 
circumscribed it depended heavily on his adherence to the theological framework of traditionalism as he understood it. With regard to his polemics, it is also significant to note that he repeatedly laid claim to several, widely respected Sufi masters to lend credence to his traditionalist vision of Sufism. He thereby aimed to effectively highlight the 'otherness' of those practices and doctrines he polemicized against by disassociating such well-known, and often legendary, shaykhs from them.

As a final observation, we may notice that al-Wāsițī and Ibn Taymiyya not only had very similar concerns when it came to the state of Sufism in their age, but also shared a common approach to address the problems they perceived therein. Their shared effort to filter Sufism of what they saw as deviations, and their utilization of a very similar language to do so, is not so much an issue of the authoritative influence of one over the other, as it is a matter of group identity. For both of them, their outlook on Islam was anchored in the tradition of the Ahl al-Hadith, or perhaps more accurately, in their specific image and understanding of this tradition. I would therefore argue that we should see the similarities between them in light of the traditionalist activism that we have noted in the previous chapter as a characteristic element of the Taymiyyan jama $\bar{a} a$ - a cause Ibn Taymiyya strove for as the group's leading jurist and theologian, and al-Wāsițī, evidently, as the group's leading authority in the field of Sufism. 


\section{Progressing Towards the Beloved through the Degrees of Witnessing}

A significant part of al-Wāsițì's work on Sufism is concerned with a sequence of degrees of witnessing (sing. mashhad, pl. mashāhid) that the sālik must go through to attain friendship with God. These represent the advanced stages of his sulūk, built on the foundations we have set out in the previous chapter. In the current chapter, we will investigate in detail how al-Wāsiți envisioned this progress, which is supposed to lead to the apex of the spiritual journey. Besides studying what his writings tell us in that regard, we will again frequently point out where he was possibly influenced by the teachings he had come across during his physical journey. It is, above all, in this part of his doctrine where we will come across instances where he appears to have appropriated certain elements not only from the teachings of Ibn Taymiyya, but also from the Shādhiliyya. By uncovering such instances we can further see how his own formulation of Sufism can be contextualized against the background of his life's story studied in part 1 of the current book. Furthermore, given the fact that he wrote primarily for traditionalists, some of whom were from the Taymiyyan circle, there is particular merit in exploring the presence of Ibn Taymiyya's teachings in the topics we will study here, as this enables us to evaluate how al-Wāsițīs membership of the jamā'a possibly affected his own ideas as a scholar in his own right.

Below we will proceed on the basis of section 2 from the previous chapter by elaborating on the steps required to ascend to the stage wherein God's names and attributes are witnessed and how this process is defined. From there we will continue to study the sequence of the most important degrees of witnessing in chronological order, ending with the final degree where the end of alWāsițīs spiritual journey is reached. Before we start, however, we must briefly draw attention to what we may call al-Wāsițīs anthropology, that is, his understanding of human nature, as it is within the framework of this anthropology that the sequence of witnessing takes place.

A recurring element in al-Wāsițī's writings is the notion that a human being is made up of five dimensions (ațwār, sing. tawr): the body (al-jism), the carnal 
soul (al-nafs), the intellect (al-'aql), the heart (al-qalb), and the spirit (al-rüh). He says:

A human being is one reality with an inward and an outward being. Its outward being is the body, and its inward being is likewise one thing. However, when it comes to that which is called the 'inner reality' (alhaqiqqa al-bātiniyya), it has attributes that are called 'the heart,' 'the intellect,' 'the carnal soul,' and 'the spirit.' Now, that which moves within these different attributes is one thing, and this is the inward human being (alinsān al-bātin): With respect to love and affection, which bear a spiritual meaning (ma'na rūhāñ̄), it is said that they are put in motion by one's spirit; with respect to one's fear, hope, reliance, determination, etc., which are practical attributes (șifät 'amalizya) by which it is possible to pursue [either] the afterlife or this world, it is said that they are put in motion by one's heart; with respect to one's concern for things and one's ability to distinguish between their truth and their falsehood, their good and their evil, it is said that they are put in motion by one's intellect and judgment $\left(r a^{\prime} y\right)$; with respect to one's carnal desire, such as the desire for food, clothing, intercourse, anger, superiority, honor, and pride, it is said that that this is put in motion by one's carnal soul. ${ }^{1}$

Thus, the body signifies one's outward physique (al-tarkìb al-qälibì), while the carnal soul, intellect, heart, and spirit are all distinct attributes of one's inward being. Each of these dimensions has its own characteristic motion: One moves outwardly with one's body parts, and inwardly - by emotions, thoughts, ideas, understanding, etc. - with the four attributes of the inner reality.

In order for the sālik to reach spiritual perfection, al-Wāsiți teaches that he is to subjugate each of these five dimensions in consecutive order. We can roughly describe this process as follows: First, he must traverse the body by observing the outward religious obligations and by guarding (ricaya) the seven body parts (his eyes, ears, tongue, stomach, private parts, hands, and legs). Second, he must traverse the carnal soul by conquering the faculty of worldly appetites, submit to God's decrees, and reject his own choice and self-direction. Third, he must traverse his intellect by becoming deeply acquainted with the Qur'an and the Sunna in order to learn the details of God's commands and prohibitions and understand them thoroughly. Fourth, he must traverse the

1 Al-Wāsițī, Qā'ida fìma'rifat al-naqș al-dākhil 'alā al-kamālmin al-'ārifín, wa-ma'rifat al-kamāl

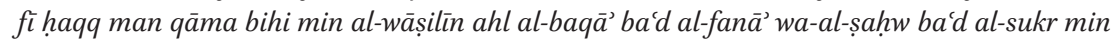
maqāmāt al-muqarrabīn, p. 238. 
heart by realizing its stations (maqāmāt), such as fear of God, hope in God, love for God, trust in God, and so on. Fifth, he must traverse the spirit by establishing steadfastness (istiqāma) in all the former dimensions. According to alWāsițî, it is only by mastering each step in its own right that the sălik will be able to move forward to the next one, to finally reach perfection in the spirit. ${ }^{2}$

Interestingly, this sequence of human dimensions somewhat resembles what can be found in the very treatise of al-Shādhili that was attacked by Ibn Taymiyya in the refutation we referred to in the previous chapter. Although the Moroccan Sufi only names three dimensions instead of five, and refers to them as stations (manāzil), he likewise designates the spirit as the highest degree:

The first station in which the lover sets foot to ascend therefrom unto the Exalted is the carnal soul ( $n a f s$ ). He must occupy himself with controlling it and disciplining it until it results in intimate knowledge of it. When he knows it and has realized it, then it is there that divine lights shine upon him. The second station is the heart (qalb). Likewise, he must occupy himself with controlling it and [acquiring] knowledge of it. If he has completed this and there remains nothing more for him to gain from it, then he ascends unto the third station, which is the spirit $(r u \bar{u} h){ }^{3}$

In his refutation, Ibn Taymiyya cites this very passage from al-Shādhilī and comments on it as follows:

It is said in response: If [al-Shādhilī] means by the carnal soul, the heart, and the spirit that there is one [human] essence to which belongs a number of attributes, then that is correct. As for mentioning that which is called the carnal soul before the heart, and that which is called the heart before the spirit, then this is a matter of a convention of terms ( $\mathrm{amr}$ isțilāhi $\bar{l}$ and there is no basis for it in the words of God and His Messenger. ${ }^{4}$

In fact, he goes on to argue, the nușuṣ actually prove that there is no one definition to these terms that would necessarily place one above the other. The carnal soul, the heart, and the spirit are all described by righteousness in some

2 Al-Wāsițī, Madkhal ahl al-figh, pp. 46-48; Qã̃ida fi habs al-nafs wa-al-'ukūf 'alā al-hamm,

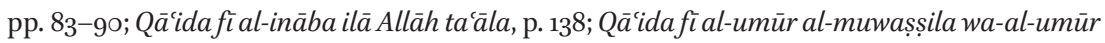
al-qāțía, pp. 224-226; Qāंida fì márifat al-naqș, pp. 230-233; Qāंida fì al-tajrīd, pp. 252-253;

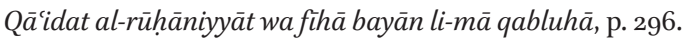

3 Ibn al-Ṣabbāgh, Durrat al-asrār, p. 134.

4 Ibn Taymiyya, al-Radd 'alā al-Shädhilī, p. 127. 
instances, and by corruption in others. Therefore, he concludes, "[t]his sequence, if it is said to be correct, is peculiar to an appointed convention of terms; it is not a scientific matter $\left(a m r^{\prime}\right.$ ' $\left.i m \bar{\imath}\right)$, nor is it generally applicable to every sālik." In other words, while he does not deny that these attributes exist within each human being, he sees no hard proof for the claim that the spirit signifies their highest degree, or that there is a particular sequence to them that applies to every believer on the spiritual path.

However, the importance of the five dimensions distinguished by al-Wāsiți lay exactly in his conviction that there is a fixed sequence to them. Here he clearly disagrees with the teachings of Ibn Taymiyya. Like al-Shādhilī, he believed that one reaches the spirit only after traversing the carnal soul and the heart. In addition, he held that it is specifically within the heart and the spirit that the required sequence of degrees of witnessing takes place, with the spirit being the locus of the most distinguished and complete of them. We can thus conclude that an essential part of his doctrine on witnessing was directly at variance with the opinion of his Hanbali master. How exactly he envisioned this doctrine we may now begin to unravel.

\section{$2 \quad$ Putting Márifa into Practice}

Picking up where we left off at the end of the second section of chapter 4, we will start by examining how the remainder of al-Wāsițīs sulūk builds on the theological foundations of ma'rifa we have thus far been able to distinguish. As we have seen, after adopting a correct understanding of the divine names and attributes, the sālik's subsequent step is to recite God's Speech, the Qur'an, and reflect on it as if hearing it directly from its Speaker. By doing so, al-Wāsitịi held that the sālik should become open to the revelation's tajalliyyāt: God's Selfmanifestations through these names and attributes.

From here al-Wāsiți quickly turns theological theory into practice, as the sălik is said to become truly acquainted with God exactly as He describes Himself in His revelation - the Qur'an, but also the Sunna - or rather, as He manifests Himself therein:

Described by the divine attributes (al-mawșüf), [God] manifests to the hearts [of the knowers] through [His] speech: Sometimes with His promise, sometimes with His threat, sometimes with His force, sometimes with His kindness, sometimes with His mercy, and sometimes with His

5 Ibid. p. 128. 
intimidation and His assault's severity; the cups circle around them, and the drinks that are required to love and glorify [Him] became manifold before them due to the variety of [His] attributes - for every attribute requires a certain taste $\left(\right.$ dhaw $\left.^{a n}\right)$, and every taste requires a certain love $\left(h u b b^{a n}\right)$. If but one attribute can enrapture the lover and take his heart, then what is one to think of the attributes when they all manifest simultaneously to the heart and their illumination is lit up inside the spirit? 6

This passage requires some elaboration. Essentially, it sums up the process of becoming a complete 'ârif, or 'knower,' of God. Again, as previously explained regarding the term ma'rifa, this is not directly a matter of receiving divine knowledge through some spiritual unveiling (commonly referred to in Sufism as ' $k a s h f$ '). Simply put, our Iraqi Sufi holds that anyone who acquires ma'rifa of some aspect of God's Being through His names and attributes becomes a knower of Him by that particular knowledge. ${ }^{7}$ There are, however, degrees to being an 'ärif; the more complete the sālik's knowledge of God, the more perfect a knower he is. The final line of the above quote alludes to this and is meant as a reference to the state wherein all attributes are witnessed at once, a subject we will get to in the final section of this chapter.

Another observation we have made before, which is also hinted at in our quote, is that each name and attribute of God can be seen as a piece of the puzzle of complete márifa; or as al-Wāsiți puts it elsewhere, each of them is an 'arch' (țāqa) or a 'door' (bāb) through which one may acquire the entirety of knowledge of God. In his view, not only do they all represent a particular aspect of God's Being, but like a puzzle, each is directly connected with other specific names and attributes. If, for example, the knower knows God by His name 'the All-Knowing' (al-'alim), then this name requires that God also possesses the attribute of life; if the knower knows that God directs His creation, which is the attribute of tadbir , then this requires that God also possesses the attributes of knowledge, volition, strength, wisdom, provision, mercy, power, and others of this kind. ${ }^{8}$ Names and attributes are thus interconnected, and it is up to the sālik to reflect and meditate on them to uncover how the pieces of the puzzle come together. The overarching purpose of this part of sulük is to thereby become acquainted with every single aspect of God's Being, because,

6 Al-Wāsițī, al-Sirr al-mașūn, p. 58; a somewhat similar explanation is given in Umdat al-țullāb, p. 206, and also in Qā'ida fì al-umūr al-muwașșila, p. 219.

7 Al-Wāsițī, Talqūh al-asrār, pp. 49-50.

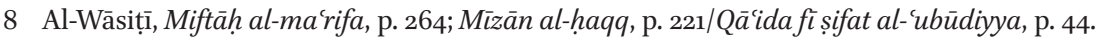


al-Wāsițī argues, servitude of God remains incomplete as long as it is not done with all His names and attributes and the magnificence of His essence. ${ }^{9}$

As for the 'taste' and 'love' required for each attribute, this pertains to the diversity that is inherent to ma'rifa. Even though God is one in His essence, His attributes are manifold. Hence, there are different meanings ( $m a a^{c} a n^{i n}$ mukhtalifa) that all subsist in one God. Because each name or attribute has its own specific meaning (ma'nā khāṣs), they all have a particular taste (dhawq khāṣs ) by which the knower becomes acquainted with God. ${ }^{10}$ According to al-Wāsițī, when the realities (haqäiq) of the names and attributes are unveiled and the knower discovers their tastes, that is when he will actually witness them. ${ }^{11}$ Each attribute then becomes a way to love God, for, as he explains, knowledge of God requires love. While it is possible that a human being knows something that he does not love, it is inconceivable that he knows something about God except that it is combined with love for Him. ${ }^{12}$ At this stage the sălik is therefore described by al-Wāsiți as "al-muhibb al-ārif al-dhä'iq," which we may render as the lover of God who knows Him by His names and attributes and has experienced their tastes. ${ }^{13}$

While these observations do reflect the essentials of the way al-Wāsitị sought to apply ma'rifa, we are still left with a rather ambiguous narrative. It fails to explain how exactly one is supposed to uncover the realities of the names and attributes to eventually acquire their taste and witness them, and it gives no clarification at all as to what these experiences actually signify. Therefore, the current section will be devoted to filling these gaps by delving deeper into al-Wāsițî̀s teachings on the divine names and attributes.

\subsection{Servitude through the Divine Names and Attributes}

When studying what al-Wāsițì's writings say regarding the practical application of the sālik's knowledge of God's Self-manifestations in the nuṣuṣs, it quickly becomes apparent that he relied heavily on Shādhili teachings for this aspect of his doctrine. Like the early Shädhili sources we studied in chapter 2, alWāsițī puts much focus on what we identified as an essential dichotomy of 'ubüdiyya and rubübiyya: mankind's absolute state of servitude as opposed to God's absolute lordship over all things. We may recall the following statement attributed to al-Shādhilī: "Sufism is to train the carnal soul to be in accordance

9 Al-Wāsițī, Qā'ida fì márifat al-naqș al-dākhil 'alā al-kamāl min al-ārifín, p. 230.

10 Al-Wāsițī, Miftāh al-márifa, p. 264; Mìzān al-ḥaqq, p. 221/Q̄ácida fì șifat al-ubūdìyya, p. 44; Qāंida fima'rifat al-naqș, p. 230.

11 Al-Wāsițī, Miftāḥ al-márifa, p. 264.

12 Al-Wāsițī, Mìzān al-ḥaqq, pp. 220-221/Qāida fì șifat al-ubūdiyya, p. 43.

13 Al-Wāsițī, Miftāḥ al-márifa, p. 264. 
with servitude, and to return it to the principles of lordship (ahkām alrubübiyya)." ${ }^{14}$ We can find al-Wāsiți stating in the same vein that "the servant's most noble state is to display the attributes of servitude and be satisfied with the principles of lordship (al-irtid ă' li-ahkām al-rubūbiyya)." ${ }^{15}$ As we will now see, Shādhili teachings permeate practically all of his further ideas on the practical use of the divine names and attributes in Sufism.

This is first apparent in what he regards as the inevitable realization that the attributes of God and the attributes of His creatures are in all respects opposites. Human beings have their very own attributes inherent to their state of 'ubüdiyya, and God has His very own attributes inherent to His rubübiyya. AlWāsiți cites a report about the Prophet David in that regard, according to which

God (T) said to David ('A): "O David, you must know Me and you must know yourself." He replied: "O Lord, I know myself by [the attributes of] weakness, feebleness, and finiteness, and I know You [by the attributes of] power, strength, and infinity!" Then God (T) said: "O David, now you know Me!" - or something similar to that. The servant must thus attend to his own attributes, know himself by them, and not overstep them lest he be counted among those who are ignorant! ${ }^{16}$

In a precept on the divine attributes he elaborates further on this notion where he advises the sālik that

if you desire to realize servitude and submit to the principles of lordship, then sit on the carpet of truthfulness (bisāt al-șidq) in reflection on your Master and what He alone possesses of [lordship] in the magnificence of His Being and the holiness of His majesty, while reflecting also on your finite attributes befitting of you. Then single out your Master by what is due to Him alone of the magnificence of His Being and the holiness of His attributes, and realize your own attributes and stick to them so that you do not overstep their limits. Reflect on [God's] attributes, then on your own attributes while reflecting on Him by them. ${ }^{17}$

It is surely no coincidence that what al-Wāsiți describes as the effort to realize what is due to God and what is due to His servants, in terms of attributes, was

\footnotetext{
14 Ibn al-Ṣabbāgh, Durrat al-asrār, p. 9o.

15 Al-Wāsițī, Qã ida fì șifat al-ubūdiyya, p. 41.

16 Al-Wāsițī, Mìzān al-haqqq, pp. 219-22o/Qã̄ida fì șifat al-ubūdiyya, p. 42.

17 Al-Wāsițī, Qā'ida fíal-șifăt, p. 318.
} 
likewise referred to as 'sitting on the carpet of truthfulness' by al-Shādhilī, as we have noted in chapter $2 .{ }^{18}$ We will take a closer look at what this requires of the sālik, and what reflecting on one's own attributes while reflecting on God exactly means.

When it comes to what is due to God, al-Wāsiți considers it an obligation to know the perfection of all the different categories of divine names and attributes that can be found in the nușūs. God is described in the revelation with active attributes (sifät filiyya), which pertain to His involvement in His creation, such as 'the Creator' (al-khallāq), 'the Bestower' (al-wahhāb), 'the Provider' (al-razzāq), 'the Opener' (al-fattāh), and so on. He is also described with attributes connected to circumstances (sifät hâaliyya) in the sense that they only manifest at particular times, such as when He will order people to enter the fire on the Day of Judgment, or when He descends to the heavenly layer that is nearest to earth in the last third of the night. He is also described with attributes that belong to His essence (șifāt dhātiyya), which are inherent to Him in pre-eternity and post-eternity, such as life (hayāt), knowledge ('ilm), creative power (qudra), hearing (sam), sight (bașr), will (iräda), majesty (jalāl), beauty (jamāl), holiness (quds), and perfection (kamāl); to this category also belong the names of His essence, such as 'Allāh,' 'He' (huwa), and 'You' (anta).19

After careful reflection on God's perfect names and attributes, al-Wāsiți teaches that the sālik must realize his own imperfect human names and attributes, seek out those which are best suited for him in his humanness, and stick to them. He recognizes two categories in that regard:

The servant has exalted names and vile names. As for his exalted names, God ('AJ) has described him by them where He (T) says: "Those who repent (al-tāìbūn), those who serve (al-'ābidūn), those who praise (alhămidūn), those who journey (al-säihüun) ..." [Q. 9:112] - until the end [of the verse] - and in His statement (T): "Men and women who have surrendered (al-muslimin wa-al-muslimāt), men and women who believe (al-mu'minin wa-al-mu'mināt), men [and women] who obey (al-qānitīn [wa-al-qānițāt]) ..." [Q. 33:35] - until the end [of the verse]. Examples of his vile names include: 'the disobedient' (al-'āșì), 'the sinner' (al-mudhnib), 'the wrongdoer' (al-zālim), and so on. ${ }^{20}$

18 As quoted in chapter 2 from Ibn al-Ṣabbāgh's Durrat al-asrār, p. 72.

19 Al-Wāsițī, Qã̄ida fì al-ṣifāt, pp. 319-320.

20 Ibid. p. $3^{20}$. 
Again, we have in this divide of vile and exalted human names a clear example of reliance on Shādhilī teachings. In fact, it seems that al-Wāsițī may have plagiarized the above-quoted words from al-Shādhilī himself, to whom the following is attributed:

The servant has vile names and exalted names. As for his exalted names, God has described him by them in His statement: "those who repent, those who serve, those who praise ..." [Q. 9:112] - until the end [of the verse] - and in His statement: "Men and women who have surrendered ..." [Q. 33:35] - until the end [of the verse]. His vile names are [also] known, such as 'the disobedient,' 'the sinner,' 'the dissolute, 'the wrongdoer,' and so on. ${ }^{21}$

Furthermore, like al-Shādhilī, our Iraqi Sufi maintains that those who uphold servitude of God may blot out their vile names with their exalted names. ${ }^{22}$ For example, the name 'sinner' may be replaced with the name 'penitent,' the name 'disobedient' with the name 'obedient,' and the name 'wrongdoer' with the name 'just.'23

For al-Wāsițī, it is through knowledge of what is due to God and what is due to the servant in terms of names and attributes that God may truly be served. In an earlier quote it was suggested that in order to uncover the realities of the divine attributes, the sălik must reflect on them and their relation to his own attributes. Our Iraqi Sufi taught that this reflection reveals what every single name or attribute of God requires, as each of them has its own particular form of servitude:

Every name or attribute with its specific meaning requires a specific servitude from the servants who know their Lord by it. If someone knows his Lord $(\mathrm{T})$ by something of His names, attributes, or actions, then an indication and a proof of the soundness of his ma'rifa of Him is that he serves God (T) - Whom he knows by that particular name or attribute - with a servitude that corresponds to what the effect imposed by [this] ma'rifa requires. ${ }^{24}$

\footnotetext{
$21 \quad$ Ibn al-Ṣabbāgh, Durrat al-asrār, p. 132.

22 Ibid. Again, the passage in question has been quoted in chapter 2.

23 Al-Wāsițī, Qā'ida fí al-ṣifāt, pp. 320-321.

24 Al-Wāsițī, Mīzān al-ḥaqq, p. 221/Q⿱ā'ida fì șifat al-'ubūdiyya, p. 45.
} 
Thus, the act of servitude that belongs to a particular name or attribute of God manifests by the realization of a corresponding name or attribute that exists in the servant. This is what al-Wāsiți refers to as upholding 'the principles of the divine names and attributes' (ahkām al-asmāa wa-al-siffāt), which is to serve each of them by fulfilling the requirements of their respective meanings; in other words, it is to serve God by means of one's ma'rifa of Him. ${ }^{25}$

We may better understand what this means by looking at several examples al-Wāsițī gives in his writings. These will simultaneously show that he relied once more on an approach that also appears to have been taught amidst the early Shādhiliyya. If, for instance, the sālik reflects on God's name 'the SelfSufficient' (al-ghani), he should come to the conclusion that this attribute requires that God is served by one's being in need of Him. Hence, an indication that the servant knows God by this particular attribute is that his heart practices the true meaning of neediness (haqiquat al-iftiqār). This principle holds true for all the names and attributes: Ma'rifa of the attribute of 'power' (qudra) requires its own corresponding servitude, which is the human attribute of incapacity ('ajz). Likewise, ma'rifa of the attribute of 'might' ('izza) requires servitude with the human attribute of lowliness towards God's might and humility towards His rulings. And ma'rifa of the attribute of 'strength' (quwwa) requires servitude with the human attribute of weakness, which manifests when the human being accepts his weak nature by seeking help from God, the Strong $(a l-q a w \bar{y} y) .{ }^{26}$ We have seen in chapter 2 that these exact same examples are also related from al-Shādhilī as the effects of 'sitting on the carpet of truthfulness. ${ }^{27}$

It is thus apparent that al-Wāsițī's method to uncover the realities of the divine names and attributes contains some unmistakably Shādhilī elements. It is relevant to add here that I have not been able to find evident traces of a similar practical use of ma'rifa in the works of Ibn Taymiyya. This would mean that, despite his critical attitude towards the Shādhiliyya, al-Wāsiți probably continued to rely on some of their teachings that he considered to be in harmony with his traditionalist vision of Sufism. We have previously noted that his method of becoming acquainted with God by studying the nuṣuṣ is clearly

25 Al-Wāsițī, Qā'ida fì márifat al-naqș, pp. 230-231; Qā'ida ya'rifu al-'abd fihà nașïbahu min rabbihi wa-bu'dahu min ḥuzüz nafsihi, p. 2o9; Talqüh al-asrār, p. 64.

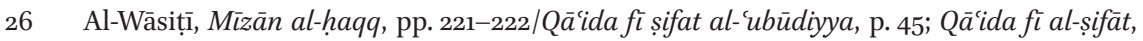
p. 318 .

27 As we see here, the examples al-Wāsiți gives were also treated in the paragraph on the divine attributes in Shādhilī doctrine in chapter 2, wherein we quoted from Ibn alṢabbāgh, Durrat al-asrār, p. 72. Al-Wāsiți gives more examples of the forms of servitude connected to specific attributes of God in: Q āंida ya'rifu al-'abd fìhā nașïbahu, pp. 210-211. 
rooted in the traditionalist principle of knowing God "as He describes Himself," which undoubtedly would have resonated well with his traditionalist pupils in Damascus. One can imagine, then, that the sober Shādhili method that utilizes ma'rifa by putting one's human attributes in the service of God's attributes would likewise have resonated well among them due to its emphasis on the absolute distinction between creation and Creator.

\subsection{The Heart as the Locus of Witnessing}

After having described the process of uncovering the reality of the divine names and attributes by fulfilling their practices of servitude, al-Wāsiți finally engages with them on the level of personal experience. This is where the academic, theological exercise we have thus far treated shifts into what al-Wāsiți refers to as the 'taste' (dhawq) or 'witnessing' (mashhad) of the names and attributes, Sufi terms that convey the possibility of a certain perception thereof. Below we will investigate how he describes this process in his writings. We will devote special attention to the theological problem he clearly recognized in using a language that runs the risk of being taken as a perception of God by the sensory faculties. As we will see, a significant part of his explanation of tasting and witnessing is therefore devoted to justifying a this-worldly perception of God.

Before we begin, it is necessary to note that while we have come across the term dhawq several times already, in relation to the topic at hand it is specifically connected to the mashhad, or witnessing, of a divine name or attribute. Because al-Wāsițī never clearly defines either term, the way in which they relate to one another sometimes appears vague. A close comparison reveals that they are without a doubt related and at times synonymous. That they do not signify separate steps is, above all, clear in one of his letters, wherein he states that the 'taster' of a divine attribute is someone who tastes the mashhad of that attribute. ${ }^{28}$

But how did he understand this experience? In the same letter he explains that it results from having traversed all the steps in sulük thus far described, which causes 'something' (shay') to become established in the heart:

This ['something'] is how the knower tastes the reality of the existence of a divine attribute, free from modality and likeness [to the attributes of creatures]. God (T) says: "His is the most exalted similitude (al-mathal $\left.a l-a^{\imath} l \bar{a}\right)$ in the heavens and the earth" [Q. 16:60/30:27] - and it is related in

28 Al-Wāsițī, Risālatuhu ilā al-shaykh al-Maghribī, p. 111, where he states: “... al-shuhūd alladhì dhāqahu al-dhā̉iq ..." 
the hadìth: "Exalted is Your greatness (ta'ālā jadduka)." Thus, His (ST) is the most exalted similitude in the heavens and the earth and in the hearts of the believers. This similitude has no similitude that resembles it, and it is this similitude that the knowers find in their hearts. ${ }^{29}$

Thus, the 'something' that becomes established in the heart of the knower is 'the most exalted similitude' - most exalted because it belongs to God alone. According to al-Wāsiți’s interpretation, it is this similitude that is meant by the word 'greatness' in the quoted supplication of the Prophet: "Exalted is Your greatness." ${ }^{30} \mathrm{He}$ holds that whatever is perceived of God's names and attributes in one's human capacity must necessarily be a similitude - although this similitude is exalted above, and thus in reality incomparable to, all other similitudes. This is so, he explains, because human beings, jinn, and angels cannot serve what is unknown, let alone witness it: ${ }^{31}$

The servant must not feel repelled by [the most exalted similitude], for he will only know God by it, only invoke Him by it, and only love Him by it. If it was not for [this similitude], [God] would neither be known nor served. It is thus inevitable that the similitude of the One to Whom nothing is similar is held in the hearts. ${ }^{32}$

In his treatise on the divine attributes, al-Wāsitị adds that, because it is by this similitude that God is served, many ignorant people err by worshipping the similitude rather than its possessor, God. ${ }^{33}$

As previously noted, he was fully aware that this approach to the process of spiritual witnessing may mistakenly be taken as an attempt to propagate an anthropomorphic conception of God. This would, of course, be at complete variance with the creed he himself advocated, according to which God has no modality and is in no way similar to His creation. In his writings, he claims to find the solution to what seems to be an inherent contradiction in the very concept of 'the most exalted similitude':

29 Al-Wāsițī, Miftāḥ al-márifa, p. 264.

30 Al-Wāsițī, Risālatuhu ilā al-shaykh al-Maghribū, p. 111. For the hadīth in question, see for instance: Muslim, al-Musnad al-șaḥ̆h, vol. 1, p. 299.

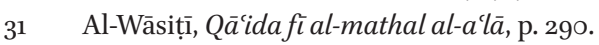

32 Al-Wāsițî, Qā'ida fíal-mathal al-a lā, p. 289. He likewise says that God can only be known, served, loved, feared, etc. by the most exalted similitude in his: Risālatuhu ilā al-shaykh al-Maghribì, p. 111; Qā̄ida fì maqāṣid al-sālikìn, p. 68. 
The sălik should know that when he directs himself [towards God], something may become established in his heart that he witnesses above the Throne. He must not feel repelled by it, because he may say: "this that I am witnessing is a body." While everything that reveals itself to your mind is either a body (jism) or an accident ('arad), it is known that imagination cannot give form to the reality of God (ST), understanding cannot encompass Him, and neither heart nor spirit can comprehend Him. However, it may be that similitudes (mithāl) become established [in the heart] upon being directed towards [God's] magnificence ('azama). These similitudes are a medium (wäsit a) between the One Who has no similarity and those who do. ${ }^{34}$

What he tells us here in a way resembles his argumentation for the affirmation of aboveness as the direction (qibla) that the servant's heart should turn towards when worshipping God. Besides the evidence he presented from the nușūs, this affirmation relied on mankind's innate nature to be in need of direction due to our inability to conceive the reality of directionlessness. In the same manner, our knowledge of God's names and attributes inevitably fixes 'something' in the heart that may be an image (khayāl), even if we profess with absolute confidence that God is nothing like His creation. ${ }^{35}$ This is due to our human inability to comprehend what cannot be grasped in our state of createdness and temporality.

Al-Wāsițîs argumentation here also leans on the essential distinction between human beings and God. Since mankind is essentially imperfect and God essentially perfect, it is impossible that they share qualities. The similitude of God that we see in our hearts through one of His names or attributes is therefore in accordance with our own imperfection and, as such, not even a reflection of His true reality:

Know that that there are two sides to this similitude that becomes established in the hearts when being directed [towards God] and supplicating [Him]: a side associated with the servant, and a side associated with the direction of [God's] magnificence. It is not said that [God's similitude] is not God, nor is it said that it is Him. Rather, it is a light in accordance with the servant's mirror, his createdness, and his feebleness. ${ }^{36}$ a'lā", wa-qawl al-nabì (Ș): "tabārak ismuka wa-ta'ālā jadduka", p. 289.

35 Al-Wāsițī, Miftāḥ al-ma'rifa, p. 264.

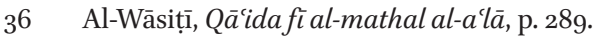


This is very much in line with al-Wāsițī's traditionalist cosmology studied in chapter 4, according to which God's essence exists outside the created realm, completely separate $(b \bar{a}$ in $)$ from His creation. Although not explicitly stated, this understanding of God's existence also forms the basis for the position that is advocated here, namely, that the true witnessing of His names and attributes cannot possibly come to pass inside the created realm, and nor is it a matter of perceiving God's reality outside of it in His own realm. There is no way that these two realities can merge.

Indirectly targeting the Akbarian school, al-Wāsițī cautions that a negligence of this differentiation will lead to the profession of divine incarnation $(h u l \bar{u} l)$ and unification $(i t t i h \bar{a} d)$. As he explained in the last quote above, it should not be said that what is perceived is God's actual reality and nothing else, nor should it be said that it is something other than Him. If, for instance, the light of divine majesty $(j a l \bar{a} l)$ is witnessed in the heart, then this is not identical with God's actual majesty - which, al-Wāsițī reminds his audience, neither heaven nor earth could bear. Rather, what is seen is a trace (athar) of His light that signifies this particular attribute due to its nearness to the heart in the unseen (al-ghayb). Nothing of God ever merges with anything, but $\mathrm{He}$ can be manifest to the heart in a true sense:

The heart's attachment [to God] does not resemble the attachment of physical bodies, because the heart is something unseen that is able to witness matters of the unseen (al-ghuyüb) without distance, and see them and be with them in truth. Even though this reality [of the unseen] exists and is tasted, seen by the taster in his human existence in accordance with his mirror, it [also] agrees with the reality outside [the created realm] (al-amr al-khārijī). Indeed, the reality as it is outside [the created realm] is the existence of the Lord (T), Who is highly exalted over His creatures with His essence above the Throne. ${ }^{37}$

Thus, what is witnessed by the heart in the unseen is not in disagreement with God's existence outside the created realm, but neither can it be taken to be of the same nature as the actual reality of His divine essence. Al-Wāsiți illustrates that it is like the difference between the name and the named:The name is not different from the named, but they are not identical either. ${ }^{38}$ As a parable, he

37 Al-Wāsițī, Risālatuhu ilā al-shaykh al-Maghribī, p. 111.

38 Al-Wāsițī, Qā'ida fì dhikr al-karāmāt al-mu'ajjala li-al-munqați'în ilā Allāh 'azza wa-jalla fì al-dunyā, pp. 287-288; Risālatuhu ilā al-shaykh al-Maghribī, p. 11; Miftāh al-márifa, p. 264 . 
urges his readers to reflect on the difference between candlelight that falls upon a wall and the actual light that is held in the fire of its lit wick. The former light is in accordance with its locus, the wall, and the latter light is in accordance with its essence, the fire. Hence, the light that falls on the wall is not identical with light as it exists in its essence, but neither is it a different light. ${ }^{39}$

The human heart is, in short, something in between the transcendent and the immanent, wherein God and His servant, despite their essential contrariety, can achieve a connection by means of similitudes of God's magnificence. In that capacity al-Wāsiți calls the heart "the throne ('arsh) of the most exalted similitude,"40 which functions as "a veil (hijāb) between the servant and the reality of [God's] essence."41 Again, what is witnessed therein by no means renders God into an actual body or accident, for the heart is but a mirror that reflects traces of divine light(s) in accordance with its imperfection as a created, finite entity. The person who witnesses perceives this reflection in the form of a similitude that is limited to the way existence manifests in the heart, wujüd $q a l b \bar{\imath}$, and in no way similar to the reality of God's existence in His essence, wujūd 'aynī. ${ }^{42} \mathrm{Al}-W a \overline{s i t} i \overline{1}$ was convinced that he had thereby solved the problem of a this-worldly witnessing of God without breaking the established theological boundaries that safeguard His divine perfection.

It must be noted that, although the Taymiyyan spirit is certainly present in this discourse, al-Wāsițị's effort to write from the angle of Sufism does set it apart from the teachings of his Hanbali master and brings a breeze of originality to it. For example, Ibn Taymiyya similarly refers to the most exalted similitude as the 'medium' (tawassut) by which the servant knows God in his heart and serves Him, but I have not found him explicitly using this interpretation with the same vigor as al-Wāsițī in relation to the subject of witnessing God. ${ }^{43}$

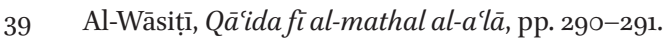

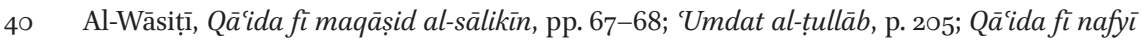
al-khawātirir, p. 246.

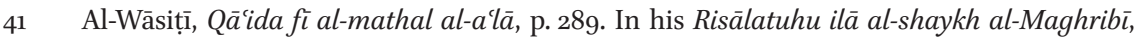
p. 111, where he similarly says that the heart "is a veil in respect to the hidden, essential reality [of God's Being]" (hijābun bi-nisbat al-amr al-khafìal-'aynī).

42 Al-Wāsițī, Risālatuhu ilā al-shaykh al-Maghribī, p. 112. We must note here that he did not intend to thereby negate a human vision of God in His essence. On several occasions he reminds his audience that direct contact between God and servant in the literal sense will occur in the afterlife, as only then God will be perceived as He truly is. Until that time, however, God's essential existence remains hidden from human beings - and from the entire created, temporal realm for that matter - and what we see of Him are "similitudes of His magnificence" that are witnessed in the heart. Cf. al-Wāsițī, Q̄àida fí al-mathal alå lā, pp. 289-29o; 'Umdat al-țullāb, p. 213; Risālatuhu ilā al-shaykh al-Maghribī, pp. 111-112. See for instance: Ibn Taymiyya, $M F$, vol. 5, pp. 465-466; vol. 6, p. 27; vol. 35, p. 275. 
We may therefore take this as yet another indication that our Iraqi Sufi would operate within the same traditionalist framework as his shaykh, but with his own input from the viewpoint of the discipline of Sufism.

\section{3} The Sequence of the Degrees of Witnessing (Tartīb al-Mashāhid)

Now that we have discerned how al-Wāsiți conceived the process of witnessing, we may turn to the actual sequence of its degrees from beginning to end. It is no easy task to extract this sequence from his writings. Although he believed that every name or attribute of God should be witnessed, I have found him elaborating specifically on only ten of them. ${ }^{44}$ The occasional minor inconsistencies in their details scattered throughout his work may be an indication that his formalization of this aspect of his doctrine was a work in progress. In most cases where he mentions particular degrees of witnessing he does not specify their order, and there are a few significant differences between those instances where he does. For example, the 'witnessing of divinity' (mashhad al-ilähiyya) is always put before the 'witnessing of lordship' (mashhad alrubübiyya), except in the book Madkhal ahl al-figh wa-al-lisān, where it is the other way round. Moreover, there are several degrees of witnessing whose exact position in al-Wāsițis's sequence remain unclear because they only sporadically appear throughout his writings, such as the 'witnessing of withness' (mashhad al-maiiyya) and the 'witnessing of divine judgment' (mashhad al-

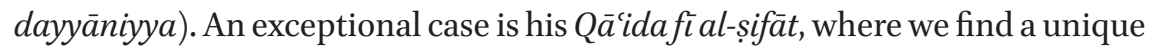
sequence that diverges considerably from others, containing several degrees that are not mentioned elsewhere.

The table on the next page gives an overview of which degrees are named across al-Wāsițî's works: The row headers contain the treatises' titles in alphabetical order, the column headers give the name of the degree(s) of witnessing mentioned therein. As can be seen, there are two degrees that are designated by two interchangeable terms: al-rubūbiyya/al-qayyūmiyya and al-jam'/alfardāniyya. Wherever degrees of witnessing are mentioned in a particular order this has been indicated by numbers; where no order is specified, their presence is simply marked by an 'x.' In both cases the corresponding page number(s) follows in superscript.

\footnotetext{
44 That all names and attributes can be witnessed is evident from al-Wāsițīs Qã ida ya'rifu al-'abd fihà nașïbahu, pp. 210-212.
} 


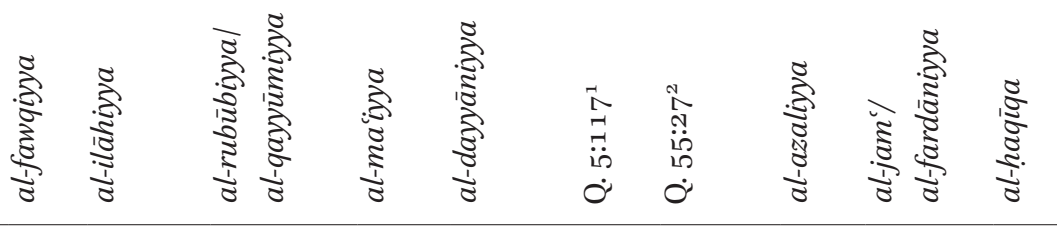

\begin{tabular}{|c|c|c|c|c|c|c|c|}
\hline Al-Sirr al-mașūn & & $1^{47-50}$ & $2^{47-50 / 62}$ & & & $3^{64-67}$ & \\
\hline Madkhal ahl al-fiqh & $2^{79}$ & $3^{79}$ & $1^{78-79}$ & $4^{79}$ & & $5^{79^{-80}}$ & \\
\hline Miftāh al-ma'rifa & & $\mathbf{1}^{265}$ & $2^{265^{-266}}$ & $3^{267}$ & & $4^{267-268}$ & \\
\hline Mizān al-shuyūkh & & $\mathrm{X}^{241}$ & $\mathrm{X}^{241}$ & & & $\mathrm{X}^{241}$ & \\
\hline $\begin{array}{l}\text { Qāंida fíal-farq } \\
\text { bayna al-‘̄abid } \\
\text { wa-al-mushāhid }\end{array}$ & & & & & & $\mathrm{X}^{260-262}$ & \\
\hline $\begin{array}{l}\text { Qāंida fi al-farq } \\
\text { bayna mushāhadat } \\
\text { al-qayyūmiyya }\end{array}$ & & & $1^{263-264}$ & & & $2^{263-265}$ & \\
\hline Qāंida fi al-șifāt & $1^{321}$ & $2^{321-322}$ & $3^{322}$ & $4^{322}$ & $5^{322} \quad 6^{322-323} 7^{323}$ & $8^{323}$ & $9^{323}$ \\
\hline $\begin{array}{l}\text { Qāंida fí al-umūr } \\
\text { al-muwașsila }\end{array}$ & & & & & & $\mathrm{X}^{222-226}$ & \\
\hline $\begin{array}{l}\text { Qāंidafi aṣnāf } \\
\text { al-ta'alluh }\end{array}$ & & $\mathrm{X}^{154}$ & $\mathrm{X}^{154}$ & & & $\mathrm{X}^{154-155}$ & \\
\hline Qāंida fi habs al-nafs & & & & & & $X^{89-90}$ & \\
\hline $\begin{array}{l}\text { Qāंida fi istijlāb } \\
\text { al-widād }\end{array}$ & & & & & & $\mathrm{X}^{275^{-2}} 7^{6}$ & \\
\hline $\begin{array}{l}\text { Qāida fìmazāhir } \\
\text { al-shuhūd }\end{array}$ & & $1^{140-141}$ & $2^{141-143}$ & $3^{143^{-144}}$ & & $4^{145^{-148}}$ & \\
\hline $\begin{array}{l}\text { Qāंida fi sulūk } \\
\text { al-awliy } \bar{a}^{\prime}\end{array}$ & & $\mathrm{X}^{164}$ & $\mathrm{X}^{164-168}$ & & & & \\
\hline
\end{tabular}

Qāंidafisulūk $\quad \mathrm{X}^{200-201} \mathrm{X}^{200-201}$

al-tahqiq

Qāidafial-tajrìd $\quad \mathrm{X}^{25^{2}} \quad \mathrm{X}^{25^{2}} \quad \mathrm{X}^{25^{2}} \quad \mathrm{X}^{25^{2}} \quad \mathrm{X}^{25^{2}} \quad \mathrm{X}^{25^{2}}$

Qāंidamin 'alāmāt $\quad \mathrm{X}^{169-172}$

al-tahqūq

Qā'ida ya'rifu al-'abd

fìhā nașïbahu

Sharh Manāzil

al-sä'irīn ${ }^{3}$

Talqīh al-afhām

$\mathrm{X}^{156} \quad \mathrm{X}^{156}$

$\mathrm{X}^{162}$

Umdat al-țullāb

$\mathrm{X}^{205} \quad 1^{210-211} 2^{211}$ 
1 This is the degree of witnessing God as the Watcher over mankind, as stated in the Qur'anic verse "You were the Watcher over them (al-raqib 'alayhim) ..."

2 This is the witnessing of the verse "but the Face of your Lord will remain, Master of majesty and glory."

3 We owe a passage from this commentary about $\operatorname{fan} \vec{a}, b a q \bar{a}^{3}$, and jam ' to Ibn al-Qayyim's Shif $\vec{a}^{\prime}$ al-'alïl, p. 16.

In spite of the obvious inconsistencies visible above, there is also a common thread. There are three degrees of witnessing that consistently recur: (1) the mashhad al-ilāhiyya, (2) the mashhad al-rubübiyya/al-qayyūmiyya, and (3) the mashhad al-jam/al-fardāniyya. This is no coincidence. In both Madkhal ahl al-figh wa-al-lisān and Qã'ida fí așnā al-ta'alluh al-Wāsițī explains that the sequence of witnessing God consists of three categories: First, those that pertain to God's law, which come together under His divinity (ilāhizya) that alone deserves to be worshipped; and, second, those that pertain to God's actions ( $\left.a f^{\prime} \bar{a} l\right)$, which come together under His lordship (rubübiyya) over the creation. Both degrees of witnessing are held in the heart. As for the third degree, this revolves around the notion that every name and attribute is but a constituent part of God's Being - al-amr al-juz'̄ - that belongs to His essence (dhāt), wherein the complete reality of His Being - al-amr al-kulli - comes together. ${ }^{45}$ The latter category is beheld when union (jam $)$ and singularity (fardāniyya) are witnessed, which occurs in the spirit. It is in this final degree that the sâlik arrives unto God and al-Wāsiți’s spiritual journey effectively comes to an end. We can thus conclude that the variations found in his writings are not such that it becomes impossible to detect something of a coherently structured system in his doctrine of witnessing. How he gave meaning to this doctrine we will analyze in the remainder of this chapter.

\subsection{The Heart's Witnessing of Divinity (Mashhad al-Ilāhiyya)}

In the following passage, al-Wāsițī imagines the manifestation (tajallī) of God's divinity, which is how the sălik may hear God address him through the Qur'an and the hadīth, manifesting His ilähiyya to him:

"I am God, there is no deity but Me!" [Q. 20:14]. These are My signs and My proofs, My arguments and My guidance. I speak through this [i.e. the Qur'an and hadith]: I command through what I command through it, I forbid through what I forbid through it, I cause fear through the fear that I cause through it, and I give hope through the hope that I give through it. So listen to My tales, obey My command, and follow My Messenger. I am 
unique in My essence and My magnificence ('azama) is above the seven heavens. Cognizant of My servants, I know their secret thought and their secret discourse. So worship Me and do not attribute anything to Me! Here I am with you, so do not think of Me as being far from you. Between you and the Afterlife there is but a veil which death will uncover. Then you will see Me manifestly, and you will see the veracity of My threat (waid) by which I filled you with fear and which I warned you about, and the veracity of My promise ( $w a^{\prime} d$ ) for which I gave you hope and which I made you desirous of and long for! ${ }^{46}$

This tajalli subtly illustrates how our Iraqi Sufi perceived, what is in the vast majority of his writings, the first category of witnessing. That he carefully chose his words to describe this experience will become apparent if we read it in the context of his other work on the subject.

As he saw it, the term 'ilähiyya' refers to God being 'al-iläh' the Divine, and as such the object of worship ( $\left.a l-m a^{\prime} b \bar{u} d\right)$ by means of the religion He revealed. God has made Himself known to mankind in that capacity through His Prophets and Messengers, His laws, and what He has made legally obligatory, recommended, or encouraged, so that they may thereby serve Him, worship Him, seek Him, love Him, and reach nearness to Him. ${ }^{47}$ Hence, divinity is witnessed as God speaking through the Qur'an with those words by which He imposes these things upon His servants (al-kalimät al-taklïfiyyāt). ${ }^{48}$ In other words, in the Qur'an God clarifies His commands and prohibitions and what He has made lawful and unlawful, rulings to which the sālik must submit with patience and contentment and without dispute. According to al-Wāsițī, this is the meaning of the Qur'anic verse "But no, by your Lord! they will not believe till they make you [the Prophet] the judge regarding the disagreement between them, then they shall find in themselves no impediment touching your verdict, but shall surrender in full submission" [Q. 4: 65] ${ }^{49}$ Evidently, in order to perform the requirements of God's divinity one must first have knowledge, ma'rifa, of its particularities.

In order to reach this márifa, al-Wāsiți relies on the aforementioned effort to recite the Qur'an while reflecting on it in order to become acquainted with the meanings of the divine names and attributes it contains. One will thereby not only know the attributes explicitly mentioned, he says, but also those that

\footnotetext{
46 Al-Wāsițī, Q̄àida fì mazāhir al-shuhūd wa-al-ma'rifa, pp. 140-141.

47 Al-Wāsițī, al-Sirr al-mașūn, p. 5o; Miftāh al-márifa, p. 265.

48 Al-Wāsițī, Miftāh al-márifa, p. 266.

49 Al-Wāsițī, al-Sirr al-mașūn, p. 47.
} 
are implicitly present. For sometimes God speaks with words that reveal His commands and prohibitions, sometimes they reveal His promise and threat, sometimes His magnificence and power, sometimes His mercy and generosity towards His servants, sometimes His subjugation of His enemies, and so on. ${ }^{50}$ As opposed to God's active attributes that pertain to His lordship (rubübiyya) by which He constantly brings into being, governs, and controls His creation, these all pertain to the reality of His revealed religion by which His divinity is given its due. After extracting them from the revelation, al-Wāsițī teaches at least two ways to invoke the practices that are meant to result in the realization of ilāhiyya.

The first is to reach the degree of witnessing God's aboveness (mashhad alfawqiyya). Although this is only indirectly hinted at in the tajalli with which we opened this section, al-Wāsițī held that the witnessing of divinity is preceded by the witnessing of aboveness. In Madkhal ahl al-figh wa-al-lisān he states that this follows after having gained the required knowledge of the aforementioned attributes of divinity through the recitation of and reflection on the Qur'an:

Marifa of the divine attributes ... becomes manifest in the purity of [one's] heart while observing the revealed law and reciting the divine revelation (al-wahì al-ilähi) within which the command and prohibition, the promise and threat, and other such things are contained. When the heart immerses itself therein and becomes absent in these meanings (ma'ān $\bar{l})$ [from the Qur'an], the witnessing of aboveness appears to the heart. ${ }^{51}$

It appears that its merit to the witnessing of ilähiyya lies in the knowledge that God manifests His attributes and their meanings through the Qur'an from above the seven heavens over the Throne; it is from there that He constantly sees each and every one of His servants, ever knowing whether He is given His full due by them or not. Al-Wāsiți believed that when the sālik becomes truly conscious of God's sight upon him from above, he will naturally hold Him in awe and reverence, and feel shy and ashamed before Him. ${ }^{52}$ A recurring method he proposes to train oneself in this sense of shame is to go into seclusion (khalwa) in a dark room or cave for an hour each day, to leave the world behind

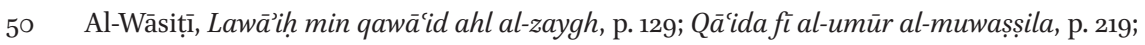
Umdat al-tullāb, p. 2o6; Madkhal ahl al-figh, p. 79 .

$51 \quad$ Al-Wāsițī, Madkhal ahl al-figh, pp. 78-79.

52 Al-Wāsițī, Qāiida fì al-șifāt, p. 321; Miftāḥ al-márifa, pp. 265-267; Qāंida mukhtașara,

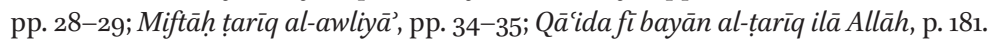


and focus only on God and supplicate Him. ${ }^{53}$ This should then motivate the sălik to uphold vigilant awareness (murāqaba) of all his movements and passing thoughts (khawātirir), constantly take himself to account (muhāsaba) for them, and guard his body parts (ricāya) so as to keep them conforming to God's commands and prohibitions with sincerity. ${ }^{54}$ We may note that such techniques had been incorporated into Sufism since its early formation, so al-Wāsițī undoubtedly relied on the teachings of his Sufi predecessors here.

The second way he mentions to invoke practice on the path towards witnessing divinity was also alluded to in the tajalli, and revolves around careful reflection on God's promise (wa'd) and threat (waid) as articulated in the revelation. In al-Sirr al-mașūn he explains that, on the one hand, the Qur'anic references to the promise of eternal happiness for the triumphant (al-fäizün) should arouse a desire in the heart to obey God's commands and perform the obligatory and recommended acts of worship for the sake of this great reward; on the other hand, the Qur'anic references to the threat of the hellfire and its punishments should arouse the desire to drive away the carnal soul from inclining to that which God has forbidden, and to take oneself to account and guard one's body parts. Thus, he concludes, the combined reflection on God's promise and threat gives both hope (rajä) and fear (khawf), which should aid the sālik in bearing the burden of obedience to God's law with patience and contentment. ${ }^{55}$

By having realized consciousness of God's sight from above, and hope for His promise and fear of His threat, al-Wāsițī believed that divinity can truly be given its due through close adherence to the revealed law:

When the servant restricts himself to the Muhammadan revealed command (al-amr al-mashrü' al-Muhammadì), his aspiration becomes united, his energy devoted to upholding what is commanded [by God] and

53 Al-Wāsițī frequently mentions seclusion (sing. khalwa, pl. khalawāt) in his works as an effective method to reflect on God and His revelation, invoke Him, and build a relationship with Him; see: Q̄̄ंida fì tasfiyyat al-akhlāq, p. 89; Qāंida fì bayān al-țarìq ilā Allāh, p. 181; Qā'ida fì dhikr al-karāmāt al-mu'ajjala li-al-munqațiīn ilā Allāh 'azza wa-jalla fì al-dunyā, pp. 283-284; al-Tadhkira, p. 27; Madkhal ahl al-fiqh, pp. 59-6o; Miftāh țarīq al-awliyä, p. 34; Talqüh al-asrār, pp. 49-5o; Q̄̃̄ida fì an al-'abd yata'ayyan 'alayhi ma'rifat al-țarìq ilä Allāh 'azza wa-jalla wa-al-ta'arruf lahu, p. 114.

54 The terms murāqaba, muhāsaba, and ricāya occur regularly throughout al-Wāsițî̀s writings and are not exclusively mentioned in the context of fawqiyya. In the following titles he also elaborates on how to apply them: Qāंida fi al-umūr al-muwașșila, p. 217; Talqüh al-afhām, p. 158; Mīzān al-shuyūkh, p. 240; Madkhal ahl al-figh, pp. 61-63, 75-77.

55 Al-Wāsițī, al-Sirr al-mașūn, pp. 47-50; see also his: Lawāiḥ min qawāid ahl al-zaygh, p. 129; Q̄ãida fì bayān al-țarīq ilā Allāh, p. 181. 
hastening towards the object of his search, and he employs whatever is sweet to his heart of the revealed acts of worship and commendable ways to remember [God] (al-adhkār al-mandūba). Indeed, he should constantly practice the remembrance of God that is sweet to his heart, for when something from that has become sweet, it is hoped that he is provided with an opening therein! ${ }^{56}$

Clearly aiming to criticize what he considers extreme ascetic interpretations of Sufism, al-Wāsiți emphasizes close adherence to the Prophet's example, the Sunna, rather than adopting practices that are not explicitly revealed by God (ghayr mash $r \bar{u}$ ). For instance, he strongly disapproves of constant fasting, and instead advises to simply lessen the amount one drinks and eats slightly, and to practice supererogatory fasting only on Mondays and Thursdays in accordance with the Sunna. ${ }^{57}$ His method of sulük thereby takes a distinctly sharíagrounded approach to Sufism by relying solely on acts of worship that have been transmitted via the nușuṣs.

It will be useful to take a look at the central role he allots to the Muslim ritual prayer $(a l-s ̦ a l a t t)$, in particular as a fitting example of this approach. He frequently mentions the significance of perfecting one's performance of the prayer as a means to draw near to God. The șalät is, as he calls it, the touchstone (mihakk) for one's spiritual state or station, as it is a moment of contact with God. He explains that if one has mastered the state of fear or love for God, this should be visible in the way one prays. If this is not the case, then one can be sure that they are not yet acquired these states. ${ }^{58}$ Because he considers the prayer a moment purely for God, he argues that it is to be performed with full attentiveness $(h u d \bar{u} r)$ from the very moment it is entered by pronouncing the 'takbir,'59 making sure that the heart remains guarded against distracting whispers (waswās); then the meanings of every word of the Qur'an recited should be understood so that it becomes as if one stands directly before God, conversing with Him. ${ }^{60}$ Besides perfecting the act of prayer itself, al-Wāsiți also emphasizes the importance of performing each particular prayer on its

$56 \quad$ Al-Wāsițī, 'Umdat al-țullāb, p. 210.

57 Al-Wāsițī, Miftāh al-márifa, p. 272.

58 Al-Wāsițī, Madkhal ahl al-figh, p. 68; Qāंida mukhtașara, p. 32.

59 The Muslim ritual prayer begins from the moment the first takbir - i.e. 'Allāhu akbar' (God is great) - is pronounced.

6o Al-Wāsițî, Qã'ida mukhtașara, pp. 30-32; Qã̄ida fí bayān 'amal yawm wa-layla li-al-abrār wa-'amal yawm wa-layla li-al-sā̉irìn ilā țarìq al-muqarrabīn ja'alnā Allāh minhum, p. 71; Qã̄ida fì istijlāb al-widād, pp. 276-277; Miftāh țarīq al-awliyā', pp. 35-36; Madkhal ahl alfigh, pp. 68-69. 
specific time, such as the voluntary prayer in the last third of the night (altahajjud), the Friday prayer (șalät al-jumu'a), and the times of the five communal prayers - because, "during these [moments] allotments [from God] descend upon the seekers, and divine gleams (bawāriq) shine upon the hearts of those who yearn [for Him] and love [Him]."61

For al-Wāsițī, it is only by vigilantly abiding by the shar ${ }^{i}$-ordained practices of worship that God will reveal the witnessing of knowledge of His attribute of divinity (mashhad ma'rifat sifat al-ilähiyya). He cautions, however, that God's gifts are according to one's ability to receive them, so it may be that the heart only sporadically perceives the realities of divinity and that they may just as fast disappear. Only when witnessing is done uninterruptedly, one knows that the heart has come to inhabit it as a spiritual station (maqām). Al-Wāsițī defines this station as a profound understanding of the Qur'an, wherein the light of the Prophet and the intimate knowledge of him and his Companions manifests. That is so, he explains, because they were the transmitters of the message (al-risāla) by which God's divinity and its requirements has been made known. Pure faith in divinity is therefore only acquired through them. ${ }^{62}$ Having thus realized the witnessing of divinity by means of its duties, the next step in the sequence of al-Wāsițîs sulūk is to witness the attribute of God's lordship.

\subsection{The Heart's Witnessing of Lordship (Mashhad al-Rubübiyya)}

After the tajallı̄ of God's divinity, al-Wāsiți likewise imagines the tajallı̄ of His lordship, which is how the sălik may hear God address him, manifesting His rubübiyya to him through His activity in the created realm:

"I am God, there is no deity but Me" [Q. 20:14], the Creator (al-khäliq), the Maker (al-bāri'), the Shaper (al-mușawwir), the Ever-Living (al-hayy), the Sustainer (al-qayyūm), the Director (al-mudabbir), Who creates the creation and spreads out provision. It is I who brought into existence this world, which you see was unprecedented! I decree the appointed time for all those who live in it, assign their provisions, and direct their affairs by the direction of My creative power (qudra) in accordance with My wis$\operatorname{dom}($ hikma). You see that [creatures] do not in themselves possess benefit or impairment, death, life, or resurrection - for who other than I calls them into being, and sustains and furnishes them? Who provides for

61 Al-Wāsițî, Umdat al-țullāb, p. 210; see also his: Miftāḥ al-ma'rifa, pp. 272-273; Miftāh țarīq al-muhibbīn, pp. 279-280; Qā'ida fì bayān 'amal yawm wa-layla, p. 72.

62 Al-Wāsițī, 'Umdat al-țullāb, pp. 210-211; Lawā̉iḥ min qawā'id ahl al-zaygh, p. 129; Qā'ida fì maz̄āhir al-shuhüd, p. 141. 
their needs? Who shapes their wondrous forms, gives them their marvelous colors, and spreads among them a variety of souls with extraordinary characteristics, each different from the other ... All this comes from My governance and My ordainment in accordance with My volition and will, which flow from the ordinances of My wisdom - "Is there a deity with God? Highly exalted be God above that which they associate!" [Q. 27:63] - So trust in Me, fear Me, and commit all your affairs to Me, for I control all things! ${ }^{63}$

As with the former category of divinity, we will again see that this tajalli aptly illustrates how al-Wāsiți perceived the witnessing of lordship.

The term 'rubübiyya' refers to God being 'al-rabb,' the Lord and Sovereign, and as such the sole force that brings into being and moves all creatures. Simply put, al-Wāsiți defines it as follows: "the attribute of rubūbiyya is the Lord's (T) solitariness in directing and sustaining [all creatures] (infiräd al-rabb bi-altadbìr wa-al-qayyūmiyya)." ${ }^{4}$ In that capacity, al-Wāsiți explains that God has complete and absolute authority over all creatures, sustains them, and nourishes them inwardly and outwardly with His blessings and bounties, thereby making Himself known to them. ${ }^{65}$ Apart from within the creation itself, he teaches that this part of God's Being also manifests in the Qur'an through the words by which He brings into existence (al-kalimāt al-takwiniyyāt), such as the verse "The only words We say to a thing when We desire it, is that We say to it 'Be,' and it is" [Q. 16:40]. ${ }^{66}$

It must be noted here that al-Wāsiți sometimes uses 'qayyūmiyya,' 'sustainment,' as a synonym for rubübiyya. The former term signifies God's fulfilment of the divine name 'al-qayyüm, 'the Sustainer,' which was, of course, not coincidentally mentioned in the above-quoted tajalli as well. ${ }^{67}$ Hence, when in some of his works he speaks of the mashhad of qayyümiyya and in others of the mashhad of rubübiyya, he is in fact referring to one and the same act of witnessing.

\footnotetext{
63 Al-Wāsițī, Qācida fìmažăhir al-shuhūd, pp. 141-142.

64 Al-Wāsițī, Umdat al-țullāb, p. 211.

65 Al-Wāsițī, al-Sirr al-mașūn, p. 5o.

66 Al-Wāsițī, Miftāḥ al-márifa, p. 266.

67 For the proof that al-Wāsiți viewed rubūbiyya and qayyūmiyya as synonyms, see the above quote from 'Umdat al-țulāab, p. 211, and also: Qāंida fì sulük al-awliyā', pp. 164-165, where he speaks of witnessing qayyumizya, "during which the servant concedes to be guided by servitude, humble before the principles of rubūbiyya." He also clearly connects both terms in: Qāंida fı̈mazāhir al-shuhüd, p. 141.
} 
If ilāhiyya required that the sālik reflect on God's Self-manifestation in the nușūs, rubübiyya requires that he reflect on God's actions ( $\left.a f^{\prime} \bar{a} l\right)$ that constantly manifest in the created realm. ${ }^{68}$ In Madkhal ahl al-figh wa-al-lisān al-Wāsițī states that

[h] e should reflect "... on the dominion of the heaven and of the earth, and what things God has created" [Q. 7:185] such as the sun and the moon, the stars and celestial bodies that circulate, the winds that blow, and the seas [waves] that crash. This will open him up to intellectual knowledge ( ${ }^{\mathrm{i}} \mathrm{im}$ ) of the origination and procreation of existents, descendants one after the other. When his thought is immersed in this, the light of intimate knowledge (márifa) will appear to his innermost secret (sirr) by means of reflection on these actions. Now this is what is called ma'rifa of God ('AJ) through His actions, which is above [mere] faith in Him. ${ }^{69}$

In other words, ma'rifa of God's lordship pertains to intimate knowledge of the activity in the creation of the earlier-mentioned category of divine attributes called 'active attributes' (șifät fíliyya). According to al-Wāsițī, this knowledge brings one to understand that nothing moves or stands still, nothing contracts or expands, nothing is lowered or raised except that God is its Doer through these attributes; all emanates from His creative power (qudra).${ }^{70}$ So, he says, when the sālik becomes a knower ('ärif) of these meanings (ma'ānī) and its realities thus become unveiled, then all existents take him back to God, so that the creation no longer veils him from its Creator. ${ }^{71} \mathrm{He}$ then witnesses that God sustains all existents, which may cause him to become absent from them altogether as he only sees God's will unfold by them. When this persists he ascends to what al-Wāsiți calls the station (maqām) of witnessing lordship. ${ }^{72}$

Like the witnessing of divinity, he teaches that this degree is brought to realization by means of specific practices. These fall under the category he calls 'servitude ('ubüdiyya) of lordship,' which he discusses quite extensively throughout his writings. A maxim he very frequently repeats is that the sālik must completely reject the notion of having any choice or self-direction (tark

\footnotetext{
68 Al-Wāsițī, Qā'ida fì bidāyāt al-awliyā', p. 175.

69 Al-Wāsițī, Madkhal ahl al-figh, p. 78.

70 Al-Wāsițī, Miftāḥ al-ma'rifa, p. 266; 'Umdat al-țullāb, p. 211; Qā'ida fì sulūk al-awliyā', pp. 164-165; Q̄̄ंida fi bidāyāt al-awliyā', p. 174.

71 Al-Wāsițī, Qā'ida fìmazāhir al-shuhūd, p. 142.

72 Al-Wāsițī, Qāंida fí al-farq bayna mushāhadat al-qayyūmiyya wa-al-tahaqquq bihā, p. 263; Qā'ida fì mazāhir al-shuhūd, pp. 142-143.
} 
al-ikhtiyār wa-al-tadbīr) to compete with God's decree. ${ }^{73}$ After all, he says, "with respect to [God's] direction the servant's self-direction is a frivolity that comes from his human nature (bashariyya) due to being blind to [God's] sustainment (qayyümiyya)." ${ }^{74}$ Seeing that autonomy and independency do not truly exist, al-Wāsițī sees no other choice but to trust in God's decree (tawak$k u l$ ) and commit all affairs to Him (tafwie $)$ ), as alluded to by the Qur'anic words "the affair belongs entirely to God (al-amr kulluhu li-lläh)" [Q. 3:154]. ${ }^{75} \mathrm{He}$ argues that when the meaning of this verse becomes firmly established in the heart, the sālik will come to understand its reality and become one in need (faqir) of his Master with his entire being. ${ }^{76}$

All this is aimed at what he refers to varyingly as the 'unification' (ittihād), 'union' (jam ), or 'conformity' (muwäfaqa) of the sālik's will with the divine will (al-iräda), a state he considers the utmost degree of realizing God's lordship. ${ }^{77} \mathrm{He}$ describes those who reach this as follows:

The majority of their affair is conformity (muwäfaqa) [with God's will] regarding all things - or rather, it is annihilation $\left(\right.$ fan $\left.\bar{a}^{\prime}\right)$ in conformity without conformity, by the divine decrees (ahkām) that flow upon them from their sources. They perceive these, ever depending on the good of [God's] direction (tadbir) [of their affairs], carrying out His commands and fleeing from His prohibitions by implementing what He revealed amongst them, which withholds them from [doing] what He dislikes.

The sālik's rejection of ikhtiyār and tadbìr are mentioned in al-Wāsițìs al-Sirr al-mașūn, pp. 61-62; Qā'ida fì bayān 'amal yawm wa-layla, pp. 74-76; Qā'ida fì tasfiyyat al-akhlāq,

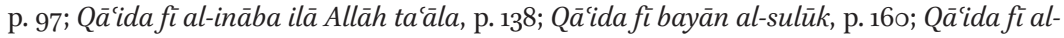
umūr allatīyanbaghī an takūn hamm al-sālik, p. 196; Qā'ida fì al-umūr al-muwașșila wa-al-

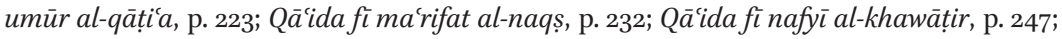
Qāंida fì al-jidd wa-al-ijtihād, pp. 249-25o; Q̄̄ंida fì dhikr al-karāmāt al-mu'ajjala, p. 286; Q̄̄ंidat al-rūhānniyyāt, p. 296; Qawā'id al-nubuwwāt, p. 301; Qā'ida fì al-șifät, p. 322; Talqüh al-afhām, p. 162; Miftāh al-ma'rifa, p. 269.

74 Al-Wāsițī, Qã ida fì al-umūr allatìyanbaghī an takūn hamm al-sālik, p. 197.

75 For references to tawakkul and tafwị̀, see al-Wāsițīs Miftạh al-márifa, p. 266; Madkhal

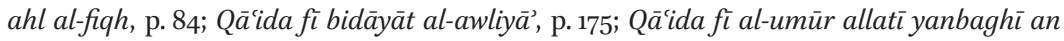
takūn hamm al-sālik, p. 197; Qāida fì al-umūr al-muwașșila, p. 223; Qā'ida fì márifat al-naqș, p. 237; Qā'ida fì nafȳ̄ al-khawāțir, p. 246; Qāंida fì al-jidd wa-al-ijtihād, p. 249; Qāंidat al-rūhāniyyāt, p. 296; Qawā'id al-nubuwwāt, p. 301.

76 The notion of becoming in need of God by realizing rubūbiyya is stated in al-Wāsițīs Qāida min 'alāmāt al-tahaqquq bi-al-qayyūmiyya, p. 169, and in Madkhal ahl al-figh, p. 84.

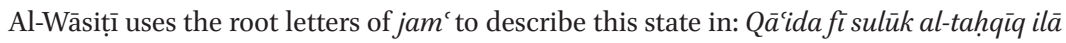

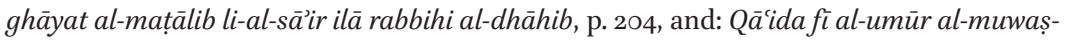

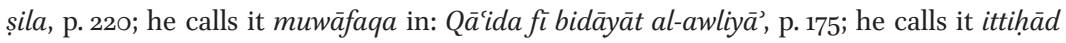

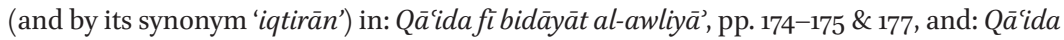
fì al-farq bayna mushāhadat al-qayyūmiyya, p. 264. 
Hence, [all] they do is for Him and through Him, and they perceive His disposal (tașrîf) of them in their deeds. So glory be to the Doer of what He desires! All those who are servants in His hand serve Him in this domain (mawtin) through the acts of servitude towards [His] lordship. ${ }^{78}$

The acts of servitude towards God's lordship are the above-mentioned practices of leaving one's choice and self-direction and trusting in Him and committing one's affairs to Him. Al-Wāsiți believed that when this servitude is mastered by the sālik, God's creative power (al-qudra) will take a hold of him; he thereby separates from his own 'self' (infișäl 'an al-nafs) by connecting with God spiritually (al-ittișāl al-mánawù̄). As this occurs, al-Wāsițī says the sālik will continue to heed the divine decree and command without being attentive thereof, for God, the Actor (al-fāil), becomes one and the servant merely acted upon (munfa $\left.{ }^{c} i l\right) .{ }^{79}$ This appears to be what is intended when he spoke of those who reach annihilation $($ fana $\vec{a})$ in conformity without conformity, which we may understand as a state wherein one's finite human will conforms with God's eternal will, so that it is blotted out in the will of God. Consequently, one can no longer speak of conformity, since only the will of God remains.

When witnessing lordship is thus realized in combination with divinity, alWāsițī considers this the fulfilment of "You alone we serve, You alone we ask for help" [Q. 1:5], the supplication from the first chapter of the Qur'an recited in each ritual prayer. He explains that the first half of this Qur'anic verse is put in effect by giving God's ilähiyya its due through the affirmation of the message (al-risāla) revealed to His Prophet and practicing its rules and regulations; the second half is put in effect by giving God's rubübiyya its due through the affirmation of Him as the sole Director of the creation and thus the sole source of succor. ${ }^{80}$ For al-Wāsițî, divinity and lordship are thus interconnected and in need of one another, so that the sālik's journey remains incomplete as long as one of the two is realized and witnessed without the other. It is only in combination that they are brought to perfection. ${ }^{81}$ As we have thereby reached the end of our analysis of the first two categories of witnessing, we can now point out where al-Wāsiți’s conception of them appears to draw from the teachings of his shaykhs.

\footnotetext{
78 Al-Wāsițī, Qā'ida fì bidāyāt al-awliyā', p. 175.

79 Al-Wāsițī, Qā'ida fì al-farq bayna mushāhadat al-qayyūmiyya wa-al-tahaqquq bihā, pp. 263-264; also clearly alluded to in: Lawä̀ih min qawā'id ahl al-zaygh, p. 13 o.

8o Al-Wāsițī, 'Umdat al-țullāb, p. 211; Miftāh al-ma'rifa, pp. 265-266.

81 Al-Wāsițī, Qā'ida fì mazāhir al-shuhūd, p. 143; Miftāh al-ma'rifa, pp. 266-267; Qā'ida fì sulūk al-tahquìq ilā ghāyat al-mațālib, pp. 200-201.
} 


\section{Al-Wāsițìs Shaykhs and Their Teachings Regarding Divinity and Lordship}

First, when it comes to servitude of God's lordship specifically, it is evident that he integrated the Shādhilī method of rejecting one's human choice and selfdirection, taught to him by Najm al-Dīn. ${ }^{82}$ We have seen in chapter 2 that this was indeed a characteristic element of the doctrine taught amidst the early Shādhiliyya.

Furthermore, when it comes to the notion that the unification and conformity of one's human will with the divine will is the utmost degree of realizing lordship, we find that al-Wāsiți probably relied on Ibn Taymiyya. He is likely speaking of his Hanbalī master when he writes that

[our] teacher (may God have mercy on him) has mentioned an issue (mas'ala) that I had forgotten about until a reminder from God ('AJ) occurred to my mind. It is as follows: There are people whose utmost degree is servitude ('ubüdiyya), but some of them ascend with servitude to something else altogether - and that is the right course! Indeed, there are some who travel the way [unto God] until they become intimately acquainted [with Him] (man yasluku hattāya'rifa). When this happens and they know the realities of the divine attributes, then these blot out their own will and their desire unifies with their Master's desire, thus becoming one - and that is His desire [alone]. ${ }^{83}$

Although it may be argued that the words "may God have mercy on him" suggest that a different teacher is intended - since Ibn Taymiyya outlived al-Wāsiți - I believe that this invocation may have been added later by a copyist. This is supported by the fact that Ibn Taymiyya actually held this very same position regarding conformity with the divine will, which he expressed as follows, in words very similar to those stated by al-Wāsiți above: "As for the servant knower of God, his desire is unified with the desire of God, so that he only desires what God desires ..." 84 In fact, the shaykh al-Islām considered this a distinct

82 This observation has also been made by Geoffroy, "Le traité de soufisme," pp. 87-88.

83 Al-Wāsițī, Qã ida fíal-farq bayna mushāhadat al-qayyūmiyya wa-al-tahaqquq bihā, p. 266.

84 Ibn Taymiyya, $M F$, vol. 11, p. 77: "wa-al-'abd al-'ârif bi-'llāh tattahidu irādatuhu bi-irādat Allāh bi-ḥaythu lā yurīdu illā mà yurīduhu Allāh." Compare this with the last sentence of the above quote from al-Wāsițī, which reads: "wa-'ttahadat irādatuhu bi-irādat mawlāhi fa-șārat wāhida wa-hiyya irādatuhu." I am indebted to Yahya Michot for pointing out the importance of muwāfaqa in the doctrine of Ibn Taymiyya. It has also been noted by Bell, Love Theory, pp. 76 \& 84 . 
feature of the so-called 'friends of God' (awliy $\bar{a}$ 'Alläh), as implied in al-Tuhfa al-Irāqiyya:

God (T) does not honor His servant with a miracle (karāma) more magnificent than his conformity (muwäfaqa) with what He loves and pleases Him, and that is obedience to Him and His Messenger, friendship with His friends, and enmity towards His enemies - such are the friends of God concerning whom God states: "Indeed, the friends of God will feel no fear and know no sorrow - they are those who have faith and piety" [Q. $10: 63-64] .^{85}$

Besides the notion of conformity, al-Wāsițī's theological basis for the witnessing of ilāhiyya and rubübiyya was in all likelihood adopted from Ibn Taymiyya as well. The latter is well known for distinguishing between both terms in his understanding of divine unity (tawhìd).${ }^{86}$ It was in all likelihood also Ibn Taymiyya's very own interpretation that the words of the fifth verse from the first chapter of the Qur'an embody the essence of divinity and lordship. The following commentary he gives on the verse correlates perfectly with the explanation of ilähiyya and rubübiyya as found in the works of al-Wāsiți:

[God's] statement "You alone we serve" refers to serving Him by what His divinity (ilähiyya) requires - such as [realizing] love, fear, and hope [in Him], and [observing] the command and prohibition - and "You alone we ask for help" refers to what His lordship (rubübiyya) requires - such as trusting [in Him], committing [all affairs to Him] (tafwìd), and submitting [to Him] (taslim ) - for the Lord (ST) is the Master! ${ }^{87}$

When the two halves of this verse are thus combined, Ibn Taymiyya concludes after this passage, they bring together all the secrets of the Qur'an. Like alWāsițī, he then goes on to emphasize that it is therefore necessary to witness divinity and lordship together, with the former referring to witnessing the revelation of God's religion ( $a l$-amr al-shar $(\bar{l})$, and the latter to witnessing God's acts of bringing into existence as He wills (al-amr al-kawnī al-irādī $){ }^{88}$ Also similar to al-Wāsiți in this regard is Ibn Taymiyya's position that God some-

85 Ibn Taymiyya, al-Tuhfa al-irāqiyya, p. 335.

86 The distinction between the unity of ilāhiyya and rubūbiyya as a typically Taymiyyan construction has been studied before. See for instance: Meier, "The Cleanest about Predestination," pp. 322-324; Hoover, Ibn Taymiyya's Theodicy, pp. 120-122.

87 Ibn Taymiyya, $M F$, vol. 1, p. 89 .

88 Ibid. pp. 89-9o; see also: $M F$, vol. 2, p. 320. 
times speaks with the attribute of divinity through the Qur'anic words that specify the religion He has revealed (al-kalimät al-diniyya), and sometimes with lordship through the Qur'anic words by which He brings into existence (al-kalimät al-kawniyya). ${ }^{89}$ Given that we know this to be a distinctly Taymiyyan approach to traditionalist theology, there remains little doubt that alWāsițīs teachings on divinity and lordship appropriated elements from the teachings of his Ḥanbalī master.

\subsection{Other Degrees of Witnessing by the Heart}

After divinity and lordship al-Wāsițī also designates 'withness' (al-maciayya) and 'divine judgment' (al-dayyanniyya) as degrees of witnessing by the heart that precede the final stage of sulük. Although they only sporadically appear in his writings, his elaboration on both degrees shows that he did at one point consider them to hold some significance for his students. Because we have no way to recover the chronology of his oeuvre, it remains impossible to say whether his limited attention to them should be taken as an indication that their place in his teachings changed over time. It is useful to note that, since neither act of witnessing appears to have relied directly on the teachings of his shaykhs, they were most likely the product of his own insights into the discipline of Sufism. So, for the sake of keeping our overview of his Sufi doctrine as comprehensive and accurate as possible, both will be briefly summarized here.

As for withness, in two separate treatises our Iraqi Sufi specifically mentions it as the final degree of witnessing by the heart from which the sālik may proceed to the most complete degree of the spirit. In both cases he states that it follows from establishing union between the attributes of divinity and lordship. ${ }^{90}$ When withness comes in sight on the basis of this union, the sälik is supposed to witness that God in His highness and aboveness over the Throne encompasses all creatures by His knowledge, hearing, sight, and nearness to them, as alluded to in the verse "He is with you wherever you are" [Q. 57:4]. ${ }^{91}$ This realization is portrayed by al-Wāsițī as follows:

89 For this distinction between the categories of divinity and lordship in the Qur'an, see for instance Ibn Taymiyya's; $M F$, vol. 2, pp. 408 \& 452; $M F$, vol. 10, p. 352; and especially his al-Furqān bayna awliyăa al-rahmān wa-awliy ă al-shayțān in $M F$, vol. 11, pp. 265-270, where he gives many examples of both categories. We have noted above that al-Wāsiṭi applies this distinction - though in a slightly different wording - in Miftāh al-márifa, p. 266, where he speaks of al-kalimāt al-taklīfyyāt and al-kalimāt al-takwìniyyāt in the Qur'an.

$90 \quad$ Al-Wāsițī, Miftāh al-márifa, p. 267; Madkhal ahl al-figh, p. 79 .

91 Al-Wāsițī, Risālatuhu ilā al-shaykh al-Maghribī, p. 111; 'Umdat al-țullāb, p. 205; Madkhal ahl al-figh, p. 79 . 
It is then, after having been desolate, that the servant reaches intimacy [with God] and becomes a companion (samir) for Him through the emanation of intimate knowledge of Him upon realizing the attribute of withness (min fayd márifatihi hina tahaqqaqa bi-sifat al-maciyya). Thus, he will not see between himself and his Lord any remoteness that veils him. Through spiritual taste and ecstasy - and not by eyesight or intellectual knowledge - he will find that [God] encompasses him and holds him by the forelock, and that He sees the darkest corners of his innermost secret: He is with him wherever he is! ${ }^{92}$

As for witnessing divine judgment, al-Wāsițī defines it as becoming unveiled to God's attribute of judgment (șifat al-dayyān) as it will manifest in the Afterlife when mankind is resurrected for the reckoning (hisāb). ${ }^{93}$ Like the witnessing of withness, we find that it is elaborated upon in two treatises only, both of which mention it specifically after the degrees of divinity and lordship. In one of these he imagines how God may manifest Himself to the sālik by this attribute in the Qur'an:

"I am God, there is no deity but Me" [Q. 20:14], the One Who gathers [all] people "for a Day about which there is no doubt" [Q. 3:25], when I'll dispense "each soul for that it has earned" [Q. 40:17], and I will not wrong "so much as the smallest speck; and if it be a good deed He will double it" [Q. 4:4O]; and "whosoever does evil shall be recompensed for it" [Q. 4:4O], and I "shall set up the just balances for the Resurrection Day, so that not one soul shall be wronged anything!" [Q. 21:47]!94

When intimate knowledge (ma'rifa) of this attribute becomes such that it is constantly witnessed, al-Wāsiți holds that this should motivate the sālik to perform good works and subdue himself from transgressing God's restrictions out of fear for the horrors that will be seen on Judgment Day. Fear ought to be balanced by hope, he says, for the intimacy and love that God will grant His loyal servants on that day. Well aware that this resembles his advice to reflect on God's promise and threat for the witnessing of divinity, al-Wāsiți notes that this

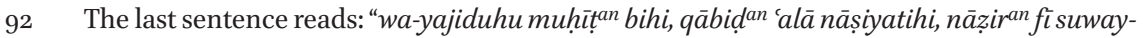
dā’ sirrihi - dhawq ${ }^{a n}$ wa-wajd ${ }^{a n}$ lā nazararan wa-ilm ${ }^{a n}$ - huwa ma'ahu haythu mā kāna." Cf. al-Wāsițī, Miftāh al-márifa, p. 267.

93 Al-Wāsiṭ̂, Qā'ida fì mazāhir al-shuhūd, p. 143.

94 Ibid. pp. 143-144. 
particular form of fear and hope belongs exclusively to the witnessing of divine judgment. ${ }^{95}$

The Spirit's Witnessing of Union (al-Jam') and Singularity (al-Fardāniyya)

As any travel plan, al-Wāsițîs directions through all the stages we have thus far described are given for the sole purpose to guide unto the destination of the journey that sulük represents. This is the overarching purpose of his entire oeuvre. For him, this destination is reached in the degree of witnessing that he sometimes designates by the term 'union' (jam) and sometimes by the term 'singularity' (fardāniyya), both of which are clearly meant to refer to one and the same experience. As we have found him do several times before, he describes a tajalli that conveys how he imagines God may manifest Himself to the one who reaches this final degree:

"I am God, there is no deity but Me" [Q. 20:14], the Master of majesty and glory, singular in singularity (fardāniyya), one in oneness (wahdaniyya), Who encompasses all the attributes of perfection and beauty (al-jāmic lijamīi șifät al-kamāl wa-al-jamāl). I am the greatest Lover, Who through the similitude of these attributes draws near unto those who love Me, who are subject to rapture from Me and burn with desire for Me. I disclose My beauty (jamālī and majesty (jalālī) to them so that their innermost secrets (asrār) become filled with their traces (āthār) and their spirits (arwāh $)$ expanded due to the rays of their lights! ${ }^{96}$

In line with the previous tajalliyyāt we have quoted, we will once more find that al-Wāsiți clearly chose his words carefully, and effectively described what are, in his view, some of the core elements of the final degree of witnessing.

Except for one treatise, al-Wāsițī consistently states that the final mashhad is usually preceded by annihilation $\left(f a n \bar{a}^{\prime}\right) \cdot{ }^{97}$ On two occasions he defines $f a n \vec{a}^{\prime}$ as the Sufi's "self-effacement from being aware of his own existence due to the

95 Ibid. pp. 143-145; Qāंida fì al-șifät, p. 322.

96 Al-Wāsițī, Qā'ida fı̀ maz̄ăhir al-shuhūd, p. 146.

97 In the following titles al-Wāsițī either directly or implicitly states that fana $\bar{a}^{3}$ precedes the witnessing of fardāniyyaljam': 'Umdat al-țullāb, p. 212; Miftāh al-ma'rifa, pp. 267-268; Qāंida fì mazāhir al-shuhūd, p. 145; Qā'ida min 'alāmāt al-tahaqquq bi-al-qayyūmiyya,

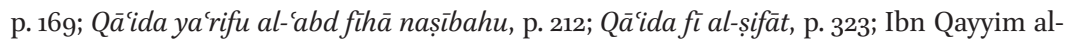
Jawziyya, Shifā’ al-'alīl, p. 16, quoted from al-Wāsiți’s Sharh Manāzil al-sā̉irīn. The only exception is in Madkhal ahl al-figh, p. 79, where he states that: "During [the witnessing of $j a m$ ] one is endowed with annihilation $\left(f a n \vec{a}^{\prime}\right)$ followed by subsistence $\left(\right.$ baq $\left.\vec{a}^{\prime}\right)$, then with intoxication $(s u k r)$ followed by sobriety (șậw)." 
severity of his absorption in [God's] Presence." ${ }^{\text {98 }}$ While he himself never labels it as such, this would be what Ibn Taymiyya calls "annihilation in the unity of lordship" (fanā’ fì tawhìd al-rubūbiyya). ${ }^{99} \mathrm{Al}-W a \bar{s}$ iți is not exactly clear in that regard, but it seems from his writings that what he defines as losing awareness of one's existence may indeed ensue from witnessing lordship. As we have seen above, he taught that practicing servitude of lordship should establish a spiritual connection with God through which one's own human will unifies with the divine will, wherein it then becomes annihilated so that only the will of God remains. Whether this annihilation is intended by him as the one that comes before the final degree of witnessing is never explicitly stated. However, one does get the impression that this may be the case, since he does describe the utmost degree of rubübiyya as a state that is between annihilation (fan $\bar{a})$ and subsistence $\left(b a q \bar{a}^{3}\right)$, and that this "is the limit of the servant and his journey (sayrihi), after which remains reaching the Real $(\mathrm{T})$ through the pull of divine attraction $(j a d h b a)^{\prime \prime 100}$ - in other words, this is the last stage of sulük before reaching the final degree of witnessing. What exactly is meant by that will become clear below when we further elaborate on the way he characterizes the witnessing of fardāniyyaljam'. For now, it is important to know that, in his view, this particular stage is preceded by an experience of annihilation that appears to result from the spiritual connection with God, realized through the witnessing of lordship.

How this subsequently leads to the final degree of witnessing in al-Wāsițîs doctrine may best be illustrated on the basis of one of the rare instances where he attempts to describe this process as he envisioned it. In the quote that now follows, he refers to it as the witnessing of jam ' instead of fardāniyya, and he discusses it in relation to the realization of rubübiyya (referred to by its synonym qayyūmiyya):

As for an indication of the realization of jam, this is a subtle secret that may be mistaken for unification (al-ittiha $\bar{d}$ ) and be regarded as monism $(a l-w a h d a)$. However, this is not the case, for the Lord (ST) is Lord and the servant is servant, their existence being at variance with one another: One exists [in pre-eternity], the other is brought into existence. An

98 "iștilām al-wājid 'an al-shu'ūr bi-wujūdihi li-quwwat istighrāqihi bi-mawjūdihi," cf. al-Wāsițī, 'Umdat al-țulläb, p. 212; The term is similarly defined by him in Sharh Manāzil al-sä̀irīn, cf. Ibn Qayyim al-Jawziyya, Shifä’' al-'alīl, p. 16.

99 See for instance Ibn Taymiyya's $M F$, vol. 2, p. 314; vol. 3, p. 116; and several times in Fașl fi qawlihi "fa-hajja Ādamu Mūsā", vol. 8, pp. 303-37o, and vol. 10, p. 516.

100 Al-Wāsițī, Qā'ida fì al-umūr allatì yanbaghī an takūn hamm al-sālik, p. 197. Note that he uses 'qayyümiyya' as a synonym for rubübiyya here. 
indication of realizing jam ' after having realized qayyumizy a is that in the latter realization the branch connects to its root, so that it becomes the root that disposes over it, employing it as it pleases in accordance with its command and law. [The branch] is thus connected to this particular attribute, that being the attribute of qayyummiyya. From there it subsequently ascends until the branch's connection with its root subsists without being limited to this attribute alone. It then connects with the reality that encompasses all the divine properties (al-haqīqa al-jāmía li-jamīi al$n u \bar{u} t)$. Now, here the branch is connected with the entirety rather than with the attribute that is specifically associated with qayyummiyya alone. It is then that [the servant] realizes [jam '], so that he may only see [God], being realized, bewildered, and immersed in Him - as if he is Him at first, but then, in the end, there is only He (ka-annahu nafsuhu awwal an thumma laysa illa huwa ākhiran)! This resembles monism and unification in some respects - but God forbid it is that, for it is a unification of attributes and qualities (ittihāa wasfi naw'ì), whereas [the monists] refer to the unification of being identical in essence (al-ittihād al-'aynī al-dhātī). The people of truth (ahl al-haqq) know that, in spite of the former unification, God is [always] separate from His creation and high above them on the Throne. But the reason for this unification of attributes and qualities is the attraction of love (jädhib al-mahabba), because it is through his love that the lover is drawn near to his Beloved - which is a spiritual proximity, not an essential one (qurban mánawiyy ${ }^{a n}$ lā dhātiyy ${ }^{a n}$ ), for that will only come to pass in the Afterlife. ${ }^{101}$

In this passage the allegory of the branch is, of course, the servant, and that of the root God. After the first couple of lines, al-Wāsiți reiterates what we have seen earlier, namely, that it is through the realization of rubübiyya that a spiritual connection with God is established. After that, however, he starts to discuss the notion of union, and here we can make two observations regarding the way he understood the final stage in Sufism. First, he essentially defines what he understands by jam', and second, he discloses how this is brought about. We will clarify both observations on the basis of his other writings.

To begin, we must draw attention to al-Wāsițīs concern that, as a technical Sufi term to describe a kind of connection between the servant and God, what he understands as jam could be, and in fact has been, misused by Sufis to

101 Al-Wāsițī, Qāंida fì al-farq bayna mushāhadat al-qayyūmiyya wa-al-tahaqquq bihā, pp. 264-265. 
espouse the doctrine of incarnation and monism. ${ }^{102}$ In one of his refutations against the Akbarian school he actually addresses their use of the term directly, saying that "... they maintain that the essence of union ('ayn al-jam) signifies witnessing the existence of the Realasbeingidentical with [created] existents."103 In the earlier-quoted passage he likewise addresses this issue by stating that, for the monists, this kind of union signifies the unification of being identical in essence, al-ittiḩâd al-'aynī al-dhātī. Of course, he felt obliged to distance himself from such an understanding of the term, which he does in the same passage by defining it instead as a unification of attributes and qualities, ittihād wasfi naw i. But what does that mean?

Simply put, in al-Wāsițīs view the witnessing of union is to be connected spiritually - not physically - with the entirety of God's names and attributes. When union is witnessed, he explains, "everything that was separated (almutafarriqa $\bar{t}$ ) and the previous degrees of witnessing of the heart become united for the servant."104 It results in what he explained in the above quote as becoming connected to the reality that encompasses all the divine properties (al-haqìq a al-jāmi'a li-jamīi al-nu'üt), a term for which we can find several variations in his writings. The most common variation he uses is ' $a l$-amr al-kulli,'105 which we have come across a few times in our study already, and which is sometimes written in full as 'al-amr al-kullìal-jāmi' li-jamī'al-asmā' wa-al-sifiāt,' the complete reality that encompasses all the names and attributes. ${ }^{106}$ Other variations are 'the complete meaning that encompasses all the meanings and constituents' (al-ma'nāa al-kullì al-jāmi' li-jamì al-ma'ānīwa-al-juz'iyyāt) ${ }^{107}$ and 'the complete knowledge that encompasses all the meanings of the names and attributes' (al-ma'rifa al-kulliyya al-jāmi'a li-jamī'ma'ānīal-asmā'wa-al-șifät). ${ }^{108}$

102 As will become implicitly clear below, for al-Wāsițī, the 'mashhad al-jam ${ }^{\circ}$ refers to what the Sufis call jam'al-jam' or 'ayn al-jam'. Note that, in the technical vocabulary of the Sufis, the 'jam ${ }^{\circ}$ on its own is generally used as a synonym for $\operatorname{fana}_{\bar{a}}$, which is not how al-Wāsițī uses it in most cases as we will see.

103 Al-Wāsițī, Lawāmi al-istirshād, p. 95.

104 Al-Wāsițī, Madkhal ahl al-figh, p. 79; he also alludes to this in Qā'ida fì așnāf al-tảalluh, p. 155, where he describes the mashhad of fardāniyya as follows: "For [God's] companion, all that is separated from the Muhammadan traveler on the roads [towards arrival] becomes united" (fajitama'at li-șāhibihial-mutafarriqātmin sā̉ir al-țuruq al-Muhammadī). Al-Wāsițī, Rịhla, p. 50; Miftāḥ al-márifa, pp. 254 \& 274; Qā'ida fì așnāf al-ta’alluh, pp. 150151; Qāंida fì al-umūr al-muwașșila, pp. 216, 222, 224; Qāंida fì márifat al-naqș, pp. 231 \& 237; Q̄ं ida fì tajrìd, p. 252.

106 Al-Wāsițī, Talqūh al-afhām, p. 162; Q̄àida fì ma'rifat al-naqș, p. 231.

107 Al-Wāsițī, Qā'ida ya'rifu al-'abd fíhā nașībahu, p. 212.

108 Al-Wāsițī, Madkhal ahl al-fiqh, p. 79 . 
For al-Wāsitịi, all these terms signify that the final degree of witnessing pertains to God's essence - 'al-dhāt al-jāmi' li-jamī' al-șifät al-kamāliyya' - because it is His essence that encompasses all His perfect attributes. ${ }^{109}$ It is therefore why he also calls it the witnessing of fardäniyya, since 'singularity' for him alludes to the loftiness (jalāl), beauty (jamāl), glory (ikrām), and magnificence ('azama) of God's pre-eternal essence. ${ }^{110}$ After all, he elucidates using the Shādhilī maxim "He was and there was nothing with Him," so none can lay claim to singularity but Him. ${ }^{111}$ It is also precisely because this particular degree of witnessing is connected to the divine essence that he sometimes labels the one who reaches it a 'servant of God' ('abd Alläh) - in other words, one who serves 'Allāh', the all-encompassing name (al-ism al-jämi') of God's essence, and the source of all other names and attributes. ${ }^{112}$ Acknowledging that all creatures are, of course, God's servants, he clarifies that someone who becomes a servant in the truest sense of the word is set apart from the rest by having ascended from constituent degrees of witnessing (al-mashāhid al-juz'iyya) to the one degree that encompasses them all. ${ }^{113}$

But how is this degree brought to fruition? Earlier in the current section we found al-Wāsițī stating that the limit of sulūk is between annihilation and subsistence, after which there only remains ' jadhba', the pull of divine attraction. Likewise, we found that the unification that occurs when witnessing jam / fardāniyya comes from something he called 'jädhib al-mahabba', the attraction of love. In using such terms, our Iraqi Sufi clearly draws on the distinction between sulük and jadhb, a notion taught amidst the early Shādhiliyya of which we have made note in chapter $2 .{ }^{114}$

As opposed to all the previous degrees, al-Wāsițī held that the final witnessing can only be brought about by the favor $(f a d l)$ of God. ${ }^{115}$ In terms of terminology, it cannot therefore be reached by means of sulük, that is, the sālik's own effort to seek God. Describing the sālik, he says:

109 Al-Wāsițī, Miftāḥ al-márifa, p. 268.

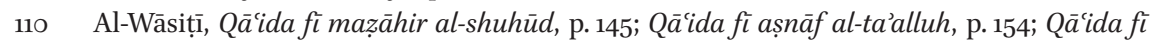
al-tajrīd, p. 252; Talqüh al-afhām, 162; al-Sirr al-Mașūn, p. 64.

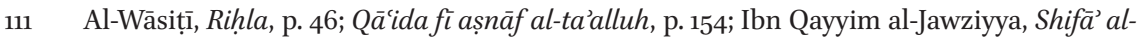
'alïl, p. 16, quoted from al-Wāsițīs Sharḥ Manāzil al-sāirìn.

112

Al-Wāsițī, Miftāh al-márifa, p. 269; Madkhal ahl al-figh, p. 80; Al-Wāsițī, Qā'ida ya'rifu al'abd fìhā nașibahu, p. 212.

113 Al-Wāsițī, Qā'ida ya'rifu al-'abd fihà nașībahu, p. 212.

114 This observation has also been made by Geoffroy, "Le traité de soufisme," p. 86.

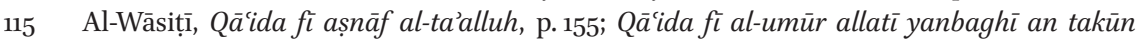
hamm al-sālik, p. 197; Q̄āida fì al-farq bayna al-ābid wa-al-mushāhid, p. 262; Madkhal ahl al-figh, p. 79 . 
There is [a great difference] between [the friend of God] and the lover who is [still] traveling unto God ('AJ) (al-muhibb al-sā̉ir ilā Allāh) by undergoing spiritual combat and struggles, taking himself to account, and guarding [his body parts]. [The latter] is restrained by these affairs, throwing himself into them heedlessly, thus traveling like someone who runs his face into thorns and rock. ${ }^{116}$

Although, al-Wāsiți admits, there are rare instances where God does choose a servant for nearness to Him by pulling him unto Himself without having first traversed the trajectory of $s u l \bar{u} k$, in most cases the previously described stages are required. ${ }^{117}$ In other words, it is principally after gradually progressing along the path, actively and persistently pursuing his destination, that God grants the sālik a rank of friendship (wilāya) with Him:

The first sign of this is a pull of divine attraction (jadhba) that seizes his spirit (rüh). This causes him to ascend unto the [world of] dominion (almalaküt) until he is taken beyond it through his spirit's ascension. He is then appointed a rank in the proximity [of God] through the spirit's vision ('iyān al-rüh). This is what is called 'arrival' (wuṣull), and what [came before] was the witnessing of the hearts through the lights of faith. ${ }^{118}$

Thus, when the sălik is chosen to become a friend of God (walī), his spirit ascends unto the world of dominion ('âlam al-malaküt), from where it continues to be drawn near unto God. Al-Wāsiṭi never clearly defines what the world of dominion is, but indeed he understands it as a synonym for the world of the unseen ('âlam al-ghayb/al-ghuyūb), or the world of spirits ('ālam al-arwāhh), as

116 Al-Wāsițī, Talqūh al-afhām, p. 163.

117 Al-Wāsițī describes this in Umdat al-țullāb, p. 202, where he says: "There are people whose flower precedes the leaves of their tree. Such are those who are pulled by divine attraction (al-majdhübūn), who are overwhelmed by the glimmers and fundamentals of the divine realities in the beginning of the spiritual path (tazhuru 'alayhim lawäih wa-mabādi' al-haqā'iq fì awwal al-sulūk). As for the majority, their flower only becomes visible after completing the states of their tree by perfecting the states of knowledge and practice."

118 Al-Wāsițî, Miftāh al-márifa, p. 269. He describes the process of jadhb in a similar way in: al-Sirr al-mașūn, p. 65: "As the spirit flies, it enters the world of dominion ('âlam al-mala$k \bar{u} t)$ and encounters the pure unseen $(a l-g h u y \bar{u} b)$. When they [the majdhūbūn] reach this utmost degree, flying with their spirits unto the seats of truthfulness (maqāंid al-șidq) and the abodes of proximity (mawātin al-qurb), they become enraptured by love for the divine essence and are allotted the witnessing of singularity (mashhad al-fardāniyya)." 
opposed to the sensible, perceptible world of witnessing ('álam al-shahāda). ${ }^{119}$ When ascension has thus occurred, the titles of 'sālik' or 'sā'ir' no longer apply, and our Iraqi Sufi speaks instead of the majdhūb, someone whose spirit God has pulled unto Himself.

It is when the spirit has reached the utmost end in the world of the unseen that the final and most exalted degree of witnessing is perceived. Al-Wāsiți holds that all previous degrees perceived during the process of sulūk were but veils of light (hujub nürāniyya), because they were degrees of witnessing by the heart (mashāhid qalbiyya), "and the hearts cannot go beyond the divine attributes." 120 Only through divine attraction of the spirit can the union and singularity that pertains to God's essence be witnessed - which is why al-Wāsiți designates it as the one degree of witnessing that is of the spirit. ${ }^{121}$

He describes the actual witnessing itself as being annihilated from temporal existence (al-fanā' 'an al-wujūd al-mudmahill) while subsisting through God, the true reality of existence (al-baqāa bi-al-wujūd al-haqiquī). In spite of being annihilated, those who reach this station remain constantly in servitude in accordance with the revealed law, because God takes care of them by granting them a protected existence. ${ }^{122}$ As many Sufis had done before him, he bases this notion on the famous hadìth qudsī, according to which God said:

119 Al-Wāsițî, Qã̄ida fì bayān 'amal yawm wa-layla, p. 76; Qã̄ida fì i'tibār ahl al-khayr waghayrihim, p. 136; Qāंida fì dhikr al-karāmāt al-mu'ajjala, p. 285; al-Sirr al-mașūn, p. 65. Here, al-Wāsițī clearly relies on cosmological terminology commonly used by classical Sufis who distinguish between the álam al-mulk (the world of the kingdom, i.e. perceptible world) and the 'ālam al-malakūt; see for instance: al-Ghazālī, Ihyä’ vol. 1, p. 269. Such vocabulary was certainly also used among the early Shādhiliyya, as attested to by: al-Iskandarī, Ibn 'Ațā' Allāh (m. 709/1309) et la naissance, p. 185, and by the same author, Tartīb al-sulūk, p. 47 .

120 Al-Wāsițī, al-Sirr al-mașūn, p. 64; see also: Qã̄ida fì maz̧āhir al-shuhūd wa-al-márifa, p. 145 .

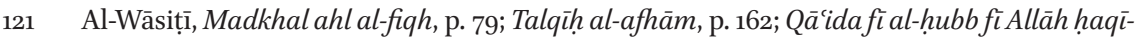

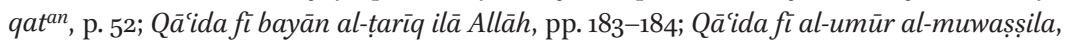
p. 224; Qã̄ida fì al-tajrìd, p. 252; Qāंida fi qawlihi ta'ālā "Inna Allāha ishtarā min almu'minin anfusahum wa-amwālahum bi-anna lahum al-janna", p. 293.

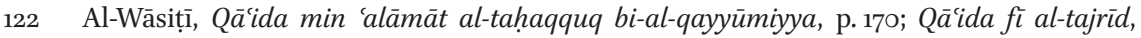
p. 253; Q̄̄ंida fì al-farq bayna al-ābid wa-al-mushāhid, p. 259; Madkhal ahl al-figh, p. 80; 'Umdat al-țullāb, p. 212; Ibn Qayyim al-Jawziyya, Shifä’’ al-'alül, p. 16, quoted from al-Wāsițìs Sharh Manāzil al-sāirìn; also alluded to in: Talqūh al-afhām, p.163. It is surely no coincidence that al-Wāsițī uses the verb ' $(y a)$ tawallă' when he speaks of God taking care of His servant; this is the same verb used in the Qur'anic verse "He [God] takes care of the righteous" (wa-huwa yatawallā al-șălihīn) [Q. 7:196], which was interpreted as a reference to the majdhüb in al-Iskandarìs Lațăif al-minan, p. 27, as noted in chapter 2. 
My servant continues to draw near to Me with supererogatory deeds (nawäfl) until I love him. When I love him, I will be his hearing with which he hears, his sight with which he sees, and his hand with which he strikes. If he asks Me [for something] I will surely give it to him, and if he seeks My refuge I will surely place him under My protection. ${ }^{123}$

To censure the Akbarian school once more, al-Wāsiți emphasizes that this is not in the sense that Creator and creature come to share one and the same existence, but rather that God's existence covers the servant's human existence, which consequently becomes like a phantom (khayāl) and a shadow $(z i l \bar{a} l) .{ }^{124}$ In a somewhat more poetic, metaphorical portrayal, he describes this experience as "the morning of divine unity (tawhid) that comes up from the horizon of the darkness of existence, which thence disappears little by little, like the night disappears from the light of dawn." 125 God should then make Himself known to His servant with knowledge of Him by Him (ma'rifatuhu bihi), which, al-Wāsițī says, "embodies everything that is made manifest of divine knowledge and the categories of [God's] names and properties - not by what the knower knows, but rather by what is known by the Known Himself as He is." ${ }^{26}$ In his understanding, this is what the Sufis call the 'station of subsistence' (maqām al-baqā'), 'the union of union' (jam' al-jam') - and its synonym 'the essence of union' ('ayn al-jam ) - or 'the second separation' (al-farq althānī). ${ }^{127}$

123 For the ḥadīth, see: al-Bukhārī, al-Jāmic al-musnad al-șaḥịh, vol. 8, p. 105. Al-Wāsițī quotes it in: Q̄ं ida fí bayān al-sulūk, pp. 157-158. He refers to it without quoting it word for word in: 'Umdat al-țullāb, p. 212; Miftāh al-márifa, p. 269; and: Ibn Qayyim al-Jawziyya, Shifä' al-'alīl, p. 16, quoted from al-Wāsițì's Sharh Manāzil al-sāirì̄n.

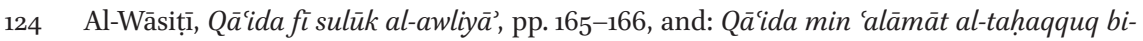
al-qayyūmiyya, pp. 169-170; Qā'ida fì al-farq bayna al-ābid wa-al-mushāhid, p. 26o; Qāंida fì al-farq bayna mushāhadat al-qayyūmiyya wa-al-tahaqquq bihā, p. 263.

125 Al-Wāsițī, Qāiida fì al-farq bayna mushāhadat al-qayyūmiyya, p. 263; a very similar wording is found in: Ibn Qayyim al-Jawziyya, Shifä' al-'alīl, p. 16, quoted from al-Wāsițīs Sharh Manāzil al-sāirìn.

126 "tandariju fì hādhihi al-ma'rifa jamīi mā abraza min al-ma'ārif wa-șunūf al-asmā’’ wa-alnu'ūt bi-mā ya lamu al-ma'rūf nafsuhu kamā huwa," cf. al-Wāsițīs Qã'ida fì bidāyāt alawliya $\bar{a}^{3}$, p. 176; for similar descriptions of this degree of márifa, see his Madkhal ahl alfiqh, p. 78; Qāंida fì mazāhir al-shuhūd, p. 145; Qā'ida fì al-farq bayna al-ābid wa-almushāhid, pp. 258-259.

127 For several references to $b a q \bar{a}^{\prime}$ in the context of the final degree of witnessing, see: alWāsițī, Qāंida fì mazāhir al-shuhūd, pp. 145-146; Qã̄ida fì al-farq bayna al-ābid wa-almushāhid, p. 260; 'Umdat al-țullāb, p. 212; Miftāh al-ma'rifa, p. 267; for him calling it 'ayn al-jam', see: Lawāmi' al-istirshād, p. 95; for him calling it jam' al-jam` and al-farq al-thānī, see: Q̄àida ya'rifu al-'abd fíhā nașībahu, p. 212. 
For this concept he relies heavily on what classical Junaydian doctrine says regarding the final stage of the Sufi path. While his choice to categorize it under the heading of jam'/fardāniyya may be rooted in later Sufi theory, and perhaps in part even his own creative thought, his description of the experiences during this stage of witnessing was undoubtedly based on the classical teachings of the Baghdad school of Sufism. What he describes is identical with what Éric Geoffroy has called the "double experience of fan $\bar{a}^{\prime} \mid b a q \bar{a}$," wherein the Sufi is "with God and with the world at the same time," which al-Junayd reportedly regarded as the very definition of Sufism. ${ }^{128}$ Al-Wāsițī would probably have been exposed to this concept among the Baghdadi Sufis already, and it was certainly taught amidst the early Shādhiliyya as well.

In conclusion to the topic at hand, we must make special note of the prominent role he allots to love in relation to the final degree of witnessing. ${ }^{129}$ Both the path towards it and the actual witnessing itself revolve around love. We have already seen that he held that the sălik's servitude of the divine names and attributes necessarily goes hand in hand with love for them; but it is also on account of this very servitude that God ultimately comes to love him back and decides to draw him unto Himself by divine attraction. After being chosen by God, the majdhüb, in turn, desires nothing but the nearness of his Beloved, which is depicted as "a whir in his chest that is like the whir of [a boiling] kettle, for his heart is boiling with love, reverence, thirst, and longing for the vision [of God] (al-'iyann)."130 It is then, with the spirit as its locus, that he acquires what al-Wāsiți calls 'distinguished love' (al-mahabba al-khạș̣a), which is love for the divine essence. It is said to flow forth from the station of subsistence that annihilates the servant from all that is not God, so that, in effect, his love for God becomes nothing other than God's love for him. ${ }^{131}$ Such is the state

128 Geoffroy, Introduction to Sufism, p. 15. For a good elaboration on the classical Sufi terms al-Wāsițī uses and how they all refer to the final station on the Sufi path, see for instance: Ali Hassan Abdel-Kader, The Life, Personality and Writings of al-Junayd: a Study of the Third/Ninth Century Mystic (London: Gibb Memorial Trust, 1976), p. 93; Michel Chodkiewicz, An Ocean Without Shore: Ibn 'Arabī, the Book, and the Law (Albany, NY: State University of New York Press, 1993), pp. 87-88; 'Alī b. 'Uthmān al-Hujwīrī, Revelation of the Mystery: (Kashf Al-Mahjúb), trans. Reynold Alleyne Nicholson (Accord, NY: Pir Press, 1999), p. 39 .

129 The importance of love in al-Wāsițī's writings has also been noted by Geoffroy, "Le traité de soufisme," pp. 86-87.

130 Al-Wāsițī, Talqūh al-afhām, p. 162.

131 On al-mahabba al-khāșṣa, see al-Wāsițī's 'Umdat al-țullāb, p. 212; al-Sirr al-mașūn, pp. 64-

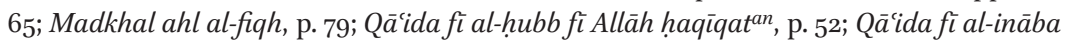
ilā Allāh ta'āla, p. 138; Qā'ida fì mazāhir al-shuhūd, p. 145; Qāंida min 'alāmāt al-tahaqquq bi-al-qayyūmiyya, pp. 169-170; Qāंida fì márifat al-naqș, pp. 231 \& 237; Q̄àida fì nafȳ̄ alkhawātir, pp. 246-247. 
al-Wāsițī describes as 'belovedness' (maḩbūbiyya) and 'intimate friendship' (khulla), which marks the true end of the spiritual journey. For as we observed at the beginning of the previous chapter, he essentially views the wali as someone who has become God's beloved (mahbüb) and intimate friend (khalīl). ${ }^{132}$

It is worth mentioning that while love is also allotted a central role by Ibn Taymiyya as the very foundation of the servant's relationship with God, his understanding of wilaya is in some respects quite different from that of alWāsiți. ${ }^{133}$ For the greater part this has to do with a completely different approach to terminology. For instance, our Iraqi Sufi occasionally calls those who become God's friends in the final degree 'the singular ones' (al-afräd) or 'the substitutes' (al-abdāl/budalä), titles for the awliy $\bar{a}$ ' that were quite common among the Sufis. ${ }^{134}$ I have not found Ibn Taymiyya ever mention the first term in this sense, and he problematizes such a use of the second term on several occasions. ${ }^{135}$ Instead, his doctrine on friendship with God relies solely on Qur'anic terms. In his view, all believers who abide by God's law are, strictly speaking, His $a w l i y \vec{a}$. However, he recognizes that the Qur'an distinguishes between two ranks: first, the rank of the common friends designated as 'the moderates' (al-muqtașidūn) or 'the companions of the right' (așhāa al-yamin), who perform all religious obligations; and second, the rank of the elite friends designated as 'the forerunners drawn near' (al-sābiqūn al-muqarrabūn), who in addition to the obligations also perform supererogatory acts of worship. ${ }^{136} \mathrm{Al}-$ though there are some parallels to be drawn here with al-Wāsițī, who also men-

132 Al-Wāsițî, Talqūh al-afhām, p. 163; Miftāh al-márifa, p. 269; Qā'ida fì bayān al-țarīq ilā

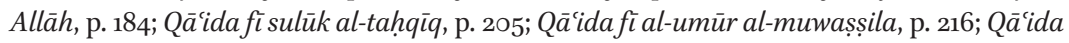
fì istijlāb al-widād fìmu'āmalat rabb al-arbāb, p. 276.

133 See for instance Ibn Taymiyya's al-Tuhfa al-irāqiyya, p. 373; and his al-Radd 'alä al-Shädhilī, p. 115, where he says: "Every friend of God (wali li-llāh) is a lover of God and beloved by God, because the servant's love for his Lord and the Lord's love for His servant are inseparable, for God only loves those who love Him." Love between God and man in Ibn Taymiyya's doctrine has been studied in: Bell, Love Theory, pp. 74-91.

134 For al-Wāsițī's mention of the afrād, see his: Lawāih min qawā'id ahl al-zaygh, p. 131; al-

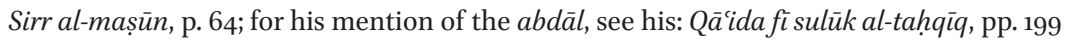
\& 204-205; Qã̄ida fì al-umūr al-muwașșila, p. 223; Lawāì min qawāid ahl al-zaygh, pp. 130-131.

135 See for instance Ibn Taymiyya's al-Furqān bayna awliyā' al-rahmmān wa-awliyă al-shayțān, MF, vol. 11, pp.167-168 \& 294; Minhāj al-sunna, vol. 1, pp. 93-94; Su’ila 'an al-hadìth almarwīfíal-abdāl, $M F$, vol. 11, pp. 433-444.

${ }_{136}$ Ibn Taymiyya takes these terms from the Qur'an, with the sābiqūn muqarrabūn being referred to in Q. 56:10-11 \& 88, Q. 35:32, and Q. 83:18 \& 21, and the așhāb al-yamin/ muqtașidūn in Q.56:8 \& 90-91 and Q. 35:32. Mention of this interpretation of the concept of wiläya is scattered throughout his writings. See for instance: al-Tuhfa al-irāqiyya, pp. 290-291; al-Istiqāma, vol. 2, p. 41; Haqiquat madhhab al-ittihādiyyīn, $M F$, vol. 2, p. 224; Sharh futūḥ al-ghayb, $M F$, vol. 10, p. 463. 
tions the term 'al-sābiqūn al-muqarrabūn' as a title for those who have attained God's friendship, it is very clear that this is never a reproduction of his shaykh's teachings on the subject. ${ }^{137}$ Conversely, Ibn Taymiyya, though acquainted with Sufi terminology, either refrains from using the terms we find in al-Wāsiți’s works or simply interprets them in a different way. For instance, he never himself adopts any variation of the term ' jadhba,' even though he was clearly aware of its existence as a Sufi concept within the subject of wilāya. ${ }^{138}$ Most striking is perhaps his (re)interpretation of the double experience of $\operatorname{fan} \vec{a}^{\prime} / b a q \bar{a}^{3}$, which is unmistakably different from the Junaydian definition al-Wāsițī adheres to. In his most basic phrasing, he defines it as: "annihilation from the worship of all that is other [than God] combined with subsistence in the worship of Him (T)." ${ }^{139}$ Much more can be said about his understanding of these terms, and this has been done by several scholars already. ${ }^{140}$ For the topic at hand it suffices to know that al-Wāsiți and Ibn Taymiyya clearly differed in their elaboration on several key Sufi terms. Finally, while we have recognized that Ibn Taymiyya does discuss the degrees of witnessing God's divinity and lordship, he never once speaks of the witnessing of union or singularity. We may therefore confidently conclude that al-Wāsițī in no way appropriated aspects of Ibn Taymiyya's teachings for his elaboration on the final stage on the Sufi path.

\section{Conclusion}

In this chapter we studied how al-Wāsiți built a sequence of degrees of witnessing on the basis of ma'rifa of God as extracted from the revealed texts. We had already observed in the previous chapter that this rests on becoming closely acquainted with all of God's names and attributes mentioned therein.

137 For al-Wāsițī's mention of the sābiqūn muqarrabūn, see his: Risāla fù ithbāt, p. 50; al-Sirr al-mașūn, p. 64.

${ }_{13} 8$ Ibn Taymiyya uses the root letters ' $\mathrm{j}$-dh-b' in Fașl fì al-șirāt al-mustaqìm fì al-zuhd wa-al-ibāda wa-al-wara', MF, vol. 10, pp.6oo-6o9, though never in the way al-Wāsițī understands the concept of jadhba. That Ibn Taymiyya was aware of its use among the Sufis is evident from his al-Radd 'alā al-Shādhilī, pp. 115-116.

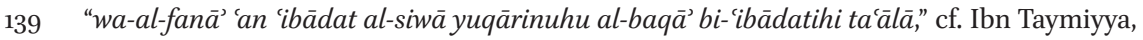
al-Radd 'alä al-Shädhilī, pp. 101-102; he repeats the same interpretation on p. 211, and it is also found in Fașl fí qawlihi “fa-hajja Ādamu Mūsā”, MF, vol. 8, p. 370.

140 See for instance: Thomas Michel, A Muslim Theologian's Response to Christianity: Ibn Taymiyya's Al-Jawab al-Sahih (Delmar, NY: Caravan Books, 1984), p. 33; James Pavlin, "Ibn Taymiyya's Theology," in Ibn Taymiyya: Epistle on Worship, trans. James Pavlin (Cambridge: Islamic Texts Society, 2015), pp. LXXXVI-XCI; Meier, "The Cleanest about Predestination," p. 325; Sarrio, "Spiritual anti-elitism," p. 287; Michot, "Ibn Taymiyya's Commentary," p. 132. 
We found that each divine name and attribute is connected to a specific human name or attribute through which it is served. This was based on the notion that the Sufi must realize the ultimate perfection and incomparability of God's names and attributes in view of the inherently imperfect nature of those of created beings. According to al-Wāsițī, this ultimately leads to the witnessing of these divine names and attributes, which is not a matter of perceiving their actual reality, since God's reality is completely separate from that of His creation. Rather, he explained it as perceiving the traces of their lights by means of the heart in the unseen (al-ghayb). These traces are to be recognized in the form of similitudes, as he held that it is through similitudes that created beings get to know God in their own terms. After this we examined the sequence of the most important degrees of witnessing he discusses in his writings, which are divinity, lordship/sustainment, withness, divine judgment, and finally, union/singularity. Throughout these steps we made note of instances where his teachings seem to have drawn from the shaykhs he studied under. This endeavor now allows us to make two important observations.

First, for his conception of witnessing he seems to have relied on the teachings of the Alexandrian Shādhiliyya and of his Damascene shaykh, Ibn Taymiyya. We found traces of Shādhili doctrine in several of the themes discussed, most notably in the practical application of ma'rifa through servitude of the divine names and attributes, but also in the notion of rejecting one's choice and self-direction, and the differentiation between sulük and jadhb. Taymiyyan doctrine was, above all, distinctly present in al-Wāsițīs understanding of the witnessing of divinity and lordship.

Second, unlike the subjects we studied in the previous chapter, we found that there are within al-Wāsitị̂s conception of the degrees of witnessing several teachings that markedly differ from, and at times even conflict with, Ibn Taymiyya's theological thought. For instance, the notion that a human being is composed of five dimensions - body, carnal soul, intellect, heart, and spirit all of which must be traversed consecutively in order to reach the end of the spiritual path, was clearly not acceptable to Ibn Taymiyya. Also, al-Wāsițîs entire elaboration on friendship with God as attained in the final degree of witnessing clearly diverges from that of his Hanbalī shaykh. Here, our Iraqi Sufi either has a different understanding of the relevant terminology, or uses terms not found in the works of Ibn Taymiyya.

This leads us to conclude that, although a follower of Ibn Taymiyya and an active member of his jamā'a, al-Wāsitịi had a voice of his own. His membership of the Taymiyyan circle did not mean that he was necessarily bound by the views of his teacher. The fact that he incorporated concepts from Shādhili doctrine into his Sufism shows that there was room for him to formulate his own 
views, which he based on the knowledge he acquired over the course of his travels - though we may add that he evidently put in effort to ensure these views were anchored in the framework of traditionalism. In the present chapter, this effort was, above all, visible in his definition of the witnessing of union, which was, in a sense, constructed around a rebuttal of the Akbarian school. By skillfully harmonizing traditional Sufi concepts, and Shādhilī and Taymiyyan teachings, our Iraqi Sufi provided his circle of pupils with an alternative form of tașawwuf that was in line with their traditionalist leanings. This Sufism was clearly not some replication of Ibn Taymiyya's views on Sufism, but rather stood on its own as an original synthesis of a centuries-old tradition. This conclusion supports the hypothesis set forth in chapter 3 that it was not Ibn Taymiyya but al-Wāsiți who fulfilled the role of Sufi master - or, shaykh al-sulük - for the members of their jamáca. 


\section{How does the Journey Continue?}

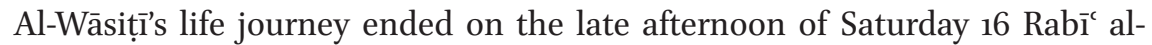
Âkhir 711/1 September 1311. At the age of fifty-four he passed away in the small hospital (al-māristān al-șaghìr) of Damascus, located next to the Umayyad Mosque, where his funeral prayer was performed the next day. ${ }^{1}$ While his circle of companions and disciples surely paid their last respects, one can imagine he would have felt the absence of his murshid, Ibn Taymiyya. The Hanbali shaykh al-Islām had by then been in Egypt for some six years, and would return to Damascus about a year later. ${ }^{2}$ Perhaps our Iraqi Sufi would have found peace in the knowledge that he was buried on the slopes of Mount Qāsyūn of the Şâlihịyya quarter, in the company of many renowned and pious traditionalist masters who preceded him, overlooking the city where he had reached the zenith of both his physical and his spiritual journey. ${ }^{3}$

Having followed him on these two journeys, it is now time for us to reflect how the present book contributes to the three topics we have outlined in the introduction, namely, (1) the trends of Sufism al-Wāsiți encountered during his lifetime, (2) the trend of Sufism that was accepted and practiced among the Hanbalīs/traditionalists of early Mamluk Damascus, and (3) more specifically within the circle of Ibn Taymiyya. Let us follow the chronology of this book and begin with the stages of al-Wāsițīs physical journey. Through our study of his autobiographical account in part 1 we have, on several occasions, been able to draw attention to the relationship that may have existed between the trends of Sufism he encountered and the normative religiosity of the context wherein these existed.

First, we found that there appears to have been a link between the trend of Sufism practiced by the Rifāis Sufis and the local religiosity of early Ilkhanid

1 On the location of the hospital, see: Aḥmad 'Īsā, Tärīkh al-Bīmāristānātfí al-islām (Beirut: Dār al-ra'id al-'arabī, 1981), pp. 205-206.

2 Ibn 'Abd al-Hādī relates that several companions of Ibn Taymiyya's inner circle had stayed behind in Damascus when he went to Egypt, cf. al-'Uqüd al-durriyya, p. 306.

3 Ibn Rajab, Dhayl, vol. 4, p. 384; al-Dhahabī, al-Dhayl, p. 126; al-Yāfi'ì, Mir'ät, vol. 4, p .188; Abū Muhammad al-Qāsim al- Birzālī, al-Wafayāt, ed. Abū Yaḥā 'Abd Allāh al-Kundarī (Kuwait: Gharrās li-al-nashr wa-al-tawzī‘ wa-al-Di'āya wa-al-i'lān, 2005), p. 137, who relates that alWāsiți was buried in front of the zāwiya of one al-Suyūfī; the funeral prayer over him was led by two imams: the Mālikī scholar Muḥammad Abū al-Walīd b. al-Ḥājj al-Ishbīlī (d. 817/1318), on whom see: Ibn Kathīr, al-Bidāya, vol. 14, p. 104; and the Shāfiī scholar Ibn Qawwām Abū Bakr b. Muḥammad (d. 746/1345), on whom see: Ibn al-Imād, Shadharāt, vol. 8, pp. 255-256. 
Wāsit and its surroundings. In spite of their portrayal as extravagant and sometimes even antinomian Sufis in both medieval Muslim chronicles and academic studies, a study of al-Wāsițīs autobiography in combination with several other primary sources has led us to conclude that they appear to have dominated this geographical area. On that basis, we hypothesized that their doctrine and practices probably represented a form of Sufism that was particular to this context and was, therefore, generally regarded as normative there. This included their practice of $s a m \bar{a}$ and miracle-working, the role of the shaykh as the absolute spiritual authority for the Sufi novice, and their high regard for the family-line of the Prophet.

Then we turned to the Shādhiliyya of Alexandria, whose Sufi doctrine was taught to al-Wāsițī by Najm al-Dīn al-Iṣbahānī, a direct disciple of the order's second shaykh, al-Mursī. Our study of the early network of Shādhilī affiliates as well as the earliest recorded teachings attributed to them led us to conclude that this was already a distinct ta $\vec{a} i f a$ by the time our Iraqi Sufi settled among them. It was then argued that there may have been a link between the success of the Shädhiliyya and the local religiosity of seventh-/thirteenth-century Alexandria. The combination of the sober, scholastic approach to Sufism of the Shādhilī shaykhs and their claim to the western Maghribī/Andalusi Sufi tradition was in all likelihood appealing to a great variety of people in this context. In that respect we made special note of the Shādhilīs' adherence to Ash'arism, the dominant local trend of theology, which may have been an important factor in shaping their image as a Sufi order grounded in what most Alexandrians of this epoch would have regarded as normative Sunni Islam.

Then we reflected on what al-Wāsitị described as a distinct presence of Akbarian Sufis in the so-called "state-sponsored" convents of seventh-/thirteenthcentury Cairo. Because we found that the Akbarian trend of Sufism appears to have been more easily accepted as normative in the Persian than in the Arab cultural context, we concluded that this may be linked to the considerable number of Sufis with a Persian background who took up residence in these convents. However, as has also been noted, this possibility needs to be studied in more detail.

Al-Wāsițīs disappointment with all the above groups of Sufis finally pushed him to move to Damascus, where he converted to the Hanbalī school and joined Ibn Taymiyya's jamāa $a$. If we presume that his autobiography faithfully conveys to us his sentiments as a wandering Sufi, then it was only among his Taymiyyan companions that he found the kind of scriptural puritanism he had been looking for during his journey. However, we must bear in mind that the way he describes his pathway to spiritual maturation may have been greatly influenced by the literary conventions of his traditionalist conversion narrative. 
Interestingly, we were able to discern a shift within this very narrative, which must have occurred in between the composition of two treatises. Where his autobiography still envisioned a synthesis between traditionalist theology and Shādhilī Sufism as its conclusion, his later work, Qā'ida fì aṣnāf al-tảalluh, displays an attitude of complete rejection of his former Sufi shaykhs in favor of absolute scripturalist traditionalism. That this was not a rejection of Sufism as such, and nor even of all the teachings of his former Sufi shaykhs, is, above all, clear from chapters 4 and 5 , where his own Sufi doctrine was closely examined.

These chapters have shown that while it has since long remained unclear in how far Sufism was included in the religiosity of the Hanbalis of early Mamluk Damascus - a religiosity that did in fact include a particular form of traditionalist zuhd-piety - al-Wāsițī himself certainly aimed to make sure that this was the case. Through his own activity as a Sufi teacher he provided the traditionalists/Hanbalīs of this context with a kind of traditionalist tașawwuf that was adapted to their notions of normativity. To put it in the words of Fritz Meier, he had put Sufism on a Ḥanbali basis - or more accurately, I would say, on a traditionalist basis. ${ }^{4}$ By prioritizing the principle of knowing God as He describes Himself, especially through the affirmation of God's aboveness, sitting on the Throne, and all attributes whose literal meanings are analogous to the attributes of creatures, al-Wāsițî̀s Sufism effectively laid claim to márifa of God as something strictly reserved for adherents of traditionalist theology. So the way he defined what Sufism is - i.e. his 'selfing' - was very much a matter of anchoring it in the theological framework of traditionalism as he understood it.

On that basis he simultaneously defined what Sufism is not - i.e. his 'othering' - by identifying the kinds of Sufis who, in his view, deviate from the true method of the early generations of Sufi masters, whom he claimed had been proponents of the creed of the Ahl al-Hadith. We noted that he thereby very consciously excluded as the 'Other' all the Sufi groups he had accompanied prior to his settlement in Damascus: those who practiced sama $\bar{a}^{c}$ (the Rifā'īs, the Baghdadi Sufis, and the Akbarians), those who adopted philosophy and/or kalām theology (the Shādhiliyya), and those who preached some form of monism (the Akbarians). Relying on a typical traditionalist line of reasoning, he argued that all these groups have in common that they deviate from Islam by going beyond what the holy texts of revelation (both Qur'an and Sunna) explicitly say.

This same combination of traditionalism with a critical attitude towards the Sufis of his age resulted in another significant aspect of his doctrine, namely,

4 Because, as we have seen, historically not all Hanbalīs adhered to traditionalist theology, while not all those who adhered to traditionalist theology were Hanbalīs. 
the tariqa Muhammadiyya. In his autobiography we found that he had developed a strong aversion to the central role allotted to the shaykh in the lives of Sufi aspirants among both the Rifāiiyya and the Shādhiliyya. In his view, their focus on attachment to the shaykh diverted attention away from the level of attachment to the Prophet required for spiritual perfection. In order to return focus to where he felt it belonged, he proposed a method of attachment to the incorporeal presence of the Prophet through ma'rifa, or intimate knowledge, of his life and times - especially by studying the Prophetic biography (sira), a genre towards which Ibn Taymiyya had previously directed him. He claimed that such a study could open the vision of one's heart to the Prophet's existence in the unseen and thus enter his guidance and companionship (suhba). What this companionship entails in his vision is never explicitly stated, however. In order to reach this Prophetic connection, our Iraqi Sufi taught that one needed the guidance of a shaykh who had already accomplished this. Here we found clear indications that he seems to have envisioned the practice of Sufism in a group structure under the supervision of a complete spiritual master, which may indicate that this was the role he himself fulfilled for his disciples.

In chapter 4 it has also been pointed out that the origins of the Muhammadan way has been a topic of discussion among scholars of Sufism, as some have deemed it a typically modern phenomenon related to what is called 'neo-Sufism.' While it was already observed by Vincent J. Cornell that the term tariqa Muhammadiyya can be traced back to the tenth-/sixteenth-century Suf 'Abd Allāh al-Ghazwānī, and thus predates its coinage by the so-called neo-Sufi groups from the late eighteenth and early nineteenth century, we found a yet earlier source for the term in al-Wāsiți. In fact, I have argued that it was possibly al-Wāsiți himself who first coined the term for his doctrine of attachment to the Prophet's incorporeal presence. Interestingly, his doctrine actually appears to be quite close to that of the neo-Sufis, for whom the term signified the method of connecting to the Prophet's reality (al-haqiqa al-Muhammadiyya). Needless to say, the intellectual genealogy of al-Wāsițīs țariqa Muhammadiyya certainly needs to be evaluated more thoroughly in order to find out whether he was indeed its true originator, what prior developments in Sufi history may have contributed to its conception, and how it was subsequently transmitted and possibly reached al-Ghazwānī or found its way into the teachings of modern Sufis.

Let us now return briefly to our reflection on the traditionalist character of al-Wāsițīs Sufism and specifically focus on how it may have drawn from the teachings of his shaykhs. In chapter 4 we found clear indications that he appears to have worked from the same traditionalist framework as Ibn Taymiyya, especially in his teachings on ithbät, the affirmation of the apparent meanings 
of the divine names and attributes. It was argued, however, that this does not necessarily mean that al-Wāsiți simply duplicated his master's opinions. It was, above all, in chapter 5 where we found that he seems to have relied on the shaykh al-Islām's doctrine for the distinction between ilāhiyya and rubübiyya, and possibly also on his interpretation of the verse on 'the most exalted similitude' (al-mathal al-ala $\bar{a}$ - although it was pointed out that al-Wāsiți appears to have elaborated upon the latter issue in much greater detail than his shaykh, and very distinctly from the perspective of Sufism. Another issue where we recognized a possible affinity with Ibn Taymiyya's teachings is the central role allotted to love for God, which for al-Wāsiți was the core ingredient in his description of the final stage on the Sufi path - the stage wherein the spiritual seeker attains friendship with God and becomes His beloved.

In the same chapter we also found that there were three notable instances where al-Wāsiți appears to have appropriated teachings of Shādhilī Sufism:He clearly relied on the Shādhilì method of 'sitting on the carpet of truthfulness,' which requires the Sufi to reflect on his own names and attributes and how they relate to those of God; his emphasis on the rejection of choice and selfdirection echoed the teachings of his own Shādhilī shaykh, Najm al-Dīn alIșbahānī; and both his differentiation between sulūk and jadhb and his Junaydian understanding of $f a n \bar{a}^{3}$ and $b a q \bar{a}^{3}$ on the final stage of the Sufi path may also have been inspired by Shädhili doctrine. In regard to the latter terms we're also able to observe that, while Ibn Taymiyya knew them and even constructed his very own interpretation of $f a n \bar{a}^{\prime}$ and $b a q \bar{a}^{\prime}$, al-Wāsițī's understanding of them was evidently much closer to that of the early Shādhiliyya than to that of his Hanbalī shaykh.

This leads us to conclude that the way al-Wāsiți formulated his own Sufism was in several crucial instances connected to experiences from his physical journey, both positive and negative. This resulted in a highly original and sophisticated Sufi doctrine in that it was constructed around an unprecedented synthesis of ideas and concepts from very different traditions. In formulating this doctrine, al-Wāsiți did not necessarily restrict his creative thought by the boundaries set by Ibn Taymiyya's teachings, as he clearly followed his own judgment in choosing what ought to be incorporated into it. A similar observation has previously been made in regard to another member of the Taymiyyan jamā'a, al-Dhahabì, who strongly disagreed with Ibn Taymiyya when it came to the role of reason in theology. ${ }^{5}$ Such space for independent thinking is in line

5 I have already made note of this in the introduction to this book, for which I referred to Bori, "al-Dhahabī" in $E I^{3}, 2016$, p. 75. I also referred to this when I mentioned the increasing fragmentation of the jamác $a$ in chapter 3 . 
with the hypothesis from chapter 3 that the bond between Ibn Taymiyya and his (elite) companions was probably closer to the relationship between peers and kindred spirits than a pure master-disciple relationship.

With this observation in mind one may question whether it is still useful to call al-Wāsiți a 'Taymiyyan Sufi,' as this may be taken to imply that he purely based himself on Ibn Taymiyya for his Sufism, thus disregarding the originality of his doctrine we have discerned in this study. I would argue that 'Taymiyyan' remains a useful label here not for the sake of connecting al-Wāsiți to his shaykh's teachings per se, but rather to highlight that he was the Sufi master or 'shaykh al-sulük' - in the Taymiyyan jamāa a. Our study of the relevant primary sources has shown that at least eleven of Ibn Taymiyya's disciples were connected to al-Wāsiți and that we can be certain that at least five of these will have sat in his classes on Sufism. It seems very likely that his life as a Sufi master was to a large degree specifically connected to the circle of individuals who had organized themselves around the person of Ibn Taymiyya.

This role, which al-Wāsițī fulfilled, shows that Sufism was not only actively taught and practiced among them, but that its form was determined not only, nor primarily, by their appointed leader, Ibn Taymiyya. In that regard it is telling that the doctrine al-Wāsiți had developed and the Sufi terminology he used to give expression to it was apparently regarded as normative by them. We may see this as an indication that the language of the Sufis had already become an integral part of Sunni religiosity in early Mamluk Damascus. Finally, al-Wāsițị's Sufi doctrine has also given us a taste of the complexity of the religious thought that was present in Ibn Taymiyya's circle - a complexity that clearly was not solely rooted in the theological ingenuity of the Hanbalī shaykh al-Islām himself.

So how do we continue from here? For future research it will first be useful to question to what degree al-Wāsițìs Sufi teachings influenced the thought of those members of the Taymiyyan circle who took him as their shaykh. There are, for instance, some seemingly Wāsițiyyan influences in the Risālat al-sulūk, the sole known Sufi tract by al-Wāsițị's disciple al-Ba'labakkī. ${ }^{6}$ Unfortunately, because this treatise is relatively short, it does not provide enough insight into al-Ba'labakkì's understanding of Sufism to make any large claims in that regard. When it comes to Ibn Qayyim al-Jawziyya on the other hand, we do have enough source material to allow for an effective comparative study. Such

6 For al-Ba'labakkìs epistle, see: Post, "A Glimpse of Sufism," pp. 173-178 for the Arabic, and pp. $179-187$ for the translation. The distinction it makes between taqwā and zuhd as the two pillars of sulūk are very similar to al-Wāsițī, Mīzān al-shuyūkh, pp. 239-240, and: Madkhal ahl al-figh, p. 73. And like al-Wāsițī, al-Ba'labakkī emphasizes the importance of knowing God as He describes Himself, and likewise regards the $a b d \bar{a} l$ as the highest degree of believers. 
an endeavor would enable us to see where al-Wāsiți possibly influenced Ibn al-Qayyim's ideas on Sufism.

Another useful step for further research would be to examine how and where al-Wāsițīs Sufi doctrine may have survived beyond the circle of Ibn Taymiyya. We know, for instance, that his writings were copied among Damascene traditionalists, although it is difficult to determine how long this continued and how far his impact reached. ${ }^{7}$ Ibn Rajab makes mention of his many writings in the field of Sufism and comments that "a group of the Sufis from the Ahl al-Hadith have derived benefit from them." ${ }^{8}$ We know that his work was copied by Nāṣir al-Dīn Muḥammad b. Ṭūlūbghā (d. 749/1348), a hadīth-scholar who was a student of al-Dhahabī. ${ }^{9}$ A century later, Shams al-Dīn Muhammad Ibn Nāșir al-Dīn (d. 842/1438), a Shāfi' traditionalist and defender of Ibn Taymiyya, likewise had our Iraqi Suf's writings at his disposal, which he considered "astonishing" ('ajīb). ${ }^{10}$ Such examples show that al-Wāsiți was still read among traditionalists after his passing and proves that there is merit in further studying the manuscripts of his works and their transmission, which would undoubtedly provide much more crucial information in that regard. It will be a lot more difficult, though certainly not less relevant, to determine how his influence may have eventually reached Sufis of other localities and denominations.

Finally, it would be valuable to investigate his influence in modern times in order to see, for instance, whether the relatively recent availability of his printed writings has affected the debates among Salafis concerning the status of Sufism.." So evidently, while our study of al-Wāsițī has been a journey in its own right, much more ground remains to be covered before we can unveil the impact of this still little-known Taymiyyan Sufi.

7 Al-Birzālī, al-Wafayāt, p. 138.

8 Post, “A Glimpse of Sufism," pp. 162-163, quoted from Ibn Rajab, Dhayl, vol. 4, p. 382.

9 On Ibn Țūblūghā, see: Ibn Nāṣir al-Dīn, al-Radd al-wāfir, p. 47; al-Sakhāwī, al-Daw' allāmic, vol. 4, p. 132. On his copying from al-Wāsițî̀s own works, see: Ibn Nāṣir al-Dīn, Tawdịh al-mushtabah, vol. 3, p. 166.

10 Ibn Nāṣir al-Dīn, Tawdịh al-mushtabah, vol. 3, p. 166.

11 In that regard it is relevant to note that the editors of al-Wāsițị's work, Muhammad Abū al-Faḍl al-Qūnawī and the late Walīd b. Muhammad al-'Alī, both appear to have a Salafi background. 
Arjan Post - 978-90-04-37755-4

Downloaded from Brill. com $04 / 26 / 2023$ 03:36:10PM via free access 


\section{Bibliography}

\section{Manuscripts}

Mukhtașar sīrat rasūl Allāh. Leiden University Special Collections, Or. 482.

Mas'alatfi al-samāc . The National Library of Israel, JER NLI AP Ar. 158/6: f. 62a-62b.

Al-Bulgha wa-al-iqnā' fi hall shubhat mas'alat al-samāc The National Library of Israel, JER NLI AP Ar. 158/7: f. 64a-72b.

\section{Abbreviations of Collective Volumes}

Imādiyyāt al-Imādiyyāt: Majmū' fîhi rasāill li-al-imām Imād al-Dīn al-Wāsițīal-ma'rūf bi-Ibn Shaykh al-Hazzāmiyya. Edited by Muhammad b. 'Abd Allāh Aḥmad (Abū al-Faḍl al-Qūnawī). Beirut: Dār al-kutub al-ilmiyya, 2010.

Qawāìd Qawāiè fì al-sulūk ilā Allāh ta'ālā aw: al-Sayr 'alā al-minhāj. Edited by Muhammad b. 'Abd Allāh Aḥmad (Abū al-Faḍl al-Qūnawī). Beirut: Dār albashāiir al-islāmiyya, 2014.

Talqūh Talqūh al-asrār bi-lawāmi' al-anwār li-al-ulamā̄al-abrār. Edited by Walīd b. Muḥammad b. 'Abd Allāh al-'Alī. Beirut: Dār al-bashāiir al-islāmiyya, 2014.

Sirr al-Sirr al-mașūn wa-al-iilm al-makhzūn fihi lawāih min al-mahabba washu'ūn. Edited by Walīd b. Muḥammad b. 'Abd Allāh al-'Alī. Beirut: Dār albashā’ir al-islāmiyya, 2013 .

\section{Al-Wāsiți’s Published Writings (in Alphabetical Order)}

"Al-Sirr al-mașūn wa-al-'ilm al-makhzūn fỉhi lawāih min al-maḥabba wa-shu'ūn." In: Sirr, pp. 37-68.

al-Tadhkira wa-al-itibār wa-al-intișār li-al-abrār. Edited by 'Alī Hasan 'Alī 'Abd alMajīd. Beirut: Dār al-bashāir al-islāmiyya, 2014.

"Ashi“'at al-nuṣūṣ fì hatk astār al-fușūṣ." In: 'Imādiyyāt, pp. 53-85, and also as: Bāshūrat al-nuṣūs fı hatk astār al-fușūs. Edited by 'Adnān Abū Zayd. Beirut: Dār al-nawādir, 2007.

"Ḥayāt al-qulūb wa-'imārat al-anfās fì sulūk al-adhkiyā’ al-akyās." In: Talqūh, pp. 69-9o.

"Lawā’ih min qawāiid ahl al-zaygh wa-al-ḍalāl al-mubțilīn wa-lawā̉ih min qawāiid țarīq al-șādiqīn." In: Imādiyyāt, pp. 119-133.

"Lawāmic al-istirshād fī al-farq bayna al-tawḥīd wa-al-ittihạd." In: Imādiyyāt, pp. 87-97.

Madkhal ahl al-fiqh wa-al-lisān ilā maydān al-maḥabba wa-al-'irfān. Edited by Walīd b. Muḥammad b. 'Abd Allāh al-'Alī. Beirut: Dār al-bashāìr al-islāmiyya, 2002. 
"Miftāḥ al-ma'rifa wa-al-'ibāda li-ahl al-țalab wa-al-irāda al-rāghibīn fī al-dukhūl ilā dār al-sa‘̄àda min al-țarīqa al-muḥammadiyya allatī laysat munḥarifat ${ }^{\text {an }}$ 'an al-jādda." In: 'Imādiyyāt, pp. 249-274.

Miftāḥ țarīq al-awliyā'. Edited by Muhammad b. Nāṣir al-'Ajmī. Beirut: Dār al-bashāiir al-islāmiyya, 1999.

"Miftāḥ țarīq al-muhibbīn wa-bāb al-uns bi-rabb al-cālamīn al-mu’addī ilā aḥwāl almuqarrabīn." In: 'Imādiyyāt, pp. 275-285.

"Mīzān al-ḥaqq wa-al-ḍalāl fì tafṣīl aḥwāl al-nujabā’ wa-al-abdāl wa sharḥ kibr al-jahala min al-'ummāl alladhīna 'adimū 'ilm al-tafṣil wa-al-ijmāl." In: 'Imādiyyāt, pp. 217225, and also in: Sirr, pp. 69-84.

"Mīzān al-shuyūkh." In: 'Imādiyyāt, pp. 227-248, and also in: Sirr, pp. 85-140.

"Qācida fĩ al-farq bayna al-c̄bid wa-al-mushāhid." In: Qawāì id, pp. 258-262.

"Q̄āida fī al-farq bayna kibr al-nafs wa-'izzat al-qalb wa-bayna al-bagyi wa-al-shajāa wa-ghayrihimā." In: Qawā'id, pp. 104-111.

"Q̄āida fī al-farq bayna mushāhadat al-qayyūmiyya wa-al-taḥaqquq bihā, wa-al-farq bayna mushāhadat al-jam` wa-al-tahaqquq bihi." In: Qawā'id, pp. 263-267.

"Q̄àida fì al-ḥubb fì Allāh ḥaqīqatan." In: Qawāi id, pp. 52-55.

"Qācida fì al-ināba ilā Allāh ta'ālā." In: Qawāìd, pp. 138-139.

"Q̄̄cida fī al-jidd wa-al-ijtihād." In: Qawāìd, pp. 249-251.

"Q̄àida fì al-mathal al-a'lā li-qawlihi Allāh subḥānahu: "wa-lahu al-mathal al-a lā", waqawl al-nabī (Ṣ): "tabārak ismuka wa-tacālā jadduka."” In: Qawāied, pp. 289-291, and also in: 'Imādiyyāt, pp. 175-178.

"Qācida fī al-mustacidd li-al-tașawwuf." In: Qawā̌id, pp. 124-128.

"Qācida fī al-șifāt." In: Qawāiid, pp. 315-324, and also in: Imādiyyāt, pp. 165-173.

"Q̄̄cida fì al-umūr allatī yanbaghī an takūn hamm al-sālik." In: Qawā id, pp. 19o-198.

"Q̄̄cida fĩ al-umūr al-muwașșila wa-al-umūr al-qāțía." In: Qawā̌id, pp. 213-228.

"Q̄āida fī al-wișāl wa-al-liqā̄, wa-hiya bughyat al-muhịbīn wa-rūḥ al-mushtāqīn." In: Qawāid, pp. 268-271.

"Q̄āida fī an al-'abd yata'ayyan 'alayhi márifat al-țarīq ilā Allāh 'azza wa-jall wa-alta'arruf lahu." In: Qawā'id, pp. 112-118.

"Q̄âcida fī anwāe al-tafārīq wa-șifat al-jam fī al-amr al-mukammil li-șāḥibihi." In: Qawāंid, pp. 206-208.

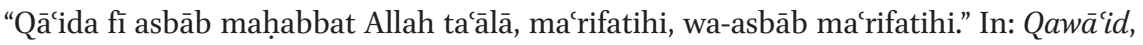
pp. 61-63.

"Qācida fĩ aṣnāf al-ta’alluh wa-khuṣūṣiyyat ta’alluh kull țāiifa min al-țawā’if." In: Qawā'id, pp. 149-155.

"Qā'ida fī bayān al-sulūk." In: Qawāiid, pp. 157-163.

"Qācida fì bayān al-țarīq ilā Allāh tacālā min al-bidāya ilā al-nihāya." In: Qawāìd, pp. 179-185. 
"Qā'ida fì bayān 'amal yawm wa-layla li-al-abrār wa- 'amal yawm wa-layla li-al-sāirīn ilā țarīq al-muqarrabīn jacalnā Allāh minhum.” In: Qawāi id, pp. 70-77.

"Qā'ida fī bidāyāt al-awliyā’ wa-manḥ ahl al-muṣaffāt al-aṣfiyā'." 173-178.

"Q̄āida fī dhikr al-karāmāt al-mu'ajjala li-al-munqațīinn ilā Allāh 'azza wa-jalla fī aldunyā." In: Qawā'id, pp. 282-288.

"Qā'ida fì dhikr asbāb al-maḥabba li-Allāh tacāāa." In: Qawāi id, pp. 56-60.

"Qā̄ida fì ḥabs al-nafs wa-al-'ukūf 'alā al-hamm." In: Qawā'id, pp. 83-91.

"Qācida fì istijlāb al-widād fī mucāmalat rabb al-arbāb." In: Qawā'id, pp. 275-281.

"Q̄̄'ida fī i'tibār ahl al-khayr wa-ghayrihim." In: Qawā'id, pp. 134-137.

"Qā'ida fī khușūṣ țāiffat al-ṣūfiyya." In: Qawācid, pp. 129-131.

"Qāìda fī maqāṣid al-sālikīn." In: Qawācid, pp. 64-69.

"Q̄̄cida fī ma'rifat al-naqș al-dākhil 'alā al-kamāl min al-ārifīn, wa-ma'rifat al-kamāl fì ḥaqq man qāma bihi min al-wāṣilīn ahl al-baqā’ ba‘d al-fanā’ wa-al-ṣaḥw ba‘d alsukr min maqāmāt al-muqarrabīn." In: Qawāiè, pp. 229-239.

"Q̄āida fī maẓāhir al-shuhūd wa-al-márifa." In: Qawā'id, pp. 140-148.

"Qā'ida fī mīzān al-istiqāma li-ahl al-qurb wa-al-karāma." In: Qawā̌id, pp. 272-274.

"Qā'ida fī nafyī al-khawāțir." In: Qawācid, pp. 240-248.

"Q̄ấida fĩ qawlihi tacāā: inna Allāha ishtarā min al-mu’minīn anfusahum wa-amwālahum bi-anna lahum al-janna." In: Qawāi id, pp. 292-295.

"Q̄ấida fĩ sharḥ ḥāl al-'ubbād wa-al-șūfiyya al-afrād (jacalnā Allāh minhum bi-mannihi wa-karamihi)." In: Qawā'id, pp. 78-82.

"Qā'ida fī șifat al-'ubūdiyya." In: Qawā'id, pp. 41-51.

"Q̄āida fī sulūk al-awliyā’ alladhīna tarāmat himamuhum ilā al-istiqrār fì 'asākir alawliyā.." In: Qawāid, pp. 164-168.

"Qā'ida fī sulūk al-taḥqīq ilā ghāyat al-mațālib li-al-sāiir ilā rabbihi al-dhāhib." In: Qawāंid, pp. 199-205.

"Qācida fì tacarruf al-nubuwwa ayḍan." In: Qawācid, pp. 310-314.

"Qācida fī tajrīd." In: Qawācid, pp. 252-257.

"Qā'ida fī tamhīd mā qabluhā wa-tanāsubuhā." In: Qawāìd, pp. 186-189.

"Qā̄ida fì taqwiyat al-sālik 'alā al-wuṣūl ilā maṭlūbihi." 119-123.

"Q̄āida fī taṣfiyyat al-akhlāq isti`dādan līyawm al-ḥashr wa-al-talāq." In: Qawāid, pp. 92-103.

"Q̄̄cida min 'alāmāt al-taḥqīq bi-al-qayyūmiyya." In: Qawā'id, pp. 169-172.

"Qācida min dalāil al-nubuwwa." In: Qawāìd, pp. 302-3०9.

“Qācida mukhtașara fī țarīq al-faqr 'alā minhāj al-rasūl." In: Qawāi id, pp. 23-40.

"Qācida tatimma li-hādhihi al-qācida fī al-ta’alluhāt." In: Qawā'id, p. 156

"Qācida ya'rifu al-'abd fīhā nașībahu min rabbihi wa-bu'dahu min ḥuẓūz nafsihi." In:

Qawāid, pp. 209-212.

"Q̄̄̄ida yudhkar fỉhā amr al-sālik fî al-ibtidā'." In: Qawāi id, pp. 132-133.

"Qā'idat al-rūḥāniyyāt wa fỉhā bayān li-mā qabluhā." In: Qawāìd, pp. 296-297. 
"Qawāiid al-nubuwwāt: Qā'ida nabawiyya." In: Qawāiid, pp. 298-301.

Rihlat al-Imām Ibn Shaykh al-Hazzāmiyyīn (657-711 H.) min al-tașawwuf al-munharif ilā taṣawwuf ahl al-ḥadīth wa-al-athar. Edited by Muḥmmad b. 'Abd Allāh Aḥmad. Konya: [publisher unknown], 2005, and also in: In: 'Imādiyyāt, pp. 25-51.

Risālat fí ithbāt al-istiwā' wa-al-fawqiyya wa-tanzīh al-bārī jalla wa-'alà 'an al-ḥașr waal-tamthïl wa-al-kayfiyya. Edited by 'Adnān b. Hamūd Abū Zayd. Cairo: Maktabat al-thaqāfa al-dīniyya, 2004, and also published as: Al-Nașịha fì ithbāt șifāt al-rabb jalla wa-'alā:tataḍmmanu 'aqìdat al-imām 'Abd Allāh b. Yūsuf al-Juwaynī. Edited by Zuhayr al-Shāwīsh. Beirut/Damascus: al-Maktab al-islāmī, 1985.

"Risālatuhu ilā al-shaykh Aḥmad al-Maghribī." In: 'Imādiyyāt, pp. 99-117.

"Talqīḥ al-afhām fì mujmal țabaqāt al-Islām wa-ijtimācihim fĩ qawl "lā ilāha illā Allāh Muḥammad rasūl Allāh" wa-iftirāqihim fī sacāyāt al-qulūb wa-al-ajsām." In: 'Imādiyyāt, pp. 147-164.

“Talqīh al-asrār bi-lawāmic al-anwār li-al-'ulamā’ al-abrār.” In: Talqīh, pp. 39-67.

“Umdat al-țullāb min mu'minī ahl al-kitāb al-mushtāqīn ilā dhawq al-aḥbāb, alrāghibīn fî rusūkh dīn al-islām fī al-sarāiir wa-al-albāb." In: 'Imādiyyāt, pp. 179-215, and also in: Talqīh, pp. 91-156.

"Wașiyya ilā bađụ qựāt al-Shām." In: 'Imādiyyāt, pp. 135-146.

\section{Primary Sources}

Anon. Risāla li-ba'd fuqarā' sayyidī al-shaykh Tāj al-Dīn Ibn 'Ațā' Allāh rad̄ì Allāh 'anhu. Leiden University Special Collections, MS. Or. 329(7b).

'Abdarī, Muḥammad b. Muḥammad Ibn al-Ḥājj al-. Al-Madkhal, 4 vols. Cairo: Maktabat dār al-turāth, date unknown.

Abū Ya'lā, Muhammad b. al-Ḥusayn b. al-Farrā'. Ibṭāl al-ta’wīlāt li-akhbar al-ṣifāt. Edited by Abū 'Abd Allāh Muḥammad b. Hamad al-Maḥmūd al-Najdī. Maktabat Dār al-imām al-Dhahabī, 1990.

Aḥmadī, Hāshim b. Sa'd al-. Ghanimat al-farīqayn min ḥikam al-ghawth al-Rifā̄è Abī alAlamayn. Edited by Aḥmad Ramza b. Hammūd Juhāa Abū al-Hudā. Published by the author, 2014.

Andalusī, Abū Ḥayyān Muḥammad b. Yūsuf al-. Al-Baḥr al-muḥit fì al-tafsīr. Edited by Șidqī Muḥammad Jamīl, 10 vols. Beirut: Dār al-fikr, 1992.

'Asqalānī, Aḥmad Ibn Ḥajar al-. al-Durar al-kāmina fí a ýān al-mỉa al-thāmina. Edited by Muhammad 'Abd al-Mu’īd Ḍān, 6 vols. Hyderabad: Majlis dāirat al-ma'ārif al'uthmāniyya, 1972.

'Asqalānī, Aḥmad Ibn Ḥajar al-. Al-Mu'jam al-mufahras aw-tajrīd asānīd al-kutub almashhūra wa-al-ajzāa al-manthūra. Edited by Muḥammad Shakkūr Maḥmūd alḤājī Amrīr al-Mayādīnī. Beirut: Mu’assasat al-risāla, 1998. 
'Aynī, Badr al-Dīn Maḥmūd al-. Iqd al-jumān fì tārīkh ahl al-zamān ('aṣr salāțīn almamālīk). Edited by Muḥammad Muḥammad Amīn et al., 5 vols. Cairo: Dār al-kutub wa-al-wathāiq, 2010.

Baqlī, Rūzbihān b. Abī al-Nașr. The Unveiling of Secrets:Diary of a Sufi Master. Translated by Carl W. Ernst. Chapel Hill NC: Parvardigar Press, 1997.

Bazzār, Sirāj al-Dīn 'Umar b. 'Alī al-. al-A'lām al-'aliyya fì manāqib shaykh al-islām Ibn Taymiyya. Edited by Ṣalāḥ al-Dīn al-Munajjid. Beirut: Dār al-kutub al-jadīd, 6791.

Birzālī, Abū Muḥammad al-Qāsim al-. al-Wafayāt. Edited by Abū Yahyā 'Abd Allāh alKundarī. Kuwait: Gharrās li-al-nashr wa-al-tawzī‘ wa-al-Di‘āya wa-al-i'lān, 2005.

Bukhārī, Muḥammad b. Ismācīl al-. al-Jāmic al-musnad al-șaḥịn al-mukhtaṣar min umūr Rasūl Allāh (Ṣ) wa-sunanihi wa-ayyāmihi. Edited by Muḥammad Zuhayr b. Nāṣir alNāṣir, 9 vols. Beirut: Dār țawq al-najāh, 2001.

Damīrī, Kamāl al-Dīn Muḥammad b. Mūsā al-. Hayāt al-ḥayawān al-kubrā, 2 vols. Beirut: Dār al-kutub al-'ilmiyya, 2010.

Dārimī, 'Uthmān b. Sa'īd al-. Naqụ al-imām Abì Sa'ìd 'Uthmān b. Sa ìd 'alā al-Marīsī alJahmī al-'anìd fìmā 'ftarā 'alà Allāh ('azza wa-jalla) min al-tawhìd. Edited by Abū 'Āṣim al-Shawāmī al-Atharī. Cairo: al-Maktaba al-islāmiyya li-al-nashr wa-al-tawzī', 2012.

Dhahabī, Shams al-Dīn Muḥammad b. Aḥmad al-. Tārīkh al-Islām wa-wafayāt almashāhìr wa-al-a lām. Edited by 'Umar 'Abd al-Salām al-Tadmurī, 52 vols. Beirut: Dār al-kutub al-'Arabī, 1993.

Dhahabī, Shams al-Dīn Muhạmmad b. Aḥmad al-. Dhayl Tārīkh al-islām. Edited by Māzin Sālim Bā Wazīr. Riyad: Dār al-mughnī li-al-nashr wa-al-tawzī', 1988.

Dhahabī, Shams al-Dīn Muhammad b. Aḥmad al-. Siyar a lām al-nubalā'. Edited by Shu'ayb al-Arnā'ūṭ et al, 25 vols. Beirut: Mu’assasat al-risāla, 1985 .

Dhahabī, Shams al-Dīn Muḥammad b. Aḥmad al-. al-Ibar fi khabar man ghabar. Edited by Abū Hājar Muhammad al-Sa'̄ìd b. Basyūnī Zaghlūl, 4 vols. Beirut: Dār alkutub al-'ilmiyya, 1985 .

Dhahabī, Shams al-Dīn Muḥammad b. Aḥmad al-. Kitāb tadhkirat al-ḥuffāz, 4 vols. Beirut: Dār al-kutub al-'ilmiyya, 1998.

Dhahabī, Shams al-Dīn Muhammad b. Aḥmad al-. al-Mujam al-mukhtașs bi-almuḥaddithīn. Edited by Muḥammad al-Ḥabīb al-Hīla. Al-Ṭāif: Maktabat al-ṣiddīq, 1988.

Dhahabī, Shams al-Dīn Muḥammad b. Aḥmad al-. al-Ṭibb al-nabawī, wa bi-ākhirihi faṣl fi al-samāc. Edited by Muḥammad 'Abd al-Raḥmān al-Mar'ashlī. Beirut: Dār alNafāis li-al-țibā'a wa-al-nashr wa-al-tawzī', 2004.

Dhahabī, Shams al-Dīn Muḥammad b. Aḥmad al-. Mújam al-shuyūkh al-kabīr. Edited by Muḥammad al-Ḥabīb al-Hīla, 2 vols. Al-Ṭāifi, Maktabat al-ṣiddīq, 1988.

Dimashqī, 'Abd al-Qādir b. Muḥammad al-Nu'aymi al-. Al-Dāris fì tārīkh al-madāris, 2 vols. Beirut: Dār al-kutub al-ilmiyya, 199 o. 
Fārūthī, 'Izz al-Dīn Aḥmad al-. Irshād al-muslimīn li-țarīqat shaykh al-muttaqīn. Edited by Aḥmad Ramza b. Ḥammūd Juḥā Abū al-Hudā. [Egypt?]: Dār al-ṭibā'a al-āmira, 2011.

Fārūthī, 'Izz al-Dīn Aḥmad al-. al-Naf̣̣a al-miskiyya fì al-sulāla al-rifāiiyya al-zakiyya. al-Āsitāna al-'Aliyya: Maṭba'at Muḥammad As'ad, 1883.

Ghazālī, Abū Ḥāmid Muḥammad b. Muḥammad al-. Ihyyā' 'ulūm al-dīn. 4 vols. Beirut: Dār al-márifa, 2011.

Ghazālī, Abū Ḥāmid Muḥammad b. Muḥammad al-. Al-Ghazali's Path to Sufism. His Deliverance from Error: Al-Munqidh min al-Dalal. Translated by Richard J. McCarthy. Louisville, KY: Fons Vitae Publishing, 2000.

Ḥallāj, al-Ḥusayn b. Manșūr al-. Dīwān al-Hallāj. Edited by 'Abduh Wāzin. Beirut: Dār al Jadīd, 1998.

Ḥamawī, Shihāb al-Dīn Abū 'Abd Allāh Yāqūt al-. Mujam al-buldān, 7 vols. Beirut: Dār al-șādir, 1995 .

Hujwīrī, 'Alī b. 'Uthmān al-. Revelation of the Mystery: (Kashf Al-Mahjúb). Translated by Reynold Alleyne Nicholson. Accord, NY: Pir Press, 1999.

Ibn 'Abd al-Hādī, Shams al-Dīn Muhạmmad. al-'Uqūd al-durriyya min manāqib shaykh al-islām Ahmad b. Taymiyya. Edited by Muḥammad Ḥāmid al-Fiqī. Beirut: Dār alkitāb al-'arabī, 2010.

Ibn Abī al-Ḥasan al-Shādhilī, Shihāb al-Dīn Aḥmad. Risālat Sayyidinā al-shaykh alimām al-'ālim al-'ārif Shihāb al-Dìn Aḥmad. MS. Or. 329(7b), Leiden University.

Ibn Abī al-Manșūr, Șafī al-Dīn al-Ḥusayn al-Azdī. La risāla de Șafi al-Dīn Ibn Abī alManșūr Ibn Zāfir: biographies des maîtres spirituels connus par un cheikh égyptien du VIIe-XIIIe siècle. Edited and translated by Denis Gril. Cairo: Institut français d'archéologie orientale du Caire, 1986.

Ibn 'Ajïba, Ahmad b. Muhammad. The Autobiography of the Moroccan Sufi. Translated by Jean-Louis Michon \& David Streight. Louisville, KY: Fons Vitae, 1999.

Ibn al-Fārị̣, Sharaf al-Dīn 'Umar b. 'Alī. Dīwān Ibn al-Fārị̣. Beirut: Dār Șādir, 1962.

Ibn al-Furāt, Nāṣir al-Dīn Muḥammad b. 'Abd al-Rahīm. Tārīkh Ibn al-Furāt, volume 8. Edited by Qusțanțīn Zurayq. Beirut: al-Mațba'a al-amīrkāniyya, 1939.

Muslim, Abū al-Ḥasan b. al-Ḥajjāj. Al-Musnad al-ṣaḥ̄h al-mukhtaṣar bi-naql al-'adl 'an al-'adl ilā Rasūl Allāh (șallā Allāh 'alayhi wa-sallam). Edited by Muhammad Fu'ād 'Abd al-Bāqī, 5 vols. Beirut: Dār ihyā̄' al-kutub al-'arabiyya, 1955.

Ibn Hanbal, Aḥmad b. Muḥammad. Musnad al-imām Aḥmad b. Hanbal. Edited by Shu'ayb al-Arna'ūt, 'Ādil Murshid, et al., 45 vols. Beirut: Mu’assasat al-risāla, 2001. Ibn al-'Imād, 'Abd al-Ḥayy al-Ḥanbalī. Shadharāt al-dhahab fı akhbār man dhahab. Edited by Mạ̣mūd al-Arnāūụt, 11 vols. Damascus/Beirut: Dār Ibn Kathīr, 1986.

Ibn al-Labbān, Shams al-Dīn Muḥammad b. Aḥmad. Izālat al-shubuhāt 'an al-āyāt waal-ahāāith al-mutashābihāt. Edited by Ayman 'Abd al-Jābir al-Buhayrī and 'Amr Mușțafā al-Wardānī. Cairo: Dār al-bayān al-'Arabī, 2002. 
Ibn al-Mulaqqin, Sirāj al-Dīn Abū Ḥaf̣̣ 'Umar. Ṭabaqāt al-awliyā’. Edited by Nūr al-Dīn Sharība. Cairo: Maktabat al-Khānjī, 1994.

Ibn al-Șabbāgh, Muḥammad b. Ab̄̄ al-Qāsim. Kitāb Durrat al-asrār wa-tuḥfat al-abrār. Tunis: Mațba'at al-tūnisiyya al-rasmiyya, 1886.

Ibn Bațtuṭa, Muḥammad b. 'Abd Allāh al-Ṭanjī. Riḥlat Ibn Bațțța al-musammāh Tuhfat al-nuzzār fì gharāìb al-amșār wa-'ajāìb al-asfār. Edited by 'Abd al-Hādī Tāzī, 5 vols. Rabat: Akādīmīyat al-Mamlaka al-Maghribiyya, 1997.

Ibn Daqīq al-'̄̄d, Taqī al-Dīn Muḥammad b. 'Alī al-Qushayrī. 'Aqìdat al-imām Taqī alDìn Ibn Daqīq al- İd. Edited by Nizār al-Ḥammādī. Tunis: Dār al-imām Ibn 'Arafa, 2012.

Ibn Fahd, Taqī al-Dīn Abū al-Fạ̣l Muhammad. Laḥz al-alhāz bi-dhayl țabaqāt alhuuffāz. Beirut: Dār al-kutub al-'ilmiyya, 1998.

Ibn Kathīr, Abū al-Fidā’ Ismācīl b. 'Umar. al-Bidāya wa-al-nihāya. Edited by 'Alī Shīr̄̄, 14 vols. Beirut: Dar iḥyā' al-turāth al-'arabī, 1988.

Ibn Khallikān, Shams al-Dīn Abū al-'Abbās Aḥmad. Wafayāt al-a'yān wa-anbā' abnā' al-zamān. Edited by Iḥsān 'Abbās, 7 vols. Beirut: Dār al-ṣādir, 1968.

Ibn Nāșir al-Dīn, Shams al-Dīn Muḥammad al-Qaysī. al-Radd al-wāfir. Edited by Zuhayr al-Shāwīsh. Beirut: al-Maktaba al-islāmī, 2010.

Ibn Nāṣir al-Dīn, Shams al-Dīn Muḥammad al-Qaysī. Taw ḍịh al-mushtaba fí dabț asmā al-ruwāt wa-ansābihim wa-alqābihim wa-kunāhum. Edited by Muhammad Na'īm al'Irqsūsī, 10 vols. Beirut: Mu'ssasat al-risāla, 1993.

Ibn Qāḍī Shahba, Taqī al-Dīn Abū Bakr b. Aḥmad. Țabaqat al-shāficiyya. Edited by 'Abd al-'Alīm Khān, 4 vols. Beirut: 'Ālam al-kutub, 1986.

Ibn Qayyim al-Jawziyya, Shams al-Dīn Muḥammad. Madārij al-sālikìn bayna manāzil iyyāka na`budu wa-ikkāka nastaīn. Edited by Muhammad al-mu'tașim bi-Allāh alBaghdādī, 3 vols. Beirut: Dār al-kitāb al-'arabī, 1996.

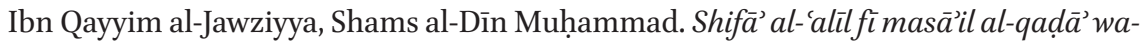
al-qadarwa-al-hikma wa-al-taclïl. Beirut: Dār al-ma'rifa, 1978.

Ibn Rāfi', Taqī al-Dīn Muḥammad. Al-Wafayāt. Edited by Ṣālị̣ Mahdī 'Abbās \& Bashshār 'Awwād Ma'rūf, 2 vols. Beirut: Mu’assasat al-risāla, 1982.

Ibn Rajab, Zayn al-Dīn 'Abd al-Raḥmān. Al-Dhayl 'alā țabaqāt al-ḥanābila. Edited by 'Abd al-Raḥmān b. Sulaymān al-'Uthaymīn, 5 vols. Riyad: Maktabat al-'Ubaykān, 2005 .

Ibn Taghrī Birdī, Jamāl al-Dīn Yūsuf b. 'Abd Allāh. Al-Nujūm al-zāhira fı́mulūk Miṣrwaal-Qāhira, 16 vols. Cairo: Wizārat al-thaqāfa wa-al-irshād al-qawmī, 1929-1938.

Ibn Taymiyya, Taqī al-Dīn Aḥmad b. 'Abd al-Ḥalīm. Majmū' Fatāwā. Edited by 'Abd alRaḥmān b. Muḥammad b. Qāsim, 37 vols. Riyad: Wizārat al-shu'ūn al-islāmiyya waal-awqāf wa-al-da'wat wa-al-irshād, 1995 . 
Ibn Taymiyya, Taqī al-Dīn Aḥmad b. 'Abd al-Ḥalīm. Bayān talbìs al-Jahmiyya fì ta'sīs bida'ihim al-kalāmiyya. Edited by Yahyā b. Muhammad al-Hunaydī et al., 10 vols. Riyad: Majma' al-malik Fahd, 2005.

Ibn Taymiyya, Taqī al-Dīn Aḥmad b. 'Abd al-Halīm. Dar' tåārud al-'aql wa-al-naql. Edited by Muḥammad Rashād Sālim, 11 vols. Riyad: Jāmi'at al-imām Muhammad b. Sa'ūd al-islāmiyya, 1991.

Ibn Taymiyya, Taqī al-Dīn Aḥmad b. 'Abd al-Ḥalīm. Minhāj al-sunna al-nabawiyya fi naqụ kalām al-shīa al-qadariyya. Edited by Muhammad Rashād Sālim, 9 vols. Riyad: Jāmi'at al-imām Muhammad b. Sacūd al-islāmiyya, 6891.

Ibn Taymiyya, Taqī al-Dīn Aḥmad b. 'Abd al-Halīm. Majmū'at al-rasāill wa-al-masāill. Edited by Muḥammad Rashīd Rị̣ā, 5 vols. Cairo: Lajnat al-turāth al-'arabī, 1976.

Ibn Taymiyya, Taqī al-Dīn Aḥmad b. 'Abd al-Ḥalīm. al-Tuhfa al-Irāqiyya fí al-a'māl alqalbiyya. Edited by Yahyā b. Muhammad b. 'Abd Allāh al-Hunaydī. Riyad: Maktabat al-Rushd, 2000.

Ibn Taymiyya, Taqī al-Dīn Aḥmad b. 'Abd al-Ḥalīm. Kitāb al-istiqāma. Edited by Muhammad Rashād Sālim, 2 vols. Riyad: Jāmi`at al-imām Muhammad b. Sacūd alIslāmiyya, 1983 .

Ibn Taymiyya, Taqī al-Dīn Aḥmad b. 'Abd al-Ḥalīm. Bughyat al-murtād fí al-radd 'alā al-mutafalsifa wa-al-Qarāmița wa-al-Bāṭiniyya ahl al-ilhād min al-qāilìn bi-al-ḥulūl wa-al-ittiḥād. Edited by Mūsā b. Sulaymān Duwaysh. Medina: Maktabat al-'ulūm wa-al-ḥikam, 1995 .

Ibn Taymiyya, Taqī al-Dīn Aḥmad b. 'Abd al-Halīm. Kitāb al-ṣafadiyya. Edited by Muhammad Rashād Sālim, 2 vols. Cairo: Maktabat ibn Taymiyya, 1986.

Ibn Taymiyya, Taqī al-Dīn Aḥmad b. 'Abd al-Halīm. Al-Radd 'alā al-Shādhilìfì Hizbayhi wa-mā șannafa-hu fì ādāb al-țarìq. Edited by 'Alī b. Muhammad al-'Imrān. Mecca: Dār al-cālam al-fawā’id li-al-nashr wa-al-tawzī', 2009.

Ibn Taymiyya, Taqī al-Dīn Aḥmad b. 'Abd al-Ḥalīm. al-Fatwā al-ḥamawiyya al-kubrā. Beirut: Dār al-kutub al-'ilmiyya, 1985.

Ibn Taymiyya, Taqī al-Dīn Aḥmad b. 'Abd al-Ḥalīm. al-Jawāb al-bāhir fi zuwwāar almaqābir. Riyad: al-Maktaba al-'arabiyya al-sa'ūdiyya, 1984.

Iṣbahānī, Abū Nu'aym Aḥmad b. 'Abd Allāh al-. Hilyat al-awliyā' wa-țabaqāt al-aşfryā', 10 vols. Cairo: al-Sa'āda, 1974.

Iskandarī, Sharaf al-Dīn Dāwūd Ibn Mākhilā al-. Al-Lațīfa al-mardịya bi-sharh du 'ā’ al-Shādhiliyya. Edited by Muḥammad 'Abd al-Qādir Nașșār. Cairo: Dārat Karaz, 2011.

Iskandarī, Tāj al-Dīn Aḥmad Ibn 'Ațā' Allāh al-. Latậif al-minan fì manāqib al-Shaykh Abì al-'Abbās al-Mursī wa-shaykhihi al-Shādhilī Abì al-Hasan. Edited by Khalīl 'Imrān al-Manșūr. Beirut: Dār al-Kutub al-'Ilmiyya, 2005.

Iskandarī, Tāj al-Dīn Aḥmad Ibn 'Ațā' Allāh al-. Ibn 'Ațā' Allāh (m. 709/1309) et la naissance de la confrérie šādilite / Ibn 'Ațā̉ Allāh (709/1309) wa-nash'at al-țarīqa al- 
Shādhiliyya. Edited and translated by Paul Nwyia. Beirut: Dar El-Machreq Éditeurs, 1990.

Iskandarī, Tāj al-Dīn Aḥmad Ibn 'Ațā' Allāh al-. Kitāb al-tanwìr fı isqāṭ al-tadbīr. Beirut: Dār al-kutub al-cilmiyya, 6002.

Iskandarī, Tāj al-Dīn Aḥmad Ibn 'Ațā' Allāh al-. 'Unwān al-tawfíqfíādāb al-țarīq. Edited by Khālid Zahrī. Beirut: Dār al-kutub al-ilmiyya, 2004.

Iskandarī, Tāj al-Dīn Aḥmad Ibn 'Ațā' Allāh al-. Min kalām sayyidī al-muṣannif wainshādihi wa-qașāidihi. MS. Or. 329(2), Leiden University.

Iskandarī, Tāj al-Dīn Aḥmad Ibn 'Ațā' Allāh al-. Tartīb al-sulūk, wa-yalīhā Risāla fì adab al-'ilm. Edited by Khālid Zahrī. Beirut: Dār al-kutub al-'ilmiyya, 2006.

Iskandarī, Tāj al-Dīn Aḥmad Ibn 'Ațā' Allāh al-. Miftāḥ al-falāḥ wa-miṣbāḥ al-arwāḥ: fì dhikr Allāh al-karìm al-fattāḥ. Edited by Muhammad 'Abd al-Salām Ibrāhīm. Beirut: Dār al-kutub al-cilmiyya, 2005.

Iskandarī, Tāj al-Dīn Aḥmad Ibn 'Ațā' Allāh al-. al-Qậd al-mujarrad fí ma'rifat al-ism al-mufrad. Edited by Khālid Muḥammad Khamīs. Cairo: Maktabat al-khānjī, 2008.

Isnawī, Jamāl al-Dīn 'Abd al-Raḥmān b. al-Ḥasan al-. Ṭabaqāt al-shāfíiyya. Edited by Kamāl Yūsuf al-Ḥùt, 2 vols. Beirut: Dār al-kutub al-ilmiyya, 2002.

Jāmī, Nūr al-Dīn 'Abd al-Raḥmān b. Aḥmad al-. Nafaḥāt al-uns min ḥaḍarāt al-quds. Edited by Muḥammad Adīb al-Jādir, 2 vols. Beirut: Dār al-kutub al-'ilmiyya, 2003.

Jazarī, Shams al-Dīn Muḥammad b. Ibrāhīm al-. Ta’rīkh hạāadith al-zamān wa-anbāihi wa-wafayāt al-akābir wa-al-a'yān min abnāihi. Edited by 'Umar Tadmurī, 3 vols. Beirut/Șaydā: al-Maktaba al-'așriyya, 1998.

Jīlānī, 'Abd al-Qādir Ibn Abī Ṣāliḥ al-. al-Ghunya li-țāibì țarīq al-ḥaqq 'azza wa jalla ( $f \grave{\imath}$ al-akhlāq wa-al-tașawwuf wa-al-adāb al-islāmiyya). Edited by Abū 'Abd al-Raḥmān Șalāh b. Muḥammad Ibn 'Uwayḍa, 2 vols. Beirut: Dār al-kutub al-'ilmiyya, 2007.

Jīlānī, 'Abd al-Qādir Ibn Abī Ṣālih al-. al-Fath al-Rabbānī wa-al-fayd al-rahmmānī. Cairo: al-Maktaba al-azhariyya li-al-turāth, 2008.

J̄̄lānī, 'Abd al-Qādir Ibn Abī Ṣāliḥ al-. Tafsīr al-Jūlānī. Edited by Aḥmad Farīd al-Mizyadī, 6 vols. Beirut: Beirut: Dār al-kutub al-cilmiyya, 2009.

Jīlānī, 'Abd al-Qādir Ibn Abī Ṣāliḥ al-. Sirr al-asrār wa maz̧har al-anwār. Dihlī: Kutubkhāna Ishā'at al-Islām, 1985 .

Juwayn̄̄, 'Abd al-Malik b. 'Abd Allāh al-. Kitāb al-Irshād ilā qawāți' al-adilla fí uṣūl ali'tiqād. Edited by Muhammad Yūsuf Mūsā \& 'Alī 'Abd al-Mun'im al-Ḥamīd. Cairo: Jamā'at al-Azhar li-al-nashr wa-al-ta'liff, 1950.

Kalābādhī, Abū Bakr Muḥammad al-. Al-Ta'arruf li-madhhab ahl al-tașawwuf. Beirut: Dār al-kutub al-'ilmiyya, 1993 .

Makkī, Abū Țālib Muḥammad b. 'Alī al-. Qūt al-Qulūb fìmu'āmalat al-Maḥbūb wa-wașf al-țarìq al-murìd ilā maqām al-tawhìd. Edited by 'Așim Ibrāhīm al-Kayyālī, 2 vols. Beirut: Dār al-kutub al-'ilmiyya, 2009. 
Maqdisī, Muwaffaq al-Dīn 'Abd Allāh Ibn Qudāma al-. Kitāb al-tawwābīn. Beirut: Dār Ibn Hazm, 2003.

Maqdisī, Muwaffaq al-Dīn 'Abd Allāh Ibn Qudāma al-. Al-Mutahāābīn fì Allāh. Damascus: Dār al-ṭibāec, 1991.

Maqdisī, Muwaffaq al-Dīn 'Abd Allāh Ibn Qudāma al-. Al-Riqqa wa-al-bukă'. Edited by Muhammad Khayr Ramaḍān Yūsuf. Damascus/Beirut: al-Dār al-shāmiyya, 1994.

Maqdisī, Muwaffaq al-Dīn 'Abd Allāh Ibn Qudāma al-. Dhamm mā 'alayhi mudda'ū altașawwuf. Beirut/Damascus: al-Maktab al-Islāmī, 1983.

Maqdisī, Taqī al-Dīn 'Abd al-Ghanī al-. Al-Iqtiṣād fí al-i'tiqād. Edited by Aḥmad b. 'Ațiyya b. 'Alī al-Ghāmidī. Medina: Maktabat al-'ulūm wa-al-ḥikam, 1993.

Makhlūf, Muḥammad b. Muhammad. Shajaratal-nūral-zakiyyafițabaqātal-Mālikiyya. Edited by 'Abd al-Majīd Khayālī, 2 vols. Beirut: Dār al-kutub al-'ilmiyya, 2003.

Maqrīzī, Taqī al-Dīn Aḥmad b. 'Alī al-. Al-Sulūk li-márifat duwal al-mulūk. Edited by Muḥammad 'Abd al-Qādir 'Ațā, 8 vols. Beirut: Dār al-kutub al-'ilmiyya, 1997.

Maqrīzī, Taqī al-Dīn Aḥmad b. 'Alī al-. al-Mawā'iz wa-al-i'tibār bi-dhikr al-khițaṭ wa-alāthār, 4 vols. Beirut: Dār al-kutub al-'ilmiyya, 1997.

Maqrīzī, Taqī al-Dīn Aḥmad b. 'Alī al-. Kitāb al-muqaffā al-kabìr. Edited by Muḥammad al-Ya'lāwī, 8 vols. Beirut: Dār al-gharb al-islāmī, 1991.

Muslim, Abū al-Ḥasan b. al-Ḥajjāj. al-Musnad al-ṣaḥh al-mukhtaṣar bi-naql al-'adl 'an al-'adl ilā Rasūl Allāh (șallā Allāh 'alayhi wa-sallam). Edited by Muhammad Fu'ād 'Abd al-Bāqī, 5 vols. Beirut: Dār iḥyā' al-kutub al-'arabiyya, 1955.

Nasā̄ì, Abū 'Abd ar-Raḥmān Aḥmad b. Shu'ayb al-. al-Sunan al-ṣughrā. Edited by 'Abd al-Fattāḥ Abū Ghudda, 9 vols. Aleppo: Maktab al-maṭbūāt al-Islāmiyya, 1986.

Nawawī, Muḥȳ̄ al-Dīn Yahyyā al-. Tahdhīb al-asmā̄ wa-al-lughāt, 4 vols. Beirut: Dār alkutub al-ilmiyya, 1977.

Qushayrī, Abū al-Qāsim 'Abd al-Karīm b. Hūzān al-. al-Risāla al-Qushayriyya. Edited by 'Abd al-Ḥalīm Maḥmūd \& Maḥmūd b. al-Sharīf, 2 vols. Cairo: Dār al-Ma'cārif, 1995.

Rāfī̄, 'Abd al-Karīm b. Muḥammad al-Qazwīnī al-. Sawād al-'aynayn fì manāqib alghawth Abī al-'Alamayn. Al-Muḥammadiyya (Egypt): al-Mațba'a al-Mīriyya, 1884.

Șafadī, Șalaḥ al-Dīn Khalīl al-. al-Wāfì bi-al-wafayāt. Edited by Aḥmad al-Arnā'ūṭ \& Turkī Mușțafā, 29 vols. Beirut: Ḍar ihyyā̄ al-turāth, 2000.

Șafadī, Șalaḥ al-Dīn Khalīl al-. A'yān al-'așr wa-a'wān al-nașr. Edited by 'Alī Abū Zayd et al., 5 vols. Beirut: Dār al-fikr al-mu'āṣir/Damascus: Dār al-fikr, 1998.

Sakhāwī, Shams al-Dīn Muḥammad b. 'Abd al-Raḥmān al-. Al-Ḍaw' al-lāmi' li-ahl alqarn al-tāsic', 6 vols. Beirut: Dār maktabat al-ḥayāt, 198o.

Sarrāj, 'Abd Allāh b. 'Alī al-. Kitāb al-luma' fì al-tașawwuf. Edited by Reynold A. Nicholson. Leiden: Brill, 1914.

Șayyād, 'Izz al-Dīn Aḥmad b. 'Abd al-Raḥīm al-. al-Ma'āif al-muḥammadiyya fí alwazā̄if al-Ahmadiyya. Cairo: 1305/1888. 
Sha'rānī, 'Abd al-Wahhāb b. Aḥmad al-. Al-Ṭabaqāt al-kubrā, al-musamma: Lawāqih alanwār al-qudsiyya fi manāqib al-ulamā’ wa-al-șüfyya. Edited by Ahmad 'Abd alRaḥīm Sāyiḥ and Tawfīq 'Alī Wahba, 2 vols. Cairo: Maktabat al-thaqāfa al-dīniyya, 2005 .

Subkī, Tāj al-Dīn 'Abd al-Wahhāb al-. Țabaqāt al-shāfíiyya al-kubrā. Edited by Maḥmūd Muḥammad al-Ṭanāḥ̄ \& 'Abd al-Fattāḥ Muḥammad al-Ḥulw, 10 vols. Cairo: Hajar li-al-țibā'a wa-al-nashr wa-al-tawzī̄', 1992.

Șumaydī, Jamāl al-Dīn Rāfic b. Muḥammad b. Shāfic al-. Zìnat al-nawāzirir wa-tuḥfat alkhawāṭir. Edited by Yūsuf Aḥmad. Beirut: Kitāb nāshirūn, 2013.

Sulamī, 'Izz al-Dīn Ibn 'Abd al-Salām, 'Abd al-'Azīz al-. Tafsīr al-qur'ān. Edited by 'Abd Allāh b. Ibrāhīm al-Wahbī, 3 vols. Beirut: Dār Ibn Hazm, 1996.

Sulamī, 'Izz al-Dīn Ibn 'Abd al-Salām, 'Abd al-'Azīz al-. "Al-Mulḥa fī i'tiqād ahl al-ḥaqq." In Rasāil fi al-tawhīd, edited by Iyād Khālid al-Ṭabbāc. Beirut: Dār al-fikr al-mu'āṣir/ Damascus: Dār al-fikr, 1995

Suyūṭị, Jalāl al-Dīn 'Abd al-Raḥmān b. Abī Bakr al-. Husn al-muhạạara fì tārīkh Miṣr wa-al-Qāhira. Edited by Muhammad Abū al-Faḍl Ibrāhīm, 2 vols. Cairo: Dār ihyā̄a al-kutub al-'arabiyya, 1967.

Suyūṭị, Jalāl al-Dīn 'Abd al-Raḥmān b. Abī Bakr al-. al-Ḥāwī li-al-fatāwā, 2 vols. Beirut: Dār al-Fikr, 2004.

Suyūṭị, Jalāl al-Dīn 'Abd al-Raḥmān b. Abī Bakr al-. Ta’yìd al-haquĩqa al-'alìyya watashyìd al-țarīqa al-Shādhiliyya. Edited by 'Ạṣim Ibrāhīm al-Kayyālī. Beirut: Dār alkutub al'ilmiyya, 2006.

Ṭabarī, Muhammad Ibn Jarīr al-. The History of al-Ṭabarī. Volume II. Prophets and Patriarchs. Translated by William M. Brinner. Albany, N.Y.: State University of New York Press, 1987.

Ṭabarī, Muḥammad Ibn Jarīr al-. The History of al-Tabarī. Volume VIII. The Victory of Islam. Translated by Michael Fishbein. Albany, N.Y.: State University of New York Press, 1997 .

Țabarī, Muḥammad Ibn Jarīr al-. The History of al-Ṭabarī. Volume XXIII. The Zenith of the Marwānid House. Translated by Martin Hinds. Albany, N.Y.: State University of New York Press, 1990.

Tādhifī, Muḥammad b. Tahyyā al-. Qalāìd al-jawāhir fì manāqib tāj al-awliyā’̀wa-ma'din al-aşfiyā' wa-sulțān al-awliyā's al-shaykh Muhyȳ al-Dīn 'Abd al-Qādir al-jūlānī. Edited by Aḥmad Farīd al-Mazīdī. Beirut: Dār al-kutub al-'ilmiyya, 2010.

Tādilī, Abū Ya'qūb Yūsuf al-. Al-Tashawwuf ilā rijāl al-tașawwuf wa-akhbār Abīal-Abbās al-Sabtī. Edited by Aḥamd al-Tawfīq. Rabat: Manshūrāt kulliyyat al-ādāb, 1997 .

Tirmidhī, al-Ḥakīm Muhammad b. 'Alī al-. Thalātatmușannafāt li-al-Hakìm al-Tirmidhī. Edited by Bernd Radtke. Beirut/Stuttgart : In Kommission bei Franz Steiner Verlag, 1992. 
'Ulaymī, Mujīr al-Dīn 'Abd al-Raḥmān al-. al-Manhaj al-aḥmad fì tarājim aṣhāo alimām Aḥmad. Edited by 'Abd al-Qādir al-Arnāūṭ \& Riyāḍ 'Abd al-Ḥamīd Murād, 6 vols. Beirut: Dār al-ṣādir, 1997.

Wāsițī, Aslam b. Sahl Baḥshal al-. Tārīkh Wāsiṭ. Edited by Kūrkīs 'Awwād. Beirut: 'Ālam al-kutub, 1986.

Wāsițī, Taqī al-Dīn 'Abd al-Raḥmān al-. Tiryāq al-muhibbìn fì țabaqāt khirqat almashāyikh al-'ārifin. Cairo: Maṭba'at Muhammad Mușțafā, 1305/1888.

Witrī, Aḥmad b. Muḥammad al-. Raw ḍat al-nāzirìn wa-khulāsat manāqib al-ṣāliḥinn. Baghdad: [publisher unknown], 1976.

Yāficī, 'Afîf al-Dīn 'Abd Allāh b. As'ad al-. Mir'āt al-jinān wa-'ibrat al-yaqzāan fì ma'rifat māya'tabaru min hạwādith al-zamān. Edited by Khalīl al-Manșūr, 4 vols. Beirut: Dār al-kutub al-ilmiyya, 1997 .

\section{$3 \quad$ Secondary Sources}

Abdel-Kader, Ali Hassan. The Life, Personality and Writings of al-Junayd: a Study of the Third/Ninth Century Mystic. London: Gibb Memorial Trust, 1976.

Abrahamov, Binyamin. Islamic Theology: Traditionalism and Rationalism. Edinburgh: Edinburgh University Press, 1998.

Abū Zayd, Bakr b. 'Abd Allāh. Ulamā’’ al-hanābila. Riyad: Dār Ibn al-Jawzī, 2001.

Addas, Claude. Quest for the Red Sulphur: The life of Ibn 'Arabī. Translated by Peter Kingsley. Cambridge: Islamic Texts Society, 1993.

Ahmed, Shahab. What is Islam? The Importance of Being Islamic. New Jersey: Princeton University Press, 2017.

'Ajmī, Daghash b. Shabīb al-. Ibn 'Arabī: 'Aqīdatuhu wa-mawqif 'ulamä' al-muslimin minhu. Min al-qarn al-sādis ilā al-qarn al-thālith 'ashr. Kuwait: Maktabat ahl al-athar, 2011.

Allard, Michel. Le problème des attributs divins: dans la doctrine d'al-Ašarì et de ses premiers grands disciples. Beirut: Imprimerie Catholique, 1965.

Amitai, Reuven. "Sufis and Shamans: Some Remarks on the Islamization of the Mongols in the Ilkhanate." JESHO 42 (1999): pp.27-46.

Amitai, Reuven. "The Conversion of Tegüder Ilkhan to Islam." JSAI 25 (2001): pp. 15-43. Amitai, Reuven. Mongols and Mamluks: The Mamluk-İlkhānidWar, 126o-1281. Cambridge: Cambridge University Press, 1995.

Anjum, Ovamir. "Sufism Without Mysticism? Ibn Qayyim al-Ğawziyyah's Objectives in Madāriğ al-Sālikīn." Oriente Moderno, XC 1 (2010): pp. 153-180.

Assef, Qais. "Le soufisme et les soufis selon Ibn Taymiyya." Bulletin d'Etudes Orientales LX (2012):pp. 91-122. 
Bābānī, Ismāêil Pāshā al-Baghdādī al-. Hadiyyat al-'ārifiñn: asmā̄ al-mu’allifin wa-āthār al-mușannifín, 2 vols. Istanbul: Wikālat al-Maārif, 1951.

Bartold, Vasilii Vladimirovich. An historical geography of Iran. Translated by Svat Soucek, edited by C. Edmund Bosworth. Princeton, N.J. : Princeton University Press, 1984.

Baumann, Gerd and Gingrich, Andre. Grammars of Identity/Alterity: A Structural Approach. New York: Berghahn Books, 2006.

Bausani, Alessandro. "Religion in the Saljuq Period." In cHIr v: pp. 283-302.

Bausani, Alessandro. "Religion under the Mongols." In chIr V: pp. 538-549.

Bazzano, Elliott A. "Ibn Taymiyya, Radical Polymath. Part 2: Intellectual Contributions.” Religion Compass 9.4 (2015): pp. 117-139.

Behrens-Abouseif, Doris. “Topographie d'Alexandrie médiévale." In Alexandrie médiévale 2, edited by Christian Décobert, pp. 113-126. Cairo:Institut Français d'Archéologie Orientale, 2010.

Bell, Joseph N. Love Theory in Later Hanbalite Islam. Albany: State University of New York Press, 1979.

Berkey, Jonathan Porter. The Transmission of Knowledge in Medieval Cairo: A Social History of Islamic Education. Princeton, N.J.: Princeton University Press, 1992.

Berryman, Charles. "Critical Mirrors: Theories of Autobiography." Mosaic: An Interdisciplinary Critical Journal, vol. 32, No. 1 (March 1999): pp. 71-84.

Bori, Caterina. "A New Source for the Biography of Ibn Taymiyya." BsoAs, vol. 67, no. 3 (2004): pp. 321-348.

Bori, Caterina. "al-Dhahabī." In $E I^{3}, 2016$, pp. 73-8o.

Bori, Caterina. "Ibn Taymiyya wa-Jamā‘atuhu." In Ibn Taymiyyah and his Times, edited by Yossef Rapoport \& Shahab Ahmed. pp. 23-52. Lahore: Oxford University Press, 2010.

Bori, Caterina. "The collection and edition of Ibn Taymīyah's works: Concerns of a disciple." MSR XIII (2009): pp. 47-67.

Bosworth, C. Edmund. "Wāsiț: the rise and disappearance of a great Islamic city." In Graeco-Arabica: Festschrift in Honour of V. Christides, edited by George K. Livadas, pp. 69-88. Athens: IGOAS, 2004.

Bosworth, C. Edmund. "Rifāiiyya." In $E I^{2}$ : vol. 8, pp. 525-526.

Braune, Walther. Die Futūḥ al-Gaib des 'Abd al-Qādir. Berlin: De Gruyter, 1933

Brice, William C. An Historical Atlas of Islam. Leiden: E.J. Brill, 1981.

Broadbridge, Anne F. Kingship and Ideology in the Islamic and Mongol Worlds. Cambridge: Cambridge University Press, 2008.

Brockelmann, Carl. Geschichte der arabischen litteratur, 6 vols. Leiden: Brill, 1996

Burns, Ross. Damascus: A History. London/New York: Routledge, 2007.

Chamberlain, Michael. Knowledge and Social Practice in Medieval Damascus, 119o-1350. Cambridge: Cambridge University Press, 1994. 
Chittick, William C. The Self-Disclosure of God: Principles of Ibn al-Arabìs Cosmology. Albany: State University of New York Press, 1998.

Chittick, William C. The Sufi Path of Knowledge: Ibn Al-'Arabi's Metaphysics of Imagination. State University of New York Press, 1989.

Chittick, William C. "The school of Ibn 'Arabī." In History of Islamic Philosophy: Part 1, edited by Seyyed Hossein Nasr \& Oliver Leaman, pp. 510-523. London/New York: Routledge, 1996.

Chittick, William C. "A History of the Term Wahdat al-wujūd." In In Search of the Lost Heart: Explorations in Islamic Thought, edited by Mohammed Rustom, Atif Khalil, and Kazuyo Murata, pp. 71-83. Albany: State University of New York Press, 2012.

Chittick, William C. "Erāqī, Faǩr-al-Dīn Ebrāhīm," EIr, vol. viıI, Fasc. 5, pp. 538-540.

Chodkiewicz, Michel. An Ocean Without Shore: Ibn 'Arabī, the Book, and the Law. Albany, NY: State University of New York Press, 1993.

Chodkiewicz, Michel. "Towards Reading the Futûhât Makkiyya." In The Meccan Revelations Volume II, edited by Michel Chodkiewicz, pp. 3-55. New York: Pir Press, 2004. Chodkiewicz, Michel. "Le procès posthume d'Ibn 'Arabī." In Islamic Mysticism Contested: Thirteen Centuries of Controversies and Polemics, edited by Frederick de Jong \& Bernd Radtke, pp. 93-123. Leiden, Netherlands: Brill, 1999.

Cook, David. Understanding Jihad. Berkeley: University of California Press, 2005.

Cook, Michael. Commanding Right and Forbidding Wrong in Islamic Thought. Cambridge: Cambridge University Press, 2000.

Coppens, Pieter. Seeing God in Sufi Qur'an Commentaries: Crossings between This World and the Otherworld. Edinburgh: Edinburgh University Press, 2018.

Cornell, Vincent J. The Way of Abū Madyan: Doctrinal and Poetic Works of Abū Madyan Shu'ayb ibn al-Husayn al-Anșārī (c. 509/1115-16-594/1198). Cambridge: Islamic Texts Society, 1996.

Cornell, Vincent J. Realm of the Saint: Power and Authority in Moroccan Sufism. Austin: University of Texas Press, 1998.

Danner, Victor. Ibn 'Ațāillāh's Șūfı Aphorisms (Kitāb al-Ḥikam). Leiden: E.J. Brill, 1973.

Décobert, Christian. "Alexandrie au Xıı re siècle: Une nouvelle topographie." In Alexandrie médiévale 1, edited by Christian Décobert and Jean-Yves Empereur, pp. 71-96. Cairo: Institut Français d'Archéologie Orientale, 1998.

Demeerseman, André. Nouveau regard sur la voie spirituelle d'Abd al-Qâdir al-Jilânî et sa tradition. Paris: Vrin, 1988.

Elmore, Gerald. "Ṣadr al-Dīn al-Qūnawī’s Personal Study-List of Books by Ibn al-'Arabī," JNES, vol. 56, No. 3 (Jul., 1997): pp. 161-181.

El-Rouayheb, Khaled. "Heresy and Sufism in the Arabic-Islamic world, 1550-1750: Some preliminary observations." BSOAS, 73 (2010): pp. 357-380.

Enderwitz, Susanne. "Classical Arabic Autobiography." In Handbook of Autobiography / Autofiction, edited by Martina Wagner-Egelhaaf, vol. II, pp. 827-849. Berlin: De Gruyter, 2019. 
Faure, Adolph. “Ibn Sab'īn.” In $E I^{2}$ : vol. 3, pp. 921-922.

Fernandes, Leonor E. The Evolution of a Sufi Institution in Mamluk Egypt: The Khanqah. Berlin: Klaus Schwarz Verlag, 1988.

Forster, Edward M. Alexandria: A History and a Guide. Garden City, N.Y.: Anchor Books, 1961.

Frank, Richard M. "Elements in the Development of the Teaching of al-Ash'arī." Le Muséon 104 (1991), pp. 141-19o.

Frenkel, Miriam. "Medieval Alexandria: Life in a Port City." Al-Masāq: Journal of the Medieval Mediterranean, 26:1, (2014): pp. 5-35.

Geoffroy, Éric. Le soufisme en Égypte et en Syrie sous les derniers Mamelouks et les premiers Ottomans: orientations spirituelles et enjeux culturels. Damascus: Institut français d'études arabes de Damas, 1995.

Geoffroy, Éric. "Le traité de soufisme d'un disciple d'Ibn Taymiyya: Aḥmad 'Imād al-dīn al-Wāsiṭī (m. 711/1311)." Studia Islamica, No. 82 (1995): pp. 83-101.

Geoffroy, Éric. "Les milieux de la mystique musulmane à Alexandrie aux XIıIe et XIVe siècles." In Alexandrie médiévale 2, edited by Christian Décobert, pp. 169-18o. Cairo: Institut Français d'Archéologie Orientale, 2010.

Geoffroy, Éric. "Entre ésotérisme et éxotérisme: les Shâdhilis, passeurs de sens (Égypte - XIII -XVe siècles)." In Une voie soufie dans le monde: la Shâdhiliyya, edited by Éric Geoffroy, pp. 117-129. Paris: Maisonneuve et Larose, 2005.

Ghunaymī, Abū al-Wafā' al-. Ibn 'Ațā' Allāh al-Sikandarīwa-taṣawwufuhu. Cairo: Maktabat al-anjlū al-mișriyya, 1969 .

Gilbert, Joan E. "Institutionalization of Muslim Scholarship and Professionalization of the 'Ulamā' in Medieval Damascus." Studia Islamica, No. 52, (1980): pp. 105-134.

Goldziher, Ignaz. Introduction to Islamic Theology and Law. Princeton: Princeton University Press, 1981.

Gramlich, Richard. Die Wunder der Freunde Gottes: Theologien und Erscheinungsformen des islamischen Heiligenwunders. Stuttgart: Steiner Verlag Wiesbaden, 1987.

Green, Nile. Sufism: A Global History. Malden: Wiley-Blackwell, 2012.

Gril, Denis. "Esotérisme contre hérésie: 'Abd al-Rahmân al-Bistâmî, un représentant de la science des lettres à Bursa dans la première moitié du Xve siècle." In Syncrétismes Et Hérésies Dans L'Orient Seljoukide Et Ottoman (XIVe-XVIIIe Siècles): Actes Du Colloque Du Collège De France, Octobre 20o1, edited by Gilles Veinstein, pp. 183-195. Paris: Peeters, 2005.

Gril, Denis. “L'enseignement d'Ibn 'Atâ' Allâh al-Iskandarî, d'après le témoignage de son disciple Râfi' Ibn Shâfi." In Une voie soufie dans le monde: la Shâdhiliyya, edited by Éric Geoffroy, pp. 93-106. Paris: Maisonneuve et Larose, 2005.

Haddad, Gibril Fouad. The Refutation of Him [Ibn Taymiyya] Who Attributes Direction to Allāh (al-Raddu 'alā Man Qāla bil-Jiha). Birmingham: AQSA Publications, 2008. 
Ḥājjī Khalīfa, Mușțafā b. 'Abd Allāh. Kashf al-ẓunūn 'an asāmī al-kutub wa-al-funūn, 2 vols. Baghdad: Maktabat al-muthannā, 1941.

Hartmann, Angelika. An-Nāṣir li-Dīn Allāh, 1180-1225: Politik, Religion, Kultur in der späten 'Abbāsidenzeit. Berlin: Walter de Gruyter, 1975.

Heller, Daniella Talmon. "The Shaykh and the Community: Popular Hanbalite Islam in 12th-13th Century Jabal Nablus and Jabal Qasyūn." Studia Islamica, No. 79 (1994): pp. 103-120.

Hodgson, Marshall G. S. The Venture of Islam, Volume 1: The Classical Age of Islam. University of Chicago Press, 1974.

Hodgson, Marshall G. S. The Venture of Islam, Volume 2: The Expansion of Islam in the Middle Periods. University of Chicago Press, 1977.

Hofer, Nathan. The Popularisation of Sufism in Ayyubid and Mamluk Egypt, 1173-1325. Edinburgh: Edinburgh University Press, 2015.

Hofer, Nathan. "The Origins and Development of the Office of the "Chief Suf" in Egypt, 1173-1325." Jss 3 (2014): pp. 1-37.

Holt, Peter M. Early Mamluk diplomacy (1260-129o): treaties of Baybars and Qalāwūn with Christian rulers. Leiden: Brill, 1995.

Holtzman, Livnat. “Ibn Qayyim al-Jawziyyah." In Essays in Arabic Literary Biography II: 1350-1850, edited by Devin J. Stewart \& Joseph E. Lowry, pp. 202-223. Wiesbaden: Harrassowitz Verlag, 20o9.

Homerin, Th. Emil. From Arab Poet to Muslim Saint: Ibn al-Fārid, His Verse, and His Shrine. Cairo, Egypt: American University in Cairo Press, 2001.

Homerin, Th. Emil. "Ibn Taimīya's al-Șūfiyah wa-al-Fuqarā’." Arabica, 32 (1985): pp. 219-244.

Homerin, Th. Emil. "Sufism in Mamluk Studies: A Review of Scholarship in the Field." In Ubi sumus? Quo vademus? History and Society during the Mamluk Era (1250-1517), edited by Stephan Conermann, pp. 187-209. Bonn: Bonn University Press, 2013.

Homerin, Th. Emil. "Sufis and their Detractors in Mamluk Egypt." In: Islamic Mysticism Contested: Thirteen Centuries of Controversies and Polemics, edited by Frederick de Jong \& Bernd Radtke, pp. 225-247. Leiden, Netherlands: Brill, 1999.

Homerin, Th. Emil. "Saving Muslim Souls: The Khānqāh and the Sufi Duty in Mamluk Lands." MSR III (1999): pp. 59-83.

Honerkamp, Kenneth. "Abū 'Abd al-Raḥmān al-Sulamī (d. 412/1201) on Samā', Ecstasy and Dance." JHS, 4 (2003): pp. 1-13.

Hoover, Jon. Ibn Taymiyya's Theodicy of Perpetual Optimism. Leiden: Brill, 2007

Hoover, Jon. "Hanbalī Theology." In The Oxford Handbook of Islamic Theology, ed. Sabine Schmitdke, pp. 625-646. Oxford: Oxford University Press, 2016.

Hoover, Jon. "Early Mamlūk Ash'arīs against Ibn Taymiyya: on the nonliteral reinterpretation ( $t a^{\prime}$ wìl) of God's attributes." Forthcoming in Philosophical Theology in 
Islam: The Later Asharite Tradition, edited by Jan Thiele and Ayman Shihadeh. Leiden: Brill.

Hurvitz, Nimrod. "Miḥna as self-defense." Studia Islamica, No. 92 (2001): pp. 93-111. 'Īsā, Aḥmad. Tārīkh al-Būmāristānāt fì al-islām. Beirut: Dār al-ra’id al-'arabī, 1981.

Kamali, Mohammed Hashim. A Textbook of Hadith Studies: Authenticity, Compilation, Classification and Criticism of Hadith. Markfield, Leicestershire: Islamic Foundation, 2005 .

Karamustafa, Ahmet T. God's Unruly Friends: Dervish Groups in the Islamic Later Middle Period, 1200-1550. Salt Lake City: University of Utah Press, 1994.

Karamustafa, Ahmet T. Sufism: The Formative Period. Berkeley/Los Angeles: University of California Press, 2007.

Landolt, Hermann. "Nasafi, 'Aziz." EIr.

Karimullah, Kamran. Aḥmad Zarrūq and the Ash'arite School. Dissertation M.A. McGill University, 2007.

Knysh, Alexander D. Islamic Mysticism: A Short History. Leiden: Brill, 2000.

Knysh, Alexander D. Ibn 'Arabi in the Later Islamic Tradition: The Making of a Polemical Image in Medieval Islam. Albany: State University of New York Press, 1999.

Knysh, Alexander D. “'Orthodoxy' and 'Heresy' in Medieval Islam: An Essay in Reassessment." The Muslim World 83:1 (1993): pp. 48-67.

Kraemer, Joel L. "The Andalusian Mystic Ibn Hūd and the Conversion of the Jews." In Israel Oriental Studies XII (1992): pp. 59-73.

Krawietz, Birgit. "Ibn Qayyim al-Jawzīyah: His Life and Works." MSR X (2006): pp. 19-64.

Krenkow, Fritz. "Al-Tilimsānī." In $E I^{2}$ : vol. 10, pp. 499-500.

Labib, Subhi \& R. Guest \& C. Edmund Bosworth. "Alexandria (al-Iskandariyya; in EI", al-Iskandariya)." In Historic Cities of the Islamic World, edited by C. Edmund Bosworth, pp. 13-22. Leiden / Boston: E.J. Brill, 2007.

Lange, Christian R. "Power, Orthodoxy and Salvation in Classical Islamic Theology." In Islamic Studies in the Twenty-First Century, edited by Léon Buskens \& Annemarie van Sandwijk, pp. 135-159. Amsterdam: Amsterdam University Press, 2016.

Laoust, Henri. Essai sur les doctrines sociales et politiques de Taki-d-Din Ahmad b. Taimiya, canoniste hanbalite né à Harràn en 661/1262, mort à Damas en 728/1328. Cairo: Impr. de l'Institut français d'archéologie orientale, 1939.

Laoust, Henri. "Le Hanbalisme sous le califat de Bagdad (241/855-656/1258)." REI I (1959): pp. 67-128.

Lapidus, Ira M. Muslim Cities in the Later Middle Ages. Cambridge: Harvard University Press, 1967.

Laugier de Beaurecueil, Serge de. Khwādja 'Abdullāh Anșārī (396-481H./10o6-1089): mystique Hanbalite. Beirut: Librairie Orientale, 1965. 
Laugier de Beaurecueil, Serge de. "La voie du privilegie: petit traité d'Abu Mansur Ma'mar al-Isfahani." In Mélanges Taha Husain: offerts par ses amis et ses disciples á l'occasion de son 7oième anniversaire, edited by 'Abd al-Raḥmān Badawī, pp. 65-76. Cairo: Dar Al-Maaref, 1962.

Lawrence, Bruce B. "Sufism and neo-Sufism." In The New Cambridge History of Islam Volume 6, edited by R. Hefner, pp. 355-384. Cambridge: Cambridge University Press, 2010.

Leder, Stefan. "Charismatic Scripturalism: The Hanbalī Maqdisīs of Damascus." Der Islam, volume 74, Issue 2 (Jan 1997): pp. 279-304.

Leder, Stefan, Yāsīn Muhammad al-Sawwās, and Ma’mūn Ṣāğarğì. Mư̆gam al-samā'āt al-dimašqiyya 550-750 h. / Les certificats d'audition à Damas: 1155-1349. Damascus: Institut français de Damas, 1996.

Leitner, Hartman. "Wie man ein neuer Mensch wird, oder: Die Logik der Bekehrung." In Biographische Sozialisation, edited by Erika M. Hoerning, pp. 61-86. Berlin: De Gruyter, 2000.

LeStrange, Guy. The Lands of the Eastern Caliphate: Mesopotamia, Persia, and Central Asia from the Moslem Conquest to the Time of Timur. Cambridge: Cambridge University Press, 1905 .

Lewis, Bernard. "The Mongols, the Turks and the Muslim Polity." TRHs, Vol. 18 (1968): pp. 49-68.

Lewis, Bernard. "Some Observations on the Significance of Heresy in the History of Islam." Studia Islamica 1 (1953): pp. 42-63.

Little, Donald P. An introduction to Mamlūk historiography: an analysis of Arabic annalistic and biographical sources for the reign of al-Malik an-Nāṣir Muhammad ibn Qalä'ün. Wiesbaden: Franz Steiner Verlag, 1970.

Little, Donald P. “Did Ibn Taymiyya Have a Screw Loose?” Studia Islamica, No. 41 (1975): pp. 93-111.

Lucas, Scott C. Constructive Critics, Hadìth Literature, and the Articulation of Sunnī Islam: The Legacy of the Generation of Ibn Sa'd, Ibn Ma'in, and Ibn Hanbal. Leiden: Brill, 2004.

Makdisi, George. Ibn 'Aqil: Religion and Culture in Classical Islam. Edinburgh: Edinburgh University Press, 1997.

Makdisi, George. "Ash'arī and the Ash'arites in Islamic Religious History." Studia Islamica, No. 17 (1962): pp. 37-80.

Makdisi, George. "Hanbalite Islam." In Studies on Islam, translated and edited by Merlin L. Swartz. New York: Oxford University Press, 1981.

Makdisi, George. "The Hanbali School and Sufism." In Humaniora Islamica, 2 (1974): pp. 61-72.

Makdisi, George. "Ibn Taymīya: A Șūfĩ of the Qādiriyya Order." American Journal of Arabic Studies, vol. 1 (1974): pp. 118-129. 
Malik, Hamza. The Grey Falcon: The Life and Teaching of Shaykh Abd Al-Qädir Al-Jülānī. Leiden: Brill, 2019.

Manz, Beatrice Forbes. "The rule of the infidels: the Mongols and the Islamic world." In NCHI: pp. 128-168.

Margoliouth, David S. "al-Rifāî̀, Ahmmad b. 'Ali." In $E I^{2}$ : vol. 8, pp. 524-525.

Ma'rūf, Nājī. Madāris Wāsiț. Baghdad: Maṭba't al-irshād, 1966.

Massignon, Louis. "Harīīya." In $E I^{2}$ : vol. 3, p. 222.

Matroudi, Abdul Hakim I. Al-. The Hanbalı School of Law and Ibn Taymiyyah: Conflict or Conciliation. London: Routledge, 2010.

Mazor, Amir. The Rise and Fall of a Muslim Regiment: The Manșūriyya in the First Mamluk Sultanate, 678/1279-741/1341. Göttingen, Niedersachs: V\&R unipress, 2015.

McGregor, Richard "Akbarian Thought in a Branch of the Shâdhiliyya." In Une voie soufie dans le monde: la Shâdhiliyya, edited by Éric Geoffroy, pp. 107-115. Paris: Maisonneuve et Larose, 2005 .

McGregor, Richard "The Problem of Sufism." MSR XIII (2009): pp. 69-83.

Meier, Fritz. Band 1. Bemerkungen zur Mohammedverehrung. Teil 2. Die tạṣliya in sufischen Zusammenhängen. Herausgegeben von Bern Radtke. Leiden: Brill, 2005

Meier, Fritz. "Der Derwischtanz: Versuch eines Überblicks." Asiatische Studien 8 (1954): pp. 108-136.

Meier, Fritz. "Profet als lebensvorbild: šādilī und ḥanbalī in personalunion," Nachlass Fritz Meier, Universitätsbibliothek Basel, NL 0323 D 1.7.

Meier, Fritz. "The Cleanest about Predestination: A Bit of Ibn Taymiyya." In Essays on Islamic Piety and Mysticism, translated by John O'Kane. Leiden: Brill, 1999 (translation of: "Das sauberste über die vorbestimmung: Ein stück Ibn Taymiyya." Saeculum 32 (1981): pp. 74-89.

Melchert, Christoper. "The Adversaries of Aḥmad Ibn Hanbal." Arabica 44:2 (1997): pp. 234-253.

Melchert, Christoper. "The Piety of the Hadith Folk." IJMES, vol. 34, No. 3 (2002): pp. 425-439.

Melchert, Christoper. "The Ḥanābila and the Early Sufis." Arabica, T. 48, Fasc. 3 (2001): pp. 352-367.

Meri, Josef W. The Cult of Saints Among Muslims and Jews in Medieval Syria. Oxford: Oxford University Press, 2002.

Michel, Thomas. A Muslim Theologian's Response to Christianity: Ibn Taymiyya's AlJawab al-Sahih. Delmar, NY: Caravan Books, 1984.

Michel, Thomas. "Ibn Taymiyya's Sharh on the Futūḥ al-Ghayb of 'Abd al-Qādir alJīlānī." Hamdard Islamicus, vol. 4, no. 2 (1981): pp. 3-12.

Michot, Yahya. Muslims under Non-Muslim Rule. Oxford: Interface Publications, 2006. 
Michot, Yahya. "Ibn Taymiyya's Commentary on the Creed of al-Hallāj." In Sufism and Theology, edited by Ayman Shihadeh, pp. 123-136. Edinburgh: Edinburgh University Press, 2007.

Müller-Wiener, Martina. Eine Stadtgeschichte Alexandrias von 564/1169 bis in die Mitte des 9./15. Jahrhunderts: Verwaltung und innerstädtische Organisationsformen. Berlin: Schwarz, 1992.

Nizami, Kkaliq Ahmad. "Faḳī." In $E I^{2}$ : vol. 2, pp. 757-758.

Northrup, Linda S. From slave to sultan: the career of al-Manșūr Qalāwūn and the consolidation of Mamluk rule in Egypt and Syria (678-689 A.H./1279-129o A.D.). Stuttgart: Franz Steiner Verlag, 1998.

O’Fahey, Rex S. \& Radtke, Bernd. "Neo-Sufism reconsidered." Der Islam, 70 (1973): pp. $5^{2-87}$.

Ohlander, Erik S. Sufism in an Age of Transition: 'Umar al-Suhrawardī and the Rise of the Islamic Mystical Brotherhoods. Leiden: Brill, 2008.

Ohlander, Erik S. "al-Fārūthī, 'Izz al-Dīn." In EI³, 2012 (1), pp. 135-136.

Pavlin, James. “Ibn Taymiyya's Theology." In Ibn Taymiyya: Epistle on Worship, translated by James Pavlin, pp. LIV-XCIII. Cambridge: Islamic Texts Society, 2015.

Poonawala, Ismail K. "Humanism in Ismāîlī Thought: The Case of the Rasāil Ikhwān al-Safä' (The Epistles of the Sincere Brethren and Faithful Friends)." In Universality in Islamic Thought, edited by M. Morony, pp. 65-144. London: I. B. Tauris, 2014.

Post, Arjan. "A Glimpse of Sufism from the Circle of Ibn Taymiyya: An Edition and Translation of al-Ba'labakkī's (d. 734/1333) Epistle on the Spiritual Way (Risālat alSulūk)." Jss 5 (2016): pp. 156-187.

Post, Arjan. "A Taymiyyan Sufi's Refutation of the Akbarian School: 'Imād al-Dīn Aḥmad al-Wāsițī's (d. 711/1311) Lawāmi ' l-istirshād." In CHESFAME Proceedings IX, ed. K. D’Hulster, G. Schallenbergh, \& J. van Steenbergen, pp. 309-325. Leuven, Paris, Bristol: Peeters, 2019.

Pouzet, Louis. Damas au VIIe-XIIIe siècle: vie et structures religieuses d'une métropole islamique. Beirut: Dar el-Machreq, 1988.

Qūnawī, Muḥammad b. 'Abd Allāh Aḥmad Abū al-Faḍl al-. al-Ṣūfiyya al-qalandariyya: tārīkhuhā wa-fatāwā shaykh al-Islām Ibn Taymiyya fìhā. Medina/Beirut: published by the author, 2002.

Radtke, Bernd \& John O'Kane. The Concept of Sainthood in Early Islamic Mysticism: Two Works by al-Hakìm al-Tirmidhī; an Annotated Translation with Introduction. Richmond, Surrey: Curzon Press, 1996.

Radtke, Bernd. "Warum ist der Sufi Orthodox?” Der Islam, 71 (1994): pp. 302-307.

Ravan Farhadi, A. G. Abdullah Ansari of Herat (1006-1089 C.E.): An Early Sufi Master. Richmond, Curzon Press, 1996.

Reynolds, Dwight F. (editor). Interpreting the Self: Autobiography in the Arabic Literary Tradition. Berkeley: University of California Press, 2001. 
Ridgeon, Lloyd. 'Azizz Nasaft. Richmond: Curzon, 1998.

Ridgeon, Lloyd. "Mysticism in Medieval Sufism." In Cambridge Companion to Sufism, pp. 125-149. Cambridge: Cambridge University Press, 2014.

Ruano, Delfijina Serrano. "Ibn Rushd al-Jadd (d. 520/1126)." In Islamic Legal Thought: A Compendium of Muslim Jurists, edited by Oussama Arabi, David S. Powers and Susan A. Spectorsky, pp. 295-322. Leiden: Brill, 2013.

Safi, Omid. "Bargaining with Baraka: Persian Sufism, "Mysticism," and Pre-Modern Politics." The Muslim World 9o:3-4 (2000): pp. 259-288.

Sakly, Mondher, and Robert Darley-Doran. "Wasit (Wāsiț)." In Historic Cities of the Islamic World, edited by C. Edmund Bosworth, 550-556. Leiden / Boston: E.J. Brill, 2007.

Saleh, Walid. "Ibn Taymiyyah and the Rise of Radical Hermeneutics: An Analysis of "An Introduction to the Foundation of Quranic Exegesis"." In Ibn Taymiyyah and His Times, edited by Yossef Rapoport \& Shahab Ahmed, pp.123-162. Lahore: Oxford University Press, 2010.

Sarrio, Diego R. "Spiritual anti-elitism: Ibn Taymiyya's doctrine of sainthood (walāya)." Islam and Christian-Muslim Relations, 22:3 (2011): pp. 275-291.

Scattolin, Giuseppe. “The Key Concepts of al-Farghānī's Commentary on Ibn al-Fāriḍ's Sufi Poem, al-Tä'iyyat al-Kubrā," JMIAS 39 (2006): pp. 33-83.

Schallenbergh, Gino. "Intoxication and Ecstasy: Sufi Terminology in the Work of Ibn Qayyim al-Ğawziya." In Proceedings of the 6th, 7 th and 8th colloquium on the history of Egypt and Syria in the Fatimid, Ayyubid and Mamluk Eras, edited by Jo van Steenbergen \& Urbain Vermeulen, pp. 459-474. Leuven: Uitgeverij Peeters, 2005.

Schallenbergh, Gino. "Ibn Qayyim al-Jawziyya's Manipulation of Sufi Terms: Fear and Hope." In Islamic Theology, Philosophy and Law: Debating Ibn Taymiyya and Ibn Qayyim Al-Jawziyya, edited by Birgit Krawietz \& Georges Tamer, pp. 94-122. Berlin: De Gruyter, 2013.

Schimmel, Annemarie. Mystical dimensions of Islam. Chapel Hill: University of North Carolina press, 1975 .

Schlamelcher, Jens. "Religious Studies." In Handbook of Autobiography / Autofiction, edited by Martina Wagner-Egelhaaf, vol. I, pp. 156-164. Berlin: De Gruyter, 2019.

Shoshan, Boaz. Popular Culture in Medieval Cairo. New York: Cambridge University Press, 1993 .

Silvers-Alario, Laury. "The Teaching Relationship in Early Sufism: A Reassessment of Fritz Meier's Definition of the shaykh al-tarbiya and the shaykh al-talim." The Muslim World 93:1 (2003): pp. 69-97.

Spuler, Bertold. Die Mongolen in Iran: Politik, Verwaltung und Kultur der Ilchanzeit 12201350. Leiden: E.J. Brill, 1985.

Sviri, Sarah. "Sufism: Reconsidering Terms, Definitions and Processes in the Formative Period of Islamic Mysticism." In Les maîtres soufis et leurs disciples des IIIe-Ve siècles 
de l'hégire (IXe-XIe): enseignement, formation et transmission, edited by Geneviève Gobillot \& Jean-Jacques Thibon, pp. 17-34. Beirut: Institut français du ProcheOrient, 2012.

Swartz, Merlin L. Ibn al-Jawzìs Kitāb al-Qușṣạṣ wa'l-Mudhakkirīn. Beirut: Dar el-Machreq Éditeurs, 1986.

Tall, 'Umar Salīm 'Abd al-Qādir. Mutașawwifat Baghdād: fì al-qarn al-sādis al-hijrī/althānī 'ashar al-mīlādī: dirāsa tārīkhiyya. Amman: Dār al-ma’mūn li-al-nashr wa-altawzì', 2009.

Tareen, Sherali. "Normativity, Heresy, and the Politics of Authenticity in South Asian Islam," The Muslim World 99:3 (2009): pp. 521-552.

Taylor, Christopher Schurman. In the Vicinity of the Righteous: Ziyāra and the Veneration of Muslim Saints in Late Medieval Egypt. Leiden: Brill, 1998.

Thorau, Peter. The lion of Egypt: Sultan Baybars I and the Near East in the thirteenth century. London: Longman, 1992.

Todd, Richard. The Sufi Doctrine of Man: Șadr al-Dīn al-Qünawì’s Metaphysical Anthropology. Leiden: Brill, 2014.

Trimingham, J. Spencer. The Sufi Orders in Islam. New York: Oxford University Press, 1998.

Udovitch, Abraham L. "Alexandria in the 11th and 12th Centuries. Letters and Documents of the Cairo Geniza Merchants: an Interim Balance Sheet." In Alexandrie médiévale 2, edited by Christian Décobert, pp. 99-112. Cairo: Institut Français d'Archéologie Orientale, 2010.

Van Donzel, Emeri. “Mudjaddid." In $E I^{2}$ : vol. 7, p. 29 o.

Van Ess, Josef. Der Eine und das Andere: Beobachtungen an islamischen häresiographischen Texten. Berlin: De Gruyter, 2011.

Van Ess, Josef. "Sufism and its opponents: reflections on topoi, tribulations, and transformations." In Islamic Mysticism Contested: Thirteen Centuries of Controversies and Polemics, edited by F. de Jong \& Bernd Radtke, pp. 22-44. Leiden: Brill, 1999.

Vasalou, Sophia. Ibn Taymiyya's Theological Ethics. New York: Oxford University Press, 2015.

Voll, John O. "Neo-Sufism: Reconsidered Again." Canadian Journal of African Studies Vol. 42, No. 2/3 (2008): pp. 314-330.

Wagemakers, Joas. "Why Salafis Have Anti-Sufi Attitudes." OAsIs, June 21, 2017. Accessed June 29, 2017. <http://www.oasiscenter.eu/articles/jihadism-and-violence/ 2017/o6/21/why-salafis-have-anti-sufi-attitudes?utm_campaign=Who+are+the+Suf is $\% 3 \mathrm{f}+-+$ Newsletter $+\mathrm{n} .+-+2017 \&$ utm_medium $=$ email\&utm_source=CamoNews letter.

Wallach, Jennifer Jensen. "Building a Bridge of Words: The Literary Autobiography as Historical Source Material." Biography 29.3 (2006): pp. 446-461. 
Wilson, Brett. "The Failure of Nomenclature: The Concept of 'Orthodoxy' in the Study of Islam," Comparative Islamic Studies 3:2 (2007): pp. 169-194.

Winter, Michael. Society and religion in early Ottoman Egypt: studies in the writings of 'Abd al-Wahhāb al-Sha'rānī. New Brunswick N.J. etc.: Transaction Books, 1982.

Ziriklī, Khayr al-Dīn al-. al-A'lām: qāmūs tarājim li-ashhar al-rijāl wa-al-nisā min al'arab wa-al-musta'ribìn wa-al-mustashriqīn, 8 vols. Beirut: Dār al-'ilm al-malāyīn, 2002. 


\section{Index of Qur'an and Hadīth References}

\begin{tabular}{|c|c|c|c|}
\hline \multicolumn{2}{|c|}{ Qur'anic Verses } & Q. $56: 8$ & $273 n 136$ \\
\hline Q. 1:5 & 259 & Q. $56: 88$ & $273 n 136$ \\
\hline Q. 3:25 & 263 & Q. $56: 90-91$ & $273 n 136$ \\
\hline Q. 3:31 & 190 & Q. $57: 4$ & 262 \\
\hline Q. 3:55 & $208 n 96$ & Q. $58: 7$ & 206 \\
\hline Q. 3:154 & $25^{8}$ & Q. 67:16-17 & 208ng6 \\
\hline Q. 4:40 & 263 & Q. 70:3-4 & 208ng6 \\
\hline Q. 4:65 & 251 & Q. 83:18 & $273^{n} 136$ \\
\hline Q. 4:158 & $208 n 96$ & Q. 83:21 & $273 n 136$ \\
\hline Q. $5: 56$ & 102 & Q. $87: 1-2$ & $113,208 \mathrm{n} 96$ \\
\hline Q. 5:117 & 249 & & \\
\hline Q.6:18 & $112,208 \mathrm{ng} 6$ & & \\
\hline Q. $7: 185$ & 257 & \multirow{3}{*}{\multicolumn{2}{|c|}{ Hadīth References }} \\
\hline Q. 7:196 & 102, $270 n 122$ & & \\
\hline Q. 9:100 & $195^{-196}$ & & \\
\hline Q. 9:112 & 240,241 & \multicolumn{2}{|c|}{ Choice between becoming a servant prophet } \\
\hline Q. 10:3 & $208 \mathrm{ng} 6,210$ & \multirow{2}{*}{\multicolumn{2}{|c|}{$\begin{array}{l}\text { or a king prophet } 98 \\
\text { "every newly invented thing is an innovation }\end{array}$}} \\
\hline Q. $10: 63-64$ & 261 & & \\
\hline Q. 16:40 & 256 & \multicolumn{2}{|c|}{$\left(b^{\prime} d^{\prime} a\right) \ldots " \quad 53,217$} \\
\hline Q. 16:50 & 112,208 & \multicolumn{2}{|c|}{ "Exalted is Your greatness (tacălā jaddu- } \\
\hline Q. 16:6o & 243 & \multirow{3}{*}{\multicolumn{2}{|c|}{$\begin{array}{l}\text { ka).” } 244 \\
\text { God's descent to the lowest heavenly sphere } \\
\text { (hadith al-nuzūl) } \quad 111,150,203\end{array}$}} \\
\hline Q. 16:102 & $208 \mathrm{ng} 6$ & & \\
\hline Q. 20:5 & 208 & & \\
\hline Q. 20:14 & $25 \mathrm{O}, 255,263,264$ & \multicolumn{2}{|c|}{ "God was and there was nothing before } \\
\hline Q. 21:47 & 263 & \multirow{3}{*}{\multicolumn{2}{|c|}{$\begin{array}{l}\text { Him...” } 97 \\
\text { Like Abraham, Muhammad is the intimate } \\
\text { friend of God } 189 n 24\end{array}$}} \\
\hline Q. 26:192-194 & $188 \mathrm{n} 20$ & & \\
\hline Q. $27: 63$ & 256 & & \\
\hline Q. $30: 27$ & 243 & \multirow{3}{*}{\multicolumn{2}{|c|}{$\begin{array}{l}\text { "My servant continues to draw near to Me } \\
\text { with supererogatory deeds (nawāfil) until } \\
\text { I love him..." } 271\end{array}$}} \\
\hline Q. 33:35 & 240,241 & & \\
\hline Q. 35:10 & $208 n 96$ & & \\
\hline Q. $35: 32$ & $273 n 136$ & \multicolumn{2}{|c|}{ On the lesser and greater jih $\bar{a} d \quad 49 n 48$} \\
\hline Q. 38:75 & 205 & \multirow{5}{*}{\multicolumn{2}{|c|}{$\begin{array}{l}\text { On the saved sect ("There will continue to be } \\
\text { a group in my community who are } \\
\text { manifestly upon the truth...") } 15 \text { on137 } \\
\text { The Prophet asking the slave girl where God } \\
\text { is } \quad 209\end{array}$}} \\
\hline Q. 40:17 & 263 & & \\
\hline Q. 40:36-37 & $208 \mathrm{ng} 6$ & & \\
\hline Q. $42: 11$ & $205 \mathrm{n} 79,207$ & & \\
\hline Q. $55: 27$ & 249 & & \\
\hline
\end{tabular}




\section{Index of Technical Terms}

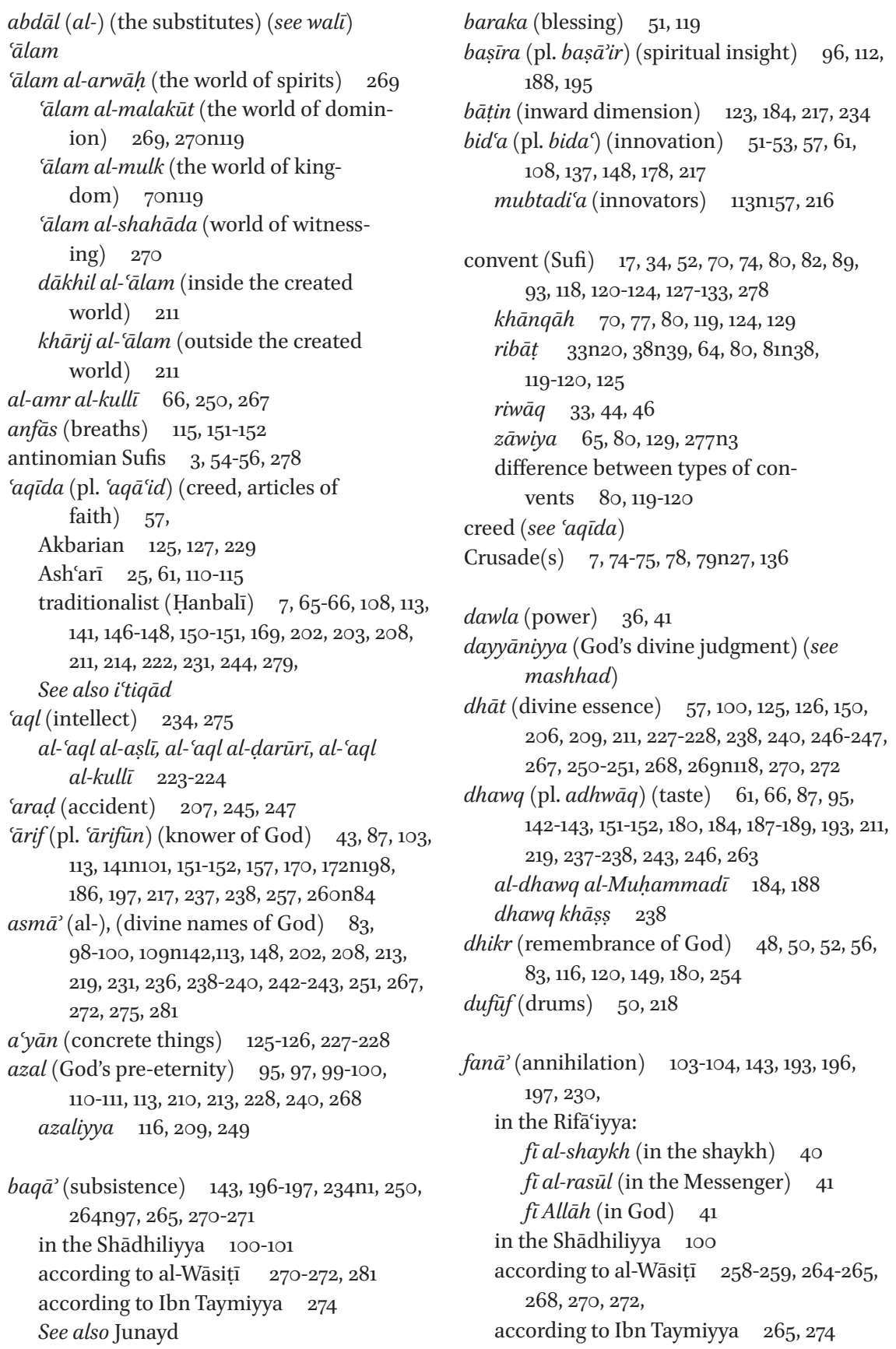

baraka (blessing) 51, 119

bașīra (pl. bașā̉ir) (spiritual insight) 96, 112, 188, 195

bāțin (inward dimension) 123, 184, 217, 234

bid'a (pl. bida) (innovation) 51-53, 57, 61, 108, 137, 148, 178, 217

mubtadi'a (innovators) 113n157, 216

convent (Sufi) $17,34,52,70,74,80,82,89$, 93, 118, 120-124, 127-133, 278

khānqāh $70,77,80,119,124,129$

ribāt $33 \mathrm{n} 20,38 \mathrm{n} 39,64,8 \mathrm{o}, 8 \mathrm{n} 38$, 119-120, 125

riwāq $33,44,46$

zāwiya $\quad 65,8$ o, 129, 277n3

difference between types of convents $80,119-120$

creed (see 'aqïda)

Crusade(s) 7, 74-75, 78, 79n27, 136

dawla (power) $\quad 36,41$

dayyāniyya (God's divine judgment) (see mashhad)

dhāt (divine essence) $57,100,125,126,15$ o, 206, 209, 211, 227-228, 238, 240, 246-247, $267,25 \mathrm{O}-251,268,269 \mathrm{n} 118,27 \mathrm{O}, 272$

dhawq (pl. adhwāq) (taste) 61, 66, 87, 95, 142-143, 151-152, 180, 184, 187-189, 193, 211, 219, 237-238, 243, 246, 263

al-dhawq al-Muhammadī 184, 188

dhawq khāṣs $\quad 238$

dhikr (remembrance of God) 48, 50, 52, 56, $83,116,120,149,180,254$

dufüf(drums) 50, 218

fana $\bar{a}^{\prime}$ (annihilation) 103-104, 143, 193, 196, 197, 230,

in the Rifāiyya: fial-shaykh (in the shaykh) 40 fíal-rasül (in the Messenger) 41 fì Allāh (in God) 41

in the Shādhiliyya 100

according to al-Wāsițī 258-259, 264-265,

$268,270,272$,

according to Ibn Taymiyya 265,274 
faqīr (pl. fuqarā’)

definition 3 ong

in the Rifā'iyya $39 n 42,40,42,47,5^{\circ}$,

in the Shādhiliyya 99

according to al-Wāsițī 258

faqr (neediness)

in the Rifā'iyya (as iftiqār) $\quad 55^{-56}$

in the Shādhiliyya 99

among the Sufis of convention 123

according to al-Wāsițī 184n6, 191, 198, 220 ,

fardāniyya (God's singularity) (see mashhad) farq (separation) $\quad 196$

al-farq al-thānī (the second separation) 271

fawqiyya (God's aboveness) (see șifa)

fiqh (jurisprudence) $3,17,22,25,38,50,54$,

6o, 67, 79, 105n128, 114-115, 149, 171,

173-174

al-Wāsițìs study of $\quad 53,60-61,63,145$,

firqa (al-) al-nājiya (see saved sect)

Geniza $\quad$ 73-74

ghawth (al-) (the helper) (see walī)

ghayb (pl. ghuyūb) (the unseen) 181, 194,

199, 246, 269-270, 275, 280

ghinā (sufficiency) 99

grammar of segmentation (the) 8

hadīth (prophetic tradition) 9, 65, 97, 109n142, 115, 135, 140, 145, 147n122, 15o, $162,167,169-174,179,183,187$, 199-20o, 202-203, 208, 222, 250

titles of hadìth literature al-Wāsitị

knew 145nu6, 192

See also Index of Qur'an and Hadìth

References, and $s a m \bar{a}^{c}$

hajj (greater pilgrimage) $\quad 32,44,70,78$

hâal (pl. ahwāal) (spiritual state) 22, 38n38-39,

$51,67,101,103,115,116,133,143,151$, 152n141, 153-154, 179, 187, 194, 196-197,

198, 201, 216n117, 217, 229-230, 237, 239,

254, 258-259, 272-273

al-hālal-Muhammadī 184, 199

al-hāl al-Ibrāhīmì al-khalīì al-

Muhammadī 188-189

haqīqa (reality) 104n125, 219, 229, 234, 249 al-ḥaqīqa al-jāmía li-jamīi al-nu'ūt 266267

al-ḥaqiqa al-Muhammadiyya 185 , 186n16, 280

haqā̃iq (pl.) (spiritual realities) 150, 153-154, 180, 191, 193, 196, 201, 238, $269 n 117$

himma

creative power of God's friends 41,116 ,

spiritual aspiration $\quad 5^{\circ}$

hubb (love) 196, 199, 237

See also mahabba

hulül (divine incarnation/indwelling) 57, 106, 211, 225, 229, 246, 267

‘ibārāt (spiritual expressions/allusions) 155, 198,229

ijāza (license to transmit a text/knowledge) 33,128

ikhtiyār (choice)

in the Shādhiliyya $\quad 94-98,260$

according to al-Wāsițī 234, 257-259, 26o, 275,281

ilāhiyya (God's divinity)

according to Ibn Taymiyya $\quad 260-261$

for al-Wāsițī see mashhad

ilhām (divine inspiration) 188

imrār (reading over Qur'anic verses) 203

irāda

for a human being: desire $\quad$ 95-96 See also shahwa

for God: express/divine will 207, 210, $240,258,26$ on 84

istighātha (see tawassul)

iștilām (self-effacement) 100, 153, 264-265

istiqāma (steadfastness) 61, 235

istiw $\vec{a}^{\prime}$ (God's sitting on the Throne) (see sifa)

ithbāt (the affirmation of divine attributes)

in al-Wāsițīs Sufism 206-208, 210, 214, 221-223, 245, 279-28。

in Ibn Taymiyya's circle $\quad$ 149-15o, 171n194, 187, 203-204

ititiqād (creed) 57, 150, 202

See also 'aqïda

ittihād

unification/monism 57, 106, 125-126, $127 \mathrm{n} 37,225,229,246,265-267$ 
unification with the Prophet 195

unification with God's will $\quad 258$

unification of God's attributes 266268

See also wahda

$$
\begin{gathered}
\text { ittihā diyya (al-) (monists) 105-107, 118, } \\
\text { 124-133, 223, 225-231 }
\end{gathered}
$$

¿ìāan (inner vision) 95, 195, 269, 272

See also bașira

jadhb $(a)$ (the pull of divine attraction)

in the Shādhiliyya 101

according to al-Wāsițī 265, 268-269,

274-275, 281

also called injidhāb 101, 153

See also sulūk and majdhūb

jam'(union) 196, 258, 267, 271

See also mashhad

jihād

holy war $78,138,191$

lesser and greater 49

jism (body) 205, 207, 233-234, 233, 245, 247,

275

kalām ('ilmal-) (speculative/rational

theology) 3, 6, 10, 61, 65n138, 110-111,

113-114, 171, 204, 279

al-Wāsiț̣’s polemics against $\quad$ 147, 214-215, 220-224

karāma (pl. karāmāt) (miracle of the friend of God)

among the Hanbalīs 139

in relation to Ibn Taymiyya $\quad$ 149, 261

in the Rifā'iyya $38 \mathrm{n} 38,39,42,48-53,58$, 278

in the Shādhiliyya $\quad 96$

kashf (unveiling) 87, 99, 115, 237

according to al-Wāsiṭī 204, 211, 238, 257, 263

khalìl (intimate friend) 189-19o, 273

khalwa (spiritual seclusion) 120, 229

in the Rifāiciyya $5^{6}$

according to al-Wāsițī 252-253

khānqāh (pl. khawāniq) (see convent)

khawātir (passing thoughts) 95, 253

khawf (fear of God) 143, 234-235, 250-251,

253-254, 256, 261, 263-264

khirqa (Sufi cloak) of the Rifāiiyya 38,42 ,

of the Baghdadi Sufis 66

of the Shādhiliyya $\quad 84,89,107$

of the Qādiriyya 139-142

khulla (or khilla) (intimate friendship) 18919o, 273

mahabba (divine love) 70, 104, 125, 180, 217 according to al-Wāsițī 266, 268, 272-273 according to Ibn Taymiyya 273

See also hubb

mahbūb (one who has become God's

beloved) 190, 273, 281

maḥbūbiyya (belovedness) 273

maiyya (withness) (see mashhad)

majdhūb (one pulled unto God)

in the Shādhiliyya 101-102

according to al-Wāsițī 269-270

See also sulük and jadhb( $(a)$

manāzil (stations) 235

See also maqām

maqām (pl. maqāmāt) (spiritual station) 15

in the Rifā'iyya $\quad 40-42$

in the Shādhiliyya $\quad 98,100-102$

according to al-Wāsițī 133, 142, 147, 190

(maqām al-khulla al-Ibrāhìmiyya

al-Muhammadiyya), 197, 218, 235,

254-255, 257, 270-272

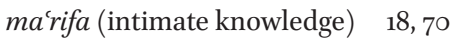

according to al-Wāsițī 22, 6o, 67, 153-154, 191, 235

of God 180, 199, 200-202, 206, 208,

212-215, 219, 230-231, 236-238, 241-243,

251-252, 255, 257, 263, 267, 271, 274-275,

279

of the Prophet 192-194, 200, 255, 231,

280

in the Shādhiliyya $\quad 98,103,110$

martaba (rank) 41

mashhad (pl. mashāhid) (witnessing) 233,

243,

mashhad al-dayyāniyya (witnessing of divine judgment) 248, 262-264

mashhad al-fawqiyya (witnessing of aboveness) $\quad 252$

mashhad al-ilāhiyya (witnessing of divinity) 214, 248, 250-255, 261-262, 281 
mashhad (cont.)

mashhad al-jam'/al-fardāniyya (witnessing of union/singularity) 248,25 , 264-274

mashhad al-maiyya (witnessing of withness) 248, 262-263

mashhad al-nubuwwa (witnessing of

Prophethood) 195

mashhad al-rubūbiyya/al-qayyūmiyya

(witnessing oflordship/sustainment)

248, 250, 255-262, 265-266, 281

overview of al-Wāsițīs system $\quad 249$

See also shuhūd

mathal (pl. mithāl) (similitude) 243-245,

$247,264,275,281$

mawsim (pl. mawāsim) (Rifā̄ī Sufi festival)

46,48

mihna (inquisition) 222

mirāj (the Prophet's heavenly journey) 209

mubāh (pl. mubāhạāt) permissible act 5 o, 57, 141

muhāsaba (taking oneself to account) 253, 269

тијіza (pl. mијizāt) (prophetic miracle)

192, 195

muqarrabūn (those drawn near to God) 95

sābiqūn muqarrabūn $\quad 273-274$

muraqqa'a (patched Sufi cloak) 66, 107

murāqaba (vigilant awareness) 103, 253

murīd (spiritual aspirant) 16o, 192n37, 212, 280

in the tarīqa Muhammadiyya 197-199

murshid (spiritual guide) 143, 156, 16o, 197, 277

al-Wāsițī as a murshid 156-157, 159-16o

in the tariqa Muhammadiyya 197-199

Ibn Taymiyya as a murshid 143, 159-16o,

277

in the Rifāiyya 40

in the Shādhiliyya $\quad 116$

mutașawwifa (would-be Sufis) 57

mutashābihāt (ambiguous references in scrip-

ture) 112, 202, 205-207, 221

muwāfaqa (conformity to God's will) $\quad 25^{8-}$ 261

nafs (pl. nufüs) (ego/carnal soul) 49, 108, according to al-Wāsițī 217-219, 233-236,

253, 275

according to Ibn Taymiyya 235

in the Shādhiliyya $\quad 98,235,238$

nawäfil (supererogatory acts of wor-

ship） 40, 56, 138, 254, 271, 273

nuzūl (God's descent) (see șifa)

$\operatorname{orthodox}(\mathrm{y}) \quad 1,104$

problematic for Islam $\quad$ 4-6

othering $8,18,182,215,279$

philosophy (falsafa) 57, 147, 215, 220, 223-225, 230-231, 279

philosophers (al-falāsifa) 125, 186, 220, 223-224

qalb (pl. quiūb) (heart) 40, 44, 56, 61, 67, 95, 98-99, 103, 112, 115, 153, 173, 179, 181, 217, 219, 222n142

according to al-Wāsițī in relation to the Prophet 187-188, 191-192, 194-195, 197-198, 280

in relation to God 201, 204, 212-214

in relation to the mashāhid $\quad 234-235$,

247, 269-270, 272, 275

qașd (goal) $5^{\circ}$

qayyūmiyya (God's sustainment) (see mashhad)

qibla (direction) 40, 201, 211-213, 245,

qidam (God's antiquity) 95, 116, 209-210

qiyām al-layl (nightly prayer) $\quad 56,138$

See also tahajjud

qurb (divine proximity/nearness) 66, 67, 101, 187, 217, 266, $269 n 118$

quțb (al-) (the axis) (see walī)

rajä' (hope in God) 234-235, 250-251, 253, 261, 263-264

raqș (Sufi dancing during sama $\bar{a}^{\top}$ ) $\quad 66,218$

in the Rifā'iyya $\quad 48,5^{\circ}-51,216$

ricayya (guarding the body parts) 234, 253, 269

ribāt (see convent)

riḍa (contentment with God) 3ong, 143, 196, 251,253

riwāq (see convent)

rubūbiyya (God's lordship)

according to Ibn Taymiyya $\quad 260-261$ 
in the Shādhiliyya $\quad$ 97-100, 112

for al-Wāsițī see mashhad

rūḥ (pl. arwāḥ) (spirit) 234-235, 264, 269-270, 272, 275

rūhāniyya (spiritual presence)

al-șüfiyya (of the Sufis) $\quad 63,187-188$

of the Prophet $187-190,195,200$

sābiqūn (forerunners) (see muqarrabūn)

șaḥw (sobriety) 143, 196-197, 264n97

să $i r$ (spiritual traveler) 53, 178, 269-270

Salaf (al-) (righteous predecessors) 134, 146, șalāt $148,15^{2-153,171, ~ 182, ~ 219, ~} 221$

ritual prayer 180, 219, 254-255

al-șubḥlfajr (morning prayer) 123, 148 al-zuhr (midday prayer) 144, al-aṣr (afternoon prayer) 123 al-maghrib (sunset prayer) 46n67, 145 al-'ish $\bar{a}^{\prime}$ (evening prayer) 145 al-jumu'a (Friday prayer) 75, 255

sending prayers upon the Prophet (tașliya) 40, 56, 191

sālik (spiritual traveler) (see majdhūb, sulūk, jadhb $(a))$

definition $\quad 178$

sama $\bar{a}^{c}$

al-ḥadīth (audition of hadìth) 8, 144, 161-162, 168

Sufi audition among Baghdadi Sufis $\quad 66-67$ in the Rifāiyya $39,46,48-53,58,278$ in the Shādhiliyya 107-108 among the Akbarians $\quad 215$ al-Wāsițī's polemics against $\quad 157$, 215-220, 226, 230-231, 279

saved sect (the) ('al-firqa al-nājiya' or 'al-țāi ifa al-manșūra') 134, 150-151

sayr (spiritual path) 178, 265

See also sulūk

selfing $\quad 8,18,182,279$

shahwa (pl. shahawāt) (desire) 66, 96, 218

See also iräda

sharĩa (revealed law) 77,

in the Rifā'iyya $\quad 5^{6-57}$

in the Shādhiliyya 104, 114, according to the Akbarians 126 according to Baghdadi Sufis 66 according to al-Wāsițī 153-154, 194, 198 , 220, 254,

shawq (longing for God) 143, 196, 217, 272 shaykh (Sufi)

shaykh al-shuyūkh 119, 121, 122n18, 128, 132

in the Rifā'iyya 39-47

in the Shādhiliyya $\quad 115-116$

among the Baghdadi Sufis 63

according to al-Wāsițī 187-191, 195, 197-200

See also murshid

shuhüd (witnessing God) 66, 180, 229

See also mashhad

șifa (pl. șifāt) (divine attribute) 57, 62, 66, 95,

in the Shādhiliyya $\quad$ 98-101, 109-113, 241

according to the Akbarians $\quad 126,227-228$

according to the Ash'arīs $\quad$ 204-205, 207

according to traditionalists 203

according to Ibn Taymiyya 149-150,

171n194, 206-207, 209, 223

according to al-Wāsițī 181, 200-210,

213-214, 219, 231, 233, 236-246, 248, 252,

255-257, 260, 262-264, 266-268, 270,

272, 275, 279, 281

șifāt dhātiyya, șifāt filiyya, șifāt

hâliyya 240

fawqiyya (God's aboveness) 110-113, 150, 187, 203, 205n8o, 208-211, 213-214, 222,

231, 245, 252, 262, 279

istiw $\bar{a}$ ' (God's sitting on the

Throne) 64n137, 111, 114n158, 150, 203,

205, 207-211, 214, 231, 279

nuzūl (God's descent) 111, 150, 203, 207

'uluw (God's highness/elevation) 112-113,

$187,203,210,212,262$

wajh (God's face) 203, 207, 250

yadayn (God's two hands) 203, 205-206

silsila (Sufi genealogy) 4, 39n42, 42-43, 64,

140-141

sīra (prophetic biography) 22, 145-146, 187,

192-193, 195, 28 o

titles of the genre al-Wāsițī

knew 146nu18

sirr (pl. asrār) ((innermost) secret) $\quad$ 188, 194, 199, 257, 264

șuhba (master-disciple relationship) 62,65 , $86,92-94,102,144$

with the Prophet $193-194,280$ 
sukr (intoxication) 143, 196-197, 264n97 sulūk (spiritual path, as opposed to spiritual attraction, jadhb(a))

in the Rifāiyya 40

according to al-Wāsițī 178-179

See also sālik, jadhb(a) and majdhūb

tadbir (direction of affairs)

for a human being: self-direction in the Shādhiliyya 94-97, 209 according to al-Wāsițī 257-258

for God: directing the creation according to al-Wāsițī 237, 256

tafsïr (interpretation, exegeses) $\quad 57,205 \mathrm{n} 83$

tafwìd (entrusting an affair to God)

in Sufism 96, 258, 261

in theology 204

tahajjud (nightly prayer) $\quad 138,255$

See also qiyām al-layl

țăiifa (pl. țawāiff) (group, Sufi order)

definition 4

al-țāifa al-manșūra (see saved sect)

tajalli (God's Self-manifestation) 112-113, 143, 213, 219, 227-228, 236, 238, 250-253,

$255^{-257}, 264$

tajsim (attributing corporeality to

God) $65 \mathrm{n} 138,112$

takyiff (modality) 207, 243-244

tamkin (spiritual stability) $\quad 38 \mathrm{n} 38,147$, 196-197

tamthïl (likening God to creatures) 204, 207 taqwā (piety) 95, 282n6

tarbiya (spiritual training) 89, 197-198

tarīqa Muhammadiyya (the Muhammadan way)

academic discussion on $185^{-186,280}$

according to al-Wāsiṭi 187-20o passim, $215,223,231$

Ibn Taymiyya's mention of $\quad$ 185-186

See also murshid, suhba

tashbih (anthropomorphism) 65n138, 112, 114n6o, 149, 204, 206-207, 209-210, 221

ta'tīl (stripping God of His attri-

butes) $65 \mathrm{n} 138,109,111,149,206,213$

tawakkul (trust in God) 94, 143, 196, 235, 258-259, 261

tawassul (seeking mediation of a friend of God) in the Rifăciyya 47

tawhìd (divine unity) 57, 125, 228-230, 261, 265,271

ta'wïl (metaphorical interpretation) 112, 149, 203-206, 208, 221n139, 222

tawr (pl. atwār) (dimension of the human being) $\quad 233-236$

'ubūdiyya (servitude)

according to al-Wāsițī $\quad 66,238-243$

passim, 257, 259, 26o, 265, 270, 272, 275

in the Shādhiliyya $\quad 98-100,112,133$

'uluw (God's highness/elevation) (see șifa)

uns (intimacy) 81, 181, 187, 217, 263

ușül al-dìn (principles of the religion) $\quad 3,6$

wahda (monism) 105n133, 225, 265

See also ittihād

wahdat al-wujüd (the unity of being) 125 , 226, 229, 231

wajd (ecstasy) 13n49, 50, 52, 95, 219, 263

wajh (God's face) (see șifa)

wäjid (ecstatic) 95, 265ng8

walì (pl. awliya $\bar{a}$ ) (friend of God) 41-43,

$52-53,65,84 n 48,96,103,119,138,218$,

222n142, 261, 269, 273

abdäl (al-) (the substitutes) 273, 282n6

afrād (al-) (the singular ones) 273

ghawth (al-) (the helper)

in the Rifấiyya 41-42

in the Shādhiliyya $\quad 115$

quțb (al-) (the axis)

in the Rifāiliyya 42

in the Shādhiliyya $84 \mathrm{n} 48,88,90$,

$115 \mathrm{n} 162,116$

wasila (see tawassul)

wilāya (or walāya) (friendship with God) 15 ,

$84 \mathrm{n} 48,87,91,101-102,181,233,269$,

$274-275,281$

wird (pl. awrād) (litany)

in al-Wāsiți’s Sufism 191-192

wuqū $f$ (refrain from judgment about divine attributes) 109, 203

wușūl (arrival unto God) 36, 67, 96, 102, 147, 191

al-Wāsițīs definition $\quad 269$

wușla 96 
yadayn (God's two hands) (see șifa)

zāhid (pl. zuhhād) (renunciant) 38n 38 , 89n66, 137, 141-142, 149, 159, 169-170, 178 zāwiya (see convent)

ziyāra (visitation of graves) 64 in the Rifā'iyya $\quad 43-44,46-48$ zuhd (renunciation) 142, 196, in the Rifāciyya $\quad 55^{-56}$ among the Hanbalīs 137-138, 140, 156, 279 according to al-Wāsițī 282n6 


\section{Index of Persons, Groups, and Places}

Abaqa (Mongol ilkhan) 32

'Abbāsid (caliphate) 27

Caliphs 27, 29, 135, 221

Abū Bakr al-Ṣiddīq 151, 218

Abū Madyan, Shu'ayb $\quad$ 79, 82-83, 107

Ahl al-Hadith

definition 6

see also: 'aqìda, sifa

Ahl al-Kalām (or mutakallimūn) (speculative theologians) 6, 109-111, 113n157, 149

See also kalām

Ahl al-Sunna 3, 110-111, 182, 212, 233

Ahl al-Sunna wa-al-Hadith 182, 183n1, 186, 222

Aḥmadī (al-), Hāshim b. Sacd $\quad 37,41-43,56$

Akbarian school (Sufism) 105-107, 118, 121, 246, 267, 271, 276, 278-279

in Cairo 124-133 passim

in Damascus 136-137

influence on al-Wāsițī $\quad$ 186nı 6

al-Wāsițî’s polemics against $\quad$ 225-231

definition 106n133

See also 'aqìda, ittihād, ittihādiyya, samā', sharīa, sifa

'Alī b. Abī Ṭālib 29n7, 43, 151

'Alī (al-), Walīd b. Muhammad 16, 283nı1

Āmidī (al-), Shams al-Dīn Muḥammad $\quad$ 161162,171

Andalus (al-) 78, 114nı6o, 127

Anjum, Ovamir 13

Anșāīi (al-), 'Abd Allāh al-Harawī 10, 159, 222

Arghūn (Mongol Ilkhan) 32-33

Aṣamm (al-), Ḥātim 220

Ash`arī (al-), Abū al-Ḥasan $\quad 6,113,114 n 157$, 207ngo

Ash'arī (theological school/madhhab) 6-8, 59, 170, 171, 204-205, 215, 278

al-Wāsițī as an Ash'arī 25, 61-62, 65n138, 203,

al-Wāsițī's refutation of $\quad 66,108-110$, 205-209, 213-214, 221-223

in Alexandria 79

in Cairo 120

in Damascus 135 in Wāsiṭ 59

See also șifa, Shādhiliyya

Aswānī (al-), 'Abd Allāh Ibn 'Arrām 92-93

Aswānī(al-), Bahā’ al-Dīn Aḥmad Ibn 'Arrām 92-93

Aswānī (al-), Zakī al-Dīn Abū Bakr Ibn 'Arrām 92-93

Aykī (or Īkīi) (al-), Shams al-Dīn

Muhammad 121-122, 128, 130-132

Ayyubid (sultanate) $\quad 73-77,80,119,135$

Ayyūbī, Șalāḥ al-Dīn (Saladin) 74-76, 8o, 119

Azhar (al-) 82

Baghdadi Sufis (muțāwi'atal-baghādida) 59, 62-67 passim

See also khirqa, samā', sharīa, shaykh

Ba'labakkī(al-),Zayn al-Dīn 'Abd al-Raḥmān $161,173,282$

Balyānī (al-), Awḥad al-Dīn 'Abd Allāh 127, 226

Banū al-Jawzī $\quad 136$

Banū al-Munajjā 135

Banū Qudāma $\quad$ 136, 138-139, 141, 149, 152n141

Banū Taymiyya $\quad{ }_{13} 6$

Bașrī (al-), al-Ḥasan $\quad 151$

Bașrī (al-), Abū Muḥammad b. 'Abd 158

Basțāmī (al-), Abū Yazīd 179

Bațāihịī (al-), Manșūr b. Yahyā 34

Baumann, Gerd 8

Baybars I, al-Malik al-Ẓāhir Rukn al-Dīn $\quad 75$, 80,132

Bazzār (al-), Sirāj al-Dīn 'Umar 144, 148

Bell, Joseph $\quad 11,14$

Bint Makkī (b. 'Alī al-Ḥarrānī), Zaynab $\quad$ 161, 169, 171, 174

Birzālī (al-), 'Alam al-Dīn (or Bahā' al-Dīn) al-Q̄āsim 152nı41, 16o-161, 170-171, $172 n 195$

Bori, Caterina $\quad 14,149,152,168 \mathrm{n} 174$

Bukhārī (al-), Muḥammad b. Ismāōil $\quad 97,183$

Bunānī (al-), Thābit $\quad 151$

Christian(s) 24, 27, 32, 75, 124

Damascus 
Old city $\quad 135^{-136,144,162,165-167,169-170 ~}$

Al-Ṣāliḥiyya $\quad 136,138,142,162-164,167$, 169-170, 277

Dār al-Hadīth 131n6o

al-Ashrafiyya $165,167,169$

al-Ashrafiyya al-Barrāniyya $\quad 136,162,164$, 167,169

al-Nūriyya $162,165,167,170$

al-Sukkariyya $136,144,162,167,172$

Dārimī (al-), 'Uthmān b. Sa'īd 146, 147n121

Décobert, Christian 81

Dhahabī (al-), Shams al-Dīn Muhammad 7, 34-35, 56-57, 65n137, 71, 12o, 127n37, 134n71, 148, 154, 156, 159n166, 161-162, 171-172, 178, 202, 281, 283

Dimashqī (al-), Ibrāhīm al-Qawwās 161, 174

Dimashqī (al-), Muḥammad b. 'Abd alRaḥmān $\quad 16$

Evans-Pritchard 8

Farghānī (al-), Sa'̄ìd (or Sacd) al-Dīn Muhammad 128, 130

Fārūthī (al-), 'Izz al-Dīn Aḥmad 34n25, $41-43,46,49,52-53,55^{-5} 6$, 6on122, 68

Rifā'̄ì affiliation $\quad 38-39$

Fāțima (daughter of the Prophet) $\quad 42$

Frenkel, Miriam 73

Geoffroy, Éric $\quad 43 n 61,58 n 116,78$ n27, 104-1o6, 137, 156n155, 159, 186n16, 187n17, 272

Gharnațī (al-), Abu Ḥayān 131-132

Ghazālī (al-), Abū Hāmid 37, 6o, 11o, 186

Ghazwānī (al-), 'Abd Allāh 185,28 o

Gingrich, Andre 8

Giza 91

Ḥabashī (al-), Yāqūt b. 'Abd Allāh 87, 89-92, 112

Ḥallāj (al-), al-Ḥusayn b. Manșūr 131, 18onıo, $1944_{42}$

Hanafī (madhhab/juridical school) 7, 59, $64 n 137$

Hanbalī (madhhab/juridical and theological school) $17,65,149,220$

and Sufism $\quad 9-15,136-142,156,168,178-179$, 222, 279

in Iraq 59,66 in Damascus $\quad 6-8,133,134-136,169-174$, 277

al-Wāsițī's switch to and education

in $62,145-147,155,278$

theology 202, 204, 207, 217, 231

See also karāma, zuhd, Ahl al-Hadīth

Harrānī (al-), Majd al-Dīn Ismā̄̄l 145

Harrānī (al-), Sharaf al-Dīn Muhammad 161, 171, 172n195, 174

Harrānī (al-), Taqī al-Dīn 'Umar 16o-161, 170-171

Hazzāmūn (a quarter of Wāsiṭ) 29, 34

Hìtī (al-), 'Alī 64

Hofer, Nathan $\quad 2-3,83 n 46,85-86,104,124$

Holtzman, Livnat $\quad 12-14$

Homerin, Emil $\quad 11,124$

Hoover, Jon $\quad 203 n 76,204 n 79$

Hülagü (Mongol Ilkhan) 29, 32, 35

Ibn 'Abd al-Salām, 'Izz al-Dīn 'Abd al-

'Azīz 110, 114, 131

Ibn Abī al-Hasan al-Shādhilī, Shihāb al-Dīn Ahmad 91-92

Ibn Abī al-Manșūr, Șafī al-Dīn 79

Ibn Abī 'Umar, Shams al-Dīn 'Abd al-

Raḥmān 139, 141, 152n141, 161, 169-173

Ibn Adham, Ibrāhīm 220

Ibn 'Allān, Shams al-Dīn Abū al-Ghanāim al-Muslim 161, 169-173

Ibn 'Arabī, Muhỵi al-Dīn １4, 17, 105n133, 106-107, 124-132 passim, 136, 215, 223 225-231 passim

al-Amr al-muhkam al-marbūt 130

Fusūṣal-hikam 129, 225-227, 229

al-Futūhāt al-makkiyya 130

See also Akbarian school

Ibn 'Asākir, Sharaf al-Dīn Ahmad b. Hibat

Allāh 161, 170-171, 173-174

Ibn 'Ațā', Abū al-'Abbās 10

Ibn 'Ațā' Allāh, Tāj al-Dīn al-Iskandarī 1, 82-87 passim, 89-91, 93-94, 96-102, 104, 107-108, 113, 116,

K. al-hikam 83, 96-100

K. al-tanwir $\quad 83,96-98,108$

Lațāif al-minan $\quad 83-86,93,102,104$

Miftāḥ al-falāh $\quad 83,113 n 157$

Unwān al-tawfíq 83,116

Ibn 'Ațiyya, Khalīa 93 
Ibn 'Awf, Wajīh al-Dīn 80

Ibn Badr, Khalìl 35

Ibn Bākhilā (or Mākhilā), Sharaf al-Dīn

Dāwūd 89-9o, 113

Ibn Bintal-A'azz, Taqīal-Dīn 'Abdal-Raḥmān 122n18, 131-132

Ibn al-Bukhārī, Fakhr al-Dīn 'Alī alMaqdisī 161, 170-174

Ibn Daqīq al-'Īd, Taqī al-Dīn Muhammad 113-114

Ibn al-Fāriḍ, Sharaf al-Dīn 'Umar 105' 106n133, 13o-131, 132n63, 133 al-Wāsitî̀'s knowledge of 131

Ibn Fūrak, Abū Bakr Muhammad 110

Ibn al-Hājj, Muhammad al-'Abdarī 114

Ibn Hanbal, Aḥmad 59, 65, 134, 142, 145n116, 152, 169, 173, 183, 202, 221

Ibn Hūd, Badr al-Dīn Hasan $\quad 71,127,134,137$, 174, 226

Ibn Idrīs, Abū al-Hasan 'Alī al-Rawhāè̄ al-Ba'qūbī $\quad 63-65,67$

Ibn 'Iyāḍ, Fựayl 220

Ibn al-Jawzī, Abū al-Faraj 'Abd al-Raḥmān 10,136

Ibn Kathīr, Abū al-Fidā’ Ismācîl 35, 17onı86, 174

Ibn al-Khuthaym, al -Rabī' $\quad 151$

Ibn Khuzayma, Muḥammad b. Ishạā 146, 147n121

Ibn al-Labbān, Shams al-Dīn

Muhammad 89,112-113, 209

Ibn Mākhilā (see Ibn Bākhilā)

Ibn al-Mar'ashī, Hudhayfa 220

Ibn Maylaq (or Malyaq), Shihāb al-Dīn Ahmad 91-92

Ibn al-Mubārak, 'Abd Allāh 152, 183

Ibn al-Mulaqqin, Sirāj al-Dīn 'Umar $\quad 84,140$

Ibn al-Munabbih, Ward 220

Ibn al-Musayyab, Sa'ìd 151

Ibn Nāșir al-Dīn, Shams al-Dīn Muhammad 283

Ibn al-Qāri', 'Alī b. Muḥammad al-Qurashī al-Wāsițī 33

Ibn Qayyim al-Jawziyya, Shams al-Dīn

Muhammad 12-14, 139, 161-162, 174, 250, 282-283

Ibn Rāhwayh, Ishạāq 145n116, $15^{2}$
Ibn Rajab, Zayn al-Dīn 'Abd al-Raḥmān $59,65,70,86,137,139-141,155^{-156}$, 158-159, 178, 231, 283

Ibn al-Ṣabbāgh, Muhammad b. Abī alQāsim 84, 91, 93, 96, 98-10o, 105, 108 Ibn Sab'īn, 'Abd al-Haqq b.

Ibrāhīm 105n133, 125, 127, 130-132, 137, 226

Ibn al-Ṣāigh, Fakhr al-Dīn Muḥammad 161, 172

Ibn al-Ṣāigh, Nūr al-Dīn Muhammad 161, 171, 173

Ibn Salama, Hammād 151-152

Ibn Shaybān, Badr al-Dīn Aḥmad 161, 169, 171-172

Ibn Taymiyya, Shihāb al-Dīn 'Abd al-Halīm, 136

Ibn Taymiyya, Taqī al-Dīn Aḥmad and Sufism 11-12, 158-16o description and daily routine $\quad 144-145$, 148-149

relationship with al-Wāsițī $\quad$ 157-16o as reviver of the Sunna $\quad 147-148$ al-'Aqìda al-Wāsițiyya 147

Dar'ta'ārud 157 al-Tuhfa al-Irāqiyya 179, 261 See also baqā', fanā', ilāhiyya, karāma, mahabba, murshid, nafs, rubūbiyya, saved sect, șifa

Ibn Ṭūlūbghā, Nāṣir al-Dīn Muhammad 16, 283

Ibn 'Uyayna, Sufyān $\quad 151$

Ibn al-Ward, Wahb 220

Ibn Zayd, Hammād 151-152

Ilkhanids/Mongols 3, 27-36 passim, 43, 54, 55n101, 59n12o, 65, 88, 124, 135-136, 227

'Irāqī (al-), Fakhr al-Dīn Ibrāhīm 128 Irbilī (al-), Amīn al-Dīn al-Qāsim 161, 169-171

Iṣbahānī (al-), Abū Nu'aym Aḥmad 138, $145 \mathrm{n}$

Iṣbahānī (or Iṣfahānī) (al-), Najm al-Dīn 'Abd Allāh 88-91, 93-95, 97-98, 102-105, 110, 113, 154, 209, 26o, 278, 281

Iṣbahānī (al-), Shams al-Dīn Muhammad 114

Iṣfahānī (al-), Abū Manșūr Ma'mar 10 
Iskandarī (al-), Tāj al-Dīn Ibn 'Ațā' Allāh (see Ibn 'Ațā̄' Allāh)

Jahmiyya (theological sect) 109, 111, 223, 226 Jahm b. Safwān $\quad 226$ Jāmic

'Aț̣āāinn (al-) 79

Ḥākimī (al-) 120

Karīmī (al-) 164, 167, 171

Muzaffarī (al-) 136, 162-163, 167, 169

Umayyad (see Umayyad)

Jandī (al-), Mu’ayyad al-Dīn $\quad$ 128, 13on 57 Jazūlī (al-), 'Abd al-Razzāq $\quad$ 79-8o, 81n38 Jīlānī (al-), 'Abd al-Qādir 10, 12, 64, 137, 139-142, 156, 222

authenticity of works $\quad 64 \mathrm{n} 137$

traditionalism in creed $65 \mathrm{n} 138,113$, $141 \mathrm{n} 101$

See also Qādiriyya (Sufi order)

Junayd (al-), Abū al-Qāsim $\quad 63,108,152,158$, 18 o, 218, 220, 222, 230

Junaydian model of fan $\bar{a} /$ baq $\bar{a}, \quad$ 101, 272, 274, 281

Karamustafa, Ahmet $\quad$ 9, 55

Karkhī (al-), Ma'rūf 220

Khabbāz (al-), 'Alī b. Sulaymān 65

Khabbāz (al-), Ḥasan (or Ḥusayn) 89, 92

Kharrāz (al-), Abū Sa'̄ì $\quad 63,230$

Kilābī Aḥmad Ibn Jahbal 111

Knysh, Alexander $\quad$ 11, 14, 131

Konya $127 n 37,128$

Krawietz, Birgit $\quad$ 12-13

Lakhmī (al-), Makīn al-Dīn al-Asmar gon69, 91-92

Laoust, Henri 11,14

Lawrence, Bruce B. 185

Leitner, Hartman 24

Madrasa (al-) 31, 32, 59, 64n137, 74, 135, 140, madrasas of Wāsit $\quad 60 n 122$

al-Dimāghiyya $\quad 162,167,173$

al-Ḍiyā’iyya $\quad 136,167$

al-Ḥanbaliyya al-Sharīfiyya $\quad 135,144,162$, 167,169

al-Jawziyya $\quad 136,167$

al-Mismāriyya $\quad$ 136, 162, 166-167, 169, 173
al-Nafĩsiyya $\quad 162,167,170$

al-Ṣaḥibiyya $\quad 136,167$

al-'Umariyya $\quad 136,162-163,167,170$

Maghrib(i) (al-) 78, 82, 115, 127

Mājirī (al-), Abū Muḥammad Șālị̣ b.

Yanșarān 79

Makdisi, George $\quad$ 9-10, 12, 137, 139-140, 142

Makkī (al-), Abū Ṭālib 37

Makkī (al-), 'Amr b. 'Uthmān 222, 230

Mālik (Ibn Anas) 151, 183

Mālikī (madhhab/juridical school) 6, 7, 79, 89, 91-93, 105, 114-115, 158, 277n3

Mamluk (sultanate) $3,6-8,14,32,35,71-72$, 74-78, 80, 85, 115, 118-119, 123-124, 128, $135,137,167,172-173,216,277,279,282$

Ma'mūn (al-), Abū Ja far Abd Allāh 221

Manbijī (al-), Abū al-Fath Nașr $\quad$ 129, 186

Maqdisī (al-), Abū 'Umar Muhammad 138140

Maqdisī (al-), Ḍiyā’ al-Dīn Muhammad 139

Maqdisī (al-), Muwaffaq al-Dīn 'Abd Allāh Ibn Qudāma 138-142, 145, 147, 152n141, 169, 203n 75,216

Maqdisī (al-), Shams al-Dīn Muhammad b. Ibrāhīm 140

Maqdisī (al-), Taqī al-Dīn 'Abd al-Ghanī 140, 145n116, 147

Marīsī (al-), Bishr b. Ghiyāth (Murji'ī theologian) 226

Marjānī (al-), 'Abd Allāh Abū Muhammad 87, 88n64, 91, 94, $114 \mathrm{n} 16 \mathrm{o}$

Mecca $\quad 70-72,88,91$

Meier, Fritz $\quad 1,9,11-12,15,17,48,185,279$

Melchert, Christopher 9

Michel, Thomas 11-12

Michot, Yahya 12

Miṣrī (al-), Dhū al-Nūn $\quad$ 18onı, 218, 220

Mizzī (al-), Jamāl al-Dīn Yūsuf $\quad$ 146, 16on171

Mongols (see Ilkhanids)

Mosque

of 'Amr b. al-'Āṣ $\quad 89$

Umayyad $136,144,162,167,277$

See also jāmic

Muhammad, al-Malik al-Nāṣir Nāṣir al-Dīn $\quad 76$

Muḥāsibī (al-), al-Ḥārith 222

Mūsā, Dịiā̄ al-Dīn (son of al- Jīlānī) 140 
Muslim, Abū al-Ḥasan b. al-Ḥajjāj 183

Murshidī (al-), Abū 'Abd Allāh

Muhammad 92-94

Mursī, Abū al-'Abbās Aḥmad $\quad$ 71, 8o-83, 86-91, 93-94, 102, 106, 108, 113, 154, 278 muțāwi'at al-baghādida (see Baghdadi Sufis)

Nwyia, Paul 107

Qabbārī (al-), Abū al-Qāsim $\quad 80$

Qādiriyya (Sufi order) 34, 139-142, 156

Ibn Taymiyya as a member of $12,15,134$, 141-142

early manifestation of $\quad 64-65$

See also khirqa

Qalāwūn, al-Malik al-Manșūr Sayf al-Dīn 75,132

Qasțallānī ((Ibn) al-), Quṭb al-Dīn $\quad 131$

Qazwīnī (al-), Najm al-Dīn 'Abd al-Ghaffār 60

Qūnawī (al-), Muḥammad Abū al-Faḍl 16, 2112, 283n11

Qūnawì (al-), Șadr al-Dīn $\quad$ 106, 124-128, 130, 133, 226

Qushayrī (al-), Abū al-Q̨āsim 36-37, 110, 222-223

Rāfi' (see al-Ṣumaydī)

Rāfi'i (al-), 'Abd al-Karīm b. Muḥammad 37, $38 \mathrm{n} 38,42,56-57,6$ o

Ra's (al-), Aḥmad Abū al-'Abbās $\quad$ 81, 107nız8

Rāzī (al-), Fakhr al-Dīn Ibn al-Khațīb 61, 109n144

Reynolds, Dwight F. 24

Rifāōì (al-), Ahmad

Abū al-'Alamayn $\quad 42$

Ahl al-Bayt $\quad 42-43$

creed 57

mausoleum 43-48

nāi ib 'an al-nabi (representative of the

Prophet) 41

Sunni credentials $\quad 55-58$

See also Rifāiciyya (Sufi order)

Rifāici (al-), Șāliḥ al-Aḥmadī 35

Rifāīi (al-), Shams al-Dīn Muhammad $\quad$ 52, 68

Rifāiiyya (Sufi order, also known as: Aḥmadiyya and Bațāihịiyya) antinomian Sufis $\quad 54-56$

dominance in Southern Iraq $\quad 36-37$

Ilkhanid friendship 33-36

miracle-working/thaumaturgy, see karāma

Shi'i inclinations $\quad 43-44$

in Alexandria $\quad 78-80$

in Damascus 137

al-Wāsițī polemics against $\quad$ 215-217, 279

See also fanā', faqīr, faqr, ghawth, khalwa,

khirqa, maqām, mawsim, murshid,

quțb, raqș, samā', sharī'a, shaykh, sulük,

tawassul, ziyāra, zuhd

Rūm (al-) (the Islamic east) $\quad 127$

Sab'inniyya (Sufi order) 137

șahāba (the Prophet's companions) 22, 43,

49, 52, 109, 141, 151, 216, 218, 230-231, 255

in the tariqa Muhammadiyya 193,

195-196, 199

Sa'īd al-su'adā’ 119, 121-122, 128-129, 132n63, 133

Salafi(s) $\quad 11,283$

Saqațī (al-), Sarī 220, 230

Șarṣarī (al-), Abū Zakariyyā Yaḥyā $\quad 65$, $67 \mathrm{n} 145$

Șayyād (al-), 'Izz al-Dīn Aḥmad $\quad 38,40,42$, $46 \mathrm{n} 67,47-52,56-57$

Schallenbergh, Gino 13

Sviri, Sara 2

Shādhilī (al-), Abū al-Ḥasan 'Alī 7o, 78-8o, 82-87, 90-93, 95-96, 98-102, 103, 105, 108, 113, 115, 18on1o, 235-236, 238, 240-241

bisāt al-șidq (the carpet of truthfulness) 99, 239-240, 242, 281

al-Wāsițī's critical attitude towards $\quad$ 154- $^{-}$

$155,215,223-224$

See also Shādhiliyya (Sufi order)

Shādhiliyya (Sufi order)

Ash'arism 110-115

the order's soberness $\quad 104-108$

"God was and there was nothing with

Him" 95, 97, 110, 209

institutionalization $\quad 85-102$

critical attitude towards other Sufis 105- $^{-}$ 107

See also baq $\bar{a}$, fana $\bar{\prime}$, faqür, faqr, ghawth, ikhtiyār, jadhb(a), karāma, khirqa, majdhūb, maqām, ma'rifa, murshid, 
nafs, quțb, rubūbiyya, samā's sharīa, shaykh, șifa, tadbìr, 'ubüdiyya

Shāfiī (madhhab/juridical school) jurisprudence $25,38,50,54,64 \mathrm{n} 137$, 104-105

jurists $6-7,17,33-34,59-63,66,70,79,89$, $91-93,113,115,120,133,146,149,15^{2}$, 169n178, 17o-173, 203-204, 277n3 combined with Ash'arism 7, 61-62, 135, 204

Shāfíī (al-), Ibn Idrīs $\quad 62,151,183$ Shahrābābī (al-), Kamāl al-Dīn 'Alī Ibn Waḍdāh 65

Shām (al-) (Greater Syria) 135, 139, 151 Sha'rānī (al-), 'Abd al-Wahhāb 84, 90 Shāțibī (al-), Abū 'Abd Allāh $\quad 80,107 n 138$ Shaybānī (al-), Yūnus b. Yūsuf (or Yūnus) 127,129

Shi'i(s) 32, 43-44, 59, 186, 226 Shirāzī (al-), Abū 'Alī Barghash 88 Shirāzī (al-), Abū Isḥāq Ibrāhīm 60 Shujāầ (al-), 'Alam al-Dīn Sanjar 121, 129 Silvers, Laury 9

Stone, Albert E. 23

Subkī (al-), Tāj al-Dīn 'Abd al-Wahhāb $38 n_{3} 8,56,171$

Subkī (al-), Taqī al-Dīn 'Alī 113 șüfyyat al-rasm (the Sufis of convention) 118, 122-124

See also faqr

Suhrawardiyya (Sufi order) 34, 38-39n42, 172
Șumaydī (al-), Jamāl al-Dīn Rāfic b.

Muḥammad 84, 90-91, 96, 98, 101, 108

Suyūṭi (al-), Jalāl al-Dīn 'Abd al-

Raḥmān 106, 108

Tanūkhī (al-), Sharaf al-Dīn Muhammad Ibn al-Munajjā 161, 172

Tegüder (Mongol Ilkhan) 32-33, 35

Thawrī (al-), Sufyān $\quad$ 151, 152nı41, 220

Tilimsānī (al-), 'Afîf al-Dīn 106-107, 126-128, 130-131, 226

Tirmidhī (al-), al-Ḥakīm $\quad$ 222-223

Tustarī (al-), Sahl 179, 220, 222, 230

Traditionalist(s) (see Ahl al-Hadith)

Udovitch, Abraham L. 73

Umayyad (caliphate) 27, 216

Umm 'Ubayda 33-34, 43-47, 52, 68

'Uthmān b. 'Affān $\quad 151$

Van Ess, Josef $\quad$ 4, 6, 12

Wallach, Jennifer Jensen $\quad 23$

Wāsițī (al-), Abū al-Fath $\quad$ 78-8o, 107nı38

Wāsițī (al-), Taqī al-Dīn Ibrāhīm b. 'Alī 140

Yāfi'ì (al-), 'Afîf al-Dīn 'Abd Allāh b. As'ad 84, 87-89, 91, 104, 105n128, 113 Yāqūt (see al-Ḥabashī)

Yūnusiyya (Sufi order) 129, 137 